( 7.7. W

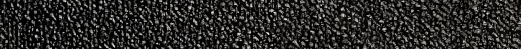

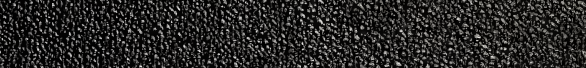

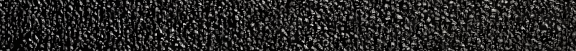

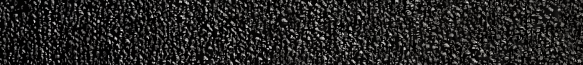

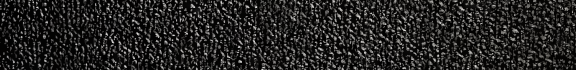
1.7.

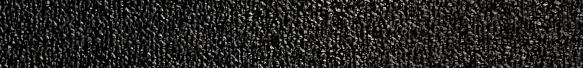

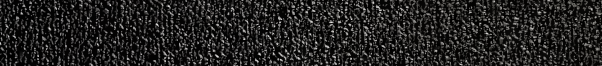
(3) 3.7.

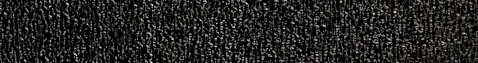

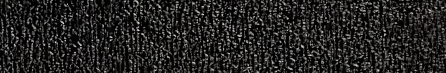

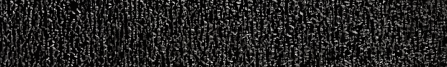
(3)

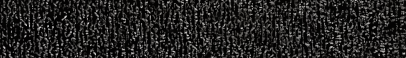

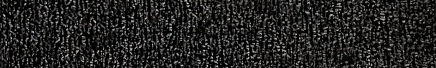

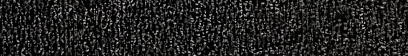

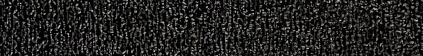

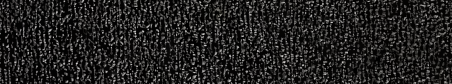

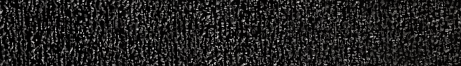

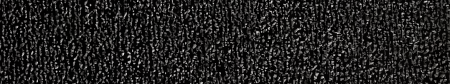
7
7

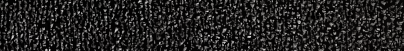
H. 


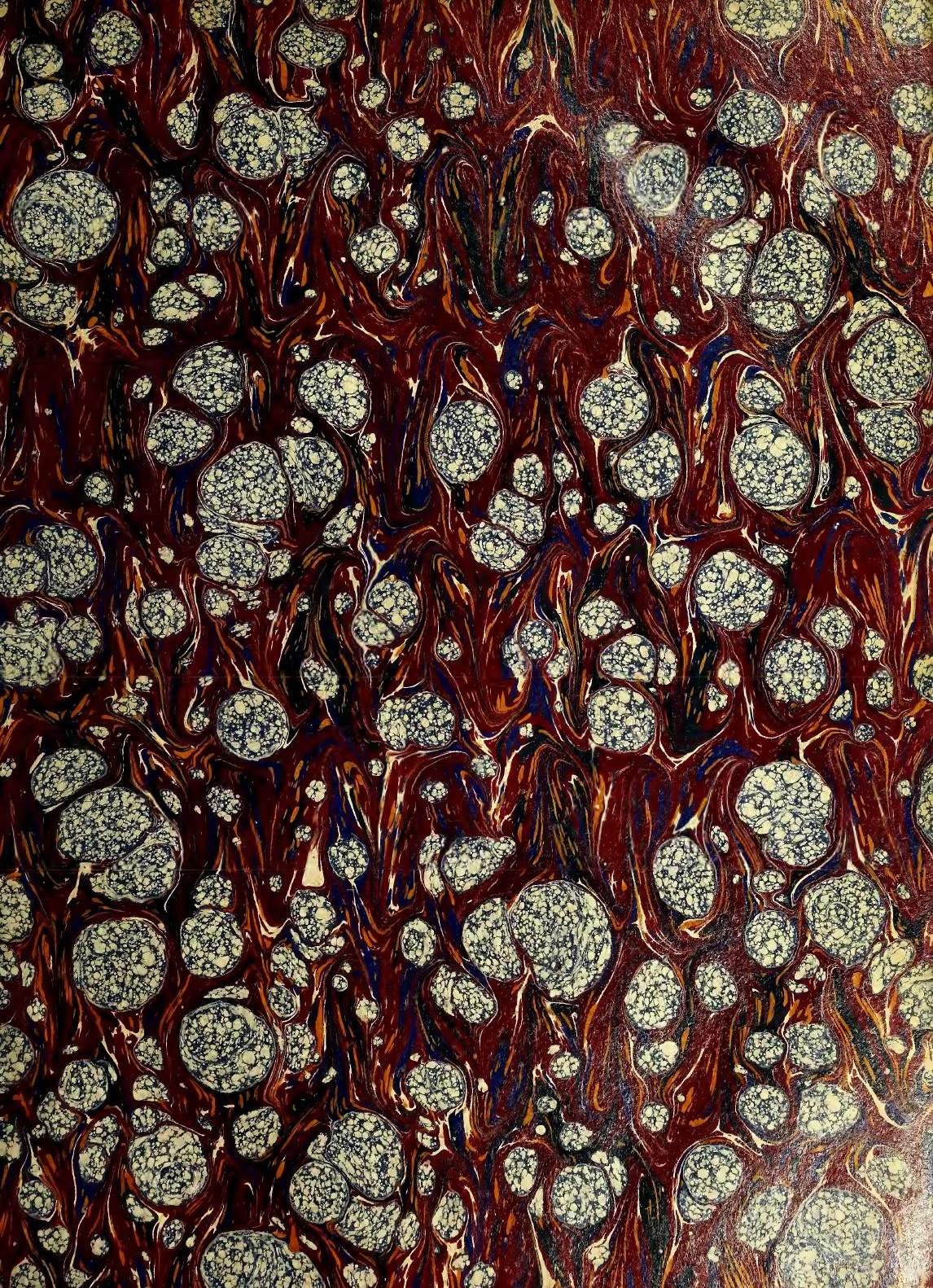


Digitized by the Internet Archive in 2016

https://archive.org/details/b24923588_0001 






\section{ATLAS}

DER

\section{OFFICINELLEN PFLANZEN.}

\section{DARSTELLUNG UND BESCHREIBUNG}

DER

IM ARZNEIBUCHE FÜR DAS DEUTSCHE REICH ERWÄHNTEN GEWÄCHSE.

\section{ZWEITE VERBESSERTE AUFLAGE}

voN

\section{DARSTELLUNG UND BESCHREIBUNG}

SÄMMTLICHER IN DER PHARMACOPOEA BORUSSIGA AUFGEFÜHRTEN

OFFICINELLEN GEWÄCHSE

$$
\text { voN }
$$

\section{O. C. BERG \\ UND \\ C. F. SCHMIDT.}

HERAUSGEGEBEN DURCH

DR. ARTHUR MEYER

PROFESSOR AN DER UNIVERSITÁT IN MARBURG.

\section{DR. KARL SCHUMANN}

PROFESSOR UND KUSTOS AM KGL. BOT. MUSEUM IN BERLIM.

MIT TAFEL I-CLXII.

\section{LEIPZIG}

VERLAG VON ARTHUR FELIX 



\section{A'TLAS}

DER

\section{OFFICINELLEN PFLANZEN.}

DARSTELLUNG UND BESCHREIBUNG

DER

IU ARZNEIBUCHE FÜR DAS DEUTSCHE REICH ERWÄHNTEN GEWÄCHSE.

\section{ZWEITE VERBESSERTE AUFLAGE}

von

\section{DARSTELLUNG UND BESCHREIBUNG}

SÄMMTLICHER IN DER PHARMACOPOEA BORUSSICA AUFGEFÜHRTEN

\section{OFEICINELLEN GEWÄCIISE}

$$
\text { voN }
$$

\section{O.C.BERG $\quad$ C.F.SCHMIDT.}

\section{HERAUSGEGEBEN DURCH}

\section{DR. ARTHUR MEYER}

PROFESSOR AN DER UNIVERSITÄT MARBURG.

\section{Dr. K. SCHUMANN}

PROFESSOR UND KUSTOS AM KGL. BOT. MUSEUM IN BERLIN.

BAND I.

DIE SYMPETALEN. MIT TAFEL I-XLIV.

\section{LEIPZIG}

VERLAG VON ARTHUR FELIX 



\section{Vorwort zur ersten Auflage.}

Der Unterzeichnete bält sich für verpflichtet, die Motive zu entwickeln, welche ihn veranlassten, unter der künstlerischen Mitwirkung des Pflanzenmalers Herrn Schmidt eine Darstellung und Besehreibung der offizinellen Pflanzen in das Leben zu rufen, obgleich schon mehrere :̈hnliche Bilderwcrke bestehen. Abgesehen von den älteren Wcrken, dem Blackwell'schen Herbar, den Plenck'schen Abbildungen und denjenigen neueren, welche sich begnügen, zu den aus anderen Werken entnommenen Copieen einen Text zu liefern, kommen kaum 6 Werke in Betracht, welche einen ähnlichen Plan verfolgen. Hayne's vorziigliches Werk, dem sich das unserige in Format und Beschreibung möglichst nahe angeschlossen hat, ist durch ganze Reihen pharmazentisch unwichtiger Pflanzen ïberladen, ïberdem unfertig und seit seimem Erscheinen (vom Jahre 1805 an) theils durch technische, theils durch wissenschaftliche Fortschritte veraltet. Die Düsseldorfer und Wagner's Abbildungen, durch ihr Folioformat begünstigt und durch sehöne, häufig prachtvolle Habitusbilder ausgezeichnct, geben gar keine oder nur unzureichende Zergliederungen und sind dieserhalb zum Studium geradezu unbrauchbar. Die Werke von Guimpel und Schlechtendal, von Brandt, Ratzeburg und Phöbus (letzteres mit Ausnahme des kryptogamischen Theils) entlehnen ohne Angabe der Quelle aus dem Hayne'schen, dem Dïsseldorfer oder anderen Werken dic Abbildungen und sind nur eigenthümlich hinsichtlich des Textes. Die Medical botany von Woodville, anch in der neueren Bearbeitung von Hooker, ist ganz unbedeutend. Von den erwähnten Werken unterscheidet sich das unserige besonders dadurch, dass es das Material nach den natiirlichen Familien behandelt und ordnet. Ansserdem sucht es die abzubildenden Pflanzen oder Pflanzentheile nicht allein so naturgetreu wie möglich, sondern auch in soleher Lage darzustellen, dass die Kennnzeichen der Art sogleich in's Auge fallen, erstrebt es ein getrenes, weder geschmeicheltes noch leichenhaftes Colorit, widmet den Zergliederungen die grösste Sorgfalt und Genauigkeit und liefert endlich mit alleiniger Ansnahme der verkleinerten Habitusbilder von Scorodosma foetidum Bge. und Dorema Ammoniacum Don, welche der Arbeit von Borszczow entlehnt sind, der Abbildung von Euphorbia Canariensis L., die uns vom Herrn Prof. H. Schacht in Bomn giitigst mitgetheilt, auch bis jetzt noch nicht publiziert ist, und einiger Entwicklungsstufen von Claviceps purpurea Tulasne nur Original-Abbildungen.

Was den Text anbelangt, so wurden die Familien ausführlich geschildert, die Gattungen mit dem natïrlichen Charakter versehen, bei beiden aber zur schnelleren Uebersicht die wesentlichen Kennzeichen durch den Druck ausgezeichnet, dann folgt der Artcharakter, auf diesen die chronologisch gcordnete 
Synonymie, in welcher zugleich die Geschichte der Pflanze liegt, hierauf die deutsche Benennung und das Vorkommen. Daran schliesst sich eine eingehende Beschreibung der Pflanze und, wenn es der Raum erlaubte, ihre Histologie und eine Zusammenstellung der nahe stehenden Gattungen und Arten, ferner die Pharmakognosie der Drogue und deren chemische Constitution.

Verf. ist sich wohl bewusst, diesen Plan nicht völlig consequent durchgeführt zu haben; theils liegt dies an dem zerrissenen Erscheinen der zusammengehörenden Pflanzen, theils an der technischen Einrichtung des Werkes, da es nach jedem beliebigen System sollte geordnet und eingebunden werden können und somit für jede Tafel Abbildung ein Blatt Text liefern musste. Der Text musste bei der einzigen offizinellen Art einer Familie mehr zusammengedrängt werden, da Familie und Gattung zu beschreiben waren, während dort, wo mehre Gattungen einer Familie oder gar mehre Arten einer Gattung zu schildern waren, sich der Raum mehr und mehr erweiterte und zu einer eingehenderen Beschreibung benutzt werden konnte.

Auch in Bezug auf die Vollständigkeit der Abbildungen lassen sich mancherlei Ausstellungen machen, denen jedoch nicht zu entgehen war, theils fehlte das Material zur erschöpfenden Darstellung, theils konnte wegen des durch das Quartformat beschränkten Raumes nicht Alles abgebildet werden, was darzustellen wïnschenswerth gewesen wäre. Es hätten auch die Abbildungen der Droguen nicht fehlen sollen, aber dann wäre das Werk 2-3mal voluminöser und um so viel theurer geworden, welcher Umstand wieder der Verbreitung desselben entgegentrat. Da tiberdem diesem Mangel durch ein anderweitiges Unternehmen abgeholfen werden wird, so konnte Verf. sich dariber fortsetzen.

Die Grenzen dieses Werkes sind, da sich die abgebildeten Pflanzen nur auf die 6 te und 7 te Auflage der Preussischen Pharmakiopöa beziehen, sehr eng gesteckt, aber Verf. erklärt sich nicht abgeneigt, w enn das betheiligte Publikum die Herausgabe durch seine Theilnahme unterstiutzt, auch noch die Pflanzen, welche die neve Pharmacopoea Germanica mehr enthält, etwa 48 Tafeln, also einen Band nach derselben Ausfuhrung und Bearbeitung herauszugeben.

Das Material für die Abbildungen der Stammpflanzen unserer offizinellen Droguen war zuweilen nur sehr schwierig, zuweilen gar nicht zu beschaffen. Die Stammpflanzen des kleinen Galgant, des Siamesischen Gutti, des Sternanis, des Westindischen Elemi sind noch gar nicht bekannt und daher hier nur durch verwandte Pflanzen repräsentiert; Curcuma Zedoaria war im bluhenden Zustande weder lebend noch getrocknet anfzutreiben und ist daher durch die auch in dem Rhizom nahe verwandte Curcuma aromatica ersetzt, welche im hiesigen Universitätsgarten zum Blühen gelangte; als Guttifere wurde eine neue Art abgebildet, die mit männlichen, weiblichen Blüthen und Frucht im hiesigen Königl. Herbar vertreten war, während Hebradendron cambogioides und andere stereotyp abgebildete, keineswegs jedoch das offizinelle Siam-Gutti liefernde Guttiferen in den Herbarien nur sehr verstïmmelt vorhanden sind. Unsere Japanische Expedition hat leider gar Nichts geliefert.

Für die freundliche Unterstitzung, die dem Verf. in Bezug auf die Litteratur durch den Bibliothekar an der hiesigen Königl. Universität, Herrn Dr. Pritzel, in Bezug auf die Pflanzen von den beiden hiesigen Königl. botanischen Gärten, dem hiesigen Königl. Herbar, dưch Herrn Prof. D. Hanbury in London, Herrn Prof. E. Fries in Upsala, Herrn Gartendirektor Kramer in Flottbeck, Herrn Prof. Schacht in Bonn, Herrn Dr. Hohenacker in Kirehheim u/T., ferner zumal durch das reiche Herbar des Herrn Dr. Sonder in Hamburg und durch das Wiener Herbar geworden ist, ohne welche es nicht möglich gewesen wäre, viele exotische und auch einige einheimische Pflanzen abzubilden, deren Bezugsquelle jedesmal gewissenhaft angegeben ist: so sagt ihnen hiermit Verf. öffentlich seinen verbindlichsten Dank. 
Da die Abbildungen, um die Tracht der Pflanze auch naturgetreu wiederzugeben, so viel als möglich nach lebenden Exemplaren hergestellt werden sollten, so konnte selbstverständlich eine systematische Anordnung bei der Publikation der einzelnen Hefte nicht eingehalten werden, als die Pflanzen eben, wie sie sich darboten, abgebildet werden mussten. Indessen ist von Anfang an auf eine spätere systematische Anordnung bedacht genommen und hat jedes Textblatt mit der dazu gehörigen Abbildung gleiche Nummer. Dieserhalb folgen mehre Register. Das erste ist Inhaltsverzeichniss des vierten Bandes; das zweite alphabetisch geordnet enthält auch die wichtigsten. Synonyme der abgebildeten Pflanzen, es dient zur Orientirung; ob die Pflanze aufgenommen ist oder nicht; das dritte giebt die Anordnung nach dem System von Endlicher; das vierte endlich die Reihenfolge nach der in meinem Handbuch durchgeführten Anordnung. Nach jeder der beiden letzteren Listen kann der Buchbinder die Tafeln und Text ordnen und nach der dort erfolgten Angabe in 4 Bände einbinden. Zum schnelleren Auffinden muss den Tafeln die in dem betreffenden Register dem Namen vorgesetzte Zahl nachträglich hinzugefügt werden.

Berlin, im Angust 1863 .

\section{O. Berg.}

\section{Vorwort zur zweiten Auflage.}

Man darf wohl behaupten, dass es der Wunsch aller Pharmakognosten war, dieses längere Zeit vergriffene Werk, seiner vorztiglichen, bisher noch unibertroffenen Abbildungen der Medicinalpflanzen wegen, wieder neu aufgelegt zu sehen. Es war den Unterzeichneten deshalb eine Freude, die Herausgabe der zweiten Auflage iibernehmen zu dïrfen.

Die Umgestaltung, welche die Heilkunst und die Pflanzenkunde im Laufe der 30 Jahre, die seit Herausgabe der ersten Auflage verflossen sind, erfahren haben, brachte es mit sich, dass der Inhalt des Werkes nach zwei Richtungen hin geändert werden musste. Zuerst musste es an das neue Arzneibuch angepasst werden, was in der Weise durehgeführt wurde, dass in den "Atlas der offizinellen PAlanzen" alle diejenigen Gewächse Aufnahme fanden, welche im Arzneibuche für das dentsche Reich (III. Ansgabe) erwähnt sind und daneben alle diejenigen, welche zu offizinellen Präparaten dieses Gesetzbuches in näherer Beziehung stehen. Eine grössere Anzahl von Tafeln konnte aus der alten Auflage des Atlas ïbernommen werden; dass sie trotz des Fortsehrittes, welchen die Botanik in den 30 Jahren gemacht hat, keiner Änderung bedurften, ist ein vorzügliches Zeugniss für ihre Vortrefflichkeit. Die nen hinzugekommenen Tafeln si nd, wie die im ersten Bande schon vorliegenden Abbildungen von Palaquium Gutta, Strophanthus, Marsdenia, Cinchona, Artemisia maritima zeigen, den alten Tafeln gleichwerthig ausgefallen. Im vorigen Jahre wurde zu unserem Schmerze unser trener Mitarbeiter, der Pflanzenzeichner C. F. Schumt, aus dem Leben abgerufen; es gelang uns in Fran Tonı GürKe, welehe sich dureh die besten Leistungen auf dem 
Gebiete der bildlichen Darstellung von Pflanzen einen grossen Ruf verschafft hat, einen Ersatz zu gewinnen. Die von der Verlagsbuchhandlung vergenommene Vergrösserung des Formates der Tafeln ist wohl der künstlerischen Wirkung derselben sehr zu Statten gekommen.

Eine vollkommene Umarbeitung musste der Text erfahren. Was BerG aus äusseren Gründen nicht konnte, die Pflanzen in systematischer Anordnung auf einander folgen zu lassen, ist jetzt trotz der neu hinzugekommenen Tafeln durehgeführt worden. Im allgemeinen ist das System ErchleR's der Anordnung zu Grunde gelegt; die Gattungen folgen sich nach Bentнaм und Ноокеr. In der Benennung haben wir uns an die vom Arzneibuche gewählten Namen angeschlossen; doch ist, wo es nöthig war, der nach den neueren Regeln der Nomenklatur zu wählenden Namen am Ende der Artikel angegeben worden. Die Beschreibung der Species erfolgte unter sorgfältiger Beriicksichtiguug der gegenwärtigen Kenntnisse der Sprossmorphologie. Beztiglich der Litteraturangaben ist hervorzuheben, dass die vorlinnéische Litteratur nicht mehr beriicksichtigt wurde. Besondere Sorgfalt haben wir der Mittheilung der geographisehen Verbreitung der offizinellen Gewächse zugewandt.

Die Angaben über die Chemie der Pflanzen, welche in der alten Auflage hie und da einen breiten Raum einnahmen, sind jetzt weggelassen, da sie relativ sehnell veralten und dann bald in Widerspruch mit den Angaben der Pharmakognosien und pharmazeutischen Chemien treten wïrden, zu deren Ergänzung dieser Atlas naturgemäss herbeigezogen werden wird.

Am Sehlusse des Werkes wird ein alphabetisches Verzeichniss iiber die Namen der Stammpflanzen, der Drogen und der erwähnten Chemikalien gegeben werden, sowie eine systematische Übersicht aller abgebildeten Gewächse.

Zn diesem "Atlas der offizinellen Pflanzen" soll ein Supplement erscheinen, in welches noch eine Reihe medicinisch wichtiger Gewächse und die technisch wichtigen Pflanzen Aufnahme finden sollen.

Marburg und Berlin, im August 1893.

Arthur Meyer. K. Schumann. 


\section{Namenregister der Pflanzen.}

Tafel Seite

XLIV. Aretostaphylos Uva ursi Spr. . . . 128

VI. Arnica montana L. . . . . . . 14

III. Artemisia Absinthium L. . . . . . 8

IV. A. maritima L. var. StechmannianaBess. 10

XXIX. Atropa Belladonna L. . . . . . . 82

XXVIII. Capsicum annuum L. . . . . . . 79

XIII. Cinchona Ledgeriana Moens . . . 36

XIV. C. succirubra Pav. . . . . . . . 38

XVI. Citrullus Colocynthis Schrad. . . . 44

VII. Cnicus benedietus L. . . . . . . . 16

XXX. Datura Stramonium L, . . . . . . 85

XXVII. Digitalis purpurea L. . . . . . . 75

XXXVII. Erythraea Centaurium Pers. . . . 107

XL. Fraxinus Ornus L. . . . . . . . 116

XXXVIII. Gentiana lutea L. . . . . . . . 109

XXXI. Hyoseyamus niger L. . . . . . 87

I. Inula Helenium L. . . . . . . . 4

XXXIII.a.b. Ipomoea Purga Hayne. . . . . . 94

IX. Lactuca virosa L. . . . . . . . . 21

XVIII. Lavandula vera DC. . . . . . . . 52

XVII. Lobelia inflata L. . . . . . . . . 48

XXXIV. Marsdenia Cundurango Rehb. . . 101
Tafel Seite

II. Matricaria Chamomilla L. . . . . . 6

XXIII. Melissa officinalis L. . . . . . . . 63

XIX. Mentha piperita L. . . . . . . 54

XX. Mentha silvestris L. var. crispa Bth. . 56

XXXIX. Menyanthes trifoliata L. . . . . 112

XXXII. Nicotiana Tabacam L. . . . . . 90

XLI. Olea europaea L. . . . . . . . 119

XLIII. Palaquium Gutta Burck. . . . . . 125

XV. Psychotria Ipecacuanha M. Arg. . . 40

XXV. Rosmarinus officinalis L. . . . . 68

XXIV. Salvia officinalis L. . . . . . . 65

XI. Sambucus nigra L. . . . . . . . 29

XXXV. Strophanthus hispidus DC. . . . 97

XXXVI. Strychnos Nux vomica L. . . . . 104

XLII. Styrax Benzoin Dryand. . . . . . . 122

VIII. Taraxacum officinale Web. . . . 19

XXI. Thymus Serpyllum L. . . . . . . 58

XXII. Thymus vulgaris L. . . . . . . 61

V. Tussilago Farfara L. . . . . . . . 12

XII. Uncaria Gambir Roxb. . . . . . 34

X. Valeriana officinalis L. . . . . . 25

XXVI. Verbascum thapsiforme Schr. . . . 72 



\section{ABTHEILUNG: ANGIOSPERMAE.}

Samenanlagen (Ovula) in einem gesehlossenen mit Narben versehenen Stempel. Der Embryosaek hat an der Seite, welehe dem Keimmund der Samenanlage zugekehrt ist, eine Eizelle und zwei Gehilfinnen; in der Regel befinden sieh am gegenüberliegenden Ende 3 Antipodenzellen; aus der Eizelle wird der Keimling (embryo), dessen Würzelehen stets auf den Keimmund zugekehrt ist. Die Übertragung des Befruehtungsstoffes gesehieht dureh den Pollensehlauch.

\section{Classe: Dicotyleae.}

Der Keimling hat fast stets 2 Keimblätter. Die Gefässbündel sind bei fast allen holzigen und vielen krautigen Pflanzen in einem Kreise angeordnet; sie werden dureh Zwisehenkambium verbunden und sind zu unbegrenztem Dickenwachsthume befähigt. Die Blätter sind fast stets fieder- oder fingernervig. In den Bliithen herrseht die 5-Zahl vor, nicht selten sind aber aueh viergliedrige Blithen vorhanden.

\section{Unterclasse: Sympetalae.}

Zwei Blïthenhiillkreise, Keleh und Krone, sind entwickelt; die Glieder der letzteren sind unter sieh verbunden*).

\section{Reihe: Aggregatae.}

Kelch, Blumenkrone und Staubgefässe sind typiseh fünfzählig; der Fruehtknoten aus 2-3 Frnehtblättern bestehend ist einfäehrig mit einer Samenanlage. Der Keleh ist nieht selten rudimentïr oder wäehst erst später hänfig zu einem Flugapparate oder einem anderen Verbreitungsorgane (Pappus) aus. Die Staubgefässe sind immer der Blumenkrone angewaehsen, ihre Zahl ist zuweilen gemindert. Die Bliithenstände sind häufig kopfig.

\footnotetext{
*) Dieser Charakter ist nicht ganz durehgreifend, es giebt unter den sympetalen Gattungen mit freien Blumenblättern, wie z. B. Oxycoceos, Rhododendrow ete.; in der zweiten Unterelasse wiederum kommen Gattungen mit verbundenen Blumenblättern vor, z. B. Crsparia bei den Rutaceen, Ilex ete.

Berg t, Schmidt, Officinelle Gewächee. 


\section{Familie: Composita e Vaillant.}

Synanthereae Rich. Asteraceae Lindl. Cassiniaceae Schnliz Bip.

Die Bliithen sind vollständig oder unvollstïndig, seltener gesehleehtslos, einem gemeinschaftlichen Blithenboden (reeptaculum eommune) aufgesetzt; von einem gemeinsehaftlichen Hiillkelche (pericliniun) eng: umschlossen, bilden sie ein Köpfehen (eapitulum) — das auch Blïtherkörbehen (anthodium) genannt wird. Der Blïthenboden ist flaeh oder gewölbt, dieht oder hohl, mit Deekblättern der Blüthen (bracteae, bracteolae, paleae) besetzt oder naekt. Der gemeinsehaftliche Hällkeleh wird aus Blättern von der Natur der Hochblätter zusammengesetzt. Bezïglieh der Gesehleehtsvertheilung kommen in den Köpfchen folgende Verhältnisse vor: Alle Blïthen sind gleichgestaltet und zwittrig: und die Blumenkronen sind röhren- oder triehterförmig (eapitula discoidea), oder zungenförmig (eap. ligulata); oder die inneren Bliithen sind wie die äusseren röhrenförmig, die letzteren aber oft dünner und weiblich (eap. diseiformia); endlieh können die inneren zwittrig und röhrenföminig sein und die äusseren zungenförmig und weiblich (eap. radiata). Die imneren Blïthen heissen dann Seheiben-, die äusseren Strahlenblïthen. Seltener sind gesehleelitslose Bliithen, noeh seltener sind die Köpfehen dielinisch. Der Fruehtknoten der Blithen ist unterständig und besteht wegen der paarigen Narben aus 2 median gestellten Fruehtblättern; er ist einfächrig und umschliesst eine am Grunde befestigte, aufreehte, gegenlänfige Samenanlage. Der Keleh ist oberständig, selten sind 5 gesonderte mit den Blumenkronenzipfeln weehselnde Elemente deutlieh ansgeprägt (Sphenogyne), die dann so orientirt sind, dass 2 auf das Deekblatt, 3 auf die Axe zugewendet sind; häufiger fehlt er ganz oder wird aus einer unbestimmten Zahl von IIaaren, Borsten oder Sehuppen gebildet; bei vielen wäehst er später zu einer aus haar- oder federförmigen Strahlen zusammengesetzten Haarkrone aus (Pappus). Die Blumenkrone ist verwaehsenblättrig, entweder aktinomorph röhren- oder triehterförmig mit fünf-(vier)zipfligem Saume und klappiger Knospenlage, oder zygomorph und dann meist zungenförmig und drei- bis fünfzähnig, seltener deutlieh zweilippig, wobei die Oberlippe zwei-, die Unterlippe dreizähnig ist. Die 5 Staubgefässe weehseln in den aktinomorphen Bliithen mit den Kronenzipfelu, sie sind in der Röhre angeheftet: die Fäden sind am Grunde meist frei, selten einbridrig verbunden; die Staubbeutel sind mit einander zu einer Röhre verklebt, sie haben zwei Fäeher, jedes Faeh zwei Fücherehen, häufig besitzen sie an der Spitze ein Anhängsel; am Grunde sind die Fächer entweder stumpf, spitz oder gesehwänzt; sie springen auf der Innenseite mit zwei Lüngsspalten auf; die Pollenkömer sind oft kugelig, entweder glatt oder höckerig, oft werden sie durch Fegehaare des Griffels aus den Fäehern herausgebürstet. Der Griffel wird am Grunde von einer Seheibe mit wulstig verdicktem Rande umgeben (Nektarkragen), die Honig absondert; er ist stielrund, an der Basis zuweilen ebenso wie an der Spitze verdiekt und läuft in zwei Narben aus, die auf der Innenseite flach oder rinnig vertieft, am Rande mit Papillen besetzt sind; seltener, besonders in gewissen sterilen Bliithen, sind die Narben verbunden. Bei den rein männliehen Blithen wird der Griffel vermisst oder es kann noeh ein Rudiment naehgewiesen werden; in den weibliehen Blüthen sind die Staubgefässe zuweilen als kurze Fäden noeh deutlieh sichtbar. Die Frucht ist ein Aehaenium : sie ist einfäehrig, einsamig, nieht aufspringend, trocken, selten fleisehig, von einem verschieden gestalteten Pappus, der bleibend oder abfällig ist, gekrönt, am Grunde mit einem Sebnabel versehen oder ungesehnäbelt. Der Same ist aufreeht mit dünner häutiger Samensehale und oft an die Fruehthaut angewachsen; Nährgewebe fehlt. Der Keimling ist gerade, die Keimblätter sind planeonvex, zuweilen halbstielrund, flach aneinandergelegt, seltener leieht eingerollt, das Würzelchen ist klein, nach unten gewendet.

Einjährige oder ansdauernde Kräuter, seltener Sträneher, sehr selten Bäume mit einfacher oder verzweigter oft unterirdischer Hauptaxe und spiral gestellten, seltener g'egen- oder wirtelständigen, nebenblattlosen, ganzen oder getheilten einfaehen Blättern. Die Köpfehen sind meist viel-, selten arm-, noeh seltener einblithig, zuweilen zusammengesetzt und sehliessen entweder die Hauptaxe ab, oder sind seitenständig und bilden dann oft vielfaeh zusammengesetzte rispige Blïthenstände, die unter Umständen in Wickeln auslaufen können. 
Die grösste aller Pflanzenfamilien umfasst nahezu 10000 Arten, welehe über die ganze Erde zerstrent sind. Die meisten wachsen in der gemässigten und der subtropischen Zone.

Die offieinellen Compositen gehören in folgende Tribus:

TRIBUS I. Inuleae Cass. Köpfehen mit Scheiben- und Strahlenblithen versehen, die ersteren zwittrig, die letzteren weiblich. Hüllkelch meist vielreihig; gemeinschaftlicher Blïthenboden nackt oder spreublättrig. Strahlenbliithen dreizähnig, Seheibenbliithen regelmässig, kurz vier- oder fünfzähnig. Staubbeutel meist geschwänzt, mit freien Anhängseln, an der Spitze mit kleiner blattartiger Endigung. Narben lineal, abgestutzt ohne Anhängsel. Haarkrone gewöhnlich aus Borsten gebildet. Blätter meist spiral gestellt und ganz; Scheiben- und Strahlenblithen gleiehfarbig.

\section{Inula Helenium L.}

TRIBUS II. Anthemileae Cass. Köpfehen mit Scheiben- und Strahlenblüthen versehen, oder die letzteren fehlend und dann alle zwittrig. Htillkelch zwei- bis dreissigreihig; gemeinschaftlicher Blüthenboden naekt oder spreublättrig. Strahlenblüthen weiblieh, zungenförmig, dreizähnig oder ganzrandig, zuweilen verkïrzt röhrenförmig, seltener fehlend. Scheibenblüthen röhrenförmig, kurz vier- oder fünfzähnig, zwittrig. Staubbeutel ungeschwänzt, an der Basis oft stumpf. Narben an der Spitze gestutzt, ohne Anhängsel. Friichte an der Spitze kahl oder mit kronenförmigem oder kurz sprenigem Pappus versehen. Blätter spiral gestellt, häufig getheilt. Seheibenblüthen meist gelb, Strahlenblitthen gewöhnlich verschiedenfarbig.

2. Matricaria Chamomilla L.

3. Artemisia Absinthium L.

4. Artemisia maritima I. var. Stechmanniana Bess.

TRIBUS III. Senccionideae Less. Köpfchen mit Scheiben- oder Strahlenblïthen versehen oder die letzteren fehlend und dann alle zwittrig. Hüllkelch ein- bis zweireihig; gemeinschaftlicher Blüthenboden gewöhnlieh nackt. Strahlenblïthen zungenförmig, weiblich, dreizähnig oder ganzrandig, oder verkürzt röhrenförmig, kurz vier- bis fünfzähnig. Röhrenblüthen zwittrig. Stanbbentel am Grunde pfeilförmig, mit stumpfen oder spitzen Öhrehen, an der Spitze mit einem Anhängsel versehen. Narben an der Spitze oft ein Anhängsel tragend oder abgestntzt und bärtig. Haarkrone gewöhnlieh aus Borsten gebildet. Blätter meist spiral gestellt; Scheiben- und Strahlenblithen gleichfarbig.

\section{Tussilago Farfara L.}

6. Arrica montana $\mathrm{L}$.

TRIBUS IV. Cynareae Less. Köpfehen meist gleichbliithig. Hüllkeleh vielreihig, Blätter oft an der Spitze trockenhäntig, dornig oder mit Anhängseln versehen; gemeinschaftlicher Blithenboden mit Borsten oder geschlitzten Bracteen besetzt. Bhumenkrone tief füntheilig. Antheren geschwänzt mit verwachsenen Anhängseln. Narben meist kurz, stumpf, ohne Anhängsel. Haarkrone borstig oder schmal sprenblättrig, meist einreihig. Blätter spiral gestellt, oft dornig; Rand- und Strahlenbliithen gleichfarbig.

7. Cnicus benedictus L.

TRIBUS V. Cichorieae Spr. Köpfehen gleichblithig. Blumenkrone zungenförmig, an der Spitze fünfä̈hnig. Staubbeutel an der Spitze mit Anlü̈ngseln versehen, am Grunde pfeilförmig, die benachbarten Lappen zweier Staubbentel mit einander verwachsen, ungesehwänzt. Narben dümn, stumpf oder spitzlich. Milehsaftfiihrende Kräuter mit spiral gestellten Blättern; Bliithen meist gelb.

S. Taraxacum officinale Web.

9. Lactuca virosa $\mathrm{L}$. 


\title{
INULA Linn.
}

Köpfehen heterogam, gewöhnlich mit Strahlenblïthen versehen, die Mittelblüthen zwittrig, jene weiblich. Hullkelch halbkugelig oder glockenförmig mit mehrreihigen, dachig deckenden Blättern. Gemeinschaftlicher Bluthenboden flach oder convex, kahl, oft etwas wabig vertieft. Strahlenblüthen zungenförmig, dreizähnig, gewöhnlich verlängert; Randblüthen röhrenförmig, kurz fünfzühnig. Staubbeutel pfeilförmig, mit langen, getrennten, haarförmigen oder verästelten Schwänzen, an der Spitze mit einem blattartigen Anhängsel. Griffeläste lineal, leicht zusammengedrïckt, oben etwas breiter, stumpf. Friichte rundlich mit $4-5$, mehr oder weniger oder kaum vortretenden Rippen. Federkrone haarförmig, $1-\infty$-reihig, Strahlen oft rauh. - Ausdauernde Kräuter, meist mit mehr oder weniger reichlicher, oft zottiger und drüsiger Bekleidung. Blätter ganz, spiralgestellt, selten zu einer bodenständigen Grundrosette zusammengedrängt. Köpfehen einzeln oder häufiger zu rispigen Blüthenständen vereint. Blüthen fast stets gelb.

Ungefähr 60 Arten in der alten Welt.

\section{Inula Helenium I.}

\author{
Tafel 1.
}

Stengel aufrecht; Blätter eiförmig oder oblong-ciförmig, gestielt, die oberen sitzend, unregelmässig gezähnt, unterseits weiss-filzig, oberseits von einfachen angedriickten Haaren rauh; Köpfehen in endständigen, armbliithigen und dann einfachen, oder mehrblüthigen und dann zusammengesetzten Trauben, gross, die endständigen lang gestielt, die seitenständigen sitzend oder kurz gestielt; Strahlenblitthen verlängert, den Griffel weit überragend; Frichte fast stielrund, Rippen nicht hervortretend.

Inula Helenium Linn. Spec. pl. ed. I. 891; Gürtn. Carp. II. t. 170; Hayne, Arzneigew. VI. t. 45; Lam. Encycl. t. 650; Nees, Düsseld. Pfl. t. 240; Guimp. und Schlecht. II. t. 191; Woodv. Med. t. 26; Fl. Dan. V.t. 725; Svensk Bot. I. t.57; Plenck Icon. t. 624; Engl. Bot. t. 1546; DC. Prodr. V. 463; Koch, Syn. 355 und viele andere deutsche Floren; Syme, Engl. Bot. V. t. 766; Stepl. and Church. Med. pl. t. 49; Reichb. Fl. Germ. XVI. t. 921; Bentl. and Trim. t. 150; Köhler, Mediz. Pf. II. t. 90; Berg u. Schmidt, Darst. u. Beschr. t. XXIf; Led. Fl. Ross. II. 500; Bert. Fl. Ital. 267; Godr. et Gren. Flore de Fr. II. 173; Willk. et Lange, Fl. Hisp. II. 46; Boiss. Flor. or. III. 186; Franch. et Sav. Flor. Jap. I. 230; Asa Gr. Syn. Fl. North Am. I (2). 236; Fliick. and Hanb. Pharmacogr. 340; Fliick. Pharmacogn. 440.

Corvisartia Helenium Mér. Pl. Par. ed. II. 261; Cass. Encycl. X. 572.

Alantwurzel, grosser Alant, Helenakraut, grosser Heinrich, Olat, Oltwurz; französisch: Racine d'aunée; englisch: Elecampane (aus Enula Campana entstanden).

Die Keimpflanze bildet im ersten Jahre eine wenigblättrige Grundrosette und eine kräftige, scnkrecht absteigende, spärlich verästelte, aussen gelblichbraune, innen weisse Pfahlwurzel; erst im zweiten Jahre kommt die Pflanze zum Blïhen. In den Achseln der Grundblätter bilden sich im ersten Jahre Seitensprosse, die im nächsten zu fingerdicken Rhizomen heranwachsen und im folgenden Blüthensprosse treiben. Jene sind im Äusseren den Wurzeln ähnlich, durch die fast stengelumfassenden Ansatzlinien der Grundblätter erscheinen sie geringelt.

Die Wurzel wird schliesslich bis $20 \mathrm{~cm}$ lang und nahe den Rhizomen bis $6 \mathrm{~cm}$ dick, sie ist verästelt und entwickelt bis $30 \mathrm{~cm}$ lange 1,5-2,5 cm im Durchmesser haltende, stielrunde Seitenwurzeln, die sonst auch aus dem Grunde der Rhizomstïcke entspringen.

Der Stengel ist aufrecht, kräftig, kantig, unten rauhhaarig und schärflich, oben weissfilzig und weich, gewöhnlich ästig, die Äste sind aufstrebend, seine Höhe beträgt $1-1,5$, selten bis $2 \mathrm{~m}$. 
Die Blätter sind spiralig gestellt, runzlig, oberseits mit kurzen, spitzen, am Grunde ein wenig verdickten, einfachen Haaren bestreut und desshalb rauh, unterseits von zahllosen, schlaffen, gewundenen Haaren dicht weissfilzig und weich anzufühlen; die Grundblätter sind gewöhnlich $30-40$, zuweilen bis $100 \mathrm{~cm}$ lang und 8-12, zuweilen bis $20 \mathrm{~cm}$ breit, von Form oblong-eiförmig, spitz, ziehen sie sich am Grunde in den die Hälfte der Länge messenden kräftigen, gestreiften, oben rinnigen, am Grunde breit scheidigen Blattstiel zusammen, am Rande sind sie unregelmässig gekerbt oder gezähnt; die Stengelblätter haben einen kïrzeren Stiel, sind erheblich kürzer und kleiner, die obersten sind sitzend, halbstengelumfassend und am Grunde oft abgerundet.

Gesammtbluthenstand traubig mit Gipfelköpfehen, das sich zuerst entwickelt, bei kräftigeren Exemplaren meist rispig, wobei die Seitenstrahlen Neigung zur Wickelbildung verrathen; Endköpfehen der Haupt- und Seitenstrahlen oft lang-, die übrigen meist kurzgestielt von zwei Zweigvorblättern begleitet.

Die Bluthenköpfehen sind endständig, den Zweig beschliessend, einzeln, gross, aufrecht, polygamisch, mit Strahlen- und Scheibenblitthen. Der Hüllkeleh ist halbkugelig, dachziegelig, vielblättrig; die äusseren Blätter sind loekerer, eiförmig spitz, zuweilen die äussersten laubig, die inneren lanzettförmig oder fast spathelförmig, aufrecht, trockenhäntig; beide Gestalten werden durch Zwischenformen verbunden. Der gemeinschaftliche Blüthenboden ist fast flach, kahl, nach Abfall der Frtichte mit eckigen, kurz gerandeten Grïbchen bedeckt.

Die Strahlenblüthen sind zahlreich, weiblich; der Fruchtknoten ist fast stielrund, leicht gekrümmt, oben etwas angesehwollen gerandet, mit borstigem, ans rauhen Haaren zusammengesetztem, schmutzig weissem Pappus, der so lang wie die gekrümmte Blumenkronenröhre ist; die Zunge ist schmal lineal, dreimal länger als die Röhre, dreizähnig, gelb. Der Griffel überragt die Blumenkronenröhre ein wenig. Die Narben sind an der Spitze etwas verbreitert, stumpf, auf dem Rücken mit sehr kurzen Papillen bekleidet.

Die Scheibenblüthen sind zwittrig. Der Fruchtknoten ist gerade, stielrund, der Pappus wie bei voriger, aber fast von der Länge der röhrenförmigen, oben etwas erweiterten, fünfzähnigen, gelben Blumenkrone. Staubgefässe 5, der Mitte der Blumenkrone angeheftet; die Staubfäden sind oberhalb der Mitte gegliedert; die Staubbeutel überragen die Krone nicht; sie sind bis auf die eiförmige, stumpfe Spitze und die dornig gesägten Schwänze mit einander verklebt. Der Pollen ist elliptisch, stachlig mit drei Meridianfurehen, in deren Mitte das kleine Fensterchen liegt. Der Griffel ist fadenförmig, am Grunde verdickt, so lang wie die Krone. Die Narben sind schmal, an der Spitze etwas verbreitert, stumpf, aussen und an den Rändern innen kurz papillös.

Die Früchte sind $4 \mathrm{~mm}$ lang und haben $1 \mathrm{~mm}$ im Durchmesser; sie sind fast stielrund, gestreift, kahl, braun, von fast doppelt so langem Pappus gekrönt. Der Keimling ist gerade, das Wuirzelchen ist halb so lang wie die halbcylindrischen Keimblätter.

Die Pflanze wächst im westlichen und sỉdlichen Norwegen, in Stid-Schweden, England und Schottland, Irland, in Portugal und Spanien, Frankreich, Deutschland, der Schweiz, Italien, Ungarn, der Balkanhalbinsel bis zum Olymp, ferner von Finnland durch ganz Russland und Sibirien bis zu den chinesischen Grenzprovinzen und lässt sich bis nach Japan verfolgen; in Persien erreicht sie die stid-östliche Grenze, denn im Himalaya fehlt sie; in Nord-Amerika ist sie verwildert. In den sïdlicheren Gegenden bewohnt sie die höheren Gebirge, in den nördlichen Theilen von Europa zieht sie den Seestrand vor. Da sie schon seit uralten Zeiten als Medicinpflanze geschätzt wurde, so ist sie durch die Cultur auch in Europa vielfach verbreitet worden und dürfte an vielen Orten Deutschlands nur als verwildert anzusehen sein.

Sie bliht im Juli, August und September.

Medicinische Verwendung finden die im Herbste oder im ersten Frühjahre gesammelten unterirdischen Theile wild wachsender oder cultivirter Pflanzen, die man von den dïnnsten Wurzeln und den Blattresten befreit, häufig auch der Länge nach in Stiucke zerschneidet und trocknet. Die Droge (Radix Helenii, Radix Inulae, Alantwurzel) besteht also aus Rhizomstidcken und dickeren Wurzeln. 
Erklärung der Abbildungen.

Fig. A. Bliithenstand, Naturgrösse.

Fig. B. Wnrzelblatt in halber Naturgrösse.

Fig. C. Bliithenköpfehen, Längsschnitt: $a$. Gemeinschaftlieher Blithenboden; $b$. Hiillkeleh; $c$. Strahlenbliithen; $d$. Scheibenblithen.

Fig. $D$. Strahlenblithe, fast 2 -fach vergrössert: $e$. Fruchtknoten; $f$. Pappus; $g$. Kronenröhre; $k$. Narben.

Fig. $E$. Scheibenbliithe, fast 3 -fach vergrössert: $e, f, g, k$ wie bei voriger.

Fig. $F$. Seheibenblïthe, Längsschnitt ungefillir 4 -fach vergrössert: $e, f, q, k$ wic bei voriger; $h$. Stanbgefiisse; $i$, Griffel.
Fig. $G$. Staubgefässröhre, e. 8-fach vergrössert.

Fig. $H$. Einzelnes Staubgefïss, c. 8 -faeh vergrössert.

Fig. I. Pollenkörner trocken.

Fig. $K$. Dieselben im Wasser.

Fig. $L$. Oberes Ende des Griffels mit den Narben, 6-fach vergrössert.

Fig. M. Frueht, natiirl. Grösse.

Fig. N. Dieselbe, reichlich 3 -fach vergrössert.

Fig. $O$. Dieselbe, Längssehnitt parallel den Keimblättern $n$; m. das Würzelehen.

Fig. $P$. Dieselbe, Längssehnitt senkrecht auf die Keimblätter. Fig. Q. Dieselbe, Qnerschnitt.

\title{
MATRICARIA Linn.
}

Bl ü thenköpfehen heterogam, strahlend, Strahlenbliithen weiblieh meist fruehtbar, einreihig; Mittelbliithen zwittrig, sehr viele. Gemeinsehaftlieher Hullkeleh halbkugelig, ans wenigreihigen, daehziegelig deekenden, häutig gerandeten Blättern zusammengesetzt, die äusseren kürzer. Gemeinsehaftlieher Bliithenboden naekt, kegelförmig; oft hohl. Randblüthen zungenförmig, fast ganzrandig; Mittelblithen regelmässig, vier- oder fünfzähnig, röhrenförmig. Staubbentel am Grunde stumpf; Narbensehenkel der Zwitterblithe gestutzt, mit einem Barte von Fegehaaren. Frueht oblong, oft gekrümmt, gestutzt, auf der Innenseite mit 3-5 mehr oder weniger vorspringenden Rippen, Pappus fehlend oder ein Krönehen darstellend. - Einjährige oder ausdauernde Kräuter von zuweilen starkem Geruehe. Blïtter spiral gestellt, fiedertheilig mit linealen Absehmitten. Blüthenköpfehen einzeln am Ende der Zweige, gestielt, meist doldentranbig vereinigt. Strahlenbliithen weiss, Mittelbliithen gelb. Friehte kahl, glatt und quer gerunzelt, zuweilen drïsig.

Ungefähr 20 Arten, von denen die Hälfte in der nördlieh gemässigten Zone der alten Welt, einige von ihnen aueh in Amerika und in den übrigen Theilen der Erde verwildert, die andere Hälfte in SïdAfrika.

\section{Matricaria Chamomilla L.}

\author{
Tafel 2.
}

Stengel aufreeht, Äste doldentraubig; Blätter doppelt fiederspaltig mit linealen, staehelspitzigen Fiederabsehnitten, wie der Stengel kahl; Blätter des gemeinsehaftliehen Hiillkelehes oblong, stumpf, am Rande weisshäutig; Strahlenblithen dreimal lïnger als der Hüllkeleh; Früehte meist ohne Pappus.

Matriearia Chamomilla L. Spee. pl. ed. I. 891; Allione, Fl. Pedem. I. t. 192; Drev. Bild. IV. 124; Svensk Bot. I. 50; Plenck, Icon. 617; Engl. Bot. XVIII. 1232; Hayne, Arzneigew. I. 3; Sehkuhr, IIandl. III. 253b; Curt. Fl. Lond. I. 142; Nees, Diisseld. Pf. t. 241; Fl. Dan. X. t. 1764; Guimp. et Schlecht. II. t. 122; Kth. Offiz. 266; Baxt. Br. Bot. V. 355; Reichb. Fl. Germ. XVI. 1.997; Koch, Syn. 377 und viele deutsche Floren; Syme, Engl. Bot. V.t. 719 ; Bentl. and Trim. Med. pl. t. 155; Berg u. Schmidt, Darst. n. Beschr. ХХIIIf. Köhler, Mediz. Pf. t. 61; Godron et Gren. Fl. de Fr. II. 149; Ledeb. Fl. Ross. II. 545; Bert. F7. Ital. IX. 350; Willk. et Lange, F7. Hisp. II. 92; Boiss. Fl. orient. HII. 323; Hook. fl. Fl. Br. Ind. III. 315; Asa Gr. Syn. Fl. North Am. I (2). 364; Flück, and Hanb. Pharmacogr. 345; Fliick. Pharmaeogn. 785.

Chrysanthemum Chamomilla Patze, Ellan et Meyer, Fl. Prov. Preuss. 135.

Chamomilla officinalis C. Koeh in Linnaea XVII. 45.

Famille, Chamille, Mägdeblumen; französiseh: Camomille d Allemagne; englisch: German camomile. 
Die Pflanze ist einjährig. Aus der kurzen, diunnen, sehr reichlich mit fasrigen, braunen Seitenwurzeln besetzten Pfahlwurzel erhebt sich der unten einfache, oben verästelte Stengel; nicht selten treten aber die Äste bereits ans den unteren, dichter gestellten Blättern hervor, sodass aus einer Wurzel mehrere Stengel hervorzugehen scheinen. Der Stengel ist 20-40 em hoch und am Grunde $2-4 \mathrm{~mm}$ diek, krautig; aufrecht, fast stielrund oder mehr oder weniger deutlich fünfkantig, gestreift, lebhaft griin, am Grunde bräunlich, kahl, die Verïstelung ist doldentraubig.

Die Blätter sind spiralig gestellt, sitzend, im Umrisse oblong oder lanzettlich, kahl, die unteren dreifach, die mittleren zweifach, die oberen einfach fiedertheilig; die Fiederabschnitte sind ein wenig fleischig, feinstachelspitzig.

Die Blïthenköpfehen sind endständig, einzeln an den Ästen, strahlend, aufrecht, langgestielt, doldentraubig zusammengestellt, wobei sich das Köpfehen der Hauptaxe zuerst entwickelt; Stiitzblättehen einzeln, linealisch, zuriickgekrïmmt, oder fehlend. Der Hüllkel $\mathrm{ch}$ wird aus vielen elliptischen oder breit linealen, stumpfen oder spitzen, grünen, am Rande trockenhüutig-weissen, in etwa 3 Reihen dachziegelig deckenden Blättchen zusammengesetzt.

Der Blüthenboden ist hohl, nackt und halbkugelig, er wächst während der Blïthezeit kegelförmig: aus; nach dem Abfallen der Friichte ist er feinwabig.

Die Strahlenblïthen, 12-18 an Zahl, sind weiblich, zuerst ausgebreitet, damn zuriickgeschlagen, weiss.

Der Fruchtknoten ist cylindrisch, etwas gekrümmt, nach dem Grunde versehmälert, leicht gestreift, $1 \mathrm{~mm}$ lang, kaum 0,5 mm breit. Der Pappus fehlt. Die Blumenkrone ist zungenförmig; die Röhre von der Länge des Fruchtknotens ist mit vereinzelten, gestielten, sehr kleinen Drïschen bestrent, sonst kahl; die Zunge ist oblong lanzettlich, am Ende gestutzt, stumpf dreizähnig, viernervig. Staubgefässreste sind nicht sichtbar. Der Griffel ist fadenförmig, am Grnnde zwiebelig verdickt, $2 \mathrm{~mm}$ lang; die Narbensehenkel spreizen und sind ein wenig nach unten gekritimmt, am Ende gestntzt.

Die Scheibenblïthen sind selır zahlreich, $2 \mathrm{~mm}$ lang. Die Blumenkrone ist unten röhrenförmig, oben glockig, kurz fünflappig mit zuriiekgekriimmten Lappen, gelb, hier und da mit gestielten Drüschen, besonders auf der Röhre bestreut. Die Staubgefässe sind am Grunde der Glocke befestigt, die Bentel zu einer $0,5 \mathrm{~mm}$ langen Röhre verklebt, am Grunde pfeilförmig, an der Spitze mit einem dreieckigen stumpflichen Anhängsel versehen. Der Pollen ist ellipsoidiseh mit 3 schwachen Längsfurchen versehen und stark bestachelt. Der Griffel ist fadenförmig, am verdiekten Grunde mit einem Nektarkragen versehen; die Narbenschenkel spreizen und sind etwas gekriimmt, am Endle gestutzt mit einem Barte von Fegehaaren besetzt, sie sind besonders am Rande auf der Innenseite papillös.

Die Frucht ist kaum $2 \mathrm{~mm}$ lang, fast ellipsoidisch, leicht gekrimmt, walzigrund oder leieht zusammengedrückt, an der Basis verschmälert, oben schief gestutzt, ohne Pappus, seltener mit einem Krönchen versehen (var. coronata), nach innen zu mehr oder weniger dentlich fünfrippig, kahl, braun.

Der Same füllt das Frnehtfach völlig aus, das Würzelehen des Keimlings ist dreimal kuirzer als die Keimblätter.

Die Kamille wächst auf Äckern und an wïsten Plätzen von Finnland und dem mittleren Schweden durch ganz Mitteleuropa bis in die Mittelmeerländer, ist aber in der T'irkei nnd Griechenland minder häufig; ausserdem findet sie sich in dem uralischen Sibirien, in den Kaukasusländern, Kleinasien, Persien, Afghanistan bis nach der oberen Ganges-Ebene und dem Pandschab; auch auf den Canarischen Inseln scheint sie einheimisch zu sein. In Nord-Amerika ist sie in den Staaten New-York und New-Jersey eingebürgert.

Die Pflanze liefert die Flores Chamomillae oder Kamillen, welehe in den Preislisten der Drogenhäuser, zum Untersehiede von den Chamomillae Romanae aueh als Flores Chamomillae vulgaris bezeichnet werden. Die Droge besteht ans dem noch mit einem Theile ihres Stieles versehenen Bliththenköpfehen der Pflanze. Der Geruch der Droge riiht von dem zwischen Membran und Cntienla der kleinen Dritsenhaare, welche an der Aussenseite des Fruchtknotens und der Blumenkrone sitzen, ansgesehiedenen ätherischen öle her. 
Erklärung der Abbildungen.

Fig. A. Spitze eines blühenden Stengels, natürliche Grösse.

Fig. $B$. Hüllkelch von unten gesehcn, 3 mal vergrössert.

Fig. C. Ein Blïthenköpfchen im Längsschnitte, 3 mal vergrössert: $a$. der gemeinschaftliche Blüthenboden; $b$. der Hiillkelch; $c$. weibliche Strahlenbliithen; d. zwittrige Scheibenblüthen.

Fig. D. Der kegelförmige, nackte, gemeinschaftliche Blüthenboden, $3 \mathrm{mal}$ vergrössert.

Fig. E. Eine Strahlenblïthe, 5 mal vergrössert : $e$. der Fruchtknoten; $g$. die Blumenkrone; $l$. der Griffel.

Fig. $F$. $G$. Seheibenblithen, $12 \mathrm{mal}$ vergrössert: $i$, die Stanbbeutelröhre; $m$. die Narben.
Fig. H. Eine Scheibenblithe im Längsschnitte, $15 \mathrm{mal}$ vergrössert: $f$. die Samenanlage; $h$. dic Staubfiden; $k$. die Anhängsel der Staubbeutel.

Fig. I. Die Staubbeutelröhre aufgeschnitten und ausgebreitet von innen, $25 \mathrm{mal}$ vergrösscrt.

Fig. $K$. Pollenkörner, das obere trocken, die unteren in Wasser, $300 \mathrm{mal}$ vergrössert.

Fig. L. Die Frucht, natürliche Grösse.

Fig. M. Dicselbe, $12 \mathrm{mal}$ vergrösscrt.

Fig. $N$. Dieselbe im Lïngsschnitte: $n$. Fruchtschale; $o$. Würzelchen; $p$. Keimblïtter.

Fig. $O$. Dicselbe im Querschnitte.

\section{ARTEMISIA Linn.}

Blüthenköpfchen heterogam, nicht strahlend; Randblüthen weiblich, fruchtbar; Mittelblüthen zwittrig; fruchtbar oder unfrnehtbar, oder homogam, sämmtliche Bliithen zwittrig und fruchtbar. Gemeinschaftlicher Hüllkelch eiförmig, oblong oder breitglockig, aus vielen dachziegelig deckenden, wenig- oder mehrreihigen, am Rande häutigen Blättchen aufgebant, die änsseren kleiner. Gemeinschaftlicher Blüthenboden flach gewölbt oder halbkuglig, nackt oder behaart. Blumenkrone der Randblithen röhrenförmig, dümn, kurz zwei- bis dreispaltig, Mittelblïthen am Grunde röhrenförmig, oben mehr oder wenig glockig, oder keulenförmig, kurz fünfspaltig. Staubbentel am Grunde stumpf. Narbenschenkel der Zwitterblüthen an der oft verbreiterten Spitze gestutzt mit einem Barte von Fegehaaren. Frïchte drehrund oder zusammengedrïckt, zweirippig oder schwach gestreift, gerade oder gekrtimmt, an der Spitze gestutzt, ohne Pappus oder von einem kurzen Ringe gekrönt. - Kränter oder Halbsträucher, nicht selten grau behaart, stark riechend. Blüthenköpfchen klein, aufrecht oder hängend, selten grösser, traubig oder rispig oder geknäult, nicht doldentraubig. Blumenkronen gelb oder bleich. Früchte kahl oder behaart.

150-200 Arten in der nördlich gemässigten Zone beider Hemisphären, besonders in den Steppen verbreitet; 3-4 Arten im aussertropischen Siid-Amerika und auf den Sandwich-Inseln.

\section{Artemisia Absinthium L.}

\section{Tafel 3 .}

Ausdauernd, Blätter der Grundrosette des ersten Jahres langgestielt, dreifach fiedertheilig, mit schmallanzettlichen Zipfeln, seidenhaarig; Blüthenstand rispig; Blüthenköpfchen heterogam, Blüthenboden behaart; Randbliithen röhrenförmig; weiblich, Blumenkrone kurz dreitheilig; Frucht schwach gestreift.

Artcmisia Absinthium L. Spec. plant. ed.I. 845; Plenck, Icon.605; Svensk Bot. II. 106; Engl. Bot. XVIII. t. 1230; Hayne, Arzneipfl. II. t. 11; Flor. Dan. X. t. 1654; Nees, Diisseld. Pfl. t. 235; Woodv. Med. Bot. I. t. 22; Guimp. et Schlecht. II. t. 197; Kth. Off. 271; DC. Prodr. VI. 125; Baxt. Br. Bot. V. 339; Dietr. Fl. Bor. IX. t. 633; Steph. and Church. Med.pl. t. 58. fig. 2; Syme, Engl. Bot. V. t. 731; Rchb. Fl. Germ, t. 1029; Bentl. and Trim. Med. pl. t. 156; Berg u. Schmidt, Darst. u. Beschr. t. XXII ; Köhler, Medizinalpfl. t. 68; Koch, Syn. 365 und viele andere deutsche Floren; Ledeb. Fl. Ross. II. 598; Godr. et Gren. Fl. de Fr. II. 126; Willk. et Lange, Fl. Hisp. II. 68; Bert. Fl. Ital. IX. 123; Boiss. Fl. or. III. 373; Hook. fl. Fl. Br. Ind. III. 325; Asa Gr. Syn. Fl. North Am. I (2). 370; Flück. Pharmacogn. 647.

Wermut, Wermte, Wurmkraut, Else, Grabekraut, bitterer Beifuss; französisch: Absinthe commune, grande absinthe; englisch: Wormwood. 
Die Keimpflanze erzeugt im ersten Jahre eine Grundrosette von spiral gestellten zahlreichen Blättern und gelangt erst im zweiten Jahre zur Blithe. Während der Bliithenspross sich entwickelt, bilden sich aus den Azhseln der Grundblätter mchrere nene Rosetten, welche wiederum im nächsten Jahre blühen; diese werden durch eine kräftige Pfahlwurzel aneinander gefesselt und es entsteht der Körper, den man früher eine vielköpfige Wurzel nannte.

Die Wurzel ist 15-20 em lang und dariber, bis kleinfingerdick, mit vielen Seitenwurzeln versehen, anssen blassbraun, innen weiss.

Die Blätter der Grundrosette sind sehr langgestielt, am Grunde seheidig die Axe umfassend, dreifach fiedertheilig, mit schmallanzettlichen, spitzen Zipfeln, sie sind seidenhaarig besonders auf der Rückseite, weissgrau.

Der Stengel ist aufrecht, gerade oder wenig gekrümmt, unten einfach, oben rispig, am Grunde verholzend, fast stielrund, längsgestreift, unten mattgrau, oben silbergran-seidig behaart, $0,30-1,30 \mathrm{~cm}$ hoch, an der Basis 3-6 mm im Durchmesser; die Stengelblätter sind kurz gestielt oder sitzend, doppelt, dann einfach fiedertheilig, die oberen einfach; die kleineren Fiederabschnitte sind spitz, die grösseren stumpf, sonst von der Natur der Grundblätter. Nach der Fruchtreife stirbt der Stengel bis anf den Grund ab.

Der Blüthenstand ist eine mehr oder weniger zusammengezogene Rispe. Die Blüthenköpfehen stehen an den Ästen I. oder II. Ordnung traubig oder fast ährenförmig; sie sind halbkuglig, übergeneigt oder nickend, fast einseitswendig, meist einzeln in der Achsel eines lanzettlichen oder spathelförmigen Deckblattes; sie haben 3-4 mm im Durchmesser; die Stiele sind so lang wie das Köpfehen oder ktirzer, mit meist zwei transversal gestellten Stiltzblättehen.

Der Hüllkeleh ist glockenförmig; die Blättchen sind dachziegelig deckend, die äusseren lanzettförmig, spitz, am Rande trockenhäutig durchscheinend, die inneren oblong, stumpf, seidig behaart.

Der gemeinschaftliche Blüthenboden ist halbkugelig, mit zahlreichen weissen Spreuhaaren bedeckt, die etwas kürzer als der Hüllkelch sind.

Die wenig zahlreichen Randbluthen sind weiblich; der Pappus fehlt; die Blnmenkrone ist röhrenförmig; dïnn, kurz ungleich zweispaltig, der Saum ist aufrecht; der Griffel ist fadenförmig, am Grunde verdickt, ohne Nektar absondernden Ring. Die Narbensehenkel sind hervorragend, schwach keulenförmig verdickt, stumpf, wenig spreizend.

Die Scheibenblüthen sind zwittrig, zahlreich, keulenförmig-glockig, mit kurzem, fünflappigem, zurückgekrtimmtem Saume, kaum $2 \mathrm{~mm}$ lang, mit sehr kleinen Drilschen hier und da aussen bestrent; der Fruchtknoten ist $0,7 \mathrm{~mm}$ lang. Die Staubgefässe sind am unteren Viertel der Blumenkrone angewachsen; die Bentel sind zu einer $0,8 \mathrm{~mm}$ langen Röhre verklebt, mit dreieckigem spitzem Anhängsel am Ende, am Grunde sind sie stumpf; Pollenkörner ellipsoidiseh, glatt mit 3 längsverlaufenden Furchen und 3 Poren. Der Griffel ist fadenförmig, wenig die Staubgefässe iiberragend; die Narbenschenkel sind breit, am Ende gestutzt, mit einem Barte von Fegeharen besetzt, oben am Rande auf der Innenseite sind sie papillös, zuletzt zurickgekriimmt; der Nektar ansscheidende Ring an der Basis des Griffels feblt: die Pollenibertragung gesehieht durch den Wind.

Die F r u c h t ist schmal, umgekehrt eiförmig, blassbraun, etwas glänzend, schwach gestreift, oben mit einer kleinen, kreisförmigen, flachen Scheibe abgeschlossen, ohme Pappus kaum $1 \mathrm{~mm}$ lang, 0,3 mm im Durchmesser.

Der Same füllt die Fruchtschale aus; das Würzelchen ist kiirzer als die planeonvexen Keimblätter.

Gegenwärtig hat der Wermut eine sehr weite Verbreitung in Dentsehland und den iibrigen Mittel-Europa, wie in Sud-Europa; in Süd-Russland ist er hänfig und gelt von hier tiber Persien bis nach Afghanistan und Kasehmir; anch in Nord-Afrika wird er noch angetroffen. In Nord-Amerika findet er sich an der Hudsons-Bay und von Neu-Fundland bis in die nördlichen vereinigten Staaten verwildert. Es ist zweifelhaft, ob er in Deutsehland urspriinglich heimisch war; er macht viclmehr den Eindruck, als ob er, der schon seit alten Zeiten kultivirt wurde, uberall nur verwildert auftritt.

Medicinische Verwendung finden die im Spätsommer gesammelten und getrockneten blithenden Zweigspitzen und Blätter der Pflanze als Merba Absinthii oder Summitates Absinthii. Die beste Droge lieferm 
die wildwachsenden Pflanzen. Grosse Mengen der Droge finden Verwendung zur Darstellung von Wermutbranntwein, welcher vorzigglich in Frankreich ein beliebtes Genussmittel ist, und zur Darstellung des ätherischen Wermutöls.

\section{Erklärung: der Figuren.}

Fig. A, Ein Blatt der Grundrosette, natiirliehe Grösse.

Fig. B. Eine Spitze des blïhenden Stengels, natiirl. Grösse.

Fig. C. Ein Bliithenköpfehen, $5 \mathrm{mal}$ vergrössert.

Fig. D. Dasselbe, im Längssehnitte, 7 mal vergrössert: $a$. gemeinsehaftlicher Blitthenboden; $b$. der daehige Hïllkeleh; $c$. weibliehe Randblïthen; $d$. zwittrige Seheibenblithen.

Fig. E. Dasselbe, die Blüthen entfernt, um die Ilaare des Bliithenbodens zu zeigen.

Fig. $F$. Randbliithe, 15 mal vergrössert.

Fig. $G$. Seheibenblithe, 15 mal vergrössert.

Fig. H. Letztere im Längssehnitte : $e$. Fruchtkuoten; $f$. Blu- menkrone; $h$. Staubbeutel; $i$. Anhängsel derselben; k. Griffel; $l$. Narben; $m$. Samenanlage.

Fig. I. Staubgefüssröhre, 20 mal vergrössert: $g$. Staubfüiden. Fig. $K$. Staubgefïss von innen gesehen, 30 mal vergrüssert. Fig. $L$ u. M. Pollenkörner, troeken und in Wasser, $300 \mathrm{mal}$ vergrössert.

Fig. N. Spitze des Griffels und die Narben, 40mal vergrüssert. Fig. $O$. Frueht, natürliehe Grösse.

Fig. $P$. Frueht, 10 mal vergrössert.

Fig. Q. Dieselbe im Lïngssehnitte: $n$. Fruehtsehale; $\boldsymbol{o}$. Wïrzelelien; $p$. Keimblätter.

Fig. R. Dieselbe im Querschnitte.

\section{Artemisia maritima I. var. Stechmamniana Bess.}

\section{'Tafel 4.}

Halbstranehig, Äste aufreeht, gerade oder sanft gebogen, vollkommen kahl, oberhall der Mitte reichlich rispig verzweigt, Köpfehen tragende $\ddot{A}$ ste anfrecht, ruthenförmig; Laubblätter zur Blüthezeit nicht vorhanden, Deckblätter der Blüthenköpfehen einfach, kurz, breit linealiseh, stumpf, etwas fleisehig, auf dem Riicken von 2 Furehen durehzogen, kahl; Blithenköpfehen sitzend oder kurz gestielt, einzeln, seltener gepaart, oblong, an der Basis verschmälert, trocken etwas kantig; Schujpen des Hüllkelehes eiförmig bis linealisch, gekielt, die inneren am Rande häutig, auf der Ritekseite nahe am Mittelnerv drüsig, Blithen 3-5.

Artemisia maritima L. var. Stechmanniana Bess. in Bull. de la Soc. impér. des natur. de Moscou VII. 31 (1531); Flïkig. et Hanb. Pharmacogn. 316; Flïck. Pharmacogn. 777, in Arch. der Pharmacognosie $1556, p .1$.

Artemisia maritima L. var. pauciflora Led. Fl. Ross. II. 571 .

Artemisia pauciftora Web. in Stechm. Artem. 26; DC. Prodr. VI. 102; Bentl. and Trimen, Mcd. pl.t. 157.

Artemisia Cina Berg in Berg u. Schmidt, Darst. u. Bescler. off. Gew. $t$. XXIX ${ }^{c}$. L-N., nicht Willkomm; Köhler, Mediz. Pfl. $t$. 48.

Die Wurzel ist holzig bis $1 \mathrm{~cm}$ dick, mit fasriger, brauner Rinde bedeckt; aus ihr erheben sich eine grössere Zahl (\$-12) holziger, stielrunder oder etwas kantiger, 1-2,5 mm dieker Stengel, die zuerst mit glatter, glänzender, rothbrauner Rinde bedeckt sind, welehe durch den unter derselben sich entwickelnden Kork gesprengt und streifenweise abgeworfen wird. Die älteren Stengel messen 2,5-6 mm im Durehmesser, sie sind von Farbe graugelb; aus ihnen brechen neue Triebe hervor, welche durch gelbe skariöse Blattscheiden am Grunde eingehüllt sind.

Die Blätter sind, wie aus den wenigen stehen bleibenden Resten gesehlossen werden kann, kaum ubber $2 \mathrm{~cm}$ lang; sie sind etwa $1 \mathrm{~cm}$ lang gestielt und haben am Grunde eine fast die Hälfte des Stengelumfanges umgreifende, gelbe, skariöse Scheide; die Spreite ist fiedertheilig, nur die untersten Fiederabschnitte sind noehmals getheilt, Zipfel linealiseh, stumpf, kurz, wenigstens in jugendlichem Zustande pulverig-grauhaarig. Zur Blithezeit sind die Fiedern abgefallen, die Mittelrippen bleiben aber stehen und bilden eine Ait weiehstachliger Bewehrung.

Der Blüthenstand ist eine zusammengezogene Rispe von 12-15 cm Länge; die Äste der Verzweigungen letzten Grades sind sehr dünn, sie messen kaum 0,2 mm im Durchmesser und sind wie die stärkeren Äste völlig kahl. Die Deckblätter sind vollkommen einfach, 1-2 mm lang und kaum $0,3 \mathrm{~mm}$ breit. 
Die Bluthenköpfehen sind aufrecht, zur Bliithezeit etwa $4 \mathrm{~mm}$ lang: und haben einen Durchmesser von $1 \mathrm{~mm}$ oder wenig darüber; zuweilen sind sie völlig sitzend, öfters aber werden sie von einem 1-2 mm langen Stielehen gestiitat; im trocknen Zustande sind sie ein wenig kantig, anfgeweicht sind sie stielrund.

Der Hullkelch besteht ans 12-17 Blättchen, von denen die untersten breit elliptiseh, kaum $0,6 \mathrm{~mm}$ lang und etwas dick sind, die oberen linealisch-oblong, stumpf, am Rande weiss-häutig, werden in der Mitte von einem kräftig vorspringenden, bräunlichgrïnen Kiele durchzogen, die grössten sind von der Länge des Köpfehens. Die Driisen, welehe den Kiel beiderseits begleiten, sind gelb.

Die 3-5 Blïthen ïberragen kaum den Hiillkeleh, sie sind sämmtlich gleich gebaut und zwittrig.

Der gemeinsehaftliche Blithenboden ist flach und kahl; der Fruchtknoten ist ungefähr $1 \mathrm{~mm}$ lang, umgekehrt kegelförmig, von den Seiten her ein wenig znsammengedriickt, gelblieh, völlig kahl, etwas glänzend; der Pappus ist nur in der Form eines änsserst schwachen, schief anfgesetzten Ringes wahrzunehmen.

Die Blumenkrone ist $2 \mathrm{~mm}$ lang und sitzt dem Frueltknoten schief anf, sie ist sehwach kenlenförmig, kurz fünflappig, mit anfrechten, spitzen Lappen, aussen ist sie im unteren Theile der Röhre drisig bekleidet, sonst ist sie kahl.

Die Staubgefässe sind unterhalb der Mitte der Blumenkrone eingefingt; die Stanbbeutel sind doppelt so lang als die Fäden und tragen am oberen Ende spitze, dreiseitige Anhängsel; der Pollen ist stumpf tetraëdrisch, glatt.

Der Stempel ist $2 \mathrm{~mm}$ lang, stielrund und kaum im ersten Viertel gespalten, die Narben sind an der Spitze gestutzt und bärtig, der Nektarkragen ist undentlich.

Die Frucht ist von der Seite zusammengedrïekt, eifürmig, 1,0-1,2 mm lang und $0,5-0,7 \mathrm{~mm}$ breit, an der Spitze etwas schief gestutzt, am Grunde spitz, von Farbe gelb, mit sehr feinen Längsstreifen geziert.

Die Pflanze wäehst in grossen Mengen in Turkestan zwisehen Tasehkent und Tsehimkent.

Anmerkung. Diejenige Pflanze, welche die Flores Cinae liefert und die wir nach Exemplaren aus Tsehimkent, sowie ans Taschkent untersuchen konnten, stimmt mit der Besser'schen $A$. maritima L. var. Stechmanniama nicht ganz iiberein, namentlich weicht sie durch höheren, krïftigeren Wuchs, dureh völlige Kahlheit der Bliithen und Inflorescenzen, sowie durch eine geringere Zahl von Blïttern des Hiillkelches ab. Es würde sich vielleicht empfehlen, die turkestanische Pflanze nnter dem Namen A. Cina Berg als eigne Art, von A. maritima L. zu unterseheiden.

Wir wollen noch darauf aufmerksam machen, dass Besser zwei Pflanzen mit dem Namen Stechmanniana belegt hat. Neben der oben besprochenen existirt cine Artemisia Stechmanniana Bess., welehe in die Section Abrotana gehört, und die mit $A$, chamaemelifolia Vill., einer Pflanze aus dem Kaukasus und der Dauphiné, zusammenfällt. Die von Willkomm (Botanisehe Zeitnng 1872. p. 130) als $A$. Cina bezeichnete Pflanze stimmt bezïglich der Köpfehen und der Form der Blïtter mit unserer Pflanze nicht überein.

Officinell sind als Flores Cimae die getroekneten, nieht völlig entwiekelten Blit thenköpfehen, deren Hiillkelch noeh gesehlossen ist. Gut gereinigte Droge besteht fast allein aus solehen ungeöffneten Blüthenköpfchen versehiedenen Alters, welehen nur wenige Deckblätter der Blithenköpfehen und Achsenstiickehen der floralen Region beigemengt sind. Die Droge wird dureh die Kirgisen von Mitte Juli bis Ende August eingesammelt. Aus der Pflanze wird ferner das Santonin fabrikmässig dargestellt, welches in den Blithenköpfehen enthalten ist.

\section{Erklürung der Abbildungen.}

Fig. A. Ganze Pflanze aus Taschkent, mitgetheilt durch Herrn Prof. von Maximowicz in St. Petersburg.

Fig. B. Zweig einer Pilanze, jugendliches Stadium, mitgetheilt von Herrn Knapp in T'sehimkent.

Fig. C. Ein Blïthenköpfchen, 6 val vergrössert.

Fig. D. Dasselbe in Längssehnitte.
Fig. E. Blïttehen des Hïllkelehes.

Fig. $F$. Bliuthe, 20 mal vergrössert.

Fig. $a$. Diesclbe im Lïngsschnitte.

Fig. $H$. Zwei Staubgefisse von innen gesehen, $25 \mathrm{mal}$ verฉтössert.

Fig. I. Griffel mit Narbe, $25 \mathrm{mal}$ vergrössert. 


\section{TUSSIIAGO Tournef.}

Bliithenköpfehen heterogam, strahlend; Strahlenbliithen viele, mehrreihig, weiblich; Mittelbliithen männlich, viele. Gemeinschaftlicher Hiillkeleh glockenförmig oder cylindrisch, Blïttchen einreihig, gleich, aussen einige verkïrzte Schuppen. Gemeinschaftlicher Bliithenboden flach, nackt. Strahlenbluthen weiblich, zungenförmig, ganzrandig, schmal. Scheibenblüthen regelmässig, röhrenförmig, fünfzühnig; Staubbentel am Grunde stumpf; Griffel am Ende eylindriseh verdickt, mit zwei sehr kurzen, dicken Narben. Frïchte linealisch, schwach fünf- bis zehnrippig, Pappus borstenförmig, Borsten dümn, schärflich, mehrreihig. - Ein Kraut mit unterirdischem Rhizome; Blätter zu einer besonderen Grundrosette dicht spiral zusammengestellt, herzförmig, eckig. Blüthenköpfehen einzeln auf verlängerten beschuppten Stielen, gelb.

Eine Art in der nördlichen gemässigten Zone der alten Welt verbreitet.

\section{Tussilago Farfara L.}

\section{'Tafel 5 .}

Blïtter herzförmig, spitz, eckig geschweift, unterscits weissfilzig; Blïthenköpfehen vor den Blättern, Blithenstiele spinnwebig wollig, mit krautigen Schuppen bedeckt.

Tussitago Farfara Linn. Spee.pl. ed.I. S65; Fl. Daniea IV. t. 595; Allione, Fl. Pedem. I. 176; Plenek, Icon.629; Gürtu. Carp. II. 147. t. 179. Fig. 6; Woodv. Hed. I. 18; Curt. Fl. Lond. III. t. 6; Sowerb. Engl. Bot. VI. t. 429; Baxt. Br. Bot. II. t. 91; Drev. Bot. Bild. II. 49; Sturm, Deutschl. Fl. I. t. 2; Schkuhr, Handb. t. 212; Lam. Eneyel.t.67t; Schrank, Fl. Monac. IV. 318; Nees, Düsseld. Pfl. t. 235, Gen. pl. X. t. 10; Ilayne, Abbild. II. t. 16; Guimp. u. Schlecht. t. 25; Wugner, Pharm.-med. Bot. t. 11 u. 72; Dietr. Fl. Boruss. VIII. t. 514; Rchb. Fl. Germ. XVI. t. 904; DC. Prodr. V. 205; Kth. Offiz. Gew.

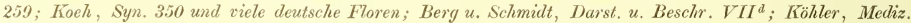
Pfl. t. 6; Bertero, Fl. Ital. IX. 203; Godr. et Gren. Fl. de Fr. II. 21; Ledeb. F7. Ross. II. 470; Willk. et Lange, Fl. Hisp. II. 29; IIook. Fl. Br. Ind. III. 330; Boiss. Fl. or. III. 377; Asa Gr. Syn. Fl. NorthAm. I (2). 375; Fliek. Pharmacogn. 604.

Huflattich, Ackerlattieh, Brustlattich, Eselslattich, Eselshuf, Rosshuf, Olmblätter, Quirinshraut, Mürzblume; französisch: Tussilage; englisch : Colt's foot, horse foot, horse shoe.

Das unterirdische, kriechende Rhizom ist von schmutzig gelbbranner bis violetter Farbe, es hat einen Durchmesser von 4-6 $\mathrm{mm}$ und ist mit abwechselnd stehenden Zweigen und Auslüufern, die letzteren von blasser Farbe, versehen. Jeder Läufer endet nach einigen Schuppenblättern mit einer Laubknospe, welche eine Blattrosette darstellt. Die letztere treibt, nachdem der Stock abgeblliht hat oder gegen die letzte Zeit der Blïthe aus und entwickelt 5-8 Laubblätter, um schliesslich in einem Köpfehen, das für das nüchste Vegetationsjahr bestimmt ist, zu enden. Dieses scheint sich abcr selten zu entwickeln, meist ist der Gipfel der Blattrosette abgestorben. Dafür brechen aber aus den Achseln der Laub- und der vorausgehenden Niederblätter zahlreiche einfache oder verzweigte Bltithentriebe hervor, welche die bisschelige Vereinigung der Blüthenstände erklären. Das Rhizom wird dureh zahlreiche, besonders aus der Unterseite, hier und da aber auch aus den Flanken und der Oberseite hervorbrechende, einfache, fadenförmige Wurzeln am Boden befestigt.

Die Laubtriebe sind gestaucht, aufsteigend und tragen 5-7 Blätter. Die Blätter sind langgestielt, herzförmig, spitz mit stumpfer Grundbucht, mehr oder weniger eckig, ausgeschweift, in den Buchten gezähnt, in voller Entwicklung nach der Blithe 12-15, selten bis $19 \mathrm{~cm}$ lang und im unteren Drittel oder Viertel ebenso breit, handnervig, oberhalb saftiggriin mit violetten Adern, unterhalb dicht weiss-filzig. Der Blattstiel ist gewöhnlich von der Länge des Blattes, zuweilen länger, zuweilen kürzer.

Die Blüthenköpfchen kommen aus den Blattachseln eines vorjährigen Laubtriebes und stehen $\mathrm{zu}$ mehreren (4-20) beisammen; sie erscheinen vor den Blättern, sind aufsteigend, einfach, stielrund, auf der ganzen Länge mit linealen oder oblongen, spitzen oder zugespitzten, grinen, am Rande und an der Spitze 
rothbraunen Schuppen bedeckt; zuerst sind sie 6-10 $\mathrm{cm}$ hoch, nach der Blithezeit bis 20, selten bis $30 \mathrm{~cm}$ verlängert, sie sind spinnwebig behart und graulichgrïn; die Köpfchen sind nur im Somnenseheine geöffnet, von Farbe gelb, $2 \mathrm{~cm}$ im Durchmesser, nach Honig duftend; nach der Bliithe sind sie nickend, zur Fruchtzeit wieder aufrecht. Der gemeinschaftliche Blïthenboden ist nackt. Der Hüllkelch ist walzigrund, unterhalb der Spitze etwas eingezogen, am Grunde ein wenig kantig, 1,0-1,4 cm lang, in der Mitte von $1 \mathrm{~cm}$ Durchmesser, griin. Die Blättchen stehen einreihig, sie sind linealisch, spitz oder stumpflich, am Rande byalin, an der Spitze mit einem rothen Flecke, anfrecht, später zuriickgesehlagen, am Grunde von einzelnen kleineren Schtippehen begleitet.

Die Strahlenblüthen sind zahlreich, mehrreihig, zungenförmig, weiblich 1,4-1,6 cm lang. Der Fruchtknoten ist schmal eylindriseh, an der Basis verjünt, 1,5 mm lang; der Pappus ist so lang wie die Corollenröhre und wird aus aufrechten, starren, feingesägten, schärflichen, einfachen, mehrreihigen Haaren zusammengesetzt. Die Blumenkrone ist zungenförmig, ganzrandig, der Saum ist sehr schmal, länger als die sehr dünne, $5 \mathrm{~mm}$ lange, an der Mündung mit einigen kuzen Härchen besetzte Röhre. Der Griffel ist fadenförmig, mit zwei kurzen, stumpflichen Narbenschenkeln. Die Scheibenbliithen, 20 an Zahl und mehr, sind dem Anseheine nach zwittrig, die Samenanlage ist aber stets verkïmmert und die Narbe nicht empfängnissfähig. Die Blumenkrone ist röhrenförmig, oben glockig, mit tief fïnfspaltigem Saume, die Zipfel sind zurïckgekrïmmt. Staubgefässe sind 5 vorhanden, sie sind unterhalb des Beutels gegliedert, die Beutel sind zu einer $2 \mathrm{~mm}$ langen Röhre verklebt. Staubbeutel an der Basis stumpf, oben mit einem kurzen, linealen, spitzen, endlich stumpfen Anhängsel versehen. Der Pollen ist kugelig, bestachelt, mit 3 oder 4 Poren. Der Griffel ist fadenförmig, am Grunde mit einem gelb durch die Röhre schimmernden, Honig absondernden Kragen, oben ist er zu einem eylindrischen Körper verdickt, der an den Seiten, besonders aber am oberen Rande, mit Fegehaaren reichlich bedeckt ist, welche den Pollen aus den Staubbeuteln biirsten; an der Spitze befinden sich 2 kurze, derbe Narbensehenkel, auf denen das ausgefegte Pollenhäufchen liegt. Die Frucht ist walzigrund, wenig gebogen, schwach fünfrippig, röthlich-gelb, 3-4 mm lang und hat fast $1 \mathrm{~mm}$ Durehmesser; der Pappus ist zweimal lïnger, weiss, brtichig.

Der Same ist meist nur $1 / 6$ kïrzer als die Frucht; die Samenhaut ist sehr dünn.

Der Huflattich wächst auf Thon- oder Kalkboden an Wegrändern, auf Schutthalden, an Eisenbahndämmen; er findet sich durch ganz Europa, dringt bis zum nördlichen Eismeere vor und steigt in den Alpen bis zu den Gletscherrändern empor; im siidlichen Europa ist er nur auf den Gebirgen vorhanden; von Russland ist seine Verbreitung ïber den Ural nach Sibirien, Transkaukasien und Armenien zu verfolgen. Er wächst ferner auf dem Libanon, den west- und südpersisehen Bergen und erreicht die Ostgrenze im westlichen Himalaya.

Anmerkung. Der Name der Pflanze findet sich bei Plinius, aber nur als Masculinum farfarus bei Plantus farferus); daher hat A scherson vorgesehlagen, den Linnéschen in Tussilago Farfarus abzu:indern.

Medicinische Verwendung finden nur die getrockncten Laubblitter als Folia Farfarae oder Huflattigblätter. Man sammelt die Blïtter im Juni oder Juli.

\section{Erklärung der Abbildnngen.}

Fig. A. Eine blühende Pflanze, natuirliche Grösse: $a$. Blatttrieb; $b$. Blithentriebe.

Fig. B. Ein Blithenköpfehen im Längsschnitte, doppelt vergrössert: $a$. gemeinschaftlicher Blithenboden; $b$. Hïllkelch; $e$. Strahlenbliithen; $d$. Scheibenblithen.

Fig. C. Eine Strahlenbliithe, 3 mal vergröss.: $a$. Fruchtknoten; $b$. Pappus; $c$. zungenförmige Blumenkrone; $d$. Griffel.

Fig. D. Oberer Theil des Griffels, 20 mal vergrüssert.

Fig. $E$ Eine Scheibenblïthe, $4 \mathrm{mal}$ vergrössert: $a$. Frnehtknoten; $b$. Pappus; $e$. röhrenförmige Blumenkrone; d. Staubbeutelröhre.

Fig. $F$. Die Staubbeutelröhre, 8 mal vergrössert.

Fig. G. Dieselbe aufgeschnitten und ausgebreitet, von innen gesehen.
Fig. $H$. Ein Staubgefäiss.

Fig. I. Pollenkörner, das obere trocken, die unteren in Wasser, 300 mal vergrössert.

Fig. $K$. Der Stempel der Scheibenblithe und der Pappus, $10 \mathrm{mal}$ vergrössert: $a$. Frnchiknoten; $b$. Griffel; c. die keulenförmige Endigung mit den zusammenneigenden Narben.

Fig. L. Dic Frucht, natïrliche Grösse.

Fig. $M$. Dieselbe, $10 \mathrm{mal}$ vergrössert.

Fig. $N$, Diesclbe im Läingsschnitte : $a$. Wiirzelchen; $b$. Keimblïtter.

Fig. O, P. Dieselbe im Qnerselnitte.

Fig. $Q$. Der Keimling, $10 \mathrm{mal}$ vergrössert. 


\section{$-14$}

\section{ARNICA Linn.}

Bliithenköpfehen heterogam, strahlend; Strahlenblïthen weiblich, einreihig, Mittelbliithen zwittrig, sehr viele. Gemeinschaftlicher Hïllkeleh kegel- oder glockenförmig, meist aus $1-2$ Reihen Blättchen zusammengesetzt; gemeinsehaftlicher Blüthenboden flach, meist behart. Randblithen zungenförmig, spitz, oder zwei- bis dreizähnig: Mittelblithen rölırenförmig oder schwach keulig, kurz fünfspaltig. Antheren am Grunde stumpf, an der Spitze nit dreiseitigem Anhängsel. Narbensehenkel der Zwitterbliithen verlängert mit gerundetem oder spitzlichem Anhängsel. Früchte kurzhaarig, linealisch, ziemlich flach oder drehrund oder fünfkantig, zuweilen mit 5-10 melı oder weniger deutlichen Rippen. Pappus borstenförmig, Borsten einreihig, starr, schärflich. - Ausdauernde Kräuter mit einfachen oder wenig verzweigten Stengeln. Bliitter zu einer Grundrosette zusammengedrüngt, wie die wenig zahlreiehen Stengelblätter kreuz-gegenständig (decussirt). Bliithenköpfehen langgestielt, einzeln, gross, gell).

Ungefähr 10 Arten in den nördlichen Theilen und den Gebirgen von Europa, Asien und Amerika.

\section{Arnica montana I.}

Tafel 6.

Grundblätter oblong oder oblong-lanzettlich, stumpf oder spitz, ganzrandig oder am Grunde sehr fein gesägt, sitzend oder gestielt, unterseits kahl, oberseits spärlich behaart. Blüthenköpfehen langgestielt, von 2 linealen Stiitzblättehen begleitet, gross; ILüllkeleh drüisig-zottig.

Arnica montana L. Spec, pl. ed. I. S54; Oed. 17. Dan. I. t. 63; Allione, I7. Ped. I. 204; Gürtn. Carp. II. t. 173; Drev. IV. t. 107; Plenck, Off. 623; Palmstr. Siensk Bot. 15.5; Schkulh, Handl. 24S; Sturm, Fl. Deutschl. IX. t. 34; Sehrank, Fl. Mon. II. 15S; Bot. Mag. t. 1749; Hayne, Arzn. VI. t. 47; Nees, Diisseld. Pfl. t. 237; Guimp. u. Sehleeht. I. t. 1; Woodv. Hed. I. t. 17; Kth. Off. 274; Dietr. Fl. Boruss. IX. G0S; DC. Prodr. VI. 317; Steph, and Chureh. Med.pl. t. 123; Berg u. Schmidt, Darst. u Besehr. XIII ${ }^{\text {; }}$ Bentl. and Trim, t. 155; Köhler, Mediz. Pf. t. 12; Koeh, Syn. 352 u. viele and. deutsche Floren; Bertero; F7. Ital. IX. 299; Godr. et Gren. F7. de Fr. II. 110; Ledeb. F7. Ross. II. 622; Willk. et Lange, F7. Tlisp. II. 110; Flüek, and Hanb. Plarmacogr. 349; Flïck. Pharmacogn. 775.

Doronieum oppositifolizem Lam. Dict. II. 312.

Doronicum Arnica Desf. Cat. hort. Paris. 101.

Cineraria cernua Thore, Chlor. Land. 344. t. 336.

Arnika, Bluttrieb, Fallkraut, Johannisblume, Stiehkraut, Wolferlei; engliseh und französiseh: Arnica.

Das horizontale oder ein wenig schief absteigende Rhizom ist bis $10 \mathrm{~cm}$ lang, gewöhnlich $6-8 \mathrm{~mm}$, selten bis $1 \mathrm{~cm}$ dick, grïnlich- oder gelblichbraun, innen weiss; an den stengelumfassenden Blattnarben bemerkt man die Reste von verrotteten Blattscheiden. Aus den Achseln der letzten Blätter entwickeln sich im Laufe des Sommers einzelne Knospen, welehe die Pflanze ziemlich reichlich auf regetativem Wege vermehren. Die Wurzeln treten hauptsächlich aus der unteren Seite und den unteren Flanken des Rhizoms, sie sind fadenförmig, weisslich, einfach, $1-2 \mathrm{~mm}$ dick.

Der Stengel ist 30-45, seltener bis $65 \mathrm{em}$ hoch und hat am Grunde einen Durchmesser von 4 bis $8 \mathrm{~mm}$; er ist aufreeht, gestreift, grïn, krautig, besonders oben dieht mit kurzen, röthlichen, secernirenden Köpfchenhaaren (Drüsen) bedeckt; er ist einfach, gewöhnlich aber verzweigt, die Seitenäste erreichen die Länge der Hauptaxe, seltener überragen sie dieselbe.

Die Blätter stehen kreuz-gegenständig (decussirt). Die untersten 2-3 Paare sind dicht gedrängt oder nur wenig von einander abgerïekt und bilden eine Grundrosette, aus deren Mitte sich der Stengel erhebt. An ihm befinden sich noeh 1-2 Paar Laubblätter, dann wird er dureh ein Köpfehen abgeschlossen, nachdem zwei abwechselnde, viel kleinere Stitzblätter vorausgegangen sind. Aus den Achseln der oberen, zuweilen aweh der unteren Laubblätter treten Seitenzweige, die meist in ein einzelnes Köpfehen ausgehen, 
die ebenfalls mit 2 Stiitz-(Vor-)Blättehen in transversaler Stellung zum Tragblatte versehen sind; seltener erzengen auch diese Zweige noch einen Seitenstrahl zweiter Ordnung.

Die Grundblätter sind gewöhnlieh 8-10 em lang nnd etwas über der Mitte 2-4 cm breit, seltener sind sie bis $20 \mathrm{~cm}$ lang und $7 \mathrm{~cm}$ breit, sie sind kurz gestielt oder sitzend, mit scheidiger Basis den Stengel umfassend und am Grunde mit einander verwachsen, oblong oder lanzettförmig, spitz oder stumpf, am Grunde verschmälert, ganzrandig oder nahe der Basis sehr sehwach gesägt, sehr kurz gewimpert, von 5-7 fast parallelen Nerven, die unterhalb der Mitte in den Hauptnerven einlaufen, durelizogen, oben sattgrïn mit kurzen Drüsen und längeren einfachen Haaren besetzt, unten fast meergrün und kahl.

Die Stengelblätter sind von der Natur jener, nur kleiner, von 3 Nerven durehzogen. Die Stittzblättehen sind linealisch, zugespitzt, $1-2,5 \mathrm{~cm}$ lang, $3-5 \mathrm{~mm}$ breit, einnervig.

Die Blüthenköpfehen sind strahlend, aufrecht, endständig und haben $5-7 \mathrm{~cm}$ im Durehmesser. Der Hüllkeleh ist zweireihig, glockenförmig, aus 20-25 gleiehlangen, lineal-lanzettliehen, spitzen, am Rande und an der Spitze braunrothen, sonst grïnen, 10-12, später bis $14 \mathrm{~mm}$ langen, 2-4 mm breiten Blättchen zusammengesetzt und ist mit längeren einfachen, weisslichen Haaren und mit braunrothen Köpfehenhaaren dicht bekleidet. Der gemeinschaftliche Blüthenboden ist flach, ein wenig wabig vertieft, dicht mit kurzen, weissen Haaren bedeckt.

Die Strahlenbliithen sind weiblich, gewöhnlich finden sich 12-17; der Fruehtknoten ist $6 \mathrm{~mm}$ lang und $1 \mathrm{~mm}$ breit, linealiseh, am Grunde versehmälert, im Quersehnitte elliptiseh, mit kurzen angedrückten Haaren reichlich besetzt, nur an der eingedrïckten Basis ist er kahl, von Farbe dunkelbraun. Der Pappus wird aus einreihigen, steifen, fein gezähnelten, daher sehärfliehen, gelblichweissen, briichigen Haaren aufgebaut, er ist so lang wie die Blumenkronenröhre. Die Blumenkrone ist zungenförmig, 3 bis 3,5 em lang und 5-6 mm breit; die Zunge ist linealisch, oben etwas versehmälert, dreizähnig, neunbis zwölfnervig, die Röhre ist $6 \mathrm{~mm}$ lang, von der Breite des Frnehtknotens, blassgelb, behaart. Staubgefässe sind stets als fadenförmige, an der Spitze oft etwas kolbig verdickte, $2-3 \mathrm{~mm}$ lange Gebilde entwickelt*). Der Griffel ist fadenförmig; an dem Grunde von einem kurzen Nektarkragen umgeben, er ïberragt die Röhre; die Narbensehenkel sind naeh aussen gebogen, dann zurüekgekrïmmt, sie sind stumpf und haben auf der Innenfläehe eine Längsfurehe.

Scheibenblüthen sind über 50 vorhanden, sie sind zwittrig, 1,5 cm lang. Der Fruchtknoten und Pappus wie bei den Strahlenblithen. Die Blumenkrone ist keulig-röhrenförmig, mit kurzem, fünfspaltigem, zurüekgekrümmtem Saume, die Lappen sind etwas fleischig, an der Spitze dieht papillös; die Röhre ist bis zur Mitte behaart, blassgelb, oben goldgelb. Die Staubgefässe sind in der Mitte der Röhre angewaehsen und die Bentel zu einer $6 \mathrm{~mm}$ langen Röhre verklebt; die letzteren sind am Grunde stumpf, an der Spitze tragen sie ein dreieekiges, spitzes Anhängsel, erst sind sie gelb, dann brännlich. Der Pollen ist kugelig, bestachelt, dreiporig. Der Griffel ist fadenförmig, die Narbensehenkel sind zuerst aneinander gelegt und bilden so eine kopfige, mit Fegehaaren besetzte Endigung, später werden sie zurülekgerollt, sie sind auf der Innenfliche papillös.

Die Frueht ist linealiseh, von den Seiten her zusammengedriekt, dunkelbratn bis schwarz, sehwach fünfrippig, mit kurzen, aufreehten Haaren besetzt, 7-9 mm lang, $1 \mathrm{~mm}$ im Durehmesser; der Pappus ist etwas länger, am Grunde zu einem Ringe verbunden; sie löst sieh von dem gewölbten, sehwach wabigen, kurzhaarigen Blithenboden, wobei in der Mitte der Waben ein fidlicher Rest des Gefässbïndels stehen bleibt.

Der Same füllt die Fruchthöhle nicht ganz aus; die Samenhaut ist dünn, weiss; das Würzelehen des Keimlings zweimal kürzer als die Keimblätter.

Die Arnika wächst auf trocknen oder etwas feuchteren, zuweilen torfigen Waldwiesen in der Ebene und auf den Gebirgen; sie steigt bis anf die höheren Matten der Alpen. Sie findet sich in Mittel- und

*) Berg gab an, dass die süddeutsehen Exemplare keine Staubgefissirudimente besäissen; ich habe dieselben an allen untersuchten Bliithen, zuweilen allerdings sehr klein und stiftförmig gesehen. Aus der Entwicklungsgesehiehte vieler Zungenblïthen geht übrigens hervor, dass die Staubgefiisse wohl immer angelegt werden; sie bleiben aber später oft so weit in der Ausbildung zuriek, dass die Rudimente nieht mehr olme mikroskopische Untersuchung nachweisbar sind. 
Süd-Skandinavien, im mittleren und siidlicheren Russland bis zum uralisehen Sibirien, dringt aber in der typisehen Form nicht weiter naeh Osten vor; in Deutschland, Dänemark, Holland, Belgien ist sie verbreitet, in Frankreich, Italien, Spanien und Portngal ist sie zerstrent.

Sie blïht im Juni und Juli.

A nmerkung. Im höehsten Norden der alten und neuen Welt wird sie vertreten von $A$, alpina Laest. (A. angustifolia Vahl.), einer wohl gut versehiedenen Art, welehe regelmïssig einküpfig und mit sehmallanzettliehen Blättern versehen ist; die Köpfe sind anfreeht und am Grunde ebenso wie die Blithenstiele am oberen Ende weiehbarig, die ganze Pflanze ist drüsenlos. Übergïnge zwisehen ihr und der typisehen Art sind mir nieht bekannt.

Von der Arnikapflanze sind alle Theile gesondert in medieinische Verwendung genommen worden. Als Radix oder Rhizoma Arnicae wird das getroeknete Rhizom mit seinen Nebenwurzeln in den Ilandel gebraeht, als Herba oder Folia Arnicae die Blätter oder aueh die letzteren und Stengeltheile zusammen. In das Arzneibneh für das Deutsehe Reieh haben nur die Blïthen, also die Röhren- und Zungenbliithen der Pflanze Aufnahme gefunden als Flores Arnicae oder Amikablitthen. Im Drogenhandel kommen die ganzen Blïthenköpfehen noch als Flores Arnicae cum ealycibus vor.

\section{Erkärung der Abbildungen.}

Fig. A.B. Die blühende Pflanze in natirlieher Grösse, naeb einem Exemplare vom Wallberge bei Tegernsee.

Fig. C. Läingsdurehsehnitt des Blumenköpfehens, von der Seite gesehen : $a$. gemeinsehaftlicher Blithenboden; b. gemeinschaftlieher Hüllkeleh; $c$. Strahlenblüthen; a. Scheibenblïthen.

Fig. D. Eine Strahlenblüthe, doppelt vergrössert: $a$. Fruehtknoten; $c$. Pappus; $d$. die zungenförmige Blumenkrone; $f$. die Narben.

Fig. E. F. Eine Seheibenbliithe und dieselbe im Lïngssehnitte, 3 mal vergrössert: $b$. Samenanlage; $d$. die röhrenförmige Blumenkrone; $e$. die röhrenförmig verbundenen Staubbeutel.

Fig. $G$. Die Stanbgefäisse der Seheibenblüthe, $6 \mathrm{mal}$ ver- grössert: $a$. die freien, oben gegliederten Staubfaiden; $b$. die verbundenen Staubbeutel.

Fig. $H$. Ein Staubgeftiss: $b$, ein nach innen zu aufspringender Staubbentel; c. das dreieekige Anbängsel.

Fig. I. Pollenkörner, $300 \mathrm{mal}$ vergrössert.

Fig. $K$. Der gemeinsehaftliehe Bliithenboden, naeh dem Abfalle der F'rïehte, nebst dem zurüekgesehlagenen Hiillkelehe, wenig vergrössert.

Fig. $L$. Die Frneht mit dem Pappus, natürliebe Grösse.

Fig. $M$. Dieselbe, 3 mal vergrössert.

Fig. $N$. Dieselbe im Quersehnitte, 6 mal vergrössert : $c$. Keimblitter.

Fig. $O$. Dieselbe im Längssehnitte; $a$. Fruehtsehale; $b$. Würzelehen; $c$. Keimblätter.

\section{CNICUS Linn.}

Köpfehen heterogam, gleiehblithig, die Blïthen des ersten Kreises unfruchtbar, die der Seheibe zwittrig, fruehtbar. Hüllkeleh ei-gloekenförmig, Blättchen wenigreihig, die äusseren blattartig, an der Spitze fiedrig-gestaehelt, die inneren schmäler mit Stachelspitze. Gemeinsehaftlicher Blithenboden flaeh, dicht borstig. Blumenkrone der gesehleehtslosen Blüthen dünn, dreispaltig, der zwittrigen oben röhrig-gloekig. Staubfäden papillös, Staubbeutel am Grunde pfeilförmig mit kurzen Sehwänzen. Griffeläste kurz, am Grunde von einem Kranze von Fegehaaren umgeben. Aehaenen oblong, fast stielrund, ein wenig gekrümmt, gestreift, mit grosser seitlicher Ansatzfläche. Pappus dreireihig, die äusseren Borsten doppelt so lang wie die inneren.

Eine Art, welehe in Sid-Europa und Nord-Afrika eine weite Verbreitnng hat.

\section{Cnicus benedictus L.}

\section{Tafel 7.}

Einjährig; Stengel aufreeht, verzweigt, fünfkantig, oben spinnwebig-filzig; Blätter oblong-lanzettlieh, buehtig-fiederspaltig, staehelspitzig, am Grunde spinnwebig-zottig; Köpfehen einzeln, endständig, von Hochblättern umhüllt. 
Cnicus benedictus Linn. Spec. pl. ed. I. \$26; Gärtn. Carpol. II. t. 162; Nees, Dilsseld. Pf. t. 223; Kth. Off. 257; DC. Prodr. VI. 606; Rchb. Fl. Germ. XV.t.745; Köhler, Mediz. Pfl.t. 29; Ledeb. Fl. Ross. II. 138; Godr. et Gren. Fl. de Fr. II. 266; Boiss. Fl. or. III. 705; Harv. et Sond. Fl. Cap. III. 609; Berg u. Schmidt, Darst. u. Beschr. $t$. XXII ; $A$. Gr. Syn. F7. North Am. I. (2.) 406; Flisch. Pharmacogn. 645.

Centaurea benedicta Linn. Spec. pl. ed. II. 1296; Plenck, Icon. t.634; Hayne, Arzneipfl. VII. t. 3t; Guimp. et Schlecht. II. t. 164; Sibth. Fl. Graec. X. t. 906; Bert. Fl. Ital. IX. 492.

Calcitrapa lanuginosa Lam. Fl. Fr. II. 35.

Carbenia benedicta Benth. et Hook. Gen. pl. II. 489.

Cardobenedictenkraut, Benedictenwurz, Bernhardinerkraut, Bitterdistel; französisch: chardon bénit; englisch: blessed thistle.

Die Pflanze ist einjährig. Aus der senkrechten, geraden oder wenig gekrümmten, einfachen, stielrunden, fasrigen, aussen bräunlichen, innen weissen, 8-15 $\mathrm{cm}$ langen, 4-7 $\mathrm{mm}$ im Durchmesser haltenden $\mathrm{P}$ fahlwurzel erhebt sich der krantige, aufrechte, selten einfache, meist kräftig verästelte, $15-40 \mathrm{~cm}$ hohe, an der Basis bis $8 \mathrm{~mm}$ dicke, gestreifte, fünfkantige, grünliche oder bräunlichrothe, unten borstige, oben drisige und ausserdem spinnwcbig behaarte Stengel.

Die Blätter sind spiral gestellt, zuerst rosettenförmig zusammengedrängt; die unteren im Anfange lanzettlich, oder linear- oder oblonglanzettlich sind spitz, am Grunde allmälig in einen dicken, dreikantigen, geflitgelten Blattstiel verschmälert, schrotsägezähnig oder fiederspaltig, $5-30 \mathrm{~cm}$ lang, 1,5-7 cm breit, am Grunde sind sie zottig, nach oben zu nimmt die Bekleidung an Dichtigkeit ab; die Sägezähne oder Fiederabschnitte stehen rechtwinklig ab, sie sind gleichschenklig dreiseitig, zuweilen etwas nach rückwärts fast sichelförmig gekrümmt, am Ende stachelspitzig, mehr oder weniger tief stachelspitzig gezähnt, auf der Unterseite sind sie von stark vortretenden Nerven netzig geadert.

Die oberen Stengelblätter nehmen an Grösse allmälig ab, sind endlich sitzend und lanfen am Stengel mit buchtig stachelspitzig gezähnten Leisten herab; allmälig gehen sie in die herzförmigen, abstehenden Hochblätter, welche am hellgrimen Grunde mit dichterer spimwebiger Bekleidung versehen sind, itber.

Die Blïthenköpfchen sind einzeln, endständig, eiförmig, kürzer als die Hochblätter, mit den letzteren $3-4 \mathrm{~cm}$ lang und haben im unteren Drittel $2 \mathrm{~cm}$ im Durchmesser.

Der Ḧ̈llkeleh wird ans vielen, dachziegelig deckenden, mehrreihigen, trockenhäutigen, gewölbten, aussen glänzenden Blättchen zusammengesetzt; die änsseren sind eiförmig und gehen in einen einfachen, langen, spitzen, am Rande spinmwebig behaarten Stachel aus, die mittleren und inneren sind eilanzettlich, bis linealisch, oben zugespitzt, von einem geknickten, nach aussen gekrïmmten, gefiederten Stachel gekrönt, der ebenfalls am Grunde spinmwebig behaart ist. Der gemeinschaftliche Bliithen boden ist flach, etwas grubig vertieft, und ist sehr dicht mit langen weissen, seidig glänzenden Haaren bedeckt.

Die Randblüthen 4-6 an Zahl sind geschlechtslos, so lang wie die Zwitterblïthen, gelb, mit dïmer, fadenförmiger Röhre und dreispaltigem Saume, die Zipfel sind linealisch, spitz. Der Pappus fehlt; Staubgefässe und Griffel sind nicht sichtbar. Der Fruchtknoten ist dünn, stielrund, ohne Samenanlage.

Die Scheibenblïthen sind zwittrig, zahlreich.

Der Fruchtknoten ist stielrund, dick, etwas gekriimmt, am Grunde auf der Innenseite mit einer stark eingedriickten Ansatzfläche versehen, er wird von 20-25 hervorspringenden Streifen durehzogen und ist kahl, weiss. Der Pappus ist dreireihig, aussen wird er aus einem zehmzähnigen Krönchen, dann aus 10 langen, steifen, schärflichen, endlich aus 10 halb so langen, inneren Borsten gebildet.

Die Blumenkronc ist röhrig, oben schlank glockig, etwas zygomorph, drcimal so lang wie die grösseren Pappusstrahlen, gelb. Die Zipfel sind dreieckig-lanzettlich, spitz.

Die 5 Staubgefässe sind am Grunde des glockenförmigen Theiles der Blumenkrone befestigt. Die Fäden sind mit sehr kleinen, gestielten Drüsen besetzt, die Beutel zn einer $5 \mathrm{~mm}$ langen, nach innen gekrimmten Röhre verklebt, am Grunde sind sie kurz geschwänzt, oben laufen sie in ein schmales, dreiseitiges, stumpfliches, gekrümmtes Anhängsel aus; der Pollen ist ellipsoidisch mit drei Längsfurchen versehen, sehr schwach gekörnt. 
Der Griffel ist fadenförmig, am Grunde mit einem Nektarkragen und unterhalb der zuerst an einanderliegenden Narben mit einem Kranz aufrechter Fegehaare versehen, die Narben sind kurz, gleichschenklig dreiseitig, planconvex, stumpflich, am Rande der Innenseite papillös.

Die Frucht ist $7 \mathrm{~mm}$ lang und hat 2-2,5 mm Durchmesser, sie ist walzig rund, schwach gekrümmt, stark gestreift, braun, am Grunde mit einer helleren, ein Drittel der Frucht umfassenden Ansatzfläche; der Pappus bleibt stehen, sein äusserer Rand ist knorplig, die äusseren Borsten sind so lang oder etwas länger als die Früchte, 3-4 mal länger als die inneren, gelb.

Der Same füllt die Fruchthöhle aus; das Würzeleben ist dreimal kürzer als die Keimblätter.

Das Benediktenkraut ist in dem europäischen Mittelmeergebiete und in Portugal verbreitet, es findet sich an steinigen, unbebauten Orten und auf wüsten Plätzen; vom südlichen Russland lässt es sich verfolgen nach Armenien, Syrien, Mesopotamien, Persien bis Afghanistan. In Amerika ist es eingeschleppt worden und kommt in den südlichen Vereinigten Staaten, in Californien, in Utah, ferner in Chile, Uruguay und Argentinien vor; auch im Caplande ist es beobachtet worden.

Es blüht im Juni, Juli.

Anmerkung. Die Pflanze wurde zuerst von Linné unter dem von uns gewïhlten Namen, dann als Centaurea benedicta beschrieben, wer Cnicus für die Gattung Cirsium verwendet, muss sie Carbenia benedicta Bth. nennen.

Man zieht von der Pflanze die jüngeren, blühenden Zweige und die Laubblätter als Herba Cardui benedicti oder Cardobenedictenkraut in Gebrauch; die Wurzeln, kräftigeren Achsen und reife Frichte dürfen in guter Droge nicht vorkommen. Die Droge, welche sich bei uns im Handel findet, stammt meist von in Deutschland cultivierten Pflanzen.

\section{Erklärung der Abbildungen.}

Fig. A. Die Spitze des blühenden Stengels, natürliche Grösse.

Fig. $B$. Ein Grundblatt, natürliche Grösse.

Fig. C. Ein Blütenköpfchen, natürliche Grösse.

Fig. D. Dasselbe im Längsschnitte: $a$. Gemeinschaftlicher Bliithenboden; $b$. äussere Reihe der Hïllkelchblätter; $c$. innere Reihe; $d$. Spreuborsten; $e$. Blüthen.

Fig. E. F. Äusseres und inneres Hillkelehblatt, $2 \mathrm{mal}$ vergrössert.

Fig. $G$. Geschlechtslose Randblüthe, 2 mal vergrössert.

Fig. $H$. Scheibenblüthe, 2 mal vergrössert : $f$. Fruchtknoten; g. Pappus; $h$. Blumenkronenröhre; $k$. Ansatzfläche des Fruchtknotens.
Fig. I. Staubbeutelröhre, 6 mal vergrössert.

Fig. $K$. Staubgefässe von der Innenseite gesehen, 9 mal vergrössert.

Fig. L. M. Pollen, troeken und in Wasser.

Fig. $N$. Der obere Theil des Griffels und der Narbe, 9 mal vergrössert.

Fig. $O$. Die Frucht, natiirliche Grösse.

Fig. $P$. Dieselbe, $3 \mathrm{mal}$ vergrössert: $l$. Achaene; $m$, der äussere, $n$, der mittlere, o, der innere Pappus.

Fig. Q. R. Dieselbe im Längsschnitte: $p$. Fruchthaut; $q$. Wïrzelchen; $r$. Keimblätter.

Fig. S. Dieselbe im Querschnitte.

\section{TARAXACUM Hall.}

Blüthenköpfchen homogam, gleichgestaltet, zungenförmig. Hüllkelch glockig oder oblong, die inneren Blättchen einreihig, aufrecht, gleich, am Grunde zuweilen verwachsen, die äusseren kürzer, mehrreihig, gewöhnlich abstehend oder zurückgekrümmt. Gemeinschaftlicher Bltithenboden flach, kahl. Blumenkrone an der Spitze gestutzt, fünfzähnig; Staubbeutel am Grund pfeilförmig mit kurzen, borstigen, zugespitzten Schwänzen; Narbenschenkel stumpflich. Achaenen stielrund oder kantig, undeutlich zehnrippig, an der Spitze in einen langen oder kurzen Schnabel verschmälert; Pappusborsten einfach, dün, ungleich. Kräuter mit stark verkürzter Grundaxe, aus der die blattlosen Bluthenschäfte mit einzelnen oder gepaarten Köpfchen hervortreten; alle Theile sind von einem reichlichen Milchsafte durchtränkt; die Blüthen sind gelb. 
In der Gattung sind über 40 Arten beschrieben worden, welche aber auf die Hälfte oder noch mehr reducirt werden müssen; sie wachsen besonders in der kalten und nördlich gemässigten Zone beider Hemisphären, fehlen aber auch der sildlichen Hemisphäre nicht ganz. Einige Arten sind durch die Cultur weit verbreitet worden.

\title{
Taraxacum officinale Web.
}

\author{
Tafel 8 .
}

Die ganze Pflanze ist kahl. Grundblätter ungleich und scharf schrotsägezähnig mit dreieckigen, auf der Vorderseite gezähnten Lappen; Schaft einfach, röhrig, einköpfig; Hüllkelch mit zurückgeschlagenen äusseren Blättern; Frilchte mit fadenförmigem, sehr langem Schnabel, gerippt, an den Rippen oberhalb der Mitte feinbestachelt.

Taraxacum officinale Web. in Wigg. Prim. Fl. Hols. 56; Vill. Dauph. III. 72; Sturm, Deutschl. Fl. XI. t. 41; Dietr. Fl. Boruss. II. 93; Koch, Syn. 428 und viele andere deutsche Floren; Berg und Schmidt, Darst. und Beschr. VIIc. Bentl. and Trim. Med.pl. t. 159; Köhler, Medizinalpfl. t. 5; Ledeb. Fl. Ross. II. 812; Willk. et Lange, Fl. Hisp. II. 230; Boiss. Fl. orient. III. 787; Hook. Fl. Brit. Ind. III. 401; Franch. et Savat. Fl. Jap. I. 269, Asa Gray, Syn. Fl. North. Am. I. (2.) 440.

Leontodon Taraxacum Linn. Spec. plant. ed. I. 798; Allione, Fl. Pedem. I. 205, Jcon. Taur. 23. t. 3. Fig. 2; Oed. Fl. Dan. IV. 574; Curt. Fl. Londin. I. t. 58; Bull. Herb. t. 217; Gärtn. Carp. II. 363. t.158. Fig. 7; Woodv. Med.I.t.16; Diev. Bot. Bild. I. 4; Plencl, Off. 593; Sowerby, Engl. Bot. VIII. 510; Hayne, Arzneipfl. III. t. 4; Schkule Handb. III. 219; Schrank, Fl. Monac. IV. 400; Guimp. u. Schlecht. t. 2; Baxt. Br. Bot. III. 163; Flück. and Hanb. Pharmacographia 351; Flïck. Pharmacognosie 406.

Hedypnois Taraxacum Scop. Fl. Carn. ed. II. p. 957.

Leontodon officinalis With. Bot. Arr. 679 .

Leontodon vulgare Lam. Fl. de Fr. II. 113; Schrank, Bayrische Fl. II. 314.

Taraxacum Dens Leonis Desf. Fl. Atl. II. 228; Lam. Illustr. III. t. 653, Dict. V. 34s.

Taraxacum Leontodon Dumort. Prodr. 61.

Gemeiner Löwenzahn, Pfaffenröhrchen, Pfaffenstiel, gelber Sonnenwirbel, Kuhblume, Hundsblume, Maiblume, Dotterblume, Butterblume, Gänseblume, Kettenblume, Wegelattich; französisch: Pissenlit, Dent de Lion; englisch: Dandelion.

Ein ausdauerndes K ra ut, das im ersten Jahre eine wenig blättrige Grundrosette erzengt, die im Frithjahr des folgenden Bliithen treibt.

Die Wurzel ist krïftig, ausdauernd, senkrecht absteigend, einfach oder verzweigt, mit fadenförmigen, dïnnen Faserwurzeln reichlich besetzt, sie ist drehrund, aussen röthlich braun, innen weiss, wie alle tibrigen Theile der Pflanze von weissem Milchsafte strotzend.

Die Blätter sind spiralig gestellt, die Hauptaxe beibt sehr verkürzt, daher bilden sie eine oft sehr reichblättrige Grundrosette; im Umrisse sind sie lanzettlich oder oblonglanzettlich, spitz, am Grunde zu einem mehr oder weniger deutlichen geflügelten, die Hauptaxe scheidig umfassenden Blattstiele verschmälert, zuweilen sind sie sitzend. Ihr Rand ist vielgestaltig, gewöhnlich sind sie schrotsägezähnig, mit grossen dreieckigen, spitzen Zähnen, die so weit nach der Mitte reichen, dass das Blatt fiederspaltig genannt werden muss, die Schrotzähne sind wieder besonders auf der Vorderseite gezähnt; in der Knospe sind die Blätter wollig behaart, später kahl, ihre Länge beträgt $6-30 \mathrm{~cm}$, die Breite im oberen Drittel $2-7 \mathrm{~cm}$. Neben dieser Form finden sich auch weniger tief gesïgte, buchtige und selbst fast ganzrandige, linealische oder spathelförmige Blätter.

Die Blïthenköpfchen sind einzeln, langgesticlt, strahlend, alle Bliithen zwittrig; die Köpfchenstiele sind röhrig, blattlos, endständig und treten aus den Achseln der Rosettenblätter hervor; sie sind gerade 
oder etwas gebogen, 5-35 cm lang, nach der Blüthezeit zuweilen bis $60 \mathrm{~cm}$ hoch und dariber, kahl oder unter dem Köpfehen weiss-wollig.

Der gemeinschaftliche Hitllkeleh ist glockenförmig aus 3 Reihen von Blättchen, die dachziegelig decken, zusammengesetzt. Die Blätter der 2 äusseren Reihen sind lanzettlich, spitz, zurückgeschlagen, die der inneren Reihe sind etwas länger (c. 1,5 cm lang), schmäler $(1,5-2 \mathrm{~mm}$ breit), lang zugespitzt, griin, unten weiss gerandet.

Der gemcinschaftliche Blüthenboden ist nackt, flach, oder seicht vertieft.

Die Blüthen sind zungenförmig; vielreihig, sehr zahlreich, gelb, 1,3-1,7 em lang. Der Fruehtknoten ist oblong umgekehrt eiförmig, zusammengedrlickt, an der Spitze stielförmig zusammengezogen, dann becherförmig erweitert, kahl. Der Pappus ist von der Länge der Blnmenkronenröhre, und besteht aus sehr zahlreichen, einfachen, dïnnen, seidigglänzenden glatten Borsten. Die Blumenkronenröhre ist halb so lang: wie die Zunge, in der Nähe der Miundung mit wenigen, schlaffen Haaren besetzt: die Zunge ist linealisch c. 1,5 mm breit, gestutzt, fünfzähnig. Die Staubgefäs se sind unterhalb des Saumes der Blumenkrone eingefügt, die Bentel zu einer 4-5 mm langen Röhre verklebt, mit drciscitigen, spitzen Endanhängseln, an der Basis mit spitzen Schwänzen versehen. Dic Pollenkürner sind polyedrisch, mit $6-8$ Stachelleisten, die an den Polen durch Sammelleisten verbunden und von einer äquatorialen Leiste geschnitten werden. Der Griffel ist fadenförmig, am Grunde mit einem schlïssclförmigen Nektarkragen versehen, in der oberen Hälfte mit nach oben gewendeten Fegehaaren bekleidet. Die Narbenschenkel sind drehrund, spitz, nach aussen halbkreisförmig gebogen, endlich weit aus der Staubgefässröhre hervorragend, $11-13 \mathrm{~mm}$ lang.

Die Frucht ist schmal umgekehrt eiförmig, ein wenig gekrimmt, schwach zusammengedriickt, längsstreifig, mit 14 tieferen Furchen versehen, sic ist besonders oben bestachelt, von Farbe graubraun, 3-3,5 mm lang; an der Spitze lang $(12 \mathrm{~mm}$ geschnäbelt; der Pappus ist von der oben beschriebenen Form, und hat schirmförmig ausgebreitet $8-9 \mathrm{~mm}$ im Durchmesser.

Der Same füllt die Fruchthöhlung aus, das Wïrzelchen ist halb so lang wie die Keimblätter.

Der Löwenzahn ist eine in der gemässigten und kalten Zone der nördlichen Erdhälfte weit verbreitete Pflanze, welche sich vom arktischen Russland durch die Nordsecländer, Mitteleuropa bis nach Sitdeuropa verfolgen lässt: in Griechenland ist sie selten und findet sich nur auf dem Olymp, anch in Macedonien und Thracien gehört sie zu den nicht häufigen Erscheinungen. Von Süd-Russland dringt sie in die Kankasusländer, nach Armenien, Mesopotamien, Afghanistan vor und wird auch noch in NordIndien, im Himalaya und West-Tibet gefunden, Sie tiberschreitet das Mittelmeer anch nach Nord-Afrika hin. Von Russland aus verbreitet sie sich östlich durch das gesammte Sibirien bis Kamtschatka und tritt auch noch jenseits der Behringstrasse in Aljaschka auf, ebenso ist sie in Japan beobachtet worden. Sie scheint daher urspringlich in Nord-Amerika einheimisch zu sein, wenn auch sicher ist, dass sie im Osten der Vereinigten Staaten aus Europa eingefuhrt worden ist; hier ist sie wie in Mittel-Europa, an Wegen, auf Wiesen und Schuttplätzen eine der gemeinsten Pflanzen geworden. Auch im sildlichen und westlichen Australien ist sie gegenwärtig sehr verbreitet. Sie findet sich in allen Höhenlagen bis zu den Gletscherrändern der Alpen und ist ziemlich veränderlich.

Als Radix Taraxaci cum herba findet die im Frühjahre vor der Blüthezeit gesammelte und getrocknete ganze Pflanze medicinische Anwendung. Rhizom und Wurzeln allein werden im getrockneten Zustande als Radix Taraxaci sine herba von den Drogisten geführt.

\section{Erklärung der Abbildungen.}

Fig. A. Eine blïhende und bereits fruchtende Pflanze.

Fig. B. Der untere Theil der Wurzel.

Fig. C. Ein Köpfchen im Längsschnitte, 2 mal vergrössert: a. der gemeinschaftliche Blüthenboden; $b$. der Hüllkelch; c. Blïthen.
Fig. D. Eine Blüthenknospe, $4 \mathrm{mal} \mathrm{vergrössert.}$

Fig. $E$. Eine Blüthe, 4 mal vergrössert: $a$. Fruchtknoten mit $b$. dem Schnabel; $c$. Pappus; $d$. die Blumenkrone; $e$. Staubbeutelröhre; $f$. Griffel mit den beiden Narben. 
Fig. $F$. Staubgefässe, mit den freien Staubfäden und den zu einer Röhre verklebten Staubbeuteln, 6 fach vergrössert.

Fig. $G$. Dieselbe, der Länge nach gespalten und ausgebreitet.

Fig. $H$. Pollenkörner, 300 fach vergrüssert.
Fig. I. Frucht, natürliche Grösse.

Fig. $K$. Der untere Theil derselben, 7 fach vergrössert.

Fig. $\tau$. Derselbe, der Länge nach gespalten : $a$. Würzelchen; b. Samenlappen des Keimlings.

Fig. $M$. Derselbe im Querschnitte, 15 mal vergrössert.

\section{IACTUCA.}

Köpfchen homogam, gleichgestaltet, zungenförmig. Hüllkelch cylindrisch, schmal, Blättchen wenigreihig, dachziegelig deckend, häutigkrautig, am Rande trockenhäutig, die äusscren kürzer. Gemeinschaftlicher Blithenboden flach, nackt. Blumenkrone an der Spitze gestutzt, fünfzähnig; Staubbeutel am Grunde pfeilförmig, kurz geöhrt oder borstlich. Achaenen mehr oder weniger zusammengedruickt, an der Spitze geschnäbelt, drei- bis funfrippig, Schnabel an der Spitze zu einer Schcibe, die den Pappus trägt, verbreitert. Pappus borstig; vielreihig. - Kahle, sehr selten rauhhaarige Kräuter mit reichlichem, weissem Milchsafte und spiral gestellten, ganzen, gezähnten oder fiedertheiligen Blättern. Köpfehen in weitschweifige, gewöhnlich reichbluthige Rispen zusammengestellt. Blithen gelb oder blau.

Die Gattung umfasst mehr als 100 beschriebene Arten, die aber auf $2 / 3$ zusammengezogen werden müssen; sie ist tiber die ganze Erde mit Ansnahme Australiens verbreitet, eine Anzahl von Arten sind hänfige Unkränter.

\section{Lactuca virosa $\mathrm{L}$.}

\section{Tafel 9 .}

Stengel steif aufrecht, in der Bluthenregion rispig verzweigt; Blätter horizontal ansgebreitet, schmal umgekehrt eiförmig; am Grunde pfeilförmig, am Rande buchtig und stachelsitzig gezähnt, die oberen ganzrandig. Blüthen gelb. Achaenen breit gerandet, beiderseits fünfrippig, an der Spitze kahl, sehwarz; Schnabel weiss, so lang als die Achaene.

Lactuca virosa L. Spec. pl. ed. I. 795; Allione, Fl. Pedem. I. 224; Gürtn. Carp. II. t. 155; Plenck, Icon. t. 594; Hayne, Arzneigew. I. t. 47 ; Schkuh, Handb. t. 217; Engl. Bot. XXVIII. t. 1957; Nees, Dïsseld. Abb. t. 250; Guimp. u. Schlecht. III. t. 201; Woodv. Med. t. 31; Brandt, Phoeb. Ratzeb. t. 23; Baxt. Brit. Bot. IV. 315; Dietr. Fl. Boruss. X. t. 664; Reichb. Jc. Fl. Germ. XIX. t. 1422; Steph. and Church. t. 12; Bentley and Trim. t. 160; Syme, Engl. Bot. V.t. 805; Berg und Schmidt, Darst. u. Beschr. t. XXXं ; Köhler, Medizinalpf. t. 44; Koch, Syn. 132 u. viele andere deutsche Floren; DC. Prodr. VII. 137; Ledeb. Fl. Ross. II. S05; Godr. et Gren. Fl. de Fr. II. 320; Bertol. Fl. Ital. VIII. 406; Boiss. Fl. orient. III. sos; Oliv. Fl.trop. Afr. III. 453; Flïck, and Hanb. Pharmacographia 353; Flück. Pharmacognosie 180.

Lactuca simuata Fork. Fl. Aeg. 215.

Lactuca silvestris Lam. Fl. de Fr. II. 84 .

?Lactuca Dregeana DC. Prodr. VII. 137.

Giftsalat, Giftlattich; französisch: Laitue vireuse; englisch: Prickly Lettuce.

Die Pfahlwurzel der zweijährigen Pflanze ist senkrecht oder steigt bogenförmig herab und verjüngt sich nach der Spitze zu, sie ist einfach odcr ästig, mit fadenförmigen Faserwurzeln besetzt, aussen weisslich oder hellbraun, getrocknet dunkelbrann, wie die iibrigen Theile der Pflanze stark milehend.

Der Stengel ist aufrecht, straff, einfach, in der Blüthenregion rispig verzweigt, stielrund, gestreift, unten borstig oder selbst bestachelt, oben kahl, zuerst markig, später hohl, 0,60-1,80 m hoch, am Grunde hat er $3-7 \mathrm{~mm}$ im Durchmesser, hier ist er braun, sonst hellgrin.

Die Blätter sind spiral gestellt, sitzend, oblong umgekehrt eiförmig, stumpf oder spitz, ganz oder 
buchtig am Rande stachelspitzig gezähnt, sitzend, geöhrt oder mit pfeilförmiger Basis den Stengel umgreifend, kahl, unterseits auf dem Mittelnerven bestachelt, horizontal ausgebreitet oder mit dem einen Rande schief gegen den Horizont gestellt, die unteren sind bis $20 \mathrm{~cm}$ lang und im oberen Fünftel bis $8 \mathrm{~cm}$ breit, die oberen gehen allmählich in die dreiseitigen, herzpfeilförmigen Hochblätter von geringer Grösse (bis $0,5 \mathrm{~cm}$ sich verkleinernd) über.

Der Bliithenstand ist eine zusammengesetzte Rispe, deren zahlreiche Äste aus den spiralgestellten Blättern hervortreten; an den kräftigen Exemplaren halten die Seitenstrahlen dieselbe Art der Verzweigung inne; dann werden kurze, wenig (4-6)-blättrige Äste hervorgebracht, welche endlich wie die Hauptaxe auch in ein terminales Köpfehen auslaufen; von den Blättern sind die oberen beiden steril, die unteren bringen ähnliche Zweigehen aus den Achseln hervor. Das Terminalköpfehen des ganzen Systems entwickelt sich stets zuerst und dann folgen die Terminalköpfehen der Seitenstrahlen in absteigender Reihe; jedes derselben wird von dem nächsten Seitenzweig bei Seite gedrängt, so dass die abgeblüthen Köpfehen blattgegenständig gestellt sind. Auf diese Weise wird ein zickzackförmig gebrochenes Scheinsympodium erzengt und die Täuschung hervorgerufen, als ob die seitlichen Inflorescenzen wickeliger Natur wären. In Wirklichkeit ist aber das System der Seitenstrahlen ebenso botrytisch wie der Gesammtblithenstand mit der Modifikation, dass die relative Hanptaxe durch ein Köpfehen abgesehlossen wird, während gewöhnlich bei den traubenförmigen Inflorescenzen die Hauptaxe unbegrenzt ist.

Die Blüthenköpfehen werden von zwei Hochblättern gestützt, sie sind gestielt, armblïthig, strahlend, alle Blithen gleich, zwittrig.

Der gemeinschaftliche $\mathrm{H} \ddot{\mathrm{i}} \mathrm{ll \textrm {kel }} \mathrm{ch}$ ist fast walzig und aus mehreren dachziegelig deckenden Blättern znsammengesetzt, die äusseren sind eilanzettlich, die inneren doppelt grösseren $1 \mathrm{~cm}$ langen lineal, spitz, weiss berandet, alle kahl.

Der gemeinschaftliche Bltithenboden ist flach, kahl, fein grubig punktirt.

Die Blithen 12-17 an Zahl sind gelb, ea. $1 \mathrm{~cm}$ lang, zungenförmig. Der Fruchtknoten ist breit elliptiseh, seitlich geflitgelt, stark zusammengedriiekt, auf den Fläehen mit einer schwachen Rippe verseben, kahl, kurz geschnäbelt. Der P appus ist von der Länge der Blumenkronenröhre und wird aus vielen, silberglänzenden, einfachen, weissen, starren, glatten Haaren zusammengesetzt. Die Blumenkronenröhre ist etwas kiirzer als die linealische, an der Spitze gestutzte, füufzähnige Zunge, sic ist um die Miundung behaart. Die Staubgefässe sind unterhalb des Röhrensaumes angeheftet und die Beutel zu einer $3 \mathrm{~mm}$ langen Röhre verklebt; sie tragen lineale, an der Spitze gerandete Endanhängsel und sind mit kurzen, unter einander verklebten Schwänzen versehen. Die Pollenkörner sind kugelig und mit 6 Stachelleisten, die an den Polen dureh eine Sammelleiste verbunden und durch eine äquatoriale geschnitten werden, versehen.

Der Griffel ist fadenförmig, am Grunde mit einem Nectarkragen und bis fast zur Hälfte mit nach aufwärts gerichteten Fegehaaren besetzt. Die Narbenschenkel sind linealisch, spitz, zuletzt halbkreisförmig zurückgekrümmt.

Die Frucht ist zusammengedrückt, geflügelt, sie wird von 10 Rippen durehzogen, ist transversal sculpturirt, an den Rändern bestachelt und schwarz gefärbt, mit langem weissem Schnabel. Der Pappus ist kürzer als der Schnabel, die Borsten sind schärflich.

Der Same füllt die Fruchtböhle aus, das Würzelchen ist 4 mal kürzer als die Keimblätter.

Der Giftlattich ist durch Mittel- und Süd-Europa ziemlich weit verbreitet; er findet sich auch noch in Nord-Afrika, in den Nil-Ländern, Cordofan und Abyssinien. Von Russland ans dringt er in das Uralische Sibirien vor, scheint aber in Kleinasien und Persien zu fehlen. Die Lactuca Dregeana DC. ist vielleicht von ihm nicht verschieden, dann würde er auch am Cap vorkommen.

Die getrockneten oberirdischen Theile der blïhenden Pflanze finden als Herba Lactucae virosae hier und da noch medicinisehe Verwendung. Von grösserer pharmaceutiseher Wichtigkeit ist das Lactucarium, der erstarrte Milchsaft der gegliederten Milchröhren der Pflanze. Das deutsche Lactucarium wird vorzüglich in der Nähe ron Zell an der Mosel von cultivirten, zweijährigen, blühenden Pflanzen gesammelt. Weder Herba Lactucae noch Lactucarium haben in das III. deutsche Arzneibuch Aufnahme gefunden. 


\section{Erklärung der Abbildungen.}

Fig. A. B. Der obere Theil einer blühenden Pflanze, natiirliche Grösse.

Fig. C. Ein Blüthenköpfehen im Längsschnitte, 3 mal vergrössert: $a$. gemeinschaftlicher Blïthenboden; $b$. Hüllkeleh; $c$. Blithen.

Fig. D. Eine Blüthe, 6 mal vergrössert: $d$. Fruchtknoten; g. Pappus; h. Blumenkrone; i. Staubbeutelröhre; $k$. Griffel; $l$. Narben.

Fig. E. Der Fruchtknoten mit der Haarkrone im Längsschnitte, 12 mal vergr.: $e$. Schnabel desselben; $f$. Samenanlage.

Fig. $F$. Die Staubgefässe, 18 mal vergrüssert: $m$. die freien Staubfäden; $n$, die verklebten Staubbeutel.
Fig. $G$. Ein Staubgefäss von innen gesehen, $18 \mathrm{mal}$ vergrössert: $o$. Endanhängsel.

Fig. H. Pollenkörner, 300 mal vergrössert : drei obere trocken, drei untere im Wasser.

Fig. $I$. Der Griffel mit den Narben, 15 mal vergrössert.

Fig. $K$. Das Köpfchen im Fruchtzustande, natürliche Grösse.

Fig. $L$. Die Frucht, natürliche Grösse.

Fig. $M$. Dieselbe, $8 \mathrm{mal}$ vergrössert; $p$. Achaene; $q$. der Schnabel.

Fig. $N$. Dieselbe im Längsschnitte: $r$. Fruchtschale; $s$. Wïrzelchen; $t$. Keimblätter.

Fig. O. Dieselbe im Querschnitte: 6 mal vergrössert. 


\section{Familie: Valerianaceae DC.}

Die Blïthen sind vollständig, zwittrig, mehr oder weniger zygomorph. Der Fruchtknoten ist unterständig, entweder deutlich aus 3 Fruchtblättern zusammengesetzt oder diese sind nur noch in den Narbenstrahlen angedeutet, im ersteren Falle dreifächrig, meist aber einfächrig; doch lassen sich die Spuren der beiden anderen Fächer oft noch dentlich nachweisen. Die Samenanlagen hängen gewöhnlich einzeln vom Scheitel der Fruchtknotenhöhle herab; sie sind anatrop, die Mikropyle ist nach der Rïckseite der Blitthe gewendet. Der Kelch ist entweder auf einen kurzen Saum reducirt, oder drei- bis fünfzähnig oder aus mehreren linealen Abschnitten (bis 20) zusammengesetzt. Die Blumenkrone ist trichterförmig, häufig: gespornt, fünflappig, mit dachziegeliger, meist absteigender Deekung; der unpaare Zipfel ist nach vorn gerichtet; zuweilen ist sie deutlicher zweilippig, die Unterlippe dabei drei- oder vierzipflig (letzteres bei Centranthus). Stanbgefässe sind gewöhnlich 3, seltener 4, 2 oder einzelne vorhanden, zwischen den Blumenkronenlappen eingefïgt; die Staubbente! sind zweifächrig;, versatil auf dem Rïcken anfgehängt, sie springen intrors in Längsspalten auf; der Pollen ist meist ellipsoidiseh, längsfurchig, gewöhnlich kurz bestachelt. Der Griffel ist fadenförmig und hat 3 spreizende Narben. Die Frucht ist ein einsamiges Achaenium, und wird von dem Kelche, der sich nicht selten vergrössert, gekrönt. Der Same ist hängend, mit dünner Samenschale, das Nährgewebe fehlt, der Keimling ist gerade, die Keimblïtter sind fleischig, flach aneinandergelegt, das Wiirzelchen ist nach oben gewendet.

Einjährige oder ansdanernde Kräuter, selten Halbsträncher oder Sträncher, meist kahl; mit krenzgegenständigen, nebenblattlosen, ganzen oder gefiederten Blättern. Die Bläthen stehen sehr häufig in decussirten Rispen, welche in Dichasien, und endlich in Wickeln ansgehen und werden von 2 Deckblïttchen, die am Grimde zuweilen verwachsen sind, gestitzt, von Farbe sind sie weiss, roth, selten gelb.

Ungefähr 300 Arten in der nördlich gemässigten und kalten Zone der alten Welt, sowie des westlichen Amerika's; ziemlich zahlreiche Arten finden sich anch im Andengebiet, einzelne im Osten Süd-Amerika's und in West-Indien; in Siid-Afrika ist eine wahrscheinlich eingefiihrte Art, in Australien sind sie nicht vorhanden.

Die Valerianaceen sind eine in sich fast völlig abgeschlossene Familie, deren Gattungen so eng verwandt sind, dass sie fast in eine vereinigt werden könnten. Ihre nächste Verwandtschaft liẹgt in den Dipsacaceen, von welchen sie sich durch den der Anlage nach dreizähligen Fruchtknoten, die nährgewebslosen Samen und die reducirte Zahl der Staubgefässe unterscheiden. Die frïher zu den Valerianaceen gezählte Gattung Triplostegia steht zwischen beiden Familien; gegenwärtig wird sie aber wegen einer vorhandenen Blüthenhülle und der ein Nährgewebe umschliessenden Samen den Dipsacaceen zugezählt. Durch den oft entwickelten Pappus zeigen die Valerianaceen eine gewisse Beziehung zu den Compositen. 


\section{VAIERIANA Iinn.}

Fruchtknoten unterständig, gewöhnlich einfächrig, zuweilen mit Andeutung von zwei anderen (nur bei $V$. salunca All. sind 3 fast gleiche Fächer entwickelt, von denen 2 steril sind); mit einer hängenden Samenanlage. Kelch aus 5-15 eingerollten, pfriemförmigen Läppchen zusammengesetzt. Blumenkrone trichterförmig, am Grunde zuweilen mit einem Höcker oder Sporn versehen; fünflappig. Staubgefissse 3, selten 1-2. Griffel kurz dreistrahlig. Achaenium zusammengedrückt, mit einem Rticken-, 2 Seiten- und 3 Bauchnerven, von dem ausgewachsenen Pappus, dessen Strahlen fiederhaarig werden, gekrönt. - Ausdauernde Kräuter, meist mit Grundrosetten, seltener Sträucher, zuweilen schlingend, gewöhnlich kahl, mit ganzen oder 1-3-fach gefiederten oder fiedertheiligen, kreuzgegenständigen Blättern. Blüthenstände von flattrigem, corymbösem oder dichtergedrängtem, ährenförmigem Habitus.

Die Verbreitung der 180 Arten ist ganz derjenigen der Familie entsprechend.

\section{Valeriana officinalis Linn.}

\section{Tafel 10.}

Rhizom mit kurzen Ausläufern versehen. Blätter der Grundrosette langgestielt, unpaarig vieljochig gefiedert, kahl, die oberen einfach, sitzend; Blättchen lanzettlich, gesägt oder ganzrandig, kahl. Stengel anfrecht, gefurcht; Bltithenstand eine lockere, decussirte Rispe; Blithen gleich, zwittrig, rosa; Fruchtknoten einfächrig; Pappus zehnstrahlig.

Valeriana officinalis Limn. Spec.pl.ed.I.31; Oed. Flora Dan.IV.570; Allione, Fl. Pedem. I. 2; Plenck, Icon. 27; Engl. Bot. X. t.695; Svensk Bot. I. 25; Sturm, Deutschl. Fl. III. 9; Hayne, Arzneigew. III. 32; Schrank, Fl. Monac. II. 178; Lam. Encycl. I. t. 24; Curt. Fl. Lond. III. 135; Woodv. Med. t. 32; Nees, Diisseld. Pfl. t. 25t; Guimp. u. Schlecht. I. 7. t. 4; Dietr. Fl. Boruss. IV. 266; Reichb. Fl. Germ. XII. 727; DC. Prodr. IV. 641; Koch, Syn. I. 396 u. viele andere deutsche Floren; Syme, Engl. Bot. IV. t. 666; Steph. and Church. Med. pl. t. 54; Nees, Gen. X. 7 ; Schnizlein, Icon. III. t. 118; Bentl. and Trim. Med. pl. t. 146 ; Berg u. Schmidt, Darst. u. Beschr. t. XXVIII ${ }^{d}$; Köhler, Mediz. Pf. I. t. 47; Ledeb. Fl. Ross. II. 438; Bertero, Fl. Ital. I. 167; Godr. et Gren. Fl. Fr. II. 54; Willk. et Lange, Fl. Hisp. II. 2; Boiss. Fl. orient. III. 89; Franch. et Sav. Fl. Japon. I. 217; Flick. and Hanb. Pharmacogr. 337 ; Fliick. Phar$\operatorname{macogn} .429$.

Baldrian, Katzenkraut, Marienuurzel, Mondwurz; französisch: Valériane; engliseh: Valerian, all-heal.

Ausdauernd, indem ans dem $2-3 \mathrm{~cm}$ dicken und ebenso langen oder noch etwas längeren, basalen Theile der Axe, 5-15 em lange, 2-3 mm dicke, stielrunde Auslänfer hervortreten, die mit 2-3 sehuppenförmigen, entfernt stehenden Niederblättern besetzt sind und dann in eimer Knospe enden. Diese wächst in dem ersten Jahre in der Regel so weit heran, dass sie im folgenden zur Blithe kommt. Zuweilen bleiben die Ausläufer kürzer oder die neuen Sprosse entstehen unmittelbar in der Axe der Grundblätter des Mutterstockes.

Die Wurzeln treten sehr zahlreich ans der unteren Axe hervor, sie haben $1 \mathrm{~mm}$ im Durchmesser, sind zuweilen etwas dicker oder dtnner, weiss, getrocknet bram, mit Fasern besetzt.

Der Stengel ist aufrecht, stielrund, gefurcht, bis zur Inflorescenz einfach, innen hohl, 0,6-1,2 m hoch, selten dartiber; er ist kahl, unter den Blattansäitzen zottig.

Die Blätter sind kreuzgegenständig, unpaarig gefiedert, 5- bis viel- (bis 16-) jochig; die grundständigen sind langgestielt, die oberen werden allmählig kleiner und sind endlich sitzend, sie umfassen mit 
scheidiger Basis den Stengel und verschmelzen paarweise mit einander; sie sind kahl, an den Scheidenrändern zottig; die Fiederblättchen sind lanzettlich, spitz, am Grunde verschmälert, mehr oder weniger deutlich an der Spindel herablanfend, gesägt oder fast ganzrandig; das oberste Paar ist mit dem Endblättehen verschmolzen, an den grösseren Blättern stehen die Fiedern von einander entfernt und mehr oder weniger abwechselnd, an den kleineren sind sie gegenständig und genähert.

Die Inflorescenz ist endständig und eine reichlich verzweigte, $5-25 \mathrm{~cm}$ lange, decussirte Rispe, deren Zweige von gefiederten, bald einfach werdenden, linealen Deckblättern gestïtzt sind; die oberen Äste derselben werden zu kleinen Dichasien, welche in Wickeln auslaufen; die Specialbliithenstände an den Seitenstrahlen II. Ordnung haben dadurch, dass die Blüthen in eine Ebene fallen, corymbösen Habitus.

Die Blüthen sind zwittrig, ziemlich klein (4-5 mm lang), fleischroth, sitzend, von 2 linealen, spitzen, am Grunde zuweilen mit einem Zahne versehenen Vorblättehen gestiitzt.

Der Fruchtknoten ist kaum 2 mm lang, oblong, etwas zusammengedriuckt, glatt und kahl, griun.

Der Kelch wird aus 10 schmal linealen, eingerollten, braungriinen Blättchen zusammengesetzt.

Die Blumen krone ist 3-4 mm lang, zygomorph, am Grunde kurz gespornt, trichterförmig, ungleich fünflappig, der über dem Sporn liegende Lappen ist der grösste, Lappen elliptisch stumpf. Der Grund der Spornaussackung ist fleischig und grỉn, er scheidet den Nektar aus.

Die Staubgefässe tiberragen im ersten männlichen Zustande die Blithe weit; im zweiten, weiblichen Zustande sind sie zurïckgekrïmmt. Die Staubbentel sind fast zweiknöpfig, gelb, die Pollenkörner ellipsoidisch mit 3 meridionalen Längsfurchen, sie sind kurz bestachelt.

Der Griffel iberragt im weiblichen Zustande die Blumenkrone, er ist doppelt gekrïmmt und hat 3 spreizende, kurze, stumpfe Narben.

Die Frucht ist oblong-eiförmig, etwas an der Spitze verjüngt, zusammengedrückt, auf der Innenseite wird sie von 3, am Rande von 2, auf der Aussenseite von einer Rippe längs durehzogen; sie ist gelbbraun, fast $5 \mathrm{~mm}$ lang und wird von einem zehnstrahligen Pappus aus gefiederten Haaren gekrönt.

Der Same füllt das Fruchtfach aus, das Wtirzelchen ist dreimal kürzer als die Keimblätter.

Der Baldrian ist von dem arktischen Russland dureh fast ganz Europa weit verbreitet, nur im Süden tritt er spärlicher auf und fehlt in Portugal, Süd-Spanien, im südöstlichen Frankreich ganz, in der Türkei ist er nur von der Halbinsel Chalcidice bekannt. Von Russland aus verbreitet er sich bis nach Kaukasien und dem türkischen Armenien. Durch das gesammte Sibirien ist er häufig, und anch in Japan gehört er nicht zu den seltenen Erscheinungen. In Süd-Afrika scheint er eingeführt zu sein, denn $V$. Capensis Thbg. (Harv, and Sond. Fl. Cap. III. 40) lässt sich von ihm nicht unterscheiden.

Anmerkung. Der Baldrian zeigt bezl̈glich der Länge der Ausläufer und der Natur der Blätter eine Neigung zu Abwandlungen, die bald als Varietäten, bald als Arten beschrieben worden sind. Die Form, welche keine Ausläufer entwickelt, dafür aber unmittelbar aus der Grundaxe mehrere blïthentragende Stengel treibt, heisst $V$. exaltata Mik., die mit langen Ausläufern und wenig -drei- bis fünfjochigen Blättern ist $V$. sambucifolia Mik., breit- und schmalblättrige Formen kommen bei der echten $V$. officinalis $L$, vor.

Die in Deutschland verkaufte Droge, Radix Valerianae oder Baldrianwurzel, stammt meist von kultivirten Pflanzen und besteht aus höchstens $5 \mathrm{~cm}$ langen Rhizomen, welche die Endknospe und meist einige kürzere Zweige tragen und mit zahlreichen Nebenwurzeln besetzt sind; die Laubblätter sind vom Rhizome abgeschnitten. An von wild erwachsenen Pflanzen gesammelter Waare findet man gewöhnlich Reste der oberirdisehen Axen. Der wirksame Bestandtheil (ein ätherisches Öl) liegt vorzüglich in der Hypodermis der Nebenwurzeln.

\section{Erklärung der Abbildungen.}

Fig. A. Der obere Theil eines Exemplares der schmalblättrigen Form von den Rüdersdorfer Kalkbergen.

Fig. B. Ein Grundblatt derselben Pflanze.
Fig. C. Die Blüthenknospe, 8 mal vergrüssert: a. Fruchtknoten; $b$. Kelch; $c$. Blumenkrone; $d$. Sporn.

Fig. D. Die Blüthe, $10 \mathrm{mal}$ vergrössert: e. Staubgefässe, 
die oberen im männlichen, die unteren im weiblichen Zustande der Blithe: $f$, Griffel mit dreispaltiger Narbe.

Fig. $E$. Dieselbe im Längsschnitte: $g$. Samenanlage.

Fig. $F$. Staubgefässe, von innen und von aussen gesehen, 20 mal vergrössert.

Fig. $G$. Pollenkörner, troeken ea. 300 mal vergrössert.

Fig. $H$. Dieselben in Wasser.

Fig. $I$ bis $O$. Friichte in verschiedenen Entwickelungszu- ständen: $h$. die Frucht; $b$. der allmählich sich aufrollende Keleh.

Fig. N. Die Frucht in natiirlicher Grösse.

Fig, P. Quersehnitt durch dieselbe, $12 \mathrm{mal}$ vergrössert: $i$. Fruchtschale; $l$. Keimblïtter.

Fig. Q. Längsschnitt dureh dieselbe, senkrecht auf den Keimblätter: $k$. Würzelehen.

Fig. $R$. Längsschnitt durch dieselbe, parallel mit den Keimblättern. 


\section{Reihe: Cinchonales Lindl.}

Blïthen aktinomorph, seltener zygomorph, sie sind entweder durch alle Kreise vier- oder fünfzählig; oder öfter im Fruchtblattkreise, sehr selten im Staubgefässkreise gemindert. Der Kelch ist krautig, zuweilen fehlt er, gewöhnlich ist die Aestivation offen; die Staubgefässe sind fast immer der Blumenkrone eingefügt. Der Fruchtknoten ist unterstïndig.

\section{Familie: Caprifoliaceae Vent.}

Die Bliithen sind vollständig, zwittrig, aktinomorph oder zygomorph. Der Fruchtknoten ist unterständig aus 2-5 Fruchtblättern zusammengesetzt, 2-5- selten einfächrig; die Samenanlagen hängen entweder einzeln von dem Scheitel des Faches herab, oder viele sind dem Innenwinkel desselben angeheftet; sie sind anatrop, mit nach oben gewendeter Micropyle und dorsaler oder seitlicher Rhaphe. Der Kelch ist drei- bis fünfzähnig- oder lappig, mit gleichen oder ungleichen Abschnitten. Die Blumenkrone ist radförmig, röhrig, trichter- oder glockenförmig, nicht selten am Grunde mit einem kurzen Höcker versehen, aktinomorph oder mehr oder weniger zweilippig, der unpaare Zipfel wird nach vorn gewendet, gewöhnlich hat sie eine dachziegelige Knospenanlage der Zipfel. Die Staubgefässe sind gleich oder ungleich lang, der Zahl nach 5, selten 4, indem das hintere fehlt (Linnaea), sie sind der Kronenröhre mit den Zipfeln wechselnd angeheftet; die Staubbentel sind zweifächrig, versatil und springen in Längsspalten auf, gewöhnlich sind sie intrors. Ein Nektarkragen (Discus) von ringförmiger, polsterartiger Gestalt fehlt selten; zuweilen wird er durch eine vordere Drïse vertreten. Der Griffel ist fadenförmig. und hat eine kopfige oder kurz zweispaltige Narbe, selten ist sie kurz dreilappig. Die Frucht ist eine Beere oder Steinfrucht, seltener ist sie kapselartig, ein- bis vielsamig. Der Keimling ist oft klein, seltener ist er verlängert mit blattartigen Kotyledonen.

Sträucher, seltener kleiner Bäume, noch seltener Kräuter, zuweilen windend, mit kreuzgegenständigen, höchst selten abwechselnden, einfachen, gelappten oder unpaarig gefiederten Blättern; die Nebenblätter fehlen gewöhnlich.

Die Familie umfasst ungeführ 200 Arten, welche besonders die nördlich gemässigte Zone beider Hemisphaeren bewohnen, wenige sind in Australien und Süd-Amerika; im tropischen und in Süd-Afrika fehlen sie.

Die Caprifoliaceen stehen mit den Rubiaceen in so engem Zusammenhange, dass sie Baillon wohl mit Recht in die letzte Familie aufgenommen hat. Kein Merkmal ist vorhanden, das sie von jenen unbedingt tremnen könnte. Die Gattung Adoxa ist zweckmässiger Weise, nach dem Vorgange von Jussie u, durch D ru de aus der Familie entfernt und den Saxifragaceen, besonders enger an die Gattung Chrysosplenium angeschlossen worden. 


\section{SAMBUCUS L.}

Blüthen aktinomorph, fünf-, seltener vierzählig (noch seltener dreizählig). Fruchtknoten kegel- oder halbkugelförmig, drei- bis fünffächrig mit je einer vom Scheitel des Faches herabhängender Samenanlage, Rhaphe dorsal. Kelch gezähnt oder gelappt. Blumenkrone radförmig oder kurz glockig mit dachziegeliger, seltener klappiger Knospenanlage. Staubgefässe an der Röhre unter den Buchten befestigt, Antheren extrors. Nektarkragen fehlend oder convex. Griffel sehr kurz und dick, Narben kurz und stumpf. Frucht eine Steinfrucht mit 3-5 Samen. Samen zusammengedriiekt, Keimling mit flachen, blattartigen Keimblättern und stielrundem Würzelchen im fleischigen Nährgewebe (Eiweiss). Bäume oder Sträncher, seltener Kräuter (S. Ebulum L.) mit kreuzgegenständigen, unpaarig gefiederten Blättern, der Battstiel am Grunde drïsig oder mit Nebenblättern versehen, auch die Fiedern sind zuweilen mit Nebenblättchen besetzt. Blïthenstände decussirte Rispen von versehiedenem Gesammtumrisse, endlich in Dichasien und Wickeln auslaufend; Blüthen weiss, gelb oder rosa, klein von 2 Deckblättchen gestiitzt.

12 Arten in den gemässigten Zonen und auf den Gebirgen der Tropen, auf der ganzen Erde mit Ausnahme des südlichen und tropischen Afrika's.

\section{Sambucus nigra Linn.}

Tafel 11.

Baum- oder strauchartig, Aste mit weissem Marke; Blätter unpaarig gefiedert mit 2-4 Paar zugespitzten, gesägten Blättchen; Nebenblätter pfriemlich, seltener blattartig; Inflorescenz mit einem Hauptund 4 primären Seitenstrahlen; Bliithen gelblich weiss; Steinfrucht schwarz mit purpurrothem Fleische und meist 3 (selten 2) Steinen.

Sambucus nigra Linn. Spec.pl. ed. I. 269; Oed. Fl. Dan. IV. t. 545; Allione, Fl. Pedem. I. 129; Gürtn. Carp. I. t. 27; Plenck, Off. 229; Engl. Bot.VII. 476; Woodv. Med. III. t. 211; Nouv. Duham. I. t. 55; Svensk Bot. 33; Rouss. Bot.t.33; Steph. and Church. Med.pl. t. 79; Syme, Engl. Bot. IV.t.637; Hayne, Arzneigew. IV.t. 16 ; Nees, Düsseld. Pfl. t. 265; Guimp. u. Schlecht. I. t. 57; Reichb. Fl. Germ. XII.t.730; Nees, Gen. X. 10; Koch, Syn. 255 und viele andere deutsche Floren; Bentl. and Trim. Med. pl. t. 137; Berg u. Schmidt, Darst. u. Beschr. XV $V^{d}$; Köhler, Mediz. Pfl. I. t. 46; Godron et Gren. Fl. Fr. II. 7 ; Ledeb. Fl. Ross. II. 383; Bert. Fl. Ital. III. 455; Willk. et Lange, Fl. Hisp. II. 329; Boiss. Fl. or. III. 2 ; Flick. and Hanb. Pharmacogr. 297; Flisk. Pharmacogn. 773.

Flieder, Holunder, Holder; französisch: Sureau; englisch: Elder tree.

Der Holunder ist ein Baum oder Strauch bis zu $6 \mathrm{~m}$ Höhe, selten darïber, mit borkiger Rinde, die sich in blattartigen, grauen oder schwärzlichen Sehollen ablöst. Die Äste sind kreuzgegenständig (decussirt) in jugendlichem Zustande vierkantig und grïn, dann drehrund und werden von dïnner, grauer Aussenrinde, welche mit grangelben, zahlreichen Lenticellen bestreut ist, bedeckt; das Holz ist gritinlich und umschliesst ein umfangreiches, weisses Mark.

Die jüngsten Schosse tragen, wenn sie in einen Blïthenstand auslaufen 2-3 Paar kreuzgegenständige Laubblätter, denen einige Paare einfacher gestalteter, endlich in die Deckschuppen der Knospe übergehender vorausgehen, die schliesslich abfallen. Nebenblätter zwei, pfriemenförmig oder stiftartig, seltener an Wassertrieben blattartig, unsymmetrisch, halbeiförmig, abfällig.

Die Blätter sind unpaarig, zwei bis funfjochig gefiedert, gestielt, kahl, oder auf der Unterseite oder auf beiden Seiten, besonders an den Nerven diinn behart; die Blättchen sind gegenständig, kurz gestielt, 
von den unteren nach den oberen Paaren an Grössen zunehmend, oblong; seltener breiter elliptisch, an der Spitze und am Grunde zugespitzt, die der mittleren Paare deutlich schief, dic der unteren mehr oder weniger abgerundet; am Rande sind sie gesägt; oberseits sind sie dunkelgriin und glänzend, unterseits heller und matt; die Blattspindel ist oberseits rinnig, über das oberste Fiederpaar verlängert und deshalb erscheint gewöhnlich die Endfieder lang gestielt. Die Nebenblätter und die unteren Zähne der Fiedern sondern einen süssen Saft $a b$, sie sind extraflorale Nektarien.

Der Bluthenstand hat einen Durchmesser von 10-15 cm; er ist endständig und bildet eine decussirte Rispe mit einem meist geschwächten Endstrahl und 4 einander genährten Hauptscitenstrahlen, die sich wieder in derselben Weise verzweigen, um endlich in Dichasien uud zuletzt in zwei bis drciblithige Wickeln auszugehen. Zur Blithezeit ist er aufrecht, schirmförmig, flach, später hängend; die Vorblättchen der Blithen sind klein, dünn, häutig, schmal dreiseitig, abfällig. Die Blüthenstiele sind gefurcht, rund, grïn, später roth; Stielchen sind nicht entwickelt.

Die Blithen sind zwittrig, aufrecht, gelblich-weiss, von sehr starkem, betäubendem Geruche und haben $4-5 \mathrm{~mm}$ im Durchmesser.

Der Fruchtknoten ist $1 \mathrm{~mm}$ lang, unterständig, halbkugelig, glatt und kahl; meist drei- (selten zwei-)fächrig. Der Kelch ist fünf- (selten vier-) zähnig, abstehend; die Lappen sind dreiseitig, spitz, bleibend, kahl, kaum 0,5 mm lang. Die Blumenkrone ist radförmig fünf- (seltener vier-) lappig; die Lappen sind oblong eiförmig, stumpf; die Röhre ist sehr kurz und weit.

Staubgefässe sind so viele als Blumenkronenlappen vorhanden; sic sind der Röhre unterhalb der Buchten eingefügt, von der Länge jener, flach ausgebreitet und so lang wie die Blumenkronenzipfel; die Staubfäden sind pfriemlich, die Stanbbentel elliptisch, gelb; die Pollenkörner sind ellipsoidisch mit 3 meridionalen Längsfurchen.

Der Stempel ist dick, halbkugelig, kahl, misst $1 \mathrm{~mm}$ und hat kein Nektar absonderndes Organ. Die 3, seltener 2 Narben sind kurz und stumpf.

Die Steinfrucht von 6-8 mm Länge ist kugelig-ellipsoidisch, am Grunde abgerundet, und wird an der Spitze von den Narben und den, diesen dicht anliegenden Kelchblïttern gekrönt; sie ist schwarz mit purpurrothem, saftigem Fleische. Die 3 (scltener 2) Samen sind oblong, kurz und schief zugespitzt, zusammengedrückt, mit harter, brauner, fester, runzliger äusserer und dünner, weisser innerer Samenschale; sie sind $5 \mathrm{~mm}$ lang und $2-3 \mathrm{~mm}$ breit. Der Keimling ist gerade oder wenig gekrümmt, das Würzelchen ist nach oben gerichtet und um die Hälfte länger als die Keimblätter.

Der Flieder findet sich in ganz Europa mit Ausnahme der nördlichsten Theile, also des nördlichen Skandinaviens und Russlands; in Griechenland und in der Türkei ist er sehr wenig verbreitet. Von dem stidlichen Russland kann er bis nach den Kaukasusländern, bis nach Armenien und Abchasien verfolgt werden; auch in Sibirien ist er besonders im östlichen Theile vorhanden.

Er hat einige Neigung zu Variationen, besonders die Formen mit zerschlitzten Blättchen und die mit weissen Früchten werden nicht selten eultivirt.

Anmerkung. In Nord-Amerika wird er dureh S. Canadensis $L$. vertreten, die durch umfangreichere, schlaffere Cymen und durch mehr röthliche Steinfrucht verschieden ist. Auch von ihr hat man eine var. laciniata beschrieben, die A. Gray (Syn. Fl. North Am. I. (2.) p. 9 ) kaum von der erwähnten Form unseres Holunders für versehieden erachtet.

Von Sambucus nigra werden die Blüthen noch allgemein, die reifen Frïchte ziemlich häufig medicinisch angewendet; die Rinde jüngerer Zweige, Cortex Sambuci, findet dagegen nur noch sehr selten Verwendung. Als Flores Sambuci oder Holunderblithen kommen die getrockneten, dünneren, blithentragenden Zweige des Blüthenstandes (Holunderblüthen in Trauben der Preislisten) oder auch die Blutthen allein (gerebelte Waare der Listen) in den Handel. Das III. Deutsche Arzneibuch gestattet nur die Anwendung der Blïthen. Als Fructus Sambuci oder Grana Actes findet man die getrockneten, reifen Steinfrïchte im Handel, und aus den lebenden Früchten bereitet man den Rob Sambuci oder Succus Sambuci inspissatus. 


\section{1}

\section{Erkärung der Abbildungen.}

Fig. A. Ein blühender Zweig in natürlicher Grösse.

Fig. B. Die Blïthe von der Unterseite gesehen, 5 mal vergrössert: $a$. Fruchtknoten; $b$. Kelch; $c$. Blumenblätter; $d$. Staubgefässe.

Fig. C. Die Blithe von der Oberseite gesehen, 5 mal vergrössert: e. Griffel.

Fig. D. Die Blithe ohne Blumenkrone, 7 mal vergr.: $f$. Narbe.

Fig. $E$. Der Stempel im Längsschnitte, $12 \mathrm{mal}$ vergrössert: $g$. Samentrïger; $h$. Samenanlagen.

Fig. $F$. Die Blumenkrone von unten gesehen: $5 \mathrm{mal}$ vergr.

Fig. $G$. Staubgefässe von aussen und innen betrachtet, $10 \mathrm{mal}$ vergrössert.
Fig. H. Pollenkörner, trocken, $300 \mathrm{mal}$ vergrössert.

Fig. $I$. Dieselben in Wasser.

Fig. $K$. Die Frucht in natürlicher Grösse.

Fig. $L$. Dieselbe $2 \frac{1}{2}$ mal vergrössert.

Fig. M. Dieselbe im Querschnitte : $i$. Fruchtfleisch; $k$. Steinschale.

Fig. $N$. Dieselbe im Längsschnitte $l$. Nährgewebe; $m$. Keimling.

Fig. $P$. Der Steinkern, $3 \frac{1}{2} \mathrm{mal}$ vergrössert.

Fig. Q. Derselbe im Längsschnitte, $4 \mathrm{mal}$ vergrössert: $n$. Würzelchen, o. Keimblätter.

Fig. $R$. Derselbe im Querschnitte. 


\section{Familie: Rubiaceae B. Juss.}

Die Blithen sind zwittrig, selten eingeschlechtig, aktinomorph, selten zygomorph. Der Fruchtknoten ist unterständig, ein- bis zehnfächrig, mit $1-\infty$ anatropen Samenanlagen in jedem Fache, die der Richtung und Aufhängung nach sehr versehieden sind; der Keleh ist becher- oder röhrenförmig, ganz, gezähnt oder gelappt, zuweilen zur Fruchtreife vergrössert, manchmal ist der eine oder der andere Abschnitt laubig vergrössert und zu einem bunt gefärbten Schauapparate ausgebildet; am Grunde ist er zuweilen innenseits drüsig. Die Blumenkrone ist trichter-, präsentirteller-, glocken- oder radförmig mit klappiger, dachziegeliger oder gedrehter Knospenlage der Zipfel, sie ist innen nicht selten besonders am Sehlunde behaart; sie ist mehr oder weniger tief vier- bis fünflappig (selten zweilappig). Staubgefässe sind meist so viele als Kronenzipfeln vorhanden und mit ihnen wechselnd an der Röhre befestigt, selten sind sie am Grunde einbrïderig: verbunden. Die Staubbeutel sind zweifichrig, meist intrors, sie springen dureh Längsspalten, selten dureh Poren auf und sind am Rüeken oder am Grunde aufgehangen. Der Nektarkragen (Diseus) ist meist entwiekelt, ringförmig oder gelappt oder zweitheilig, polsterförmig. Der Griffel ist fadenförmig oder kurz, einfach oder zwei bis zehnspaltig oder er hat eine kopfige Narbe. Die Frucht ist kapsel-, beeren- oder steinfruchtartig, sie springt auf oder löst sich in Kokken oder bleibt geschlossen, sie ist ein- bis zehnfächrig. Die Samen sind wie die Anlagen derselben sehr mannigfaltig; der Keimling ist gerade oder gekrimmt und liegt in fleisehigem oder hornigem Nührgewebe mit flachen oder planeonvexen Keimblättern.

Bäume, Sträucher oder Kräuter, zuweilen schlingend, mit kreuzgegenständigen oder quirligen, meist ganzen und ganzrandigen Blättern. Die Nebenblätter befinden sich zwischen den Blattstielen (stipulae interpetiolares) oder vor denselben (st. intrapetiolares), sie sind nicht selten unter sich und auch mit den Blattstielen verbunden, umfassen dann oft seheidig den Stengel und sind zweispaltig oder vielfach getheilt, manchmal sind sie von gleicher Gestalt mit den Blättern (Stellatae). Der Blithenstand ist verschieden, am häufigsten ist er eine decussirte Rispe, die in Dichasien und endlich in Monochasien ausläuft. Die Blitthen sind nicht selten di- oder trimorph, zuweilen sind sie sehr eng verbunden und bilden endlich ein Syncarpium (Morinda, Sarcocephalus ete.)

Die Familie umfasst gegenwärtig etwa 4000 beschriebene Arten, welche mit Ausnahme der Stellaten und Anthospermeen fast nur in den tropischen und subtropischen Gebieten beider Hemisphären wachsen, ganz besonders ist das wärmere und trockene Süd-Amerika reich daran; die Stellaten sind hauptsächlich in der nördlieh gemässigten, die Anthospermeen in der sïdlich gemässigten Zone verbreitet.

Die Rubiaceen sind zunächst mit den Caprifoliaceen verwandt, mit denen sie, wie oben erwähnt, zuweilen zu einer Familie zusammengefasst werden. Von den Loganiaceen unterseheiden sie sich nur durch den unterständigen Fruchtknoten, so dass einige Formen, bei denen derselbe halboberständig ist Oldenlandia, Synaptantha von den Rubiaceen, Polypremum, Mitreola von den Loganiaceen), Übergangslieder bilden. Gärtnera und Pagamea rechnet man gegenwärtig aus Grïnden, die der Anatomie entnommen sind, trotz der fast oberständigen Fruehtknoten zu den Rubiaceen. Zu den Bignoniaceen zeigen sie dureh die Vermittelung der Henriquezieen nahe Beziehungen. Auch die Umbelliferen halte ich, trotzdem dass sie nicht in dieselbe Unterklasse gehören, mit ihnen verwandt.

Die officinellen Rubiaceen gehören in folgende Tribus:

TRIBUS I. Naucleeae. Fruchtknoten zweifächrig, in jedem Fache $\infty$ Samenanlagen. Frucht eine trockene, zweiklappig aufspringende Kapsel oder eine vielfächrige, zuweilen fleisehige Sammelfrucht (nur Cephalanthus hat einsamige Fruchtfäeher). Samen klein, meist geflügelt. Bliithen auf einem kugeligen, gemeinschaftlichen Blïthenboden kopfig zusammengedrängt, sitzend oder gestielt. Blumenkrone trichterförmig, mit meist dachziegelig deckenden, kurzen Lappen; Griffel weit hervorragend mit kopfiger oder mitraförmiger Narbe.

\section{Uncaria Gambir Roxb.}


TRIBUS II. Cinchoneae. Fruchtknoten zweifächrig, in jedem Fache $\infty$ Samenanlagen, die einer an der Scheidewand befestigten, selten von der Basis aufstrebenden oder hängenden Samenleiste angeheftet sind. Frucht trocken, zweiklappig aufspringend; Samen meist gefligelt. Blïthen gewöhnlich in decussirten Rispen, zahlreich, selten in einfachen Dichasien oder einzeln. Nebenblätter einzeln zwischen den Blattstielen.

2. Cinchona Ledgeriana Moens.

3. Cinchona succirubra Pav.

TRIBUS III. Psychotrieae. Blumenkronenzipfel mit klappiger Knospenlage. Fruchtknoten meist zweifächrig, in jedem Fache eine aufrechte Samenanlage, die am Grunde der Scheidewand befestigt ist. Frucht eine Steinfrucht mit 2 Steinen von plan-convexer Form, an der Bauchseite gefureht oder eingedrïckt, selten flach. Nährgewebe gewöhnlich hornig; Keimling etwas gekriimmt, Wtirzelchen nach unten gewendet. Nebenblätter einzeln zwischen den Blattstielen, zuweilen an der Spitze getheilt oder mehrspaltig.

4. Psychotria Ipecacuanha M. Arg. 


\section{UNCARIA Schreb.}

Fruchtknoten spindelförmig, gestielt, zweifächrig mit zahlreichen, aufrechten, schildförmigen, dachziegelig sich deckenden Samenanlagen, welche an einer, der Scheidewand aufsitzenden, flach gewölbten Samenleiste befestigt sind. Kelch trichterförmig verlängert, oder glockenförmig, kurz fünflappig. Blumenkrone trichter- oder präsentirtellerförmig, innen kahl, aussen nicht selten seidig behaart, fünflappig, mit dachziegeliger Knospenanlage. Staubgefässe am Schlunde befestigt, fast sitzend; Antheren am Grunde kurz geschwänzt. Nektarkragen fehlend. Stempel fadenförmig, lang hervorragend, mit kopfiger Narbe. Kapsel verlängert spindelförmig, zweifächrig, wandtheilig-zweiklappig aufspringend, vielsamig. Samen nach oben dachziegelig sich deckend, geflügelt, Flïgel am Grunde oft zweischwänzig; Keimling keulig, in fleischigem Nährgewebe, zusammengedrückt, Wurzel nach unten gewendet. - Klettersträucher, welche sich durch hakenförmige, aus verkümmerten Seitenzweigen entstandene Klimmorgane festhalten. Nebenblätter zwisehen den Blattstielen ganz oder zweispaltig. Blüthen gestielt, auf dem kugelförmigen, gemeinschaftlichen Bliithenboden dicht gedrängt sitzend und kopfförmige Inflorescenzen darstellend; diese gestielt, achselständig, einzeln oder zu decussirten Rispen verbunden.

Über 30 Arten, ron denen der grösste Theil dem malayischen Gebiete angehört, einige in Ostindien; in Afrika findet sich eine Art, in Siid-Amerika sind zwei vorhanden.

\section{Uncaria Gambir Roxb.}

Tafel 12.

Blätter oblong oder oblong-eiförmig, zugespitzt, ganzrandig, am Grunde gerundet oder in den Blattstiel kurz zusammengezogen, auf beiden Seiten fast ganz kahl; Bliithenstände einzeln, blattwinkelständig; Blumenkrone aussen seidenhaarig, gelblichweiss, getrocknet braun.

Uncaria Gambir*) Roxb. Fl. Ind. I. 517; DC. Prodr. IV. 437; Korth. in Temm. Nat. Geschied. Bot. t. 34; Miq. Fl. Ind.-Bat. II. 145; Hook. fl. Fl. Brit.Ind. III. 31; Bentl. and Trim. Med.pl.t. 139; Köhler, Mediz. Pf. t. 104; Flick. and Hanb. Pharmacogr. 298; Flïck. Pharmacogn. 210.

Uncaria acida Berg u. Schmidt, Darst. u. Beschr. t. XXXIII, kaum Roxb. od. Miq.

Nauclea Gambir. Hunt. in Trans. Limn. soc. IX. 218. t. 22; Hayne, Arzneigew. X. t. 3; Nees, Düsseld. Pf. Suppl.t. 7 .

Ourouparia Gambir Baill. Hist. des pl. VII. 350 mit Fig. 349-353.

Gambirstrauch; englisch: Gambier; französisch: Gambir.

Ein kräftiger, kletternder Strauch, der sich dureh fast kreisförmig gebogene, seitlich zusammengedriickte, kahle oder fast kahle, spitze oder von Rudimenten eines Blüthenstandes gekrönte Hakenzweige festhält. Die Zweige sind schlank und dünn, gerundet vierkantig, die jüngeren sind zuweilen fast stielrund und mit graubrauner, dïnner Rinde, die mit helleren Lenticellen bestreut ist, bekleidet.

Die Blätter sind gestielt, oblong oder eiförmig-elliptisch mit dem ca. $1 \mathrm{~cm}$ langen Stiele $8-12 \mathrm{~cm}$ lang, in der Mitte oder darunter $4-5,5 \mathrm{~cm}$ breit, kurz zugespitzt mit ein wenig verlängerter, zuweilen seitwärts gekriimmter Spitze, am Grunde gerundet, dann plötzlich in den Stiel kurz versehmälert, ganzrandig, lederartig, von 5-8 Paar aufstrebenden, auf der Rückseite vorspringenden Seitennerven durchzogen, in deren Achseln mehr oder weniger reichlich behaarte Domatien (Scrobiculae) befindlich sind, sonst sind die Blätter beiderseits kahl. Die Nebenblätter sind etwa $1 \mathrm{~cm}$ lang, an der Basis 6-7 mm breit, dreiseitig, spitzlich oder stumpf.

*) Die Schreibweise Gambir ist der englischen Gambier vorzuziehen.

Gewöhnlich wird noch der Funis uncatus angustifolius Rumph. Herb. Amboin. V. 64. t. 34. Fig. 2 unter den Synouymen aufgeführt; er gehört aber sicher nicht zu Uncaria Gambir Roxb. 
Der Blüthenstand ist achselständig, kugelförmig-kopfig; er hat 4,5-5,5 cm im Durchmesser und wird von einem $3-5 \mathrm{~cm}$ langen, festen, seitlich zusammengedrückten, horizontal abstehenden oder mehr nach unten gekrilmmten Stiele getragen; der letztere ist im oberen Drittel oder-Viertel gegliedert und wird hier von einer vierblättrigen Hülle, die als aus einem Blattpaare mit seinen Nebenblättern zusammengesetzt angesehen werden muss, umgeben. Der gemeinschaftliche Blithenboden ist etwas narbig, feinbehaart, kugelförmig.

Der Fruchtknoten ist mit den sehr kurzen Stielehen etwa $3 \mathrm{~mm}$ lang, schlank kreiselförmig, kurz und angedriickt grauseidig behaart. Der Keleh von der Länge des Fruchtknotens ist ebenfalls kreiselförmig, aber breiter und mehr oder weniger tief (bald nur zu einem Viertel, bald weit über die Hälfte) in 5 dreiseitige oder lineale mehr oder weniger stumpfe, an der Spitze ein wenig verdickte Lappen getheilt; aussen ist er dünn granhaarig, innen am Grunde mit einem deutliehen Haarringe versehen.

Die Blumenkrone ist sehlank trichterförmig, 1,2-1,3 cm lang und ist in 5 stumpfe, sehr breit zweircihig dachziegelig deckende Lappen getheilt, die von verkehrt eiförmiger Gestalt, stumpf, aussen wie die Röhre aber dichter behaart sind, innen am Grunde des Lappens befindet sich ein in der Mitte stehendes Haarbiischel; die Röhre ist innen kahl.

Die Staubgefässe sind fast sitzend, etwas nach aussen convex gekrïmmt; der Faden ist nahe an der zweischwänzigen Basis befestigt, oben haben die Beutel eine stumpfe, kurze Spitze. Die Pollenkörner sind klein, fast kugelig, mit 3 Poren, sie sind nahezu glatt.

Der Stempel ist fast von der doppelten Länge der Blumenkrone; er ist fadenförmig mit keulenförmiger, stumpfer, ungetheilter, graupapillöser Narbe.

Die Frucht ist den $0,5 \mathrm{~cm}$ langen Sticl und ebenso langen, stebend bleibenden Kelch eingerechnet, 2,5-3 em lang, 5-6 mm breit, 3-4 mm dick; sie ist lineal spindelförmig, etwas zusammengedrückt und wird von einer längs verlaufenden Furche jederseits durchzogen; sie springt in zwei auf dem Rücken fünfnervigen Klappen vom Grunde her auf.

Die Samen sind 7-8 mm lang, linealisch, oben zugespitzt, am Grunde mit 2 sehr schmalen Sehwänzen versehen, sie sind hell kupferroth mit braunem, kleinem kreisförmigem Nucleus.

Der Gambirstrauch ist auf der Halbinsel Malakka und auf den benachbarten Sunda-Inseln heimisch; er wird auch von Ceylon als wild vorkommend angegeben, indess scheint mir diese Pflanze, so weit ich sie aus den vorliegenden Exemplaren kenne, durchaus versehieden zu sein. Gegenwärtig wird sie in der Umgebung von Singapore, auf Java, Ceylon u. s. w. in grossem Massstabe cultivirt.

A nmerkung 1. Beziiglich der Länge des Kelehes und der Blumenkronenröhre fand ieh ziemlich erhebliche Differenzen; der erstere ist auch zuweilen nur bis zum ersten Viertel seiner Länge, zuweilen bis iiber die Hilfte getheilt. Bei einer cultivirten Pflanze sind solche Veränderungen nicht ungewöhnlich.

Anmerkung 2. Die Abbildung Tafel 12 giebt dieselbe Pflanze wieder, welehe in der ersten Auflage unter der Bezeichnung $U$. acida Roxb. gefïhrt wurde. Diese Art ist durchaus unsicher; Miquel vermuthete, dass sie mit $U$. ovalifolia Roxb. ïbereinstimmte. Ich habe das Original der Darstellung (Zollinger n. 133) lntersueht und gefunden, dass es unzweifelhaft Uncaria Gambir Roxb. ist.

Anmerkung 3. Die genate Befolgung der Gesetze über die Benennung der Pilanzen wirre erfordern, dass diese Art Ourouparia Gambir Baill. heissen muss.

Die lebenden Blätter und jungen Sprossspitzen der enltivirten Pflanze werden zur Darstellung einer Sorte Katechu (Terra japonica, Gambir-Katechu, Gutta Gambì) verwendet. Man koeht zu dem Zwecke die Pflanzentheile mit Wasser aus, dickt das Extract ein und lässt es dann in Holzkisten erstarren.

Erklärung der Abbildungen.

Fig. A. Oberer Theil eines Zweiges aus Java: a. Klimmhaken mit nicht entwickelten Bliithenständen.

Fig. B. Die Blithe, 3 mal vergr. : $b$. Fruchtknoten; $c$. Kelch; d. Blumenkrone; $c$. Staubgefitsse; $f$. Griffel.

Fig. C. Der Fruchtknoten im Längsschnitte, 6mal vergrös. sert: h. Samenleiste mit den Samenanlagen.

Fig. D. Derselbe im Querschnitte, 8 mal vergrössert.

Fig. E. Die Blumenkrone, 3 mal vergrüssert.
Fig. $F$. bis $H$. Staubgefässe $12 \mathrm{mal}$ vergrössert, von der Seite, von aussen und von innen betraehtet.

Fig. I. Pollenkörner, 200 mal vergrössert.

Fig. $K$. Der obere Theil des Griffes m. $d$. Narbe $g, 12$ mal vergr.

Fig. L. Die Frnelıt, natürliche Grösse.

Fig. $M$. Eine Klappe, von der Berïlirungsflitehe aus gesehen.

Fig. $N$. Eine Klappe im Qnerschnittc.

Fig. $O$. Der Same einer anderen Art. 


\section{CINCHONA L.}

Fruchtknoten zweifächrig mit sehr vielen aufsteigend dachziegelig deckenden, aufrechten Samenanlagen, an schmalen Placenten, welche der Scheidewand aufsitzen, befestigt. Kelch kurzglockig, fünfzähnig, im Innern zuweilen mit einzelnen Drüsen unter den Buchten. Blumenkrone präsentirtellerförmig, funflappig, aussen dïnnfilzig, Lappen am Rande mit langen Haaren besetzt, klappig deckend; Röhre cylindrisch oder fünfkantig, am Schlunde meist behaart. Staubgefässe 5 entweder an der Mitte oder in der Nähe des Grundes angeheftet, eingeschlossen oder den Schlund etwas überragend, Antheren linealisch. Nektarkragen Discus) einen polsterförmig'en Ring bildend. Griffel fadenförmig cingeschlossen oder hervorragend, mit 2 auf der Innenseite papillösen Narben. Kapsel fachtheilig vom Grunde her aufspringend, oben durch den stehenbleibenden Kelch zusammengehalten, die Spalte setzt sich in das Bluthenstielehen fort; die Placenten lösen sich von der Scheidewand und werden von den Klappen umsehlossen, die sich später zuweilen flach ausbreiten. Samen sehildförmig, gefligelt, am Grunde geschwänzt; Keimling klein, im fleischigen Nährgewebe, Würzelchen nach unten gewendet, Keimblätter flach, oblong. - Bäume, selten Sträucher, mit ganzen, abfälligen Nebenblättern, die zwischen den Blattstielen stehen, sie sind anf der Innenseite am Grunde drisig. Blithen dimorph, mässig gross, in reichblüthige decussirte Rispen zusammengestellt, weiss oder rosa, wohlriechend.

Etwa 30-35 schwer zu unterscheidende Arten, welche nur auf den Anden des tropischen Amerikas, besonders in Peru, Bolivia und Quito wachsen. Mehrere Arten in vielen Formen und anch deren Bastarde werden gegenwärtig in den Gebirgen der Tropen vielfach eultivirt.

Anmerkung. Da der Name nach dem der Grifin Chinchon gebildet worden ist, so sollte man dem Vorgange von Markham, Seemann u. A. folgen, welche die Bezeichnung Chinchona vorgezogen haben, falls man nicht den der Prioritit nach berechtigten Namen Quinquina Condam. voranstellen will.

\section{Cinchona Ledgeriana Moens.}

\section{Tafel 13 .}

Blätter oblong oder oblong-lanzettlich, spitz, kahl, oberseits saftiggrïn, unterseits rothviolett; Blüthen klein, griinlich, innen weiss, oft hängend; Früchte kurz, schwach gerippt, von dem kleinen Kelche gekrönt.

Cinchona Ledgeriana Moens in Trimen, Journ. of bot. XIX. 323. t. 221 u. 222.

Cinchona Calisaya Wedd. et How. in Quinol. Ind. plant. 84. t. 4-0. (1576); Fliickig. Pharmacogn. 495; Bentl. and Trim. Med. pl. t. 141.

Das mässig hohe, spärlich verzweigte Bäumchen hat eine pyramidale, lockere Krone und zeigt keineswegs die stattliche äussere Erscheinung der tibrigen Cinchona-Arten. Die Rinde ist ziemlich glatt und gewöhnlich rein von Flechten und Moosen. Die noch grinen Äste sind stumpf vierkantig, später werden sie stielrund und sind dann mit kastanienbrauner Rinde bekleidet; die jünsten seitlich zusammengedrückten Schosse tragen eine anliegende broncefarbene oder röthlicholivgrüne Behaarung, welche sich bald verliert, die aber die Bäumchen schon von weitem kenntlich macht.

Die Blätter sind kurz gestielt; der Stiel ist im Querschnitte halbkreisförmig, oben flach; er ist dicht mit orangefarbenen Punkten bestreut und erreicht höchstens eine Länge von $1 \mathrm{~cm}$; die papierartige, nicht lederartige Spreite durehläuft alle Formen vom Lanzettlichen zum Oblongen, sie ist $5-15$ (selten bis 20 ) $\mathrm{cm}$ lang und fast genan in der Mitte $1-5$ (selten bis 6,5 ) $\mathrm{cm}$ breit; am oberen Ende ist sie spitzlich oder 
stumpflich, am Grunde verschmälert sie sich oder sie spitzt sich kurz zu; sie ist im erwachsenen Zustande auf beiden Seiten kahl, nur in den jüngsten Zuständen ist sie behaart; anf der Oberseite ist sie saftig grün und ein wenig glänzend; auf der Unterseite ist sie matt, heller, später gewöhnlich schön rothviolett; der Mittelnerv, welcher wie die 5-7 Seitennerven hier vorspringt, ist am Grunde mit orangefarbenen Punkten bestrent; die Blattscrofeln (scrobiculae) sind nur an dem oberen Theile des Blattes wahrnehmbar, sie sind stark vertieft und berandet, aber nicht behaart; sie dienen wie bei anderen Arten Milben zur Wohnstätte (Domatien Lundström's). Die Nebenblätter sind eiförmig-dreiseitig, spitz, kahl, auf dem Rücken gekielt, innenseits tragen sie am Grunde zahlreiche fingerförmige Drüsen; sie fallen sebr schnell ab.

Der Blïthenstand ist eine endständige, aufrechte, decussirte, nicht sehr umfangreiche Rispe, welche durch Zweige aus den obersten Laubblättern bereichert wird und deren Seitenstrahlen in Dichasien auslanfen; sie ist mit einer kurz filzigen Behaarung versehen. Die Bliithen sind kurz, aber deutlich gestielt, sie stehen am Ende der Seitenzweige gehäuft, spreizen oder sind nach unten geneigt. Die Vorblättchen sind kurz (1 mm lang), sitzend, oblong-dreiseitig, spitz, schuppenförmig, anf dem unteren Rücken kurz filzig; sie fallen bald ab.

Der Fruchtknoten ist umgekehrt kegelförmig, 1,5 mm lang und hat $1 \mathrm{~mm}$ im oberen Durchmesser; er ist sehr fein behart. Der Kelch misst $1 \mathrm{~mm}$ in der Länge, er ist kurz becherförmig und kaum bis zur Mitte in 5 dreiseitige, spitze Zähne getheilt; seine Bekleidung nimmt von unten, wo sie so dicht wie die des Fruchtknotens ist, nach oben hin ab, an der Spitze sind die Zähne kahl. Die Blumenkrone ist 7-8 mm lang, im Knospenzustande leicht keulenförmig, da die Röhre am Ende nur wenig erweitert ist; sie ist im oberen Drittel in oblong-dreiseitige, stumpfliche, mit langen Randhaaren besetzte Zipfel von weisser oder crêmegelber Farbe getheilt; die Röhre ist aussen gelblichgriin. Bei der langgriffligen Form erreichen die mit schmallinealen, oben stumpflichen Beuteln versehenen Staubgefässe den Kronensaum nicht, während der Griffel um $1 \mathrm{~mm}$ iber denselben hervorragt; in der kurzgrifflichen Form ist das Verhältniss umgekehrt; dem Procentsatze nach kommen beide in Asien etwa gleich häufig vor. Der Griffel ist fadenförmig und trägt am Ende 2 ei-lanzettliche, zusammengeneigte Narben.

Die Frucht ist eine $8-12 \mathrm{~mm}$ lange, $6-8 \mathrm{~mm}$ unterhalb der Mitte breite, bis $5 \mathrm{~mm}$ dicke Kapsel von ei-oblongem, zuweilen auch kurz-elliptischem Umrisse; sie ist nach oben hin zugespitzt und wird von dem kurzen Kelche, dessen Zähne aufrecht stehen, gekrönt; die brannen Kapselklappen sind fünfnervig.

Die Samen sind c. $5 \mathrm{~mm}$ lang und $2 \mathrm{~mm}$ breit, von Farbe hellbraun, auf der einen Seite convex, auf der anderen concav; am Rande sind sie gefranst, am oberen Ende ansgerandet oder eingeschnitten, am unteren zweischwänzig.

Der Keimling misst kanm $1 \mathrm{~mm}$ in der Länge und $0,7-0,8 \mathrm{~mm}$ in der Breite, er ist flachgedrückt und hat einen oblongen Umriss.

Diese Pflanze, gregenwärtig die wichtigste aller cultivirten Cinchonen Asiens, wurde zuerst in einer Gruppe von 50-60 Exemplaren an den fast unzugänglichen Felsenufern des Rio Namore in Bolivia von einem Diener Ledger's Namens Manuel Inera Mamani Juni 1865 gefunden; seitdem hat sie wohl Niemand mehr in wildem Zustande gesehen. Die Samen wurden von der holländischen Regierung gekauft und nach Java geschickt. Gegenwärtig wird sie auch in Oatacammnd, in Sikkim und auf Ceylon enltivirt.

Anmerkung. Gewöhnlich wird C. Ledgeriana Moens für eine Varietät der C. Calisaya Wedd. gehalton; wir können dieser Meinung nicht beipflichten, sind vielmehr der Ansicht, dass sie in die Verwandtschaft der C. micrantha R. et Pow. gehört. Sie hat mit ihr vor allem die klcinen, grïnlichweissen Blithen gemein, welche sonst keiner der bekannten Arten zukommen; sie unterscheidet sich aber durch die Form der viel breiteren Frichte und durch die schmäleren, weniger lederartigen Blätter, die am Grunde, wie der Stiel, orangefarben sind. 


\title{
Erklärung der Abbildungen.
}

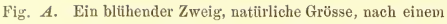
von $0 . \mathrm{K} n \mathrm{nze}$ in Java gesammelten Exemplare.

Fig. B. Ein Fruchtzweig.

Fig. C. Eine Bliithenknospe, 3fach vergrössert.

Fig. D. Eine Blithe, 4 fach vergrössert.

Fig. $E$. Die Blumenkrone, längs aufgeschnitten (kurzgrifflige Form), 4fach vergrössert.
Fig. F. Der Frnchtknoten im I ïngsehnitte mit dem Griffel der langgriffligen Form, 4fach vergrössert.

Fig. $G$. Der Fruchtknoten im Querschnitte, Smal vergrüssert.

Fig. $H$. Der Same, natïrliche Grösse.

Fig. I. Derselbe, $10 \mathrm{mal}$ vergrössert.

\section{Cinchona succirubra Pav.}

\author{
Tafel 14.
}

Blätter breit elliptisch bis eiförmig, spitz oder stumpflich, am Grunde gerundet oder gestutzt, unterseits kurz behaart, oberseits fast ganz kahl, krautig; Blüthen aufrecht, sitzend, fast doppelt so lang als an der vorigen Art, rosenroth mit weissen Randhaaren; Frucht sehr lang, linealisch, an beiden Seiten zugespitzt, von dem ein wenig vergrösserten Kelche gekrönt.

Cinchona succirubra Pavon ms. bei Mlotzsch in Abhandl. der Kgl. Akad. der Wissensch. zu Berlin 155s. p. 60.t. 1 u. 2; How. in Pharmac. journ. XI. 497; How. Nueva Quinologia t. 8; Bentl. and Trim. t. 142; Baill. Hist. pl. VIII. 342, xylogr. 341; Flìckig. Pharmacogn. 425; Köhler, Mediz. Pfl. t. $79^{b}$.

C. concava Pav. ms.

Cinchona ovata Ruiz et Pav. var. $\gamma$. erythroderma Wedd. Hist. nat. des Quinquinas p. 63; in Bull. soc. bot. France 1855. n. 7 .

Der stattliche Baum erreicht eine Höhe bis $25 \mathrm{~m}$, gewöhnlich aber übersteigt er 10-12 m nicht und hat an dem Grunde einen Durchmesser von $0,6-0,9 \mathrm{~m}$; der Stamm ist aufrecht und kräftig, die Krone ist gross und gerundet; die Rinde ist braun, querrissig und mit Flecken von hellerer Farbe versehen; die jïngeren Zweige sind mit dem charakteristischen, silberartig schimmernden Periderm der rothen Chinarinde bedeckt; die blühenden $Z$ weige sind stumpf vierkantig; etwas zusammengedrickt und an der Spitze mit einem kurzen, in trockenem Zustande rostfarbigen Filze bekleidet.

Die Blätter sind verhältnissmässig gross und haben eine ziemlich dünne, krautige Beschaffenheit; der Blattstiel misst $1,5-5 \mathrm{~cm}$ in der Länge, er ist von halbkreisförmigem Querschnitte, oben flach und in der Mitte von einer seichten Rinne durchzogen; er ist rostfarbig behaart; die Spreite hat eine Länge von $10-30 \mathrm{~cm}$ und unterhalb der Mitte eine Breite von $10-25 \mathrm{~cm}$; sie ist breit elliptisch oder echt eiförmig, an der Spitze stumpflich oder spitz, am Grunde gerundet oder gestutzt und kurz in den Blattstiel zusammengezogen; sie wird jederseits des Mittelnerven von 8-10 Paar Seitennerven durchzogen, deren unterste rechtwinklig mit dem Mittelnerven znsammenstossen; die Unterseite ist kurz und dünn, nur an den Nerven dichter behaart, sie fühlt sich aber weich an, von Farbe ist sie hellgrïn; die Oberseite ist an ausgewachsenen Blättern fast ganz kahl, sie ist saftig grün; die Blattscrofeln (scrobiculae) sind nicht sichtbar. Die Nebenblätter sind breit linealisch, spitz mit abgestumpftem Ende, aussen sind sie wenig behaart, am Grunde der Innenseite tragen sie zahlreiche fingerförmige Drüsen; sie fallen schnell ab.

Der Blüthenstand ist eine grosse, weitschweifige, endständige, decussirte Rispe, die durch Äste ans den oberen Blattpaaren bereichert wird; hie und da werden in derselben kleinere und schmälere laubige Deckblätter beobachtet. Die Deckblättchen sind eiförmig dreiseitig, aussen kurz behaart, sie sind abfällig.

Die Blüthen stehen gedrängt an den Enden der letzten Verzweigungen in dichasialen Verbänden; sie sind sitzend und aufrecht. Der Fruchtknoten ist umgekehrt kegelförmig, er hat 2 mm Länge und einen Durchmesser von $1 \mathrm{~mm}$; er ist kurz behaart. Der Kelch ist 1,5 mm lang, kurz glockenförmig, oben etwas erweitert, bis zur Hälfte in 5 eiförmig-dreiseitige, spitze Zähne gespalten, aussen ist er wie 
der Fruchtknoten, doch minder dicht behaart, innen kahl und unter jeder Bucht mit einer sehr kurzen, derben, fleischigen Drtise versehen. Die Blumenkrone ist 1,5 cm lang, im oberen Viertel fünflappig, die Lappen sind oblong-dreiseitig, innen mit weissen Randhaaren dicht bedeckt; sie ist aussen kurzfizig, von Farbe rosaroth; die Knospe ist deutlich keulenförmig. Die Sta ubgefässe der kurzgriffligen Form *) sind unterhalb der Röhrenmitte befestigt und ragen mit den Spitzen ein wenig tiber den Sehlund hervor, sie sind $7 \mathrm{~mm}$ lang, wovon auf die Beutel die reichliche Hälfte kommt. Der Griffel hat die halbe Länge der Blumenkronenröhre, er endet in 2 Narben von lanzettlicher Form.

Die Kapsel ist verhältnissmässig sehr lang (sie ist die längste in der ganzen Gattung), sie misst mit dem sehr kurzen Fruchtstielchen bis zu 5,5 cm, hat eine Breite von 7 -8 und eine Dicke von $4 \mathrm{~mm}$; sie ist linealisch bis lanzettlich, an beiden Enden mehr oder weniger zugespitzt, von Farbe braun, dünn und kurz behaart, von dem sich ein wenig vergrössernden Kelche gekrönt; die Klappen werden von 5, nur mässig vorspringenden Nerven durehzogen.

Der Same ist verhältnissmässig gross; er wird bis $1 \mathrm{~cm}$ lang und $2 \mathrm{~mm}$ breit, er ist hell kupferfarben und gewöhnlich oben kurz, unten lang zweischwänzig.

Dieser Chinabaum war ehedem in der Serra de S. Antonio der Provinz Huaranda in Quito weit verbreitet, ist aber dort fast völlig ausgerottet worden; gegenwärtig findet er sich hauptsächlich in den Gebirgen stidlich vom Chimborazzo, in den Distrikten von Riobamba, Cuenca und Alausi, wo er bis tief in die Thäler herabsteigt. Er wächst besonders an steinigen und abschüssigen Abhängen zwischen 800 bis $1600 \mathrm{~m}$ und stellt somit diejenige Art von Cinchona vor, welche die Höhengrenze nach dem Meere hin bildet. In den Nilgherris von Vorder-Indien wird er zwischen $1600-2400 \mathrm{~m}$, auf Ceylon zwischen 600 bis $1600 \mathrm{~m}$ cultivirt; auch auf Java wird er in den Chinagärten gezogen. Die Blithezeit fällt in der Heimath in den Juli und Augnst.

Anmerkung. Die Pflanze fällt in ihrer Umgebung dureh das während des Absterbens lebhaft roth gefärbte Lanb ausserordentlich auf. Der Name rïht daher, dass der austretende wasserhelle Saft bald milchig wird und schnell eine blutrothe Farbe annimmt.

Cinchona Ledgeriana Moens und Cinchona succirubra Pav. liefern einen Theil der Chinarinden, welche in den Apotheken verbraucht werden, und dienen anch in hervorragendem Maasse zur Gewinnung des Chinins. Die Drogistenrinden sind Rinden der Stämme und dickeren Zweige der Bäume. Ihre Anwendnng in der Medicin verdanken die Rinden dem in ihrem Parenchym vorkommenden Alkaloiden, vorzüglich dem Chinin, neben dem sich in grösseren Mengen auch Chinidin, Cinchonin und Cinchonidin finden. Die Rinde von Cinchona Ledgeriana kann bis $13 \%$ Alkaloide, darin bis $11 \%$ der Rinde Chinin enthalten, doch ist der Alkaloidgehalt der Ledgeriana-Rinde sehr wechselnd und kann selbst bis auf $0,1 \%$ sinken. Der Wurzelrinde der beiden Pflanzen ist reich an Alkaloiden, gelangt aber nicht in die Apotheken.

\section{Erklärung der Abbildungen.}

Fig. A. Ein blühender Zweig nach einem Pavon'schen Originalexemplare von der Serra de S. Antonio, natïrliche Grösse.

Fig. B. Die Blüthenknospe, 3mal vergrössert.

Fig. C. Die Blïthe, kurzgrifflige Form, 3mal vergrössert.

Fig. D. Die Blumenkrone, aufgeschnitten, 3mal vergrössert.

Fig. E. Ein Staubgefäss von innen betrachtet, $5 \mathrm{mal}$ vergr.
Fig. $F$. Dasselbe von aussen betrachtet.

Fig. $G$. Der Fruchtknoten mit dem Griffel, 5mal vergrössert.

Fig. $H$. Derselbe im Längsschnitte.

Fig. I. Derselbe im Querschnitte.

Fig. $K$. Frïchte, natiurliche Grösse.

Fig. $L$. Samen, natürliche Grösse.

*) Wir haben nur diese untersucht. 


\section{PSYCHOTRIA L.}

Fruchtknoten zweifächrig, mit je einer am Grunde der Scheidewand angehefteten Samenanlage. Kelch sehr verschieden, kurz becherförmig oder verlängert röhrenförmig, bleibend oder abfällig, zuweilen bei der Fruchtreife sich vergrössernd. Blumenkrone röhren-, trichter-, glocken- oder radförmig, meist fünf(seltener vier-, oder sechs- bis acht-)lappig mit klappiger Knospenlage, Röhre gerade, seltener gebogen, am Schlunde kahl, behaart oder bärtig. Staubgefässe so viel wie Blumenkronenabschnitte, der Röhre oder dem Schlunde in verschiedener Höhe angeheftet, eingeschlossen oder hervorragend. Nektarkragen ringförmig oder zweilappig, gewöhnlich dick polsterförmig. Griffel eingeschlossen oder hervorragend, an der Spitze in meist 2 stumpfe oder spitze, innen papillöse Narben getheilt. Frucht steinfruchtartig mit fleischigem, oft wässrigem, endlich eintrocknendem Exocarp, mit meist 2 Steinen, die gewöhnlich planconvex, oft auf dem Rïcken gerippt, auf der Bauchseite eingedriickt sind. Same von der Form der Steine, mit fleischigem, gleichförmigem oder zerkliftetem (ruminatem) Nährgewebe. Keimling meist klein, mit flachen, blattartigen, Keimblättern und nach unten gervendeten Wiirzelchen. - Sträucher, selten Bäume oder Kränter, zuweilen kletternd oder epiphytisch wachsend, mit krenzgegenständigen, seltener quirligen Blättern, Nebenblätter zwischen den Blattstielen frei oder scheidig verwachsen, zuweilen in viele Zipfel zersehlitzt. Blïthen nicht selten dimorph, gewöhnlich in decussirten, weitschweifigen, lockeren oder gedrängten Rispen, die manchmal zu halbkugeligen, von Hochblättern umhtillten Köpfen zusammengezogen sind; die lockeren Inflorescenzen gehen in Dichasien aus.

Über den Umfang der Gattung ist man sehr verschiedener Ansicht und demgemäss wird die Zahl der Arten verschieden angegeben. Nach Baillon's Meinung, welcher die weitgehendste Zusammenfassung der urspriinglichen Gattung mit den benachbarten geïbt hat, mitsste sie zu den umfangreichsten des ganzen Pflanzemreiches zählen und mindestens 1000 beschriebene Arten in sich begreifen. Lässt man dagegen auch geringere Unterscheidungsmerkmale für die Charakterisirung der Gattungen zu, eine Anschauung, die ich für angemessen erachte, so sinkt die Zahl bis auf c. 600 Arten. Diese sind innerhalb der Tropen der ganzen Erde verbreitet, besonders aber sind sie in Siid-Amerika entwickelt, Brasilien allein beherbergt fast die Hälfte aller Arten.

\section{Psychotria Ipecacuanha Müll. Arg.}

Tafel 15.

Unterirdisches Rhizom horizontal kriechend, mit theils fadenförmigen, theils angeschwollenen, wulstigen oder geringelten Wurzeln; oberirdischer Stengel aufstrebend, endlich aufrecht, oben dicht kurzhaarig; Blätter oblong; schmal umgekehrt eiförmig oder eiförmig-elliptisch, beiderseits schärflich rauh, dünnhäutig; Nebenblätter scheidig verwachsen, tief zerschlitzt; Blüthenstand kopfig, gewöhnlich von 4 herzförmigen Hïllblättern gestützt, wenigbliithig, erst aufrecht, dann hängend.

Psychotria Ipecacuanha Miull. Arg. Flora Brasil. VI. (5.) 341. t. 52; Flückig. Pharmacogn. 390; Köhler, Mediz. Pfl. t. 105.

Psychotria emetica Vellozo, Fl. Fluminensis II. t. 22, text. ed. Netto, 62.

Cephaëlis Ipecacuanha Willd. in Berlin. Jahrb. Pharmac. 1804.p. 75. t. 1 (1804); Ach. Rich. in Bull. fac. méd. IV. 92 (1818); Hist. diff. esp. d’Ipéc. du commerce 21. t. 1 (1820); Hayne, Arzneigew. VIII. t. 20; St. Hit. Pl. us. t. 6; Mart. Spec. mat. med. Brasil. 1825. p. 4. t. 1 u. 8; Nees, Düsseld. Abb. t. 257; 
DC. Prodr. IV. 535; Guimp. u. Schlecht. Abt. I. 75. t. 43; Woodv. and Hook. Med. bot. IV. t. 274, V.t. 6; Bot.Mag. t. 4063; Berg u. Schmidt, Darst. u. Beschreib. XV ${ }^{c}$; Bentl. and Trim. Med. pl. t. 145; Flick. and Hanb. Pharmacogr. 331; Balf. pat. in Trans. Edinb. soc. XXVI. 781. t. 31 u. 32.

Cephaëlis emetica Pers. Enchivid. I. 203.

Ouragoga Ipecacuanha Baill. Hist. pl. VIl. 281 u. 282, xylogr. 262-264.

Ipecacuanha officinalis Arruda, Disc. 44.

Callicocca Ipecacuanha Brotero in Trans. Linn. soc. VI. 187. t. 11.

Ouragoga Linn. Hort. Cliff. 486 (1736), Gen. pl. ed. I. 378; Wickman in Linn. Amoen. acad. VIII. 240.

Ipecacuanha Marcgr. Brasil. ed. 1645. p. 17; Piso, Hist. nat. Ind. utriusque ed. 1645.p. 101, ed. 165s. p. 231, cum xylogr.; B. A. Gomez, Memoria sobre a Ipee. fusca do Brasil ou Çipo das nossas boticas, Lisboa 1801 cum icone.

Ipé-cá́-geéne der Eingeborenen Brasiliens (nach Martius), corrumpirt zu Picahonha; Poaya, Poaya preta oder Poaya verdadeira der anderen Brasilianer.

Brechwurzel; französisch: Racine d'Ipécacuanha annelée; englisch: Ipecacuan.

Das verholzte, 2-3 mm im Durehmesser haltende Rhizom kriecht horizontal in mässiger Tiefe unter der Erdoberfläche und sendet abwechselnd rechts und links aufstrebende, endlich aufrechte, krantige Stengel uiber dieselbe, welche gewöhnlich nur $15-25 \mathrm{~cm}$, seltener bis $40 \mathrm{~cm}$ in der Länge messen. Jenes ist stielrund und mit entfernt stehenden Narben der kreuz-gegenständigen, schuppigen Niederblätter versehen, in trocknem Zustande ist es gelbgran.

Die Wurzeln erreichen eine Länge von $10-20 \mathrm{~cm}$, sie sind hin- und hergebogen, zuerst fadenförmig, dann schwellen sie an, und es entstehen die eharakteristischen Einschnïrungen, welche spiralförmig den Körper umziehen und ihn zerklüften; sie sind in jugendlichem Zustande weiss, später werden sie graugelb.

Der oberirdische Stengel ist deutlich vierkantig; die Kanten entspringen unterhalb der Blattansätze, und sie weehseln desshalb von Internodium zu Internodium; die jüngsten Theile sind mit sehr kurzen, abstehenden, bräunlichgriinen Haaren dicht bekleidet.

Die Blätter befinden sich zu 3-5 Paaren an der blühenden Pflanze, die untersten fallen frïhzeitig ab und hinterlassen wulstige Narben; der Blattstiel ist 5 bis höchstens $15 \mathrm{~mm}$ lang und verhältnissmässig sehwach; er ist von den Seiten her zusammengedrückt, auf der Oberseite rinnig und ringsum wie der jungere oder obere Stengel bekleidet; die Spreite misst 6-12 cm in der Länge und hat in der Mitte oder im oberen Drittel eine Breite von 2,5-3,5 cm; sie ist oblong oder schmal eiförmig oder umgekehrt eiförmig, am oberen Ende spitzlieh, am Grunde in den Blattstiel versehmälert; sie wird von 5-6 Paar Nebennerven durchzogen; in der Jugend ist sie gleich dem Stengel behaart, später fallen die Haare ab, die stehenbleibenden Basen bringen damn auf dem Blatte an beiden Seiten eine gewisse Rauhigkeit hervor. Die Nebenblätter sind 6-8 mm lang, unter einander und mit dem Blattstiele $2 \mathrm{~mm}$ hoeh scheidig verwachsen; sie sind bis tiber die Hälfte in $7-9$ pfriemförmige, in frischem Zustande an der Spitze mit einem Drïsenköpfchen versehene Zipfel gespalten, die von der Mitte nach der Seite hin an Grösse abnehmen.

Der Blïthenstand ist ein endständiges Köpfehen, das 1,5-4 cm lang gestielt ist; zuerst steht es anfrecht, später hängt es über; der Stiel ist mit kurzen, griübraunen Haaren dicht bekleidet; das Köpfchen wird von 4 herzförmigen oder gerundet rhombisehen, kurz zugespitzten, krautigen, anssen diunn weichhaarigen Hüllblättern eingeschlossen, wclehe in der Länge den Blüthen gleichen. Der letzteren sind nur wenige (9-12) vorhanden, sie können zu 4, vor den Blättern stehenden Gruppen zusammengefasst werden, welche eine mittelständige Blüthe umgeben; jede Gruppe wird wieder von häutigen, ei-lanzettlichen Hüllblättern eingeschlossen, welche die Vorblätter der Hauptblitthe und die Deckblätter der Seitenblüthen jeder Gruppe ausmachen. Der Fruchtknoten ist 1,5 mm lang, oblong, ein wenig seitlich zusammengedrïckt und besteht aus 2 Fruchtblättern; er ist kurz weichhaarig. Der Keleh ist wenig länger als $0,5 \mathrm{~mm}$, kurz fünfähnig, kahl, nur die Zähne sind sehr fein bewimpert. Die Blumenkrone ist 
5-6 mm lang, weiss, glockig-trichtertörmig, im oberen Viertel fünflappig, aussen an der oberen Hälfte kurz weichhaarig, innen an der unteren Hälfte zottig. Bei der langgriffligen Form sind die sitzenden Staubgefässe in der Mitte der Röhre angeheftet, der kurz zweispaltige Griffel überragt die Blumenkrone ein wenig; die Narben sind zuriickgekriimmt; bei der kurzgriffligen sind die Staubbeutel auf langen Filamenten über den Blumenkronensaum gehoben, und der Griffel mit wenig spreizenden Narben äberragt kaum die halbe Röhre. Der Nektarkragen ist verhältnissmässig hoch und polsterförmig.

Die Steinfrucht hat zuletzt nur ein diinnes, weiches Fleiseh; sie ist zuerst von purpurrother, dann schwarzvioletter Farbe; sie zeigt getrocknet eine eigenthümliche spirale Drehung der drei schwach auf dem Rïcken jeder Hälfte vorspringenden Rippen und wird von dem kurzen, bleibenden Kelche gekrönt.

Der Same ist planeonvex, auf der Innenseite von einer Furche durehzogen.

Die Ipecacuanha wächst nicht selten und gewöhnlich sehr gesellig in den schattigen Wäldern der Provinzen Rio de Janeiro, Minas Geraës, Mato Grosso, Bahia, vielleicht auch Pará und Maranhão Brasiliens und findet sich auch noch in Bolivien und Neu-Granada. Sie blitht Januar und Februar.

Anmerkung I. Schon Balfour pat. hat zwei Formen der Pflanze unterschieden, von denen die eine durch einen mehr verholzten, dickeren Stengel, lederartige, glatte Blätter mit ein wenig gebuchteten Räudern und nur sehr spärlicher Behaarung ausgezeichnet ist, während die zweite, welche wir oben beschrieben haben, durch einen mehr krautigen, dïnneren Stengel, bäutige, rauhe Blïtter und dichtere Behaarung gekennzeichnet wird. Jene wird seit alten Zeiten in den botanischen Gärten cultivirt, diese aber ist nur selten in den Gärten gezogen worden, die vorliegende Tafel giebt ein Exemplar aus dem Berliner Universitätsgarten wieder. Gegenwïrtig ist dieselbe kaum noch irgendwo in Europa vorhanden. Die erstere ist in dem Edinburger botanischen Garten in grossen Mengen vermehrt worden, und die so gewonnenen Pflanzen sind der Grundstock der umfangreichen Culturen zu Rungbi in Ost-Indien geworden. Die Pflanze kann durch Würzelstïcke und selbst dureh Blätter leicht und reichlich vermehrt werden.

Ob beide Pflanzen wirklich in dieselbe Art eingeschlossen werden können, scheint nicht ganz sicher, doch können erst genaue Untersuchungen darïber Aufschluss geben.

In Brasilien führen noch eine Menge anderer Pflanzen den Namen Poaya, welche theilweise zu den Rubiaceen, theilweise zu anderen Familien gehören. Von den ersteren nenne ich die Poaya branca oder Poaya do campo und die Poaya do Rio oder da Praya. Als Poaya branca oder do campo fassen die Brasilianer mehrere Spermacoceen zusammen, besonders wird die Richardsonia Brasiliensis Gomez, welche mit R. scabra L. durchaus nicht identisch, sondern durch die Beschaffenheit der Samen, von ihr vollkommen verschieden ist - alsdann werden aber auch Borreria capitata DC., B. Poaya DC. und Diodia polymorpha Cham. et Schlecht. mit diesem Trivialnamen belegt. Die Poaya do Rio oder da Praya ist Machaonia Brasiliensis Ch. et Schl, alle diese Pflanzen scheinen in den Wurzeln brechenerregende Eigensehaften zu besitzen, und die eine oder die andere hat friher wohl ein Surrogat der Ipecacuanha geliefert. Aus anderen Familien seien Polygala Poaya Mart. (P. angulata DC., beide Namen sind in demselben Jahre 1824 veröffentlicht) und Jonidium Ipecacuanha Vent. erwähnt.

Anmerkung II. Der von Piso ganz vortrefflich abgebildeten Pllanze gab Linné zuerst den Namen Ouragoga, den er auch als Gattung in den Gen.pl. ed. I. beibehielt. Diese Gattungsbezeichnung ist allen anderen vorzuziehen, mag man nun Müller Arg. folgend, die Pflanze bei Psychotria unterbringen, oder sie bei Cephaëlis belassen, denn Psychotria wurde von Linné erst in Syst. ed. X. 929 (1759) und Cephaètis von Swartz in Prodr. 4 (1788) aufgestellt. Nach den Regeln der Prioritï heisst die Ipecacuanha also Ouragoga Ipecacuanha Baill.

Medicinische Verwendung finden die als Reservestoffbehälter dienenden verdickten Nebenwurzeln der Pflanze, in deren stärkehaltigem Rindenparenchym das giftige Emetin vorkommt, als Radix Ipecacuanhae. Die grösste Menge der Droge wird jetzt noch von wildwachsenden Pflanzen in Brasilien gesammelt, doch ist es wahrscheinlich, dass die von den Engländern in Indien eingerichtete Cultur der Pflanze bald eben so grosse Quantitäten der Droge in den Handel liefern wird, wie Brasilien.

\section{Erklärung der Abbildungen.}

Fig. A. Eine blühende Pflanze nach einem in Berlin cultivirten Exemplare, natïliche Grösse: a. Rhizom; $b$. oberirdischer Stengel; $c$. Wurzeln; $d$. Nebenblätter.

Fig. B. Nebenblattscheide, aufgeschnitten, 2 fach vergrössert.

Fig. C. Ein Blïthenköpfchen, schief von unten gesehen, um die 4 Hüllblätter zu zeigen, natürliche Grösse.

Fig. D. Eine Blithenknospe mit dem Deckblatte, 4 mal vergrössert: $e$. Deckblatt; $f$. Fruchtknoten; $g$. Kelch; $\hbar$. Blumenkrone.

Fig. E. Eine geöffnete Blïthe, 4 fach vergrössert: $i$. Staubgefässe.
Fig. $F$. Dieselbe, der Länge nach aufgespalten und ausgebreitet: $k$. Nektarkragen; $l$. Griffel.

Fig. $G$. Der Stempel, 7mal vergrössert: $m$. Narben.

Fig. $H$. Der Fruchtknoten im Längsschnitte, 12mal vergrössert: $n$. Samenanlagen.

Fig. $I$. Derselbe im Querschnitte.

Fig. $K$. Der Kelch aufgeschnitten und ausgebreitet, 14mal vergrössert.

Fig. $L$, Staubgefässe von innen, von aussen und von der Seite betrachtet, $16 \mathrm{mul}$ vergrössert.

Fig, $\boldsymbol{M}$. Pollenkörner, c. $300 \mathrm{mal}$ vergrössert. 


\section{Reihe: Campanulinae A, Br.}

Blüthen aktinomorph oder zygomorph, sie sind durch alle Kreise fünfzählig, nur im Frnchtblattkreise nicht selten gemindert. Der Fruchtknoten ist unterständig. Der Kelch ist krautig mit offener Aestivation. Die Staubgefässe sind gewöhnlich nicht mit der Blumenkrone verbunden.

\section{Familie: Cucurbitace ae Hall.}

Die Blüthen sind getrenntgeschlechtig, ein- oder zweihäusig. Der Fruchtknoten ist unterständig, selten ragt er an der äussersten Spitze in den Kelch hinein; er ist gewöhnlich dreifächrig; zuweilen sind 1 bis 2 Fächer leer; die Samenleisten sind wandständig und fleisehig, in der Mitte des Fruchtknotens verschmelzen sie nicht selten; in jedem Fache finden sich $\infty$ Samenanlagen, sie sind meist horizontal aufgehangen und anatrop. Der Kelch ist rad-, glocken- oder röhrenförmig, drei- bis sechslappig, mit dachziegeliger, meist offener Knospenlage. Die Blumenblätter, an Zahl gewöhnlich 5 (selten 3 oder 6). sind an dem Saume des Kelches angewachsen, sie sind entweder frei oder selten verwachsen, znweilen sind sie gelappt oder gefranzt, in der Knospenlage klappig oder eingerollt. Die Staubgefässe sind an dem Rande oder dem Grunde des Kelches angeheftet, sie sind frei oder einbrüderig gebündelt, meist sind 3 vorhanden, von denen das eine znweilen einfächrig, die übrigen immer zweifächrig sind; die Staubbeutel sind den Fäden angewachsen, sie sind frei, hängen zusammen oder sind zu einem Köpfchen verwachsen, sie sind entweder gerade oder gekrümmt oder darmförmig hin- und hergebogen. Der Griffel ist einfach, ganz, oder an der Spitze getheilt. Die Frucht ist eine fleischige, dünnhäutige oder berindete Beere, die sich gewöhnlich nicht öfnet, zuweilen aber klappig oder mit einem Deckel aufspringt; die Fruchtwände und Samenleisten verschmelzen gewöhnlich zu einem Brei, sodass die Frucht einfächrig erscheint. Samen sind meist $\infty$, gewöhnlich sind sie flach, scheibenförmig zusammengedrückt, aussen nicht selten gekörnt oder gebuckelt und an den Rändern gelappt oder gezähnt, zuweilen auch von einem dicken Saume umzogen. Das Nährgewebe fehlt, die Keimblätter sind dick, blattartig, znsammengedrïckt oder planconvex; das Würzelchen ist kurz.

Einjährige oder durch die am Grunde verholzenden oder die unterirdischen Axen ausdanernde Kränter, seltener Halbsträncher oder Sträucher mit kletternden oder niedergestreckten, ranhen oder behaarten Stengeln und abwechselnden, gestielten, einfachen oder getheilten, gelappten, handförmigen oder fussförmigen Blättern. Die Ranken treten seitlich aus den Achselsprossen hervor, sie sind einfach oder gespalten und spiral aufgerollt. Die Bliithen stehen, besonders die weiblichen, häufig einzeln, zuweilen sind sie auch zu Trauben und Rispen verbunden.

Die Familie umfasst etwa 86 Gattungen mit c. $630-640$ Arten, die hauptsächlich in der tropischen Zone beider Hemisphären vorkommen. 


\section{CITRULLUS Schrad.}

Blïthen einhäusig, männliche und weibliche einzeln. Männliche Blitthe: Kelch glockenförmig, fünflappig. Blumenkrone tüber die Mitte fünftheilig mit stumpfen Lappen. Staubgefässe 3, mit kurzen, freien Fäden; Bentel leicht zusammenhängend, sämmtlich zweifächrig, Fächer linealisch, gekriimmt, den Rand des nicht vorgezogenen Connectivs bekleidend. Fruchtknoten rudimentär, drüsenartig. - Weibliche Blüthe: Kelch und Blumenkrone wie bei der männlichen. Stanbgefässrudimente 3, borsten- oder zungenförmig. Fruchtknoten eiförmig mit 3 Samenleisten und $\infty$ horizontalen Samenanlagen; Griffel kurz, säulenförmig, mit 3 kurzen, nierenförmigen Narben. Frucht kugelförmig, seltener oblong, nicht anfspringend, fleischig oder trocken, $\infty$ samig. Samen oblong, flach, gewöhnlich nicht berandet. - Ausdanernde, niedergestreckte Kränter mit gerundet herzförmigen, tief drei- bis fünflappigen Blättern, die Lappen wieder gelappt; Ranken zwei- bis dreispaltig, seltener ungetheilt, zuwcilen gerade und in Stacheln umgebildet.

4 Arten, die im östlichen Mittelmeergebiete, im tropischen und sủdlichen extratropischen Afrika und im westlicheren Asien beimisch und zum Theil weit verbreitet sind; eine Art, die Wassermelone, wird vielfach in den tropischen und den wärmeren Gegenden der gemässigten Zone cultivirt.

\section{Citrullus colocynthis Schrad.}

Tafel 16.

Ausdauernd; Stongel behaart, Blätter gestielt, handförmig, fünf- oder tief dreilappig, die Lappen buchtig-fiedertheilig, rauh; Ranken kurz, einfach oder zweispaltig; Fruchtknoten behaart, umgekehrt eiförmig; Frucht kugelrund mit trocknem, schwammigem, sehr bitterem Marke; Samen unberandet.

Citrullus Colocynthis Schrad. in Linnaea XII. 414; Wight, Icon. t. 498; Woodv. t.71; Steph. and Church. t. 139; Naud. Annal. se. nat. IV. sér. XII. 99; Miq. Fl. Ind.-Bat. I. (2.) 662; Bischoff, Medec. Bot. 442; Harv. et Sond. Fl. Cap. II. 194; Berg u. Schmidt, Darstell. u. Beschreib. XXV' ; Hook. fil. in Oliv. Fl. trop. Afr. II. 545; Boiss. Fl. orient. II. 759 ; Bentl. and Trim. Med. pl. t. 114; C. B. Clarke in Hook. fll. Fl. Br. Ind. II. 620; Cogn. in Suit. au Prodr. III. 510; Fliek. and Hanl. Pharmacogr. 263 ; Flïck. in Arch. Pharm. 1872. p. 235; Pharmacogn. 83.5; Köhler, Mediz. Pfl. $t .118$.

Cucumis Colocynthis Linn. Spec. pl. ed. I. 1012; Sér. in DC. Prodr. III. 302; W. et Arn. Prodr. 342; Woodv. Med. pl. t. 71; Nees, Düsseld. Pf. t. 265; Plenck, Icon. t. 699. Willk. et Lge. Prodr. Fl. Hisp. II. 276 .

Cucumis Pseudo-Colocynthis Wender. Sel. sem. hort. Marb. 1834, in Linn. X. Litt.-Ber. 77.

Colocynthis officinarum Schrad. in Linn. XII. 421.

Citrullus Pseudo-Colocynthis Roem. et Schult. Syn. II. 50.

Cucumis bipinnatifidus Wight, nach Naud. l. c.

Koloquinthe oder Koloquinte; französisch: Coloquinte; englisch: Colocynth oder Bitter apple.

Aus den ausdauernden, verholzenden, unteren Theilen der Axe treten zahlreiche, diinne, krautige, auf den Boden hingestreckte, hin- und hergebogene, höchstens 2-3 mm im Durchmesser haltende, gefurchte, mit wasserhellen Haaren besonders an den jüngeren Theilen dicht bedeckte, zahlreiche Stengel hervor, welche durch eine holzige, zuweilen bis $4 \mathrm{~cm}$ und mehr im Durchmesser haltende Wurzel im Boden befestigt sind.

Die Blätter sind zweizeilig gestellt und werden von 1,5-2 (1-2,5) $\mathrm{cm}$ langen Stielen getragen, die gleich den Stengeln bekleidet sind; die Spreite misst 2,5-7 cm in der Länge und hat oberhalb der Basis eine Breite von 1,5-5 cm; im Umrisse ist sie gleichschenklig dreiseitig, am Grunde mchr oder weniger 
herzförmig; sie ist dreilappig oder wird, indem jeder Seitenlappen mit einem grösseren, äusseren Abschnitte versehen ist, fünflappig; der Mittellappen überragt die seitlichen in der Regel um das zwei- bis dreifache, diese sowohl wie jener sind buchtig fiederspaltig, die Lappen sind spitz; die Blätter sind ziemlich starr, auf der Oberseite hellgriin mit weissen, an der Basis zwiebelig verdickten, mehrzelligen, brüchigen Haaren bestrent, auf der Unterseite sind sie dureh die dichtere, fast zottige Bekleidung gran; sie fühlen sich wegen der stehenbleibenden Haarbasen später gewöhnlich rauh an.

Die Blïthen sind einhäusig, sie stehen einzeln in den Achseln der Blätter, und zwar am unteren Theile des Stengels die männlichen, oben die weiblichen; neben jeder Blüthe befindet sich ein znweilen sehr verktimmerter Spross, und seitlich von diesem tritt mehr oder weniger dentlich extraaxillär die 3 bis $5 \mathrm{~cm}$ lange, fadenförmige, am Grunde gefurchte und behaarte, einfache oder zweitheilige Ranke hervor; bei den aufeinander folgenden Blättern liegt dieselbe abwechselnd rechts und links von der Knospe; sie wird fuir ein metamorphosirtes Blatt angesehen.

Die männliche Blüthe wird von einem 1-1,5 cm langen, behaarten Stiele gestützt; der Kelch ist kurz kreiselförmig und geht in 5 etwa $2 \mathrm{~mm}$ lange, lanzettlich-dreiseitige, spitze Zipfel ans, die beiderseitig' mehr oder weniger dicht weiss behaart sind. Die Blumenkrone ist radförmig, sie ist an den Kelehbuchten eingefügt und $6-7 \mathrm{~mm}$ lang, bis über die Mitte in 5 eiförmige, spitze, 5-6 mm am Grunde breite Zipfel getheilt*); ihre Farbe ist gelb, von griinen Adern durchzogen, aussen ist sie behaart. Staubgefässe sind 3 vorhanden, von denen 2 beträchtlich breiter als das dritte sind, sie sind $5 \mathrm{~mm}$ lang und $4-5$, bez. $3 \mathrm{~mm}$ breit; die Beutel messen die Hälfte der Länge, sie sind dreilappig, an der Innenseite flach, an der Aussenseite befinden sich je 2 zweifächerige Pollenbehälter, die zusammen einen flinffach wurmförmig gekrümmten Körper darstellen; die Pollenkörner sind kugelrund, glatt und mit 3 Poren versehen; ein Griffelrudiment fehlt.

Die weibliche Blithe ist $1,5-2,5 \mathrm{~cm}$ lang gestielt. Der Fruchtknoten hat $7 \mathrm{~mm}$ im Durchmesser und eine Länge von $7-8 \mathrm{~mm}$; er ist birnförmig und behaart; er bat im Innern 3 kräftige, wandständige Samenleisten, die nach dem Centrum zu vorspringen, sich dort beriihren und nach der Aussenwand 2 Lamellen ansschicken, welche sich wieder nach dem Fussstïck einkriimmen und an den Rändern die zahlreichen, anatropen, mit der Micropyle nach unten gewendeten, flachen, horizontal gestellten Samenanlagen in je 3 Reihen tragen; auf diese Weise hat jeder Fruchtknoten 6 gesonderte, mit Samenanlagen angefilltte Hohlräume. Der Keleh und die Blumenkrone sind wie bei der männlichen Blïthe, nur etwas grösser (die letztere misst bis $9 \mathrm{~mm}$ in der Länge). Die Staubgefässrudimente stellen 3 kurze $(2 \mathrm{~mm}$ lange) fleischige Stummel dar. Der Griffel ist $5 \mathrm{~mm}$ lang und bis zur Hälfte in 3 fleischige, papillöse, nierenförmig zweilappige Narben getheilt.

Die Frucht ist kugelförmig und hat einen Durchmesser von 5 bis höehstens $10 \mathrm{~cm}$; sie ist völlig kahl und wird von einer dïnnen, zerbrechlichen Schale nmhtillt; ihre Farbe ist bei völliger Reife goldgelb; im Innern ist sie von einem sehwammigen, weissen, trockenen, sehr bitteren Marke erfüllt, in dem die Samen nahe der Fruchtschale zu 6 Gruppen vereinigt liegen.

Die Samen sind umgekehrt oblong-eiförmig, 8-10 mm lang und in der Nähe des abgerundeten Endes 5-6 mm breit; an der Anheftungsstelle sind sie spitz und haben oberhalb derselben jederseits 2 kurze Vertiefungen, die mit Schleimzellen versehen sind; ihre Farbe ist gelblichbraun; ein verdickter Rand ist nicht vorhanden.

Der Keimling hat ein kurzes Würzelchen und fast flache Keimblätter.

Die Koloquinte findet sich im Mittelmeergebiete, und zwar von Siidspanien ïber Italien (Pescara), die Inseln Melos und Kreta bis nach Cypern; ferner wächst sie auf den Canarischen Inseln, auf den Inseln des grtunen Vorgebirges und wird dann durch Marokko, Algier, Tunis bis in die Libysche Wüste verfolgt; in Ägypten und Nubien ist sie an manchen Stellen sehr häufig; südlich von dieser Linie wird sie im

7) An der Anheftungsstelle der Blumenkrone werden zwischen den Stanbfitden Haare angegeben; wir haben dieselben nicht beobachtet. 
tropischen Afrika nicht selten angetroffen und geht tiber den Wendekreis hinaus, doch nicht bis nach dem Capgebiete; von Abyssinien ans geht ihr Verbreitungsgebiet nach Sokotra und nach Arabien; in Syrien ist sie weniger bäufig, dann kommt sie in Persien vor und erreicht in den Ebenen von Vorder-Indien und in Ceylon die Ostgrenze.

Anmerkung. Ob sie in allen den erwähnten Gebieten wirklich einheimisch ist, bleibt zweifelhaft, da sie schon seit langen Zeiten an manchen Orten cultivirt wird; namentlich gilt dies von Spanien.

Medicinische Verwendung findet als Fructus Colocynthidis die von der änssersten, harten, etwa $1 \mathrm{~mm}$ dicken Perikarpregion befreite, reife Frucht der Pflanze. Der wirksame Bitterstoff ist in dem trockenen, lockeren, lufthaltigen Parenchym des Perikarps enthalten. Die im Handel vorkommende Droge stammt aus Spanien, Marokko und Syrien.

\section{Erklärung der Abbildungen.}

Fig. A, Der obere Theil eines Stengels nach einem in Syrien gesammelten Exemplare: $a$, die männlichen Blutthen; b. die weiblichen Blithen.

Fig. $B$, Eine männliche Blithe, der Lïnge nach aufgeschnitten und ausgebreitet, 2 mal vergrössert: $c$, die Kelchröhre; $d$. die Kelchzipfel ; e. die Blumenkrone f. die Staubgefässe.

Fig. C. D. Das kleinere Staubgefíss von aussen und innen gesehen, 6mal vergrössert: g. das Connectiv; $h$. die Staubbentel.

Fig, $E, F$. Ein grüsseres Staubgefïss, von aussen und von innen gesehen, 6 mal vergrössert.

Fig. G. Ein Pollenkorn, c. $300 \mathrm{mal}$ vergrössert.
Fig. $H$. Die weibliche Bliithe im Längsschnitte, 2mal vergrössert: $f$. die Staubgefïssreste; $i$. der Fruchtknoten; $k$, der Griffel; $l$. die Narben.

Fig. I. Der Fruchtknoten im Querschnitte, 4mal vergrössert: $m$, die Samenleiste; $n$. die zurìckgebogenen Lamellen, welche $o$. die Samenanlagen tragen.

Fig. $K$. Die Frucht im Querschnitte, natürliche Grösse; die Samenleisten sind an den Berïhrungsflächen auseinander gewichen: $p$, die Samen.

Fig. $L$. Ein Same, 11/2-2fach vergrössert: $q$. der Nabel $r$. Furchen mit Schleimzellen.

Fig. M. $N$. Derselbe in Lüngsschnitten.

Fig. O. Derselbe im Querschnitte. 


\section{Familie: L o beli a cea e Juss.}

Die Blüthen sind gewöhnlich zwittrig, sehr selten sind sie durch den Fehlschlag eines Gesehlechtes getrenntgeschlechtig, sie sind stets zygomorph, wobei die Symmetrieebene der Anlage nach in die Ebene des Deekblattes fällt. Der Fruchtknoten ist unterständig oder er ragt mit einer freien Spitze in den Kelch hinein, gewöhnlich ist er zwei-, seltener dreifächrig; die Samenleisten sind an den Seheidewänden oder den Innenwinkeln der Fächer angewachsen: sie tragen $\infty$ Samenanlagen, die horizontal angeheftet und anatrop sind. Der Kelch ist fünfblättrig, actinomorph, oder die der Entstehung nach oberen Blätter sind etwas grösser, die Knospenlage ist offen; er bleibt nach der Bln̈thezeit stehen oder fällt ab. Die Blumenkrone ist fünflappig, die der Entstehung nach oberen 3 Zipfel sind gewöhnlich grösser, als die beiden gegenüberliegenden, zwischen denen die Blumenkrone zuweilen gespalten ist, sehr selten sind alle fünf Glieder bis zum Grunde frei (Dialypetalum). Die 5 Stanbgefässe wechseln mit den Blumenkronenzipfeln ab und sind mit der Röhre gleich hoch angeheftet, seltener sind sie an ihr höher eingefügt (Isotoma); die Staubfäden sind am Grunde frei, oben sind sie wie die zweifächrigen Bentel zu einer gekrtimmten Röhre verbunden; die letzteren sind ungleich lang, und zwar sind die der Anlage nach oberen zwei die kleinsten, das untere ist das grösste; sie sind an der Spitze, zuweilen anch am Grunde bebärtet, oder laufen in Stachelspitzen oder Borsten aus. Der Griffel ist fadenförmig und trägt nnterhalb der kurz zwei- oder dreilappigen Narbe einen Kranz von Fegeharen, der beim Durehwachsen der Stanbgefässröhre die Pollenkörner aus den längsspaltig anfspringenden Fächern herausbürstet. Die Frucht ist gewöhnlich kapselartig, sie springt an der Spitze oder der ganzen Länge nach oder unterhalb der Spitze fachspaltig, seltener mit einem Deckel auf, zuweilen ist sie fleischig und geschlossen; sie wird gewöhnlich von dem bleibenden Kelehe gekrönt. Die Samen sind zahlreich, klein, mit glatter oder grubig vertiefter Samenschale, selten sind sie geflügelt. Der Keimling ist gerade, mit planeonvexen Keimblättern; er liegt in einem reichlichen Nährgewebe.

Einjährige oder ansdauernde Kräuter, selten Sträncher, die zuweilen schlingen, noch seltener Bäume mit Milchsaftgefässen und spiralig gestellten Blättern, ohne Nebenblätter. Bläthen achselständig, gewöhnlich einzeln zu Trauben vereinigt, ohne dentliche Vorblättehen, resupinirt.

Die Familie umfasst incl. der Cyphieen 28 Gattungen mit ungefähr 550 Arten, von denen ein erheblicher Theil durch die Gattung Lobelia in Anspruch genommen wird. Sie bewohnen die gemässigten Theile der westlichen Hemisphäre, sowie die wärmsten Gegenden beider Erdhälften; in Europa sind ihrer nur wenige vorhanden.

Anmerkung. Die Lobeliaceen werden nicht selten mit den Campanulaceen vereinigt; uns scheint aber eine Trennung derselben wegen der zygomorphen Blüthen angemessen. Die Zygomorphie ist übrigens nicht, wie bei den Labiaten, Scrophubariaceen etc., schon in der ersten Anlage der Blithen begrindet, diese vollzieht sich vielmehr ganz in dem Sinne einer aktinomorphen, sie wird erst später durch einseitige Förderung der morphologischen oberen Hälfte gewonnen. Da sich die Blïthe vor dem Öffnen wendet, so wird diese zur Unterseite resp. Unterlippe. In diesem Zustande liegen 3 Zipfel der Krone bodenwärts gewendet, mit anderen Worten, 2 Kelchblïtter sind nach vorn gerichtet. Die Bliithe muss demgemüss der Anlage nach, weil sie eben eine Drehung vollzogen hat, 2 Kelchblätter nach hinten, 3 nach vorn orientirt haben. Diese Disposition des Kelches ist für fünfgliedrige Dicotylenblüthe sehr ungewöhnlich. Die Wendung der Blïthen oder die Resupination wird in der Gattung Lobelia auf doppelte Weise gewonnen: bei den Blitthen mit langem Stiele, welche die Spitze des Bliithenstandes überragen, kippt die Bliithe vor dem Öffnen in der Richtung nach hinten, d. $\mathrm{h}$. über das dorsale Kelchblattpaar über, auf diese Weise kommen die 3 grösseren Blumenkronenabschnitte nach unten zu liegen und bilden die Unterlippe; diejenigen Blïthen aber, welche in der Achsel der Blätter anf kurzen Stielen sitzen, machen eine Viertelwendung nach rechts oder links und kippen dann über das jetzt vordere Kelchblattpaar iiber. 


\section{LOBELIA Linn.}

Blutthen zygomorph, zwittrig, resupinirt. Fruchtknoten unter- oder zuweilen halb oberständig, kreiselförmig, eiförmig oder halbkugelig;, gewöhnlich zweifächrig mit $\infty$ Samenlagen. Kelch fünfblättrig, zuweilen mit zurïickgeschlagenen Anhängseln in den Buchten, Blätter mässig ungleich. Blumenkrone gekrïmmt oder an der Mündung schief mit 5 Lappen, die meist deutlich zweilippig vereinigt sind, auf dem Riicken (in der Stellung der Blïthezeit) bis zum Grunde gespalten. Staubgefässe nicht oder nur sehr kurz mit der Blumenkrone verbunden; die kleineren oder sämmtliche Staubbeutel an der Spitze behaart. Kapsel innerhalb des Kelches zweiklappig fachtheilig aufspringend. - Kräuter oder Halbstrüucher, selten Sträucher von sehr verschiedener Tracht. Blitthen einzeln in den Blattachseln, durch Verkürzung der Deckblätter nicht selten deutliche Trauben bildend; Deckblättchen fehlend, doch werden 2 zuweilen vorhandene Köpfehendrüsen von manchen Botanikern dafür gehalten.

Etwa 220 Arten in den heissen und gemässigten Ländern beider Hemisphären; in Europa nur 2 Arten.

\section{Lobelia inflata Linn.}

Tafel 17.

Stengel aufrecht, krautig, behaart, einfach oder oben verästclt, kantig; Blätter eiförmig oder obloug, auf beiden Seiten spitz, unregelmässig gesägt-gezähnt; Blithen klein, kurz gestielt, in verlängerte ährige Trauben zusammengestellt; Fruchtknoten eiförmig, kurz behaart; Kelchblätter pfriemlich zugespitzt, am Grunde nicht geöhrt, wenig kürzer als die Blumenkrone; nur die 2 kleineren Staubbeutel an der Spitze behaart; Kapsel aufgeblasen, eiförmig.

Lobelia inflata Linn. Hort. Cliff. 500, Spec. pl. ed. I. 930, Act. Upsal. 1741. p. 23. t. 1; Pursh, Fl. Americ. II. 445; Nutt. Gen. Amer. II. 77; Bigel. Am. med, bot. t. 19; Sweet, Brit. flow. gard. t. 99; DC. Prodr. VII. 350; Schk. HIandb. t. 269; Nees, Dïsseld. Pf. t. 205; Bentl. and Trim. t. 162; Bart. Med. t. 16; Torr. New York fl. t. 63; Berg u. Schmidt, Darst. u. Beschreib. I ${ }^{a}$; Asa Gr. Synopt. fl. I. (1. 7; Flickig. and Hanb. Pharmacogr. 357; Flück. Pharmacogn. 650; Köhler, Mediz. Pf. t. 106.

Lobetiakraut; französisch: Lobélie enflée; englisch: Indian tobacco.

Das einjährige, aufrechte Kraut wird durch verhältnissmässig kurze, fasrige, weisse Wurzeln im Boden befestigt.

Der Stengel ist anfrecht, nicht selten etwas hin- und hergebogen, dureh die von dem Blattgrunde beiderseits herablaufenden Linien kantig, unterhalb des Blattstieles nicht selten gefurcht; er ist $0,3-0,7 \mathrm{~m}$ hoch und besonders unten von gelblichen Haaren rauh; iiber der Wurzel hat er einen Durchmesser von $2-5 \mathrm{~mm}$ und ist dort zuweilen violett oder röthlich gefärbt.

Die unteren Blätter sind ziemlich lang gestielt, spathelförmig, am oberen Ende stumpf, am Grunde allmählich in den Blattstiel verschmälert, die mittleren sind die grössten, sie werden bis $10 \mathrm{~cm}$ lang und in der Mitte bis $5 \mathrm{~cm}$ breit, diese sind nahezu oder vollkommen sitzend, an beiden Seiten spitz, und werden gewöhnlich von 4 Paar grösseren Seitennerven durchzogen; die Laubblätter tiberhaupt sind saftig grün, die unteren zuweilen violett, unterseits sind sie heller, sie sind dünn, krautig, ihre Zähne enden in ein callöses Spitzchen, sie sind auf beiden Seiten mit kurzen, hyalinen Härchen bestreut, die am Rande etwas dichter stehen; nach der Spitze zu gehen sie allmählich in die kleinen, lanzettlichen, ganzrandigen Blüthendeckblätter tuber.

Die Blüthen sind klein, sie werden von einem höchstens $5 \mathrm{~mm}$ langen, dünnen, kaum behaarten Stielchen gestïtzt. Der Fruchtknoten ist $2 \mathrm{~mm}$ lang und hat $1 \mathrm{~mm}$ im Durchmesser, er ist fast ganz unterständig; nur die Spitze, in der sich keine Samenanlagen befinden, ragt auf etwa $0,5-0,8 \mathrm{~mm}$ über 
den Kelehgrund; er wird von 8-10 wenig vortretenden Rippen durchzogen und ist kahl; die zwei Fächer liegen in der Symmetrieebene und enthalten an halbcylindrischen Samenleisten sehr viele äusserst kleine, horizontal gestellte, anatrope Samenanlagen. Der Kelch ist $4-5 \mathrm{~mm}$ lang, die Kelehblätter sind schmal pfriemlich, lang zugespitzt und werden von einem Nerven durchlanfen, sie sind kahl. Die Blumenkrone misst 5-7 mm; sie ist deutlich zweilippig, blassblau, die Röhre ist heller, anssen kahl, innen von der Basis bis zum Schlnnde behaart; die Lappen der Oberlippe sind lanzettlich, zugespitzt, gerade, die der Unterlippe sind eiförmig, kurz zugespitzt, an beiden Seiten des Mittellappens ist eine gelbliche Schwiele, die nach unten in einen blasseren Streifen ausläuft. Die 5 Staubgefässe sind neben der Blumenkrone eingefiigt, sie sind $5 \mathrm{~mm}$ lang, erreichen also den Röhrenschlund der Krone, sie sind am Grunde etwa $1 \mathrm{~mm}$ hoch frei, dann zu einer Röhre verbunden; die Staubfäden sind verbreitert, sehr fein gewimpert, blassbläulich; die Staubbentel neigen sich nach unten (in der Blüthenstellung), daher sind die oberen etwas grösser ( $2 \mathrm{~mm} \mathrm{lang})$, als die beiden unteren $(1,5 \mathrm{~mm})$; sie sind dunkel blaugran, die oberen auf dem Rücken fein weiss behaart, die unteren an der Spitze weiss bebärtet. Die Pollenkörner sind elliptisch, dreifächrig und dreiporig. Der Griffel ist $4 \mathrm{~mm}$ lang, weiss, in der Nähe der Narbe von einem Kranze weisser Haare umgeben.

Die Frucht ist eine 8-10 $\mathrm{mm}$ lange, $4-7 \mathrm{~mm}$ im Durchmesser haltende, häutige, umgekehrt eiförmige Kapsel, die von dem Kelche gekrönt wird; sie springt zwischen den Kelchblättern zweiklappig fachtheilig auf; die kurzen, gerundet trapezoiden Klappen tragen in der Mitte die gespaltene Scheidewand.

Der Same misst $0,6-0,8 \mathrm{~mm}$ in der Länge und hat eine Breite von $0,3-0,4 \mathrm{~mm}$; er ist goldig braun und schimmert, die Oberfläche ist netzgrubig; die Keimblätter sind so lang wie das Würzelchen.

Das Lobeliakraut findet sich auf offenen, ziemlich trockenen Wiesen, Weiden und Heiden in NordAmerika, von der Hudsons-Bay bis zum Saskatshewan, und von dieser Linie sülich bis Georgien und Arkansas.

Man benntzt in der Medicin die blühende, von der Wurzel befreite Pflanze. Die Droge "Herba Lobeliae" stammt hauptsächlich aus New-Lebanon (Staat New-York). Die Pflanze enthält ein giftiges Alkaloid.

\section{Erklärung der Abbildungen.}

Der obere Theil einer im Berliner UniversitätsGarten eultivirten Pflanze; natïrliche Grösse.

Fig. A. Eine Blïthe von der Oberlippe aus betrachtet, 3 mal vergrössert.

Fig. B. Eine Blüthe im Längsschnitte, 31/2mal vergrössert $a$. der Fruchtknoten; $b$. der Kelchgrund; $c$. der Kelch; d. die Blumenkronenröhre; e. die Staubgefässröhre; $f$. der über den Kelch hervorragende freie Theil des Fruchtknotens; $g$. der Griffel; $h$, die Narben.

Fig. C. Die Blüthe ohne Kelch und Blumenkrone: $b$, die Staubfäden; $c$. die Staubbeutel.
Fig. D. Pollenkörner, e. 300 fach vergrössert, in Wasser und Luft.

Fig. E. Der Fruchtknoten mit dem Griffel und der Narbe, $4 \mathrm{mal}$ vergrössert.

Fig. F. Die noch geschlossene Narbe, von dem Kranze der Fegehaare umgeben, von oben gesehen, smal vergr.

Fig. $G$. Dieselbe von unten gesehen.

Fig. H. Die Frucht, 2 mal vergrössert.

Fig. I. Dieselbe im Querschnitte, 3mal vergrössert.

Fig. $K$. Der Same, natïrliche Grösse.

Fig. $L$. Derselbe, $25 \mathrm{mal}$ vergrössert.

Fig. $M$. Derselbe im Längsschnitte. 


\section{Reihe: Labiatiflorae DC.}

Blithen zygomorph, in Kelch und Blumenkione oft fünfgliedrig;, die letztere ist gewöhnlich zweilippig, und zwar so, dass 2 Zipfel die Ober-, 3 die Unterlippe bilden. Die Stanbgefässe sind selten mit Kelch und Krone gleichzählig, meist finden sich 4, die dann didynamisch sind, zuweilen sind nur 2 vorhanden, die meist dem vorderen Paare entsprechen.

\section{Familie: Labiat a e B. Juss.}

Die Blüthen sind zwittrig und zygomorph, selten fast aktinomorph. Der Kelch ist unterständig, bleibend, meist röhren- oder glockenförmig, fünf-, seltener vierzähnig oder -lappig, nicht selten zweilippig. Die Blumenkrone ist verwacbsenblättrig mit kurzer oder verlängerter Röhre und fünf-, oder durch Verschmelzung der oberen 2 Lappen vierlappig, gewöhnlich zweilippig, selten fast regelmässig glockenförmig. Staubgefässe sind 4 vorhanden, die dann didynamisch, selten gleich sind, oder 2, die dem vorderen Paare entsprechen; die Stanbbentel sind meist zweifächrig und springen in 2 Längsspalten auf, zuweilen laufen dieselben ïber dem Scheitel zusammen und bilden einen scheinbar einfachen Beutel; auch wirklich einfächrige kommen vor. Ein unter dem Fruchtknoten stehendes Polster (Diseus) sondert Honig ab, der sich in der Röhre ansammelt. Der Fruchtknoten ist oberständig und gewöhnlich bis auf den Grund in 4 Theile (Clausen) gespalten, aus deren Mitte der Griffel aufsteigt; er ist fadenförmig, an der Spitze gewöhnlich zweispaltig, wobei der grössere Ast nach vorn, der kleinere nach hinten gekehrt ist. In jedem Abschnitte des Fruchtknotens befindet sich eine aufrechte, anatrope Samenanlage, deren Mikropyle nach unten und aussen gekehrt ist. Die Fritchte werden von dem Kelche umschlossen und stellen 4 oder durch Fehlschlag 3-1 Nüsschen dar, die gewöhnlich trocken, zuweilen aber auch fleischig sind und mit einer kleineren oder grösseren Fläche dem Stempelpolster aufsitzen. Die Samen sind einzeln in jedem Niisschen, sie haben planconvexe Keimblätter und ein kleines, gerades, selten umgebogenes Wïrzelchen.

Kräuter oder Halbsträucher, selten Sträucher mit meist vierkantigen Ästen und kreuzgegenständigen, seltener gequirlten Blättern, die ganzrandig oder gezähnt oder getheilt sind und wie die ubrigen Theile der Pflanze nicht selten Köpfchenhaare tragen, in denen stark duftende ätherische Öle ausgeschieden werden. Blithenstände rispig oder in zusammengesetzte, oft unterbrochene Ähren zusammengezogen; die letzteren werden aus Halbquirlpaaren aufgebaut, die als verkïzte Cymen (Dichasien oder Wickeln) aufzufassen sind; zuweilen entspringen die Blithen vor einander unmittelbar aus der Blattachsel und bilden dann seriale Blithenschaaren. Deckblätter und Blättchen sind gewöhnlich entwickelt.

Die Familie umfasst in etwa 140-145 Gattungen c. 2700 Arten, die von der Tropenzone bis in die kalte vorkommen; die grösste Entwickelung zeigt sie im östlichen Mittelmeergebiete.

Die officinellen Labiaten gehören in folgende Tribus:

TRIBUS I. Lavanduleae Endl. Blumenkronenzipfel gleich, oder der vordere bildet mit den beiden seitlichen eine Unterlippe; Staubgefässe eingeschlossen.

1. Lavandula vera DC.

TRIBUS II. Mentheae Rchb. Blumenkronenzipfel gleich oder Ober- und Unterlippe flach. Staubgefässe hervorragend, aufrecht, 4 oder 2, gleich oder die vorderen lïnger, spreizend.

2. Mentha piperita L.

3. Mentha silvestris L. var. crispa Benth.

4. Thymus Serpyllum L.

5. Thymus vulgaris $\mathrm{L}$. 
TRIBUS III. Melisseae Spreng. Blumenkrone zweilippig. Staubgefässe am Grunde aufsteigend, 4 oder 2, oben auseinander fahrend oder unter der Oberlippe parallel, die vorderen länger.

6. Melissa officinalis $\mathrm{L}$.

TRIBUS IV. Monardeae Bth. Blumenkrone deutlich zweilippig; fertile Staubgefässe 2, aufsteigend oder aufrecht; Staubbeutel linealisch, von einander weit getrennt oder nach dem Aufspringen in einen linealischen zusammenfliessend.

7. Salvia officinalis $\mathrm{L}$.

8. Rosmarinus officinalis $\mathrm{L}$. 


\section{LAVANDULA Linn.}

Kelch röhrenförmig, oben etwas erweitert, 13-nervig, kurz fünfzähnig, der hintere Zahn etwas breiter oder in ein blattartiges Läppchen vergrössert, nach der Fruchtreife kaum auswachsend. Blumenkrone am Schlunde verbreitert, mit schiefem, zweilappigem Saume. Staubgefüsse 4, nach unten geneigt, in der Röhre eingeschlossen; Staubbeutel zusammenfliessend, einfächrig. Discus kurz eylindrisch oder vierlappig, ringsum gleich. Griffel an der Spitze kurz zweilappig. Nüsschen glatt und kahl, Ansatzstelle klein, ein wenig sehief. - Ansdauernde Kräuter, Halbsträucher oder Sträncher, mit einfachen oder fiederspaltigen, am Grunde der Zweige oft gedrängt gestellten Blättern. Blïthen in unterbrochenen, zusammengesetzten Ähren; Deckblätter der Halbquirle zuweilen dachziegelig, manchmal die obersten gefärbt und schopfig. Bluthen blan oder violett.

Ungefähr 20 Arten, die von den Canarischen Inseln durch das Mittelmeergebiet bis nach VorderIndien wachsen.

\section{Lavandula vera DC.}

\section{Tafel 18.}

Strauchartig; Blätter linealisch-lanzettlich oder schmal linealisch, ganzrandig, im ausgebildeten Zustande grau, am Rande zurïckgerollt; Ähre unterbrochen, mit fünf- bis siebenblithigen Halbquirlen; Deckblätter ei-rhombisch, zugespitzt, häutig; Deckblättchen an den letzten Blüthen sehr klein; unpaarer Kelchzipfel breit-eiförmig, bäutig.

Lavandula vera DC. Fl. Fr. Suppl. V. 39S; Benth. in DC. Prodr. XII. 145; Willk. et Lange, Prodr. Fl. Hisp. II. 391; Gingins, Mon. 6; Guimp. u. Schlecht. Abb. I. t. 41; Fliickig. and Hanbury, Pharmacogr. 425; Flïck. Pharmacogn. 770; Koehler, Mediz. Pf. t.60.

Lavandula officinalis Chaix in Vill. Fl. dauph. II. 355 u. 363; Berg u. Schmidt, Darst. u. Beschr. $X X V I^{b}$.

Lavandula angustifolia C. Bauh. Pin. 216; Tournef. Instit. 198; Ehrh. Beitr. VII. 147; Mnch. Meth. 359; Hayne, Arzn. VIII. t. 37.

Lavandula Spica a. Linn. Spec. pl. ed. I. 572; Plenck, Ic. 471; Nees, Düsseld. Abb. t. 175; Godr. et Gren. Fl. Fr. II. 647; Bertol. Fl. Ital. VI. 75.

Lavandula vulgaris $\alpha$. Lam. Fl. Fr. II. 403.

Lavandula pyrenaica DC. Fl. Fr. V. 399.

Lavendel, schmalblüttrige Spike; französisch: Lavande; englisch: Lavender.

Der stark verästelte Strauch erreicht eine Höhe von $0,3-0,6 \mathrm{~m}$, in cultivirtem Zustande kann er aber auch fast die doppelte Grösse erreichen. Der gedrungene, stark gekrümmte, mit brauner, sich ablösender Borke bekleidete Stamm zertheilt sich endlich in sehr dünne, ruthenförmige Zweige, welche mit einem dünnen, grauen Filze aus Büschelhaaren bekleidet sind; die blühenden Zweige sind gewöhnlich 25-35 (seltener bis 45) em lang; sie sind nur am Grunde beblättert, oben sind sie bis zu den Blüthenständen nackt, sie sind vierkantig, die Kanten sind heller grün.

Die Blätter sind kreuzgegenständig, linealisch bis schmal lanzettlich, spitz; die an dem Grunde des blïhenden Zweiges befindlichen sind 1-2 $\mathrm{cm}$ lang und nur etwa 1,5-2 mm breit, sie sind von dem Filze aus Büschelhaaren dichter bekleidet und grau; ihre Ränder sind so weit zurückgerollt, dass sie sich endlich berihhren; besonders auf der Unterseite finden sich zahlreiche, im trockenen Zustande goldgelbe, glänzende Köpfchenhaare, die oberseits nur spärlich auftreten; die weiter oben am blühenden Zweige 
stehenden Blätter erreichen ein Länge von $2-3,5 \mathrm{~cm}$ und eine Breite von $3-6 \mathrm{~mm}$, sie sind viel spärlicher behaart, von Farbe graugrün und an den Rändern nur wenig zurïckgekrïmmt.

Der Blüthenstand ist eine bis 8 , gewöhnlich aber nur $3-5 \mathrm{~cm}$ lange, unterbrochene Ähre, die aus 4-5 Paaren von Halbquirlen zusammengesetzt wird; jeder der letzteren besteht wieder aus 2 Paaren von zwei- bis vierblïthigen Wickeln, deren Axenstïcke sehr verkürzt sind; die Deckblätter der Halbquirle sind etwa 3-5 mm lang, breit eiförmig, am Grunde abgerundet, oben plötzlich in eine feine, verhältnissmässig ziemlich lange Spitze zusammengezogen, sie sind trockenhäutig, bräunlichgelb, von dunkleren Adern durchzogen und besonders an dem Rande kurz flaumig; die Deckblättchen, die wieder zu Deckblättern der Blitthen höherer Ordnung: werden, sind sehr schmal, pfriemlich oder eilanzettlich, und wenig mehr als $1 \mathrm{~mm}$ lang.

Die Blïthen sind proterandrisch, d. h. die Stanbgefässe kommen zur Reife, ehe die Narbe empfangsfähig ist; sie sind sehr kurz gestielt. Der Kelch ist röhrenförmig, oben etwas erweitert, stark gestreift, 13-nervig, 5-6 mm lang, am Rande ist er undentlich vierkerbig und trägt ansserdem ein $1 \mathrm{~mm}$ langes, breit eiförmiges, stumpfes, dorsal gestelltes Läppchen; er ist aussen von einem dichten Filze, der aus Büschelhaaren besteht, graublau und ausserdem mit gelben Köpfehenhaaren bestreut, im Inneren ist er kahl, nur gegen den Rand hin dïnn behaart; nach dem Abfall der Blumenkrone ist er geschlossen. Die Blumenkrone ist 11 mm lang, zweilippig und veilchenblau; die Röhre ist aussen auf der ganzen Fläche, innen nur von der Mitte bis zum Schlunde und anf der Oberlippe mit kurzen Härchen bestreut; die zweilappige Oberlippe ist fast doppelt so lang wie die dreilappige Unterlippe, die Lappen sind gerundet. Die Staubgefässe sind im oberen Viertel der Röhre befestigt und in derselben eingeschlossen; sie sind fast gleich lang, die oberen sind fast $1 \mathrm{~mm}$ höher angeheftet, als die unteren, die Staubfäden messen 1,5 mm, die nierenförmigen Stanbbentel $1 \mathrm{~mm}$; die letzteren sind blassviolett, später braun, sie springen durch einen iiber den Scheitel verlaufenden Spalt anf und werden durch Verschmelzen der beiden Theken einfächrig; sie sind in der Nähe der Spalte mit violetten Haaren besetzt. Die Pollenkörner sind gelb, im Wasser werden sie kugelförmig oder ellipsoidisch und zeigen 8 undentliche Poren. Der Stempel sitzt auf einem cylindrischen, etwa $0,4-0,6 \mathrm{~mm}$ hohen Polster, welches den Honig absondert; die 4 Theile des Fruchtknotens sind $0,5 \mathrm{~mm}$ lang, ellipsoidisch und dem Discus fast gerade aufgesetzt; der Griffel ist $3-3,5 \mathrm{~mm}$ lang, fadenförmig und vom unteren Drittel bis zu den 2 ungleichlangen aneinander gelegten Narbenästen mit feinen Härchen bestreut.

Von den $\mathrm{N}$ uisschen wird in der Regel nur eins zur vollen Reife gebracht, es misst $2 \mathrm{~mm}$ in der Länge und hat einen Durchmesser von $1 \mathrm{~mm}$; es ist ellipsoidisch, an der Spitze abgerundet, braun, glatt und glänzend.

Der Same hat ein ausserordentlich kurzes Wïrzelchen und planconvexe Keimblätter.

Der Lavendel wächst auf trockenen, unfruchtbaren Hügeln in grosser Menge dureh das ganze südliche Frankreich; an der Rhone steigt er bis Lyon herauf und erreicht den Schweizer Jura; über die Pyrenäen geht er bis Catalonien und Aragonien; von Nord-Italien ats dringt er ïber den Garda-See vor bis Trient und stidlich bis Corsica; auch in Calabrien wird er noch gefunden, und ebenso wird er von Nord-Afrika angegeben, wo er auf dem Atlas wächst. Zuweilen hat er sich an fruheren Culturstätten verwildert erhalten, zu diesen Vorkommen zählte ohne Zweifel der Lavendelberg bei Kreuznach; gegenwärtig ist er aber dort nicht mehr vorhanden.

Anmerkung. Der Priorität wegen ist der Name Lavandula officinalis Chaix dem *in dem Arzneibuche gewählten und auch von uns oben angenommenen vorzuziehen.

Die im Juli und August gesammelten Blïthen der Pflanze kommen als Droge (Flores Lavandulae) in den Handel. Thre Anwendung verdankt die Droge hauptsächlich dem ätherischen öle, welches in den Drïsenhaaren der Pflanze vorkommt und bis zu $3 \%$ aus der Droge erhalten werden kann. In Südfrankreich gewinnt man aus den Blüthen wildwachsender, in England aus den Blithen cultivirter Pflanzen das Oleum Lavandulae. Durch Destillation der ganzen Pflanze erhält man Lavendelöl geringerer Qualität. 


\section{Erklärung der Abbildungen.}

Fig. A. Ein Ast der blïhenden Pflanze, nach einem im Berliner Universitätsgarten cultivirten Exemplare.

Fig. $B$. Eine von dem Deckblatte gestiitzte Blüthenknospe, 3 mal vergrössert: $a$. Deckblatt; $b$. Kelch; $c$. grosser Kelchzahn; $\boldsymbol{d}$. Blumenkrone. ${ }^{*}$ )

Fig. C. Eine Bluithe, 3mal vergrössert.

Fig. D. Der auf der Vorderseite aufgeschlitzte und ausgebreitete Kelch, 4mal vergrössert.

Fig. E. Die durch die Mitte der Unterlippe aufgeschnittene und ausgebreitete Blumenkrone von innen betrachtet, 5mal vergrössert: $e$. Staubgefüsse.

Fig. $F$. Das Staubgefäss, von innen und von aussen betrachtet, $10 \mathrm{mal}$ vergrössert.
Fig. G. Pollenkörner unter Wasser, c. 300 fach vergrüssert.

Fig. $H$. Der Stempel, 3 mal vergrössert: $f$. Polster; $g$. Fruchtknoten; $h$. Griffel; $i$. Narben.

Fig. I. Der obere Theil des Griffels mit der Narbe, 12mal vergrüssert.

Fig. $K$. Der untere Theil der Blithe im Längsschnitte, 15 mal vergrössert: $g$. Samenanlagen.

Fig. $L$. Die vom Stempelpolster getragene Frucht, nat Grösse.

Fig. $M$. Niisschen von der Vorder- und Rückseite gesehen, $6 \mathrm{mal}$ vergrössert: $k$. die Ansatzstelle des Nüsschens.

Fig. N. Dieselben im Quer- und Längsschnitte: $l$. Würzelchen; $m$. Keimblätter.

\section{MENTHA Linn.}

Blithen zygomorph, gynodioecisch. Kelch fast regelmässig oder wenig zweilippig, röhren- oder glockenförmig, fünfzähnig, zehnnervig, im Schlunde kahl oder mit einem Haarringe versehen; im Fruchtzustande aufrecht. Blnmenkrone nur wenig zweilippig oder fast regelmässig, die Röhre vom Kelche eingeschlossen: der hintere Zipfel der Blumenkrone ganz oder mässig ausgerandet. Staubgefässe 4, gleichlang, gerade, auseinanderspreizend; Staubfäden kahl; Staubbentel zweifächrig, Fächer parallel, mit gesonderten Längsspalten aufspringend. Stempelpolster gleichförmig, fast ungelappt; Griffel an der Spitze kurz zweispaltig mit fusst völlig gleichen, pfriemlichen Ästen. Niisschen eiförmig, oben glatt, schwach grubig punktirt. - Aufrechte oder niederliegende, zuweilen zwergartige Kräuter mit kreuzgegenständigen, oft gezähnten Blättern. Halbquirle meist vielblithig, von laubigen oder kleinlaubigen, nicht gefärbten Deckblïttern gestiitzt, zu Ähren oder Köpfchen vereinigt.

Ungefähr 25 wohl zu unterscheidende Arten, die aber von einigen Botanikern ausserordentlich vervielfältigt worden sind; sie haben eine grosse Neigung zur Variabilität und zur Bastardirung; sie finden sich hauptsächlich in den gemässigten Zonen, doch fehlen sie nicht ganz in der heissen der alten Welt.

\section{Mentha piperita Linn.}

\section{Tafel 19.}

Krautig mit aufrechten, vierkantigen, kahlen oder spärlich behaarten Stengeln; Blätter gestielt, eiförmig-oblong bis eilanzettlich, spitz, am Grunde abgerundet, scharf gesägt, kahl oder unterseits an den Nerven behaart; Bliithenstand am Grunde unterbrochen, oben dicht, verlängert kopfig oder ährenförmig; Kelchröhre kahl, Zähne am Rande behaart.

Mentha piperita Linn. Spec. pl. ed. I. 576 (non lib.); Huds. Fl. Angl. ed. I. 222; Engl. Bot. X. t. 657; Woodv. Med. pl. II. t. 120; Nees, Diisseld. Abb. t. 164; Hayne, Arzneigew. XI. t. 37; Guimp. und Schlecht. II. t. 110; Benth. in DC. Prodr. XII. 169; Koch, Syn. 549. und viele andere deutsche Floren; Steph. and Church. Med. pl. t. 45; Syme, Engl. Bot. VII. t. 1024, 1025; Bentl. and Trim. t. 202, 203; Köhler, Mediz. Pf. I. t. 67; Berg und Schmidt, Darstell. u. Beschr. XXIII ; Willk. et

* In Fig. B. muss die Blüthe um $90^{\circ}$ gewendet werden, sodass das Kelchläppchen c, auf den Beschauer zugekehrt ist. 
Lange, Fl. Hisp. II. 395; Hook. fl. Fl. Br. Ind. IV. 647; Fliick. and Hanb. Pharmacogr. 432; Fliick. Pharmacogn. ed. III. 722 .

Mentha piperita L. var. officinalis Sole, Menth. Brit. 15. t. 7; Bak. On Engl. mints. 5s; Briquet Lab. alp. marit. 71 .

Mentha viridi $\times$ aquatica $F$. Schultz in Flora 1854. p. 227.

Mentha viridi $\times$ citrata $F$. Schultz in Poll. XII. 31.

Mentha silvestris var. piperita Reichb. Icon. XVIII. 48. $t .83$.

Pfeffermünze; französisch; Menthe poivre; englisch: Peppermint.

Aus einer unterirdischen bis $4 \mathrm{~mm}$ dicken, stumpfvierkantigen, verholzten, aussen schwarzbraunen, kriechenden Grundaxe entwickeln sich ähnlich gestaltete, zuerst weisse, dann violette Ausläufer, die schliesslich über die Erde treten und zu beblätterten Stengeln werden. Jene sind an den Knoten mit kreuzgegenständigen, weissen, 1-2, höchstens bis $4 \mathrm{~mm}$ langen, oblongen Niederblättern versehen, die allmählich an den beblätterten Stengeln in Laubblätter tibergehen; aus den Knoten treten über den Niederblättern die Ausläufer hervor, ausserdem sind an ihnen ringsum die 5-20 em langen, weissen, einfachen, seltener verzweigten, manchmal am Ende knollig verdickten, faserigen Wurzeln befestigt.

Der Stengel wird 0,6-0,9 $\mathrm{m}$ hoch, er ist vierkantig, unten einfach, nur in der Bltithenregion verzweigt, dunkelgriln, oft purpurroth überlaufen, kahl oder an den Kanten, seltener auch auf den Flächen mit kurzen, zerstreuten, abstehenden Haaren bekleidet; die in Blithenstände auslaufenden Äste erreichen die Spitze der Hauptaxe nicht.

Die Blätter sind kreuzgegenständig; der Blattstiel wird höchstens $1 \mathrm{~cm}$ lang, er ist oberseits flach rinnig, kahl oder spärlich behaart, an den oberen Blättern ist er kürzer, wirklich sitzend sind aber nur die Deckblätter der Halbquirle; die Blattspreite ist gewöhnlich $3-6$, zuweilen aber bis 8 em lang und unterhalb der Mitte 1,2-2, selten bis 2,5 cm breit, sie wird jederseits des Mittelnerven von 5-6 (4-7), oben eingesenkten, unten vorspringenden Seitennerven durchzogen und ist scharf gesägt, im untersten Theile nicht selten aber ganz randig, entweder ist sie kahl oder mit spärlichen, hyalinen Härchen, besonders auf den Nerven unterseits bestreut und mit sitzenden Drïsen auf beiden Seiten versehen; sie ist dunkelgrün, die Nerven sind häıfig auf der Unterseite violett.

Der Bluthenstand wird aus 6-7, selten mehr Paaren von Halbquirlen zusammengesetzt, deren unterste von einander entfernt stehende von Laubblättern, die oberen genäherten bis ährenförmig gedrängten von allmählich verkleinerten, mehr häutigen Hochblättern gestiitzt werden; die Halbquirle sind gestielt und bestehen jederseits der Mittelblïthe ans $6-8$ wickelig verbundenen, kurz gestielten Blitthen; die Deckblättchen sind 1-2,5 mm lang, pfriemlich, zugespitzt und an der Spitze gewimpert.

Die Blithen sind gynodioeeisch ${ }^{*}$ ) in der Weise, wie wir bei Thymus genauer auseinander setzen werden; da fast nur die weiblichen Exemplare cultivirt werden, an die sich auch unsere Beschreibung hält, so sind die Früchte nur äusserst selten beobachtet worden; die Blithen fallen meist unmittelbar nach dem Aufblithen ab. Der Kelch ist 3,5-4 mm lang und im oberen Drittel in 5 nahezu gleiche, zugespitzte Zähne getheilt; er ist zehnnervig, auf beiden Seiten kahl, an den Zähnen gewimpert, und aussen drüsig punktirt; er ist grỉn und an den Spitzen der Zähne dunkel purpurroth. Die Blumenkrone ist 4,5-5 mm lang, im oberen Viertel vierlappig; die Oberlippe ist ein klein wenig grösser, als die übrigen Zipfel, sie ist wie der Mittellappen der Unterlippe ausgerandet, innen und aussen ist sie kahl; die Röhre ist weiss, die Zipfel sind bläulich lila. Staubgefässe sind 4 vorhanden, die am Schlunde angeheftet sind; ihre Grösse ist nur sehr unwesentlich verschieden und beträgt noch nicht $1 \mathrm{~mm}$; von dem auf den unfruchtbaren, elliptischen Staubbeutel die Hälfte kommt.

Das weissliche, schwach vierlappige Stempelpolster misst mit dem Fruchtknoten $0,7-0,8 \mathrm{~mm}$, der Griffel ist $4 \mathrm{~mm}$ lang, er ist fadenförmig und hat eine kaum $1 \mathrm{~mm}$ lange, zweispaltige Narbe mit ungleichen Schenkeln.

*) Über die Bestäubungsverhältnisse und die Geschlechtervertheilung der Labiaten vergl. die sorgfältige Arbeit von Aug. Schultz in Bibliotheca botanica Heft 10,17 u. s. f. Cassel 1859/90. 
Die Frucht haben wir nicht gesehen, sie soll aus 4 elliptischen, röthlichbraunen, eingedrïckt punktirten Nüsschen bestehen.

Als Heimath der Pfeffermünze findet man gewöhnlich England genannt; gegenwärtig wird sie in vielen Gärten gebant; im grossen wird sie in England, Deutschland, Frankreich, Russland, besonders aber in Nordamerika und Japan cultivirt.

Sie blüht vom Juli den ganzen Sommer hindurch.

Anmerkung. Der neueste Monograph der Gattung Mentha Briquet sieht mit F. Schultz unsere Pflanze für einen Bastard von $M I$. aquatica L. $\times M$. viridis L. an; sie ist nur zum Theil identisch mit $M$. piperita Linn., die wenigstens nach den Original-Exemplaren in seinem Herbar eine Subspecies von $M$. aquatica L. ist (M., aquatica L. subsp. Bakeri Briq.). Ihm zufolge findet sich die Pfeffermünze wild hier und da in ganz Europa und ist (wenigstens in der Subspec. citrata Ehrh.) heute in den Chilenischen, Peruvianischen und Bolivianischen Anden bis zu $2000 \mathrm{~m}$ tiber dem Meere vielfach verwildert. Für die frühzeitige Verbreitung dieses Bastardes durch die Cultur spricht der Umstand, dass 'sie bereits durch Todtenkränze aus den Mumiengräbern in Ägypten für das Jahr 1000 v. Chr. constatirt worden ist, wo wenigstens heut weder die eine noch die andere der Stammarten vorkommt.

Die Pfeffermünze wird in grosser Ausdehnung in Nordamerika und England, auch in Japan angebaut, kleinere Mengen produciren Frankreich, Russland und Deutschland. Die Culturformen, welche in den verschiedenen Ländern gebant werden, und welehe man uberall dureh Ableger fortpflanzt, sind nicht ganz gleich, liefern auch ein etwas verschiedenes öl. In Deutschland ist der Pfeffermünzban vorzüglieh in der Nähe von Cölleda zu Hause. Man benutzt die gebrochenen Blätter als Folia Menthae piperitae. Die Hauptmenge der Droge dient zur Darstellung des ätherischen Öles, Oleum Menthae piperitae, dessen wichtigster Bestandtheil das Menthol ist.

\section{Erklärung der Abbildungen.}

Fig. A. Der obere Theil eines Stengels nach einem im Universitätsgarten zu Berlin cultivirten Exemplare.

Fig. $B$. Die Blüthe der weiblichen Form, $8 \mathrm{mal}$ vergrössert: $a$. der Kelch; $b$. die Blumenkrone; $f$. der Griffel; g. die Narie.

- Fig. C. Der Kelch vorn aufgespalten und ausgebreitet, 10mal vergrössert.

Fig. D. Die Blumenkrone ebenfalls vorn längs aufgespalten und atcsgebreitet, $10 \mathrm{mal}$ vergrüssert: $c$. Staubgefüss.
Fig. E. Das Staubgefäss von vorn und von hinten gesehen, $20 \mathrm{mal}$ vergrössert.

Fig. F.G. Pollenkörner, trocken und in Wasser, 300mal vergrössert.

Fig. H. Das Stempelpolster und der Stempel, 10mal vergrössert: $d$. das Stempelpolster; $e$, der Fruchtknoten.

Fig. I. Der untere Theil des vorigen, $12 \mathrm{mal}$ vergrössert: h. die Samenanlage.

\section{Mentha silvestris L. var. crispa Benth.}

Tafel 20.

Krautig mit aufrechten, vierkantigen von zurückgebogenen Haaren rauhen Stengeln; Blätter kurz gestielt oder halb stengelumfassend, rundlich eiförmig, kurz zugespitzt, am Grunde abgerundet bis herzförmig, krausgefaltet, scharf und grob gezähnt, beiderseits, aber dichter unterseits behaart; Blüthenstand am Grunde unterbrochen, oben dicht, verlängert ährenförmig; Kelch fast kahl, nur an den Zähnen bewimpert.

Mentha silvestris Linn. var. crispa Benth. in DC. Prodr. XII. 167.

Mentha aquatica Linn. var. crispa Benth. in Berg. u. Schmidt, Darst. u. Beschreib. XXIII ${ }^{d *}$ ).

Der Bau und die Sprossverhältnisse der Grundaxe sind wie bei der vorhergehenden.

Der Stengel ist 50-60 $\mathrm{cm}$ hoch und 2-3 mm dick, er ist unten einfach, krautig, in der Blüthenregion verästelt, behaart, die Haare sind zuritckgebogen, an den Kanten stehen sie dichter; die Äste erreichen die Stengelspitze nicht, sind unverzweigt und laufen in einen Bluthenstand aus.

* Da in den verschiedenen pharmacognostischen Werken mehrere verschiedene Pflanzen unter dem Namen Kra usemilnze abgebildet sind, so haben wir darauf verzichtet, die Litteratur ausfihrlicher anzugeben, zumal es oft schwer ist, aus jenen die Pflanzen richtig zu bestimmen. 
Die Blätter sind kreuzgegenständig; der Blattstiel ist höchstens $1 \mathrm{~cm}$ lang, er ist oben flachrimnig, allseits behaart, die oberen Blätter sind fast oder völlig sitzend; die Blattspreite ist bis $10 \mathrm{~cm}$ lang und kann fast ebenso breit werden, gewöhnlich ist sie aber nur von der Hälfte dieser Dimension, sie ist rund oder eiförmig, länft in eine kurze Spitze aus und trägt an jeder Seite 8-10 ungleiche und etwas verbogene Sägezähne; jederseits des Mittelnerven wird sie von 5-6 am Grunde sehr genäherten Seitennerven durchzogen, zwischen den Nervenmasehen ist die Blattsubstanz ein wenig nach oben blasig anfgetrieben: sie ist auf beiden Seiten, besonders aber unterseits auf den Nerven mit Haaren bestreut und mit sitzenden, goldglänzenden, kleinen Drüschen versehen.

Der Blïthenstand ist eine unten unterbrochene, oben aber dichte, walzige, zusammengesetzte Ähre mit stumpfer Endigung; die Halbquirlpaare werden von verkleinerten Laubblättern, endlich von Hochblättern gestiitzt; sie sind sehr reichblüthig; die Blüthen sind gynodioecisch, vorzïglich kommen an den cultivirten Exemplaren nur weibliche Bliithen vor, die männlichen sind uns nicht bekannt geworden; sie sind kurz gestielt, wickelig verkettet und werden von schmal pfriemlichen Deckblättern gestitzt. Der Keleh ist 2,5-3 mm lang, röhrenförmig bis kreiselförmig, im oberen Drittel fünfzähnigg, fast kahl und nur die Zähne sind gewimpert. Die Blumenkrone ist $3-3,5 \mathrm{~mm}$ lang, im oberen Drittel vierlappig; die Oberlippe ist ein klein wenig länger, wie die ibrigen Zipfel, sie ist wie der Mittellappen der Unterlippe ausgerandet, innen und aussen ist sie kahl: die Röhre ist weiss, die Zipfel sind lila gefärbt. Staubgefässe sind 4 vorhanden, die am Schlunde angeheftet sind; sie sind der Grösse nach fast völlig gleich und messen c. $1 \mathrm{~mm}$, wovon etwa $1 / 3$ auf die unfruchtbaren oder sterile Pollenkörner umschliessenden Staubbeutel kommt. Das weissliche, schwach vierlappige Stempelpolster und der Fruchtknoten zusammen sind $1 \mathrm{~mm}$ lang; der Griffel misst $4 \mathrm{~mm}$, er ist fadenförmig und hat eine kaum $0,7 \mathrm{~mm}$ lange, zweispaltige Narbe mit ungleichen Schenkeln.

Die Frueht ist uns nicht bekannt.

Die ursprüngliche Heimath der Krausemünze lässt sich nicht mehr nachweisen; sie wird gegenwärtig* vielfach in Gärten und besonders in England und Nordamerika im Grossen auf Feldern gebaut.

Sie blüht vom Ende Juni den Sommer hindureh.

Anmerkung. Die vorliegende Tafel 20 stellt eine Pflanze dar, die in der I. Auflage als M. aquatica Linn. var. crispa Benth. bezeichnet wurde. Si $\ominus$ kann wegen des endständigen, nicht achselständigen Blüthenstandes nicht wohl zu jener Art gerechnet werden, wenn sie auch der ziemlich dicken, walzigrunden Ähre halber keine typische Form der $M$, silvestris Linn. darstellt. Wahrscheinlich ist sie ein Bastard jener beiden Arten, oder enthält daneben auch noch eine dritte Art, vielleicht die MI, viridis Linn. Solche mehrfache Bastarde sind nach den besten Mentha-Kennern keine Seltenheit. Briquet, der neueste Monograph der Gattung, äusserte uns gegentiber die Ansicht, dass die Pflanze vielleicht eine Form der $M$. piperita $\mathrm{L}$. ausmache, die er, wie oben erwähnt fïr $M$. arvensis $\mathrm{L} . \times$ viridis $\mathrm{L}$. ansieht. Er theilte uns ferner mit, dass nicht wenige andere Formen der Gattung in solchen crispaten Abänderungen auftreten und dass mit der Abwandlung der Blätter regclmässig der eigenthïmliche Krausemïnzegeruch in mehr oder minder deutlicher Ausprägung sich einstelle. Diese Thatsache erklairt vielleicht die Wahrnchmung, dass in die botanische Bestimmung der Pflanzen, von welchen die Blätter gesammelt werden, so wenig Übereinstimmung zu bringen ist.

Die Krausemünze wird der Blätter wegen cultivirt. Die Folia Menthae crispae enthalten ein ätherisches Öl, dessen speeifiseher Geruch von Links-Carvol herrihit.

\section{Erklärung der Abbildungen.}

Fig. $A$, Die Spitze einer bliihenden Pflanze nach einem Exemplare aus dem Universitätsgarten zu Berlin.

Fig. $B$. Die Blüthenknospe, $10 \mathrm{mal}$ vergrössert: $a$, der Kelch.

Fig. $c$. Die weibliche Bliuthe, $8 \mathrm{mal}$ vergrössert: $b$, die Blumenkrone; $f$. der Griffcl; $g$. die Narbe.

Fig. D. DerKelch, vorn aufgespalten und ausgebreitet, 12mal vergrössert.

Fig. E. Die Blumenkrone, ebenso der Länge nach gespalten und ausgebreitct, $12 \mathrm{mal}$ vergrössert: $c$, die Staubgefisse.
Fig. F.G. Das Staubgefäss, von vorn und von hinten betrachtet, $20 \mathrm{mal}$ vergrössert.

Fig, H.I. Pollenkörner, trocken und in Wasser, $300 \mathrm{mal}$ vergrössert.

Fig. $K$. Das Stempelpolster und der Fruchtknoten, 12mal vergrössert: $d$. das Stempelpolster; $e$. der Fruchtknoten.

Fig. $L$. Dieselben im Längsschnitte: $h$, die Samenanlage. 


\section{THYMUS Linn.}

Blüthen zygomorph, meist gynodioecisch. Keleh zweilippig, röhrig-glockenförmig, 10-13 nervig, die Oberlippe breit, aufrecht, kurz oder bis zur Mitte dreizähnig, die Unterlippe aus 2 pfriemlichen, schmalen, bewimperten Zähnen gebildet, im Schlunde zottig; im Fruchtzustande herabgebogen oder schräg aufrecht. Blumenkrone nicht immer aufällig zweilippig, die Röhre vom Kelche umschlossen oder hervorragend, innen kahl; der Saum vierzipflig: die Oberlippe nur schwach ausgerandet, die Unterlippe dreizipflig mit entweder gleichen Zipfeln, oder einem längeren Mittelzipfel. Staubgefässe 4, hervorragend, seltener eingeschlossen, aufrecht, spreizend, gleich lang oder die vorderen länger, in den weiblichen Blüthen oft nicht mehr nachweisbar; Staubbeutel zweifächrig, mit parallelen oder spreizenden Fächern, die durch ein bald breites, dickes, bald schmales Mittelband vereinigt sind. Stempelpolster gleichförmig, ungelappt. Griffel an der Spitze kurz zweispaltig, mit pfriemlichen Ästen, von denen der hintere zuweilen kürzer ist. Nïsschen eiförmig oder oblong, glatt. - Halbsträucher oder Sträucher mit kleinen, ganzrandigen Blättern. Blüthen in wenigblüthigen Halbquirlen, die von einander getrennt oder ähren- oder kopfförmig zusammengezogen sind; sie werden von laubigen oder gefärbten Deckblättern gestiutzt; Deckblättchen sehr klein.

Die sehr schwierig zu trennenden Arten werden an Zahl zwischen 40 und 80 geschätzt; sie gehören fast alle dem Mittelmeergebiete an, eine ist durch die ganze nördliche gemässigte Zone der alten Welt verbreitet und dringt bis tief in die kalte ein, einige Arten wachsen auf den canarischen Inseln und in Abyssinien.

\section{Thymus Serpyllum Linn.}

Tafel 21.

Halbstrauchartig mit niederliegenden oder kriechenden hin und hergebogenen und verschlungenen Stämmchen und aufsteigenden Ästen; Blätter linealisch bis elliptisch, in den kurzen Blattstiel verschmälert, meist am Grunde borstig gewimpert, flach, oder nur am Grunde wenig zurückgerollt; Seitennerven auf der Rückseite deutlich hervortretend; Halbquirle öfter kopfig gedrängt, seltener die unteren von einander entfernt.

Thymus Serpyllum Linn.*) Spec. pl. ed. I. 590; Fl. Dan. VII. t. 1165; Sturm, Deutschl. Fl. II. 5. XVI. 70; Engl. Bot. XXII. t. 1514; Svensk Bot. V. t. 320; Schrank, Fl. Mon. IV. t. 342; Lam. Encycl. t. 512; Curt. Lond. III. t. 60; Hayne, Arzneigew. XI. t. 1; Woodv. Med. V. t. 320; Baxt. Brit. Bot. II. t. 127; Nees, Düsseld. Pfl. t. 180; Guimp. u. Schlecht. t. 115; Dietr. Fl. Bor. V. t. 338; Spenn. in Nees, Gen. pl. XVIII. t. 343; Koch, Syn. ed. II. 640 und viele andere deutsche Floren; Benth. in DC. Prodr. XII. 200; Reichb. Icon. XVIII. 37. t. 1264. Fig. 2, t. 1265-1268; Berg u. Schmidt, Darstell. und Beschr. XVIIIf; Köhler, Mediz. Pfl. t. 39; Bertol. Fl. Ital. VI. 201; Ledeb. F7. Ross. III. 345; Willk. et Lange, Fl. Hisp. II. 405; Godr. et Gren. Fl. Fr. II. 657; Boiss. Fl. orient. IV. 554; Franch. et Savat. Fl. Jap. I. 367; Hook. fl. Fl. Brit. Ind. IV. 554; Asa Gray, Synopt. Fl. I. (1.) 359; Flïk, Pharmacogn. ed. III. 733.

Thymus pulegioides et Zygis Linn. Spec. pl. ed. I. 591 et 592.

Thymus pannonicus All. Ped. I. 20; Sturm, Deutschl. Fl. XVI. t. 70. Dietr. Fl. Bor. V. 341.

Thymus Marschallianus W. Spec. III. 141; Reichb. Icon. XVIII. 37. t. 1267. Fig. III.

Thymus citiatus Lam. Fl. Franc. II. 392.

Thymus odoratissimus Mill. Dict. n. 9; Reichb. Icon. XVIII. 37. t. 1268. Fig. IV.

*) Mit dieser schon sehr umfangreichen Synonymik ist die Zahl der Namen durchaus noch nicht erschöpft. 
Thymus montanus et acicularis Waldst. et Fit. Pl. Hung. I. 72. t. 71 et II. 157. t. 147.

Thymus nummularius, collinus et odoratissimus Bieberst. Fl. Taur. Cauc. II. 59, III. 401 et 405 ; Bot. Mag. t. 2666; Reichb. Icon. XVIII. 37. t. 1264. Fig. 2.

Thymus citriodorus et silvestris Schreb. in Schweigg. et Körte, Fl. Erlang. 89; Lk. Enum. pl. hort. Berol. II. 115 ; Dietr. Fl. Bor. V. t. 339; Nees, Diisseld. Abb. t. 181. A.

Thymus angustifolius Pers. Ench. II. 130; Nees, Diisseld. Abb. t. 181; Reichb. Icon. XVIII. 37. t. 1265. Fig. I. II. 1, 2.

Thymus citratus Dum. Fl. Belg. 47.

Thymus variabilis Lk. et Hoffmegg. Fl. Port. I. 17.

Thymus majoranifolius Desf. Cat. hort. Paris. 74; Pers. Encycl. Suppl. V. 306.

Thymus laevigatus Vahl, Symb. II. 65.

Thymus lanuginosus Schk. Handb. II. t. 164; Dietr. Fl. Bor. V. t. 340.

Thymus reflexus et inodorus Lej. Rev. 122, et in Fl. Belg. 47.

Thymus effusus Host, Fl. Austr. II. 137.

Thymus spinulosus Ten. Fl. Neapol. prodr. 35.

Thymus micans Lowe, Prim. A. Mader. 19.

Thymus comptus Frivaldsk, in Fl. 1836. p. 439.

Thymus exserens Ehrh. Arb. 159; Dietr. Fl. Bor. V. t. 339.

Cunila thymoides Linn. Spec. pl. ed. II. 3 .

Hedeoma thymoides Pers. Ench. II. 131.

Ziziphora thymoides Roem. et Schult. Syst. I. 209.

Thymbra ciliata Ten. Fl. Neap. prodr. Suppl. II. 69.

Quendel, wilder Thymian, Feldkümmel, Feldpolei; französiseh: Serpolet; englisch: Betony, Thyme.

Eine oft ausserordentlich grosse Zahl etwa $1 \mathrm{~mm}$ dicker und bis $20 \mathrm{~cm}$ langer Stämmehen geht von einer gemeinschaftlichen, senkrecht absteigenden Pfahlwurzel ans. Jene sind in der Jugend gewöhnlich dunkelroth oder gelbbraun gefürbt und von einer kurzen Behaarung grau; die Bekleidung zieht sich bald in zwei, bald in vier Längslinien an den Stengeln herab, bald bedeckt sie ihn gleichmässig, sie kann auch gänzlich fehlen; an den Knoten schicken sie zahlreiche faserige Wurzeln in den Boden. Die blïhenden Äste, welche an den Knoten der Stämmchen entspringen, sind entweder sanft aufsteigend oder mehr aufrecht, zuweilen sind sie nur 3-4, zuweilen $15-20 \mathrm{~cm}$ lang.

Die Blätter sind kreuzgegenständig, 7-15 $\mathrm{mm}$ lang und 1-8 $\mathrm{mm}$ in der Mitte breit; der Stiel ist kurz, zuweilen kaum bemerkbar; die Spreite ist oblong oder umgekehrt eiförmig-elliptisch, oder schmäler spathelförmig, oder lanzettlich, stumpf, am Grunde verschmälert, hier ist sie gewöhnlich mit Wimpern reichlich besetzt, die aber auch (bei den breitblättrigeren Formen) fehlen; sonst ist sie meist auf beiden Seiten kahl; anf der Unterseite treten selbst an den schmalblättrigen Formen die Nebennerven (bis zu drei Paaren) dentlich hervor; anf dieser Seite befinden sich auch zahlreiche, eingesenkt liegende Drüsen, die so tief in der Blattsubstanz eingebettet sind, dass die Spreite gegen das Licht gehalten durchscheinend punktirt ist; Blattbïschel, ans Kurztrieben bestehend, sind seltener in den Blattachseln entwickelt.

Die Blüthen stehen meist in kopfig gedrängten Halbquirlen, an den breitblättrigen Formen sind die unteren oft abgerïckt; jeder besteht aus zwei neben einer Mittelblüthe befindlichen, 2-5 blithigen, sitzenden Winkeln; die Blüthen sind gestielt, die Stielchen haben die Länge der Kelchröhre und sind aufsteigend, ringsum kurz, aber dicht grauhaarig; sie sind nicht selten wie die Kelche violett gefärbt; die Deckblättchen sind lanzettlich, ungefähr $1 \mathrm{~mm}$ lang und gewimpert. Es finden sich zwei Formen von Blüthen: kleinere weibliche mit mehr oder minder deutlichę Resten von Stanbgefässen und grössere zwittrige mit lang hervorragenden Staubblättern. Der Kelch ist 2,5-3 mm lang und bis zur Hälfte in 2 Lippen gespalten; die Röhre ist röhrig glockenförmig, von 10 mässig vorspringenden Nerven durchzogen, sie ist besonders nnterseits an den Nerven behaart; die Unterlippe besteht aus zwei vorgestreckten, ein wenig gekrimmten, gewimperten Zähnen und überragt dic nach oben gewendete, flache dreizähnige Oberlippe um ein geringes; die Zähne der letzteren sind dreiseitig, spitz; die Mïndung des Kelehes ist 
mit einem Kranze steifer Borsten ausgekleidet, welche sieh nach Abfall der Blumenkrone zu einem weissen, den Schlund verschliessenden Kegel zusammenneigen. Die Blumenkrone ist $3-6 \mathrm{~mm}$ lang, schräg aufreeht, sie ist aussen von der halben oberen Röhre an fein und kurz behaart, innen ist sie kahl; die Oberlippe ist breit elliptisch, an der Spitze eingesehnitten, ebenso lang wie die dreizipflige Unterlippe; sie ist blasspurpurroth, nur am Grunde des Mittelzipfels der Unterlippe befinden sich dunklcre Fleeke, zuweilen ist sie rein weiss. Die längeren, unteren Staubgefässe messen $3-4$, die oberen $2-3 \mathrm{~mm}$, jene haben die lilafarbenen, durch gesonderte Längsspalten aufspringenden Staubbentel naeh innen, diese naeh aussen gewendet; die letzteren sitzen an breiten, oben etwas ausgerandeten Mittelbändern; die Staubgefässe sind im Schlunde der Blumenkrone angewaehsen, die grossen streben auseinander, dic kleineren sind einander sehwaeh bogenförmig genähert; die Pollenkörner sind ellipsoidisch und tragen 6 meridionale Falten, in deren Mitte die kleinen Poren aequatorial gestellt sind. Das dunkelgrïne, Nektar abseheidende Stempelpolster misst mit dem Fruehtknoten wenig tiber $0,5 \mathrm{~mm}$; jenes ist ganz schwaeh gekerbt; der Griffel ist $3-6 \mathrm{~mm}$ lang, die Narbe misst kaum $1 \mathrm{~mm}$.

Die $N$ tissehen sind ellipsoidisch, sie haben einen Längsdurehmesser von $0,6-0,7 \mathrm{~mm}$, und sind 3-4 mm diek: ihre Farbe ist kastanienbraun, unter der starken Lupe sind sie fein eingedriickt punktirt; das Wtirzelchen ist sehr kurz und nach unten gewendet, die Keimblätter sind planconvex.

Der Quendel wäehst auf trocknen, sonnigen Haiden, Wiesen und Waldblössen der Ebenen und Gebirge in ganz Europa bis in die nördlichen Theile, und geht über Island bis nach Grönland; über Sibirien wird er verfolgt bis zur Nord-Insel des Japanisehen Arehipels, Jeso; stidlich dringt er bis nach dem westlichen Himalaya und nach West Tibet vor; auch in Abessinien und im Atlas wird er in den höheren Lagen gefunden; in den Vereinigten Staaten ist er nur selten z. B. in Massaehusetts und Pennsilvanien eingeschleppt beobachtet worden. Er blitht vom Juni bis in den Herbst.

Anmerkung. Der Quendel ist, wie aus der Boschreibung hervorgeht, eine ungewöhnlich veränderliche Pflanze, die man in zahlreiche Varietäten getheilt, oder atch in mehrere Arten zerspalten hat. Die auf unserer Tafel wiedergegebene, auf ditrren, sonnigen Plitzen wachsende Form ist besonders aromatisch; sie entspricht der Varietät $\%$. vulgare Benth. Eine Beschreibung der Varietäten hat für uns um so weniger Bedeutung, als die Frage nach der Abgrenzung derselben, so wie tiber die Beanspruchung des Artrechtes noch durchaus nicht gesiehert entschieden ist. Viele dieser Formen sind durch eine eígenthümliche, oft sehr beständige Vertheilung der Geschlechter ausgezeichnet; über diese biologischen Rassen vergl. die oben citirte Arbeit von Aug. Schulze.

Die bltihenden Zweige des Quendel finden als Droge (Herba Serpylli) Verwendung. Die wirksamen Bestandtheile gehen in das ätherische öl tiber, welches man aus der Droge herstellen kann.

\section{Erklärung der Abbildungen.}

Fig. A. Eine blithende Pflanze mit Zwitterblithen.

Fig. B. Das Laubblatt von unten gesehen mit den Nerven, öldrüsen und Wimpern, 3mal vergrössert.

Fig. C. Die Zwitterblithe von vorn gesehen, 5 mal vergrössert: $a$. der Keleh; $b$. die Blumenkrone; $c$. die Staubgefässe; $f$. der Griffel.

Fig. D. Der Keleh, smal vergrössert: $g$. die Narbenschenkel.

Fig. E. Die Blumenkrone der Länge nach aufgeschnitten und ausgebreitet, 8 mal vergrössert: $b$. die Blumenkronröbre.

Fig. $F$. Ein Staubgefäss von vorn und von hinten betrachtet, $25 \mathrm{mal}$ vergrössert.

Fig. $G$. Pollenkörner trocken und in Wasser, 300mal vergrössert.
Fig. $H$. Der Kelch längs aufgespalten und ausgebreitet, $10 \mathrm{mal}$ vergrössert: $d$. das Stempclpolster; $e$. der Fruchtknoten; $f$. der Griffel.

Fig. I. Das Stempelpolster und der Fruchtknoten im Längsschnitte, 15 mal vergrössert: $h$, die Samenanlagen.

Fig. $K$. Der Fruchtknoten im Querschnitte.

Fig. L. Die Frucht ein wenig tiber natiirliche Grösse.

Fig. M. Dieselbe, 12mal vergrössert: $e$. Nüsschen.

Fig. $N$. Ein Nüsschen von anssen gesehen.

Fig. $O$. Dasselbe von innen gesehen: $i$. Ansatzstelle.

Fig. $P$. Dasselbe im Längssehnitte $: k$. Wiirzelehen; $1, \mathrm{~K}$ eimblätter.

Fig. Q. Dasselbe im Querschnitte. 


\section{Thymus vulgaris Linn.}

Tafel 22.

Stranch- oder halbstrauchartig, in der Cultur besonders der nördlichen Gegenden ein ausdauerndes oder nur einjahhriges Kraut, mit dichter, graner Behaarung oder fast kahl; Blätter lineallanzettlieh, elliptisch, oder gerundet rhombisch, spitz, am Rande zuriekgerollt, kahl oder fein behaart; Halbquirle von einander entfernt, nur die oberen kopfig zusammengezogen.

Thymus vulgaris Linn. Spec. pl. ed. I. 591; All. Fl. Ped. I. 20; Nees, Diisseld. Abb. t. 181; Hayne, Arzneigew. XI. t. 2; Woodv. Med. pl. II. t. 125; Guimp. u. Schlecht. II. 18. t. 116; Koch. Syn. 557; Benth. in DC. Prodr. XII. 199; Reichb. Icon. XVIII. 36. t. 126t. Fig. I; Bentl. and Trim. Med. pl. t. 205; Berg und Schmidt, Darstell. und Beschreib. XVIII ; Köhler, Mediz. Pfl. t. 58; Bertol. Fl. Ital. VI. 210; Godr. et Gren. Fl. Fr. II. 687; Willk. et Lange, Fl. Hisp. II. 403; Flück. and Hanb. Pharmacogr. 437; Flïck. Pharmacogn. ed. III. 729.

Thymian, römischer Quendel; französisch: Thym; englisch: Thyme, Garden thyme.

In der Heimath erreichen die knorrigen, verholzten Stämmehen eine Dieke von $5 \mathrm{~mm}$, sind sehr verästelt und mit grauer, rissiger Borke bekleidet; sie liegen dem Boden an oder steigen bogenförmig auf; dabei erreichen sie eine Höhe von höchstens 35-40 cm; mehrere werden durch eine gemeinsehaftliche, holzige, verästelte Pfahlwurzel verbunden; die jüngeren, mehr krautigen, oberen Theile sind durch starre, abwärts gewendete Haare graubraun oder grïnlichgrau; die bei uns eultivirten Pflanzen sterben in der Regel bis auf die Grundaxe ab und treiben im Frühjahre etwa $1-1,5 \mathrm{~mm}$ dicke, $15-25 \mathrm{~cm}$ hohe krautige, kahle oder spärlich behaarte, verzweigte Stengel von vierseitigem Querschnitte.

Die Blätter sind kreuzgegenständig und tragen in den Achseln reichbeblätterte Kurztriebe; sie sind mit einem 1, höchstens $2 \mathrm{~mm}$ langen, oberseits seicht gefurchten Blattstiele befestigt; die Spreite misst 6 - $S$ (5-9) $\mathrm{mm}$ in der Länge und am unteren Drittel 2,5-4 2-5) $\mathrm{mm}$ in der Breite; sie ist etwas fleischig; am Rande zurtickgebogen, spitz oder stumpflich, am Grunde in den Blattstiel verlaufend; bei den sehmäleren Blättern ist nur der Mittelnerv und zwar besonders unterseits sichtbar, an den breiteren bemerkt 'man noch Spuren von Seitennerven; die Oberseite ist etwas dunkler als die Unterseite, jene ist deutlich, diese undeutlicher eingedrïckt drüsig punktirt; die Blätter der cultivirten Exemplare sind gewöhnlich kahl, die der wildwachsenden mit kurzen, geraden, oder geknieten Haaren besonders unterseits bekleidet.

Die Halbquirle sind kurz (bis $1 \mathrm{~mm}$ lang) gestielt und bestehen neben der Mittelbluthe aus jederseits 2-5blithigen Wickeln; die Deekblättchen sind lanzettlich und kaum iber $1 \mathrm{~mm}$ lang; neben den entwickelten Blüthen finden sich stets noch 2-3 nicht vollkommen zur Ausbildung gelangte am Grunde der letzten. Der Gesammtbliithenstand ist eine unten unterbrochene, oben continuirliche, zusammengesetzte Ähre. Die Blïthen sind gestielt und zwar sind die Blüthenstiele so lang oder etwas länger als der Keleh. Sie sind von zweierlei Gestalt: die grösseren sind zwittrig, die kleineren nur weiblieh. Der Kelch der zwittrigen Blüthe ist etwa $4-5 \mathrm{~mm}$ lang, davon misst der röhrig-glockenförmige, untere Theil die Hälfte; die Unterlippe ist etwas länger wie die im oberen Drittel dreizähnige Oberlippe; er ist aussen und zwar unterseits etwas länger und dichter als oberseits behaart und mit sitzenden, goldgelben Druischen bestreut; am Schlunde ist er innen mit einem Ringe dichter, schräg aufrecht stehender und zu einem flachen Kegel zusammenschliessender, weisser Borsten bekleidet; die Nerven treten nur wenig deutlich hervor. Die Blumenkrone ist schräg aufsteigend, 4-6 mm lang und im oberen Drittel vierzipflig; sie ist gleichfarbig lila, am Grunde weiss; die Oberlippe ist aufrecht, flach und ausgerandet, die Unterlippe grösser, horizontal gestellt oder schief abwärts geneigt und dreizipflig, der mittlere Zipfel ist nur wenig länger, wie die seitlichen und an der Spitze kaum ausgerandet; von der mittleren Röhre an ist die Blumenkrone nach oben hin mit kurzen Härehen bestrent. In der Zwitterbltithe sind die Staub- 
gefässe am Schlunde befestigt, die grösseren vorderen messen $2,5-3 \mathrm{~mm}$, die kleineren hinteren die Hälfte, sie sind kahl; die Staubbeutel sind herzförmig mit spitzlichem, dickem Mittelbande, an dem die beiden Hälften von oben nach unten auseinander fahrend befestigt sind; jede Hälfte springt mit einer gesonderten Längsspalte auf. Das dunkelgrine Stempelpolster misst mit dem Fruchtknoten kaum $0,5 \mathrm{~mm}$; der Griffel ist im weiblichen Zustande der Bluthe so lang wie die Blumenkrone; er ist etwas gekrimmt und verdickt sich nach dem Grunde zu, wobei er vorn und hinten ein wenig abgeflacht ist; sein mittlerer und oberer Theil ist stielrund; die ein wenig ungleichen Narbenäste sind $0,8-1 \mathrm{~mm}$ lang, spitz und spreizen endlich. In der weiblichen Blithe sind die Staubgefässe nicht entwickelt; in der Röhre der Blumenkrone sieht man aber stets die Reste derselben in der Gestalt zuweilen äusserst winziger Wärzchen.

Die N iisschen sind $1 \mathrm{~mm}$ lang und in der Mitte $0,7 \mathrm{~mm}$ breit, sie sind ellipsoidisch; das Würzelehen ist sehr kurz, nach unten gewendet, die Keimblätter sind planconvex.

Der Thymian wächst an trocknen, sonnigen, felsigen Orten von Portugal, durch ganz Spanien, SiudFrankreich, an der Riviera und an der Kuiste Italiens bis Terracina, auch aus dem neapolitanisehen Gebiete ist er bekannt, weiter östlich ist er nicht gefunden worden; in den Seealpen steigt er bis $1000 \mathrm{~m}$ hoch; an der Rhone entlang dringt er bis ins Wallis vor. Er wird häufig in Gärten cultiviert und gedeiht noch, freilich als einjährige Pflanze, unter dem $70^{\circ} \mathrm{n}$. Br. an der Westküste von Norwegen.*) Er bluht von Anfang Juni bis in den Herbst.

Anmerkung. In Deutschland hat man gewöhnlich nur die beiden oben erwïhnten Bltithenformen beobachtet; in Italien dagegen und in England finden sich auch alle Übergänge von den Zwitterblüthen zu rein männlichen, indem der Griffel nach und nach bis zum völligen Verschwinden sich verkleinert. Für die weiblichen Blüthen konnte selbst dann, wenn scheinbar keine Spur von Staubgefïssen zu sehen war, die Anlage derselben entwicklungsgeschichtlich nachgewiesen werden; nach dieser Erfahrung wurden später auch an scheinbar rein weiblichen Bliithen in sehr geringer Entfernung von dem Röhrengrunde die Reste der Staubgefässe regelmässig wahrgenommen.

Die beblätterten, bltihenden Zweige der wildwachsenden oder cultivirten Pflanze finden im getrockneten Zustande als Herba Thymi, Thymian oder römischer Quendel medicinische Verwendung. Die Droge liefert etwa $1 \%$ ätherisehes $0 ̈ 1$, dessen wichtigster Bestandtheil das Thymol ist.

\section{Erklärung der Abbildungen.}

Fig. A. Eine junge, blühende, cultivirte Pflanze mit Zwitterblüthen.

Fig. B. Die weibliche Blithe schräg von vorn gesehen, $5 \mathrm{mal}$ vergrössert: $a$. der Kelch; $b$. die Blumenkrone; f. der Griffel.

Fig. C. Die Zwitterblithe, 3mal vergrössert: $c$. die Staubgefässe.

Fig. D. Dieselbe längs aufgcschnitten und ausgebreitet, 5mal vergrössert

Fig. E. Ein Staubgefäss von vorn und von hinten betrachtet, $10 \mathrm{mal}$ vergrössert.

Fig. F. Pollenkörner trocken und im Wasser, 300mal vergrüssert.

Fig. $G$. Der Kelch, 5mal vergrüssert: $f$. der Griffel; $g$. die Narbenschenkel.
Fig. H. Derselbe der Länge nach aufgespalten und ausgebreitet: $d$. das Stempelpolster; e. der Fruchtknoten; $f$. der Griffel.

Fig. I. Das Stempelpolster und der Fruchtknoten, 12mal vergrössert.

Fig. $K$. Dasselbe im Längsschnitte: $h$. die Samenanlagen.

Fig. L. Der Fruchtknoten im Querschnitte.

Fig. $M$. Die Frucht, natïrliche Grösse.

Fig. $N$. Dieselbe, $7 \mathrm{mal}$ vergrössert.

Fig. $O$. Ein Nüsschen von innen gesehen: $i$. die Ansatzstelle.

Fig. $P$. Dasselbe im Längsschnitte.

Fig. Q. Dasselbe im Querschnitte: $l$. die Keimblätter.

*) Vielfach wird auch Marokko als Fundort angegeben; aber weder in Ball, Spicilegium, noch in Battandier et Trabut, Flore d Alger ist der Thymian erwähnt. 


\section{MELISSA Linn.}

Blüthen zygomorph, zwittrig, homomorph. Kelch zweilippig, röhrig-glockenförmig, 13 nervig, die Oberlippe flach, aufrecht, dreizähnig; die Unterlippe aus 2 pfriemlichen vorstehenden Zipfeln gebildet; im Schlunde spärlich behaart; im Fruchtzustande herabgebogen. Blumenkrone deutlich zweilippig, die Röhre aus dem Kelche hervorragend, gekrïmmt aufsteigend, oben etwas erweitert, innen kahl; der Saum vierzipflig: die Oberlippe aufrecht zweizähnig, die Unterlippe mässig vorgestreckt, dreispaltig, der Mittelzipfel grösser, ganz oder ausgerandet. Staubgefässe 4 , zweimächtig, die vorderen länger, unter der Oberlippe gebogen-zusammengeneigt; Staubbeutel zweifächrig, mit ubereinandergestellten, durch eine gemeinschaftliche, zusammenfliessende Spalte aufspringenden Hälften. Stempelpolster gleichförmig, kurz vierzähnig. Griffel an der Spitze kurz zweispaltig, Äste pfriemlich, ziemlich gleich lang, zuriickgerollt. Niisschen eiförmig, glatt. - Ausdanernde Kränter mit gezähnten Blättern. Blüthen in wenigblüthigen Halbquirlen, die von einander getrennt sind und von laubigen Blättern gestiitzt werden. Deckblättehen kleinlaubig.

3 Arten in Süd-Europa, Vorder-Asien und Ost-Indien.

\section{Melissa officinalis Linn.}

Tafel 23.

Stengel aufrecht, ästig, mehr oder weniger behaart, kantig; Blätter eiförmig, am Grunde gestutzt oder herzförmig, grob gekerbt-gesägt, gestielt. Halbquirle sehlaff, einseitswendig; Deckblättehen eiförmig bis lanzettlich; Blumenkrone um ein Viertel bis die Hälfte länger als der Kelch.

Melissa officinalis Linn. Spec. pl. ed. I. 592; All. Fl. Ped. I. 37; Sturm, Deutschl. Fl. III. 11; Lam. Ill.t. 512; Hayne, Arzneigew. VI. t. 32; Nees, Diisseld. Abb. t. 180; Woodv. Med. pl. II. t. 119; Guimp. u. Schlecht. II. t. 143; Koch, Syn. 561; Spenn. in Nees, Gen. pl. VI. t. 11; Benth. in DC. Prodr. XII. 240; Berg u. Schmidt, Darstell. u. Beschr. t. XXVII ; Köhler, Mediz. Pf. t. 65; Bertol. Fl. Ital. VI. 229; Ledeb. Fl. Ross. III. 356; Godr. et Gren. Fl. Fr. II. 668; Willk. et Lange, Fl. Hisp. II. 417; Boiss. Fl. orient. IV. 584; Asa Gray, Syn. Fl. I. (1). 361; Flück. Pharmacogn. ed. III. 734.

Melissa graveolens Host, Fl. Austr. II. 128.

Melissa foliosa Opiz, nach Bentham.

Melissa romana Mill. Dict. $n, 2$.

Melissa hirsuta Balbis, nach Bentham.

Melissa cordifolia Pers. Ench. II. 132.

Melissa altissima Sibth. et Sm. Fl. Graec. VI. 63. $t .579$.

Melisse, Citronenmelisse, Gartenmelisse, Citronenkraut, Bienenkraut; französisch: Mélisse, citronelle; englisch: Balm.

Aus einer federkieldicken, hin und hergebogenen, stielrunden oder vierkantigen, aussen dunkelbraunen, innen weissen Grundaxe, die später verholzt, treten Ausläufer hervor, die sich mehr oder weniger zuerst horizontal fortbewegen, dann senkrecht aufsteigen und sich zu nenen beblätterten Stengeln entwickeln. Sie nehmen ihren Ursprung aus den Achseln von etwas fleischigen, linealischen oder pfriemlichen, weissen Niederblättern, erzeugen deren selbst zunächst 2-4 Paar, die später wieder Ausläufer hervorbringen und sind besonders an den Knoten mit zahlreichen, fadenförmigen, gelblichbraunen Wurzeln bedeckt.

Der Stengel erreicht eine Höhe von $0,5-1 \mathrm{~m}$ und wird $3-4$ selten bis $5 \mathrm{~mm}$ dick, er ist fast kahl oder besonders an den jüngeren Theilen mit abstehenden Börstehen bekleidet; er ist stumpf vierkantig, krautig, oben grün, unten weisslich und gern violett angeflogen. 
Die Blätter sind kreuzgegenständig; der Blattstiel misst $1-3(0,5-4) \mathrm{cm}$ in der Länge, er ist von der Seite mässig zusammengedriickt und oben flach gefurcht; seine Bekleidung ist die des oberen Stengels. Die Spreite ist 3-4,5 (1-8) cm lang und im unteren Viertel 2-3,5 (1-5) cm breit; sie ist gewöhnlich eiförmig oder oblongeiförmig, spitz und am Grunde gestutzt, breit keilförmig oder herzförmig; sie ist am Rande mit gewöhnlich 5-8 spitzlichen oder stumpfen Zähnen versehen und wird meist von 3-4, selten mehr Paaren von Seitennerven durchzogen; der Consistenz nach ist sie krautig; oberseits ist sie mit hyalinen, angepressten Haaren bestreut, unterseits ist sie unter der Lupe mit goldglänzenden, eingesenkten Öldrüsen und spärlichen Köpfehenhaaren besetzt, sonst kahl oder an den Nerven behaart.

Die Halbquirle aus den Achseln der Blätter sind am Grunde mit zwei kleinlaubigen elliptischen, oder lanzettlichen, oben weichhaarigen, unten fast kahlen Deckblittchen versehen, welche eine Mittelblïthe stitzen; aus ihnen treten unten $3-5$, oben $1-3$ wickelig verkettete Blithen hervor, so dass an jedem Knoten 12-20 Bluthen sitzen; vermöge der Blüthenstiele können sich die Halbquirle einseitswendig stellen.

Die Blüthen sind stets zwittrig, kurz gestielt. Der Keleh ist $6-8 \mathrm{~mm}$ lang, röhrig-glockig von 13 stark vorspringenden Nerven durchzogen und aussen behaart, sowie mit sitzenden Driisen bekleidet. Die Oberlippe ist nach oben gerichtet, ziemlich ausgebreitet und mit 3 Kerbzähnen, die fein zugespitzt sind, versehen; die Unterlippe ist sebr schwach nach oben gekrümmt, zweispaltig mit pfriemlichen, bewimperten Zähnen: der Schlund ist nur mässig mit angepressten Haaren besetzt, die Röhre ist innen kahl. Die Blumenkrone ist $\mathrm{S}-12 \mathrm{~mm}$ lang, weiss; die Röbre von der Länge des Kelehes hat keinen eigentlichen Haarring, ist vielmehr in der Mitte nach der Oberlippe lin mit hyalinen, angepressten Haaren bedeckt; sie ist im oberen Theile deutlich, wenn auch wenig, nach oben gekrimmt und etwas erweitert, hier ist sie innen blassgelb; die Oberlippe ist gerade, gerundet und an der Spitze ansgerandet; die Unterlippe ist niedergebogen, dreilappig;, der Mittellappen mehr als doppelt so lang wie die Seitenlappen. Die unteren Staubgefässe sind $3-4$, die oberen 1-1,5 mm lang, sie sind paarweise bogenförmig einander genähert: die Staubbeutel messen $0,8-1 \mathrm{~mm}$; zuerst spreizen die beiden Hälften gegen einander, später stellen sie sich übereinander und springen mit einer zusammenfliessenden, bogenförmigen, gemeinschaftlichen Längsspalte auf; die Pollenkörner sind ellipsoidisch und werden von 6 Meridionalfalten durchzogen, in denen einzelne, äquatorial gestellte Poren liegen. Das Honig abscheidende Stempelpolster ist breitcylindrisch, an der Spitze kurz vierzähnig, kahl. Der Fruchtknoten besteht aus 4 ellipsoidischen, stumpfen, glatten Theilen, die aus 2 Fruchtblättern entstanden sind; jeder Theil umschliesst eine aufrechte, gewendete Samenanlage. Der Griffel erhebt sich vom Grunde aus der Mitte jener, er ist fadenförmig, gekrïmmt, 7-11 mm lang, kahl; die Narbe ist zweispaltig, mit zuletzt zuriekgekrümmten Sehenkeln von $1 \mathrm{~mm}$ Länge.

Die $\mathrm{N}$ üsschen sind 1,5-2 mm lang, umgekehrt eiförmig-oblong, undeutlich dreikantig, obeıt stumpf, glatt oder nur unter der Lupe feinnetzig skulpturirt, glänzend hellbran, nur die vertiefte Ansatzstelle ist weiss gerandet.

Der Same enthält kein Nährgewebe, sein Würzelchen ist kurz, nach unten gewendet, die Keimblätter sind planconvex.

Die Melisse wächst besonders in Sïd-Europa um das Mittelmeer häufig; auch in Nord-Afrika ist sie nicht selten; von Italien aus berïhrt sie in ihrer Verbreitung auch noch die weitere deutsche Flora; ron den Gegenden der unteren, mittleren und niederen Donau geht sie iber die Krim nach dem Kaukasus, dem Ural, Sibirien und Turkestan, in Nord- und Ost-Persien erreicht sie ihre Ostgrenze. Sie wird in Gärten nicht selten cultivirt und gedeiht noch als einjährige Pflanze im sỉdlichen Schweden.

Sie blitht von Ende Juni bis in den Herbst.

Die enltivirte Pflanze liefert die Folia Melissae, deren Anwendung durch die geringe Menge des wenig untersuchten ätherischen Öles bedingt ist, welches die Droge enthält. 
Erklärung der Abbildungen.

Fig. A. Die Spitze eines blühenden Stengels, nach einem im Universitätsgarten zu Berlin cultivirten Exemplare.

Fig. B. Eine Blüthe, 4mal vergrössert: $a$. der Kelch; $c$. die Oberlippe; $c^{\prime}$. die Unterlippe; $d$. die Blumenkrone; e. die Staubgefitsse.

Fig. C. Der Kelch von der Seite gesehen, 8mal vergrössert.

Fig. D. Derselbe von vorn gesehen.

Fig. $\boldsymbol{E}$. Die Blumenkrone der Länge nach gespalten und ausgebreitet, $10 \mathrm{mal}$ vergrössert: $d$. Staubgefässe.

Fig. F.G. Ein Staubgefïss vor dem Verstäuben, von vorn und von hinten betrachtet, $16 \mathrm{mal}$ vergrössert.

Fig. H. Dasselbe nach dem Verstäuben.

Fig. I. Pollenkörner, 200mal vergrössert.

Fig. $K$. Der Kelch der Länge nach aufgespalten und ausgebreitet, von innen betrachtet, $10 \mathrm{mal}$ vergrössert: $f$. das Stempelpolster; $g$. der Fruchtknoten; $h$. der Griffel; $i$. die Narbenschenkel.

Fig. L.M. Das Stempelpolster und der Fruchtknoten von aussen betrachtet und im Längsschnitte, 30 mal vergrössert: $f$. das Stempelpolster; $g$. der Fruchtknoten; $k$. die Samenanlagen.

Fig. N. Ein Querschnitt durch den Fruchtknoten, 40mal vergrössert.

Fig. O. Die Spitze des Griffels mit den beiden Narbenschenkeln, $25 \mathrm{mal}$ vergrössert.

Fig. P. Ein Nüsschen in natürlicher Grösse.

Fig. $Q$. Dasselbe, von innen und von anssen betrachtet.

Fig. R. Dasselbe im Querschnitte, 10mal vergrössert: $m$. Keimblïter.

Fig. S. Dasselbe in Längsschnitten senkrecht und parallel zu der Rückenfläche: $l$ das Würzelchen.

\section{SAIVIA Linn.}

Blüthen stark zygomorph, zwittrig oder gynodioecisch, selten kleistogam. Keleh zweilippig, Röhre trichterförmig; die schief aufrechte, längere Unterlippe aus zwei pfriemförmigen Zähnen gebildet, die Oberlippe kürzer, dreizähnig oder ungetheilt; im Schlunde kahl, zur Fruchtzeit wagerecht abstehend oder aufrecht. Blumenkrone zweilippig, gerade aus dem Kelch aufsteigend, Röhre iiber denselben hervorragend; Oberlippe helmförmig, von der Seite zusammengedriickt; Unterlippe wagerecht abstehend, von der Mitte an nach unten gebogen, dreilappig; zuweilen offnet sie sich niemals (kleistogame Blïthen). Staubgefässe 4, von denen aber nur die vorderen fruchtbar, die hinteren zu gestielten, keulenförmigen Körpern verkümmert; jene unter der Oberlippe aufsteigend, parallel oder spreizend; Mittelband aussergewöhnlich verlängert, fadenförmig, gegliedert an dem Staubfaden angeheftet und beweglich, Staubbeutelfächer mit Längsspalten aufspringend, durch jenes weit von einander getrennt, das obere Fach viel grösser als das untere, dieses meist völlig steril, zuweilen aber Pollenkörner enthaltend; die beiden kleineren Fächer der benachbarten Staubgefässe sind zu einer Platte verbunden, welehe nicht selten den Zugang in den Blumenkronenschlund verschliesst. Stempelpolster gleichförmig, kurz vierzähnig; Griffel bogenförmig nach oben gekrïmmt, an der Spitze zweispaltig mit ungleich langen Narbenschenkeln. Nüsschen kugel- oder eiförmig, glatt. — Kräuter, Halbsträucher oder Sträucher mit sehr vcrschiedener Tracht; Blätter ganzrandig, gezähnt, gelappt oder mehr oder minder eingeschnitten. Die Halbquirle 2-8blüthig, zu Ähren, Trauben oder Rispen verbunden, und von laubigen, häufiger aber häutigen und gefärbten Deckblättchen gestlutzt; Blüthen oft gross und ansehnlich, schön gefärbt, zuweilen aber auch klein oder sehr klein.

Wohl an 500 Arten, die in den gemässigten, besonders aber den heissen Gegenden beider Hemisphären heimisch sind.

\section{Salvia officinalis Linn.}

Tafel 24.

Halbstrauchig mit ruthenförmigen, straff aufrechten, diinnfilzigen, jiingeren blühbaren Zweigen; Blätter gestielt, oblong oder oblong-lanzettlich, spitz, am Grunde spitz, gerundet oder gestutzt, fein gekerbt, runzlig, beiderseits oder unterseits mehr oder weniger filzig; Blitthenstand eine unterbrochene, zusammen- 
gesetzte Ähre; Kelch glockenförmig-kreiselig, häutig, 15 nervig, weichhaarig und drïsig punktirt, Oberlippe dreizähnig; Blumenkrone 2-3mal länger als der Kelch; Röhre innen gegen den Grund mit einem Haarringe versehen, Oberlippe aufrecht; Staubgefässe oben spreizend; die kleineren Fächer der Beutel meist Pollen führend, verwachsen, den Schlnnd der Blumenkrone nicht versehliessend.

Salvia officinalis Linn. Spec. pl. ed. I. 23; Lam. Encycl. t. 20; All. Fl. Ped. I. 12; Rousseau, Bot. t. 22 ; Sturm, Fl. Deutschl. III. t. 9; Schkuhr; Handb. t. 4; Trattin. Arch. III. t. 261; Hayne, Arzneigew. V. t. 1; Nees, Düsseld. Abb. t. 161; Guimp. et Schlecht. 1. 69. t. 39; Woodv. Med. Bot. II. t. 127; Spenn. in Nees, Gen. pl. VI. t. S; Koch, Syn. 554; Benth. in DC. Prodr. XII. 264; Berg u. Schmidt, Darst. und Bescheib. XVII ; Bentl. and Trim. Med. pl. t. 206; Köhler, Mediz. Pfl. t. 38; Bertol. Fl. It. I. 136; Godr, et Gren. Fl. Fr. II. 670; Willk. et Lange, Fl. Hisp. II. 420; Fliuckig. Pharmacogn, ed. I1I. 736 .

Salvia chromatica Hffmegg, Verz, 1821. p. 194.

Salvia grandiflora Ten. Fl. Neap. prodr. App. V. p. 3.

Salbei; französisch: Sauge officinale; englisch: Sage, garden sage.

Der sehr reiehlich verzweigte, holzige Sta mm wird bis $40 \mathrm{~cm}$ hoch und ist mit graubrauner, dünner Rinde bedeckt; die blühenden Zweige sind krautig, sie erreichen eine Länge von $20-35 \mathrm{~cm}$ und sind am Grunde 1-2 mm diek; sie sind vierkantig und namentlich in der Jugend von einem hellgrauen Filze bedeckt, sie verzweigen sich gewöhnlich nur in der Blithenregion.

Die Blätter sind kreuzgegenständig; die unteren haben einen 1,5-2,5 (1-3) em langen, oberseits besonders am Grunde rinnigen, grau filzigen Blattstiel, die oberen sind nicht selten vollkommen sitzend; die Blattspreite ist $3,5-6(1-7) \mathrm{em}$ lang und in der Mitte $1-2(0,3-2,5) \mathrm{em}$ breit, an cultivirten Exemplaren kann sie aber $10 \mathrm{~cm}$ in der Länge und $5 \mathrm{~cm}$ in der Breite erreichen; auf jeder Seite des Mittclnerven wird sie von $6-8$, besonders unterseits deutlichen, oben vertieft gelegenen Seitennerven durchzogen; das kleinmaschige Nerrennetz wird dadurch sehr deutlich, dass sich zwischen ihnen die Blattsubstanz blasig nach oben erhebt: beiderseits ist die Spreite mit einem bald dichteren, bald diunneren, grauen Filze bedeckt und mit winzig kleinen, goldgelben, sitzenden Drüschen bestreut.

Der $\mathrm{Bl}$ uthenstand ist endständig und wird aus $5-8$ Specialblüthenständen aufgebaut; die letzteren sind paarige Halbquirle, welche jederscits der Mittelblithe aus 2-3, unmittelbar aus der Blattachsel hervortretenden Blithen zusammengesetzt werden, sie werden gestiitzt von häutigen, eiförmigen, zugespitzten, gefärbten, frïh abfälligen Deckblättern; die Blithenstiele sind 2-5 mm lang, stielrund, dünnfilzig, schräg aufrecht: die Deckblättchen sind häutig, oblong lanzettlich, zugespitzt. Der Kelch ist c. $1 \mathrm{~cm}$ lang, kreiselförmig glockig, im oberen Drittel zweilippig, und wird von 15 stark hervortretenden Nerven durchzogen. an den letzteren und am Rande ist er behaart und aussen mit sitzenden Drüsen bestreut; die Oberlippe ist dreizähnig, bräunlich-violett, die Unterlippe zweispaltig, dunkelgrün. Die Blumenkrone ist $2 \mathrm{~cm}$ lang*), im oberen Drittel zweilippig, violett (seltener weiss); die am Grunde weisse Röhre ist oberhalb der Basis eingeschnuirt und dort innen mit einem Haarkranze versehen, nach oben hin erweitert sie sich und ist sehr schwach gekrummt, sie ist fast kahl; die gewölbte, oben ausgerandete, schwach behaarte Oberlippe ist kleiner als die breite, dreilippige, am umgekehrt herzförmigen Mittelzipfel niedergebogene Unterlippe, deren Seitenlappen schief eiförmig, spitz sind; beide sind mit Drüsen bestreut. Die 4 Staubgefässe sind in gleicher Höhe im Schlunde angeheftet; die hinteren Staminodien sind kaum 1 mm lang, die Staubfäden der fruchtbaren vorderen sind gekrümmt und $5-6 \mathrm{~mm}$ lang; das ebenfalls gekrümmte Mittelband des Stanbbeutels misst $3 \mathrm{~mm}$, der grosse Staubbeutel 2,5-3, der kleine $1 \mathrm{~mm}$; das Mittelband liegt dem Staubfaden gelenkig verbunden auf und ist diesem mittelst einer kleinen Spitze angewachsen; die beiden zusammenhängenden, kleinen Staubbeutelfächer verschliessen den Blumenkronenschlund nicht ganz; durch grossköpfige Insekten werden sie aber nach rïckwärts verschoben und somit das bewegliche Mittelband nach unten gedrüekt; beide Beutelfächer berïhren dann den Riticken des

* Zuweilen kommen auch kleinbluthige Formen vor, die aber gegen die grösseren keinen Geschlechtsunterschied zeigen. 
Insektes und streifen auf ihm Pollenkörner ab. Das Stempelpolster und der Fruchtknoten sind fast $2 \mathrm{~mm}$ lang, das erstere ist weisslich, vorn aber violett gefärbt; der leicht bogenförmig gekrïmmte, fadenförmige Griffel misst $2 \mathrm{~cm}$, der längere in der Mitte oberseits gefurehte Narbenschenkel 2, der kiirzere $1 \mathrm{~mm}$.

Die $\mathrm{N}$ ï sschen sind $2 \mathrm{~mm}$ lang und haben 1-2 mm Durchmesser, je nachdem $1-4$ entwickelt sind, sie haben gewöhnlich eine fast kugelförmige, manchmal aber ellipsoidische oder eiförmige Gestalt und besitzen am Ende ein winziges Spitzchen; sie sind kastanienbraun, nur unter der starken Lupe fein grubig punktirt, und haben eine weiss gerandete Ansatzstelle; das Würzelehen ist knrz, nach unten gewendet, die Keimblätter sind dick, planconvex.

Die Salbei findet sich wild auf trocknen, sonnigen Stellen in Nord-, Mittel- und Ost-Spanien, in dem siidwestlichen Frankreich und der Provence, in Nord-Italien und Corsica, bei Triest, in Dalmatien; auch in Sïd-Italien ist sie vorhanden. Sie wird sehr häufig in Gärten gezogen und gedeiht als einjährige Pflanze in Norwegen noch jenseits des Polarkreises. Sie bliht rom Juni bis in den Herbst.

Die wildwachsende oder auch die eultivirte Pflanze liefert die Folia Salviae. Aus der Droge kömnen ungefäbr 1, 5\% eines ätherischen Öles erhalten werden, dessen charakteristischer Bestandtheil das Salviol ist.

\section{Erklärung der Abbildungen.}

Fig. A. Ein zweijühriger Ast mit zwei blïhenden Zweigen nach einem im Universitätsgarten zu Berlin cultivirten Exemplare.

Fig. B. Die Blüthe um die Hälfte vergrössert: $a$. der Kelch.

Fig. C. Die Blumenkrone der Länge nach aufgespalten und ausgebreitet, 2mal vergrössert: $b$. Blumenkronenröhre mit $c$, dem Haarringe; $d$. die oberen unfruchtbaren Staubgefïsse; $e$. die unteren fruchtbaren Staubgefässe; $g$. das Mittelband; $h$. das grosse Fach des Staubbeutels.

Fig. D. Das fruchtbare Staubgefässpaar, 4mal vergrössert: bei $i$, den kleineren Fächern zusammenhängend; f. der Staubfaden.

Fig. F. Ein fruchtbares Staubgefäss, 6mal vergrössert: das kleinere Fach durch eine Lüngsspalte aufgesprungen.

Fig. $F$. Das obere Ende des Staubfadens $f$ mit der Gelenkfläche $g$ des Mittelbandes, 8mal vergrössert.
Fig. G. Pollenkörner, trocken und im Wasser, c. $300 \mathrm{mal}$ vergrössert,

Fig. H. Der Kelch mit dem Griffel, 2mal vergrössert: $n$. Griffel; o. Narbe.

Fig. I. Derselbe der Länge nach aufgespalten und ausgebreitet, 2 mal vergrössert: $k$. das Stempelpolster ; l. der Fruchtknoten.

Fig. $K$. Das Stempelpolster mit dem Stempel, 5mal vergrössert.

Fig. $L$. Dasselbe im Längsschnitte: $m$. Samenanlage.

Fig. $\boldsymbol{M}$. Der Fruchtknoten im Querschnitte.

Fig. $N$. Die Frucht, natïrliche Grösse.

Fig. $O$. Dieselbe, 6mal vergrössert.

Fig. $P$. Die Nuss, 6mal vergrössert: o. Ansatzstelle.

Fig. Q. Dieselbe im Querschnitte.

Fig. $R$. Dieselbe im Längsschnitte senkrecht zur Ritckenfläche: $p$. die Keimblätter, $q$. das Wiirzelchen.

Fig. S. Dieselbe im Längsschnitte parallel zur Rïckenfläiche.

*) Weiter östlich dringt sie nicht vor, in der Flora orientalis von Boissier ist sie nicht erwähnt; in Nord-Afrika wird sie nur cultivirt. 


\section{ROSMARINUS Linn.}

Blitthen stark zygomorph, zwittrig. Kelch zweilippig, Röhre eiformig-glockig; die sehief aufrechte Oberlippe gerade, concav, sehr kurz, zuweilen verschwindend dreizähnig, die gerade vorgestreckte Unterlippe zweispaltig, mit spitzen Lappen; im Schlunde kahl, zur Fruchtzeit abstehend oder nach unten gebogen. Blumenkrone zweilippig, gerade aus dem Kelche aufsteigend; Röhre iber jenen etwas hervorragend, im Schlunde erweitert, innen ohne Haarring; Oberlippe aufrecht, ausgerandet oder kurz zweispaltig, nicht helmförmig; Unterlippe wagerecht abstehend, dreilappig, der genagelte an der Spitze ausgerandete, concave Mittellappen der grösste, nach unten gebogen. Staubgefässe 4, von denen aber nur die vorderen 2 fruchtbar, die hinteren zu kleinen, gestielten, sehief Tförmigen, oder stiftförmigen, winzigen Körpern verkümmert, zuweilen kaum sichtbar; jene unter der Oberlippe anfsteigend, sie weit überragend, parallel, mit den Beuteln zusammenhängend; Mittelband aussergewöhnlich verlängert, allmählich in den Faden übergehend; Staubbeutelfäeher weit von einander getrennt, nur das obere fruchtbar, mit einer Längsspalte aufspringend, das untere zu einem gekrimmten, kurzen, nach unten gewendeten Spitzchen verkümmert. Stempelpolster gleichförmig, kurz vierzähnig; Griffel halbkreisförmig nach oben gekrümmt, an der Spitze zweispaltig mit ungleich langen Narbenschenkeln. Nüsschen von elliptischem Umrisse, glatt, am Grunde anf der Bauchseite ansgehöhlt, Aussatzstelle auf einer mittleren Leiste, zuweilen zitzenförmig vorgezogen. - Ein Strauch mit schmalen, ganzrandigen, am Rande zurückgerollten Blättern. Blithen mässig gross, in wenigblüthigen, achselständigen, kurzen, deeussirten Trauben; die unteren Deekblätter zuweilen laubig, die oberen klein, hoehblattartig, aber nicht gefärbt.

Eine Art im Mittelmeergebiete.

\section{Rosmarinus officinalis Linn.}

Tafel 25 .

Strauchig, verästelt, mit reichbeblätterten, straff aufrechten oder gekrümmten, in der Jugend vierkantigen, dünn filzigen Zweigen; Blätter schmal linealisch, spitz, am Grunde etwas verschmälert, fast sitzend, gerade oder sichelförmig gekrtimmt, am Rande stark zurtickgerollt, oberseits kahl, unterseits weissfilzig; Blithenstand knrz, wenigbliithig, einfach traubig oder in den untersten Blättern 2 blithige Wickeln tragend; Blïthen kurz gestielt.

Rosmarinus officinalis Linn. Spec. pl. ed. I. 23; Lam. Encycl. t. 19; Kerner, Hort. semperv. t. 360 , All. Fl. Ped. I. 15; Duham. ed. II. vol. III. t. 44; Sibth. et Sm. Fl. Gr. I. 11. t. 14; Lk. et Hoffmegg, Fl. Port. 1. 145; Hayne, Arzneigew. VII. 27; Nees, Düsseld. Abb. t. 161; Guimp. und Schlecht. I. t. 54; Koch, Syn. 553; Woodv. Med. Bot. II. 117; Spenner in Nees, Gen. pl. V. t. 10; Benth. in DC. Prodr. XII. 360; Berg u. Schmidt, Darst. und Beschr. X ${ }^{c}$; Köhler, Mediz. Pfl. t. 122; Bertol. Fl. It. I. 134; Godr. et Gren. Fl. Fr. II. 669; Willk. et Lange, Fl. Hisp. II. 419; Battand. et Trab. Fl. d'Alg. II. 695; Boiss. Fl. or. IV. 636; Flückig. and Hanbury, Pharmacogr. 438; Flück. Pharmacogn. ed. III. 738.

Salvia Rosmarimus Spenner, Handb. II. 445.

Rosmarin; französisch: Romarin; englisch: Rosemary.

Der sehr reichlich verzweigte, holzige Stamm erreicht eine Höhe von $0,6-2 \mathrm{~m}$ und einen Durchmesser bis zu $60 \mathrm{~cm}$; er ist aufrecht, seltener kriecht er tiber Felsen; die stärkeren Zweige sind abstehend sparrig und rund; sie werden von einer schmutzig grauen, in Längsstreifen sich ablösenden Rinde bedeckt; die jüngeren sind hellbräunlichgrau oder rein weiss filzig, vierkantig.

Die Blätter sind kreuzgegenständig, an der Basis sind sie durch eine sehwach vorspringende Leiste 
verbunden; der Blattstiel ist gewöhnlich äusserst kurz, er misst kaum jemals $1 \mathrm{~mm}$; die Blattspreite ist $2-2,5(1-3,2) \mathrm{cm}$ lang und in der Mitte meist $1-1,5 \mathrm{~mm}$, selten $2-3 \mathrm{~mm}$ breit, sie ist linealisch, an den Rändern oft so stark eingerollt, dass sie sich anf der Riickseite beribren; sie ist lederartig, die glänzende, gerunzelte Oberseite ist kahl, grün und wird von einer Mittelfurche durchzogen; die Unterseite ist weissfilzig, schwach blasig zwischen den kleineren Nerven vertieft und mit einem stark vorspringenden Mittelnerven versehen; zwischen den Büschelhaaren des Filzes liegen zahlreiche Öldriisen, die aber auch der Oberseite nicht ganz fehlen. Die Blätter dauern 2-3 Jahre aus; indem sehr früh in ihren Achseln gestauchte Kurztriebe auftreten, erhält die Pflanze ihr reich beblättertes Aussehen.

Die Blüthen stehen in decussirten Trauben und treten gewöhnlich einzeln aus den Achseln von 1-1,5 mm langen und c. $1 \mathrm{~mm}$ breiten oblongen, spitzlichen, auf der Unterseite und besonders am unteren Rande dünnfilzigen, oben kahlen Deckblättern, sie sind mit einem 2-4 mm langen Stiele versehen, an dessen Grunde 2 lanzettliche, kaum 0,5 mm lange Vorblättchen befestigt sind; am Grunde des Blithenstandes befinden sich 2 bis mehr Paare meist verkleinerter Laubblätter, ans deren Achseln an sehr kräftigen Exemplaren noch weitere Blüthenstände hervorbrechen können; zuweilen sind auch die untersten Blüthen durch eine zweite bereichert, wodurch die Einleitung zur Rispenbildung gegeben ist. Der Kelch ist $5 \mathrm{~mm}$ lang und bis zum oberen Drittel zweilippig, er ist aussen von einem Filze aus Büschelhaaren weiss und ausserdem mit Drüsen bestrent, innen ist er kahl; die Oberlippe wird von 3, die Unterlippe von 2 stärker vorspringenden Nerven durchzogen, zwischen denen noch 7 schwächere Nerven erkennbar sind. Die Blumenkrone ist 8-9 mm lang, bis zur Hälfte 2lippig gespalten und blassblau; die Oberlippe ist aufrecht, ausgebreitet und in 2 etwa $1 \mathrm{~mm}$ lange, spitze, am Ende und aussen sehr fein behaarte Läppchen getheilt; die Unterlippe misst 5-6 mm, der Mittellappen ist nach unten gebogen, breit eiförmig, an der Spitze seicht ausgerandet, am Grunde in einen Nagel zusammengezogen, am Rande feingekerbt; er ist satter blan gefärbt, dunkel punktirt und in der Mitte von einem weissen Streifen längs durchzogen, die Seitenlappen sind schief oblong, spitz und nach oben gewendet; die ganze Unterlippe ist aussen fein behaart und mit spärlichen Drïsen bestreut, die Röhre ist anssen kahl; innen ist die Blumenkrone ebenfalls kahl. Die zwei fruchtbaren sta ubgefässe sind am Ausgange der Röhre angeheftet, sie sind 10-11 mm lang; die stark, zuweilen fast halbkreisförmig nach unten gekrümmten Fäden sind von den Seiten her zusammengedrückt, sic gehen so allmälig in die gleichartigen Mittelbänder über, dass eine Grenze zwischen beiden nicht unmittelbar sinnfällig ist; der Vergleich mit Salvia lehrt aber, dass das Mittelband bis zu dem, an dem Faden vorhandenen, nach unten gewendeten, winzigen Spitzchen reicht, das für ein Rudiment der zweiten Staubbeutelhälfte angesehen werden muss; aus diesem Grunde ist auch der $2 \mathrm{~mm}$ lange asymmetrische Staubbeutel einfächrig; die Pollenkörner werden von drei sehr wenig deutlichen, meridionalen Längsfalten durchzogen; die zwei rudimentären Staubgefässe sitzen etwas höher, sie sind höchstens $1 \mathrm{~mm}$ lang, zuweilen aber an der entwickelten Blüthe kaum oder überhaupt nicht mehr nachweisbar; ihre Gestalt wechselt von winzigen Höckerchen zu T-Gestalten mit etwas gekrümmten Armen. Das Stempelpolster und der Fruchtknoten sind zusammen 1,5 mm lang, das erstere ist grün und am Rande schwach vierlappig, der fadenförmige Griffel misst 1,4-1,5 cm, er ist stark nach unten gebogen, die Narbe ist ungleich zweispaltig und kaum $1 \mathrm{~mm}$ lang.

Die Nüsschen sind 1,5-2,5 mm lang und haben einen grössten oberen Querdurchmesser von 0,8-1 mm, sie sind rothbraun und am Grunde auf der Bauchseite stark ansgehöhlt; in dieser Vertiefung befindet sich die Ansatzstelle, zuweilen auf einem zitzenförmig vorgezogenen Fortsatze; sie sind mit einer im Wasser stark quellenden Schleimschicht ïberzogen; das Würzelchen ist sehr kurz und nach unten gewendet.

Der Rosmarin wächst auf trocknen oder felsigen Hitgeln des Mittelmeergebietes und zwar mit Vorliebe in der Nähe der See, doch dringt er auch in die Binnenländer ein; er findet sich besonders im westlichen Theile des erwähnten Gebietes und zwar von Portugal dureh Spanicn, in den Pyrenäen und Süd-Frankreich, anf den Balearen steigt er bis $1300 \mathrm{~m}$ über den Meeresspiegel; seine Nordgrenze erreicht er im Wallis und Süd-Tyrol, die Südgrenze in Algier und der benachbarten Sahara; in Italien wäehst er von Piemont bis Neapel und Sicilien; von Istrien lässt er sich verfolgen bis zur Insel Zante, Macedonien, 
Thrazien und Boeotien; auf den Inseln des griechischen Archipels ist er selten und nur von Melos bekannt; auf dem asiatischen Continente ist er nur in Fichtenwäldern des Strandes von Cilicien gefunden worden.

Anmerkung. Spenner hat die Gattung Rosmarinus mit Salvia vereinigt, die erstere lässt sich aber durch die nicht gegliederten, sondern continuirlich in das Mittelband fortlaufenden Staubfiden, durch die aufrechte und flache Oberlippe, besonders aber auch durch die Natur des Bliithenstandes, der in der mehr als 500 Arten umfassenden Gattung Salvia niemals auftritt, gut untersehieden.

Von der Pflanze finden die getrockneten Blätter als Folia Rosmarini Verwendung. In Süd-Frankreich und Dalmatien stellt man ein ätherisches Öl, das Rosmarinöl, durch Destillation der Zweige der Pflanze mit Wasser dar.

\section{Erklärung der Abbildungen.}

Fig. A. Ein Ast einer blühenden Pflanze nach einem in dem Berliner Universitätsgarten cultivirten Exemplare; natürliche Grösse.

Fig. B. Ein Bliuthenstandsknoten mit einem Kelehe, das Deckblatt umschliesst den Grund des Blüthenstieles so weit, dass die beiden Vorblätter nicht sichtbar sind; 3 mal vergrössert: $a$. die Oberlippe des Kelches; $b$. die Unterlippe.

Fig. C. Eine Blïthe schief von vorn gesehen, 3mal vergrössert: $a$, der Kelch; $b$. die Oberlippe der Blumenkrone; $c$. die Unterlippe derselben.

Fig. D. Eine Blüthe der Länge nach aufgespalten und ausgebreitet, $3 \mathrm{mal}$ vergrössert: $a$. unfruchtbare, $b$, fruchtbare Staubgefässe.

Fig. $E$. Ein fruchtbares Staubgefäss, 9mal vergrössert.

Fig. F. Ein Staubbeutel von vorn gesehen, 9mal vergrössert.
Fig. G.H. Pollenkörner trocken und unter Wasser, $350 \mathrm{mal}$ vergrössert.

Fig. I. Der Kelch vorn aufgespalten und ausgebreitet, $3 \mathrm{mal}$ vergrössert: $a$. der Kelch; $b$. das Stempelpolster; c. der Fruchtknoten.

Fig. K. L.Das Stempelpolster und der Stempel, 8mal vergrössert: $b$. das Stempelpolster; $c$. der Fruchtknoten; $d$. der Griffel.

Fig. M.N.Dieselben im Längsschnitte und Querschnitte.

Fig. $O$. Die Frucht, 5mal vergrössert.

Fig. $P$. Dieselbe, natürliche Grösse.

Fig. Q. R. Ein Nüsschen von der Innen- und Seitenfläche gesehen, $5 \mathrm{mal}$ vergrössert.

Fig. S. Dasselbe im Längsschnitte: $a$. das Würzelchen; b. die Keimblätter. 


\section{Familie: Scrophulariaceae R. Br.}

Die Bluthen sind zwittrig und fast ausnahmslos zygomorph. Der Keleh ist unterständig, bleibend, glocken- oder röhrenförmig, fünf- selten vierzähnig oder-lappig. Die Blumenkrone ist verwachsenblättrig, zuweilen rad- oder breitgloekenförmig, nicht selten mit am Grunde verengter, oben angeschwollener Röhre; der Saum ist entweder gleichförmig fünf- bis vierlappig, oder öfter zweilippig mit dachziegeliger Deckung der Zipfel. Staubgefässe sind meist 4 vorhanden, die didynamiseh sind, zuweilen aber nur 2, selten sind $5 \mathrm{da}$, von denen das dorsale dann zuweilen steril ist; die Staubbeutel sind gewöhnlich zweifächrig und springen mit Längsspalten auf, sie hängen nicht selten paarweise zusammen; ein Polster ist unter dem Stempel nicht immer entwickelt. Der Fruchtknoten ist oberständig, sitzend, ungetheilt, meist vollständig zweifächrig, die Samenleisten laufen gewöhnlich an der Scheidewand herab; der Griffel ist einfach, ganz oder an der Spitze in 2 kurze Narbenlappen gespalten; Samenanlagen sind $\infty$ in jedem Fache, sehr selten finden sich nur 2, sie sind anatrop und die Mikropyle ist nach unten gewendet. Die Frueht ist kapselartig und springt versehieden auf, selten ist sie beerenartig. Die Samen sind meist sehr zahlreich und sind grund- oder seitenständig befestigt; sie haben ein fleischiges Nährgewebe; der Keimling ist meist gerade.

Kräuter oder Halbsträucher, selten Sträucher oder kleine Bäume mit entweder ausschliesslich spiral oder kreuzgegenständig und wirtelig gestellten Blättern, häufig wechseln die Stellungen, indem die Blätter unten kreuzgegenständig, oben spiral angeordnet sind; die Spreite ist zuweilen gelappt oder eingeschnitten; Nebenblätter 0 . Blüthenstände rispig oder traubig, zuweilen stehen die Bluthen einzeln in den Blattachseln; Deckblätter und Vorblättchen sind meist vorhanden.

Die Familie umfasst 170 Gattungen mit ubber 2000 Arten, die über die ganze Erde zerstreut sind, besonders aber in den gemässigten Zonen gedeihen; sie fehlen auch den alpinen und den kältesten polaren Gegenden nicht.

Die officinellen Scrophulariaceen gehören in folgende Tribus:

TRIBUS I. Verbasceae Benth. Blätter sämmtlich spiral gestellt; Blüthenstände rispig oder ährenförmig; in der Knospenlage stehen die oberen 2 Blumenkronenzipfel aussen; Blumenkrone radförmig; das füfte Staufgefäss ist oft vorhanden.

\section{Verbascum thapsiforme Schrad.}

TRIBUS II. Digitaleae Benth. Blätter versehieden; Blüthenstände ährenförmig oder rispig; in der Knospenlage der Blumenkrone sind die beiden seitlichen Zipfel die äusseren, oder es gehört der eine derselben zu ihnen; das fünfte Staubgefäss fehlt, die Staubbeutel liegen mit den Spitzen eng aneinander oder verschmelzen vollkommen.

\section{Digitalis purpurea Linn.}




\section{VERBASCUM Linn.}

Keleh tief fünftheilig, selten kurz fünfzähnig mit dachziegelig deckenden Lappen. Blumenkrone radförmig, meist flach, fünflappig, Lappen fast vollkommen gleich, in der Knospenlage die hinteren die äussersten. Staubgefässe 5, dicht ïber dem Grunde der Blumenkrone eingefügt, Staubbeutel quer aufgelegt oder dem Faden angewachsen, in Längsspalten aufspringend und zusammenfliessend. Stempel 1; Fruchtknoten zweifächrig, die Fächer hinter einander in der Flucht des Deckblattes; Samenanlagen $\infty$ horizontal, anatrop; Griffel fadenförmig, an der Spitze von vorn nach hinten zusammengedrückt; Narbe kopfig. oder zweiseitig am Griffel herablaufend. Kapsel kugelig bis ciförmig, wandtheilig zweiklappig, Klappen an der Spitze zweispaltig mit eingebogenen Seitenrändern. Samen zahlreich, gerunzelt, der gerade Embryo in reichlichem fleisehigem Nährgewebe. - Zweijährige, selten ausdanernde Kräuter oder Halbsträucher, mehr oder weniger mit einem Filze oder einer flockigen Wolle aus Büschelhaaren bekleidet, mit spiralgestellten, oft weichhaarigen Blättern, die ganzrandig, gebuchtet oder fiederspaltig sind. Blüthen in einfachen Trauben, meist aber in lockeren oder dicht gedrängten Rispen, mit oder ohne Deckblättchen, gelb, schmutzigpurpurn oder roth, selten ins Weisse abwandelnd.

Von den 150 beschriebenen Arten sind ein erheblicher Theil Bastarte, so dass kaum 100 wohl zu unterscheidende Arten bleiben; sie wachsen in Europa, Nord-Afrika, West- und Central-Asien.

\section{Verbascum thapsiforme Schrad.}

\section{Tafel 26.}

Zweijährig mit einfachem, aufrechtem, dichtbeblättertem Stengel; Blätter oblong oder schmal umgekehrteiförmig, sitzend, am Grunde bis zum nächst unteren Blatt herablaufend, gekerbt, zugespitzt; Blïthen in dichten ährenartigen, am Grunde unterbrochenen Rispen; Blumenkrone ausgebreitet; obere 3 Staubgefässe weisswollig, die unteren $2 \mathrm{kahl}$ mit weit herablaufenden Beuteln, die nur 2 mal kürzer sind als die Fäden.

Verbascum thapsiforme Schrad. Monogr. Verb. I. 21; Mert. und Koch, Deutchl. F7. 1I. 206 und viele andere deutsche Floren; Nees, Düsseld. Abb.t. 159; Hayne, Arzneigew. XII. t. 39; Guimp. und Schlecht. II. 62. t. 153; Dietr. Fl. Bor. IV. t. 261; Benth. in DC. Prodr. X. 226; Berg und Schmidt, Darstell. u. Beschr. t. XXI ; Köhler, Mediz. Pfl. sub t. 45; Bertol. Fl. Ital. II. 573; Ledeb. Fl. Ross. III. 194; Godr. et Gren. II. 549; Willk. et Lange, Fl. Hisp. II. 540; Boiss. Fl. or. IV. 301; Flïck. Pharmacogn. ed. III. 787 .

Verbascum Thapsus Poll. Palat. I. 217, non Linn.; Gmel. Fl. Bad. I. 495; Meyer, Chlor. Hannov. 325; Koch, Syn. 510 .

Verbascum Thapsus Linn. var. thapsiforme Hook. fil. Fl. Brit. Ind. IV. 250.

Verbascum cuspidatum Schrad. Monogr. I. 23. t. 1. Fig. 1.

Verbascum Kicxianum Dumort. Florul. belg. (nach Bentham.).

Verbascum phlomoides Mey. Fl. Hann. excurs. 381; Franch. Étud. sur Verbascum 37.

Königskerze, Wollkraut, Himmelskerze, Fackelkraut; französisch: Molène; englisch: Torch-weed, mollein.

Die Keimpflanze erzeugt im ersten Jahre eine grosse Rosette von oblongen, spitzen, am Grunde allmälig in den geflügelten und endlich deutlich verbreiterten Blattstiel zusammengezogenen, am Rande grobgekerbten, beiderseits filzigen Blättern, die im zweiten Jahre einen 0,60-2 $\mathrm{m}$ hohen steifaufrechten, unverzweigten, oder am untersten Grunde einige blühende Äste erzeugenden Stengel treibt; er ist krautig, undeutlich fünfkantig und von den herablaufenden Blättern geflügelt, später verholzt er. 
Die Wurzel ist spindelförmig, einfach oder wenig verzweigt und mit Fasern dicht besetzt.

Die Blätter stehen am Stengel in spiraler Ordnung; die unteren sind gestielt, die oberen sind sitzend und laufen mit zwei Seitenflugeln auf beiden Flanken des Stengels ungleich weit herab; die unteren erreichen eine Länge bis zu $35 \mathrm{~cm}$ und sind bis $10 \mathrm{~cm}$ im oberen Drittel breit, die oberen werden allmälig viel kleiner; die Spreite ist oblong bis breitelliptisch, am Rande ist sie gekerbt, anf der Oberseite ist sie runzlig und auf der Unterseite von einem vorspringenden Adernetz durchzogen; sie ist wie der Stengel beiderseits, aber unten dichter dureh einen Überzug von Büschelhaaren filzig.

Die Bläthen entstehen zuerst einzeln in den Achseln von spiralgestellten, kleinlaubigen, sitzenden, sehr lang zugespitzten Deckblättern, sie sind mit zwei eilanzettlichen bis lanzettlichen Vorblättchen versehen, aus deren Achseln zwei neue, ebenfalls von Vorblättchen begleitete Bliithen entspringen, die mit der Hauptblïthe ein dreigliedriges Dichasium bilden; der Blïthenstand wird dadurch bereichert, dass, ehe die beiden Seitenblithen angelegt werden, unter der Hauptblüthe eine untere Beiknospe mit Vorblättchen entspringt, der sich später noch mehrere gleiche zugesellen; aus ihren Vorblättchen entwickeln sich später ebenfalls Blüthen, nicht minder bilden sich unter den Seitenblüthen solche Genossenschaften, deren Elemente aber keine Vorblättchen besitzen. Auf diese Weise wird jener Blüthenstand gebildet, den man Blüthensehwanz genannt hat und der die Eigenthïmlichkeit bietet, dass er immer wieder von unten her aufblïht, indem die Aufblïhfolge von der Entstehungsfolge der Blüthen abhängt.

Der Blüthenstiel ist kurz, nur selten bis $5 \mathrm{~mm}$ lang, aber kräftig $(1,5-2 \mathrm{~mm}$ diek $)$, er ist diinnfilzig. Der Kelch misst während der vollen Blüthe $6-8 \mathrm{~mm}$, er ist glockenförmig, bis zur Mitte gespalten, der unpaare obere Zipfel ist ein wenig kleiner, wie die beiden unteren; die Abschnitte sind eilanzettlich, spitz und wachsen nach dem Verblïhen aus; er ist aussen filzig, innen kahl. Die Blumenkrone ist radförmig und hat einen grössten in der Ebene durch das Deckblatt gelegenen Durchmesser von 3,3-3,8 cm; sie ist bis zum unteren Drittel getheilt. Die Lappen sind fast kreisrund, die beiden oberen sind um ein Drittel kleiner, wie der grösste untere; sie ist aussen, die Basis der Röhre ausgenommen, dünnfilzig, innen kahl und glänzend, die Farbe ist kanariengelb, selten weiss. Die Staubgefässe sind oberhalb des Röhrengrundes befestigt; die oberen drei sind 5-7 mm lang; die pfriemförmigen, gelben Fäden sind über der Mitte mit langer, weissgelber Wolle bedeckt, der orangegelbe, gekrimmte $2 \mathrm{~mm}$ lange Staubbeutel ist in der Mitte quer aufgelegt; die unteren zwei Staubgefässe messen $9-10 \mathrm{~mm}$, die $3-4 \mathrm{~mm}$ langen Beutel sind der Innenseite des nach oben gekrümmten, kahlen Fadens der ganzen Länge nach angewachsen; die Pollenkörner sind orangeroth, ellipsoidisch, werden von drei meridionalen Längsfalten durchzogen und sind zart punktirt. Der Fruchtknoten ist eiförmig, schwach zweilappig, er misst $2 \mathrm{~mm}$ in der Länge und hat denselben Breitendurchmesser; er ist schief, da das untere der beiden Fächer etwas grösser ist wie das obere und aussen filzig; die $\infty$ Samenanlagen haben nur ein Integument und sitzen senkrecht gestellt an den halbkugelig verdickten, der Mittelwand angewachsenen Samenleisten; der Griffel ist 1,2-1,3 cm lang, er ist zuerst nach unten, dann aber, der Biegung der unteren Staubgefässe entsprechend, nach oben gekrïmmt; es ist kahl, stielrund, am Ende aber ein wenig seitlich verbreitert und in zwei winzige Narbenläppchen getheilt, von denen das untere etwas grösser wie das obere ist; die Narbenpapillen laufen an den Seiten von der Spitze in einem allmälig schmäler werdenden $4 \mathrm{~mm}$ langen Felde herab.

Die Kapsel ist $8-10 \mathrm{~mm}$ lang und $7-8 \mathrm{~mm}$ breit, sie ist fast kugelig, an den Seiten schwach zusammengedrückt und von einer Furche durchzogen, sie trägt oben ein kleines Spitzehen, ist zuerst sternhaarig, später kahl; sie springt wandspaltig in zwei Klappen auf, die bis zur Mitte wieder zweispaltig sind; die nach innen gebogenen Rïnder der Klappen lösen sich endlich von der Samenleiste.

Der Same misst kaum $1 \mathrm{~mm}$, er ist fast eylindrisch, oben gestutzt, unten abgerundet; er wird von 10 Reihen kleiner Verticfungen längs durchzogen; die deutliche Rhaphe ist fadenförmig; seine Farbe ist braun. Der Keimling ist gerade, das Wiirzelchen ebenso lang wie die Keimblitter.

Diese Königskerze wächst in ganz Mittel- und Süd-Europa, von Frankreich bis Dänemark und Russland und von Spanien bis Mittel-Italien, Creta, Griechenland und in der Krim; im Himalaya findet sie 
sich von Kaschmir bis Butan und West-Tibet; sie wächst auf trockenen Hïgeln und Haiden, sowie an Wegrändern und blüht von Anfang Juli bis in den Oktober.

Anmerkung. G. F. W. Meyer hat zuerst die Meinung ausgesprochen, dass $V$. thapsiforme Schrad. von $V$. phlomoides Linn. nicht specifisch zu trennen sei; wir können dieser Meinung, die auch Franchet und Flückiger getheilt haben, wohl beipflichten, da sich das aus den Blättern hergenommene Merkmal als kaum geniigend erweist, um unserer Pflanze einen anderen Werth als vielleicht den einer Varietät zuzuerkennen. Dagegen können wir der Ansicht von Hooker fil. nicht folgen, der in dieser Art eine Varietät von $V$. Thapsus L. erkannte.

Die leicht ablösbaren Blumenkronen, denen das Andröceum aufsitzt, kommen in getrocknetem Zustande als Flores Verbasci in den Handel.

\section{Erklärung der Abbildungen.}

Fig. A. Der obere Theil des Stengels unter dem Blithenstande.

Fig. $B$. Der Blüthenstand.

Fig. C. Eine soebeu abgeblühte Blüthe ohne Blumenkrone, 3 mal vergrössert: a. der Kelch; $h$. der Griffel; i. die Narbe.

Fig. D. Die Blumenkrone vorn aufgespalten und flach ausgebreitet, natürliche Grösse: $c$. Vorderlappen; $d$. obere Stuubgefïsse; $e$. untere Stanbgefässe.

Fig. E. Das mittlere der oberen Staubgefässe, 3mal vergrüssert.

Fig. $F$. Eins der unteren Staubgefïsse, vor und nach dem Anfspringen, 3 mal vergrössert.

Fi. G.H. Pollenkürner trocken und unter Wasser, $300 \mathrm{mal}$ vergrüssert.
Fig. I. Der Kelch und Fruchtknoten im Längsschnitte, 5mal vergrössert: $b$. der Blüthenbodeu; $f$. der Fruchtknoten; $g$. der Samenträger; $h$. die Griffelbasis.

Fig. $K$, Der Fruchtknoten im Quersehnitte, 5 mal vergrössert.

Fig. $L$. Die Kapsel, 3mal vergrössert: $g$. die Samenleiste; k. die Klappen.

Fig. $M$. Die Länge der Kapsel in natürlicher Grösse.

Fig. N. Samen in natürlicher Grösse.

Fig. O. Der Same, 12mal vergrössert.

Fig. P.Q. Derselbe in Lïngs- und Querschnitte: $l$. das Nährgewebe; $m$. das Würzelchen; $n$. die Keimblätter.

Fig. $R$. Der Keimling, 20 mal vergrüssert.

\section{DIGITALIS Linn.}

Kelch tief fïnftheilig mit aufsteigend deckenden Zipfeln, bleibend. Blumenkrone rachenförmig mit bauchiger oder glockenförmiger Röhre; Saum mehr oder weniger deutlich zweilippig, die Oberlippe kurz, ausgerandet, die Unterlippe dreizipflig, der Mittelzipfel zuweilen vergrössert, immer vorgestreckt, mit absteigender Deckung der Zipfel. Staubgefässe 4, zweimächtig, aufsteigend, in der Röhre eingeschlossen, paarweise oft bogenförmig genähert; Staubbeutel zweifächrig, Fächer zuerst parallel, dann auseinanderspreizend, endlich übereinander gestellt, mit Längsspalten aufspringend und zusammenfliessend. Stempel aus zwei vorn und hinten gestellten Fruchtblättern gebildet; Fruchtknoten zweifächrig, das untere (vordere) Fach etwas grösser wie das obere; Samenanlagen $\infty$ anatrop, die oberen aufrecht, die mittleren horizontal, die unteren hängend, der verdickten, an der Scheidewand befestigten Samẹnleiste angeheftet; Griffel fadenförmig, an der Spitze kurz zweilappig. Kapsel eiförmig, wandtheilig zweiklappig, Klappen ungetheilt. Samen $\infty$, sehr klein, grubig punktirt. — Zweijährige oder ausdauernde Kräuter, deren Stengel nur selten am Grunde verholzt, ohne oder mit filziger oder wolliger Bekleidung aus einfachen Haaren. Blätter am Grunde oft rosettig gedrängt, an dem Stengel spiralig gestellt, ganzrandig oder gezähnt. Blüthen in oft verlängerten, enḋständigen, nicht selten einseitswendigen Trauben, von gelber, purpurner, oder weisser Farbe, im Schlunde oft gefleckt und behaart.

18 Arten in Europa, West- und Mittel-Asien. 


\title{
Digitalis purpurea Linn.
}

\author{
Tafel 27.
}

Zweijährig mit einfachem, aufrechtem Stengel; Blätter eioblong bis oblong, am Grunde in den Blattstiel versehmälert, an der Spitze stumpflich, die oberen sitzend, runzlig, gewöhnlich beiderseits, aber unterseits stets dichter behaart; Traube verlängert, einseitswendig; Kelchzipfel eilanzettlich; Blumenkrone aussen kahl, nach oben glockig erweitert, purpurroth, innen weiss gefleckt.

Digitalis purpurea Linn. Spec. pl. ed. I. 621; Plenck, Ablild. t. 506; Fl. Dan. I. t. 74; Lam. Encycl. t. 525; Gärtn. Fr. I. t. 53; Engl. Bot. XIX. t. 1297; Rousseau, Bot. 27; Hayne, Arzneigew. I. t. 45; Woodv. Med. t. 78; Steph. and Church. Med. pl. t. 18; Brandt und Ratzeb. Giftgew. t. 12; Guimp. und Schlecht. Arzneipfl. t. 7; Nees, Düsseld. Abb. t. 154; Dietr. Fl. Boruss. XI. t. 762; Baxt. Br. Bot. II. t. 113; Lindl. Monogr. t. 2; G. F. W. Mey. Fl. Hannov. II. t. 1; Koch, Syn. 518 und viele andere deutsche Floren; Benth. in DC. Prodr. X. 451; Reichenb. Icon. Fl. Germ. XX. t. 1688; Berg und Schmidt, Darst. und Beschr. t. XXI ${ }^{b}$; Bentl. and Trim. Med. pl. t. 195; Ledeb. Fl. Ross. III. 225; Godr. et Gren. Fl. Fr. II. 602; Willk. et Lange, Fl. Hisp. II. 589; Asa Gr. Syn. Fl. I. suppl. 438; Flückig. and Hanb. Pharmacogr. 422; Flück. Pharmacogn. ed. III. 669.

Digitalis tomentosa Lk. et Hffmegg. Flor. Portug. 220. $t$. 29.

Rother Fingerhut; französisch: Digitale; englisch: Foxglove.

Die Keimpflanze erzeugt im ersten Jahre eine grössere oder kleinere Blattrosette, die im zweiten Jahre den Stengel austreibt.

Die Wurzel steigt senkrecht hinab, sie ist bis zu $0,3 \mathrm{~m}$ lang und oben gewöhnlich rübenförmig angeschwollen; hier und da verzweigt sie sich und bringt auch zuweilen im zweiten Jahre eine neue Blattrosette hervor, so dass die Pflanze eine Neigung zum Ausdauern verräth; sie ist dicht mit verüstelten Faserwurzeln besetzt.

Der Stengel erreicht eine Höhe bis 2, selten sogar bis $3 \mathrm{~m}$ und hat einen Durehmesser von $1-3 \mathrm{~cm}$ an der Basis; er ist durch die hervortretenden Blattspuren unregelmässig fünfkantig, kurz weichhaarig, zuerst einfach, doch treibt er nach dem Abblühen nicht selten aus den unteren Blättern einige im Spätsommer bliihende Ästc.

Die Blätter sind spiralgestellt; die der Grundrosette können eine Länge von $60 \mathrm{~cm}$ und eine in der Mitte der Spreite gelegene grösste Breite von $17 \mathrm{~cm}$ erreichen, sie sind eioblong, am Ende stumpflich, am Grunde in den oft die Hälfte des ganzen Blattes messenden dreikantigen, gefliigelten Blattstiel verschmälert; die Stengelblätter werden allmälig kleiner, wobei sich der Blattstiel so weit verkiirzt, dass sie schliesslich sitzend sind, sie sind auch gewöhnlich schmäler, eilanzettlich oder oblong-lanzettlich; die Blattspreite ist am Rande gekerbt; jede Kerbe endet in eine gelbliche Driise, die später ein schwarzes Spitzchen darstellt, sie wird jederseits des Mittelnerven von 4-7, ebenso wie das Adernctz, oben eingesenkten, unten stark vorspringenden Nerven durchzogen; indem sich zwischen den Maschen die Blattsubstanz nach oben verwölbt, wird die Fläche runzlig; sie ist oberseits dunkelgrün, matt und kurz weichhaarig, wird aber in der Cultur fast kahl, unterseits ist sie hellgrïn und dichter behaart, zuweilen fast filzig, die Haare sind einfach und gegliedert, sehr spärlich finden sich Köpfehenhaare.

Der Blüthenstand ist eine einseitswendige Traube, die bis $1 \mathrm{~m}$ Längc erreicht, gewöhnlich aber nur 20-30 cm misst; die unteren Deckblätter sind eilanzettlich und kleinlanbig, zugespitzt, ganzrandig und parallelnervig, die oberen werden allmälig kleiner und lanzettlich bis pfriemlich; Vorblättchen fehlen. Die Blüthenstielchen sind $1-1,5 \mathrm{~cm}$ lang und $1 \mathrm{~mm}$ dick, sie steigen schräg auf und sind wic die stark gestreifte Spindel weichhaarig. 
Die Blüthen sind zwittrig, stehen einzeln und hängen. Der Kelch ist 1,0-1,4 cm lang und fast bis auf den Grund in funf aufsteigend deckende Zipfel getheilt; der oberste ist meist kleiner als die anderen und schmäler, lanzettlich und zugespitzt, die mittleren und unteren sind breitelliptiseh und stumpflich, fünfnervig; innen ist er kahl, aussen unter der Lupe fein behaart. Die Blumenkrone ist $3,5-4 \mathrm{~cm}$ lang und an der Mündung quer gemessen bis $1,5 \mathrm{~cm}$ breit, sie ist rachenförmig, aussen purpurroth, innen etwas heller und auf der Unterlippe mit dunkelrothen Flecken bestreut, die von einem weissen Hofe umsäumt werden und anssen durchschimmern; sie ist am Grunde röhrenförmig, erweitert sich aber noch in Kelchhöhe glockenförmig, dabei ist sie schwach s-förmig gekrümmt und von oben her etwas zusammengedrïckt; der Saum ist schief, er ist am ganzen Rande von einem feinen Flaume umsăumt, der auch auf die Aussenseite der Blumenkrone, besonders auf den Mittclzipfel der Unterlippe tibergeht, auf der Innenseite ist der letztere ausserdem mit Wimperhaaren besetzt; die Oberlippe ist sehr kurz und ganz seicht ausgerandet; die Unterlippe ist etwa 4mal länger und misst $6-8 \mathrm{~mm}$, sie ist dreilappig, der längste Mittellappen ist vorgezogen, die Knospendeckung der Blumenkrone ist absteigend. Die Staubgefässe sind 8-10 mm hoch über der Basis in der Röhre angeheftet; die vorderen oder unteren sind die längeren, sie sind tiefer angeheftet und messen $3 \mathrm{~cm}$; die oberen oder hinteren sitzen höher und sind nur $2 \mathrm{~cm}$ lang; die Staubfaden sind über dem Grunde geknict und neigen zusammen, die der längeren Staubgefässe sind fadenförmig, die der kürzeren bandartig zusammengedrückt; die Staubbeutel sind 2,5-3 mm lang, ihre beiden Fächer stehen zuerst parallcl und senkrecht, später spreizen sie auseinander und stellen sich endlich tibereinander; sie springen in Längsspalten auf, dic zuletzt vollkommen zusammenfliessen; die Pollenkörner sind bleich-gelb, sehmal-cllipsoidisch, und werden von drei meridionalen Längsfurchen dureblaufen, sie sind schr fein gekörnt. Der Stempel sitzt auf einem fast kreisförmigen Polster; der Fruchtknoten ist 8-9 mm lang, er ist schief-kegelförmig und zweifächrig, das untere Fach ist etwas grösser als das obere, er ist drüsig, weichhaarig; die $\infty$ Samenanlagen sitzen auf einer dicken, halbeylindrischen Samenleiste, dic der Scheidewand angeheftet ist, der Griffel ist $2 \mathrm{~cm}$ lang, er steigt der Oberseite der Blumenkrone angepresst auf und ist bogenförmig nach unten gekrümmt, er ist, die Basis ausgenommen, kahl; die Narbe ist zweilappig, etwa $1 \mathrm{~mm}$ lang, der untere Lappen ist ein wenig länger.

Die Kapsel misst 1,2-1,5 cm; sie ist eikegelförmig, etwas von der Seite zusammengedrückt und hier von einer Furehe durehzogen, sie ist behaart und wird von dem abstehenden Kelche umfasst; sie springt wandspaltig zweiklappig auf; die Klappen haben eingebogene Ränder und lösen sich von den frei stehenbleibenden Samenträgern; die untere springt nicht selten nochmals von unten her mehr oder weniger weit auf.

Die Samen sind hellbraun, etwa $1 \mathrm{~mm}$ lang und haben einen Durchmesser von 0,5 mm; sie sind abgestumpft kegelförmig und mit Längsreihen grubiger Punkte bedeckt, die fadenförmige Rhaphe ist deutlich.

Anmerkung. Bei der Verfolgung der Blïthenentwicklung kann ausnahmslos die Anlage eines fünften Staubgefässes beobachtet werden, das seine Stelle zwischen den beiden oberen Blumenkronenabschnitten findet. Bei gewissen abnormen, zur Regelmässigkeit neigenden Formen der Blïthe (Pelorien) wird dieses, sonst nicht sinnlich wahrnehmbare, rudimentäre Organ zu derselben Grösse herangebildet, wie die iubrigen Staubgefässe.

Der purpurrothe Fingerhut findet sich in Gebirgswäldern mit Vorliebe auf kieselhaltigem Boden, zuweilen (in Westphalen) anch in der Ebene; er ist in West-Europa, Portugal, Spanien, Frankreich bis zur Auvergne häufig, ferner findet er sich in England, Schottland und an der Westküste von Skandinavien, wo er bei Trondjem unter $64^{\circ}$ die Nordgrenze erreicht; in West-Deutschland ist er weit verbreitet, doch uberschreitet er nirgends die Elbe; er fehlt in der Schweiz und dem gesammten Österreich, in Italien wird er nur auf Sardinien und Corsica gefunden; er wird wegen der schönen Blüthen vielfach in Gärten cultivirt und ist von hier aus verwildert, wie z. B. in Mittel- und Süd-Russland und Britisch Columbien.

Die Laubblätter der wildwachsenden Pflanze werden zur Bltithezeit gesammelt und als Folia Digitalis medicinisch verwendet. Die Blätter cultivirter Pflanzen sollen weniger wirksam sein. 


\section{Erklärung der Abbildungen.}

Fig. A. Blätter der Grundrosette einer Pflanze vom ersten Jahre, etwas verkleinert.

Fig. $B$. Der obere Stengel einer blühenden Pflanze, natïrliche Grösse.

Fig. C. Der Blüthenstand, natïrliche Grösse.

Fig. D. Die Blumenkrone, vorn aufgespalten und ausgebreitet, natürliche Grösse.

Fig. E. F, Eins der grösseren und eins der kleineren Staubgefässe vor dem Aufspringen, 4mal vergrössert.

Fig. G. Das letztere mit aufgesprungenem Beutel.

Fig. H.I. Pollenkörner trocken und im Wasser, $300 \mathrm{mal}$ vergrössert.

Fig. $K$. Der Fruchtknoten, 3mal vergrössert: $b$. das Stempelpolster; $c$. der Fruchtknoten; $d$. die Griffelbasis.
Fig. L. Das Griffelende, 5mal vergrössert: $e$, die Narbe.

Fig. M. Der Fruchtknoten im Längsschnitte, 4mal vergrössert: $a$. der Kelch; $g$. die Samenleisten; $h$. die Samenanlagen.

Fig. $N$. Der Fruchtknoten im Querschnitte, 6mal vergrössert: $f$. die Scheidewand.

Fig. $O$. Die Kapsel, um die Hälfte vergrössert: $g$. die Samenleisten; $v$. die Klappen.

Fig. P. Die Samen, natürliche Grösse.

Fig. $Q$. Ein Same, $12 \mathrm{mal}$ vergrössert: $i$. der Nabel; $k$. die Chalaza, dazwischen die Rhaphe.

Fig. R.S. Derselbe im Längs- und Querschnitte: 7 . das Nährgewebe; $m$. das Würzelchen; $n$. die Keimblätter.

Fig. T. Der Keimling, 15mal vergrössert. 


\section{Reihe: Tubiflorae DC.}

Blüthen aktinomorph, selten zygomorph; in Kelch, Krone und Staubgefässe typisch fünfgliedrig; Fruchtblätter sind 2-5 vorhanden, sie bilden einen oberständigen Fruchtknoten. Die Blätter sind meist spiralig angeordnet seltener kreuzgegenständig.

\section{Familie: Solanaceae Hall.}

Die Bluthen sind zwittrig, aktinomorph, selten ein wenig zygomorph. Der Kelch ist unterständig, bleibend, fünfgliedrig, meist fünflappig, die Abschnitte in der Deckung dachziegelig oder klappig. Die Blumenkrone ist verwachsenblättrig, radförmig, glockig, trichter- oder röhrenförmig, meist fünflappig, mit klappiger oder dachziegeliger Knospenlage. Die Staubgefässe wechseln mit den Zipfeln der Blumenkrone und sind ihr an der Röhre angewachsen, sie sind gleich*); die Beutel springen mit Längsritzen oder endständigen Poren auf, zuweilen fliessen sie dureh einen über den Scheitel verlaufenden Spalt zusammen. Ein Stempelpolster ist nicht selten vorhanden, seine Gestalt ist veränderlich. Der Fruchtknoten ist oberständig, gewöhnlich zwei- (selten drei- bis fünf-)fächrig, die Fächer sind zum Hauptschnitte der Blüthe nicht selten schief gestellt; die $\infty$ Samenanlagen in jedem Fache sind anatrop und verschieden gestellt, mit einem Integumente versehen und einer an der Scheidewand befestigten, zuweilen einer wandständigen Samenleiste angeheftet; der Griffel ist endständig, fadenförmig, einfach, mit kleiner oft gelappter Narbe. Die Frucht ist beeren- oder kapselartig. Samen sind $\infty$ in jedem Fache vorhanden; sie haben ein fleischiges Nährgewebe, in dem der selten gerade, gewöhnlich gekrümmte oder spiral gerollte Keimling: liegt. - Kräuter oder Sträucher, zuweilen auch Bäume, die entweder kahl sind oder eine sternfilzige Bekleidung tragen, mit ganzen, gelappten oder geschlitzten Blättern, die oft paarweise unter einem rechten Winkel zusammenstehen. Die Blithenstände sind gewöhnlich eymös, sie sind nicht selten an den Tragaxen emporgehoben (an ihnen angewachsen); die Blithen sind verschiedenfarbig und haben keine hochblattartigen Vorblättchen.

Die Familie umfasst in 75 Gattungen etwa 1300 Arten, die über die gemässigten und warmen Gegenden beider Hemisphären verbreitet sind.

Die officinellen Solanaceen gehören in folgende Tribus:

TRIBUS I. Solaneae Dum. Blumenkrone gefaltet, Lappen klappig deckend; Frucht beerenartig; Keimling spiral eingerollt oder kreisförmig.

1. Capsicum annuum L.

TRIBUS II. Atropeae Reichb. Blumenkrone nicht gefaltet, Lappen dachziegelig deckend; Frucht beerenartig; Keimling kreisförmig oder spiralig.

2. Atropa Belladonna L.

TRIBUS III. Hyoseyameae Reichb. Blumenkrone gefaltet oder nicht gefaltet, Lappen dachziegelig deckend; Frueht kapselartig; Keimling kreisförmig oder spiralig.

3. Datura Stramonium L.

4. Hyoscyamus niger L.

TRIBUS IV. Cestreae Dum. Blumenkrone nicht gefaltet, Lappen dachziegelig oder klappig deckend ; Frucht beeren- oder kapselartig; Keimling wenig gekrümmt oder gerade.

5. Nicotiana Tabacum L.

*) Die Salpiglossideae, die von manchen Autoren zu den Solanaceae gebracht werden, scheinen uns besser ihren Platz bei den Scrophulariaceae zu finden. 


\section{CAPSICUM Irinn.}

Blüthen aktinomorph, zwittrig. Kelch glockenförmig, gestutzt oder mehr oder minder tief fünflappig, nach der Befruchtung kaum vergrössert. Blumenkrone radförmig, tief fünftheilig, mit klappiger Knospenlage der Zipfel. Staubgefässe 5, nahe am Grunde der Röhre angeheftet mit pfriemförmigen oder fadenförmigen Fäden und Staubbeuteln, die auseinander spreizen, so lang oder kürzer sind als die Fäden und mit Längsspalten aufspringen. Stempelpolster wenig deutlich. Fruchtknoten zwei-, selten dreifächrig; Griffel fadenförmig mit kopfiger, oder etwas verbreiteter Narbe. Beere trocken oder nur wenig saftig, mit fleischigem oder lederartigem Exocarp und verschwindenden Scheidewänden, sehr vielgestaltig. Samen zusammengedrückt, scheibenförmig, gerunzelt oder fast glatt; der kreisförmig gekrümmte Keimling mit halbstielrunden Keimblättern. - Einjährige oder ausdauernde Kräuter, seltener Sträncher, oft sehr reich und sparrig verzweigt mit ganzrandigen oder geschweiften Blättern. Blüthen einzeln oder zu mehreren, weissgelb oder violett; Friichte aufrecht oder nickend.

Mehr als 50 Arten sind aus dieser Gattung beschrieben worden, die aber mindestens zur Hälfte als Culturformen weniger Arten zu betrachten sind; sie wachsen wild in den Tropen der westlichen Hemisphäre, eine wird auch in der gemässigten Zone häufig gebaut.

\section{Capsicum annuum Linn.}

\section{Tafel 28 .}

Krantig, einjährig, mit aufrechtem, sparrig reich verzweigtem Stengel, kahl; Blätter lang gestielt, lanzettlich, eilanzettlich bis eiförmig, zugespitzt, am Grunde keilförmig, granzrandig; Bliuthen einzeln oder gepaart, überhängend; Kelch gestutzt mit kurzen Zähnen; Frucht kugelig bis walzig, aufrecht oder überhängend, gewöhnlich aufgeblasen und mit durch Zerreissung wandständig werdenden Samenleisten.

Capsicum annuum Linn. Spec. pl. ed. I. 188; Gärtn. Fr. II. t. 132; Schluhr. Handb. t. 47; Descourt. Antill. VI. t. 422; Fingerh. Monogr. t. 2; Hayne, Arzneigew. X. t. 24; Guimp. und Schlecht. I. t. 16; Woodv. Med.t. 80; Steph. and Church. Med.t. 44; Nees, Gen. V.t. 57; Dun. in DC. Prodr. XIII. 412; Bentl. and Trim. Med. pl. t. 189; Köhler, Med. Pfl. t. 127; Flück. and Hanb. Pharmogr. 406; Flück. Pharmacogn. ed. III. 889 .

Capsicum longum DC. in Cat. hort. Monsp. 86; Poir. in Encycl. suppl. IV. 415; Fingerh. Monogr. t. 6 et 7 ; Berg und Schmidt, Darst. und Beschr. t. XX $\left.\mathrm{X}^{a *}\right)$.

Spanischer Pfeffer, Paprika; französisch: Piment, corail des jardins, poivre d'Inde, poivre de Guinée; englisch: Pod pepper, red pepper, Guinea pepper, chillies, capsicum.

Die Pfahlwurzel ist gerade oder wenig gekrümmt, sie ist sehr reichlich mit langen Faserwurzeln besetzt und aussen weiss.

Der Stengel wird bis $1 \mathrm{~m}$ und dariber hoch, bei uns ist er gewöhnlich niedriger; er ist aufrecht, steif, krautig und grün, unten oft verholzend und braun, unregelmässig kantig, unten später stielrund, er ist an den Knoten mehr oder weniger verdickt; am Grunde ist er zuweilen einfach, öfter aber auch hier,

*) Ausser diesen gehört noch der grösste Theil der als besondere Arten beschriebenen cultivirten Formen der Gattung sicher zu C. annum L., so z. B. C. pyramidale Mill., C. conoides Mill., C. conicum G. F. W. Mey., C. cerasiforme W., C. grossum W., C. bicolor Jacq., C. ovatum DC., C. cordiforme Mill. ete.; aber auch die strauchartigen, besonders das typische, weit verbreitete $C$. frutescens $\mathrm{L}$., von dem $C$. fastigiatum Bl. nach dem mir vorliegenden Material nicht versehieden ist, dürfte nur eine ausdauernde und verholzende Form sein. Die ganze daraus erwachsende Synonymie bier zu behandeln, würde zu weit führen. 
wie in der oberen Region stets, stark verzweigt; die unteren Äste stehen spiralig, die oberen aber gepaart oder quirlig; in der Bliithenregion werden die Äste sehr regelmässig gabelspaltig; der Stengel ist wie alle ïbrigen Theile der Pflanze kahl.

Die Blätter sind gestielt; der Stiel wird bis $7 \mathrm{em} \mathrm{lang,} \mathrm{er} \mathrm{ist} \mathrm{im} \mathrm{Quersehnitte} \mathrm{halbkreisförmig} \mathrm{und}$ oberseits von einer flaehen Rinne durehlaufen; die Spreite erreieht eine Länge von 4-6 (2-8) em und in der Mitte oder dem unteren Drittel eine Breite von 2-4 (1-6) em, sie ist gewöhnlich eioblong, die der oberen Blätter aber eilanzettlich, sonst finden sieh alle Übergänge von der eiförmigen bis zur lanzettliehen Gestalt, sie ist zugespitzt und am Grunde keilförmig, seltener abgerundet; sie ist saftig grün und glänzend und wird gewöhnlieh von 3-4 Paar grösseren Seitennerven durehzogen.

Um die etwas sehwieriger zu verstehende Blattstellung zu beschreiben, müssen wir sogleich die Anordnung der Blüthen mit ins Ange fassen: Die Keimpflanze erzeugt nach den Keimblättern ein System von spiralig gestellten Blättern, die, weil das neunte Blatt ungefähr ïber einem unteren steht, sieh der Disposition 3/8 nähern; aus den Achseln dieser Blätter brechen Äste hervor, die sogar sehon von den Keimblättern erzengt werden können nnd die zunäehst wieder Blätter in spiraler Anreihung hervorbringen, endlieh aber wie die Hauptaxe durch eine Griffelbliithe abgeschlossen werden. Indem die obersten Blätter nicht selten zll zweien, dreien oder vieren sehr genähert stehen, werden die oben erwähnten gepaarten oder wirteligen Äste erzeugt. Die obersten Äste, unmittelbar unter der Gipfelblüthe, bringen kein eigentliehes Spiralsystem von Blättern mehr hervor, sie legen vielmehr blos zwei Blätter an, die, wie gewöhnlieh an Seitenstrahlen, reehts und links zum Deekblatte orientirt sind oder sogar ein wenig naeh der Hauptaxe hin zusammenrỉeken (sie convergiren naeh hinten oder axoskop) und werden sogleieh durch eine Blithe abgesehlossen. Die Deekblätter dieser Äste werden nur am Grunde derselben vermisst; sie stehen nackt unter der Hauptgipfelblütlıe; dagegen findet man regelmässig ein Blatt dort, wo die Seitenzweige näehst höherer Ordnung unter der Gipfelblüthe des Astes abgehen. Man meinte früher, das Blatt sei an seinem eigenen Achselprodukte in die Höhe gewaehsen oder bis zu dem Punkte versehoben worden, wo die eigene Gipfelblüthe und die Seitenzweige sieh berühren. In Wirklichkeit ist diese Emporhebung dadurch zu Stande gekommen, dass sieh unterhalb der Blattinsertion eine Gewebezone eingeschaltet hat, dureh deren Waehsthum sieh nieht allein der Zweig in die Länge streckte, sondern auch das Blatt von seiner ursprüngliehen Anheftungsstelle entfernt wurde. Unterhalb der Gipfelbluthe des Astes treten wiederum zwei Blätter hervor, die von ihren Aehselprodukten abermals in die Höhe gehoben werden und dieser Modus kann sieh nochmals wiederholen. Endlich findet aber eine Dehnung der Aehselprodukte nieht mehr statt, die Blätter, aus denen jene hervorgehen, werden also von ihrer Insertionsstelle nicht mehr entfernt und daher kommt es, dass an den äussersten Zweigenden die Absehlüsse derselben, d. h. die Gipfelblüthen, von drei Blättern begleitet werden, die so gestellt sind, dass ein vorderes von den beiden seitliehen um $90^{\circ}$ absteht, während die beiden seitliehen mit einander einen Winkel von $180^{\circ}$ bilden.

Die beiden Blätter unterhalb der Gipfelblüthen sind der Grösse nach nieht völlig gleieh, ebenso wenig sind es die aus ihnen hervortretenden Sprosse; in der Ungleiehheit herrseht aber ein bestimmtes Gesetz, wenn nämlich der geförderte Spross zum Deekblatte reehts liegt, so befindet sieh an ihm wieder der geförderte links, an dem geförderten zweiter Ordnung ist der geförderte dritter Ordnung wieder reehts. Diese Art der Verzweigung ist eine cymös-diehasisehe mit Wiekeltendenz, d. h. eine reine Wiekel würde dann resultiren, wenn der geminderte Spross nach und naeh so weit zurüektritt, dass er endlich ganz verschwindet.

An Stelle einer Gipfelblüthe sind bei Capsicum annum L. deren fast stets mindestens zwei, zuweilen aueh drei und bei Capsicum fasciculatum Bl. bis sechs entwiekelt, die dann zwisehen den beiden Gabelzweigen sitzen und abwechselnd naeh rechts und links herabgebogen sind. Die Entwicklungsgeschiehte zeigt, dass die zweite und die folgenden Blüthen Knospen sind, die zwisehen der Gipfelblüthe und ihrem Deckblatte aus dem Blattaehselgrunde ihren Ursprung nehmen, dass sie untere Beiknospen sind, die, falls sie in grösserer Zahl vorhanden sind, eine ziekzaekförmige Anreihung aufweisen; solehe Blüthenverkettungen, die aus unteren Beiknospen entstehen, werden Blüthenschaaren genannt. Zuweilen treten an 
Stelle der Blithen Blattknospen auf. Da die Endigung der Hauptaxe kein Deckblatt hat, aus dessen Achsel sich eine Knospenschaar bilden könnte, so steht die primäre Terminalbluthe immer einzeln.

Die Blüthen sind lang gestielt und nicken auch in den Formen, deren Frïchte später aufrecht stehen. Der Blüthenstiel ist kräftig, 1,2-2 cm lang und fast $2 \mathrm{~mm}$ dick, er ist kantig, die Kanten werden von den stark vorspringenden Blattspuren der Kelchzipfel gebildet. Der Keleh ist 3-5 mm lang, glockenförmig oder fast halbkugelig, gestutzt und mit 5-6, zuweilen auch 7 kurzen, stumpfen, anfrechten Zähnen versehen. Die Blumenkrone misst $8-15 \mathrm{~mm}$ in der Länge, sie ist bis zum unteren Viertel in 5-6, zuweilen auch 7 oblonge oder breit elliptische, spitze, am Rande papillöse Zipfel getheilt, die klappig decken; die Röhre hat zwischen je zwei Staubgefässen ein Paar von seitlichen, fleischigen Wucherungen, die sich dicht berïhren und eine sehr enge Spalte zwischen sich lassen; sie ist weiss und wird von 3-5 hyalinen Adern durehzogen. Die Staubgefässe sind der Röhre 1,5-2 mm über der Basis angeheftet; es sind ihrer so viele als Blumenkronenabschnitte; die pfriemlichen Staubfäden sind 1,5-3 mm, die violetten, an der Spitze ausgerandeten, in der Mitte des Rückens aufgehangenen, mit seitlichen Längsspalten aufspringenden Beutel sind etwa $2 \mathrm{~mm}$ lang; die gelblichen Pollenkörper sind schmal ellipsoidisch nnd werden von drei Meridionalfurchen durchlanfen. Der Stempel besteht entweder aus zwei oder aus drei Fruchtblättern, die ersteren finden sich in vielen fünfgliedrigen Blüthen, sie stehen schief zu der Halbirungsebene der Blththe durch das Deckblatt; drei Fruchtblätter haben viele mehrgliedrige Blüthen und auch einzelne fünfgliedrige, die Stellung dieser scheint nicht immer regelmässig zu sein, gewöhnlich ist ein unpaares vorderes oder hinteres nicht deutlich zu erkennen; ein Stempelpolster oder ein anderweitiges Honig absonderndes Organ fehlt, die Blüthe ist honiglos; der Fruchtknoten ist cylindrisch oder eiförmig, er misst $3-4 \mathrm{~mm}$ in der Länge und $2-3,5 \mathrm{~mm}$ im Querschnitte; der fadenförmige, aufrechte Griffel hat die Länge des vorigen, die Narbe ist kopfig oder etwas verbreitert nnd kurz zwei- oder dreilappig.

Die Frucht ist eine aufrechte oder hängende trockene, mehr oder weniger aufgeblasene, hohle, kegel-walzen-, spindel- oder herzförmige, zugespitzte, seltener kugelrunde Beere, von glänzend zinnoberrother, gelber oder schwarzer Farbe; sie ist zwei- oder dreifüchrig, durch die blasenförmige Erweiterung des Innenraumes wird der Zusammenhang der Samenleisten gewöhnlich zerstört und die letzteren werden wandständig; die Fruehthaut ist sehr dünn und brüchig.

Die Samen haben einen Durchmesser von $3,5-4,5 \mathrm{~mm}$, sie sind sehr zahlreich, flach scheibenförmig, fast kreisrund, aussen undeutlich fein warzig, blassgelb; der Keimling ist spiralig eingekrïmmt, das fast gerade Würzelehen hat die halbe Länge der halbstielrunden Keimblätter.

Der spanische Pfeffer ist ohne Zweifel im tropischen Amerika heimisch, wird aber jetzt in den heissen und wärmeren gemässigten Zonen beider Hemisphären cultivirt und reift auch bei uns noch seine Früchte. Er blüht im Hochsommer.

Medicinische Verwendung findet die ganze Frucht der enltivirten Pflanze, obgleich der wirksame Körper nur in dem Gewebe der Scheidewände der Frucht seinen Sitz hat. Die grösste Menge der Droge n Fruetus Capsici « wird unter dem Namen Spanischer Pfeffer, Paprika oder auch Cayennepfeffer als Gewürz verwendet.

\section{Erklärung der Abbildungen.}

Fig. A. Ein Ast der blühenden Pflanze nach einem cultivirten Exemplare: $a$. die Knospe; $b$, die Blithe; $c$. eine junge Frucht; $d$. dicselbe, ctwas weiter entwickelt; $e$. der Keleh; $f$. die Blumenkrone; $g$. die Staubgef:isse; $i$, der Fruchtknoten.

Fig. B. Längssehnitt dureh eine Blithe, $2^{1 / 2} \mathrm{mal}$ vergrössert.

Fig. C. Die Blumenkrone aufgesehnitten und ausgebreitet: g. die callöse Verdickung der Röhre mit dem engen Spalte.
Fig. D. Das Staubgefïss von innen und aussen gesehen, 5 mal vergrössert.

Fig. E. Ein Pollenkorn trocken und im Wasser, $300 \mathrm{mal}$ vergrüssert.

Fig. $F$. Der Stempel, 2mal vergrössert: $h$. die Ansatzstelle der Blumenkrone: $i$. der Fruchtknoten; $k$. der Griffel; $l$. die Narbe.

Fig. G.H.Querschnitt durch einen dreifächrigen Fruchknoten, der oben bereits einfächrig, ist wenig vergrössert: 
m. die Samenleiste; $n$. die Mittelsäule; o. die Scheidewand.

Fig. I. Das obere Griffelende mit der Narbe, 6mal vergrössert.

Fig. $K$. Die Frucht, natürliche Grösse.
Fig. L.MT. Quersehnitt durch dieselbe: $p$, der Same.

Fig. $\boldsymbol{N}$. Ein Same, 3mal vergrössert: $q$. der Nabel; $r$, die Micropyle.

Fig. O.P. Derselbe im Quer- und Längsschnitte: s. das Nährgewebe; $t$. das Würzelchen; $u$. die Keimblätter.

\section{ATROPA Linn.}

Blüthen aktinomorph, zwittrig. Kelch laubig, glockenförmig, tief fünftheilig, mit klappiger Deckung der Zipfel, bleibend, nach der Blüthezeit etwas vergrössert. Blumenkrone breit röhrig-glockenförmig mit fünf kurzen, breiten, flachen, dachziegelig deckenden Zipfeln. Staubgefässe 5, oberhalb des Röhrengrundes angeheftet, gekniet und oben zusammenneigend mit fadenförmigen, gekrümmten Staubfäden; Staubbeutel zweifächrig; mit Längsspalten aufspringend; endlich sind die Klappen der Fächer ausgebreitet und bertihren sich mit den Ritckenflächen. Stempelpolster deutlich, schwach wulstig. Fruchtknoten zweifächrig, Fächer gegen das Deckblatt schief gestellt; Samenanlagen $\infty$, der halbcylindrischen, mit schmaler Leiste an der Scheidewand befestigten Samenleiste angeheftet, die oberen aufrecht, die mittleren horizontal, die unteren hängend, anatrop mit einem Integumente; Griffel fadenförmig, mit zweilappiger, nierenförmiger Narbe. Frucht kugelig, saftig von dem ausgebreiteten Kelche gestitzt. Samen zahlreich, netzig geadert, zusammengedriickt; Keimling kreisförmig gekrümmt in reichlichem, fleischigem Nährgewebe mit halbcylindrischen Keimblättern. - Ein ausdauerndes, aufrechtes, verzweigtes, fast kahles Kraut mit ganzen, gestielten, krautigen Blättern. Blüthen einzeln, schmutzig-purpurroth oder gelb.

Die eine Art wächst in Europa und West-Asien bis Indien.

\section{Atropa Belladonna Linn.}

\section{Tafel 29.}

Krautartig, ausdauernd mit aufrechtem, oben verzweigtem Stengel, fast ganz kahl; Blätter gestielt, eiförmig, zugespitzt, am Grunde in den Stiel verschmälert, oberseits kahl, unterseits unter der Lupe mit kurzen Köpfchenhaaren bestreut; Bluthen einzeln, nickend; Frucht aufrecht, kugelförmig, schwarz, glänzend.

Atropa Belladonna Linn. Spec. pl. ed. I. 181; Jacq. Austr. IV. t. 309; Fl. Dan. V. t. 758; All. Fl. Ped. I. t. 125; Gürtn. Fr. II. t. 131; Sturm, Deutschl. Fl. I. t. 3; Engl. Bot. IX. t. 502; Schluhtr, Handb. t. 45; Schrank, Fl. Mon. I. t. 62; Curt. Fl. Lond. I. t. 79; Lam. Encycl. t. 114; Wood. Med. pl. t. 82; Steph. and Church. t. 1; Hayne, Arzneigew. I. t. 43; Nees, Duisseld. Abb. t. 191; Guimp. und Schlecht. I. t. 8; Meyer, Fl. Hann. t. 3; Brandt und Ratzeb. Giftgew. t. 17; Dietr. Fl. Bor. XI. t. 727; Nees, Gen. pl. V. t. 60; Syme, Engl. Bot. VI. t. 934; Koch, Syn. 508 u. viele andere deutsche Floren; Dunal in DC. Prodr. XIII. 464; Berg und Schmidt, Darst. und Beschreib. $t . X^{c}$; Bentl. and Trim. Med. pl. t. 193; Köhler, Mediz. Pfl. t. 10; Bertol. Fl. Ital. II. 624; Ledeb. Fl. Ross. III. 190; Godr. et Gren. Fl. Fr. II. 545; Willk. et Lange, Fl. Hisp. II. 530; Boiss. Flor. or. IV. 291; Hook. fil. Fl. Br. Ind. IV. 241; Battand. et Trab. Fl. d Alg. 622; Flück. Pharmacogn. 701.

Tollkirsche; französisch: Belladonne; englisch: Belladonna.

Die spärlich verzweigte, sehr kräftige, senkrecht absteigende $\mathrm{Pfahlwurzel}$ erreicht eine Länge bis zu $40 \mathrm{~cm}$ und wird im oberen Theile bis $5 \mathrm{~cm}$ dick; sie ist aussen gelblich-braun, innen weiss, etwas fleischig. An kräftigeren, älteren Pflanzen werden stets mehrere Stengel durch eine Wurzel verbunden, die letzteren werden gewöhnlich $1 \mathrm{~m}$, zuweilen aber fast $2 \mathrm{~m}$ hoch und haben am Grunde einen Durchmesser 
von 1-2 cm; so weit sie in der Erde stecken, sind sie durch die vortretenden Blattspuren etwas kantig und weisslich-gelb, der oberirdische Theil ist mehr stielrund, grün und nicht selten am Grunde ein wenig röthlich angelaufen; sie sind unten einfach, in der Mitte spalten sie sich gewöhnlich in drei Äste, welche sich wieder gabelig theilen, um endlich in wickelig verkettete Sympodien auszulaufen. Die Pflanze dauert dadurch aus, dass in der Achsel der unterirdischen, unteren Schuppenblätter eines Stengels Knospen angelegt werden, welche, den Winter überdauernd, im nächsten Jahre zum Austrieb gelangen. Die Blätter stehen im unteren Theile des Stengels, bis zu seiner Spaltung in die drei Äste, spiralig; die unterirdischen sind schuppenförmig, eiförmig, sitzend, stumpflich, etwas fleischig, 6-8 mm lang; die oberirdischen grünen Blätter haben einen 1-2 cm langen, halbstielrunden, ein wenig geflügelten Blattstiel; die Spreite ist 8-12 (3-17) cm lang und im unteren Drittel 4-8 (2-9) cm breit, sie ist eiförmig, zugespitzt, am Grunde in den Blattstiel verschmälert, ganzrandig; sie wird jederseits des Mittelnerven von 5-6 unterseits vorspringenden, grösseren Nerven durchlaufen; sie ist oberseits tief dunkelgrïn und kahl, unterseits ist sie heller und auf den Nerven ebenso wie der obere Stengel mit kleinen Köpfchenhaaren bestreut. Von dem Theile des Stengels an, wo die Blththenregion beginnt, die Wickelbildung also den Anfang nimnit, stehen immer zwei Blätter neben einander, ein grösseres, relativ äusseres, horizontal stehendes und ein immer um etwa die Hälfte kleineres, relativ inneres, das nach unten gewendet ist; beide bilden mit einander einen Winkel von $90^{\circ}$. Die Erklärung für dieses eigenthümliche Arrangement ist folgende: Wie bei Capsicum läuft auch hier der Stengel, nachdem er ein Spiralsystem von Blättern erzeugt hat, in eine Blüthe aus. Ehe dies aber geschieht, entwickelt die Pflanze aus zwei einander sehr genäherten Blättern kräftige Seitenzweige, die nun in Gemeinschaft mit der sich gleich kräftig weiter entwickelnden Hauptaxe jene oben erwähnte Dreitheilung des Stengels erzeugen. Nachdem die Axe in eine Blïthe aufgegangen ist, entstehen unter ihr zwei Blätter, die beide in ihren Achseln Seitenknospen anlegen; aber nur diejenige, welche sich in der Achsel des oberen, zweiten Blattes befindet, entwickelt sich, treibt aus und hebt das cigene Deckblatt wieder bis zu dem Punkte in die Höhe, an welchem ein Seitenzweig aus ihm selbst abgehen wird. Fassen wir nun diese Stelle ins Ange, so befinden sich hier später eine Blïthe und das eigene Deckblatt derselben. Unterhalb der Blithe haben sich nun abermals zwei Blätter entwickelt, eins, dessen Knospe sich nicht entwickelt, eins, dessen Knospe sich sehr erheblich gestreckt hat. Die beiden Blätter treten, wie die ersten Blätter an Knospen ïberhaupt rechts und links, zum eigenen Deckblatt um $90^{\circ}$ abstehend. Als die Ursache der Emporhebung der Blätter habe ich die intercalare Dehnung unterhalb der Blattinsertion genannt. Wenn nun in der Achsel allein des einen Blattes eine Knospe auswächst, so wird auch nur dieses Blatt in die Höhe gehoben und von dem Deckblatte der Bluthe entfernt; das zweite Blatt bleibt, da die Knospe sich nicht entwickelt und somit die Ursache der Emporhebung wegfällt, bei dem Deckblatte sitzen und muss mit ihm einen Winkel von $90^{\circ}$ bilden. Nach dem Abblühen treibt in vielen Fällen auch die Knospe des zweiten Blattes aus, die aber das Blatt nicht mehr emporzuheben vermag; man muss sich hüten, dieselbe für eine untere Beiknospe, etwa von der Art, wie die Glieder der Blithenschaar bei Capsicum, anzusehen.

Der Blüthenstiel ist etwa $2 \mathrm{~cm}$ lang und hat $1 \mathrm{~mm}$ Durchmesser, er ist stielrund, nach oben etwas verdickt und mit Köpfchenhaaren dicht bedeckt. Der Kelch ist griin; er misst 1,5-2 cm; er ist ähnlich bekleidet; die Zipfel sind eiförmig, zugespitzt und werden von einem vorspringenden Mittelnerven und zwei schwachen Seitennerven durchzogen, der unpaare, hintere Zipfel ist etwas länger als die anderen. Die Blumenkrone ist 2,5-3 cm lang; oberhalb der engen, $5 \mathrm{~mm}$ langen Grundröhre erweitert sie sich glockenförmig und trägt am Ende fünf etwa $4 \mathrm{~mm}$ lange, spitze, nach aussen umgerollte, in der Knospenlage dachziegelig deckende Zipfel, sie ist am Grunde weiss-gelb, sonst innen gelb, aussen bräunlich und purpurroth geadert, am Ende schmutzig-purpurroth, es giebt auch eine gelbblithende Form; sie ist bis auf die beharte Ansatzstelle der Staubgefässe auf beiden Seiten kahl, aussen ist sie matt, innen glänzend. Die Staubgefässe sind $4 \mathrm{~mm}$ uber dem Grunde angewachsen und laufen in vorspringenden Leisten bis zum Grunde herab; die Fäden sind 2,0-2,5 cm lang, oben nach innen gebogen, kahl, nur am Grunde behaart; die Staubbeutel sind 2-2,5 mm lang, gelb; die Pollenkörner sind blassgelb, schmal ellipsoidisch 
und werden von drei meridionalen Furchen durchlaufen. Das honigabscheidende Stempelpolster ist kaum $0,5 \mathrm{~mm}$ hoch, gelb, der Honig sammelt sich in den Grtibchen zwischen den Leisten, die von den Staubgefässen herablaufen, und dem Fruchtknoten an. Der Fruchtknoten ist weiss, kegelförmig, von den Seiten ein wenig zusammengedrückt; der Griffel ist $2,0-2,5 \mathrm{~cm}$ lang, er ist nach abwärts gekrïmmt, hellgrün, die nach oben gewendete $1,5 \mathrm{~mm}$ breite Narbe ist lebhaft grün.

Die Beere hat einen Durchmesser von $1-1,5 \mathrm{~cm}$, sie ist niedergedrïckt kugelig, sitzt auf dem verdickten, lang-kreiselförmigen Stiele und wird von dem abstehenden, ein wenig vergrösserten Kelche umgeben; sie ist glänzend schwarz und mit einem violett-blauen Safte gefullt, selten ist sie gelb.

Der Same ist scheibenförmig, c. $2 \mathrm{~mm}$ breit, schwach netzig skulpturirt, schwarz; der Keimling liegt nahe der Wand in dem ölig-fleischigen Nährgewebe; er ist fast kreisförmig gekrïmmt, das Würzelchen ist halb so lang wie die halbstielrunden Keimblätter.

Die Tollkirsche wächst in Gebirgswäldern und auf Waldwegen im sïdlichen, mittleren und westlichen Europa, in Spanien ist sie selten, dagegen in Italien, der Schweiz (wo sie bis $1300 \mathrm{~m}$ iber dem Meere aufsteigt), Frankreich und Deutschland häufig; auch in Dänemark wächst sie noch, während sie in England kaum wild vorkommt; über Östreich und die Balkanstaaten kann sie verfolgt werden bis nach der Krim und dem Kaukasus, nach Kleinasien, dem nördlichen Persien und dem westlichen Himalaya; die Sidgrenze erreicht sie in Algier.

Die von zwei- bis vierjährigen, wildwachsenden Pflanzen gesammelten und getrockneten Blatter sind die Folia Belladonnae der Apotheken. In Nordamerika und England wird die Pflanze zum medicinischen Gebrauche cultivirt.

\section{Erklärung der Abbildungen.}

Fig. A. Ein mit Blithen und Früchten beladener Zweig nach einem im Berliner Universitätsgarten cultivirten Exemplare: $\boldsymbol{a}$. der Kelch; $\boldsymbol{b}$. die Blumenkrone.

Fig. B. Die Blumenkrone der Länge nach aufgespalten und flach ansgebreitet, $2 \mathrm{mal}$ vergrössert: $c$. die Blumenkrone; $d$. die Staubgefässe; $e$. das honigabsondernde Polster; $f$. der Fruchtknoten; $g$. der Griffel; h. die Narbe.

Fig. C. Das Staubgefäss von vorn und von hinten gesehen, $31 / 2 \mathrm{mal}$ vergrössert.

Fig. D.E. Die Pollenkörner, trocken und in Wasser, $300 \mathrm{mal}$ vergrössert.
Fig. F. Der untere Theil des Stempels, 5mal vergrössert. Fig. $G$. Die Narbe, 5 mal vergrössert.

Fig. $H$. Der Fruchtknoten im Längsschnitte : $i$, die Samenleiste.

Fig. I. Derselbe im Querschnitte: $k$. die Scheidewand.

Fig. K.L. Die Beere im Längs- nnd Querschnitte.

Fig. $M$. Der Same.

Fig. $\boldsymbol{N}$. Derselbe im Längsschnitte: $l$. der Nabel; $m$. das Nährgewebe; $n$. das Würzelchen; $o$. die Keimblätter.

\section{DATURA Linn.}

Blithen aktinomorph, zwittrig. Kelch lang röhrenförmig, krautig, an der Spitze deutlich fünfzähnig oder die Zähne eng verklebt und dann scheidig einseitig aufspaltend, nach dem Verblïhen bleibend oder an der Basis durch einen Ringspalt abfallend. Blumenkrone trichterförmig, am Schlunde mehr oder weniger erweitert, gefaltet, kurz fünflappig, mit zugespitzten oder geschwänzten Zipfeln. Staubgefässe fünf, in der Röhre befestigt, aufrecht; Staubfäden fadenförmig, gerade; Staubbeutel zweifächrig, mit Längsspalten aufspringend, zuweilen zusammenhängend. Fruchtknoten zweifächrig, mit wechselnder Richtung der Fächer, diese am Grunde durch je eine Wand wieder zweifächrig getheilt; Samenanlagen $\infty$ anatrop, einer halbcylindrischen, mit schmaler Leiste an der Scheidewand befestigten Samenleiste angeheftet; Griffel gerade, fadenförmig, an der Spitze verbreitert, zweilappig; Narbenpapillen an den Seiten herablaufend. Kapsel mit fleischiger Fruchthaut vier-, oben zweifächrig, vierklappig aufspringend oder geschlossen 
bleibend. Samen zusammengedrïckt, rundlich nierenförmig, gckörnt, mit fast randständigem, eingekrümmtem Keimling; Keimblätter halbcylindrisch. - Einjährige Kräuter oder Sträucher und Bäume mit sehwach filziger Bekleidung oder kahl und grossen ganzrandigen oder buchtig-gezähnten Blättern. Blüthen einzeln, gestielt, gross, weiss, gelb oder violett.

Etwa 12 Arten, die in den wärmeren und gemässigten Gegenden beider Hemisphären wachsen, eine Art, ein weit verbreitetes Unkraut, findet sich noch an dem nördlichen Polarkreise.

\title{
Datura Stramonium Linn.
}

\author{
Tafel 30 .
}

Einjährig, krautig, mit aufrechten, kahlen, stielrunden, einzelnen, unten einfachen, oben gabelspaltigen Stengeln und gestielten, kahlen, eiförmigen, zugespitzten, ungleich buchtig-gezähnten, spitzen, am Grunde keilförmigen Blättern; Kelch lang röhrenförmig, kantig, fünfzähnig, am Grunde umschnitten abfällig; die doppelt so lange, trichterförmige, am Schlunde wenig erweiterte Blumenkrone ist weiss; Kapsel aufrecht, bestachelt.

Datura Stramonium Linn. Spec. pl. ed. I. 179; All. Fl. Ped. I. t. 103; Fl. Dan. III. t. 436; Svensk Bot. I. t. 43; Engl. Bot. t. 1285; Dietr. Fl. bor. III. t. 203; Schkuhr, Handb. t. 43; Jacq. Austr. IV. t. 309; Lam. Encycl. t. 113; Descourt. Ant. III. t. 173; Schrank, Fl. Monac. II. t. 118; Hayne, Arzneigew. IV. t. 7; Woodt. Med. t. 74; Steph. and Church. Med. pl. t. 6; Curt. Fl. Lond. I. t. 33; Guimp. und Schlecht. t. 45; Nees, Dïsseld. Abb. t. 192; Dietr. Fl. Bor. t. 203; Nees, Gen. pl. V. t. 53; Koch, Syn. 510 und viele andere deutsche Floren; Brandt. und Ratzeb. Giftgew. t. 15; Dunal in DC. Prodr. XIII. 540; Berg und Schmidt, Darstell. und Beschreib. $t . \mathrm{XX}^{d}$; Bentl. and Trim. Med. pl. t. 192; Köhler, Mediz. Pfl. t. 23 ; Bertol. Fl. Ital. II. 606; Ledeb. Fl. Ross. III. 182; Godr. et Gren. Fl. Fr. II. 546; Willk. et Lange, Fl. Hisp. II. 533; Boiss. Fl. or. IV. 292; Hook. fil. Fl. Br. Ind. IV. 242; Asa Gray, Syn. Fl. I. (1.) 240; Battand. et Trab. Fl. d'Alg. II. 623; Flisck. and Hanb. Pharmacogr. 412; Flück. Pharmacogn. ed. III. 707.

Datura Wallichii Dun. in DC. Prodr. XIII. 539.

Datura ferox Nees in Trans. Linn. soc. XVII. 75, non Linn.

Stramonium vulgare Gärtn. Fr. II. 243. t. 132. fig. 4 .

Stramonium foetidum Scop. Carn. II. ed. 157.

Stramonium vulgare Mnch. Meth. 456 .

Stechapfel; französisch: Stramoine; engliseh: Thornapple.

Die Wurzel ist eine Pfahlwurzel, welche die Stärke eines Fingers erreicht und reichlich mit ziemlich

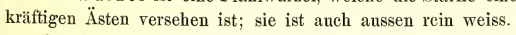

Der Stengel ist krautig, stielrund, am Grunde einfach, dann gabelig gespalten und länf, nachdem sich die Gabelung mehrfach wiederholt hat, in wickelig verkettete Sympodien ans; er ist kahl oder sehr fein behaart, innen hohl; er wird gewöhnlich nur $0,40-0,70$, zuweilen aber bis $1,2 \mathrm{~m}$ hoch und an der Basis 1-2 em dick. Die Stellung der Blätter ist folgende: Nach den beiden Keimblättern entwickelt die Pflanze zunächst ein System spiralig gestellter Blätter, um dann in einer Gipfelbliithe zum Absehluss zu kommen. Diese Blätter bringen bis auf die zwei letzten gewöhnlich nur Achselknospen hervor, die sich nicht erheblich entwickeln, deswegen bleibt der untere Theil des Stengels einfach; aus den Achseln der obersten beiden Blätter aber treten sehr kräftige Seitenzweige hervor, welche die Fortsetzung des Sprosssystems übernehmen. Durch eine intercalare, unter der Blattinsertion auftretende Dehnungszone werden die Deckblätter dieser Sprosse in die Höhe gehoben und stehen, nachdem diese Sprosse in je eine Blüthe ausgelaufen sind, in unmittelbarer Nachbarschaft der letzteren. Unter der Blitthe brechen zwei Laubblätter hervor, ans deren Achsel abermals Seitensprosse entstehen; anch diese heben ihre eigenen 
Deckblätter in die Höhe und bilden Gabelzweige zweiter Ordnung; diese Art der Verzweigung kann sich nochmals wiederholen. Gleich dem Verhältnisse, das bei Capsicum gesehildert wurde, ist der eine Zweig gefördert, der andere gemindert und diese Grössendifferenz erreicht endlich den Betrag, dass die geminderte Knospe ganz klein bleibt, sich nicht entfaltet und ihr Deckblatt selbredend nicht mehr von dem Platze der ursprünglichen Insertion entfernt. Das letatere bleibt also bei dem Deckblatte nächst niederer Ordnung sitzen und bildet mit ihm einen Winkel von $90^{\circ}$. Der geförderte Zweig läuft in eine Blüthe aus, unter der wieder zwei Blätter hervortreten, die beide Knospen erzengen. Von diesem Paare wird abermals nur das eine Element entfaltet; lag der vorige geförderte Spross rechts, so liegt der jetzige links von dem Deckblatte. Diese Förderung abwechselnd auf der rechten und linken Seite bedingt jene Anordnung der Sprossglieder zu einer scheinbar einheitlichen Axe, welche als wickelige bezeichnet wird. In den letzten Verzweigungselementen wird auch der geförderte Zweig nur noch sehr wenig gestreckt oder bleibt fast ganz unentwickelt, dann können die beiden Blätter, welche nnter der letzten Blithe sitzen, nicht mehr entfernt werden und diese Thatsache bedingt, dass die letzten Bluthen von drei Blättern gestiltzt werden: dasjenige, welches mit den beiden anderen um $90^{\circ}$ divergirt, ist dann das Deckblatt der Blüthe, jene sind als die beiden Vorblätter anznsprechen.

Die Blätter sind langgesticlt; der Blattstiel ist gewöhnlich 2-4 cm lang, er kann aber bis $6 \mathrm{~cm}$ Länge erreichen, er ist stielrund und wird auf der Oberseite von einer engen Furche durehzogen; die Spreite misst $10-15(5-20) \mathrm{cm}$ in der Länge und hat im unteren Viertel eine grösste Breite von $10-12$ $(3-15) \mathrm{cm}$; sie ist breit eiformig, die der unteren Blätter aber eioblong bis lanzettlich, sie ist am Ende zugespitzt und am Grunde keilförmig; sie ist ungleich oder doppelt buchtig gezähnt, kahl, krautig, fast fleichig, oberseits dunkel-, unterseits heller grïn und wird von $3-5$ stärkeren Seitennerven jederseits des Mittelnerven durchlaufen.

Die Blüthe ist gestielt, aufrecht und nur einen Tag dauernd. Der Kelch ist $3,5-4,5 \mathrm{~cm} \mathrm{lang}$, er ist prismatisch funfkantig, am Grunde ein wenig aufgeblasen, und wird hier von einer Querlinie umzogen, welche der Trennungsstelle entspricht, durch die später die obere Röhre abgeworfen wird; der stehenbleibende Theil wird nach der Bluthezeit zurtickgesehlagen; er ist am oberen Ende mit fünf etwa $5 \mathrm{~mm}$ langen Zähnen versehen und beiderseits kahl. Die Blumenkrone misst $6-7,5 \mathrm{~cm}$ in der Länge und hat am Sanme einen Durchmesser von $5 \mathrm{~cm}$; sie ist trichterförmig und am Schlunde ein wenig, aber nicht sehr auffällig erweitert; sie ist oben längsgefaltet, geht in fünf zugespitzte, dreiseitige Zipfel aus und ist beiderseits kahl. Die fünf Staubgefässe sind 2,5-3 cm über der Basis in der Röhre angewachsen; ihre fadenförmigen Fäden messen 2-3 cm, sind weiss und am Grunde sehr spärlich behaart oder kahl; die Beutel sind etwa 4-5 mm lang, gelblich-weiss und an den Rändern sowie den Näthen behaart. Der Fruehtknoten hat eine Länge von 5 und einen Querdurchmesser von 4,5 mm, er ist kegelförmig und mit vier Feldern derber Weichstacheln bedeckt, die später zu harten Stacheln auswachsen; er ist unten vier- oben zweifächrig; die Samenträger sind herzförmig, durch eine ziemlich schmale Leiste der Scheidewand angeheftet; die anatropen, mit einem Integumente versehenen Samenanlagen sind allwärts gerichtet; das Honig absondernde Polster unter dem Fruchtknoten ist sehr niedrig und wenig auffällig, der Griffel ist fadenförmig, er ist 4-4,5 cm lang; die Narbe misst 2-2,5 mm, die Narbenpapillen laufen an den Rändern der kurzen Lappen herab.

Die Frucht ist eine grïne, später gelblich-grïne Kapsel von 3-4,5 cm Länge und 2,5-4 cm Durchmesser; sie ist gerundet vierseitig und wird auf den Flächen von je einer Längsfurche durchzogen; sie steht auf einem kräftigen, 1-1,5 cm langen, aufrechten Stiele und wird am Grunde von der zurïckgeschlagenen, fast knorpeligen, längsstreifigen Kelchbasis gestützt; sie ist oben abgerundet, stachlich und springt fast bis zum Grunde in vier Klappen auf, welche die Samenleiste in der Mitte frei umgeben.

Der Same ist $3-3,5 \mathrm{~mm}$ lang und etwa $3 \mathrm{~mm}$ breit, er ist zusammengedrückt, nierenförmig, grubig punktirt, sehwarz, matt; der Keimling ist fast wandständig, kreisförmig eingekrümmt; die Keimblätter sind halbeylindrisch, doppelt so lang wie das Würzelehen. 
Der Stechapfel ist gegenwärtig eine der allerverbreitetsten Schuttpflanzen, welcher mit Ausnahme der heissesten und kältesten Gegenden alle Continente bewohnt. Seine ursprïngliche Heimath ist nicht mit Sicherheit auszumachen, doch nimmt man vielfach an, dass er in den Gegenden um das Kaspische und Schwarze Meer wild wachse; er blüht den ganzen Sommer hindurch.

Wildwachsende Pflanzen liefern die Folia Stramonï und die Semina Stramonii.

\section{Erklärung der Abbildungen.}

Fig. A. Ein Zweig der blühenden Pflanze nach einem im Berliner Universititsgarten enltivirten Exemplare: $a$. die Kelchbasis; $b$. die Kelchröhre; $c$. die Blumenkrone.

Fig. $B$. Die Blumenkrone lings aufgespalten und ausgebreitet, natürliche Grösse: $d$. die Staubgefïsse.

Fig. C. Der Staubbentel von vorn und von hinten gesehen, 5 mal vergrössert.

Fig. D. Pollenkörner trocken und in Wasser, 300mal vergrössert.

Fig. $C_{2}$. Der Fruchtknoten, 4 mal vergrössert: $e$, das Honig absondernde Polster; $f$. der Fruchtknoten; $g$. die Griffelbasis.
Fig. $D_{2}$. Der obere Theil des Griffels mit der Narbe: $h$. die Narbe.

Fig. E.F. Die unreife Frucht, im Quersehnitte oberhalb und unterhalb der Mitte, natürliche Grösse; $i$, die Scheidewand; $k$. die Samenleiste; $l$. die secundäre Scheidewand des Faches.

Fig. $G$. Die Frncht, natürliche Grösse: $m_{+}$die Klappen $n$. die Scheidewand mit den Samenleisten.

Fig. $H$. Der Same, natïrliche Grösse.

Fig. $I$. Derselbe, 5mal vergrössert: 0 . der Nabel; $p$. die Micropyle.

Fig. $K$. Derselbe im Längs- und Querschnitte: $q$. das Nährgewebe; $r$. das Würzelchen; $s$. die Keimblätter.

\section{HYOSCYAMUS Linn.}

Blüthen zygomorph, zwittrig. Kelch röhrig-glockenförmig, kurz fünfspaltig, bleibend, nach der Bliithe vergrössert. Blumenkrone breit trichterförmig, am Schlunde stark erweitert, oft einseitig geschlitzt, fünflappig mit dachziegeliger Deckung der mehr oder weniger ungleichen Zipfel. Staubgefässe der mittleren Röhre angewachsen, hervorragend, einseitig nach unten gebogen; Staubbeutel zweifächrig, mit Längsspalten aufspringend. Stempelpolster kaum oder nicht deutlich. Fruchtknoten zweifächrig, Füicher zum Deckblatte schief gestellt; Samenanlagen $\infty$, anatrop, die oberen aufrecht, die mittleren horizontal, die unteren hängend, an einer halbcylindrischen, der Scheidewand lïngs angewachsenen Samenleiste befestigt; Griffel fadenförmig, gekrümmt, mit kopfiger, verbreiterter Narbe. Kapsel völlig oder fast vollkommen zweifächrig, umschnitten mit einem ganzen oder zweispaltigen Deckel aufspringend. Samen $\infty$, schwach oder stärker zusammengedrückt, grubig punktirt oder höckerig, mit fast randständigem, kreisförmig eingerolltem Keimling; Keimblätter halbcylindrisch. - Ein- und zweijährige oder ausdanernde Kräuter, gewöhnlich drüsig-zottig, seltener kahl mit gebuchteten, fiedertheiligen oder geschweiften Blättern. Blüthen in meist verlängerten, beblätterten Wickeln, weiss oder gelb, häufig purpurroth geadert.

Etwa 10 Arten, hauptsächlich in der Mittelmeerregion, doch anch von den Canarischen Inseln bis nach Inner-Asien verbreitet.

\section{Hyoscyamus niger Linn.}

Tafel 31 .

Krautig, ein- oder zweijährig, mit aufrechten, verzweigten, seltener einfachen, stielrunden, drüsigzottigen Stengeln; Blätter sitzend, stengelumfassend and herablaufend, nur die untersten gestielt, oblong, geschweift gezähnt oder fiederspaltig, drusig-zottig; Blithen sehr kurz gestielt, in einfachen, endständigen Wickeln, gelb, purpurroth geadert. 
Hyoscyamus niger L. Spec. pl. ed. I. 179; Lam. Encycl. t. 117; Engl. Bot. IX. t. 591; Fl. Dan. t. IX. t. 1452; Svensk Bot. t. 21; Woodv. Med. 1I. t. 76; Schkuhr, Handb. t. 44; Sturm, Deutschl. Fl. I. t. 3; Schrank, Fl. Mon. I. t. 88; Hayne, Arzneigew. I. t. 28; Guimp. und Schlecht. t. 153; Brandt und Ratzeb. Giftgew. t. 14; Steph. and Church. t. 9; Nees, Diisseld. Abb. t. 191; Dietr. Fl. Boruss. III. t. 203; Nees, Gen. pl. V. t. 54; Koch, Syn. 509 und viele andere deutsche Floren; Dunal in DC. Prodr. XIII. 546 ; Berg und Schmidt, Darst. und Beschreib. t. XVIf; Bentl. and Trim. t. 194; Köhler, Mediz. Pfl. t. 11; Bertol. Fl. Ital. II. 611; Ledeb. Fl. Ross. III. 183; Godr. et Gren. Fl. Fr. II. 546; Willk. et Lange, Fl. Hisp. II. 534; Boiss. Fl. or. IV. 294; Hook. fil. Fl. Br. Ind. IV. 244; Asa Gray, Syn. Fl. I. (1.) 240; Battand. et Trab. Fl. d'Alg. II. 624; Flïck. et Hanb. Pharmacogr. 418; Flück. Pharmacogn. ed. III. 70s.

Hyoscyamus niger $\beta$ anmus Sims. in Bot. Mag. t. 2394.

Hyoscyamus niger var. agrestis Nees in Trans. Linn. soc. XVII. 77; Dun. in DC. Prodr. XIII. 547. Hyoscyamus agrestis Kitaib. in Schult. Oestr. Fl. I. 393; Sweet, Br. Alow. gard. I. t. 27.

Hyoscyamus verviensis Lejeune, F7. Spaa I. 116.

Hyoscyamus pallidus Schmidt, Fl. Boehm. III. 31; non Waldst. et Kit.

Hyoscyamus persicus Buhse, Reise Transkauk. 155.

Hyoscyamus pallidus Waldst. et Kit. in Willd. Enum. pl. hort. berol. I. 228.

Bilsenkraut; französisch: Jusquiame; englisch: Henbane.

Die Pflanze ist entweder zweijährig und erzeugt dann im ersten Jahre eine oft sehr grosse Rosette aus dicht gedrängten, bis $40 \mathrm{~cm}$ langen und $12 \mathrm{~cm}$ breiten Blättern, die im zweiten den Stengel hervortreibt, oder sie kommt schon im späten Sommer des ersten Jahres zur Blitthe.

Die Wurzel ist eine Pfahlwurzel, die mehr oder weniger senkrecht in den Boden herabsteigt und sich nur spärlich verzweigt, dafür ist sie aber dicht mit Faserwurzcln besetzt; sie wird bis $10 \mathrm{~cm}$ lang nnd erreicht an dem oberen, nicht selten rübenförmig angeschwollenen Theile cinen Durchmesser von $1-2,5 \mathrm{~cm}$, sie ist aussen gelblich bis bräunlich, innen weiss.

Der Stengel ist krautig, aufrecht, stielrund oder undeutlich kantig; er wird bis $1 \mathrm{~m}$ hoch und am Grunde $1-1,5 \mathrm{~cm}$ dick, ist drïsig-zottig und schmierig anzufüblen, im Innern hohl; er verzweigt sich aus den Achseln der unteren spiral gestellten Blätter, zuweilen aber treibt er gar keine grösseren Äste oder deren nur zwei, die mit der Hauptaxe eine ähnliche dreizinkige Gabel bilden, die wir oben bei der Tollkirsche beschrieben haben.

Die B lätter der Grundrosette sind gewöhnlich 15-20 cm lang und in der Mitte 8-15 cm breit; diese gehen am Grunde in den bis $6 \mathrm{~cm}$ langen, im Querschnitte halbkreisförmigen Blattstiel über; sie sind sehr grob und bald tiefer, bald seichter gezähnt; die Stengelblätter, welche in der Grösse um ein Drittel, endlich die Hälfte kleiner werden, sind sitzend, umfassen mit zwei dem Stengel angewachsenen und an ihm herablaufenden Lappen jenen, sie sind spitz und tragen jederseits zwei bis vier grosse, breit dreiseitige, zugespitzte Zähne; sie sind krautig und ein wenig fleischig und werden von einem sehr kräftigen Mittel-, sowie jederseits von so viel grösseren Seitennerven durchzogen, wie Zähne vorhanden sind; sie sind mehr oder minder reichlich mit Köpfchenhaaren besetzt, zuweilen aber (besonders in der Cultur) werden sie fast kahl.

Um den Blüthenstand zu verstehen, gehen wir wieder zu der Tollkirsche zurïck, indem wir die letzten Äste derselben, welche ein wenig zickzackförmig hin- und hergebogen sind, ins Auge fassen. Auch bei dem jetzt zu untersuchenden Gewächse läuft der Gipfel des Sprosses endlich in eine Bliithe aus. Unter ihr erzeugen die beiden letzten Blätter in ihren Achseln Seitenzweige und auch hier wird der Spross aus dem oberen Blatte gefördert, mit dem das eigene Deckblatt in die Höhe gehoben wird; die Knospe aus dem anderen Blatte bleibt aber in ganz unentwickelter Form zurïck. Diese einseitige Förderung erreicht nun hier gewöhnlich das Maass, dass das untere Blatt mit seiner Knospe in den meisten Fällen überhaupt nicht mehr angelegt wird; indem abwechselnd zu dem jeweiligen Deckblatte das einzige Blatt mit seiner Achselknospe abwechselnd rechts und links entsteht, und indem die Dehnungen unterhalb des Deckblattes nur sehr kurz sind, entsteht jener Blüthenstand, welcher den Namen Wickel führt, und der dadurch ausgezeichnet ist, dass die sämmtlichen Blüthen auf der einen Seite der Axe stehen 
und um $90^{\circ}$ von einander divergiren; die andere Seite der Axe ist frei von Blüthen. Aus dieser Thatsache hat sich die Meinung gebildet, dass diese Inflorescenz eine dorsiventrale, einseitswendige Traube wäre. Indem sich jede Axe horizontal stellt oder sich ein wenig nach unten biegt, fallen die Blïthenzeilen nach dem Zenith zu. Jedes Deckblatt steht zu seiner Blithe so, dass der Mittelnerv in die Litcke zwischen die Blithe und die benachbarte Fortsetzung des Sympodiums, die scheinbare Hauptaxe des ganzen Blithenstandes, fällt; man hat deshalb gemeint, die Blüthe sei etwas nach rückwärts verschoben worden, eine Annahme, die sich aber durch die Entwicklungsgeschichte als irrthümlich nachweisen lässt.

Die Blüthen verkürzen sich an der Spitze des Bltithenstandes sehr schnell, so dass die Inflorescenz spiralig eingerollt erscheint und auch gewöhnlich derartig beschrieben wird; sie werden von einem $1 \mathrm{~mm}$ langen Blüthenstiel gestiitzt. Der $\mathrm{Kel} \mathrm{ch}$ ist $1-\mathbf{1 , 5} \mathrm{cm}$ lang, krug-becherförmig, mit schiefer Mündung und fünf breit dreiseitigen, spitzen Zähnen; er ist grün und besonders im unteren Theile dicht weissdrüsig-zottig; nach der Bliithezeit vergrössert er sich, so dass er zuweilen fast die doppelte Länge erreicht; der obere Theil der Röhre hebt sich dann deutlich von dem unteren ab und wird zehnnervig, zwischen den Nerven entwickelt sich ein Adernetz, die Zähne werden stechend. Die Blumenkrone ist $2-2,5 \mathrm{~cm}$ lang, sie ist so gestellt, dass die Öffnung nach dem Grunde des Blithenstandes, also nach rückwärts hin gewendet ist; nach dieser Richtung stehen zwei vordere Zipfel, zwischen denen ein tieferer Spalt verläuft als zwischen den anderen; sie ist aussen mit Köpfchenhaaren bestreut, innen ist sie völlig kahl; ihre Farbe ist gewöhnlich trubgelb mit purpurrothem Schlunde und einem reichen, ebenso gefärbten Adernetz; es giebt aber auch reingelbe Farbenabänderungen. Die fünf Sta ubgefä sse sind etwa 5-6 mm ïber dem Röhrengrunde angeheftet, sie sind in der Richtung nach dem tieferen Schlitze in der Blumenkrone herabgebogen und etwas ungleich; die drei längeren messen etwa 10, die zwei kürzeren 8 mm; die Fäden sind am Grunde behaart; die Staubbeutel sind $3 \mathrm{~mm}$ lang vor dem Aufspringen, sie sind am Rüicken nahe dem Grunde befestigt; die Pollenkörner sind schmal-ellipsoidisch, fein gekörnt und werden von drei meridionalen Falten durchzogen. Der Stempel ist 1,6-2,2 cm lang; ein Honig abscheidendes Polster ist nicht nachweisbar, jener wird von der Basis des Fruchtknotens erzeugt; der letztere ist etwa $3 \mathrm{~mm}$ hoch, kegelförmig, doch von den Seiten zusammengedritckt, kahl oder an der Spitze spärlich behaart; etwa in der Mitte wird er von einer hellen Linie umzogen: der Stelle, an der sich später der Deckel, löst, mit dem die Frucht aufspringt; die Samenanlagen sitzen an einer halbeylindrischen Samenleiste, die aber der Scheidewand nicht der ganzen Länge nach angewachsen ist; der Griffel ist fadenförmig, ein wenig nach unten gebogen, kahl oder am Grunde spärlich behaart und hat eine kopfige Narbe.

Die Frucht ist $1-1,5 \mathrm{~cm}$ lang und hat einen grössten Querdurchmesser von $1-1,2 \mathrm{~cm}$; sie wird von dem unteren bauchigen Theile des vergrösserten Kelches dicht umschlossen; sie ist eiförmig, von den Seiten zusammengedrïckt und hier von einer Furche durchzogen; der untere Theil ist häutig, von den vortretenden Samen höckerig; der Deckel ist knorpelig, oben von dem sitzenbleibenden Griffelgrunde bespitzt, zweifächrig; der untere Theil des Fruchtknotens ist zweifächrig; die Samenleiste ist herzförmigschwammig, durch eine schmale Leiste der dünnen Scheidewand angeheftet.

Der Same ist 1-1,3 mm lang und $1 \mathrm{~mm}$ breit, er ist nierenförmig, wenig zusammengedrỉckt, hellbräunlich-grau, grubig punktirt.

Das Bilsenkraut wächst auf Schuttplätzen, in Dorfstrassen, Zäunen, in der Nähe menschlicher Wohnungen durch ganz Europa, das nördlichste ausgenommen; auch in den übrigen Continenten ist es, die arktischen und tropischen Gegenden ausgenommen, gefunden worden. Überall macht es den Eindruck einer erst durch Menschen versehleppten Pflanze, deren eigentliche Heimath zwar heute unbekannt ist, die aber doch in Ost-Europa oder dem Mittelmeergebiete zu suchen ist; die Blithezeit beginnt im Juli und danert bis in den Herbst.

A n merkung. Die friher als eigene Arten, später als Varietiten angesehenen H. agrestis Kit. und H. pallidus W. et K. sind unserer Meinung nach nur unwesentliche einjährige Formen oder leichte Farbenabänderungen des Typus.

Die oberirdischen Theile der blühenden Pflanze liefern die Herba Hyoscyami, Auch die Samen der Pflanze finden hier und da noch medicinische Verwendung. 


\section{Erklärung der Abbildungen.}

Fig. A. Ein blühender Ast der typischen, zweijährigen Form.

Fig. B. Der Kelch mit dem Griffel, um die Hälfte vergrössert: $a$. der Kelch; $e$, der Griffel; $f$. die Narbe.

Fig. C. Die Blumenkrone in der tiefsten Spalte aufgeschnitten und ausgebreitet, um die Hälfte vergrössert: $b$. Blumenkrone; $c$. Staubgefässe.

Fig. D. Ein Staubgefïss, von aussen und von innen betrachtet.

Fig. E.F. Pollenkörner, trocken und in Wasser, $300 \mathrm{mal}$ vergrössert.

Fig. $G$. Der Kelch, aufgeschnitten und ausgebreitet: $d$. der Fruehtknoten.

Fig. $H$. Der Fruchtknoten, 4 mal vergrössert.

Fig. I. Derselbe im Längsschnitte, 5mal vergrössert: $i$. der Samenträger.
Fig. $K$. Derselbe im Querschnitte: $h$. die Scheidewand; $k$. die Samenanlagen.

Fig. $L$. Der obere Theil des Griffels mit der Narbe, $7 \mathrm{mal}$ vergrössert.

Fig. M. Die Kapsel, natürliche Grösse.

Fig. $N$. Dieselbe, aufgesprungen, um die Hälfte vergrössert: l. der Deckel.

Fig. O.P. Dieselbe, im Quer- und Längsschnitte, doppelt vergrössert.

Fig. Q. Der Same, natïrliche Grösse.

Fig. $R$. Derselbe, Smal vergrössert: $m$. Nabel.

Fig. S. Derselbe im Längssehnitte: $n$. Nährgewebe; $o$, Würzelchen; $p$. Keimblätter.

\section{NICOTIANA Linn.}

Blïthen actinomorph oder mehr oder weniger dureh die Schiefe der Blumenkrone und die ungleiche Länge der Staubgefässe zygomorph, zwittrig. Keleh eiförmig oder röhrig-glockenförmig, fünfspaltig, bleibend. Blumenkrone gleichförmig röhrig oder am Schlunde erweitert trichterförmig mit geradem oder schiefem Sanme, fünflappig mit eingebogen klappiger Knospenlage der Zipfel. Stanbgefässe fünf in dem unteren Theile der Röhre befestigt, gleich oder wenig ungleich; Staubbentel zweifächrig, in Längsspalten aufspringend. Das Honig absondernde Polster klein, ringförmig oder gelappt oder gefureht. Fruchtknoten zwei- (selten vier- $\infty$-)fäehrig mit $\infty$ anatropen Samenlagen in jedem Fache, die einer halbcylindrischen, durch eine schmale Leiste der Scheidewand angehefteten Samenleiste angewachsen sind; Griffel fadenförmig mit verbreiterter, schwach zweilappiger Narbe. Kapsel zwei- (selten mehr-)fächrig, Klappen zweispaltig. Samen $\infty$, klein, kaum zusammengedrïckt, grubig punktirt; der Keimling gekrümmt oder fast gerade mit halbstielrunden Keimblättern. - Einjährige, seltener ausdanernde, am Grunde verholzende Kräuter, oder Bäumehen, oft mit drïsiger Bekleidung, mit ganzrandigen Blättern. Blüthen in reichblitthigen Wickeln oder in Rispen, die endlich in Wickeln ausgehen, weiss, gelblich, griunlich oder purpurroth.

Die beschriebenen 50 Arten sind wahrscheinlich um ein Drittel zu reduciren; sie wachsen grösstentheils in Amerika, einige scheinen auch in Australien und auf den pacifischen Inseln heimisch zu sein.

\section{Nicotiana Tabacum Linn.}

\section{Taf. 32 .}

Einjährig, krautig mit aufrechten, runden, drïsig behaarten Stengeln und oblong-lanzettlichen bis eiförmigen, zugespitzten, sitzenden oder gestielten Blättern, von denen die unteren den Stengel halb umfassen und ein wenig herablanfen; Bltthen gestielt, rispig; Keleh oblong, mit etwas ungleichen, zugespitzten Zipfeln; Blumenkrone trichterförmig, aussen behaart, am Schlunde erweitert, Saum ausgebreitet; Kapsel zweiklappig, mit zweispaltigen Klappen, von der Länge des Kelches.

Nicotiana Tabacum Linn. Spec. pl. ed. I. 150; Gürtn. Fr. I. t. 55; Lam. Encycl. t. 113; Ruiz et Pav. Fl. Peruv. II. t. 15; Wnodv. Med.pl. t. 77; Schkuhr, Handb. t. 44; Hayne, Arzneigew. XII. t. 41; 
Steph. and Church. t. 37; Bigel. Med. 40; Nees, Düsseld. Abb. t. 193; Descourt. Ant. VI. t. 413; Guimp. und Schlecht. t. 105; Koch. Syn. 509; Wight, Ill. t. 166 bis; Nees, Gen. pl. V. t. 52; Dunal in DC. Prodr. XIII. 557; Berg und Schmidt, Abb. und Besehr. t. XII ; Bentl. and Trim. Med. pl. t. 191; Tröhler, Mediz. Pfl. t. 18; Willk. et Lange, Fl. Hisp. 535; Hook. fll. Fl. Br. Ind. IV. 245; Asa Gray, Syn. Fl. I. (1.) 241; Flïckig. and Hanb. Pharmacogr. 418; Flïck. Pharmacogn. ed. III. 712.

Tabacum Nicotianum Bercht u. Opiz, Oekon. Fl. Boehm. III. 307.

Tabak; französisch: Tabac; englisch: Tobacco.

Die Wurzel ist eine reichlich verzweigte und mit zahlreichen Fasern besetzte, aussen weisslich-gelbe Pfahlwurzel.

Der Stengel ist am Grunde einfach oder wenig verzweigt, in der Region der Blüthen aber treibt er aus jedem der sich allmälig verkleinernden Blätter Seitenzweige; er ist krautig, stielrund, drïsig behaart, etwas klebrig und wird 1-2 $\mathrm{m}$ hoch, während er am Grunde einen Durchmesser von $1-2 \mathrm{~cm}$ erreicht.

Die Blätter sind spiralig angeordnet; ihr Stiel wird bis $5 \mathrm{~cm}$ lang, er kann aber auch fast ganz verschwinden, er ist halbstielrund und auf der Oberseite flach, besonders an den mittel- und grundständigen Blättern ist er mehr oder weniger gefliigelt, die Flïgel umfassen den Stengel bis zur Hälfte und darïber und laufen oft ein wenig herab; die Spreite erreicht eine Länge bis $60 \mathrm{~cm}$ und ist dann in der Mitte oder im unteren Drittel bis $20 \mathrm{~cm}$ breit; sie ist eiförmig oder eioblong oder lanzettlich, ist spitz und am Grunde abgerundet, gestutzt oder in den Blattstiel verschmälert; sie ist hellgrïn, unten etwas blasser, driisig behaart und klebrig, ein wenig fleischig, leicht zerbrechlich und wird jederseits des Mittelnerven von fünf bis sieben Seitennerven durchzogen.

Die Blüthen stehen in Rispen, deren oberste zwei bis drei Seitenstrahlen einander so weit genähert sind, dass die Blüthen schirmförmig fast in einer Ebene liegen; nach ihnen länft die Hauptaxe in eine Endblüthe aus; die unteren Seitenstrahlen aus den Achscln der entfernter stehenden Blätter wiederholen genau den Bau der Hauptaxe, die oberen genäherten können zuweilen auch noch ein aus drei bis vier Elementen bestehendes spirales Blattsystem erzengen, ans deren Achseln Dichasien mit Förderung des Astes aus dem oberen Deckblatte hervorgehen, gewöhnlich halten sie aber dadurch, dass sie nur zwei Blätter hervorbringen, schon den dichasischen Typus inne; an den letzten Auszweigungen des Blüthenstandes werden Wickeln hervorgebracht, bei denen, wic an den Dichasialzweigen schon, wenn auch in geringerem Masse, die Deckblätter emporgehoben werden. Die Bliithenstiele sind 1-2 cm lang, stielrund, am Grunde gegliedert, wie die Spindel drïsig-klebrig. Der Keleh ist 2-2,5 cm lang, glockigröhrenförmig, bis zur Hälfte in fünf pfriemförmige, lang zugespitzte Zipfel getheilt, von denen der eine, welcher der Entstehung nach der erste ist und seitlich vorn steht, etwas grösser und breiter wie die übrigen ist, die Knospenlage der Zipfel ist dachziegelig; er ist aussen drïsig-klebrig, innen kahl. Die Blumenkrone ist 4,5-5,5 cm lang, trichterförmig, am Schlunde erweitert und hat einen flach ausgebreiteten Sanm mit eiförmig-dreiseitigen, zugespitzten, rosenrothen, in der Knospenlage gefalteten, am Rande gewimperten Zipfeln; die Röhre ist oben röthlich, dann gelblich-grün, aussen drïsig-klebrig, innen ist sie kahl, nur dort, wo die Stanbgefässe angeheftet sind, ist sie flaumig von einfachen, weichen Haaren. Die fünf Stanbgefässc sind etwa $1 \mathrm{~cm}$ über dem Grunde der Röhre angeheftet; die in der unteren Hälfte flaumigen, fadenförmigen Staubfäden sind 3,5-4 cm lang, das eine Staubgefäss aber, welches vor dem ersten Kclchblatte steht, ist stets um etwa $5 \mathrm{~mm}$ kürzer als die übrigen, das Androecum erreicht demgemäss das Ende der Kronenröhre; die vor dem Aufspringen 3,5-4 mm langen Beutel sind am Grunde pfeilförmig; die Pollenkörner sind schmal elliptisch und werden von drei ziemlich breiten, mcridionalen Längsfalten durchzogen. In der ungleichen Länge der Stanbgefässe ist eine Zygomorphie ansgeprägt, die bei einiger Anfmerksamkeit anch in der Blumenkrone erkannt wird. Die Ebene, welche die Blithe in zwei symmetrische Häften theilt, verläuft dureh das kleinere Staubgefäss und somit dureh das der Entstehung nach erste Kelehblatt; die Blumenkrone ist dam schief anfgehängt und zwar stehen dabei drei Zipfel einer Oberlippe nach oben, zwei Zipfel einer Unterlippe nach unten sehicf zum Deckblatte der Blüthe. Andere Arten der Gattung, besonders Nicotiana suaveolens Lehm., zeigen diese Zygomorphie um 
vieles dentlicher. In die Symmetrieebene fallen auch die zwei Blätter, welche den Fruchtknoten zusammensetzen, dieser liegt demgemäss, wie bei den meisten Solanaceae, schief zum Deckblatte; er ist 6-7 mm hoch und hat 4-4,5 mm im Durchmesser; er ist kegelförmig, spitz, kahl, grün und sitzt auf einem gelben, wenig vorspringenden Honig absondernden Polster; die sehr zahlreichen Samenanlagen sind einem breiten, im Querschnitte halbelliptischen, mit einer schmalen Leiste der Scheidewand angehefteten Samenträger angewachsen, sie sind anatrop, allwärts gerichtet und haben ein Integument. Der Griffel ist 3,5-4 cm lang, stielrund und kahl; die schwach zweilappige Narbe ist kreisförmig und hat $2 \mathrm{~mm}$ im Durchmesser.

Die Frucht ist eine 1,5-2 $\mathrm{cm}$ lange, $1-1,5 \mathrm{~cm}$ im Durchmesser haltende, eiförmige, spitze, von zwei schwachen Rippen und zwei seichten Furchen durchzogene, dünnhäutige, braune Kapsel, die wandspaltig in zwei Klappen aufspringt; die Klappen sind an der Spitze zweispaltig.

Die Samen messen wenig tiber $0,5 \mathrm{~mm}$ im grössten Durchmesser, sie sind schwach nierenförmig, kaum zusammengedrïckt, fein grubig punktirt und braun; der Keimling ist bogenförmig gekrtimmt, er liegt in einem ölig-fleischigen Nährgewebe; das Würzelchen ist noch einmal so lang wie die planconvexen Keimblätter.

Der Tabak ist wahrscheinlich in Süd-Amerika, und zwar in Peru oder Quito heimiseh; er wird jetzt in den heissen und den wärmeren gemässigten Zonen eultivirt und gedeiht noch im südlichen Norwegen.

Die an der Luft getrockneten Laubblïtter der Pflanze (Rohtabak) werden in den Apotheken als Folia Nicotianae verwendet. Die zum Rauchtabak bestimmten Tabaksblätter werden nach dem Trocknen noch einer Gährung unterworfen, indem man die in Bïndel gebundene Droge in Haufen zusammenstellt und einige Zeit der Selbsterwärmung tiberlässt. Gewöhnlich behandelt man den fermentirten Tabak zuletzt noch mit Saucen, welche Gewürze und Salze enthalten.

\section{Erklärung der Abbildungen.}

Fig. A. Das obere Ende einer blühenden Pflanze nach einem im Berliner Universitätsgarten cultivirten Exemplare.

Fig. B. Der untere Theil der Blüthe im Längsschnitte, 2mal vergrössert: $a$. der Blüthenboden; $b$. der Kelch; $c$. die Blumenkrone; $e$. der Fruchtknoten; $f$. der Griffel.

Fig. C. Der Kelch mit dem Griffel, natürliche Grösse.

Fig. D. Die Blumenkrone, längs aufgesebnitten und ausgebreitet, natïrliche Grüsse.

Fig. E. Das Staubgefäss von vorn und von hinten gesehen, 3 mal vergrössert.

Fig. F. Pollenkörner trocken und in Wasser, $300 \mathrm{mal}$ vergrössert.
Fig. H. Der Fruchtknoten, 2mal vergrüssert: o. das Honig ausscheidende Polster.

Fig. I. Derselbe im Querschnitte, 5mal vergrössert: $h$. die Scheidewand; $i$. die Samenleiste; $k$. die Samenanlagen.

Fig. $K$. Der obere Theil des Griffels mit der Narbe, 4mal vergrössert: g. die Narbe.

Fig. $L$. Die Kapsel, natïrliche Grösse.

Fig. M. Dieselbe im Querschnitte: k. die Samen.

Fig. $N$. Der Same, $15 \mathrm{mal}$ vergrössert: $l$. der Nabel.

Fig. 0 . Derselbe im Längsschnitte: $m$. das Nährgewebe; $n$. das Wirzelchen. 


\section{Familie: Convolvulaceae Vent.}

Die Blüthen sind aktinomorph, zwittrig, sehr selten durch Fehlschlag polygam, bis zum Fruchtknoten fünfgliedrig. Der Kelch ist unterständig, bleibend, gewöhnlich sind die Abschnitte bis zum Grunde frei, sie decken sich dann quincuncial. Die Blumenkrone ist verwachsenblättrig und meist trichterförmig; der Saum ist gewöhnlich nur wenig gelappt und häufig eingebrochen-gefaltet, dem entsprechend ist dann auch die Knospenlage eingebrochen-klappig. Die Stanbgefäße sind entweder nahe am Grunde oder oberhalb der Röhrenmitte angeheftet und wechseln mit den Kronenlappen; die Staubfäden sind häufig am Grunde verbreitert, die Beutel sind eiförmig, am Rïcken oberhalb des Grundes befestigt und springen mit 2 inneren oder seitlichen Längsspalten auf. Das unter dem Fruchtknoten sitzende, Honig absondernde Polster ist ringförmig, ganz oder gelappt, zuweilen ist es nur g'eringfügig entwickelt oder es fehlt ganz. Der Fruchtknoten ist oberständig und besteht meist ans 2 (selten 3-5) Fruchtblättern; er zeigt ebensoviele Fücher, die zuweilen durch eine falsche Scheidewand nochmals getheilt sind; jedes Fruchtknotenfach umschliesst 2 (selten einzelne oder 4) Samenanlagen, die anfrecht, sitzend und anatrop sind. Der Griffel ist endständig und hat eine einfache, kopfförmige, zweilappige oder zweiknöpfige Narbe. Die Frucht ist mehrsamig, gewöhnlich kapselartig und zwei- bis vierklappig, seltener springt sie unregelmässig oder mit Deckel auf; zuweilen ist sie beerenartig, seltener zerfallt sie in nicht aufspringende Cokken. Der Same ist aufrecht, mehr oder weniger dentlich kugelig oder durch gegenseitige Pressung kantig; er ist kahl oder behaart; das Nährgewebe ist fleischig, zuweilen sehr spärlich; der Keimling ist gewöhnlich gekrummt, die Keimblätter sind häufig gefaltet, blattartig, ganz, ausgerandet oder zweilappig, selten fehlen sie (Cuscuta).

Kräuter, Sträucher oder selten Bäume mit schlaffen, oft windenden Stengeln und spiralgestellten, der Form nach weehselreichen Blättern, ohne Nebenblätter, sehr selten fehlen sie (Cuscuta); die Pflanzen sind kahl oder mit einer, nicht selten sehr dichten Bekleidıng versehen. Die Blüthen stehen entweder einzeln oder zu wenigen in den Blattachseln oder sie bilden reichblïthige, rispige Verbände, die oft in Schraubeln auslaufen, zuweilen sind sie auch kopfig zusammengezogen. Deckblätter und Vorblättchen sind häufig entwickelt.

Die Familie umfasst 40 Gattungen mit etwa $830 \mathrm{Arten}$, die hauptsächlich in den wärmeren Gegenden der Erde wachsen; die baumförmigen und holzigen iiberhaupt sind besonders den Tropen eigen. 


\title{
IPOMOEA Linn.
}

\section{(Untergattung EXOGONIUM Choisy.)}

Kelchblätter völlig frei, breit dachziegelig deckend, stumpf, ohne oder mit sebr kleiner aufgesetzter Pfriemspitze, meist ungleich lang. Blumenkrone präsentirtellerförmig ins Trichterförmige übergehend, mit gefaltetem Saume und breiten, durch seichte Buchten getrennten Lappen. Staubgefässe oberhalb des Grundes der Röhre angeheftet, unter sich nicht verbunden; Staubfäden lang, pfriemlich, oft etwas gekrlimmt, hervorragend. Fruchtknoten zweifächrig, mit zwei Samenanlagen in jedem Fache; Griffel fadenförmig, gerade mit zweiknöpfiger Narbe. Kapsel zweifächrig, vierklappig aufspringend. Samen kahl. Windende Kräuter mit rïbenförmig verdickten Wurzeln, spiralig gestellten, ganzen Blättern und arm(zwei- bis drei-)blüthigen, achselständigen Dichasien.

Etwa 16 Arten, die nur im tropischen und subtropisehen Amerika, hauptsächlich auf den Antillen und in Mexiko wachsen.

\section{Ipomoea (Exogonium) Purga Hayne.}

\author{
Tafel $33^{\mathrm{s}}$ u. $33^{\mathrm{b}}$.
}

Krautig oder halbstrauchartig, windend; Blätter herzförmig, zugespitzt, ganzrandig, kahl, ziemlich langgestielt; Blüthenstand achselständig, zwei- bis dreiblïthig; Kelehblätter ungleich gross, stumpf oder seicht ausgerandet; Röhre der Blumenkrone 4-5 mal länger als die grössten Kelchblätter, Saum flach, roth wie die Röhre.

Ipomoea Purga Hayne, Arzneigewächse XII. t. 33 und 34; Guimp. et Klotzsch, Abbildg. offiz. Gew. t. 21 und 22; Choisy in DC. Prodr. X. 374; Nees, Düsseld. Suppl. t. 61; Berg u. Schmidt, Darst. u. Beschr. Va.t.b.; Köhler, Mediz. Pfl. t. 150; Baill. Bot. méd. 1264; Flïck. and Hanb. Pharmacogr. 398; Flückiger, Pharmacogn. III ed. 429; Arth. Mey. Drogenk. I. 293.

Convolvulus Purga Wender. Pharm. Centrbl. 1830. I. 457.

Exogonium Purga et dumosum Benth. Pl. Hartweg. 46; Bot. Reg. XXXIII. t. 49; Bot. Mag. t. 4280; Benth, and Trim. Med. pl. t. 186.

Ipomoea Schiedeana Zucc. in Flora XV (2.) 801, in Abh. München. Akad. I. t. 12, non Ham.

Ipomoea Jalapa Royle, Ill. Himal. 309, non Pursch.

Convolvulus officinalis Pellet. nach Steudel.

Jalapenwinde; französisch : Jalap; engliseh: Jalap.

Aus einer kriechenden, verzweigten, bräunlichen oder grauschwarzen Grundaxe von der Dieke eines Tauben- bis Rabenfederkieles, die mit schuppenförmigen Niederblättern besetzt und an der Spitze ein wenig angeschwollen ist, erheben sich mehrere Meter lange, windende Stengel. Dort, wo die letzteren sich von der Grundaxe abzweigen, sind die Nebenwurzeln ganz besonders stark rübenförmig verdickt; sie erreichen die Grösse einer Faust und darïber, sind fast kugel- oder mehr spindelförmig und laufen, meist plötzlich zusammengezogen, in den dünnen, an der Spitze verzweigten, unteren Theil der Wurzel aus; ihre Farbe ist aussen bräunlich oder grauschwarz, innen weiss, beim Durchschneiden milehen sie stark, sehr selten sind sie mehr oder minder tief zweispaltig.

Der Stengel windet links (d. h. gegen den Gang des Uhrzeigers), er ist krautig, nur am Grunde verholzt er in der Heimath, stielrund, läng'sgestreift, kahl, dunkelgrün und mehr oder weniger röthlich angelaufen.

Die Blätter sitzen auf Stielen, die bis $5 \mathrm{~cm}$ lang werden, am Grunde etwas verdickt sind und oben von einer Rinne durchzogen werden; die Blattspreite ist $9-10(4-12) \mathrm{cm}$ lang und im unteren Drittel 
5-6 $(3-10) \mathrm{em}$ breit, herzförmig, mit breiter, flacher oder enger gerundeter, tieferer Bucht und haarfeiner Spitze; sie wird von 7 Grund- und jederseits des Medianus von 2-3 stärkeren Seitennerven durchzogen; sie ist lebhaft grin, beiderseits kahl und zart laubig.

Die Bluthen treten einzeln oder in dichasischen Verbänden gepaart, selten zu dreien, von $4-10 \mathrm{~cm}$ langen e. $1 \mathrm{~mm}$ dicken Stielen getragen aus den Blattachseln; die schuppenförmigen Deckblätter sind etwa 1,5-2 mm, die in der Mitte der etwa $1 \mathrm{~cm}$ langen Blithenstielehen sitzenden Vorbliittehen sind nur $1 \mathrm{~mm}$ lang. Die kleineren äusseren Kelchblätter sind 5-7, die grösseren inneren 7-10 mm lang. jene $3-4$, diese 5-6 mm breit, sie sind am Rande diunner als in der Mitte und dort durchscheinend; ihre Form ist elliptiseh oder kurz eiförmig, an der Spitze sind sie mehr oder weniger deutlich ausgerandet und unterhalb der Bucht befindet sich ein kleines Spitzehen; sie sind beiderseits kahl, griin und undeutlich röthlich punktirt. Nach der Blïthe neigen die Kelchblätter kegelförmig zusammen.

Die Blumenkrone ist präsentirtellerförmig; die Röhre misst $4-4,5 \mathrm{~cm}$, sie ist oben ein wenig keulenförmig erweitert, innen und aussen völlig kabl; der Saum hat 4,5-5,5 cm im Durehmesser; er ist flach, schwach funflappig, gefaltet, die Lappen sind sehr stumpf, in der Mitte ein wenig ausgerandet; die ganze Blitthe ist purpurroth. Die Staubgefüsse sind 1-1,2 cm iber der Basis in der Röhre befestigt, sie messen $5,2-5,5 \mathrm{~cm}$ in der Länge und sind stets etwas ungleich; die weissen Staubfäden sind stielrund und nehmen nach der Basis ein wenig an Umfang zu; die Staubbentel messen e. $4 \mathrm{~mm}$ in der Länge und $1 \mathrm{~mm}$ in der Breite, sie sind gelb und springen auf der Innenseite anf; die kugelrunden Pollenkörner sind verhältnissmässig schr gross, sie sind gefeldert und bestachelt. Der Fruchtknoten ist 1-1,5 mm lang und hat einen Durchmesser von $1 \mathrm{~mm}$; er ist kegelförmig und geht allmälig in den fadenförmigen Griffel über; am Grunde wird er von einem noch nicht $1 \mathrm{~mm}$ hohen Drissenring umgeben, er umschliesst in zwei Fächern je 2 aufrechte, gewendete Samenanlagen, deren Micropylen nach aussen gerichtet sind und die anf dem Grunde des Fruchtknoten angeheftet sind. Der Griffel ist 5,5-6,5 $\mathrm{cm}$ lang, die beiden Narbenknöpfchen haben einen Durchmesser von 1,5-2 mm, sie sind gelblich.

Frucht und Samen sind noch nicht bekannt.

Die Jalapenwinde wächst in schattigen Laubwäldern der östlichen Abhänge der mexicanischen Anden, und zwar in der Nähe der Städte Orizaba und Cordoba besonders zwischen 1500 und $2500 \mathrm{~m}$ Meereshöhe; sie wird aber auch in Mexico, auf Jamaica und vorzïglich bei Oatacamund, der ostindischen Chinaculturstation, zum Export gebaut; bei uns gedeiht die Pflanze leicht, erzeugt auch Wurzelknollen und blitht im Ausgange des Herbstes.

Anmerkung. Wahrscheinlieh wegen der reiehlichen vegetativen Vermehrung scheint die Pflanze nur selten Frïchte zu bringen; sie sind bis jetzt nicht gesehen worden.

Als "Tubera Jalapae" sind die fleisehig verdickten Nebenwurzeln officinell, welche der Pflanze als Reservestoffbehälter dienen. Die wirksamen Bestandtheile liegen in den Sekretzcllen dieser Knollen. Durch Ausziehen der trockenen Knollen mit Weingeist, Verdampfen des letzteren und Auswaschen des Rückstandes mit Wasser erhält man das als "Resina Jalapae« gebräuchliche Harz.

\section{Erklärung der Abbildungen.}

Tafel 33a, Oberer Theil eines Zweiges der blühenden Pflanze, nach einem im $\mathrm{kgl}$. botanischen Garten zu Berlin

Tafel $33 \mathrm{~b}$ cultivirten Exemplare.

Fig. A. Grundaxe mit einer grossen und vielen kleinen Wurzelknollen, natïrliche Grösse.

Fig. B. Querschnitt durch die Knolle.

Fig. C. Der Keleh von vorn und von hinten gesehen, 2mal vergrössert.

Fig. D. Die Blumenkrone, vorn aufgespalten und ausgebreitet, natürliche Grösse.
Fig. E. Das Staubgefuss, von aussen und von innen betrachtet, 5mal vergrössert.

Fig. F. Follenkörner, 40mal vergrössert.

Fig. G. Der Keleh mit dem Griffel, natiirliche Grösse.

Fig. H. Der Frnehtknoten mit dem Honigpolster, 10mal vergrössert.

Fig. I. Derselbe im Lüngsschnitte, 12 mal vergrössert.

Fig. $K$, Derselbe im Quersehnitte, 18 mal vergrössert.

Fig. $L$. Die Narbe, 5mal vergrössert. 


\section{Reihe: Contortae Linn.}

Blüthen aktinomorph, selten mit Neigung zur Zygomorphie, in Kelch, Blumenkrone und Staubgefässen typisch fiunfgliedrig mit 2 Fruchtblättern. Die Blumenkronenabschnitte meist in der Knospenlage gedreht. Blätter häufig' kreuzgegenständig, ganz, meist ohne Nebenblätter.

\section{Familie: Ap ocy naceae Lindl.}

Die Blüthen sind aktinomorph, zwittrig und fast stets durch alle Kreise, mit Ausnahme des Fruchtknotens, fünfgliedrig. Der Kelch ist bleibend, allermeist freiblättrig mit breiter quincuncialer Deckung; häufig ist er am Grunde mit Driisen oder Schuppen versehen. Die verwachsenblättrige Blumenkrone ist präsentirteller-, trichter-, seltener krug- oder radförmig mit gewöhnlich gedrehter Knospenlage der oft sehr schiefen Zipfel. Die Staubgefässe sind mehr oder minder hoch tiber dem Grunde der Blumenkronenröhre eingefügt, gewöhnlich sind sie eingeschlossen, seltener überragen sie den Röhrenmund; die Staubbeutel sind entweder oblong-linealiseh bis eiförmig oder deutlich pfeilförmig; im ersteren Falle sind die Theken bis zum Grunde mit Pollenkörnern gefüllt, im letzteren sind die unteren Enden (oft bis zur Hälfte) leer; sie neigen sehr häufig kegelförmig zusammen, die pfeilförmigen sind aber noch dazu mittelst eines von der Innenseite ausgehenden Fortsatzes mit dem Griffelkopfe verwachsen; die Theken springen in nach innen gewendeten Längsspalten auf und entlassen einen kömigen, nicht verklebten Blüthenstaub. Ein honigabsonderndes, ringförmiges oder gelapptes Polster ist sehr oft vorhanden. Der Fruchtknoten ist ober-, nicht selten aber halbunterständig, ein- oder zweifächrig, im letzteren Falle sind die Fruchtblätter häufig von einander ganz getrennt; sic werden aber durch einen gemeinsehaftlichen fadenförmigen, am Ende kopfig verdickten, hier oft mit einem Kragen gezierten, in 2 Narben auslaufenden Griffel zusammengehalten. In jedem Fache des Fruchtknotens befinden sich meist vicle, seltener zwei oder nur einzelne Samenanlagen, die anatrop und meist hängend, seltner aufrecht sind. Die Frucht ist entweder einfach oder zweitheilig, fleischig nnd nicht aufspringend, oder trockenhäutig, balgkapselartig, mit einer Längsspalte an der Bauchseite sich öffnend, selten sind echte Kapseln oder Flügelfrüchte. Die Samen der Trockenfrüchte sind meist gefligelt oder mit einer Federkrone versehen, welche die der saftigen nicht besitzen. Der Keimling ist gerade, die Keimblätter sind blattartig, sie liegen flach an einander und sind nur selten gefaltet oder gerollt; das Nährgewebe ist nur zuweilen umfangreich und dann knorpelig oder hornig, meist ist es spärlich, zuweilen fehlt es ganz.

Kräuter und Sträucher, die sehr häufig winden, selten aber durch Ranken klettern, oder Bäume, mit reichlichem, weissem, kautschukhaltigem Milchsafte und einfachen, kreuzgegenständigen oder gequirlten, selten spiral gestellten, ganzrandigen Blättern, die häufig parallel verlaufende Nebennerven zeigen, der Nebenblätter entbehren, nicht selten aber in den Achseln Drüsen tragen. Die Blüthenstände sind häufig reichblithig, kreuzgegenständig-rispig und laufen in Dichasien, endlich in Wickeln aus; Bluthen mit Deck- und Vorblättern.

Die Familie umfasst in etwa 120 Gattungen mindestens 1000 Arten, die hauptsächlich der tropischen und subtropischen Erde angehören; in den gemässigten Zonen giebt es wenige, in den kalten fehlen sie. 


\section{STROPHANTHUS DC.}

Bluthen aktinomorph, zwittrig, bis auf den Fruchtknoten fünfgliedrig. Kelch fünfblättrig, am Grunde mit 5 bis vielen Drüsen. Blumenkrone trichterförmig mit meist kurzer Röhre und glockig erweitertem Schlunde, an dessen Saume 5, an der Spitze tief ansgerandete oder 10 Schuppen sitzen; die 5 Zipfel sind entweder lang zugespitzt oder hänfig geschwänzt, mit rechts deckender, gedrehter Knospenlage. Staubgefässe im oberen Theil der Röhre eingefügt, nicht über den Schlund hervorragend mit kurzen Fäden; die Beutel schliessen zu einem den Griffelkopf verbergenden Kegel zusammen und sind diesem angeheftet; sie sind pfeilförmig und in den unteren Theilen der Theken leer. Das Driisenpolster fehlt. Fruchtknoten aus zwei gesonderten Fruchtblättern gebildet; jedes Fach mit $\infty$, in viele Reihen gestellten hängenden, anatropen Samenanlagen; Griffel fadenförmig, der Kopf am Grunde mit einem ringförmigen, leicht in Lappen zerreissenden Kragen versehen; Narbe kurz zweilappig. Frueht balgkapselartig mit getrennten, spreizenden, Hälften; Samen zusammengedrïckt, spindelförmig, an der Spitze mit sehr langer, oben allseitig behaarter, endlich abfallender Granne versehen. Keimblätter flach, Eiweiss spärlich. Sträucher oder kleine Bäumchen mit kreuzgegenständigen Blättern, die kahl oder behaart sind. Blüthen in end- oder seitenständigen, zuweilen zusammengezogenen Rispen mit Dieck- und Vorblättern.

25 Arten aus dem tropisehen Afrika und Asien, 1 vom Cap.

\section{Strophanthus hispidus DC.}

\section{Tafel 34 .}

Strauchartig mit aufrechtem, gabelig verzweigtem Stamme; Äste durch einen vielblüthigen Blüthenstand abgeschlossen; Blätter meist oblong, kurz zugespitzt, krautig, wie die jüngeren Zweige rauhhaarig, Seitennerven unterseits vorspringend; Kelchzipfel zugespitzt; Blumenkrone glockig mit sehr langen, zuerst aufrechten, damn schlaff herabhängenden linealischen Zipfeln.

Strophanthus hispidus A. DC.*) in Annal. mus. d'liist. nat. I. 408. 412, in Bull. soc, philos. III. t. 8. fig. 2, Prodr. VIII. 419; Christy, New commerc. plants and drugs X. 24; Fraser in Trans. roy. soc. Edinb. XXXV. 955 (z. Theil); Holmes in Pharmac. journ. III. ser. XXI. 233; Flick. Pharmacogn. III. ed. 1021; Baill. in Bull, soc, Linn. Paris 555; Blondel, les Strophanthus du commerce, Paris 1883. pag. 14; Pax in Engl. Bot. Jahrb. XV. 365.**)

Rauhhaariger Strophanthus; französisch: Strophanthe hérissé; englisch: Hairy Strophanthus.

Der verästelte Strauch erreicht eine Höhe von $4 \mathrm{~m}$. Die geraden Zweige sind in der Jugend mit einem dichten Überzuge von gelblichen, einfachen Haaren bekleidet; nach dem Abfall der Epidermis sind sie mit einer schwarzen Rinde bedeckt.

Die Blätter sitzen kreuzgegenständig auf $2-5 \mathrm{~mm}$ langen, dicht behaarten Stielen; die Spreite misst $6-9(4-10) \mathrm{cm}$ in der Länge und hat eine grösste Breite von $3-4(2,5-4,5) \mathrm{cm}$; sie ist kurz und stumpf zugespitzt, gewöhnlich von elliptischer Form, zuweilen mit einer geringen Neigung in das Ei- oder Umgekehrteiförmige; sie ist dümnkrautig mit beiderseits vorspringenden Seitennerven, die Behaarung ist an den Rändern und unterseits stärker als oberseits.

Der nicht allzu reichblüthige B 1 iu thenstand beschliesst die Enden der Zweige; er stellt ein $3-4$ fach gabelspaltiges Dichasium dar. Die ersten Bracteen sind oft umgekehrt eiförmig und plötzlich in eine lange, lineale Spitze zusammengezogen, die iibrigen entsprechend kleiner und sehmaler; sie sind gewöhnlich minder dieht als die diunen Blithenstiele behaart.

*) Den von De Candolle im Prodromus citirten Namen Str. hirta Poir. habe ieh nieht auffinden können.

**) Die von Pax mitgetheilte Tafel, welche St*oph. Emini Asehers. et Pax darstellt, ist sehr naturgetreu, bedarf aber bezïglich des Griffuls einer Korrektur. 
Die Kelehbätter sind 1,5-2 cm lang, die äusseren eilanzettlichen beträchtlich breiter (7 mm) als die inneren lanzettlichen $(4 \mathrm{~mm})$; sie sind besonders auf dem Mittelnerven und dem Rande mit langen, gelblichen Haaren bestreut; zwischen ihnen befinden sich am Grunde die 1-2 mm langen, spindelförmigen Drisen.

Die Blumenkrone hat eine $7 \mathrm{~mm}$ lange, cylindrische Röhre, dann folgt der glockenförmige, $8 \mathrm{~mm}$ lange Schlund, und endlich geht sie in die 10-16 cm langen, etwa $1 \mathrm{~mm}$ breiten linealischen, zuerst aufrechten, dann zuriickgekrímmten und zuletzt schlaff herabhängenden Zipfel aus. Im Schlund sind zwischen den letzteren $2 \mathrm{~mm}$ lange, am Grunde verbundene, fleischige Schuppen befestigt; diese sind von rother Farbe, während der Schlund und die Schwänze citronengelb gefärbt sind; jener ist indess noch mit rothen Tupfen und Strichen geziert; aussen ist die Blumenkrone, besonders aber der Schlund mit angepressten Haaren bestreut, nur die untere Hälfte der Röhre ist kahl; auch innen sind hier und da kurze Härchen vom oberen Theile des Schlundes an wahrzunehmen.

Die Staubgefässe sind etwa $7 \mathrm{~mm}$ oberhalb des Grundes in der Blumenkronenröhre angeheftet; ihre Fäden sind 1,5 mm lang, die Beutel messen $4 \mathrm{~mm}$. Der Bau der letzteren ist sehr eigenthïmlich: sie sind lanzettlich-pfeilförmig, mit parallelen, am Ende gestutzten Sehwänzen; ihre Substanz ist fast hornartig, auf der Rückseite sind sie convex, an der Spitze von einer seichten Furche durchzogen. Auf der Innenseite liegen dic beiden Theken; das Conneetiv endet in eine $1 \mathrm{~mm}$ lange, dünnhäutige, dreiseitige Spitze. Die Theken nehmen nur wenig mehr als das obere Drittel des Beutels (kaum $1 \mathrm{~mm}$ ) in Anspruch; am unteren Ende derselben befinden sich 2 minutiöse, sich berührende, callöse Knötchen. Der untere Theil des Beutels ist vertieft und wird in seiner Mitte von einer ebenfalls eallösen Längsleiste durchzogen, an deren Ende der Staubfaden sitzt; dieser ist nach innen gekrümmt und gleichfalls callös verdickt.

Der Fruchtknoten ist 1,5-2 mm lang, zu einem Drittel bis zur Hälfte unterständig; er ist dicht mit langen Haaren bedeckt und besteht aus 2 getrennten Fruchtblättern, die durch den $10 \mathrm{~mm}$ langen Griffel zusammengehalten werden. Die Samenanlagen sind sehr zahlreich und sitzen in vielen Reihen an der Ausscnseite einer häutigen, in der Mitte durch eine Längsleiste befestigten, nach rỉckwärts eingerollten Placenta. Der Griffel ist am Ende kopfig verdiekt; der Kopf trägt am Grunde einen sehief nach unten gerichteten, oberflächlich fünflappigen oder ganzrandigen Kragen, der sehr leicht in mehrere (gewöhnlich fünf Lappen ${ }^{*}$ zerreisst; oben ist er ziemlich gerade abgestutzt; er misst 1,5 mm in der Länge und an ihm sind die Staubbeutel mittelst der oben erwähnten callösen Stellen befestigt, so dass sie einen aussen mit hornartigen Schildern bekleideten, itber dem Kopf zusammenneigenden Kegel bilden. Die einwärts gekrïmmten Staubfäden sind dem fadenförmigen Theil des Griffels der ganzen Länge nach angeklebt, so dass der Blumenkronenschlund fast verschlossen ist, bis auf 5 kleine Öffnungen zwisehen den Staubbeuteln, die den Insekten einen Zugang zu dem Honig ausseheidenden Blithengrunde gestatten. Wenn jene nun den Rüissel durch eine der Öffnungen stecken, berühren sie mit dem Kopfe die Spitzen der Staubbeutel, an welchen der körnige Blüthenstaub hervorquillt; beim Besuch einer zweiten Blüthe streifen sie ihn an den Narbenlappen ab, so dass eine Fremdbestäubung ermöglicht wird.

Die Frü breite, unter einem rechten Winkel vom Stiele spreizende Balgkapseln, deren innere Fruchtschale dünn holzig und brïehig ist.

Der Same ist 1,2-1,7 cm lang und etwa $4 \mathrm{~mm}$ breit, oblong-linealisch, stark zusammengedrückt, an beiden Seiten gespitzt, gelblich seidig behaart, oft windschief gedreht und innenseits von einem Nerven durchzogen; er wird von einer 10-15 cm langen Granne gekrönt, die am Ende auf $4-5 \mathrm{~cm}$ Länge mit aufrecht abstehenden, briichigen, allseitswendigen, weissen Haaren dicht besetzt ist und leicht abfällt. Der Keimling ist von der Form des Samens, das ziemlich lange Würzelchen ist nach oben gewendet, nur um dasselbe herum ist Nährgewebe nachweisbar.

*) Daher findet man in allen Büchern die Angabe, das er stets fünflappig sei. 
Der rauhhaarige Strophanthus wächst nur auf der Westküste des tropischen Afrikas und zwar findet er sich von Senegambien an bis nach der Sierra Leone, wahrscheinlich aber noch südlicher, vielleicht bis Kamerun, da ihn Mann, der diese Gegend besuchte, gesammelt hat.

Anmerkung. Vielfach meint man, dass Str. Kombe Oliv. aus dem tropischen 0stafrika mit ihm identisch sei; diese Ansicht dürfte aber schwerlich haltbar sein. Der Name wird von dem griechischen Wort oxpéşetv "drehen " abgeleitet, indem die Schwänze der Blumenkronenzipfel gedreht sein sollen; diese Erscheinung dürfte aber nur getrockneten Exemplaren zukommen und mit der Art der Conservirung zusammenhängen.

Die von der Granne befreiten Samen der Pflanze sind als "Semen Strophanthi" officinell. Die wirksamen Bestandtheile der Droge liegen im Endosperm und im Embryo des Samens. Angewendet wird in der Medicin meist die weingeistige Tinetur der Samen als "Tinctura Strophanthi».

\section{Erklärung der Abbildungen.}

Fig. A. Oberer Theil eines Zweiges mit einem Blïthenstande nach einem von Mann gesammelten Exemplare.

Fig. B. Die Blumenkrone aufgeschnitten und ausgebreitet, die Schwänze und der untere Theil der Röhre sind abgeschnitten, 2mal vergrössert.

Fig. C. Staubgefïsskegel, an der Spitze etwas aufgelockert, 5 mal vergrössert.
Fig. D. Derselbe um den Griffelkopf herumstehend, 2 Staubgefässe sind entfernt.

Fig. E.F. Das Staubgefäss vom Rücken und von der Seite.

Fig. $G$. Die eine Hälfte der Frucht, geschält, nach einem Exemplare im Besitze von Gehe u. Co., natürliche Grösse.

Fig. $H$. Der Same, natürliche Grösse.

Fig. $I$. Derselbe im Längsschnitt, 2mal vergrössert. 


\section{Familie: Asclepiadacea Lindl.}

Die Bliithen sind aktinomorph, zwittrig und durch alle Kreise, mit Ausnahme des Fruchtknotens, fünfgliedrig. Der Keleh ist bleibend, gewöhnlieh bis zum Grunde freiblättrig mit breiter, quincuncialer Deekung, nicht selten trägt er am Grunde Drïsen. Die verwaehsenblättrige Blumenkrone ist rad-, glockenoder krug-, selten präsentirteller- oder triehterförmig; mehr oder weniger tief gespalten, die Zipfel decken klappig oder sind in der Knospenlage gedreht. Zwischen ihr und dem Staubgefässkreise ist häufig noch ein fünfgliedriger, mannigfach differenzirter Cyklus (Corona) eingesehaltet. Die 5 Stanbgefässe sind meist in der Nähe des Grundes der Blumenkronenröhre angewaehsen, die flachen, breiten Fäden sind meist mit einander zu einer Röhre verwachsen; die Staubbeutel sind breit aufgesetzt, gewöhnlieh unter sich und mit dem Stempel verbunden, neigen sie über der Narbe daehförmig zusammen und bilden mit den Fäden jenen eigenthïmliehen Apparat, den man Gynostegium genannt hat; es sind zwei Theken vorhanden, die naeh innen gewendet aufspringen und welche von einem verbreiterten Connectiv iiberragt werden. Der Pollen jeder Theke hängt mehr oder weniger fest zu einem, seltener zwei Massen (Pollinia) zusammen und wird durch 5 zwischen den Staubgefässen befindliche Corpuscula aus den Theken entfernt. Ein Honig absonderndes Polster fehlt. Der Fruehtknoten besteht aus zwei völlig gesonderten Fruehtblättern, die durch den meist sehr kurzen Griffel oder die dieke, scheibenförmig verbreiterte Narbe zusammengehalten werden. Die Samenanlagen sind hängend, anatrop und sitzen in grosser Zahl mehrreihig auf einer ziemlich dieken Samenleiste. Die Frucht ist stets balgkapselartig, gedoppelt oder durch Fehlschlag einzeln; sie springt auf der Banchseite auf, die Samenleiste wird frei von der Wand umschlossen. Die Samen decken sich absteigend, sie sind zusammengepresst und häufig gerandet, zugespitzt und meist mit einem weissen, seidenglänzenden Haarschopfe versehen. Der gerade, mit flaehen Keimblättern versehene Keimling liegt in einem gewöhnlieh sehr spärlichen Eiweiss.

Kräuter oder Sträucher, die nieht selten winden, sehr selten Bäume, mit kreuzgegenständigen, ganzrandigen, nebenblattlosen Blättern ${ }^{*}$; Milchsaftschläuehe sind stets vorhanden. Bluthen meist in reichbliithigen Cymen, häufig klein, oft mit Deek- und Vorblättern.

Die Familie umfasst etwa 150 Gattungen mit 1400 Arten, die hauptsäehlich die wärmeren Theile der Erde bewohnen, in der gemässigten Zone sind sie spärlicher vorhanden, nur das südliche Afrika ist sehr reich daran.

*) Selten sind sie fleischig und blattlos. 


\section{MARSDENIA R. Br.}

Kelch fünfblättrig, innen am Grunde mit drïsigen Anhängen oder Schuppen versehen. Blumenkrone glocken- oder radförmig, selten trichterig, fünfspaltig, im Schlunde behaart, mit stumpfen, rechts gedrehten Zipfeln oder fast klappiger Knospenlage; die 5 Schuppen der Corona sind der Staubgefässröhre oder den Beuteln angeheftet, selten fehlen sie oder sind am Grunde zu einem Ringe verwachsen. Staubgefässe am Grunde der Blumenkrone angeheftet, Beutel mit häutigem Connectivfortsatze; Pollinien oblong oder umgekehrt-eiförmig, aufrecht. Narbe eingedriickt, flach, convex oder geschnäbelt. Balgkapseln ziemlich dick, zugespitzt, zuweilen geflügelt. Samen mit Haarschopf. - Windende, selten aufrechte Sträncher oder Halbsträucher, die entweder kahl oder mit mehr oder minder dichtem Filze bekleidet sind. Die Cymen sind gewöhnlich verkürzt, zuweilen doldenförmig und brechen fast stets nur aus der einen Blattachsel hervor. Die Blïthen sind gewöhnlich klein.

60 bis 70 Arten in den wärmeren Gegenden beider Hemisphären, eine auch in Süd-Europa.

\section{Marsdenia Condurango Reichb. fil.}

\section{Tafel 34 .}

Strauchartig; Blätter gestielt, eiförmig, kurz und stumpf zugespitzt, am Grunde gestutzt oder mehr oder weniger herzförmig, beiderseits weichfilzig, unterseits heller; Blïthenstände hänfig aus einer Achsel des Blattes gepaart, gestielt, Stiel so lang oder wenig länger als die Blätter; die Corona fehlt; Frucht schwach gerippt

Marsdenia Condurango (Cundurango) H. G. Reichb. in Bot. Zeit. 1572. p. 551, Archio für Pharm. CCI. (1872) 274; Fliuckig. Pharmacogn. ed. III. 590; Arth. Mey. Drogen. II. 130.

Marsdenia Reichenbachii Triana in Bullet. soc. bot. Fr. XX. 36.

Condurango in allen Sprachen.

Der im frischen Zustande biegsame Stamm der hoch kletternden Liane kann einen Durehmesser von $10 \mathrm{~cm}$ erreichen; er ist mit einer granen Rinde bedeckt, während die jüngeren Zweige einen dichten olivgrïnen bis rostfarbenen Filz von kürzeren gewundenen und längeren mehr geraden, einfachen Haaren tragen, und im Gegensatz zu dem runden Querschnitte jener dentlich vierkantig sind.

Die Blätter stehen kreuzgegenständig auf 1,5-2,5, höehstens $3,5 \mathrm{~cm}$ langen, oberseits schwach rinnig vertieften, olivfarben filzigen Stielen, die in der Achsel einen reichlichen Driisenbesatz tragen; die Spreite ist 8-11 $(4-15) \mathrm{cm}$ lang und im unteren Drittel $5-8(4-10) \mathrm{cm}$ breit, gewöhnlich von rein eiförmiger Gestalt, zeigt sie zuweilen Neigung zum Oblongen oder durch parallel verlaufende Ränder zum Linealen; sie ist beiderseits mit einem nnten dichteren Filze ans gegliederten Haaren bekleidet, die Unterseite fühlt sich dentlich weich an; sie wird jederseits des Mittelnerven von etwa 7 stärkeren, unterseits dentlicher sichtbaren Seitennerven durehzogen und ist von ziemlich derber Textur.

Die Blïthenstände brechen nur ans den Achseln des einen Blattes jedes der krenzgegenständigen Paare hervor und bilden an dem gerade gestreekten Zweige zwei Reihen; sie sind oft gepaart und werden von einem 2-3, selten mehr em langen, $1 \mathrm{~mm}$ dicken Stiele gestutzt, der die gleiche Bekleidung wie

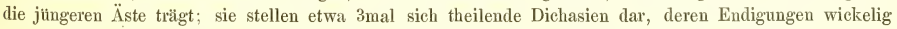
auslaufen; die kleinen Blüthen sind wenigstens in der letzten Verzweigung zusammengedrängt, da sie nur anf 1-2 mm langen Stielchen sitzen; Deck- und Vorblättchen sind e. $1 \mathrm{~mm}$ lang und verschwinden fast ganz unter der dichten Bekleidung.

Der Keleh ist nur wenig uber $2 \mathrm{~mm}$ lang, er ist aussen olivgrün-filzig und am Rande kurz gewimpert, im Innem ist er kahl; die bis auf den Grund freien Blätter sind oblong und stumpflich, 
zwischen ihnen sitzt am Grunde eine einzelne kaum $0,5 \mathrm{~mm}$ lange, fingerförmige Drüse. Die Blumenkrone ist von griulicher, getrocknet von brauner Farbe, sie misst $4 \mathrm{~mm}$ in der Länge und ist bis zur Hälfte in 5 oblong-dreiseitige, häutig berandete, an der Spitze mit einem asymmetrischen Läppchen versehene, aussen kahle, innen mehr oder weniger dicht behaarte Zipfel gespalten.

Die 1,5 mm langen Staubgefässe sind kaum 0,5 mm über dem Grunde der Röhre angeheftet; nur die sitzende Anthere mit dem häutigen, abgerundeten Connectivanhang ist frei. Die beiden Theken springen nach innen zu auf; ihr Inhalt bildet ein 0,5 mm langes, wachsartiges, oblong-umgekehrteiförmiges, in ein gekriimmtes Stielchen verschmälertes Pollinium, das mit Hülfe des letzteren dem dunkelbraunen, an dem Griffelkopfe sitzenden Corpusculum angeheftet ist. Indem je ein Corpusculum zwischen zwei Staubgefässen sich befindet, stehen mit ihm die Hälften zweier benachbarter Staubgefässe in Verbindung. Die Corpuscula sind von besonderer Wichtigkeit für die Übertragung des Bltithenstaubes. Sie sind von spindelförmiger Gestalt und am unteren Ende durch einen Längsspalt geschlitzt. Wenn ein Insekt, angelockt durch den starken Duft der Asclepiadaceen, die Blïthen nach Honig absucht, so gelangen die Krallen der Füsse durch einen besonderen Leitapparat sehr leicht in die Spalte. Das Corpuseulum wirkt nun wie eine Wäscheklammer; die gekrímmte Kralle kann nicht unmittelbar aus dem Klemmapparat heraus, zieht das Insekt nun mit einem kräftigen Ruck den Fuss an sich, so reisst das Corpusculum vom Griffelkopfe ab und nimmt die beiden Pollinien aus den Theken heraus. Diese stehen dann aufrecht und liegen beide mit dem Corpusculum in einer Ebene. Beschreitet später das Insekt eine andere Blüthe, so bleibt das eine oder das andere Pollinium an der unter den zusammengeneigten Connectivenden verborgenen, klebrigen Narbe haften und die Pollenübertragıung ist vollzogen.

Der Fruchtknoten ist etwa $1 \mathrm{~mm}$ lang, er besteht aus zwei dentlich gesonderten, halbeiförmigen, seitlich etwas zusammengedrickten Karpiden, welche auf der Innenwand an einer halbcylindrischen Samenleiste zabllose, in mebrere Reihen gestellte Samenanlagen tragen. Sie sind mit zerstreuten Haaren besetzt und werden durch einen äusserst kurzen Griffel zusammengehalten, der zu einem dicken, plumpen, pyramidenförmigen, spitzen Griffelkopf anschwillt.

Die Frucht erreicht eine Länge von $10 \mathrm{~cm}$ und ist in der Mitte 2,5-3 cm dick, sie ist spitz, von etwa oblong-lanzettlichem Umrisse, aussen schwarz und wird von vielen seichten Längsfurchen durchzogen.

Der Same ist $1 \mathrm{~cm}$ lang, $6 \mathrm{~mm}$ breit, von eiförmigem Umrisse, zusammengedrückt, gerandet und von einem seidigen, weissen, 1,5-2 $\mathrm{cm}$ langen Haarschopfe als Flugapparat gekrönt.

Diese Condurango-Liane wächst in Ecuador.

Anmerkung. Cortex Condurango wird ohne $\mathrm{Zweifel}$ von verschiedenen Asclepiadaceae gewonnen. Die vorliegende Pflanze, welche wir der Güte des Herm Prof, Flückiger verdanken, stimmt in allen wesentlichen Merkmalen mit dem Original überein, das der Reichenbachschen Marsdenia Condurango zu Grunde gelegen hat und von Roezl eingesandt wurde. Sie zeigt indess einige Abweichungen: die Blätter sind deutlicher herzförmig, die Blumenkronenzipfel sind innen viel weniger stark behaart, die Blïthenstände sind ein wenig lockerer. Die Differenzen sind zu gering, um der Pflanze den Titel einer eigenen Art zu verschaffen, wir schlagen vor, sie als Varietät zu betrachten und belegen diese mit dem Namen var. Flüchigeriana.

Die Stammptlanze von "Cortex Condurango «, welche jetzt im Handel allgemein vorkommt, ist nicht genau bekannt. Die Rinde der oberirdischen Achsen von Marsdenia Condurango kommen als Condurango blanco in den Handel.

\section{Erklärung der Abbildungen.}

Fig. A. Ein bltihender Zweig der Liane, nach einem aus Ecuador stammenden, von Herrn Prof. Flückiger mitgetheilten Exemplare.

Fig. B. Die Blüthe, 4 mal vergrössert.

Fig. C. Der Kelch mit den Drüsen und dem Fruchtknoten, $5 \mathrm{mal}$ vergrössert.

Fig. D. Die Blumenkrone, aufgeschnitten und ausgebreitet, 5 mal vergrüssert.

Fig. $E$. Die Staubgefässröhre, $10 \mathrm{mal}$ vergrössert.
Fig. F. Dieselbe, ein Staubbeutel ist zurückgeschlagen, um die Art des Aufspringens zu zeigen.

Fig. $G$. Das Corpusculum, mit 2 Pollinien, 30 mal vergrössert. Fig. H. Der Fruchtknoten im Längsschnitte, 14mal vergrössert.

Fig. I. Die Frucht, natiirliche Grösse.

Fig. $K$. Der Same, natürliche Grösse.

Fig. L.M. Derselbe im Längs- and Querschnitte, 2mal vergrössert. 


\section{Familie: Log a niaceae Lindl.}

Die Blüthen sind aktinomorph oder zeigen nur eine geringe Neigung zur Zygomorphie, sie sind zwittrig oder seltener durch Fehlschlag eingeschlechtig, gewöhnlich durch alle Glieder bis auf den Fruchtknoten vier- bis fünfzählig. Der Kelch ist mehr oder minder tief in dachziegelig oder tiberhaupt nicht deckende Zipfel gespalten. Die Blumenkrone ist verwachsenblättrig, trichter- oder präsentirteller-, seltener glockenoder radförmig mit klappiger, dachziegeliger oder gedrehter Knospenlage der Zipfel. Staubgefässe sind so viele vorhanden als Blumenkronenzipfel, sie wechseln mit ihnen ab, sehr selten findet sich nur eins; die Staubbeutel sind am Riucken befestigt und springen mit 2 parallelen, nach innen gewendeten, selten spreizenden und oben zusammenfliessenden Längsritzen auf. Ein Honig absonderndes Polster ist nur zuweilen entwickelt. Der Fruchtknoten ist oberständig, gewöhnlich zwei-, selten drei- bis fünffächrig; er umschliesst meist zahlreiche, aufrechte, seltener hängende, an einer scheidewandstïndigen, halbcylindrischen, seltener schildförmigen Samenleiste sitzende, gewendete Samenanlagen; der Griffel ist einfach mit kopfiger oder zweispaltiger Endigung. Die Frucht ist kapselartig und springt fach- oder wandtheilig mit Klappen auf, oder sie ist steinfrucht- oder beerenartig. Die Samen sind netzig oder höckerig sculpturirt oder glatt, zuweilen geflügelt; der gewöhnlich gerade Keimling hat kürzere halbstielrunde oder breitere blattartige Keimblätter und liegt in einem fleischigen oder knorpligen, meist reichlichen Nährgewebe.

Sträucher oder Bäume, seltener Kräuter mit kreuzgegenständigen Blättern, die mit Nebenblättern versehen sind. Die Blüthenstände sind gewöhnlich reichblüthige Rispen, die in Cymen, endlich in Wickeln ausgehen, sie sind locker oder zu Köpfchen zusammengedrängt. Die Deckblätter sind häufig klein und unansehnlich, die Vorblättchen fehlen oft.

Die 30 hierher gehörigen Gattungen umfassen etwa 350 Arten, welche hauptsächlich in den tropischen Gegenden der Erde wachsen; in Europa fehlen sie ganz. 


\section{STRYCHNOS Linn.}

Kelch tief fünf-, seltener viertheilig mit offener Knospenlage. Blumenkrone präsentirtellerförmig oder glocken- oder fast radförnig, mit klappig deckenden Zipfeln. Staubgefässe am Schlunde der Röhre angeheftet mit kurzen Fäden; Staubbeutel am unteren Rücken befestigt, mit gesonderten Längsspalten aufspringend. Fruchtknoten zweifächrig, in jedem Fache zahlreiche Samenanlagen an einer halbkugeligen Samenleiste befestigt; Griffel einfach mit kopfiger, schwach zweilappiger Endigung. Frucht beerenartig; ein-, zwei- bis mehrsamig. Samen in einer weichen Masse eingebettet, meist zusammengedrückt, mit mittelständigem Nabel; der Keimling ist klein, mit blattförmigen Keimblättern und liegt in einem knorpligen Nährgewebe. - Bäume und Sträucher, die zuweilen mit Hülfe von umgebildeten, rankenartigen Zweigen hoch in die Bäume steigen mit kreuzgegenständigen, krautigen oder beerenartigen, häufig deutlich drei(bis fünf-)nervigen Blättern und nur sehr kleinen, interpetiolaren Nebenblättern. Die Rispen sind meist wenig verzweigt und bäufig eng zusammengezogen.

Von der Gattung sind ungefähr 60 Arten bekannt, welche in den Tropen beider Erdhälften gedeihen.

\section{Strychnos Nux vomica Linn.}

Tafel 36.

Baumartig ohne Ranken und Stacheln, mit wechselndem Laube; Blätter mässig gestielt, eiförmig, spitz, am Grunde gestutzt oder in den Stiel zugespitzt, kahl, drei- bis funfnervig, erst krautig, dann lederartig; Blüthenstände gestielt, endständig, in doldenartigen Dichasien; Blumenkrone grün oder grünlichweiss, im Schlunde kahl; Beere kuglig, roth, wenig- (meist zwei- bis vier-)samig.

Strychnos Nux vomica Limn. Spec. pl. ed. I. 189; Lour. Fl. Cochinch. I. 154; Gärtn. Fr. t. 179. fig. 7; Roxb. Corom. pl. I. 8. t. 4; Lam. Encycl. VIII. 694; Illust. genr. n. 2446. t. 119; Hayne, Arzneipft. I. t. 17; Nees, Düsseld. Abb. t. 205; Woodv. Med. pl. II. t. 79; Guimp. et Schlecht. t. 136; DC. Prodr. IX. 15; Schnizl. Icon. t. 131; Benth, in Journ. Linn. soc. I. 103; Wight, Icon. t. 434; Griff. Icon. pl. Ind. or. t. 411; Dalz. et Gibs. Bomb. Fl. 155; Bedd. Fl. sylvatica t. 143; Brand. For. Fl. 317; Kurz, For. Fl. Br. Burma II. 166; Miq. Fl. Ind.-Bat. II. 378; Berg und Schmidt, Darst. und Beschr. XIII ; Bentl. and Trim. Med. pl. t. 178; Köhl. Mediz. Pf. t. 107; Baill. Bot. med. 1212. fig. 3126; Flïck. and Hanb. Pharmacogr. 384; Flück. Pharmacogn. ed. III. 1015; Hook. fil. Fl. Brit. Ind. IV. 90; Arth. Mey. Drogen. I. 151.

Stryclenos ligustrina Bl. Rumph. I. 6S. t. 25.

Strychnos lucida R. Br. Prodr. 469; DC. Prodr. IX. 16; F. v. Müll. Fragm. phyt. IV. 44; Benth. Fl. Austr. IV. 369 .

Der $10-13 \mathrm{~m}$ hohe und 1-1,3 $\mathrm{m}$ im Umfang messende Baum hat ein weisses oder ins Graue ziehendes, feinkörniges, hartes und sehr bitteres Holz; er wirft in der kalten Jahreszeit die Blätter ab und treibt im März neue, mit denen zugleich die Blüthen erseheinen. Die jüngeren Zweige sind stumpfvierkantig und zuerst mit glänzend glatter, grüner, dann mit lenticellenreicher, grauer Rinde bedeckt; nur äusserst selten scheint sich einmal einer der Seitentriebe in die für viele Arten der Gattung characteristischen, stark verdickten Holzranken umzuwandeln.

Die Blätter sind kreuzgegenständig und durch sehr niedrige, breite, interpetiolare Nebenblätter mit einander verbunden. Der Blattstiel ist 5-10, selten bis $12 \mathrm{~mm}$ lang, ziemlich kräftig, nach oben abgeflacht. Die Spreite ist 7-9 $(3-12) \mathrm{cm}$ lang und im unteren Drittel $5-6,5(3-10) \mathrm{cm}$ breit, spitz oder stumpflich, am Grunde zugespitzt oder gerundet und plötzlich in den Blattstiel zusammengezogen; zuerst ist sie krautig. später wird sie deutlich lederartig; sie wird von 3 oder 5 beiderseits vorspringenden Nerven längs 
durchlaufen, die dureh ein deutlich sichtbares Queradernetz verbunden sind; sie ist glänzend und auch im jugendlichen Zustande völlig kahl; die Nebenblätter sind kaum 0,5 mm hoch, später trocknen sie ab und es bleibt nur eine verbindende Linie zwisehen den beiden Blattstielen.

Der Blüthenstand ist endständig und wird von einem 1-1,5 $\mathrm{cm}$ langen, zusammengedrückten, kahlen Stiele getragen; er hat gewöhnlich einen Durchmesser von $4-5 \mathrm{em}$ und ist im oberen Umfange flach gewölbt; die Blüthenstiele und -stielehen sind mit einem kurzen, olivgrinen Filze bedeckt. Die Blïthenstiele sind höchstens $2 \mathrm{~mm}$ lang, zuweilen sind aber die Blïthen völlig sitzend; die Deek- und Vorblättchen sind winzig klein (kaum $1 \mathrm{~mm}$ lang) und werden gewöhnlich in dem filzigen Überzuge übersehen; von den letzteren seheint manehmal nur eins entwiekelt zu sein.

Der Kelch ist $1 \mathrm{~mm}$ lang und fast bis auf den Grund in 5 gleichseitig dreiseitige, spitze, nur wenig behaarte Zipfel getheilt. Die Blumenkrone misst $10-12 \mathrm{~mm}$ und ist im oberen Fünftel in oblongdreiseitige, spitze, oben dreikantig verdiekte und fleisehige, wagerecht abstehende Zipfel gespalten; sie ist aussen völlig kahl, oberhalb des Grundes aber innerseits mit einigen längeren, schlaffen Haaren besetzt; ihre Farbe ist grtin oder griunlich-weiss. Die Staubgefässe sind $7-9 \mathrm{~mm}$ thber dem Grunde der Blumenkronenröhre angeheftet; die 1,5 mm langen Beutel sind oblong, fast völlig sitzend und springen innenseits mit zwei parallel verlaufenden Längsspalten auf; die Pollenkörner sind gerundet-tetraëdriseh mit 4 kleinen Poren und glatter Exine. Der Fruchtknoten ist zweifächrig, die Fäeher stehen transversal, er misst $1 \mathrm{~mm}$ im Durehmesser, ist völlig kahl und hat in jedem Fache an einer flach gewölbten Samenleiste zahlreiche gewendete, aufrechte bis hängende Samenanlagen; er geht allmälig in den 9-11 mm langen, fadenförmigen, an der Spitze schwach kopfig verdickten und undeutlich zweilappigen Griffel über.

Die Frucht ist eine kugelige, bis $5 \mathrm{~cm}$ im Durchmesser haltende, gewölnlich aber kleinere, erst grüne, dann orangeroth bis braun gefärbte Beere mit fester, 1-3 mm dieker Schale. Im Innern derselben umschliesst ein saftiges, sehr bitteres Fleiseh höchstens 8, gewöhnlich aber nur 2-4 Samen, welche aufrecht gestellt sind und durch einen fadenförmigen, aus der Nitte hervorgehenden Nabelstrang befestigt sind.

Die Samen haben einen Durchmesser von 12-25 mm und zeigen einen dureh zahllose, dicht gedrängte, radial gestellte Haare hervorgebrachten, stark seidigen Glanz; sie sind kreisrund, flach zusammengedrückt, scheibenförmig und gerandet. Der grösste Theil besteht aus dem in zwei Hälften spaltbaren, hornigen Nährgewebe, zwischen jenen liegt der 5-7 mm lange, mit herzförmigen, drei- bis fünfnervigen Keimblättern versehene Keimling.

Der Brechnussbaum wächst in dem ganzen tropischen Indien, besonders häufig an der Kuiste von Malabar und geht von dort anch weiter in das Innere, seltener ist er in Bengalen, dagegen ist er in den laubwechselnden Wäldern von Birma bis Tenasserim häufig; sonst findet er sich in Cochinchina, dem malayisehen Archipel, namentlich auf Java und Timor und geht bis nach Nord-Australien, da die Strychnos lucida $\mathrm{R}$. Br. von unserer Pflanze sicher nicht versehieden ist.

Offieinell sind die Samen der Pflanze als nSemen Strychni «. Die giftigen Alkaloide, welehe die Wirkung der Droge bedingen, liegen im Endosperm des Samens.

\section{Erklärung der Abbildungen.}

Fig. A, Ein blithender Zweig nach einem Exemplare aus Vorder-Indien.

Fig. B. Die Blumenkrone, aufgespalten und flach ausgebreitet, $5 \mathrm{mal}$ vergrössert.

Fig. C.D. Die Stanbgefïsse von vorn und hinten, $10 \mathrm{mal}$ vergrössert.

Fig. $E$. Pollenkörner in Wasser, 250mal vergrössert.

Fig. $\boldsymbol{F}$. Der Kelch mit dem Stempel, 5mal vergrössert.

Fig. G. Der Fruchtknoten im Lingsschnitte, 20mal vergrössert.
Fig. H. Derselbe im Querschnitte.

Fig. I. Dic Frucht im Querschnitte, natürliche Grösse; nach Roxburgh.

Fig. $K$. Der Same, natürliche Grösse: $a$. der Nabel; $b$. die Micropyle.

Fig. $L$. Dersclbe: $a$. das Nïhrgewebe; $b$, die Keimblätter; c. das Würzelchen.

Fig. M. Derselbe im Qucrschnitte. 


\section{Familie: Gentianaceae Dumort.}

Die Blüthen sind fast stets völlig zygomorph und zwittrig. Der Kelch ist unterständig, bleibend, meist glockenförmig vier- bis fünf- (selten sechs- bis zehn-)zähnig oder -lappig, mit dachziegeliger Deckung, seltener offen. Die Blumenkrone ist verwachsenblättrig, trichter- oder präsentirtellerförmig, glockig oder radförmig, vier- bis fün- (seltener sechs- bis zwölf-)theilig mit gewöhnlich links (entgegen dem Uhrzeiger) gedrehter, sehr selten eingebogen klappiger Knospenlage. Staubgefässe sind so viele als Blumenkronenabschnitte vorhanden, sie wechseln mit jenen ab, sie sind meist gleich und alle fertil, selten sind einige unfruchtbar oder abortirt; die Staubbeutel sind oberhalb des Grundes am Rücken befestigt und springen in zwei nach innen, selten nach aussen gelegenen Längsspalten auf. Das Honig absondernde Polster ist ringförmig, besteht aus 5 Drïsen oder fehlt. Der einzelne Fruchtknoten ist oberständig, meist einfächrig: mit 2 wandständigen Samenleisten, seltener ist er zweifächrig, dann sind die Samenleisten an der Scheidewand befestigt; der Griffel ist einfach mit kopfförmiger oder zweilappiger, seltener vierspaltiger Narbe; die Samenanlagen sind zahlreich und gerundet. Die Frucht ist kapselartig und springt entweder zwreiklappig auf, reisst unregelmässig auf oder bleibt geschlossen. Die Samen sind kugelförmig oder eckig, seltener zusammengedriickt, zuweilen etwas geflügelt; der Keimling ist gerade und liegt in einem reichlichen, fleischigen Nährgewebe.

Einjährige oder ausdanernde Kräuter, seltener Sträucher ohne Bekleidung mit in der Regel ganzen und ganzrandigen, kreuzgegenständigen Blättern, die nicht selten am Grunde verwachsen, durch eine Linie oder eine intrapetiolare Scheide verbunden sind, ohne Nebenblätter. Der Blüthenstand ist meist cymös oder eine decussirte Rispe, zuweilen ist er kopfig oder büschelig zusammengezogen, selten eine Rispe oder Traube mit spiral gestellten Blïthen.

Ungefähr 550 Arten in 50 Gattungen sind in der Familie gekannt, welche in den gemässigten, besonders den bergigen Gegenden beider Hemisphären wachsen; einige Gattungen sind tropisch, mehrere Arten sind hochalpin und arktisch.

TRIBUS I. Chironieae Reichb. Blätter kreuzgegenständig. Knospenlage der Blumenkronenzipfel gedreht. Griffel fadenförmig mit kopfiger Narbe.

\section{Erythraea Centaurium Linn.}

TRIBUS II. Swertieae Griseb. Blätter kreuzgegenständig. Knospenlage der Blumenkronenzipfel gedreht. Griffel meist fehlend mit zweilappiger Narbe.

2. Gentiana lutea Linn.

TRIBUS III. Menyantheae J. Gray. Blätter zweizeilig oder gebüschelt. Blumenkronenzipfel in der Knospenlage eingebogen-klappig.

3. Menyanthes trifoliata Linn. 


\section{ERYTHRAEA Pers.}

Blüthen aktinomorph, zwittrig, durch alle Kreise, bis auf den der Fruchtblätter, fün- (seltener vier-) gliedrig. Keleh röhrig, kurz oder höher gespalten, mit gekielten Zipfeln und kantiger Röhre. Blumenkrone rad- oder präsentirtellerförmig mit gedrehter Knospenlage der Zipfel. Staubgefässe der Röhre angeheftet mit kurzen Fäden; Staubbeutel hervorragend, nach dem Verstäuben schraubenförmig gedreht. Fruchtknoten einfächrig mit zahllosen gewendeten Samenanlagen an den zweilappigen, wandständigen Samenleisten; Griffel einfach, in zwei blattartige Lappen ausgehend, die randlich und innen mit Narbengewebe bedeckt sind. Kapsel fachtheilig aufspringend. - Einjährige oder ausdauernde, steif-aufrechto oder niederliegende Kräuter mit kreuzgegenständigen Blättern. Blüthen entweder in lockeren oder gedrängten Cymen oder zu ährenförmigen Wickeln verbunden, die kreuzgegenständige Rispen bilden.

In der Gattung sind über 30 Arten beschrieben worden, die aber grösstentheils nur Varietäten der unten behandelten zu sein scheinen; sie wachsen hauptsächlich in der nördlichen gemässigten und subtropischen Zone, eine aber dringt bis Chile, eine andere bis Australien vor.

\section{Erythraea Centaurium Pers.}

\section{Tafel 37.}

Einjähriges Kraut mit steif-aufrechtem, kantigem, verzweigtem, kahlem Stengel; Blätter sitzend, oblong oder schmal umgekehrt-eiförmig, drei- bis fünfnervig, stumpf; Blüthen zu einer krenzgegenstündigen, endlich ebensträussigen Rispe verbunden, die in Dichasien ausgeht; Kelchzipfel doppelt so lang als die Röhre; Blumenkrone um die Hälfte länger als der Kelch; Narbenlappen halbkreisförmig.

Erythraea Centaurium Pers. Enchirid. I. 255; Hoffmsegge, Fl. Port. I. 350; Schrant, Fl. Monac. I. 5; Mert. et Koch, F7. Deutschl. II. 232; Guimp. und Schlecht. I. 5. t. 3; Sturm, Deutschl. Fl. III. t. 12; Baxt. Br. Bot. V. t. 367; Nees, Gen. X. t. 10; Dietr. Fl. Bor. III. t. 160; Griseb. in DC. Prodr. IX. 55; Reichb. Icon. XVII. 12. t. 20; Bertol. Fl. Ital. III. 642; Ledeb. Fl. Ross. III. 49; Godr. et Gren. Fl. Fr. II. 453; Willk. et Lange, Fl. Hispan. II. 663; Berg u. Schmidt, Darst. u. Beschr. $\mathrm{XXIV}$; Köhler, Mediz. Pf. t. 22; Boiss. Fl. orient. IV. 68; Asa Gr. Syn. Fl. I. 112; Battand. et Trab. Fl. d'Alger. II. 589; Flück. Pharmacogn. ed. III. 676; Wittrock in Bot. Centralbl. XIX. 58.

Gentiana Centaurium Linn. Spec. pl. ed. I. 229; Fl. Dan. IV. t. 617; Svensk bot. IV. t. 219; Schkuhr, Handb. t. 59; Nees, Dïsseld. Abb. t. 203.

Chironia Centaurium F. W. Schmidt, Fl. boëm. I. n. 130; Engl. bot. IV. t. 417; Hayne, Arzneigew. I. t. 29; Curt. Fl. Lond. I. t. 22; DC. Fl. Fr. III. 660.

Centaurium vulgare Rafn in Schumach. Saell. fl. I. GS.

Hippocentaurea Centaurium Schult. Oestr. II. (1.) 283.

Tausendgüldenkraut; französisch: Centaurée; englisch: Centaury.

Die hin- und hergebogene weisse Pfahlwurzel ist spärlich verzweigt und erreicht eine Länge bis zu $15 \mathrm{~cm}$, und an dem oberen Ende einen Durchmesser von $3 \mathrm{~mm}$.

Die unteren Blätter der Pflanze sind rosettenförmig zusammengedrängt; häufig treten bei stärkeren Exemplaren bereits aus dem zweiten der auf die Keimblatter folgenden, kreuzgegenständigen Paare Seitenzweige, welche wie der Hauptstengel sich senkrecht erheben, aber niedriger als jener bleiben. Der Stengel erreicht eine Höhe von $30-35 \mathrm{em}$ bei einem Durchmesser von 2-2,5 mm, gewöhnlieh zeigen die Pflanzen aber geringere Masse; er hat an der Basis 6, weiter oben meist 4 Kanten, welehe durch die bis zum nächsten Internodium herablaufenden Blattspuren gebildet werden; er ist zur Blüthezeit durch Schwinden eines Theils des Marks hohl, völlig kahl wie die übrigen Theile der Pflanze und grïn.

Die Blätter sind bis 3,5 , selten bis $5 \mathrm{~cm}$ lang und oberhalb der Mitte oder im oberen Drittel bis 1,5 bis höchstens $2,5 \mathrm{~cm}$ breit, sie sind ganzrandig, an der Spitze stumpflich, am Grunde verschmälert 
und sitzend, den halben Stengel umfassend; ihre Form ist gewöhnlieh oblong, geht aber einerseits in das Spathel-, andererseits in das umgekehrt Eiförmige ïber, sie werden von 3, die unteren von 5 rüekseits vorspringenden Nerven durehzogen und sind von etwas fleisehiger Consistenz.

Die Bliththen werden von Deck- und Vorblättern gestïtzt, sie bilden gestielte achsel-, und kreuzgegenständige Dichasien, von denen die oberen zu einem »Ebenstrausse « zusammentreten; sie sind zuerst fast kopfig zusammengezogen, später gehen sie dureh Dehnung der Axen mehr auseinander; die Mittelbliuthen in jeder Gabel sind sitzend.

Der Keleh ist c. $5 \mathrm{~mm}$ lang, fünfkantig und bis über die Hälfte in 5 pfriemliche, auf der Rüekseite gekielte, lang zugespitzte Zipfel gespalten; von diesen ist gegen das gewöhnliche Vorkommen bei Dikotylen der unpaare nach vorn, auf das Tragblatt zugewendet; hiermit im Zusammenhange steht eine Convergenz der Vorblättehen ebenfalls naeh vorn. Die Blumenkrone ist präsentirtellerförmig, sie ist dünnhäutig; ihre Röhre misst 6-7 mm, die 5 Zipfel sind 5-6 mm lang; jene ist weisslieh an der Mündung und am Grunde etwas verengt; die rosarothen Zipfel sind oblong, stumpf; in der Knospenlage und nach dem Verbluhen sind sie rechts gedreht. Die Staubgefässe sind am Sehlunde der Blumenkrone angeheftet; ihre sehr zarten, fadenförmigen Staubfäden sind 3, die nahe am Grunde angehefteten, linealen oder eiförmig-oblongen, oben kurz gespitzten Bentel sind $2 \mathrm{~mm}$ lang. Sie springen mit 2 naeh innen gewendeten Längsritzen auf und enthalten Pollenkörner von ellipsoidiseher Form mit 3 Meridianfalten; nach dem Verstänben sind sie spiralig gedreht. Der Fruehtknoten besteht aus 2 leieht von einander lösbaren, transversal gestellten Fruehtblättern, an deren eingebogenen Rändern die gewendeten aufrechten Samenanlagen in mehreren Reihen sitzen; er ist $6-8 \mathrm{~mm}$ lang und hat einen Durehmesser von $1 \mathrm{~mm}$, seine Form ist sehmal-linealisch und ein wenig zusammengedriiekt; der Griffel ist $2 \mathrm{~mm}$, die Narbenlappen sind $1 \mathrm{~mm}$ lang, sie sind am gewulsteten Rande und innen papillös.

Die Frueht ist eine bis $10 \mathrm{~mm}$ lange und 1,5 mm breite, gelbe Kapsel, die leicht in ihre beiden Klappen wandtheilig zerfällt, zuweilen wird sie an der Spitze noeh dureh den Griffel zusammengehalten; jede Klappe ist dureh einen inneren, mittleren Längsspalt geöffnet.

Die Samen sind 0,3-0,4 mm lang, sehr zahlreieh, etwa keilförmig oder oblong, zusammengedrückt, netzgrubig, braun. Der Keimling ist kurz und plump, das dicke Würzelehen ist länger als die eiförmigen Keimblätter.

Das Tausendgüldenkraut wäehst auf sonnigen Triften und Wiesen des nördliehen, mittleren und südliehen Europa's, in Nord-Afrika und West-Asien. Es erreicht die Nordgrenze in Finnland, Süd-Sehweden und Gross-Britannien, und geht bis Algier und Tunis; in den kühleren Gegenden kommt es in der Ebene vor, in Griechenland aber wäehst es bereits nur in der Bergregion, ebenso in Syrien und Kaukasien; sein östliehstes Vorkommen liegt im nördliehen Persien.

Die zur Blüthezeit gesammelten, oberirdischen Theile der Pflanze liefern die Droge „Herba Centaurii

\section{Erklärung der Abbildungen.}

Fig. A. Eine blühende Pflanze aus der Mark.

Fig. $A_{1}$. Ein Specialblïthenständehen (Dichasium), $4 \mathrm{mal}$ vergrössert: $c$. die Gipfelblïthe, die nahe dem Aufblithen ist und die gedrehte Knospenlage zeigt; $b$. der Kelch; $a$. die Vorblätter der Gipfelblüthe und zugleich Deckblätter der Seitenblüthen.

Fig. $A_{2}$. Die blïhende Blïthe, 4 mal vergrössert.

Fig. $B$. Dieselbe im Längsschnitte: e. Fruchtknoten; $f$. Griffel; g. Narben.

Fig. C. Die Blumenkrone längs aufgeschnitten und ausgebreitet, $5 \mathrm{mal}$ vergrössert.

Fig. D. Das Staubgefäss, von vorn und von hinten betrachtet; $10 \mathrm{mal}$ vergrössert.

Fig. E. F. Dasselbe nach dem Verstäuben.

Fig. G.H.Pollenkörner trocken und im Wasser, $300 \mathrm{mal}$ vergrüssert.
Fig. $I$. Der Stempel von vorn und von der Seite, $4 \mathrm{mal}$ vergrössert.

Fig. $K$. Querschnitt durch den Fruchtknoten, 20mal vergrössert: $h$. die Samenleiste; $i$, die Samenanlagen; $q$. die Naht.

Fig. L.M. Längsschnitte durch den Fruchtknoten, 6mal vergrössert.

Fig. $N$. Die Kapsel in natürlicher Grösse.

Fig. $O$. Dieselbe, 4mal vergrössert.

Fig, $P$. Dieselbe, eine Klappe: $l$. Samen,

Fig. Q. Der Same, natürliche Grösse.

Fig. $R$. Derselbe, 30mal vergrössert.

Fig. S. T. Derselbe im Längs- und Querschnitte: $m$. Samiensehale; $n$. Nährgewebe; $o$. Würzelchen; $p$. Keimblätter.

Fig. $U$. Der Keimling, 55mal vergrössert. 


\title{
GENTIANA Linn.
}

Blüthen aktinomorph, zwittrig, durch alle Kreise, den der Fruchtblätter ausgeschlossen, fünf- (seltener vier-, sechs- oder sieben-) gliedrig. Kelch röhrig, kantig, zuweilen geflügelt, gewöhnlich nicht sehr tief gespalten, selten einseitig aufgerissen. Blumenkrone meist trichterförmig, zuweilen aber auch röhrigglockig, selten radförmig, die Zipfel decken mit gedrehter Knospenlage; sie ist in den Buchten nicht selten gefaltet. Staubgefässe der Röhre eingefügt, fast immer eingeschlossen; die Beutel sind eiförmig oder oblong und springen nach anssen gewendet auf; zuweilen kippen sie aber nach aussen über und öffnen sich dann in Längspalten nach innen zu. Der Fruchtknoten ist einfäehrig, die zahlreichen Samenanlagen sitzen an wandständigen Samenleisten; der Griffel ist kurz ader kaum bemerkbar und endet in zwei blattartige, manchmal zurïckgerollte Narben. Die Kapsel springt an der Berührungsstelle der Fruchtblätter zweiklappig auf. Samen zahlreich, ein- bis zweireihig, kugelig oder flach und dann zuweilen geflïgelt. - Meist ausdanernde, aufrechte, zuweilen einjährige, niedergestreckte Kräuter mit kreuzgegenständigen, bäufig sitzenden Blättern. Bläthen entweder rein achselständig oder dureh Verkleinerung der Deckblätter zu kreuzgegenständigen Trauben und Rispen verbunden.

Ungefähr 200 Arten, die hauptsächlich in der nördlich gemässigten Zone wachsen; sie begleiten die Anden und gelangen so nach Stud-Amerika; einige sind in Neu-Seeland, von denen eine wieder nach Tasmanien und Neu-Siid-Wales geht.

\section{Gentiana lutea Linn.}

\author{
Tafel 38.
}

Ausdanerndes Krant mit steifem, aufrechtem, hohlem, kahlem, einfachem Stengel; Blätter elliptisch, spitz, dentlich längsnervig. Blüthen gelb, in reichblïthigen Rispen, die ans gestanchten Dichasien aufgebaut werden, radförmig, mit lanzettlichen Zipfeln; Staubblätter hervorragend.

Gentiana lutea Limn. Spec. pl. ed. I. 227; Scop. Fl. Carn. ed. II. 29S; Allione, Fl. Pedem. I. 100; Lam. Encycl. méth. II. 635, Illustr. genr. t. 109. fig. 1; Vill. Delph. II. 521; Plenck, Icon. t. 156; Froel. Gent. 15; Woodv. Med. pl. t. 95; Steph. and Ch. t. 132; Reichb. Icon. Al. Germ. VII. 1059; Mert. et Koch, Deutschl. Fl. II. 334 und viele and. deutsche Floren; Nees, Diisseld. Abb. t. 199; Hayne, Arzneigew. XIII. t. 28; Guimp. et Schlecht. Gew. Pharmac. III. 50. t. 242; Griseb. in DC. Prodr. IX. 86; Berg und Schmidt, Darstellg. und Beschr. t. XXVI ${ }^{a}$; Bentl. and Trim. Med. pl. t. 182; Köhter, Mediz. Pf. t. 134; Baill. Bot. médic. 1291. xyl. 3245-3248; Willk. et Lge. Fl. Hisp. II. 657; Godr. et Gren. Fl. Fr. II. 485; Boiss. Fl. orient. IV. 69; Parlat. Flora Ital. VI. 746; Fliuck. and Hanb. Pharmacogr. 389 ; Flïck. Pharmacogn. ed. III. 417; Arth. Mey. Drogenkunde I. 275.

Asterias lutea Borkh. in Roem. Arch. I. (1). 26; G. Don, Gen. syst. IV. 184.

Swertia lutea Vest. in Tratt. Ausgemalte Taf. n. 518 (ex Koch).

Gelber Enzian; französisch: Gentiane jaune oder grande; engliseh: Gentiane.

Die Keimpflanze bringt im ersten Jahre ausser den Keimblättern nur zwei krenzgegenständige zu einer Rosette gedrängte Paare von Laubblättern hervor; sie ist durch eine relativ kräftige, nur spärliche Äste treibende Pfahlwurzel im Boden befestigt. Im zweiten Jahre erhebt sich die Knospe nur 6-8 mm über den Boden und entwickelt 3-4 Paare von ebenfalls rosettig gestellten Blättern; die Pflanze bleibt auch in diesem Jahre noeh einfach, erzeugt aber ans der Axe unterhalb der Blätter 1-2 Wurzeln, die mit der Pfahlwurzel von gleieher Stärke sind und den Eindruek hervorbringen, als ob die Primärwurzel tiberhaupt nicht entwickelt sei. Neben der Terminalknospe bringt die Pflanze ans dem von unten 
gezählt zweitem Blattpaare eine sehr kräftige Knospe hervor, die im dritten Jahre austreibt und die Verzweigung der Grundaxe einleitet. Viele, unter Umständen bis 10, ja sogar 20 Jahre vergehen, ehe sich die Pflanze anschickt, einen Blüthen tragenden Stengel zu treiben. In dieser Zeit entwickelt sie nur Blattrosetten, die von dem Orte der zunächst vorausgehenden durch ein kurzes Internodium getrennt sind. Man erkennt die letzteren selbst an den ältesten Pflanzen daran, dass die Knoten von den Insertionsmarken der Blattbasen geringelt erscheinen.

Die Grundaxe der blühenden Pflanze erreicht die Stärke eines Mannesarmes (sie hat bis $10 \mathrm{~cm}$ Durchmesser); von ihr dringen die innen weissen, aussen gelblich-granen, nicht sehr reichlich verzweigten Wurzeln bis zur Tiefe eines Meters in die Erde; sie ist gewöhnlich kurz verzweigt, und die Zweige sind an der Spitze von den Resten der scheidigen Blattbasen umgeben.

Der Stengel ist straff aufrecht, bis zur Blüthenregion unverzweigt, kahl*), wie die ganze Pflanze und hohl; er wird 60-120 $\mathrm{cm}$ hoch und erreicht am Grunde einen Durchmesser von $1-2 \mathrm{~cm}$.

Die Blätter stehen am Grunde des Stengels dicht gedrängt, nach oben zu werden sie dureh die Dehnung der Internodien lockerer. Die unteren erreichen eine Länge von $20-25 \mathrm{~cm}$ und eine Breite von 12-15 cm, die oberen werden allmälig kleiner; jene sind elliptiseh, spitz, am Grunde in einen kurzen oberseits rinnigen, unten gekielten Blattstiel zusammengezogen. Die langen (bis $6 \mathrm{~cm}$ messenden) Blattscheiden jedes Blattpaares sind verwachsen; die Blattspreite ist oberseits saftig- und dunkel-, unterseits blänlichgrïn; sie wird ausser dem Mittelnerven von zwei Paar bogenläufigen, beiderseits vorspringenden Nerven durchzogen. Die oberen Blätter nähern sich allmälig der eiförmigen Gestalt, sie sind mehr zugespitzt, in ihrer Textur zarter; die Blattseheide verkïrzt sich allmälig, versehwindet endlich ganz und die Blätter werden sitzend.

Die Blüthen $\left.{ }^{-*}\right)$ treten aus den Achseln der oberen Stengelblitter; nach der Spitze des Sprosses zu sind sie kopfig gehïuft, in der Mitte sind die Speeialinflorescenzen weiter von einander entfernt. Aus der Achsel jedes Deckblattes tritt zunäcbst ein ganz kurz gestieltes Dichasium, dessen Seitenstrahlen von je einem häutigen Deckblatte, den Vorblättern der Terminalblithe gestitzt werden; unter diesen Seitenblüthen erscheint noch je eine weitere Blithe als untere Beiknospe. In absteigender Folge werden dann zwischen dem Deckblatte des Dichasiums und diesem selbst noch zwei Reihen von deckblattlosen Blithen eingeschaltet, die sich in die Räume zwischen den vorhandenen Blithen einfügen. Beide Specialblüthenstände aus den Achseln der Elemente eines Blattpaares bilden die "Scheinquirle " der früheren Botaniker. Nach der Spitze zu werden die Specialinflorescenzen durch Verminderung der Beiknospen armblüthiger. Die Blüthenstiele sind kräftig, seitlich zusammengedriickt und erreichen eine Länge von $2-4 \mathrm{~cm}$.

Der Kelch ist 1,3-1,7 cm lang, eiförmig, häutig, bleibend, grün gefärbt; er reisst an der einen Seite bis zum Grunde auf und hat an der Spitze $5-6$ ungleiche, höchstens $5 \mathrm{~mm}$ lange, lineale Zipfel. Die Blumenkrone ist radförmig, einfarbig gelb, oder innen dunkler punktiert, gewöhnlich bis fast auf den Grund in 5 oder 6 lineallanzettliche, spitze, Zipfel gespalten; sie ist 2,2-2,5 cm lang, die Röhre misst gewöhnlich nur 2-3 mm; sie bleibt nach dem Verblühen erhalten. Die Staubgefässe sind kürzer als die Blumenkronenzipfel; der linealische, unten nur sehr wenig verbreiterte Faden ist 11, der lineale am Grunde angeheftete und aufrechte Beutel ist $7 \mathrm{~mm}$ lang. Die Pollenkörner sind ellipsoidisch, glatt und werden von drei meridionalen Furchen durehlaufen. Der Stempel ist von der Länge der Staubblätter; er ist von der Seite zusammengedriickt; der Fruchtknoten verjuingt sich am Grunde und sitzt auf einem fünflappigen, Honig absondernden Polster; er ist einfächrig und trägt die zahlreichen Samenanlagen in mehreren Reihen zu beiden Seiten der Commissur; die letzteren sind anatrop und horizontal aufgehangen. Der Griffel misst $3-4 \mathrm{~mm}$; die nach rückwärts eingerollten Narben sind $2-3 \mathrm{~mm}$ lang.

Die Frucht ist eine in den Commissuren der Fruchtblätter aufspringende, länglich eiförmige, häutige Kapsel, die von sämmtlichen Blüthentheilen in abgetrocknetem Zustande umhüllt wird.

* Baillon hat den Stengel in seiner Abbildung mit abstehenden Haaren versehen gezeichnet; wir haben diese Bekleidung niemals beobachten künnen.

**) Die Stellung der Blüthe zum Tragblatte ist, wie es scheint, nicht constant. 
Die Samen sind elliptiseh, breit geflitgelt, $4 \mathrm{~mm}$ lang, $3 \mathrm{~mm}$ breit; der Keimling ist sehr klein, die Keimblätter spreizen aus einander, das Würzelchen ist nach unten gewendet; er liegt in einem verhältnissmässig reichlichen Nährgewebe.

Der gelbe Enzian wächst in den mittleren Höhen der central- und siid-europäischen Gebirge; von Portugal findet er sich im nördlichen, mittleren und östlichen Spanien, durch Frankreich bis zum Côte d'Or und dem Jura; in den Vogesen ist er häufig, seltener aber im Schwarzwalde und der rauhen Alp; an den übrigen deutschen Standorten (Thüringen, Rheinprovinz, wahrscheinlich auch bei Würzburg) ist die Pflanze ganz oder nahezn ganz ausgerottet; im nördlicheren Europa fehlt sie. Gewisse Theile der Alpen beherbergen ihn in Menge, auch in den Apenninen, auf Corsica und Sardinien wächst er; von Italien aus kann man ihn bis in die Gebirge der Donaugebiete und bis Macedonien verfolgen. In Asien kommt er nur in Bithynien und Lydien vor. Er blüht je nach den mehr oder minder sïdlicher gelegenen Standorten von Juni bis August.

Als Radix Gentianae oder Enzianwurzel werden hauptsächlich das Rhizom und die Wurzel von Gentiana lutea, in getrocknetem Zustande, medicinisch verwendet; doch kommen auch die unterirdischen Theile von Gent. pannonica, Gent. purpurea und Gent. punctata als Enzianwurzel in den Handel.

\section{Erklärung der Abbildungen.}

Fig. $A$, Oberer Theil eines blühenden Stengels nach einem im Berliner Universitätsgarten cultivierten Exemplare.

Fig. $B$. Die Blüthenknospe, natïrliche Grösse: $a$, der Kelch; b. die gedrehte Blumenkione.

Fig. C. Die Blüthe im Längssschnitte, um die Hälfte vergrössert: $c$. das Staubgefäss; $d$. der Fruchtknoten; e. der Griflel; $f$. die Narbe.

Fig. D. Der geschlossene Staubbeutel, von aussen und von innen gesehen, 3 mal vergrössert.

Fig. $E$. Der aufgesprungene Staubbeutel.

Fig. F.G. Pollenkörner trocken und in Wasser, $300 \mathrm{mal}$ vergrössert.
Fig. $H$. Der Stempel, $2 \frac{1}{2}$ mal vergrössert: $h$. das Honig absondernde Polster.

Fig. I. Derselbe im Längsschnitte.

Fig. $K$. Der Fruchtknoten im Querschnitte, 5mal vergrössert: g. die Samenanlagen.

Fig. L. Die Frucht ausgesprungen, natïrliche Grösse: $i$. Kapselklappen.

Fig. Mr. Der Same, natïrliche Grösse.

Fig. $N$. Derselbe, 7 mal vergrössert: $k$, der Flügel; $l$. das Nährgewebe; $m$. der Keimling.

\section{MENYANTHES Linn.}

Blüthen aktinomorph, zwittrig, dimorph. Keleh fïnf-(vier- bis sieben-) theilig mit oblong-lanzettlichen Zipfeln, bleibend. Blumenkrone trichterförmig mit so vielen Lappen als Kelchzipfel, Lappen auf der Imnenseite durch lange, einfache Haare zottig, oder mit einem mittleren Kamme versehen. Staubgefässe so viele als Kelchzipfel, der Blumenkronenröhre angeheftet, kürzer oder länger als jene; Stanbfäden fadenförmig, am Grunde nicht mit einander verbunden; Staubbentel oblong versatil, in Längsritzen auf der Innenseite aufspringend, nach dem Verstäuben nicht spiral gedreht. Fruchtknoten aus 2 Fruchtblättern gebildet, schief zum Deckblatte gestellt, einfächrig, von einem gewimperten, ringförmigen Stempelpolster gestützt. Samenanlagen viele, einer wulsiigen, wandständigen Samenleiste angeheftet, anatrop. Griffel fadenförmig, Narbe zweilappig. Kapsel häutig, fachtheilig zweiklappig anfspringend. Samen zusammengedriiekt, glänzend, glatt; Keimling gerade, mit stielrundem Würzelchen und ovalen flachen Keimblättern in reichlichem, fleischigem Nährgewebe. - Ausdauernde Sumpfkräuter mit kriechender Grundaxe und zweizeiligen, am Grunde scheidig die Grundaxe umfassenden, ganzen oder geteilten Blättern, ohne Nebenblätter. Blïthen in Trauben oder Rispen mit Gipielblithe auf der Spitze von blattlosen Schäften mit Deck- zuweilen anch Vorblättern, weiss oder aussen röthlich, oder bläulich.

2 Arten, von denen die eine in Europa, Asien und Nord-Amerika weit verbreitet ist, die andere im westlichen Nord-Amerika gedeiht. 


\title{
Menyanthes trifoliata Linn.
}

\author{
Tafel 39.
}

Blätter gedreit, Blättchen oblong, lanzettlich, oder oblong-umgekehrteiförmig, sitzend, ganzrandig oder gesehweift; Blithen in einer Traube, die am Grunde zuweilen rispig wird; Blumenkronröhre länger als der Kelch, Zipfel innen zottig.

Menyanthes trifoliata Linn. Spec. pl. ed. I. 145; Fl. Dan. IV. t. 541; All. Fl. Pedem. I. t. 88; Schkuhr, Handb. I. t. 35; Engl. Bot. VII. t. 495; Sturm, Deutschl. Fl. II. t. 8; Trattin. Arch. I. t. 119; Hayne, Arzneigew. III. t. 14; Svensk Bot. I. t. 22; Curt. Fl. Lond. I. t. 14; Bigel. Med. t. 46; Schrank, Fl. Monac. IV. t. 309 ; Nees, Düsseld. Abb. t. 204; Guimp. und Schlecht. t. 93; Woodv. Med. II. t. 97; Koch, Syn. 485 und viele andere deutsche Floren; Nees, Gen. X. t. 10; Dietr. F7. Bor. VI. t. 404; Baxt. Br. Bot. IV. t. 45; Griseb. in DC. Prodr. IX. t. 137; Reichb. Fl. Germ. XVII. t.1043; Berg und Schmidt, Darst. u. Beschr. X ${ }^{d}$; Bentl. and Trim. Med.pl. t. 194; Köhler, Mediz. Pf. t. 89; Ledeb. Fl. Ross. III. 76; Godr. et Gren. F7. Fr. II. 497; Willk. et Lange, Fl. Hisp. II. 651; Parlat. Fl. Ital. VI. 785; Boiss. Fl. or. IV. 64; C. B. Clarke in Hook. fil. Fl. Br. Ind. IV. 130; Franch. et Savat. Fl. Jap. I. 325; Asa Gray, Syn. Fl. I. (1). 125; Flïck. Pharmacogn. ed. III. 678.

Bitterlilee, Bieberklee, Fieberklee, Zottenblume, Dreiblatt; französisch: Trèfle aquatique, trèfle d'eau, trifle de castor; englisch: Bockbean, Marsh rocket, marsh trefoit.

Die knotig gegliederte, horizontal auf dem Boden der Gewässer oder im Seblamme liegende Grundaxe richtet sich an der Spitze auf und trägt hier 1-2 Blüthenstände, so wie oberhalb derselben einen Schopf von 3-4 Blättern; sie ist durch weisse, fadenförmige, spärlich verzweigte Wurzeln, die hauptsïchlich aus dem nach dem Boden gewendeten Theile der Grundaxe einzeln oder paarweise jedem Zwischenknotenstlicke entspringen, in dem Untergrunde befestigt; sie erreicht eine Länge von $30-50 \mathrm{~cm}$ und hat einen Durchmesser von 6-15 mm; ihre Farbe ist dunkelgrỉn, auf der Unterseite etwas heller.

Die gedreiten Blätter stehen zweizeilig und zwar sind sie auf der rechten und linken Seite der Grundaxe befestigt; sie liegen aber nicht ganz genau in einer Ebene, sondern sind, wie besonders aus den in ihren Achseln befindlichen Knospen erkannt wird, auf der Oberseite der Grundaxe einander genähert, das Blattsystem ist, wie man sich ausdrickt, schwach dorsiventral. Mit einer grossen Seheide von schwammiger Consistenz umfassen sie die Grundaxe, wobei sich die Ränder derselben übergreifen; die Umfassung der beiden Hälften gesehieht stets derart, dass die Scheiden symmetrisch gerollt sind, die links stehenden Blätter beschreiben in ihren Scheiden von innen nach aussen eine Spirale im Sinne des Uhrzeigers, die rechts stehenden im entgegengesetzten. Die Scheide erreicht eine Länge von $5-10 \mathrm{~cm}$, sie ist am Rande häutig und geht am oberen Ende, indem die Scheidenränder vor dem Blattstiele sich vereinigen, in ein kappenförmiges Blatthäutchen (ligula) aus; der Blattstiel ist 6-16 cm lang, stielrund und wie die ganze Pflanze kahl; die Blättehen der Spreite sind 3-10 cm lang und in der Mitte 1-3,5 cm breit; sie sind sitzend, lanzettlich oder elliptisch, spitz, am Grnnde keilförmig, schwach geschweift und in den Buchten mit einem Drüsehen versehen; ihre Consistenz ist etwas fleisehig; sie sind saftig grün und werden jederseits des Mittelnerven von 5-6 grösseren, fast parallelläufigen Seitennerven durchzogen.

Der Bluthenstand ist seheinbar seitenständig, in Wahrheit aber beschliesst er die Hauptaxe, so dass die dem Äusseren nach monopodiale Grundaxe in Wirklichkeit ein Sympodium ist. Jeder Spross nämlich, der stark genug ist, um eine Inflorescenz zu erzeugen, bringt zunäehst etwa 7 Blätter hervor, von denen die untersten kleinlaubig sind, erst allmälig entwickeln sich die grösseren Spreiten. In der Achsel jedes Blattes entsteht eine Knospe; die der ersten 5 Blätter blciben aber gewöhnlich sehr klein, die aus dem nächsten Blatte ist schon stärker, sie treibt auch in der Regel aus, während die tubrigen als Reserveknospen meist nicht zur Entwicklung gelangen. Aus der Achsel des letzten Blattes entsteht aber die kräftigste Knospe, welche sich, während das Sprossende zu einem Bliuthenstande umgebildet wird, 
so ausserordentlich mächtig entfaltet, dass sie jenen bei Seite drängt und sich in die gerade Fortsetzung der Grundaxe stellt. Die Anlage des Bliithenstandes für das nächste Jahr vollzieht sich bald nach dem Abblühen der diesjährigen Inflorescenz, so dass im Juli nicht blos sämmtliche Blüthen schon entwickelt sind, sondern auch die Axe für das kommende Jahr schon zum Abschlusse gelangt ist.

Das erste Blatt des neuen Sympodialgliedes (sein Vorblatt) steht gegeníber dem Deckblatte desselben, so dass hier das für die Dicotylen ungewöhnliche Verhältniss eines adossierten Vorblattes vorliegt; auch die übrigen Blätter halten, wenn von der geringen Dorsiventralität abgesehen wird, die Distichie ein. Aus dieser Ursache kann das Sympodium nur entweder eine Fächel oder Sichel sein. Wenn die Zahl der Blätter jedes Fortsetzungssprosses 7 beträgt, so muss stets eine Fächel resultieren, wenn sie aber wechselt, so kommt bei geraden Zahlen der Blätter eine Sichel, bei ungeraden eine Fächel zu Stande. Der Blïthenstand ist eine Traube, die dadurch, dass die unteren Strahlen zuweilen noch eine Seitenblüthe erzengen, eine Neigung zur Rispe hat. Jede Blïthe hat ein Deckblatt, das der untersten ist besonders gross, es steht stets nach vorn und umfasst die Knospe der Inflorescenz fast wie eine Scheide. Die unteren Blïthen haben gewöhnlich zwei Vorblätter, und aus der Achsel des einen bricht nicht selten eine Blutthe hervor; an dieser bemerkt man in der Regel nur ein Vorblatt; da dasselbe auf das Deckblatt der Hauptbliithe zu gestellt ist, so ist der kleine, zweiblüthige Specialblüthenstand eine Wickel.

Die Blüthen sind zwittrig; der Blïthenstand wird immer durch eine Gipfelbluthe abgesehlossen, welche zwar später entstcht, als die untersten Blüthen, aber doch früher als die oberen und demgemäss anch eher aufblüht als diese. Die Zahl, in weleher die Glieder der Bliuthenkreise auftreten, wechselt, am häufigsten sind fünf-zählige Blüthen, nicht selten kommen aber auch vier- und seehsgliedrige vor, ja, selbst nach der 7 Zahl werden besonders die Gipfelblithen aufgebaut gefunden. Der Bläthenschaft ist länger als die Frühjahrsblätter, er erreicht eine Länge von $12-20 \mathrm{em}$; während die unten lockere, oben diehtere Traube zur Blüthezeit $5-8 \mathrm{~cm}$ misst; jener ist stielrund und kahl. Die Deckblätter sind breiteiförmig bis eilanzettlich, spitz und häutig, von glcicher Gestalt sind die kleineren Vorblätter. Die Blïthen werden von einem 5-15 mm langen Stiele getragen. Bei den fünf-gliedrigen Kelohen ist die Stellung der Zipfel schon der Anlage nach sehr verschieden, gewöhnlich stehen zwei quer zum Tragblatte, ein unpaares inneres steht bald vorn, bald hinten, sie decken sich dachziegelig, sind von oblong-lanzettlicher Form und stumpflich; sie sind grün und ebenso wie die Deck- und Vorblätter oft röthlich gerandet. Die Blumenkrone ist trichterförmig und fast bis zur Hälfte in $4-7$ oblonge, stumpfliche, zurïckgekrïmmte, aussen kahle und röthliche, innen zottige und weisse Zipfel gespalten; die Röhre ist auch innen kahl. Die Staubgefässe wechseln mit den Blumenkronenabschnitten, sie sind kahl und der Röhre bis zum Schlunde angeheftet; entweder ïberragen sie die Blumenkrone (forma longistila) oder sie sind vicl kürzer wie diese (forma brevistila); die Staubfäden sind fadenförmig, die Beutel sind zuerst mennigroth, dann violett, sie sind am mittleren Rüicken angeheftet, oblong und stumpf, zuerst sind sie gerade, nach dem Aufspringen, das mit zwei Längsspalten geschieht, krïmmen sie sich nach oben und werden am Grunde pfeilförmig; die Pollenkörner sind goldgelb, schmal ellipsoidisch, mit drei engen Meridionalfalten. Der Fruchtknoten ist eiförmig, er besteht gewöhnlich aus zwei zum Deckblatte sehief gestellten Fruchtblättern; er ist einfächrig mit zwci wandständigen Samenleisten und wird von einem ringförmigen, gewimperten, Honig absondernden Polster umgeben. Die zahlreichen, anatropen Samenanlagen sind horizontal angeheftet und haben ein Integument; der Griffel überragt bei den Blitthen mit kurzen Staubgefässen die Blumenkronenröhre, bei der anderen Form ist er nur so lang wie diese, - er ist aufreeht, fadenförmig und hat eine zweilappige Narbe.

Die Frucht ist eine eiförmige Kapsel, welche in zwei Klappen fachtheilig aufspringt und von dem bleibenden Kelche gestiitzt wird.

Die Samen sind 2-2,5 mm lang und 1,5 mm breit, nur wenige (6-8) gelangen in jeder Kapsel zur Reife; sie sind ellipsoidiseh, ctwas zusanmengedrückt und haben einen seitenständigen Nabel; die Samenschale ist diunn und zerbrechlieh, glïnzend blassgelb; der Keimling ist gerade und liegt in einem fleischigen Nährgewebe; das Würzclehen ist so lang wie die flachen Keimblätter. 


\section{4}

Der Bitterklee ist in der nördlichen Hemisphäre circumpolar weit verbreitet; er geht vom arktischen Russland durch ganz Nord- und Nittel-Europa, Frankreich bis nach Nord-Spanien und Mittel-Italien, Macedonien und Thracien, den Kaukasusländern und Armenien; nach Osten zu tiberschreitet er den Ural und erreicht uber die Amurländer die Inseln Yezo und Nipon; seine Südgrenze findet er in Asien auf dem westlichen Himalaya in Kaschmir. In Amerika bewohnt er ein weites Gebiet von Labrador bis nach Ohio, von den Rocky Mountains bis Californien und nordwärts zu den Alëuten. In den gemässigten Breiten wächst er in Sümpfen der Ebenen und an den Rändern langsam fliessender Gewässer, während er in stidlicheren Breiten die höheren Lagen aufsucht, so steigt er in Armenien bis $2300 \mathrm{~m}$. - Seine Blïthezeit fällt in den Mai und Juni.

Als Folia Menyantlis oder Folia Trifolii fibrini werden die getrockneten Laubblätter der Pflanze verwendet, welehe in ihren Parenchymzellen einen Bitterstoff, das Menyanthin, enthalten.

\section{Erklärung der Abbildungen.}

Fig. A. Ein bltihendes Exemplar der kurzgriffligen Form: $a$. die Grundaxe; $b$. die Blatter; $c$. das untere Ende des Bluithenschaftes.

Fig. B. Der obere Theil des Schaftes.

Fig. C. Dic Blüthe im Längssehnitte, 3 mal vergrössert: $a$. der Kelch; $b$. die Blumenkrone; $c$. die Staubgeftisse; $d$. der Stempel.

Fig. D. Die Blumenkrone der Länge nach aufgeschnitten und ausgebreitet, 2mal vergrössert.

Fig. E. Das obere Ende eines Haares, welche die Innenflïche der Blumenkronenzipfel bekleiden.

Fig.F.G. Die Staubgefässe vor und nach dem Verstäuben von innen und aussen betrachtet, $6 \mathrm{mal}$ vergrössert.
Fig. H. Pollenkörner trocken und in Wasser, 300mal vergrössert.

Fig. I. Der Stempel, $4 \mathrm{mal}$ vergrössert: $a$. das Stempelpolster; $b$. der Fruehtknoten; $c$. der Griffel; $d$. die Narbe.

Fig. $K$. Der Fruchtknoten im Querschnitte, $5 \mathrm{mal}$ vergrössert. Fig. L. Die Kapsel, natïliche Grösse.

Fig. $M$. Eine Fruchtklappe, um die Hälfte vergrössert.

Fig. $N$. Der Same, natürliche Grösse.

Fig. O.P. Der Same von der Seite und vom Rücken betrachtet, 5 mal vergrössert.

Fig. Q. R.S. Derselbe im Längsschnitte, parallel der Seitenund Riickenflïche, und im Querschnitte. 


\section{Familie: 0 leace a e Lindl.}

Die Blïthen sind stets aktinomorph, zwittrig oder oft durch Fehlschlag eingeschlechtlich, im Kelch und Krone häufig vier- zuweilen auch fünf- und mehrgliedrig, selten sind beide durch Fehlschlag geschwunden. Die Blumenkrone ist praesentirteller-, trichter- oder glockenförmig mit dachiger oder klappiger Knospenlage der Zipfel; zuweilen sind diese ganz frei; Staubgefässe sind fast stets zwei vorhanden, sie sitzen in der Blumenkronenröhre oder, wenn diese fehlt, unter dem Fruchtknoten; die gewöhnlich breiten, eiförmigen oder elliptischen Beutel sind meist am Grunde befestigt, sie springen seitlich oder nach aussen auf. Der oberstïndige Fruchtknoten ist zweifächrig; die Fächer wechseln mit den Staubgefässen, in jedem befinden sich meist zwei anatrope Samenanlagen. Die Frucht ist kapsel-, oder beeren- oder steinfruchtartig, sie hat wenige, zuweilen durch Fehlschlag nur einzelne Samen. Der Keimling ist gerade, er ist meist von Naihrgewebe umgeben und hat flache Keimblätter.

Aufrechte oder klimmende Sträucher oder Bäıme mit kreuzgegenständigen oder quirligen, nebenblattlosen, einfachen oder gefiederten Blättern. Die Blithen stehen in kreuzgegenständigen Rispen oder in Cymen, sie sind nicht immer mit Deck- und Vorblättern versehen.

Die 19 Gattungen, welche in der Familie anerkannt werden, umfassen ungefähr 300 Arten; sie sind besonders in den wärmeren Gegenden der Erde verbreitet, den kalten Zonen und den Hochgebirgen fehlen sie ganz.

Die offizinellen Oleaceen gehören in folgende Tribus :

TRIBUS I. Fraximeae Bartl. Die Fligelfrichte springen nicht auf. Samenanlagen gepaart, anatrop, die Rhaphe nach aussen.

1. Fraxinus Ornus Linn.

TRIBUS II. Oleineae Bartl. Die Steinfriichte oder Beeren springen nicht auf. Samenanlagen gepaart, anatrop, die Rhaphe nach innen.

2. Olea europaea Linn. 


\section{FRAXINUS Linn.}

Blïthen vielehig oder zweihänsig. Kelch klein, vierspaltig, oder fehlend. Blumenblätter 2 oder 4, frei oder (?) am Grunde verbunden, in der Knospenlage cingebogen klappig, zuweilen fehlend. Staubgefässe 2, in der Blımenkrone befestigt, oder unter dem Stempel sitzend; die Staubbeutel springen seitlich, doch etwas nach aussen gewendet auf. Der Fruchtknoten ist zweifächrig; er umschliesst in jedem Fache zwei von der Spitze der Scheidewand herabhängende, anatrope Samenanlagen, dcren Rhaphe nach aussen gelegen ist. Der kürzere oder längere Griffel läuft in zwei dicke, blattartige Narben aus. Die Frucht springt nicht auf; sie ist geflugelt und umsehliesst allermeist nur einen Samen; dieser ist zusammengedriickt und enthält in fleischigem Nïhrgewebe einen geraden Keimling mit nach oben gewendeter Wurzel. Bäume mit unpaarig gefiederten, sehr selten einfachen Blättern. Die Blẗthen sind verhältnissmässig klein und bilden reichblithige, kreuzgegenständige Rispen.

Man hat etwa 30 Arten beschrieben, die aber auf eine viel geringere Zahl zu reducieren sind; sie bewohnen die gemässigten und wärmeren Gegenden der nördlichen Hälften beider Hemisphären.

\section{Fraxinus Ornus Linn.}

Tafel 40.

Mässig hoher Baum oder Stranch mit unpaarig gefiederten drei- bis vier-jochigen Blättern; Blättchen eiförmig oder elliptisch, zugespitzt, gesägt, kurz gestielt, kahl, nur am Grunde des Mittelnerven unterseits weichhaarig; Rispen dicht, meist kürzer als die Bliitter; Blumenblaitter 4, frei. Flügelfrucht schmallanzettlich, stumpf, beiderscits verschmälert.

Fraxinus Ormus L. Spec.pl.ed. I. 1057; All. Fl. Pedem. II. t. 95, Icon. Taur. XXII. t. 28; Lam. Enoycl. S55; Woodv. Med. bot. I. 104. t. 36; Duham. Traité des arbr. ed. II. IV. 61. t. 15; Sibth. F7. Gi. I. t. 4; Nees, Diiss. Abb. t. 372; Guimp. u. Schlecht. Pfl. Pharmac. t. 292 u. 293; DC. Prodr. VIII. 274; Godr. et Gr. Fl. Fr. II. 473; Willk. et Lge., Fl. Hisp. III. 563; Bergu. Schmidt, Darst. u. Beschr. t.III ; Bentl. et Trim. MIed. pl. t. 170; Töhler, Mediz.-Pft. t. 115; Boiss. Fl. orient. IV. 39; Parl. Fl. Ital. VIII. 165; Battand. et Trab. Fl. d'Alg. II. 552; Flitck. and Hanb. Pharmacogr. 366; Flieck. Pharmacogn. 24; Reichb. Fl. Germ. XVII. t. 1072; Baill. Bot. méd. 1306. xylogr. 3273-3275.

Fraxinus panniculata Mill. Dict. n. 4 .

Fraxinus florifera Scop. Fl. carn. II. ed. II. 252.

Fraxinus argentea Loss. Fl. Gall. 697.

Fraxinus vulgatior Seg. Veron. II. 290*).

Ornus europaea Pers. Ench. I. 9; Loud. Arbor. II. 1241. t. 166 et 167; Hayne, Arzneigew. XIII. 11; Mert. u. Koch, Deutschl. Fl. I. 357.

Manna-Esche; französisch: Frêne à Manne; englisch: Manna-ash.

Der Baum erreicht gewöhnlich eine Höhe von $5-7$, selten über $10 \mathrm{~m}$; zuweilen verästelt er sich vom Grunde aus und bildet einen höheren Strauch; der Stamm ist gerade, cylindrisch, mit grauer, glatter Rinde bedeckt, die Zweige sind an den Knoten ein wenig verdickt.

Die Blätter sind unpaarig gefiedert, die unteren sind mit dem Endblättchen 5- die obersten zuweilen nur 3-jochig; der Blattstiel ist oberseits ausgekehlt, am Grunde ist er stark angeschwollen. Die Blättchen sind $5-6(3-10) \mathrm{cm}$ lang und in der Mitte $2-2,5(1-3) \mathrm{cm}$ breit; sie sind zuweilen sehr kurz, zuweilen

*) Fraxinus rotundifolia Lam. ist gewiss nicht specifisch von F. Ornus L. zu trennen; Fr, americana Pers. ist gleichfalls wie eine Reihe anderer von Persoon beschriebener Arten mit ihr identisch, indem jene Formen irrthümlich als aus Amerika stammend angegeben werden. 
länger (bis $5 \mathrm{~mm}$ ) gestielt, von oblongem, seltener eioblongem oder kreisrundem Umrisse, das Endblättehen ist zuweilen rautenförmig; sie sind meist kurz zugespitzt, manchmal ist aber die Spitze ansgezogen: der Grund der Seitenblättchen ist spitz und stets, zuweilen sogar sehr auffallend sehief, die kirrzere Blatthälfte ist nach der Spitze des Blattes zu gelegen; der Rand der Blättehen ist mit Ansnahme der Basis gesägt, die Sägezähne werden zuweilen stumpf, so dass er mehr gekerbt erscheint; sie werden jederseits des Mittelnerven von 9-11, unterseits vorspringenden Seitennerven durchzogen und sind im Alter entweder völlig kahl oder tragen nur am Grunde des Blattes beiderseits am Mittelnerven eine flockige Bekleidung aus braunen, einfachen Haaren; die Consistenz ist ziemlich derb, fast lederartig.

Der Blüthenstand erscheint mit oder bald nach dem Ausbruche der Blätter; er ist eine endstïndige, reichbliithige, kreuzgegenständige, mehr oder weniger tiberhängende Rispe, die zuerst immer kürzer als das Blatt, sich später zuweilen so weit streckt, dass sie der Länge desselben gleich kommt; sie wird durch Zweige aus den Achseln der 2-3 obersten Blattpaare bereichert. Deckblätter sind nur an den untersten Seitenstrahlen der Rispenäste entwickelt, und anch dort scheinen sie bisweilen zu fehlen, die Zweigchen höherer Ordnung, wie die Blüthen entbehren der Begleitblätter.

Die Blüthen stehen*) gebiischelt nach der Ausdrucksweise der früheren Botaniker; in Wirklichkeit sind diese Büschel sitzende Dichasien, welche dort paarweise angebracht sind, wo ein Zweig höherer Ordnung die Äste verlässt. Die Inflorescenzstrahlen sind stark zusammengedrïckt. Sie sitzen auf haarfeinen 2-5 mm langen Stielen. Man kann zweierlei Formen unterscheiden: Zwitterblithen und männliche. Die ersten besitzen einen $0,7-0,8 \mathrm{~cm}$ gelbliehgrimen, bleibenden $\mathrm{Kelch}$, der fast bis auf den Grund in 4 dreiseitig-lanzettliche, spitze Zipfel getheilt ist. Blumenblätter sind 4 vorhanden; sie sind vollkommen ${ }^{* *}$ ) frei, aber paarweise dort, wo die Staubblätter sich befinden, genähert. Als Ursache des weiteren Abstandes zwischen den Paaren lässt sich leicht der Fruchtknoten nachweisen, der sich zwischen sie gedrängt hat. Sie sind $6-8$ zuweilen bis $10 \mathrm{~mm}$ lang und in der Mitte $0,5-0,7 \mathrm{~mm}$ breit, schmal lanzettlich und an beiden Seiten zugespitzt; ihre Farbe ist gelblichweiss, sie fallen leicht ab. Die Staubgefässe sitzen unter dem Fruchtknoten und hängen mit den Blumenblättern nieht zusammen; ihre linealen Fäden messen 3, die oblongen Bentel, welche an der Spitze und am Grunde leicht ausgerandet sind, $2 \mathrm{~mm}$ in der Länge; die Pollenkörner sind glatt, ellipsoidisch und werden von drei Meridionalfurehen durchzogen. Der Stempel ist $3 \mathrm{~mm}$ lang, davon kommen auf den Griffel 1-1,5, auf die dicken blattartigen, breit eiförmigen, stumpfen Narben $0,5-0,6 \mathrm{~mm}$. Der Fruchtknoten ist eiförmig, etwas zusammengedrückt, zweifächrig, die Scheidewand verbindet die Breitseiten. Die Samenanlagen sind an dem obersten Theile der Scheidewand angewachsen, die Rhaphe ist nach aussen gekehrt. Die weiblichen Blithen sind durch kleinere Blumenblätter gekennzeichnet. Ihre Stanbgefässe sind mit ganz kurzen (noch nicht 1 mm langen) Fäden versehen. Die dunkelbraunen, getrocknet fast schwarzen Beutel sind ein wenig grösser, als an den vorigen; sie enden in ein kurzes Spitzchen und enthalten zwar einige Pollenkörner, der Inhalt derselben ist aber collabiert; sie werden fleisehig und springen nicht auf. Der Stempel ist nicht versehieden. Durch die kurzen, dunkel gefärbten Staubgefässe fallen diese durch Fehlschlag weiblichen Blithen leicht ins Auge.

Die Frucht ist 2-3 cm lang und meist in der Mitte 4,5-5,5 mm breit, sie ist gestielt und hängend; sie ist schmal lanzettlich, nach dem Grunde hin verschmälert, an der Spitze ist sie abgerundet und of an demselben Fruchtstande stumpf, spitz oder ausgerandet; der endständige Flügel ist pergamentartig und längsnervig, der untere, den Samen umschliessende Theil ist im Querschnitte elliptiseh; die Farbe der Frucht ist braun.

Der Same ist c. $1 \mathrm{~cm}$ lang und 2,5-3 mm breit, schmal oblong, an beiden Seiten stumpf und längt an einem verlängerten, gekrümmten Nabelstrang. Dieser ist an der Scheidewand befestigt, welche sich

*) Da wir nur getrocknetes Material untersuchen konnten, so wurde die Stellung der Bliithe bezliglich der Axe nicht sicher ermittelt; es scheint, als ob eine doppelte Disposition vorkommt, indem einmal die Scheidewand, ein andermal die Fächer des Fruchtknotens auf jene zu gewendet sind.

**) Die in allen Biichern wiederkehrende Angabe, dass die Blumenblätter paarweise am Grunde verwachsen seien, haben wir unbedingt nicht bestätigen können.

Berg u. Sehmidt, Officinello Gewishse. 
von den Wänden des Fruchtknotens beiderseitig oder nur einseitig loslöst und einer Fortsetzung des Nabelstranges ähnlich ist; an ihr befinden sich noch die drei übrigen nicht entwickelten Samenanlagen, deren Nabelstrang sich ein wenig gestreckt hat. Der Keimling ist von der Länge des Samens, die Wurzel ist nach oben gewendet, die Keimblätter sind flach und blattartig, er liegt in einem fleischigen Nährgewebe.

Die Mannaesche wächst an den nördlichen, westlichen und östliehen Gestaden des Mittelmeeres, in Afrika wird sie nur cultiviert. Sie findet sich von Valencia durch Sïd-Frankreich, bis nach Italien. Hier ist besonders Sicilien desswegen wichtig, weil das Land gegenwärtig die grösste Menge der von ihr stammenden Droge aus den Frassineti liefert; diese liegen in der gleichen Höhe wie die Kastanienwälder. In Istrien beriihrt sie die äussersten Grenzen der weiteren deutsehen Flora; von hier ist sie dureh Dalmatien und die Donauländer bis Macedonien, Thessalien (wo sie am Olymp bei $1600 \mathrm{~m}$ tiber dem Meere wohnt) und Griechenland zu verfolgen; endlich wächst sie auch in der Umgegend von Smyrna und in Bithynien, am Taurus und Libanon.

Fraxinus Ornus L. liefert die Manna, welehe wesentlich aus Mannit und Zueker besteht. Sie wird erhalten, indem man die Rinde ungeführ 9-30jähriger Bäume im August und September mit Einschnitten versieht, welehe bis zum Holze dringen; aus den Einsehnitten fliesst ein bräunlieher Saft aus, welcher, am Baume erstarrend, die Manna vorstellt.

\section{Erklärung der Abbildungen.}

Fig. A. Ein blithender Ast von einem in dem Universitätsgarten zu Berlin eultivierten Baume.

Fig. B. Die $Z$ witterblithe, 5 mal vergrössert: $a$. der Kelch; $b$. die Blumenblätter; $c$. die Staubblätter; $d$, der Stempel.

Fig. C. Der Stempel, von der breiten Seite gesehen, 10mal vergrüssert.

Fig. D. Das Staubgefäss, von aussen und innen gesehen, $10 \mathrm{mal}$ vergrössert.

Fig. E.F. Die Pollenkürner, trocken und in Wasser, 200mal vergrössert.

Fig. $G$. Der Stempel von der schmalen Seite gesehen.
Fig. H. Der Fruchtknoten im Lïngsschnitte, $20 \mathrm{mal}$ vergrössert: $a$. die Scheidewand; $b$. der Nabelstrang; $c$, die Samenanlage.

Fig. I. Derselbe im Querschnitte.

Fig. $K$. Der Same, 3mal vergrössert im Fruchtgehäuse; $a$, die Scheidewand; $b$. die unentwickelten Samenanlagen; $c$. der Nabelstrang; $d$. der Same.

Fig. $L$. Die Frucht, natïrliche Grösse.

Fig. M. Dieselbe, im Längsschnitte.

Fig. $N$. Der Same, natürliche Grösse.

Fig.O.P. Q. Derselbe, im Quer-u. Längsschn. 3mal vergrössert: a. Nährgewebe; $b$. Wiirzelchen; $c$. Keimblätter.

\section{OLEA Linn.}

Blitthen zwittrig, zwreihäusig oder vielehig. Kelch kurz, entweder vierzähnig oder vierlappig. Blumenkrone radförmig mit vier eingebogen klappig deckenden Zipfeln, oder fehlend. Staubgefässe zwei, mit kurzen Fäden an der Kronenröhre oder, wenn diese fehlt, unter dem Fruchtknoten befestigt; Staubbeutel eiförmig, nach aussen oder seitlich in Längsspalten aufspringend. Fruehtknoten zweifäehrig; in jedem Fache zwei ron der Spitze der Scheidewand herabhängende Samenanlagen, die anatrop sind und die Rhaphe nach innen gelegen haben. Die Frucht ist steinfruchtartig mit dickem, hartem oder diunnerem krustenförmigem Endocarp; durch Fehlsehlag umsehliesst sie gewöhnlieh nur einen Samen. Keimling gerade in fleisehigem Nährgewebe. - Bäume oder Sträucher, die häufig silbergrau- oder braun beschuppt sind. Blätter kreuzgegenständig, einfach. Blüthen klein in kreuzgegenständigen, seitliehen, selten endständigen Rispen.

Etwa 35 Arten sind beschrieben worden, die im Mittelmeergebiete, im tropischen und subtropischen Asien und Afrika, auf Madagaskar und Neu-Seeland wachsen. 


\title{
Olea europaea Linn.
}

\author{
Tafel 41.
}

Baumartig mit lanzettlichen, spitzen, ganzrandigen Blättern, die oberseits grün, unterseits silberfarben beschuppt sind; Bluthenstände aufrecht, kürzer als das Blatt; Bluthen vielehig, Frucht länglich eiförmig.

Olea europaea Linn. Spec. pl. ed. I. 8; Allione, Fl. Pedem. I. 121; Gaertn. Fr. II. 75. t. 93; Lam. Encycl. IV. 537, Illustr. genr. t. 8. fig. 2; Sm. in Sibth. Fl. Gr. I. 3. t. 3; Lois. in Nouv. Duh. I. 70. t. 25, 27-32; Mert. et Koch, Deutschl. Fl. I. 298; Plenck, Ic. t. 11; Hayne, Arzneipfl. X. 10; Nees, Dïsseld. Abbild. t. 212; Guimp. u. Sehlecht, Gew. Pharmac. III. 57. t. 248; Woodv. Med. pl. t. 98; Steph. and Chalm. Med. bot. I. t. 15; Spach. Bot. VIII. 262, t. 106; DC. Prodr. VIII. 284; Ledeb. Fl. Ross. III. 38; Godr. et Gren. Fl. Fr. II. 47t; Reichb. Fl. Germ. XVII. t. 1074; Willk. et Lge. Fl. Hisp. II. 672; Boiss. Fl. orient. IV. 36 ; Parlat. Fl. Ital. VIII. 155; Berg u. Schmidt, Abbild. u. Beschr. XXXIII ${ }^{b}$; Bentl. and Trim. Med.pl. t. 172; Köhler, Mediz.-PAl. t. 109; Baill. Bot. méd. 1304, xylogr. 3270-3272.

Olea Oleaster et O. sativa Hoffmegg. et Lk. Fl. Port. I. 357.

Ölbaum; französisch : Olivier; englisch: Olive-tree.

In der Regel wird der Baum nur bis $10 \mathrm{~m}$ hoch, indess giebt es auch deren, die an Höhe und Dicke das gewöhnliche Mass bei weitem überragen und ungeheure Dimensionen erreichen; die Rinde ist grau, glatt und wird im Alter rissig; die Äste sind ausgebreitet, stielrund oder vierkantig; die wilde oder richtiger vielerorts verwilderte Form ist stranchartig und die kürzeren Äste lanfen in Dornen aus.

Die Blätter sind kreuzgegenständig, zuweilen stehen sic in dreigliedrigen Quirlen; sie sind immergrïn, lederartig, oberseits sind sie blaugriin und nur hier und da mit silbergrauen Schuppen bestreut, unterseits dagegen sind sic von dicht gedrängten Schuppen silberfarben-schuppig; sic sitzen auf einem kurzen 3-4 mm langen, am Grunde verdickten, oben von einer engen Rinne durehzogenen Stiele; die Spreite ist meist $5-6 \mathrm{~cm}$ lang und $10-12 \mathrm{~mm}$ breit, bei der verwilderten Form ist sie gewöhnlich kleiner, oft aber verhältnissmässig breiter; sie ist lanzettlich und verjitngt sich am Grunde allmälig, ist am oberen Ende spitz und mit einer Stachelspitze versehen; der völlig ganze Rand ist ein wenig zurückgebogen; sie wird jederseits des Mittelnerven von 6-9 nur sehr wenig oberseits vorspringenden Seitennerven durchzogen.

Der Bluthenstand ist eine kreuzgegenständige Rispe, die nur in den unteren Seitenstrahlen und auch hier spärlich dichasisch verzweigt ist, sie hat eine Länge von $3-4$ selten bis $5 \mathrm{~cm}$; die Spindel ist ähnlich den Blätter, aber minder dicht schmpig bekleidet.

Die Blüthen sind entweder zwittrig oder durch Verklimmerung des Stempels männlich; sie sitzen auf einem sehr kurzen, gewöhnlich nur $1 \mathrm{~mm}$ langen Stiele, der gegen die Axe gegliedert ist. Die Deekblätter sind pfriemförmig und an der Spitze mit kmrzen Härchen besetzt. Der K eleh ist 1,5 mm lang, er ist glockenförmig und ganz scieht vier-zähnig, zwei Zähne stehen davon seitlich, zwei median; er ist kahl, nur die Spitze der Zähnchen tragen einige Härchen, von häutiger Consistenz, weiss, oder am Grunde grünlich. Die Blumenkrone ist kurz glocken- oder fast radförmig, sie misst $4 \mathrm{~mm}$ in der Länge nnd ist bis über die Hälfte in vier eiförmige, spitze, klappig deckende Zipfel getheilt, die von drei Nerven längs durchzogen werden; die Farbe ist weiss. Die Staubgefässe sind in der Mitte der Röhre angeheftet; ihr linealiseher, kräftiger Faden ist sehr kurz; die $2 \mathrm{~mm}$ langen Beutel sind breit elliptisch, oben kurz gespitzt, unten herzförmig; sie springen nach innen zu auf; die Pollenkörner sind sehr fein gekörnt, ellipsoidiseh oder fast kugelig und mit drei meridionalen Falten verschen. Der Stempel ist nur wenig länger als die Kronenröhre $(2 \mathrm{~mm})$. Der oberständige Fruchtknoten ist zweifächrig, wobei sich die Fächer mit den Staubblättern krenzen; von dem obersten Theile der Scheidewand bängen zwei nebenständige anatrope Samenanlagen herab, deren Rhaphe nach der Scheidewand zn gewendet ist. Der Griffel ist kurz 
und endet in zwei am Rande verdickte, eiförmige, blattartige Narben. In den männlichen Bliithen, die seltener zu sein scheinen, fehlt der Stempel und an seiner Stelle ist nur ein kleines grïnes Höckerchen, sonst stimmen sie mit den weiblichen tiberein.

Die Frucht (Olive) ist eine bald ellipsoidische, bald kugelige Steinfrucht von $2-3 \mathrm{~cm}$ Länge und $2 \mathrm{~cm}$ Breitendurchmesser; die wilde Olive ist kleiner, sie ist bei der Reife dunkelgrün oder sehwarz purpurn; ihr Exocarp ist dünnhäutig, das Mesocarp ist fleischig und mit fettem Öle angefüllt; in der verwilderten Form ist es sehr bitter. Der sehr harte Steinkern ist $1,4-2 \mathrm{em}$ lang und $0,6-0,8 \mathrm{~cm}$ breit; er ist netzig sculpturirt.

Der Same ist etwa um $1 / 4$ kleiner als der Steinkern und enthält in einem ölig fleischigen Nährgewebe einen Keimling mit oblongen Keimblättern; das kurze Würzelehen ist nach oben gewendet.

Der Ölbaum ist urspringlich in Kleinasien, Nord-Persien, in der arabischen Landschaft Maskât und in der subalpinen Region der nubischen Berge am arabisehen Meerbusen heimisch, wird aber jetzt im ganzen Mittelmeergebiete, in der Krim und in Transkaukasien eultiviert und ist an vielen Stellen in solcher Masse verwildert, dass er undurehdringliche Dickichte bildet; an dem Nordufer des Garda-See's und in Istrien bei Görz berührt er noeh die Grenzen der weiteren deutschen Flora.

Im Parenchym des Fruchtfleisehes von Olea europaea liegt ein fettes öl, welches durch Zerquetschen der Fritchte und darauf folgendes Pressen derselben gewonnen wird und als Olivenöl oder Provenceröl (Oleum Olivarum) in den Handel kommt.

\section{Erklärung der Abbildungen.}

Fig. A. Ein blühender Zweig nach einem in der Provence cultivierten Exemplare.

Fig. B. Eine Schuppe, 50mal vergrössert.

Fig. C. Die Blüthenknospe, 5mal vergrössert: $a$. der Kelch; b. die Blumenkrone.

Fig. D. Die Blüthe, 4 mal vergrüssert: $c$, das Staubblatt.

Fig. $\mathcal{E}$. Die Krone, längs aufgeschnitten und ausgebreitet.

Fig. $F$. Das Staubblatt von vorn und von hinten gesehen, 6 mal vergrössert.

Fig. G. Der Staubbeutel.

Fig. $H$. Pollenkörner in Wasser, $200 \mathrm{mal}$ vergrössert.

Fig. $I$. Der Kelch mit dem Stempel, 6 mal vergrössert d. der Fruchtknoten; $e$. der Griffel; $f$. die Narbe.
Fig. $K$. Dasselbe im Längsschnitte: $g$. die Samenanlagen. Fig. L. Der Fruchtknoten im Querschnitte.

Fig. M. Die Frueht, natïrliche Grösse.

Fig. N. Dieselbe, der vordere Theil des Fruchtfleisches abgetragen: $h$, der Same.

Fig. $O$. Der Steinkern, natïrliche Grösse: $i$, die Naht.

Fig. $P$. Derselbe, der vordere Theil der Steinschale entfernt: $k$. die Scheidewand; $l$. der Same.

Fig. Q. Der Same.

Fig. $R$. S. Derselbe im doppelten Längsschnitte: $m$. das Nährgewebe; $n$. das Würzelchen; $o$. die Keimblätter.

Fig. T. Derselbe im Querschnitte. 


\section{Reihe: Ebenales Bth, et Hook,}

Bliuthen stets aktinomorph, in Kelch und Krone gleich, meist funf-zuweilen drei- oder sechs- und mehrgliedrig; Staubgefässe gewöhnlich 2-3 mal so viel als Blumenkronenabschnitte, zuweilen in noch höheren Zahlen, selten nur im einfachen Kreise. Fruchtknoten zwei- bis vielfächrig mit binnenwinkelständigen Samenleisten. Holzpflanzen.

\section{Familie: Styracaceae A. DC.}

Die Blüthen sind aktinomorph, zwittrig, den Fruchtknoten ausgeschlossen, vier- oder fünfgliedrig. Der Kelch ist verwachsenblättrig, entweder offen oder wenn seine Abschnitte grösser sind mit dachziegliger Deckung derselben. Die Blumenblätter sind zuweilen ganz frei, gewöhnlich aber bis etwa zur Hälfte verwachsen; die Knospenlage ist dachzieglig oder klappig. Die Staubgefässe sind in der Doppelzahl der Blumenkronenabschnitte vorhanden, sie sind am Grunde, seltener höher hinauf verwachsen und der Kronenröhre angeheftet; die Staubbeutel springen nach innen zu entweder mit einem Längsspalte oder durch einen Querriss, und dann klappig auf. Der Fruchtknoten ist halb unterständig oder oberständig; er besteht aus 3-5 Fruchtblättern und enthält ebenso viele Fächer, die oben häufig in eins zusammenfliessen. Die Samenanlagen sind einzeln oder zu mehreren bis vielen an dem Innenwinkel der Fächer angeheftet, sie sind anatrop, hängend oder aufrecht. Die Frucht ist eine Beere oder Steinfrucht, die durch Fehlschlag ein- bis wenigsamig ist. Der gewöhnlich gerade Keimling liegt im Nährgewebe.

Bäume und Strätcher, die nicht selten mit Haaren oder Schuppen bekleidet sind, mit spiral gestellten, nebenblattlosen Blättern. Die Blithen bilden gewöhnlich kurze Trauben oder Rispen, die zuweilen cymös auslaufen; die Deckblätter sind klein und leicht aḅfällig. Vorblättchen sind nicht vorhanden.

In den 6 Gattungen sind etwa 70 Arten beschrieben worden, die in den tropischen Gegenden der alten und neuen Welt verbreitet sind; einige wenige gehen auch in die gemässigte Zone, in Afrika und Australien sind sie bisher nicht gefunden worden. 


\title{
STYRAX Linn.
}

Kelch glockenförmig, gestutzt oder kurz gezähnt. Blumenblätter frei oder nur am Grunde kurz, seltener bis zur Mitte locker verbunden, dachziegelig oder klappig deckend. Staubblätter 10, einreihig, am Grunde der Blumenkrone angeheftet mit freien oder unter sich verwachsenen Fäden. Fruchtknoten fast stets ganz oberständig, dreifächrig, im oberen Theile namentlich später nur einfächrig; Griffel mit drei-lappiger- oder zähniger, znweilen gestutzter Narbe. Samenanlagen nur wenige in jedem Fache, von dem Grunde der Scheidewand anfstrebend. Frucht steinfruchtartig, später zuweilen in drei Klappen spaltend. Samen durch Fehlschlag einzeln oder höchstens zwei mit breitem Nabel. — Bäume oder Strüucher, die in allen ihren Theilen beschuppt oder filzig behaart sind mit ganzen, meist ganzrandigen, spiralig gestellten Blättern; die weissen Blithen stehen in mässig grossen Rispen, die zuweilen hängen.

Von den 60 Arten gehören der grösste Theil dem tropischen Asien und Amerika an, einige wenige bewohnen das gemässigte Asien und Süd-Europa.

\section{Styrax Benzoin Dryander.}

\author{
Tafel 42
}

Baumförmig mit gestielten, elliptischen, zngespitzten, oberseits kahlen, unterseits von kurzen Sternhaaren dicht weissfilzigen Blättern, die unregelmässig und klein gezähnt sind; Rispen seiten- und endständig, mit sternfilziger Spindel; Blumenkrone anssen seidig behaart.

Styrax Benzoin Dryand. in Phit. Trans. LXXVII. 305. t. 12; Woodv. Med. bot. 200. t. 72. (ed. II. t. 102); Steph. and Church. Mcd. bot. III. t. 112; Plenck, Icon. t. 342; Blume, Bijdr. 671; Nees, Diusseld. Abb. t. 210; DC. Prodr. VIII. 260; Hiq. Fl. Ind.-Bat. I. (2). 462; Berg u. Schmidt, Darst. u. Beschr. t. IX.f; Bentl. et Trim. Med. pl. t. 169; Köhler, Mediz.-Pf. t. 113; Baill. Bot. med. 1324; Flück. and Hanb. Pharmacogr. 361; Flick. Pharmacogn. III. ed. 120; Tschirch, Ind. Heit-und Nutzpflanzen 133. t.84.

Benzoin officinale Hayne, Arzneigew. XI. $t .24$.

Benzoeharzbaum; französisch: Arbre de Benjoin; englisch: Benjamintree.

Ein Baum von mässiger Höhe erreicht er in seinem Stamme die Stärke eines Mannes; seine Rinde ist graubraun und das Holz braunroth, wenigstens im trocknen Zustande; die jüngsten Äste sind wie die Axen des Blüthenstandes von einem Filze ans Büschelhaaren weisslich oder bräunlich gelb und ein wenig rauh.

Die spiralig gestellten Blätter stehen anf etwa $1 \mathrm{~cm}$ langen von der Seite zusammengedrückten, oben rinnigen, gelblich filzigen Stielen; die Spreite ist $10-12(5-15) \mathrm{cm}$ lang, und ungefähr in der Mitte $4-5(3-6,5) \mathrm{cm}$ breit; sie ist oblong oder eioblong, seltner an das Lanzettliche herangehend, mehr oder weniger kurz zugespitzt und in eine Stachelspitze auslaufend; der Blattgrund ist gewöhnlich gerundet und meist deutlich asymmetrisch; sie ist krautig oder etwas derber, fast lederartig, in der oberen Hälfte unregelmässig gezähnt; oberseits ist sie in erwachsenem Zustande kahl, nur in der Jugend trägt sie einen leicht abfalligen Filz, unterseits ist sie mit einem bleibenden, kurzen, angedrickten Filze von Sternhaaren bekleidet; er verleiht ihr eine weisse oder rostgelbliche Färbung, aus der sich die 7-9 Seitennerven, so wie die parallel gehenden transversalen Verbindungsnervchen durch eine dunklere Färbung scharf abheben; in trocknem Zustande ist die Oberseite der Spreite stets bräunlich.

Der Bluthenstand ist eine endständige kurze Rispe, die durch Seitenstrahlen aus den oberen Laubblättern bereichert wird oder er ist rein seitenständig; die letzteren sind bäufig mit einer unteren, ebenfalls zu einer Rispe oder auch nur zu einer Traube auswachsenden Beiknospe versehen. Die Blüthen 
werden von kurzen, eifö̀migen, sehr frïh abfallenden, weissfilzigen Deckblättern gestiitzt und stehen auf 2-3, höchstens $4 \mathrm{~mm}$ langen, kantigen, ebenfalls weissfilzigen Stielen. Der Keleh ist 2,5-3 mm lang, becherförmig und schwach fünfzähnig, er ist anssen von Sternhaaren weiss, innen kahl. Die Blumen$\mathrm{krone}$ ist weiss, sie hat eine Länge von 1,2 cm; sie ist trichterförmig und bis zum unteren Achtel in fïnf lanzettliche, spitze, anssen filzige, innen am Rande und an der Spitze ebenso, aber diinner behaarte, klappig deekende Zipfel getheilt. Die zehn Staubgefässe sind 9-10 mm lang; sie sind am Grunde bis zu einer Höhe von $4 \mathrm{~mm}$ röhrig verbunden und dort der Blumenkronenröhre auf deren ganzer Länge angewachsen; die Röhre ist kahl, die etwa 1,5-2 mm langen, freien Staubfäden sind aber mit kurzen, krausen Haaren bekleidet; der breitlineale Staubbeutel misst $4 \mathrm{~mm}$; die beiden Theken sind nach innen gewendet*). Die Pollenkörner sind ellipsoidiseh und werden von drei Meridionalfalten durehzogen. Der weissfilzige Fruchtknoten ist 1,5 mm, der fadenförmige Griffel mit der gestutzten Narbe $10 \mathrm{~mm}$ lang. Der erstere ist in der untern Hälfte dreifächrig, an der Spitze aber einfächrig; die seehs anatropen Samenanlagen jeden, Faches sitzen an den binnenwinkelständigen Samenleisten und bilden eine Doppelreihe.

Die Frucht in eine Steinfrucht von 1-1,5 cm Höhe und 2-2,5 cm Durchmesser; sie ist nicht sehr dentlich dreilappig, an der Spitze seicht genabelt, am Grunde wird sie von dem etwas vergrösserten und gesprengten Kelche gestlitzt. Die Steinschale ist gelbbraun, nicht so deutlich sechsstreifig, wie bei anderen Arten der Gattung.

Der Same ist in der Mitte der Steinschale seitlich aufgehangen und hat ellipsoidische Gestalt; er hat eine braune schuppige Testa und umschliesst in hornig-fleischigem Nïrgewebe den quer gestellten geraden Keimling, dessen kreisherzförmige Keimblattspreiten nach Spitze und Basis der Frucht gerichtet sind.

Dor Benzoëharzbaum wächst in vielen Gegenden der Insel Sumatra und ist auch auf Java heimisch; er wird gegenwärtig an manchen Orten im Grossen cultiviert.

Styrax Benzoin liefert die sumatranische Benzoë. Die beste Sorte der Droge gewinnt man durch Einschneiden der Rinde junger Bäume, schlechtere Sorten werden aus den lysigenen Harzbehältern der gefällten Bäume herausgenommen. Das Sekret besteht aus amorphen Harzen und etwa 20\% Benzoësäure und Vanillin.

\section{Erklärung der Abbildungen.}

Fig. A. Ein Zweig der blühenden Pflanze nach cinem von Blume auf Java gesammelten Zweige.

Fig. $B$, Die Blüthe im Längsschnitte, 4mal vergrössert: $a$. Kelch; $b$. Blumenkrone; $c$. Staubblätter; $d$. Stempel,

Fig. C. Der Kelch, 3mal vergrössert.

Fig. D. Die Blumenkrone, 3mal vergrössert.

Fig. E. Das Staubblatt von vorn und von hinten gesehen, 6mal vergrössert.

Fig. F. Pollenkürner, 200mal vergrössert.
Fig. $G$. Der Fruchtknoten, 10mal vergrössert.

Fig. H. Derselbe, im Längsschnitte.

Fig. I. Derselbe, Querschnitt durch den unteren Theil.

Fig. $K$. Die Frucht, natïrliche Grösse.

Fig. $L$. Dieselbe, der obere Theil des Exocarp's ist entfernt.

Fig. $M . N$. Der Same im Längsschnitte, parallel und senkrecht auf die Keimblätter.

*) Getrocknet sind sie so aneinander gepresst, dass Hayne in den Irrthum verfiel, die Staubbeutel wären monotheisch und auf Grund dieses Charakters eine besondere Gattung Benzoin anfstellte. 


\section{Familie: Sapotaceae Dumort.}

Die Bluthen sind aktinomorph und meist zwittrig, selten werden sie durch Fehlsehlag polygam; sie sind den Fruchtknoten zuweilen ausgeschlossen, fünf- (vier-sechs-) gliedrig. Der Kelch ist entweder verwachsen oder freiblättrig; im letzteren Falle stehen die Blätter deutlich in zwei Kreisen, die äussersten sind dann oft grösser, als die innern, sämmtliche decken dachziegelig, oder die äusseren schliessen die inneren klappig. ein. Die Blumenkrone ist glocken- oder krugförmig, seltener verlängert, mit dachziegelig deckenden Zipfeln, deren Zahl entweder derjenigen der Kelchblätter gleicht, oder sie um das 2-4 fache ïbertrifft. Staubgefässe sind entweder so viel als Blumenkronenabschnitte vorhanden, die dann nicht selten den letzteren gegenüberstehen, oder doppelt so viel; sie sind in ein oder zwei Reihen befestigt, nicht selten finden sich lineale oder blumenblattartige Staminodien; die zweifächrigen Staubbeutel sind ei- oder pfeilförmig, am Grunde angeheftet oder höher oben und dann sind sie versatil; sie springen mit zwei parallelen Längsspalten auf, die entweder nach innen oder nach aussen gerichtet sind; das Mittelband ist häufig über den Beutel hinaus verlängert. Ein Honig absonderndes Polster ist nur selten deutlich entwickelt. Der Fruchtknoten ist oberständig, zwei-fünf- seltener vielfächrig; jedes Fach enthält eine, an der Spitze oder am Grunde befestigte, anatrope Samenanlage; der einfache Griffel geht in eine punktförmige, manchmal ein wenig gelappte Narbe aus. Die Frucht ist beerenartig mit meist dickem Fleische, die zuweilen durch Fehlschlag einsamig wird. Die Samen sitzen mit einem umfangreichen Nabel an, der sich von der glatten, glänzenden Testa durch seine rauhe Oberfläche deutlich abhebt; er umschliesst einen grossen Keimling in einem mehr oder weniger umfangreichen Nährgewebe, das letztere fehlt manchmal gänzlich.

Bäume oder Sträucher, die entweder kahl oder mit einem dichten Filze bekleidet sind. Die Blätter sind spiralig gestellt, gewöhnlich sind sie lederartig und ganzrandig, die Nebenblätter fehlen oder sind doch sehr hinfällig. Die Blüthen stehen häufig gebüschelt, sie kommen aus den Blattachseln oder dem alten Holze und sind gewöhnlich von Deck- und zuweilen auch von Vorblättern begleitet.

Die Zahl der Gattungen ist in der neueren Zeit wesentlich vermehrt worden, so dass sie von 24, die um 1876 untersehieden worden, fast auf das doppelte gestiegen ist; die Umgrenzungen sind aber nicht immer einheitlich fest gestellt und allgemein anerkannt. Die etwa 300-350 Arten wachsen in den Tropen beider Hemisphären, einige sind als Nutzpflanzen in der gesammten heissen Zone verbreitet worden. 


\title{
PAIAQUIUIM Blanco.
}

Bliithen gewöhnlich sechsgliedrig. Kelch einblättrig, tief sechstheilig, die Zipfel ziemlich gleichartig, zweireihig, die äusseren umschliessen mit fast klappiger Knospenlage die inneren. Blumenkrone glockenförmig, sechstheilig, mit dachziegeliger Knospenlage. Staubgefässe 12, (selten 18 oder weniger als 12), nahe dem Grunde der Blumenkrone ein- oder zweireihig angeheftet, mit gleich- oder abwechselnd ungleichlangen Fäden und eilanzettlichen, fast nach aussen zu aufspringenden Benteln, deren Mittelband zuweilen ansgerandet oder zweispaltig vorgezogen ist. Fruchtknoten dicht behaart sechsfächrig, in jedem Fache eine hängende Samenanlage. Frucht eine fleischige dureh Fehlschlag einsamige Beere. Same mit glänzender Schale und sehr breiter, matter Ansatzfläche; Keimling mit dicken Keimblättern und kurzem Stämmehen, ohne Nährgewebe. - Hohe Bäume mit sehr reichlichem Milchsafte und spiralig angeordneten, an den Spitzen der Zweige büschelig gehäuften, gestielten Blättern. Blüthen in mehrblüthigen Büscheln aus den Achseln der Blätter oder hänfig ans dem alten Holze.

Über 50 Arten, die bis auf eine Art in Vorderindien, nur von Ceylon bis nach dem malayischen Arehipel und den Philippinen verbreitet sind.

\section{Palaquium Gutta Burck.}

\author{
Tafel 43 .
}

Ein hoher Baum mit ziemlich lang gestielten, oblong-spathelförmigen, oder schmal umgekehrt eiförmigen, kurz zugespitzten, am Grunde in den Stiel verschmälerten, unterseits goldig filzigen oder seidenglänzenden Blättern. Blithen in armblithigen Büscheln, kurz gestielt.

Palaquium Gutta Burck in Annales du jardin de Buitenzorg V. 24. t. 4; Engler, in Engl. u. Prantl, Natïrl. Pflanzenfam. IV. (1.) 135. Fig. 71.

Isonandra Gutta Hook. fil. in Lond. Journ. of botany VI. 463. t. 16; Miquel, Fl. Indico-Batava II. 1038 t. 36 . a; de Vriese, Tuinbouw-Flora III. 226; Bentl. and Trim. Medic. plants t. 167.

Dichopsis Gutta Benth, et Hook. Gen. plant. II. 655; C. B. Clarke in Hook. Fl. Brit. Ind. III. 543. Gutta-Percha Baum; engliseh: Gutta Percha tree; französisch: Arbre de Gutta Percha.

Der Baum wird bis $13 \mathrm{~m}$ hoeh, er strotzt in allen Theilen von einem weissen, bald erhärtendem Milchsafte; die jüngeren Triebe sind mit einem rostfarbenen, seidenglänzenden Filze dicht bedeekt.

Die Blätter sind spiralig angeordnet, sie stehen auf einem 1,5-2,5 $\mathrm{cm}$ langen, zierlichen, oberseits gefurchten Stiele; die Spreite ist 8-10 (4-12) $\mathrm{cm}$ lang und im oberen Drittel oder Viertel 3,5-4,5 $\mathrm{cm}$ breit; sie ist fast lederartig, ganzrandig, am Ende in eine kurze und stumpfe Spitze plötzlich verjingt; oberseits ist sie dunkelgriun, unterseits mit einem rostgelben, seidig und goldig glänzenden Filze bekleidet; die Seitennerven sind sehr zahlreich $(20-30)$, im frischen Zustande aber in der Blattsubstanz fast verborgen und wenig sichtbar.

Die Blüthen stehen in armblïthigen Büscheln, die wahrseheinlieh cymösen Ursprungs sind; sie treten aus den Achseln der Blätter. Da sie sich sehr lange Zeit immer von neuem entfalten, so fallen die Blätter früher $a b$, als die Blüthenstände in der Entwicklung erlahmen; die Blïthen erseheinen dann "aus dem alten Holze", die Pflanze ist in einem beschränkten Maasse cauliflor. Sie sind ausgeprägt proterogyn d. h. der Griffel überragt die Blithe schon im Knospenzustande. Die Blithenstielchen sind $2-3 \mathrm{~mm}$ lang und wie die jungen Schosse behaart.

Der Kelch ist $4-5 \mathrm{~mm}$ lang und ziemlich tief in 6 eiförmige, stumpfe Lappen getheilt, die aussen rostgelb behaart und goldglïnzend sind; die in der :iusseren Reihe stehenden 3 sind lederartig, die inneren 
dünner. Die Blumenkrone ist rad-glockenförmig, weiss, sie hat eine Länge von $7-8 \mathrm{~mm}$ und ist in 6 häutige, stumpfe Zipfel getheilt. Die 12 Staubgefässe stehen in 2 Reihen; die Staubfäden sind in der Röhre der Blumenkrone angeheftet, sie sind fadenförmig und kahl, von der Länge der Blumenkrone; die Staubbeutel sind 1-1,5 mm lang, eilanzettlich, spitz, das Mittelband ist nur wenig vorgezogen; Staminodien fehlen. Der Stempel ist 10-11 mm lang, er ist am Grunde des Kelches eingefügt; der Fruchtknoten ist fast kugelig und dicht behaart; er ist sechsfächerig und enthält in jedem Fache eine gewendete hängende, in der Mitte dem Innenwinkel des Faches angeheftete Samenanlage; der Griffel ist fadenförmig, leicht gebogen und kahl; die Narbe ist stumpf.

Die eiförmige, kurz zugespitzte und oben gerundete kahle Beere misst $3,5 \mathrm{~cm}$ in der Länge und hat einen Durchmesser von $2,5-3 \mathrm{~cm}$; sie ist fast stets einsamig und wird von dem bleibenden, rostfarben filzigen Kelche gestitzt.

Der Same ist elliptisch, oder sofern mehrere $(2-3)$ in einer Frucht sind anf einer oder zwei Seiten abgeflacht; die Samenschale ist hart, brüchig, glänzend gelbbraun, der matte Nabel aber nimmt mehr als die Hälfte der Oberfläche in Anspruch.

Der Gutta-Percha Banm ist bisher nirgends als in der Umgebung von Singapore gefunden worden und auch dort scheint er völlig oder fast ganz ausgerottet worden zu sein; in der neueren Zeit hat man angeblich in einer verlassenen Zimngrube 3 Bäume gefunden. Er wird aber in dem botanischen Garten von Buitenzorg cultiviert und ist von dort dureh Samen nach andern Gärten verbreitet worden.

Der Milchsaft der Pflanze, welcher durch Einschneiden der Rinde zum Ausfliessen gebracht und dann gesammelt wird, ist rohe Gutta-Percha; diese wird durch Kneten und heisses Wasser von fremden Beimengungen befreit und kommt dann als ngereinigte Gutta-Percha in den Handel.

\section{Erklärung der Abbildungen.}

Fig. A. Ein Zweig des Baumes nach einem Exemplare aus dem Garten von Buitenzorg.

Fig. $B$. Die Blüthe, 5 mal vergrössert.

Fig. C. Die Knospe, 5mal vergrössert.

Fig. D. Das Staubgefäss, $10 \mathrm{mal}$ vergrössert.

Fig. E. Der Fruchtknoten, 6mal vergrössert.
Fig. F.G. Derselbe im Quer- und Längsschnitte, 10mal vergrössert.

Fig. $H$. Die Frucht, natürliche Grösse.

Fig. I. $K$. Der Same, natürliche Grösse mit dem sehr breiten Nabel. 


\section{VIII, Reihe: Ericales Lindl.}

Blüthen meist aktinomorph, zuweilen aber deutlich zygomorph, funf- oder viergliedrig. Stanbgefüsse gewöhnlich doppelt so viele als Kelch- oder Blumenblätter; die letzteren zuweilen frei. Fruchtknoten ober- seltener unterständig mit zwei bis vielen Fächern, bei Gleichzahl mit den Blumenblättern vor diesen stehend.

\section{Familie: Ericaceae DC.}

Die Blüthen sind entweder aktinomorph oder zygomorph mit schiefer Symmetrale; sie sind vier- oder fünfgliedrig. Die Blumenkrone ist meist verwachsenblättrig, doch sind die Blätter znweilen frei, in der Knospenlage sind die Zipfel dachziegelig oder selten klappig. Die Staubgefässe sind meist unter dem Stempel oder am Rande einer zwischen die Kelchzipfel sich ziehenden Scheibe befestigt, zuweilen sind sie auch dem Grunde der Blumenkrone eingefügt; meist sind sie an Zahl doppelt so gross als die Abschnitte der Blumenkrone; die Staubbeutel sind dithecisch, meist am Rücken befestigt, sie springen mit Löchern auf und besitzen fast stets hörnchenartige Anhängsel; die Pollenkörner sind zu Tetraden verbunden. Die Honig absondernde Scheibe ist meist ringförmig und gekerbt, zuweilen fehlt sie. Der Fruchtknoten ist ober- seltener unterständig und zwei- bis vielfächerig, an der Spitze werden die Fruchtblätter zuweilen frei; in jedem Fache befinden sich einzelne oder zahlreiche hängende, am Innenwinkel befestigte, gewendete Samenanlagen. Der Griffel hat eine kopfige Narbe. Die Frucht ist meist eine fach- oder wandspaltige Kapsel, die Klappen lösen sich gern von einer Mittelsäule, seltener zerfällt sie in Kokken, ebenso finden sich nicht häufig Beeren oder Steinfrüchte. Die Samen sind oft sehr klein und mit einer lockeren, flügelartig über den Kern vergrösserten Samenschale versehen, selten sind sie grösser und kantig; das Nährgewebe ist fleischig, der Keimling meist sehr klein.

Bäume oder häufiger Sträucher und Halbsträucher mit meist spiralig gestellten, zuweilen aber kreuzgegenständigen oder wirteligen, oft immergrünen, ganzen Blättern ohne Nebenblätter. Die Blitthen stehen meist in armblithigen Trauben.

Die c. 90 Gattungen umfassen ungefihr 1400 Arten, die in allen Klimaten angetroffen werden. 


\section{ARCTOSTAPHYLOS Adans.}

Blïthen fünfgliedrig. Kelch tief fïnftheilig, bleibend. Blumenkrone kugelig, krugförmig, oder glockig, fünflappig, mit dachziegeliger Knospenlage der Zipfel. Staubgefässe zehn, unter dem Fruchtknoten eingefügt, eingeschlossen; Beutel unterhalb der Spitze auf dem Rücken angeheftet mit zwei endständigen Poren aufspringend und mit zwei abwärts gekrtimmten Hörnchen versehen. Das Honig absondernde Polster ist schwach zehnlappig oder ganzrandig. Fruchtknoten sitzend, fünffächrig; in jedem Fache eine hängende, gewendete Samenanlage; Griffel einfach mit kopfförmiger, undentlich zweilappiger Narbe. Frucht steinfrnchtartig, mit fünf oder durch Fehlschlag ein bis vier hartschaligen Steinen oder einem einzigen gefächerten Steine. Samen hängend, mit Nährgewebe und einem mittelständigen Keimlinge. Bäume oder Sträucher, zuweilen klein und an die Erde gedrickt mit spiralig gestellten, lederartigen, ganzrandigen oder gezähnten, meist immergriinen Blättern. Blithen für die Familie klein, in tranbigen oder rispigen Inflorescenzen, nickend.

Von den 21 beschriebenen Arten wachsen 2 in der gemässigten und kalten Zone der ganzen nördlichen Erdhälfte, die ibrigen in Californien und Mcxiko.

\section{Arctostaphylos Uva ursi Spr.}

\section{Tafel 44.}

Ein niedriger, viel verzweigter, sparriger am Boden liegender Strauch; Blätter spathelförmig, oder schmal umgekehrt eiförmig, an der Spitze gerundet oder gestutzt, am Grunde in den verhältnissmässig langen Blattstiel verschmälert, am Rande fein behaart; Blithen in armblithigen, endständigen Trauben; Beeren roth.

Arctostaphylos Uva ursi Spreng. Syst. veget. II. 257; Dietr. Fl. boruss. V. t. 349. DC. Prodr. VII. 5S4; Baxt. Brit. Bot. VI. t. 502; Led. Fl. Ross. II. 909; Godr. et Gren. Fl. de Fr. II. 426; Willl.

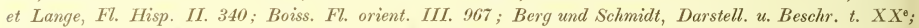
Bentl. and Trim. Hed. pl. t. 163; Köhler, Mediz. Pfl. t. 137; Asa Gray, Synopt. Fl. I. 28; Flück. Pharmacogn. 655; Arth. Meyer, Drogenkunde II. 219.

Arbutus Uva ursi Linn. Spec. pl. ed. I. 395; Fl. Danica I. t. 33; Lightf. Fl. Scot. I. 216. t. 14; Allione, Flor. Pedem. I. 135; Plenck, Offic. t. 340; Dreves, Bildb. II. 119. t. 64; Svensk Bot. II. t. 65; Schkuhr, Handb. I. 365. t. 115; Schrank, Fl. Monac. I. t. 34; Guimpel, Holzgew. I, 74. t. 57; Hayne, Arzneigew. IV. t. 20; Nees, Dilsseld. Abb. t. 215; Guimp. et Schlecht. Pf. Pharm. I. 120. t. 58; Woodv. Med. pl. 258. t. 100; Bert. Fl. Ital. IV. 436.

Arctostaphylos officinalis Wimm. et Grab. Fl. Siles. I. 391; Mert. et Koch, Deutschl. Fl. III. 100; Koch, Syn. 475 .

Arbutus procumbens Salisb. Prodr. 269.

Arbutus buxifolia Stokes, Bot. 509.

Uva ursi procumbens Moench, Method. 470.

Uva ursi baxifolia Salisb. in Gray, Arr. II. 400.

Macrania Uva ursi Deso. Journ. Bot. III. 39.

Bürentraube, Mehlbeere; englisch: Bear grape; französisch: Bousserole, raisin d'ours.

Die von einer kräftigen Pfahlwurzel ausgehenden, strahlenförmig ausgebreiteten, dem Boden angepressten, nur an den Enden aufstrebenden, holzigen, an der Spitze krautigen Zweige erreichen eine Länge von $40-50 \mathrm{~cm}$; sie sind mit einer schwarzen Rinde bedeckt, von der eine dünne, papierartige Borke abspringt. Die jährigen Schosse sind krautig, mit einem dünnen Überzuge von gekrümmten und yewundenen Haaren versehen, zwischen denen Köpfchenhaare eingestreut sind; das Sekret der letateren lässt sie ein wenig lackiert erscheinen. 
Die Blätter sind spiralig, annähernd an $2 / 5$ gestellt, richten sich aber an den niederliegenden Zweigen in eine Ebene; sie werden von einem $3-5 \mathrm{~mm}$ langen Stiele getragen, der gleich den jungen Schossen behaart ist; die Spreite ist 1,5-1,7 $(1,0-2,2) \mathrm{cm}$ lang und im oberen Viertel $6-8(3-10) \mathrm{mm}$ breit; sie ist spathelförmig, selten oblong oder umgekehrt eiförmig, lederartig, zwei Jahre danernd; die Ränder sind flach und mit einem zarten Flaume bedeckt, der anch im Alter nicht ganz verschwindet; die Unterseite ist nur ein wenig heller als die obere und ganz oder fast ganz kahl, hier ist das dentliche Nervennetz eingedriickt, dort ist es leicht vorspringend.

Der Blüthenstand ist eine wenigblüthige, hängende, kurz gestielte Traube, die von einer Knospe unentwickelter Blitthen beschlossen wird. Die Spindel ist kräftig und wie die jungen Sehosse behaart; die Blüthen stehen in der Achsel von oblong-dreiseitigen Deckblättern, die etwa 2-3 mm lang sind; sie werden von zwei weissen, 1-1,2 mm langen, fast kreisrunden, einander übergreifenden, häutigen Vorblättern gestïtzt, die eine Röhre um den 2-3 mm langen Blüthenstiel bilden.

Der Keleh ist 1,5 mm lang, seine kreisförmigen, spitzen, dachziegelig deckenden, weissen Zipfel sind am Rande ein wenig gewimpert und fast völlig frei. Die Blumenkrone ist 5,5-6 mm lang, krugförmig und nur im oberen Fünftel in eiförmige Zipfel getheilt, aussen ist sie ganz oder fast völlig kahl und röthlich weiss mit rosafarbenem Zipfel; innen aber mit weissen, ziemlich langen Haaren bestreut. Die Staubgefässe sind 2,2 mm lang, die Fäden sind bandförmig, an dem unteren Ende etwas verbreitet und unter dem Stempel angeheftet, sie sind anssen behaart. Die Staubbeutel sind $0,8 \mathrm{~mm}$ lang und die nach unten und aussen gekrümmten Hörner messen $1 \mathrm{~mm}$. Die Pollenkörner sind zn Tetraden vereint und wie die Bentel von schön carmoisinrother Farbe. Das Honig absondernde Polster ist schwach gelappt und fleischig, in ihm sitzt der $1 \mathrm{~mm}$ hohe, kugelförmige, fünffächerige Fruehtknoten; die Samenanlagen sind hängend und mit der Mikropyle nach anssen gewendet, der Nabelstrang ist sehr dick und kegelförmig; der Griffel misst $3 \mathrm{~mm}$.

Die Frueht ist eine rothe, fade süsslich und mehlig schmeckende Steinfrucht von $7-8 \mathrm{~mm}$ Durehmesser; sie ist glänzend, an der Spitze etwas genabelt und wird von dem Kelche gestützt. Die Steinkerne sind gerundet dreikantig, mit innenseits etwas vorspringender Leiste und dentlichem Nabel; ihre Schale ist knochenhart und gelbbraun.

Der Sa me ist oblong, der verdickte Nabelstrang wird zu einer kegelförmigen Caruneula; der Keimling ist etwas zusammengedrïckt, er hat kleine Keimblätter und ein grosses nach oben gewendetes Würzelchen.

Die Bärentraube wächst als cireumpolare Pflanze in den Ebenen von Canada und den nördlichen Vereinigten Staaten von Nord-Amerika, sowie in den Gebirgen der mittleren und siidlichen Staaten; ebenso ist sie in den gleichen Lagen der alten Welt verbreitet nnd findet die Südgrenze in einer Linie, die vom siidöstlichen Spanien dureh Nittel-Italien, nördlich von der Balkanhalbinsel dureh Mittel-Russland über den Kankasus, Ural, Altai- und Baikal-See verlänft.

Die von April bis Juni gesammelten Blätter der Pflanze sind als Folia Uvae ursi im Gebraneh; die Wirksamkeit der Droge berult vorzïglich auf dem Gehalte derselben an Arbutin.

$$
\text { Erklärung der Abbildungen. }
$$

Fig. A. Ein Zweig der blithenden Pflanze, naeh einem Exemplare aus der Provinz Brandenburg.

Fig. B. Ein Zweig der fruehtenden Pflanze.

Fig. C. Die Blithe, 3mal vergrössert: $a$. die Vorblättehen; $b$. der Kelch; $c$. die Blumenkrone.

Fig. D. Die Blithe im Längsschnitte, naeh Wegnahme der oberen Blumenkrone, 6mal vergrössert: $d$. dieStaubgefässe; $e$. das Honig absondernde Polster; $f$. der Fruehtknoten; $g$. der Griffel; $h$. die Narbe; $i$. die Samenanlage.

Fig.E. bis $G$. Das Staubgefäss von innen, der Seite u. aussen, 12 mal vergrössert.

Fig. H. Pollentetraden, $100 \mathrm{mal}$ vergrössert.
Fig. I. Der Stempel, 6mal vergrössert.

Fig. $K$. Der Fruehtknoten im Quersehnitte.

Fig. $L$. Derselbe im Längssehnitte, 18 mal vergrüssert: $l$. der Nabelstrang.

Fig. $M$ Die Frucht, 3mal vergrössert.

Fig. N. Dieselbe im Quersehnitte: s. der Steinkern.

Fig, $O$. bis $Q$. Der Steinkern von innen, der Seite u. im Längssehnitte, 3mal vergrössert: $m$. der Nabel; $n$. die Naht; $o$, das Niahrgewebe; $p$. der Keimling.

Fig. $R$. Der Same, 5mal vergrössert: $l$. die Caruneula.

Fig. S. Der Keimling, 7 mal vergrössert: $q$. dasWürzelehen; $r$ die Keimblitter. 



\section{Berichtigungen.}

Seite 68 Zeile 16 von oben lies: Ansatzstelle « statt Aussatzstelle.

Seite 97 ist die Tafelnummer von Strophanthus hispidus DC, in: Tafel 35 umzuändern. 

Taf 1.

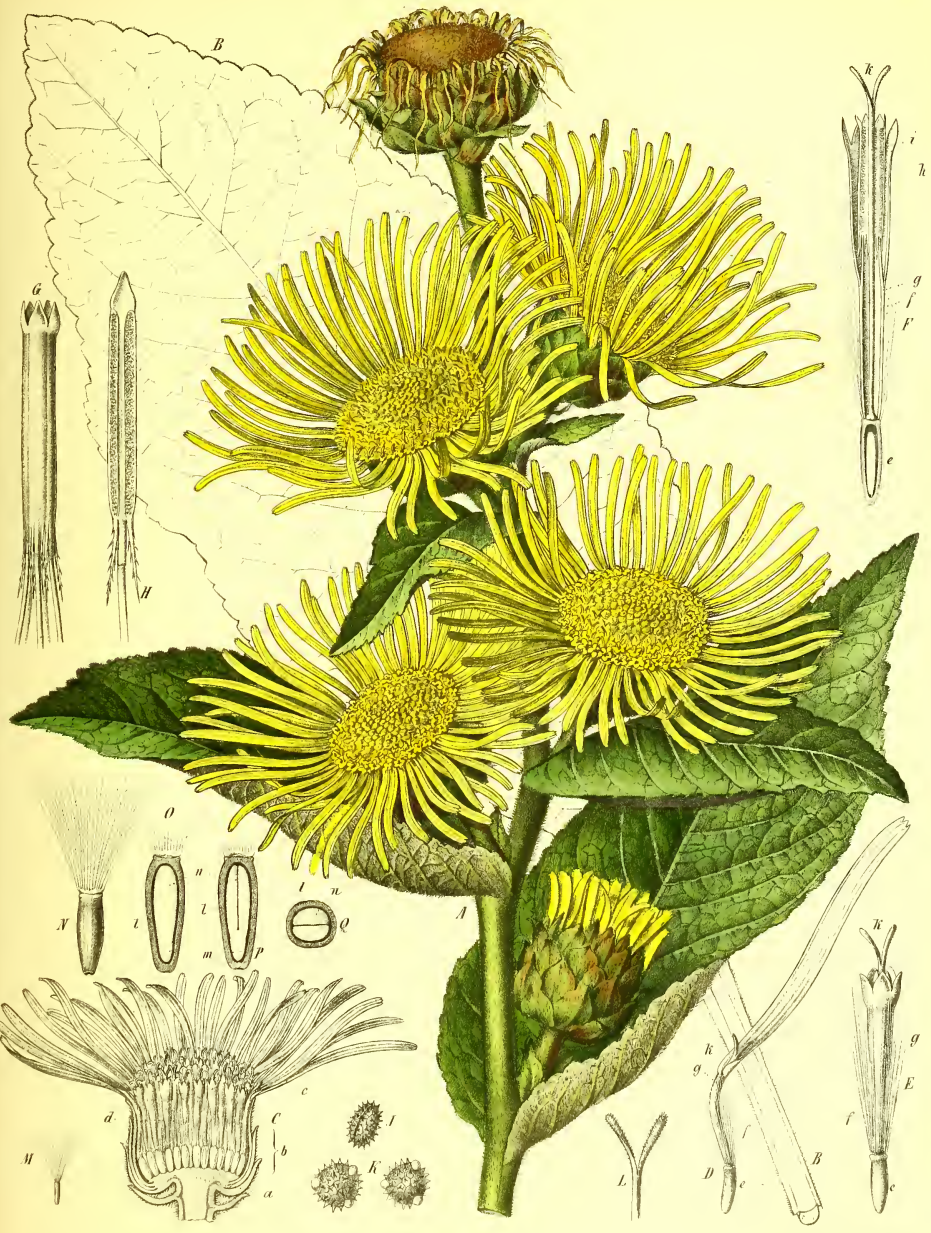





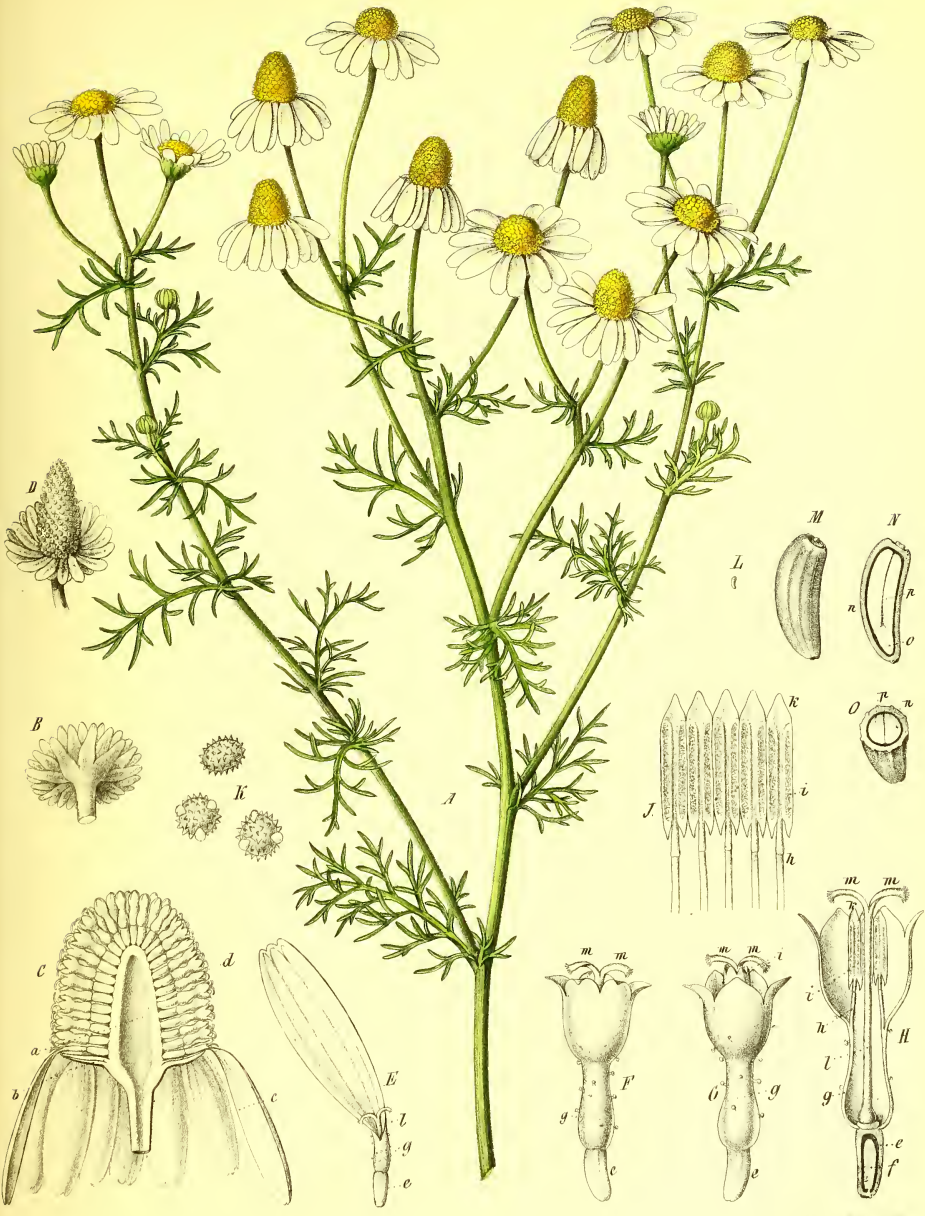

Mallicalda C'hamomulla L. 


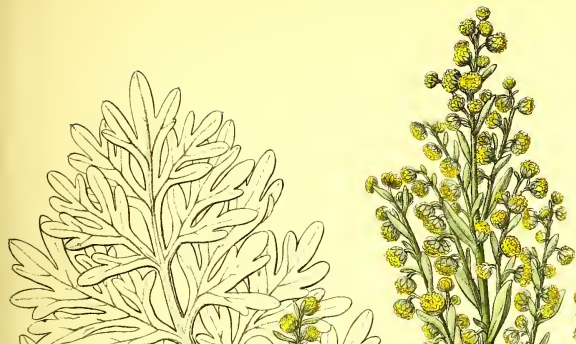

1.

wan

(1)

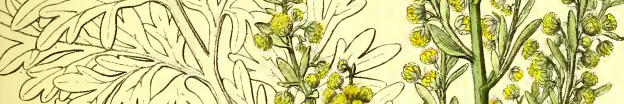

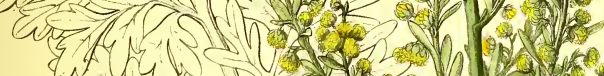

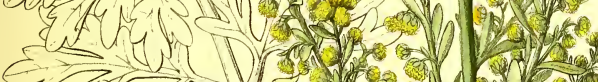

(-2.) J

. $0^{\prime}$. An (f)

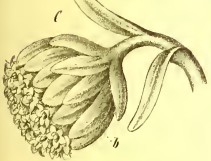
m

(ropop.

"I)
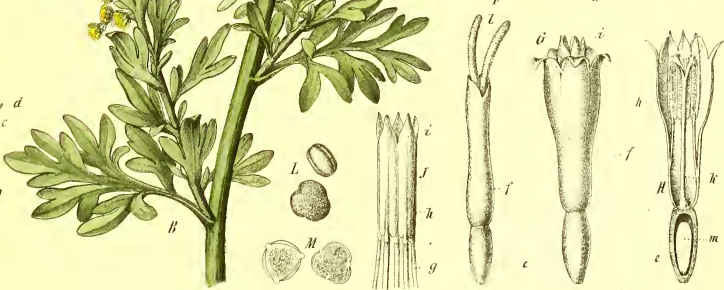

Alomista Nosinthimm I. 



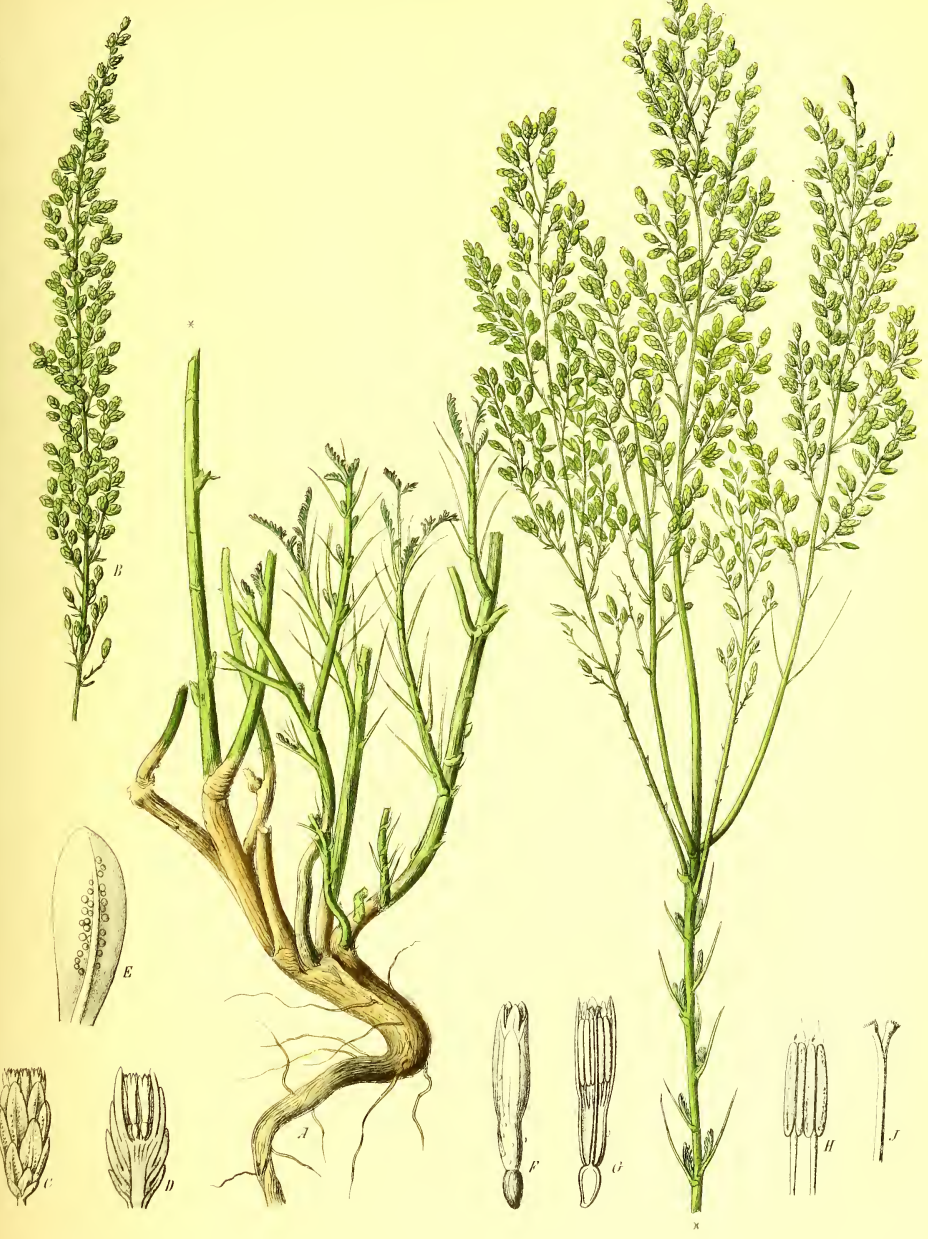

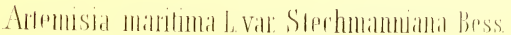



Taf. 5.

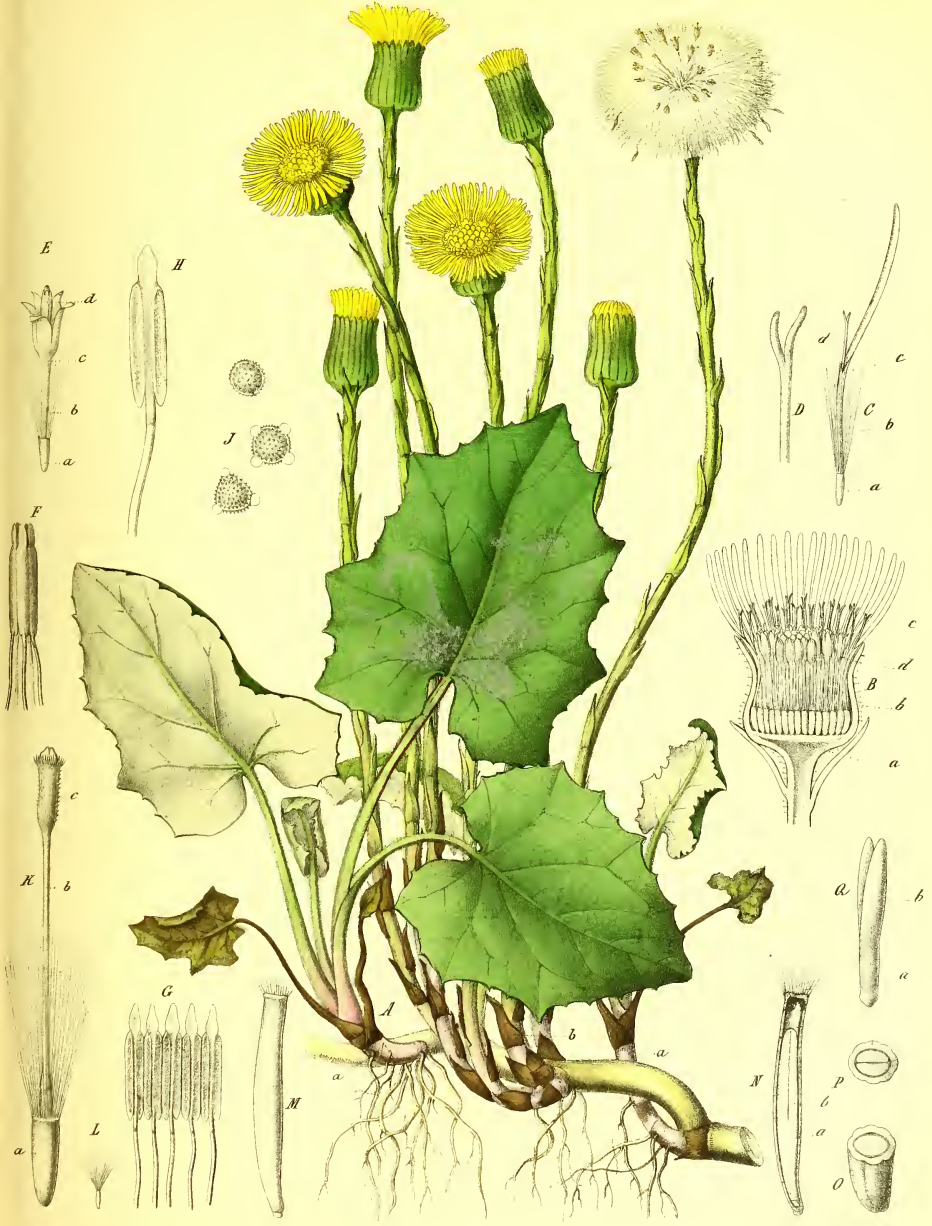

Tusfilago farlara t. 

Taf 6.

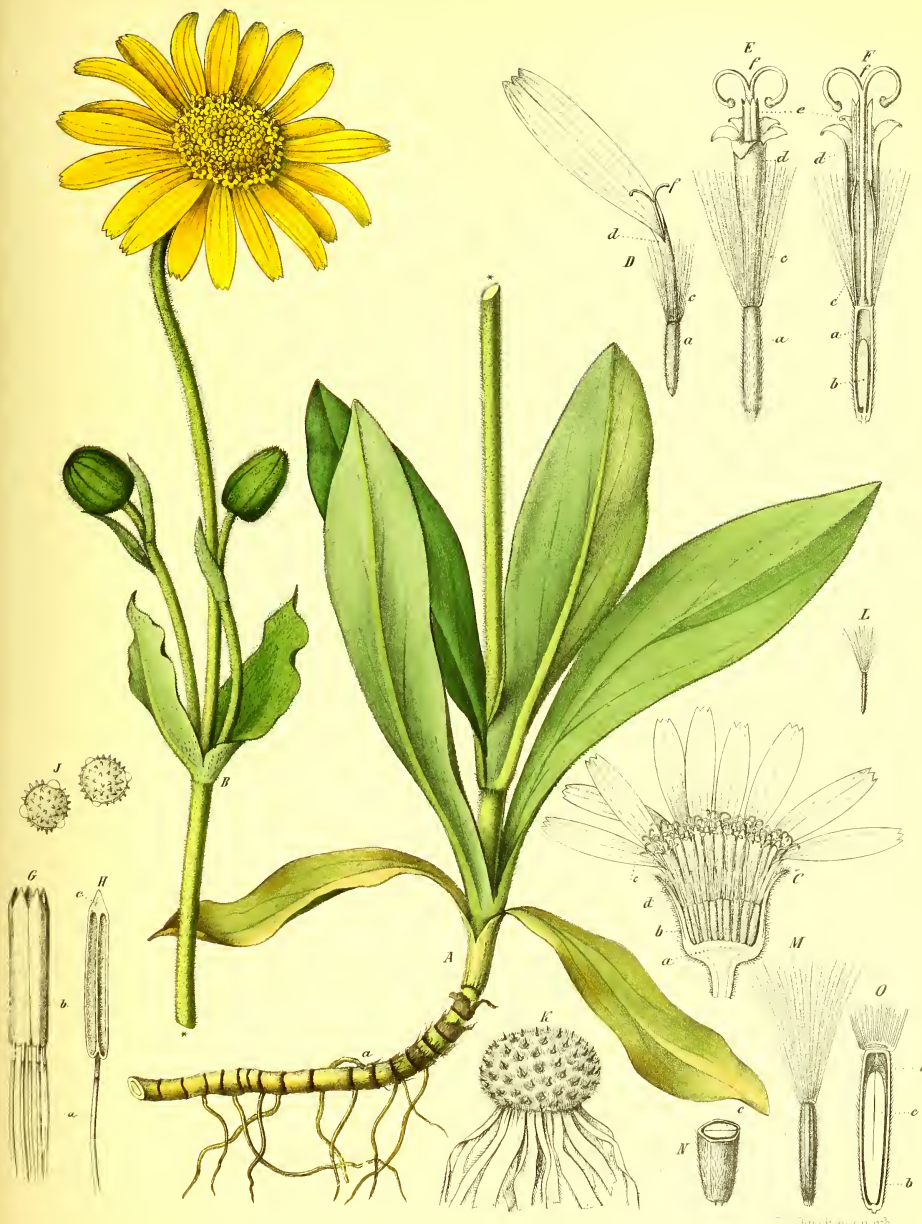

Armicia montalla $\mathrm{L}$. 



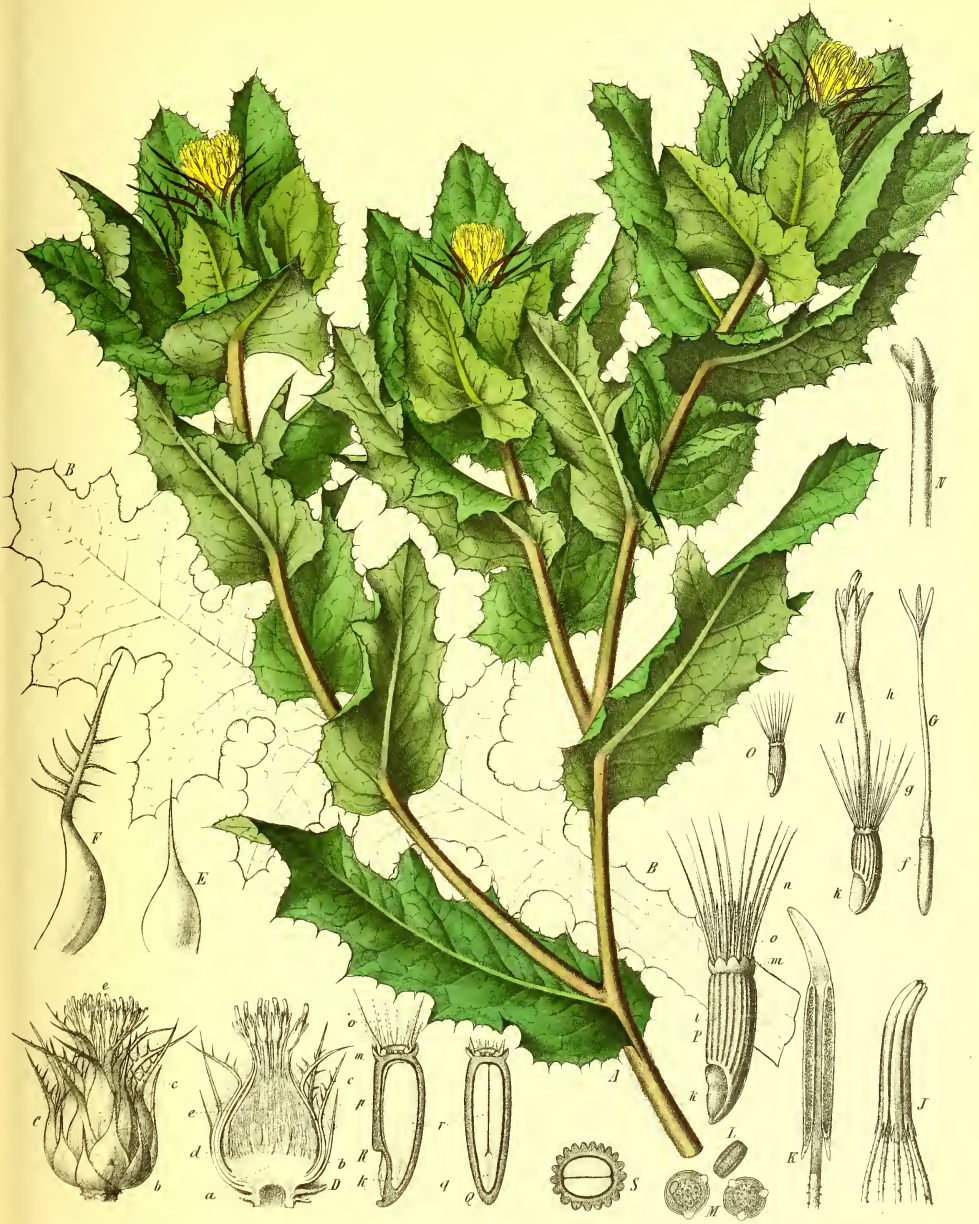

Cuicus benedictus. L 



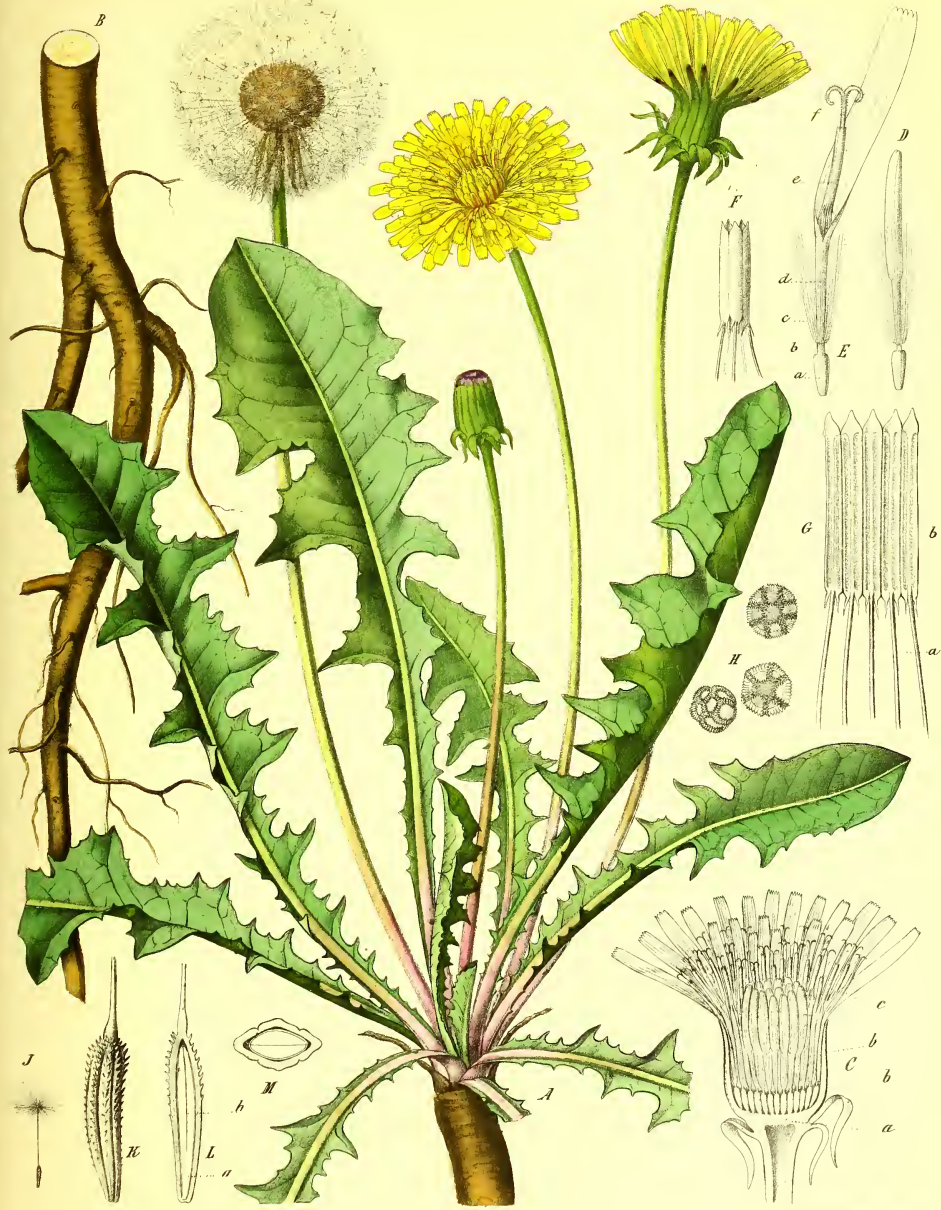

Taraxarum offomale the 



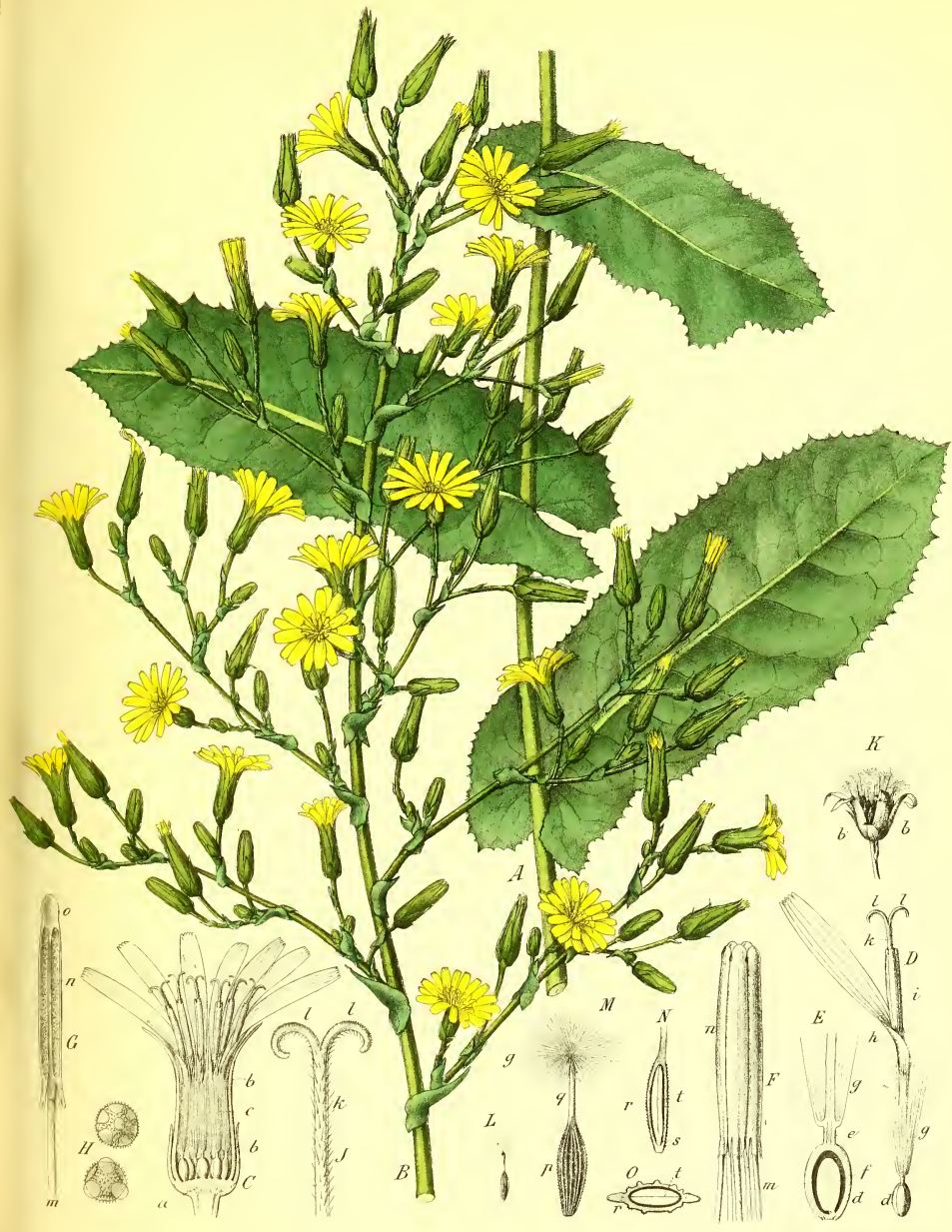

lanlluca vilosal 



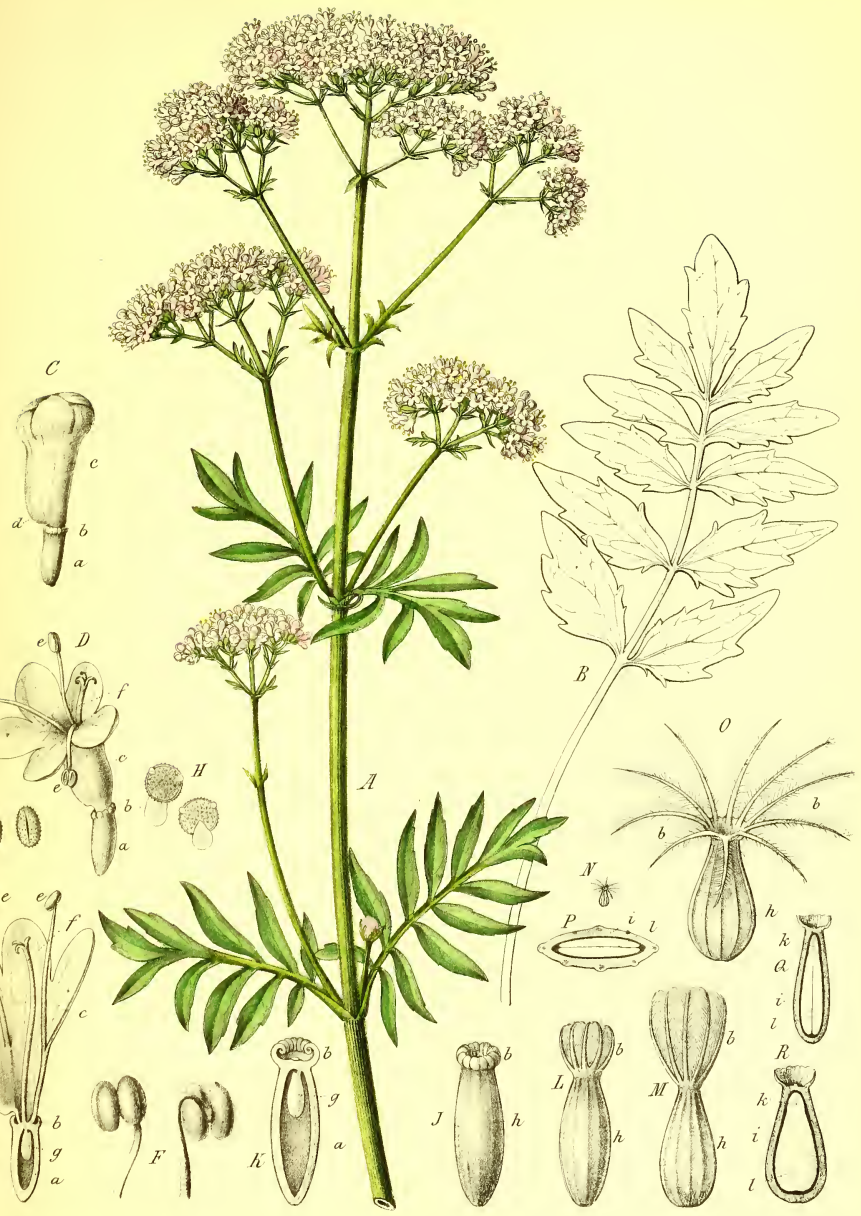

Valemantat offermalis L. 

Taf. 11.

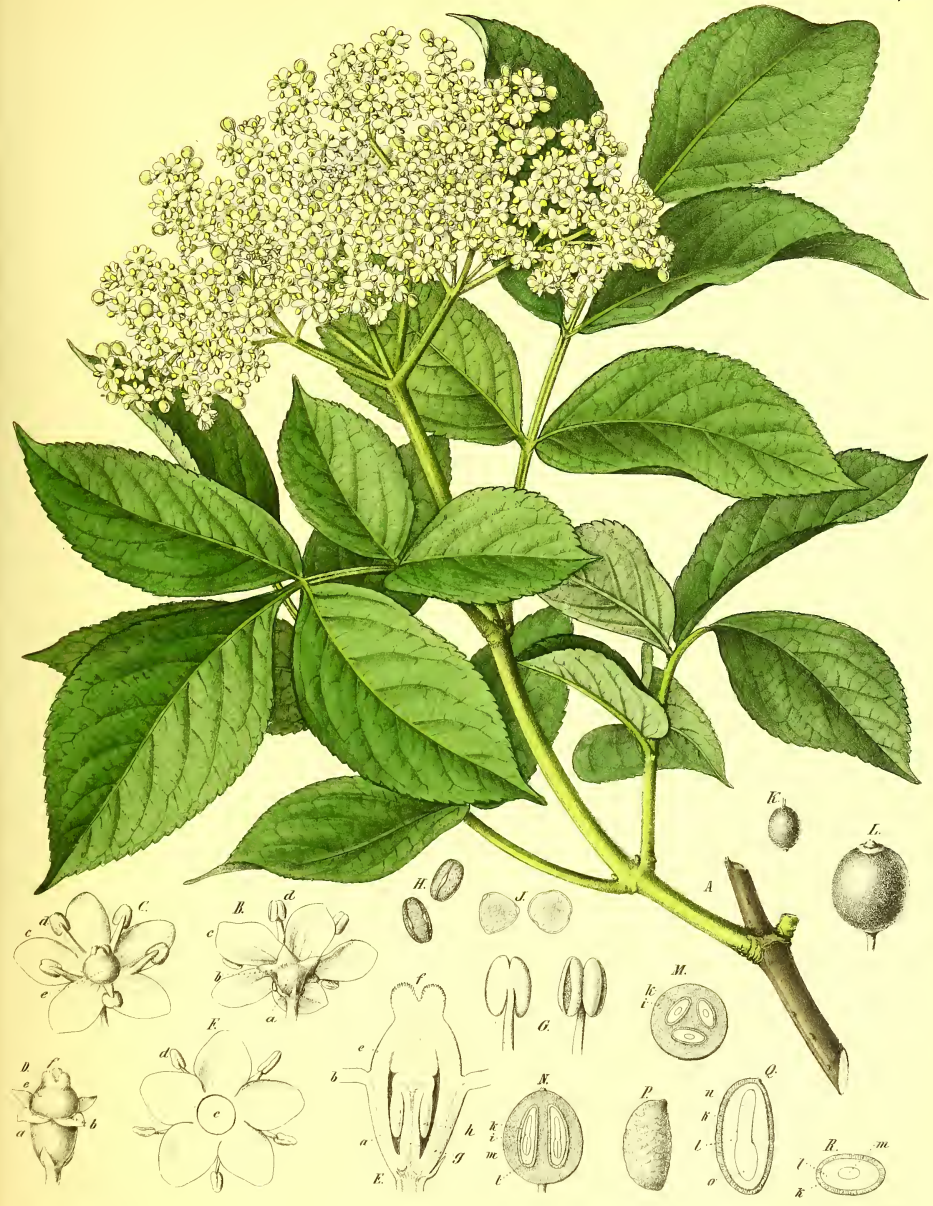

Sianbucus niona I 

Lit' t?

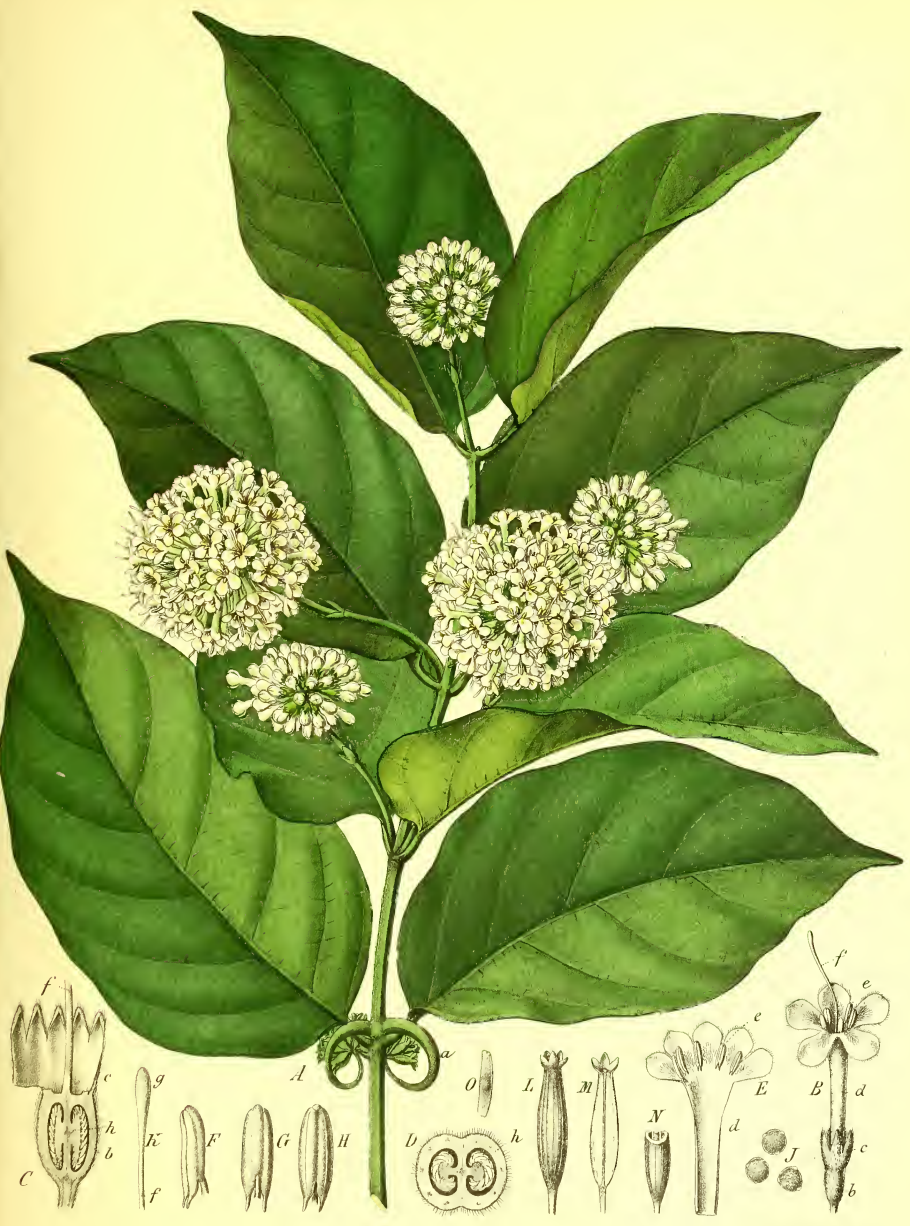

Intalla lidmber Roxb. 



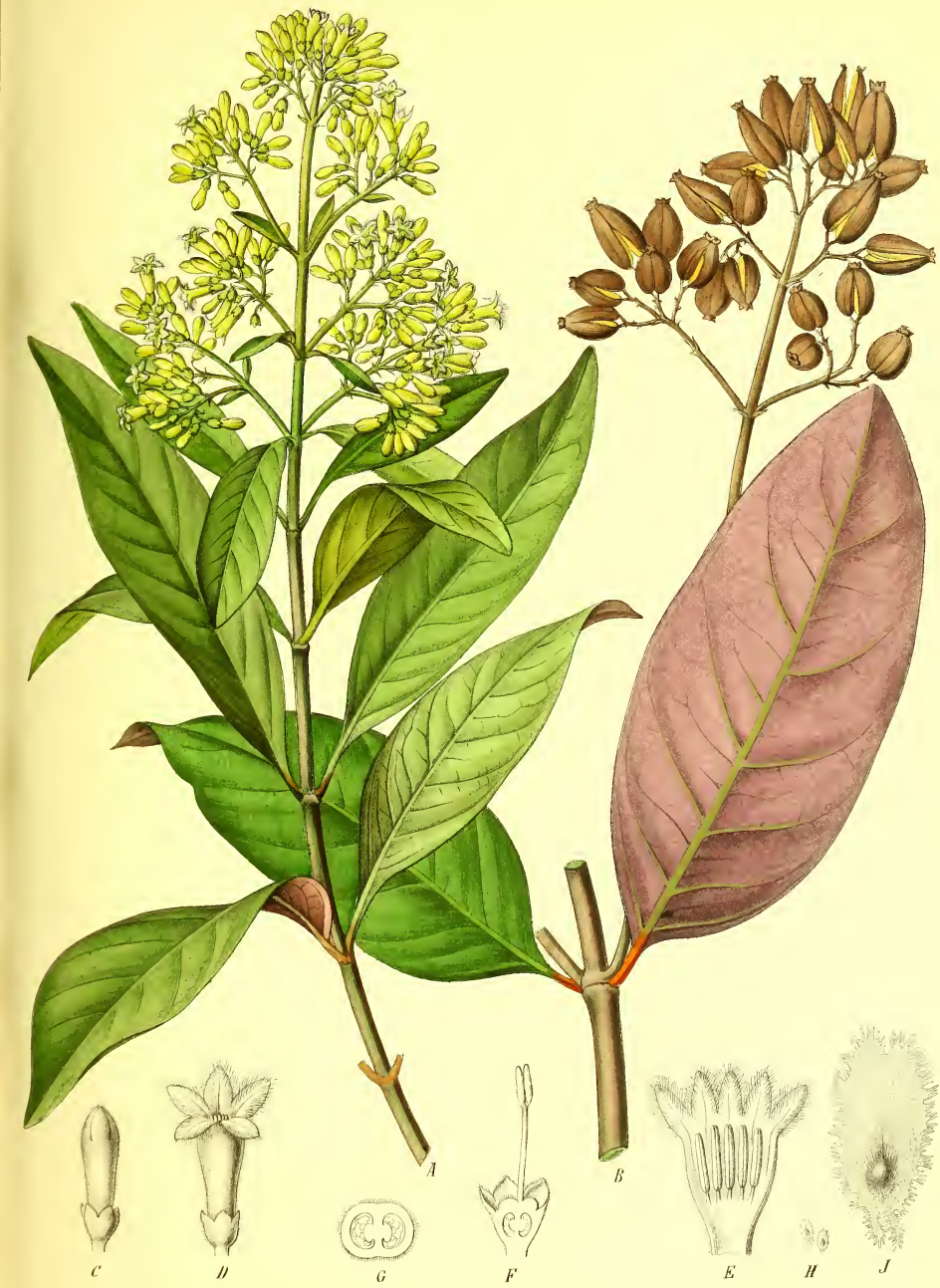

Cinchona Ledoeriana Moens. 




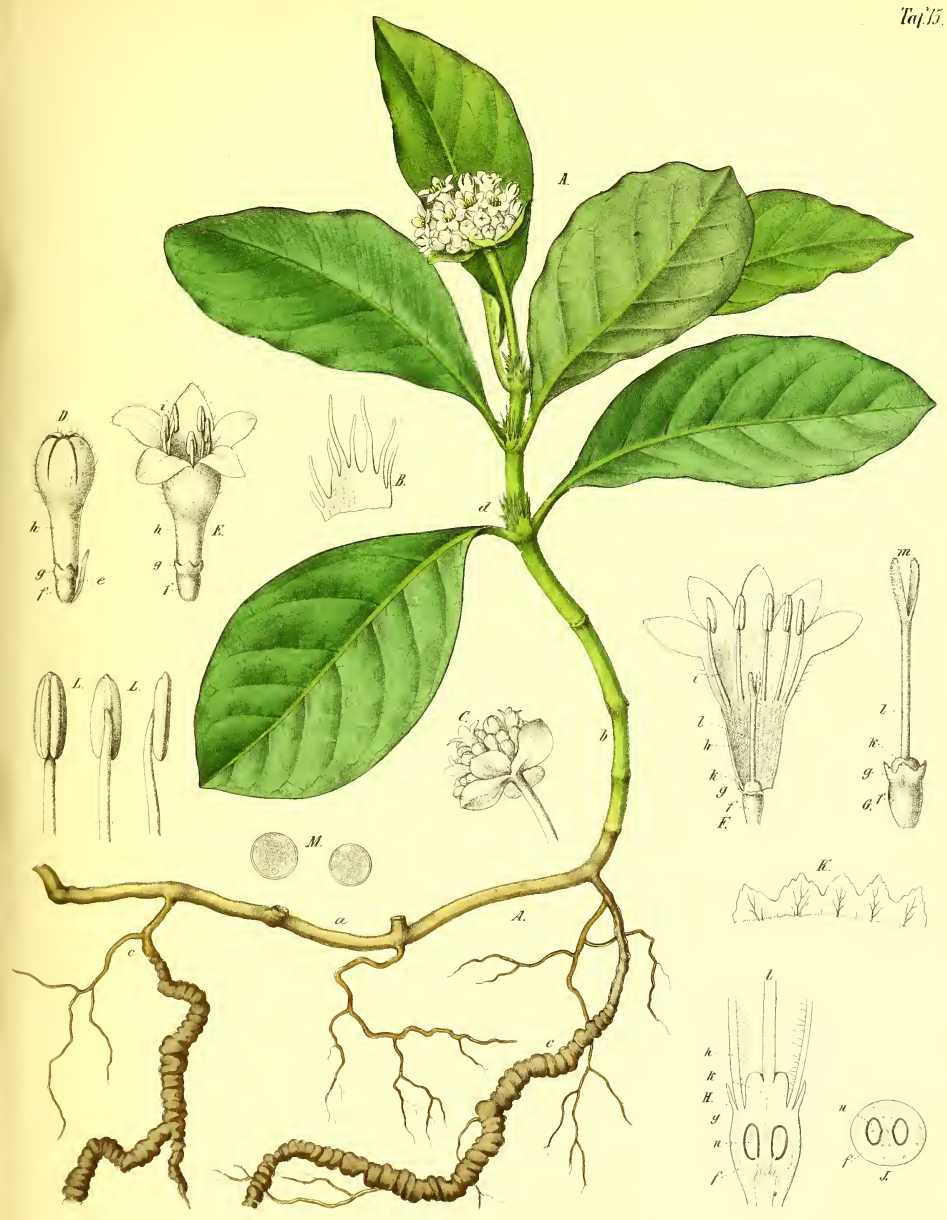

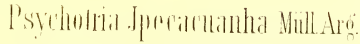




Taf17.
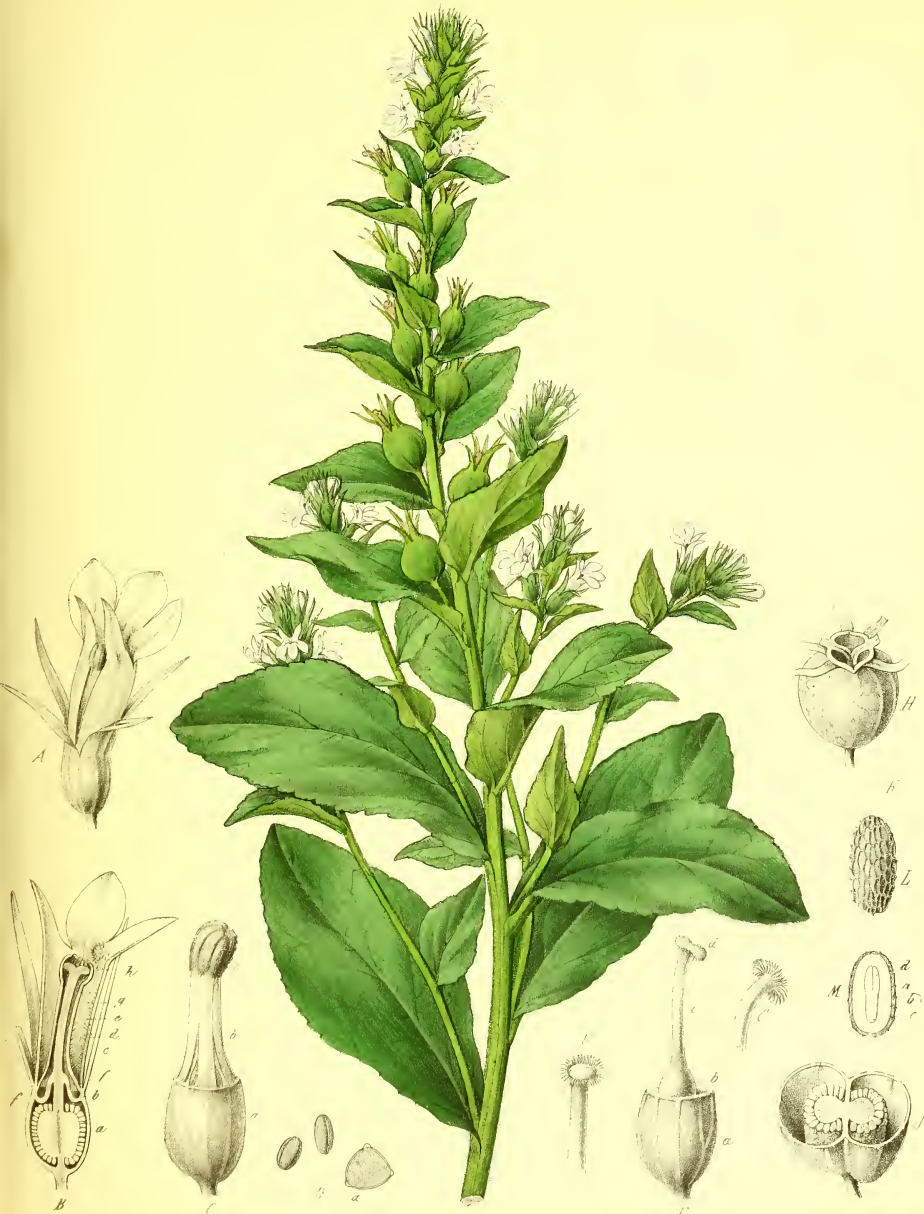

Jobela millatio 

Tax.18.

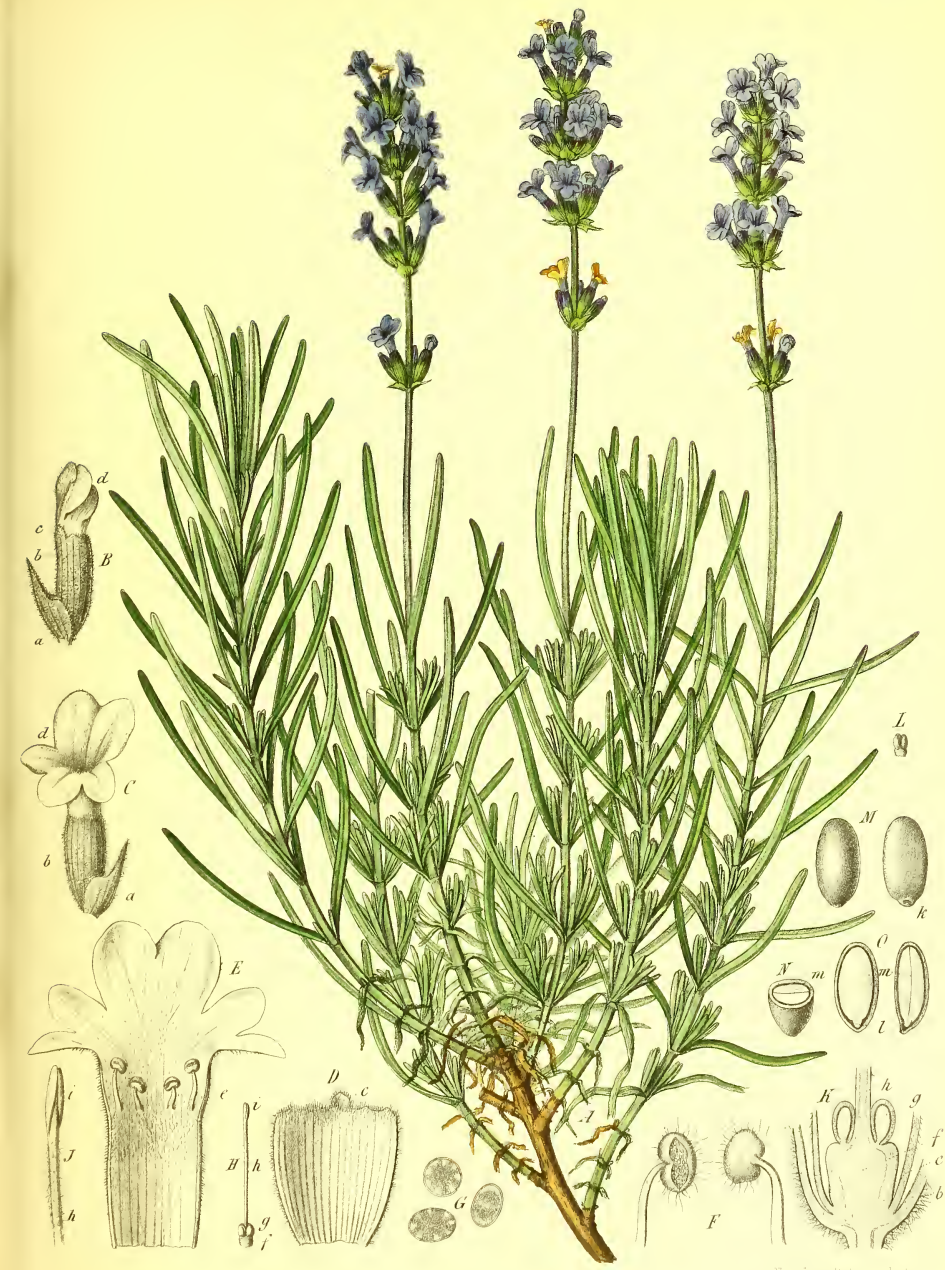

Lavandula vera no 



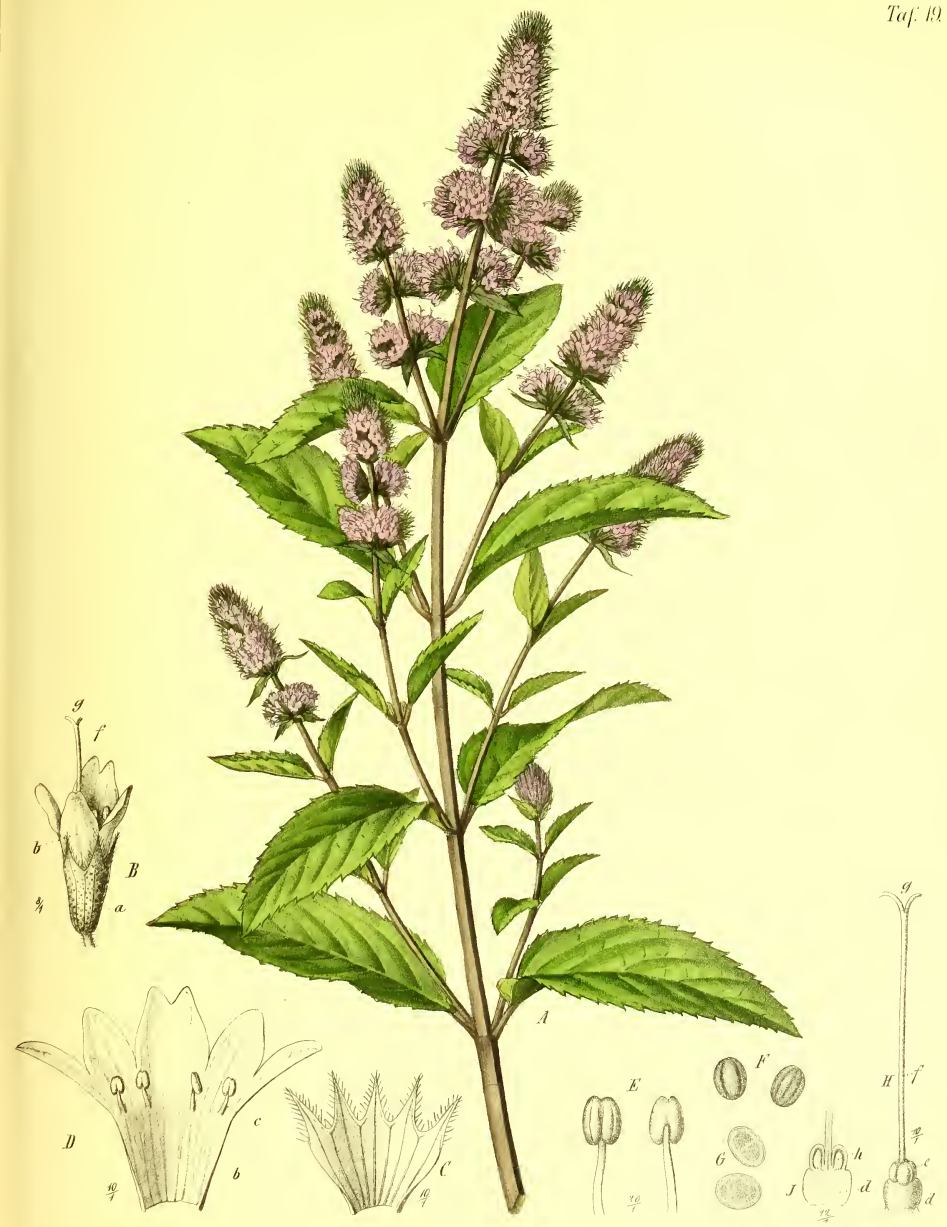

Nenthat piperila. I. 


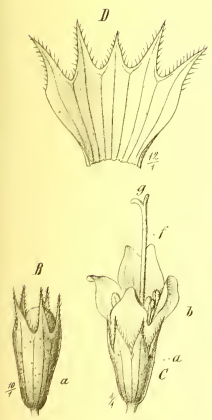

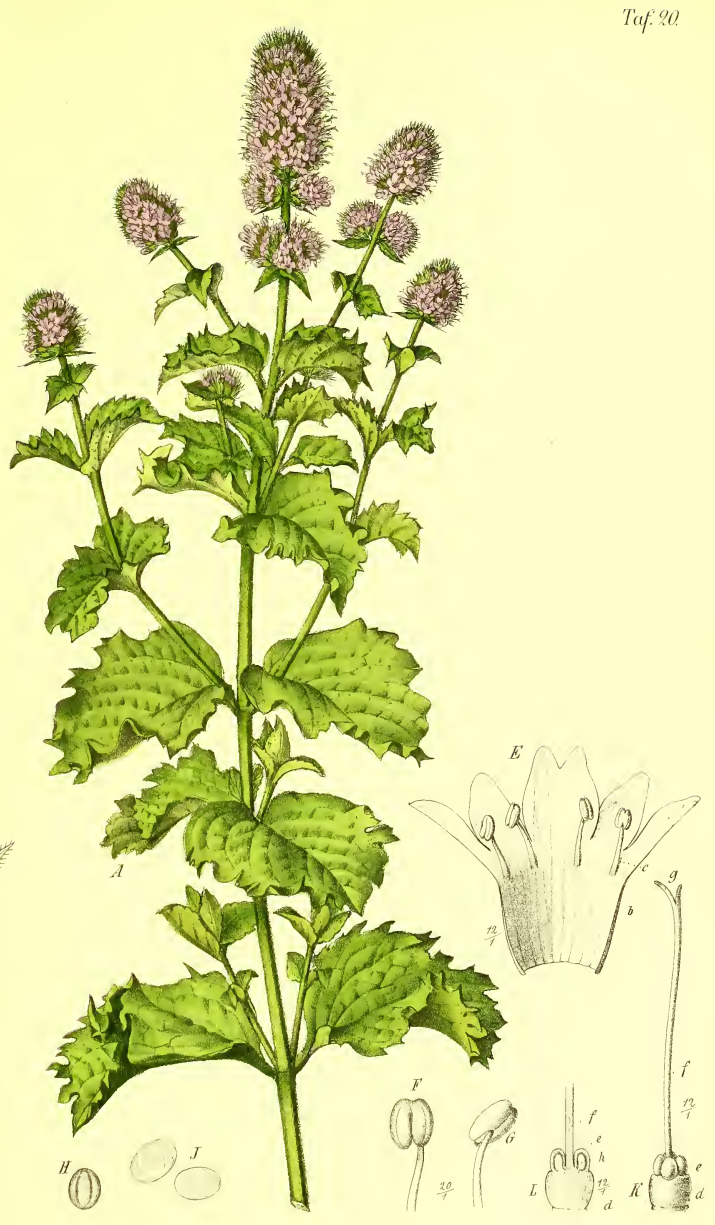

Mentha silvestris L. var. cmispa Benth 



\section{Hoifs}

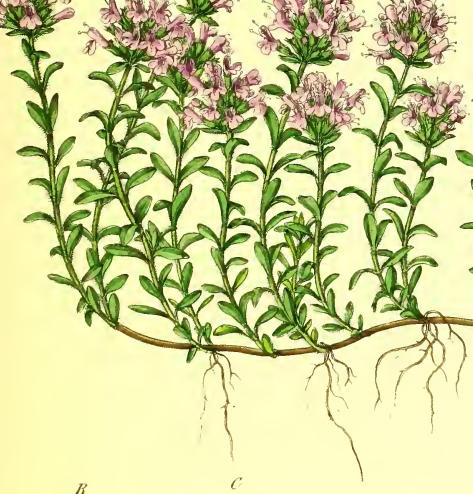

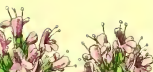
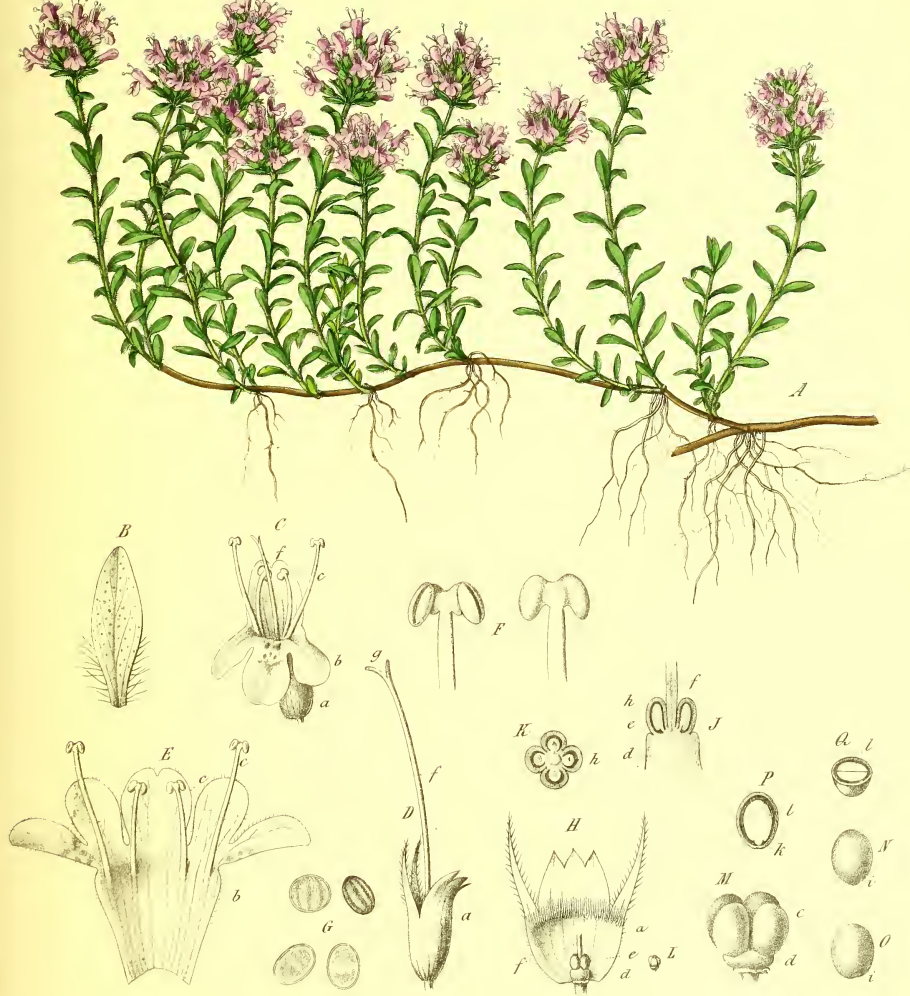

"as. "ab́,

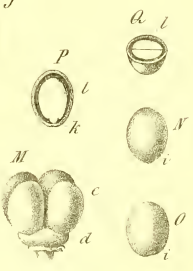

Thromess Serpollum. L. 



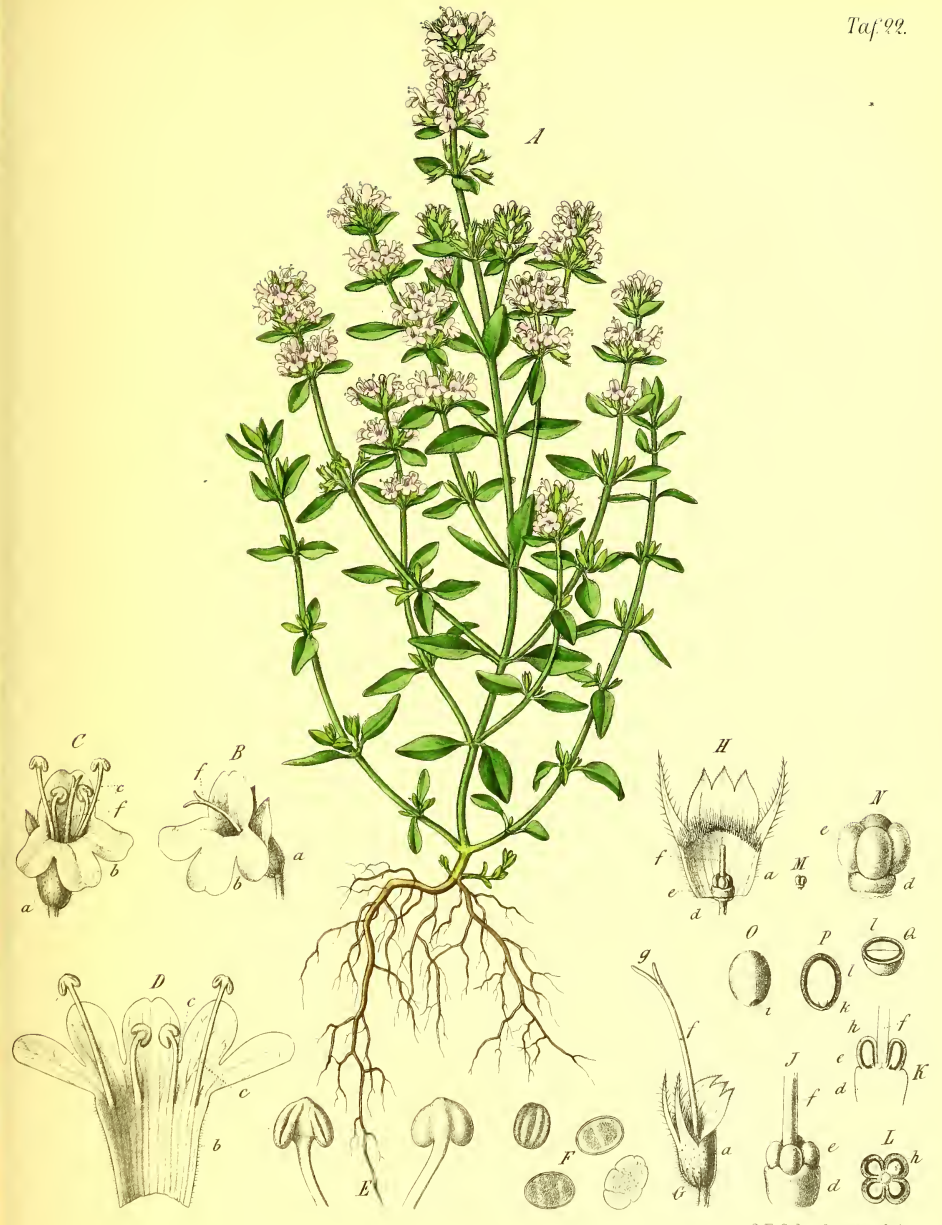

Thumens vulgaris. I. 




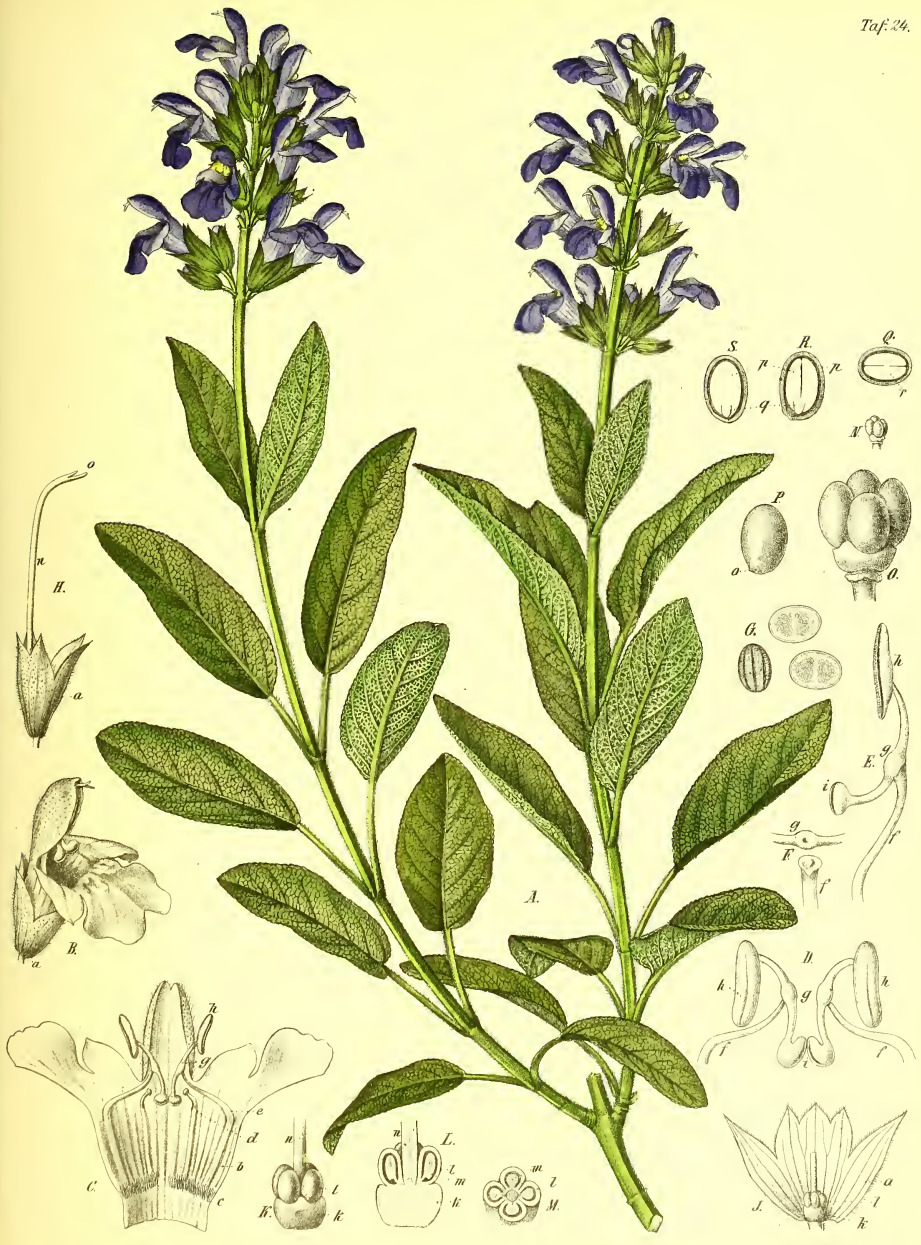

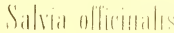



Taf. 25
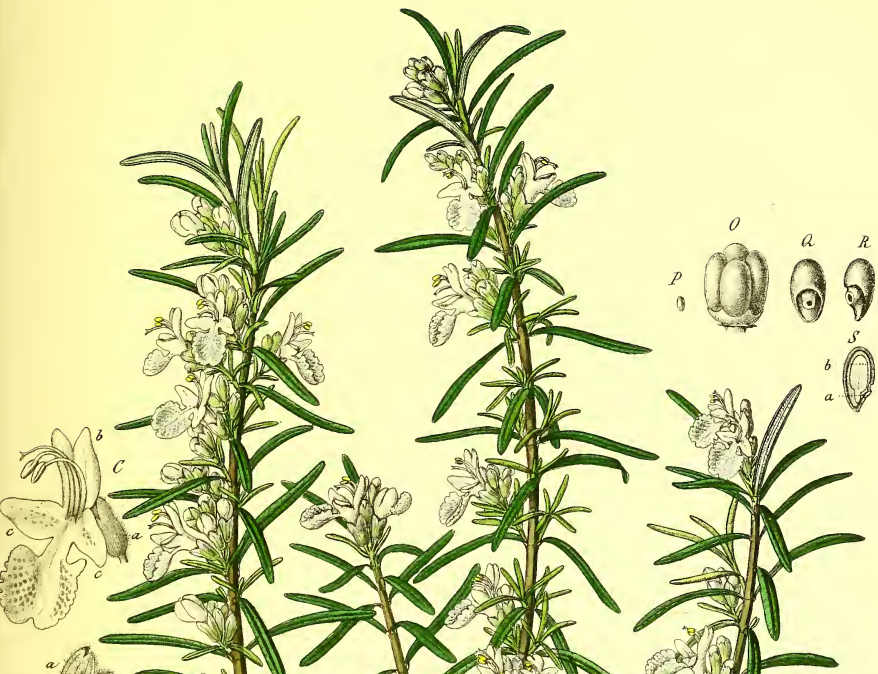

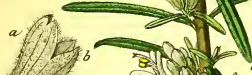

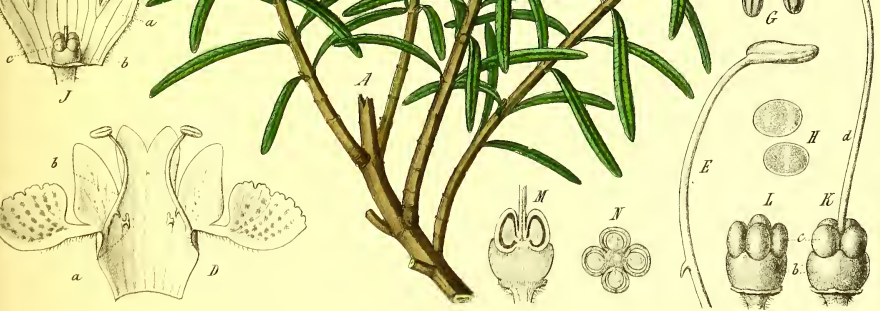

Posmintimus officmatis L 

$T a i \%$

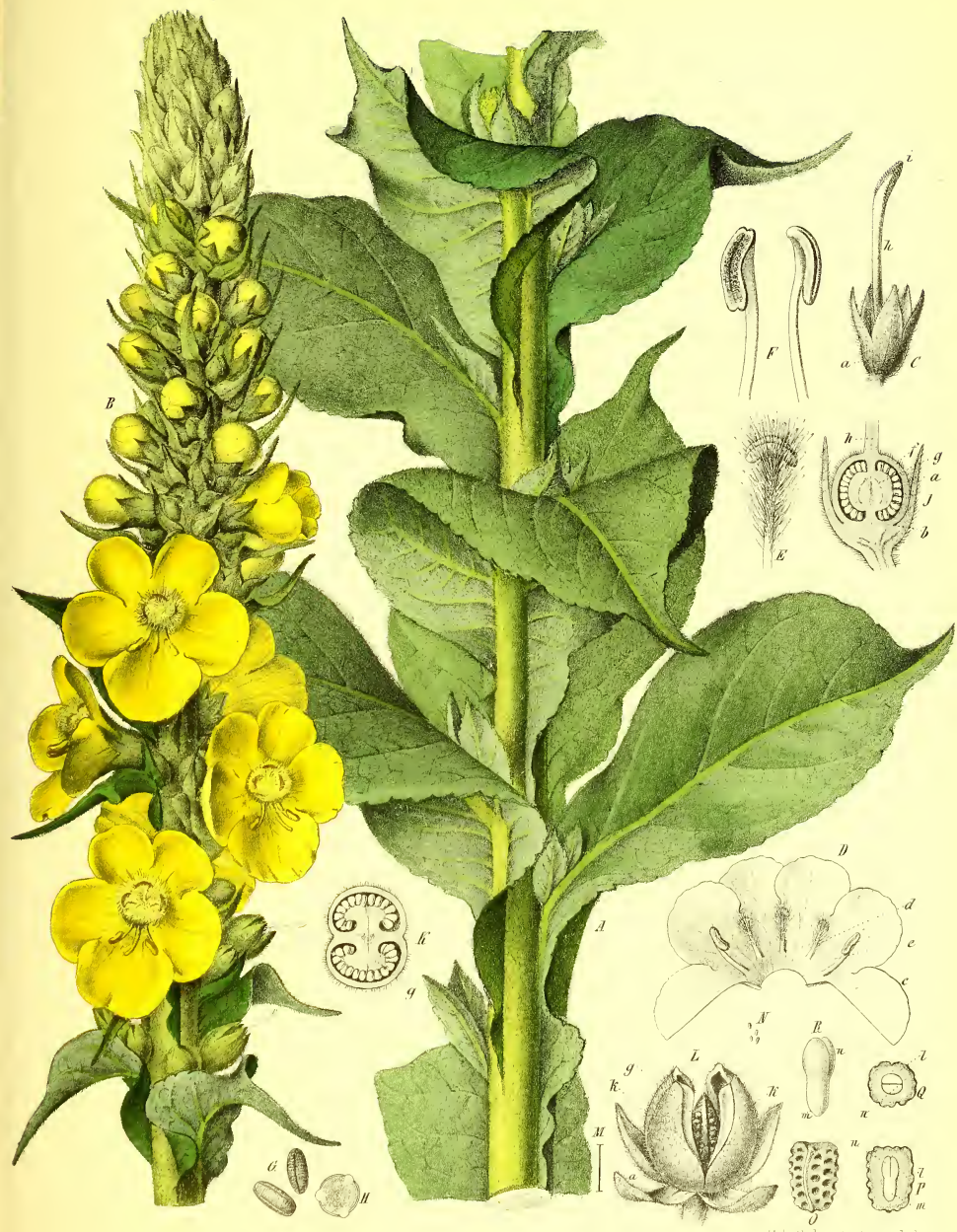

Verbascum thapsilome. Schrad. 



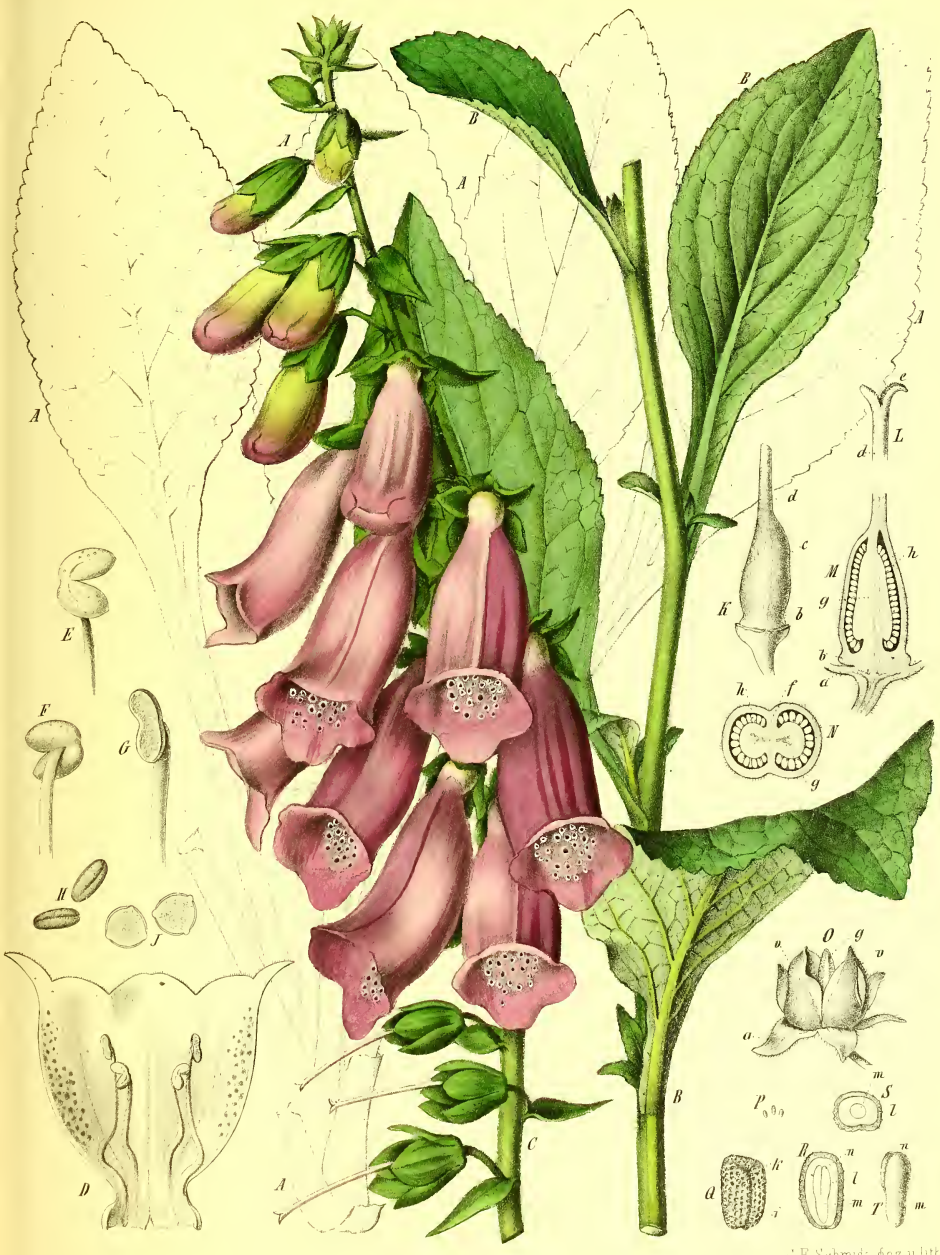

Joilalis purpurea. L. 


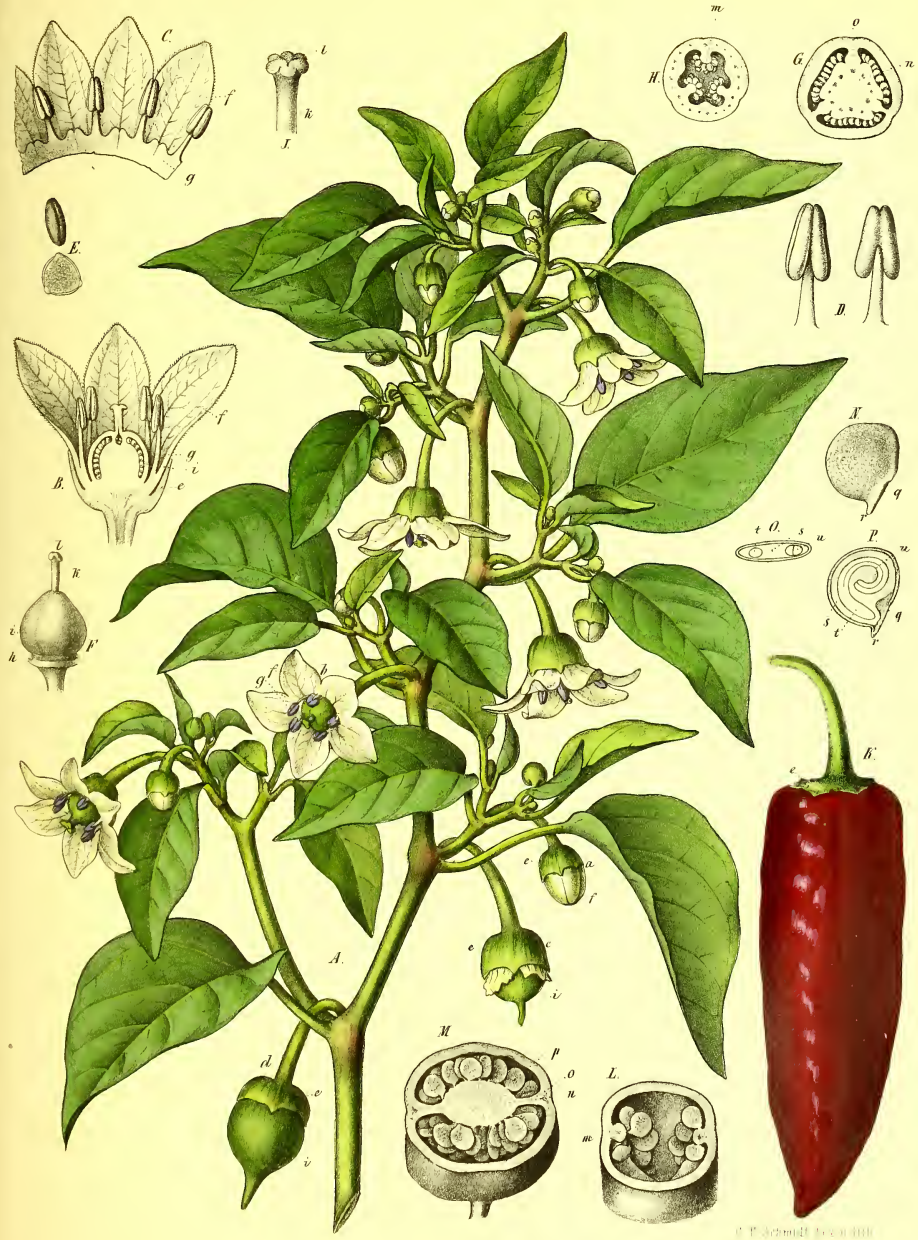

Capsicum anıuum l. 

Taf $\% 9$

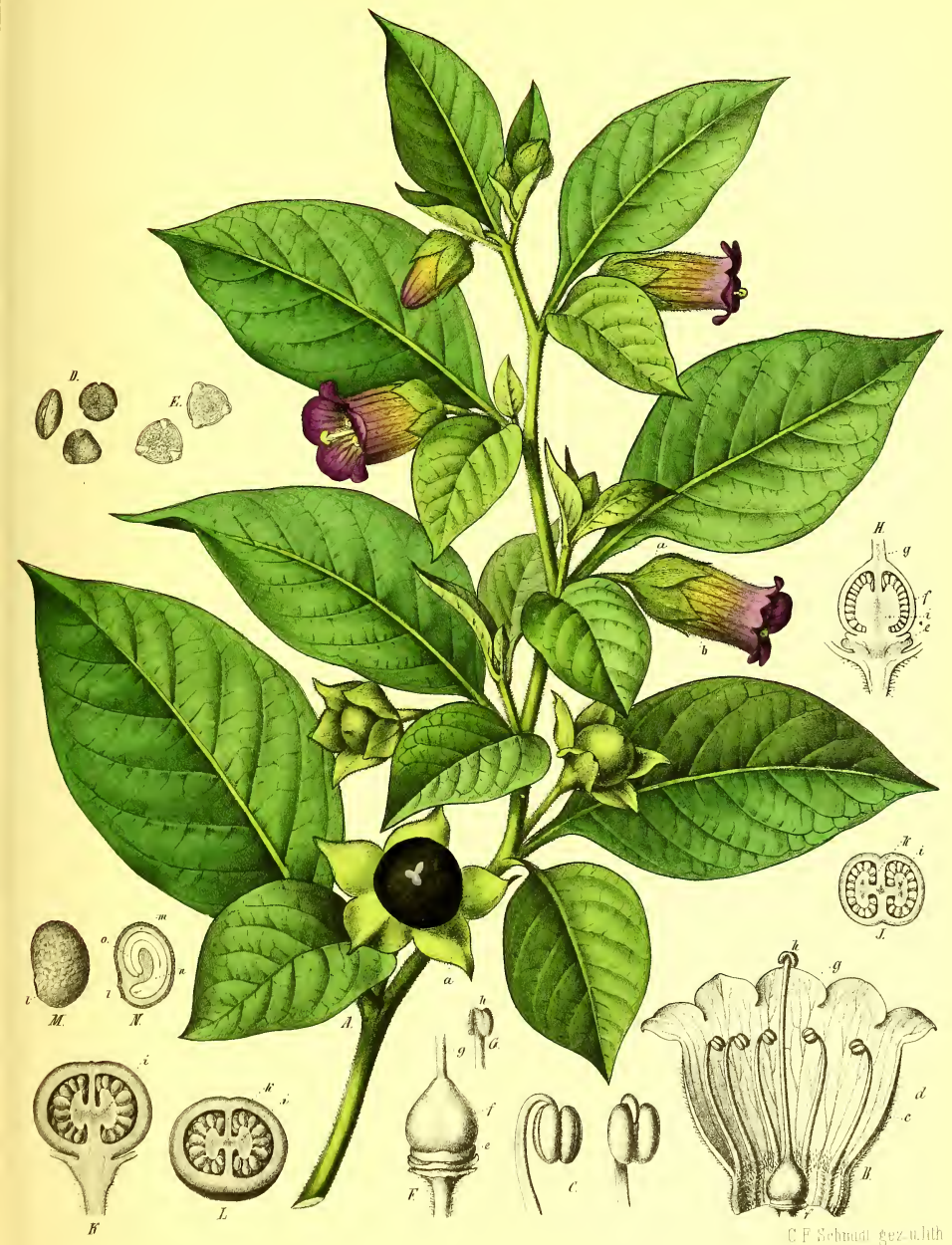

Aropa Belladomna $L$ 

Taf.30

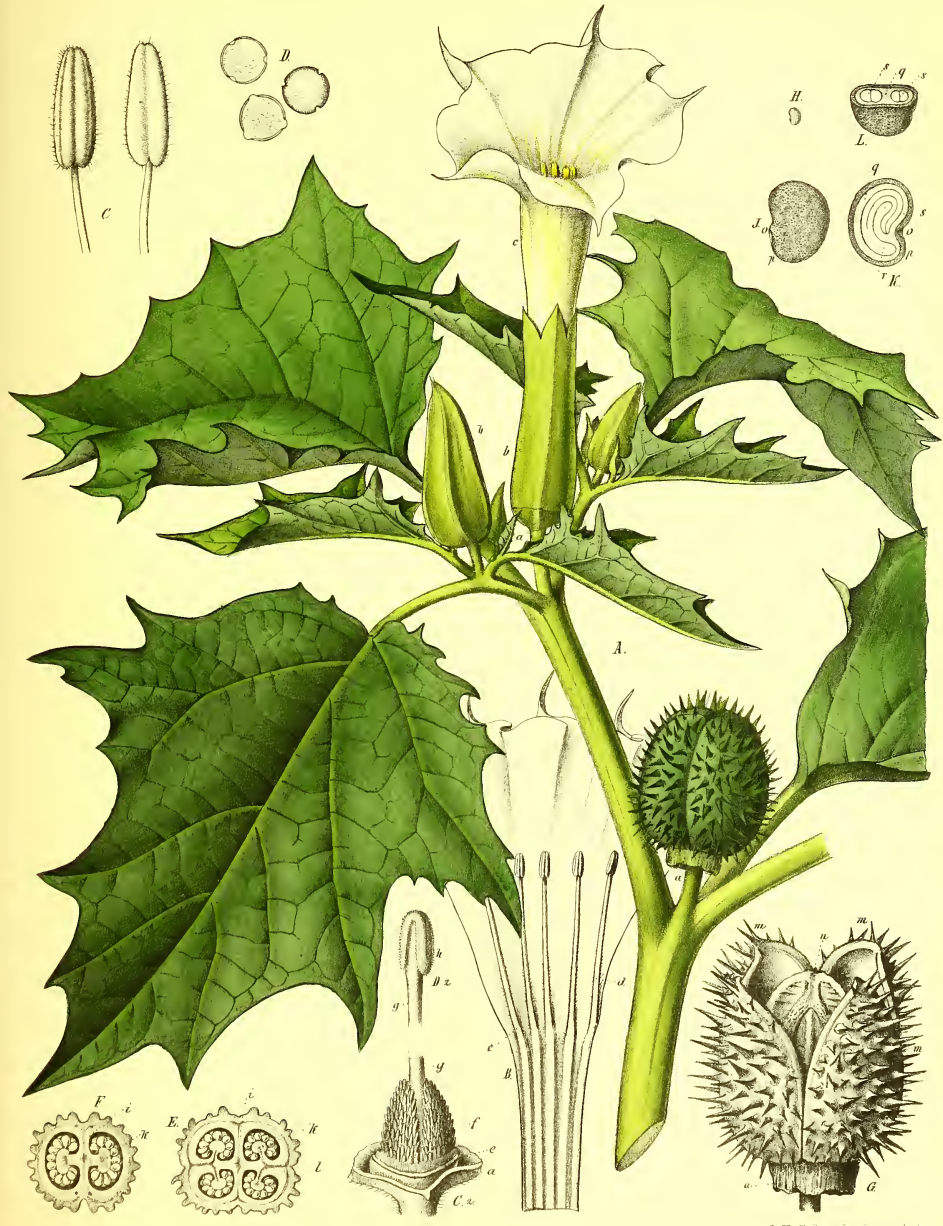

Datura Stramoniums. L 



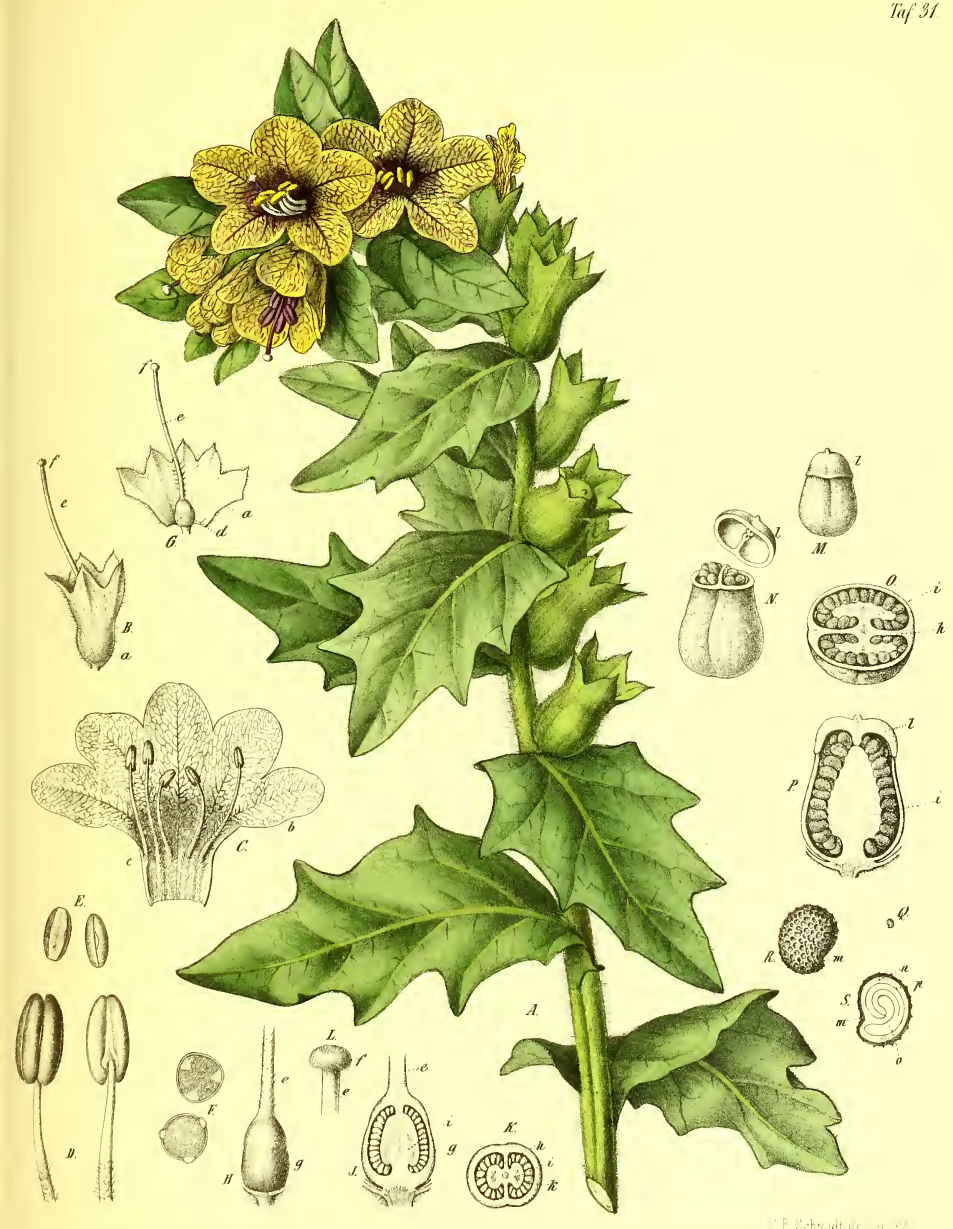

Hyoscyamus nioner L. 




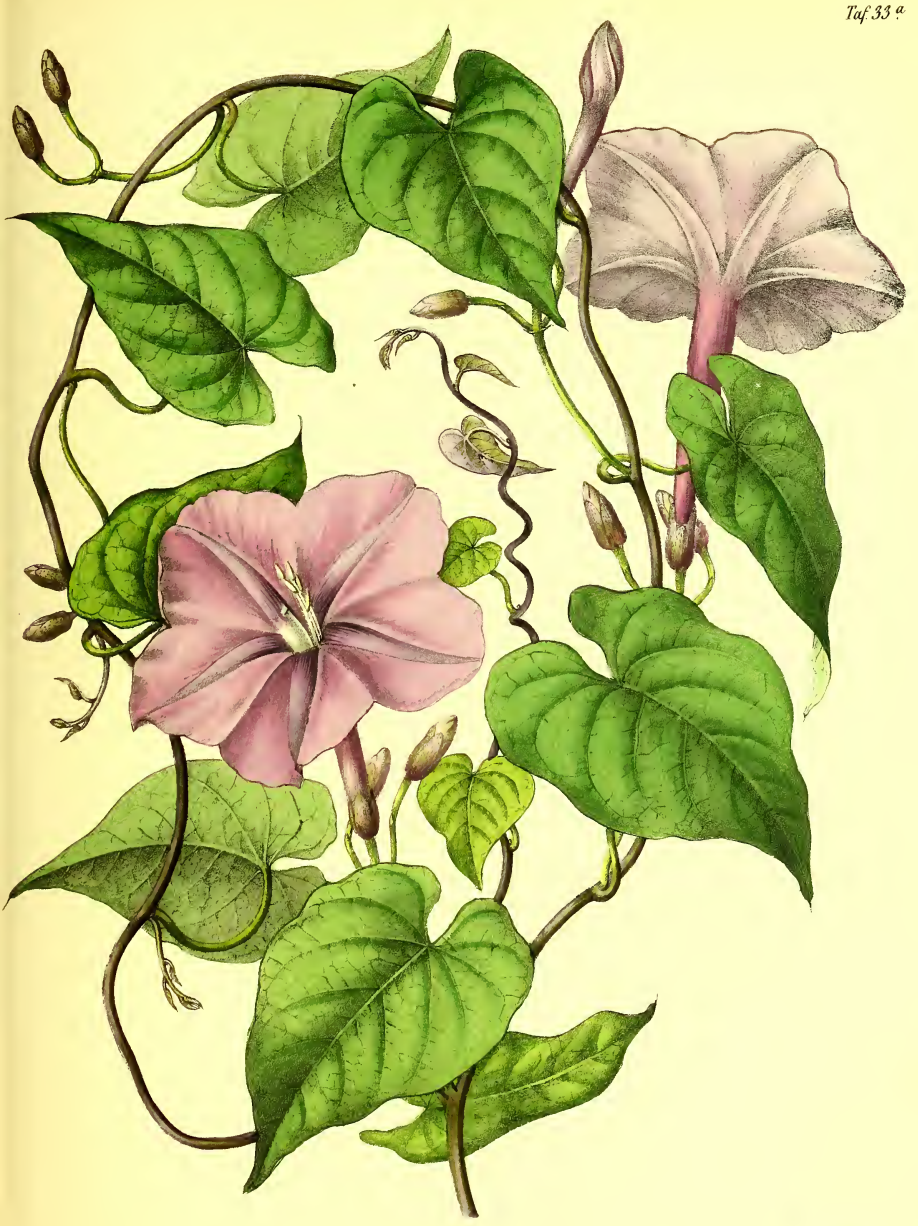

Schmidt lith

Jpomoed purga Wenderoth 



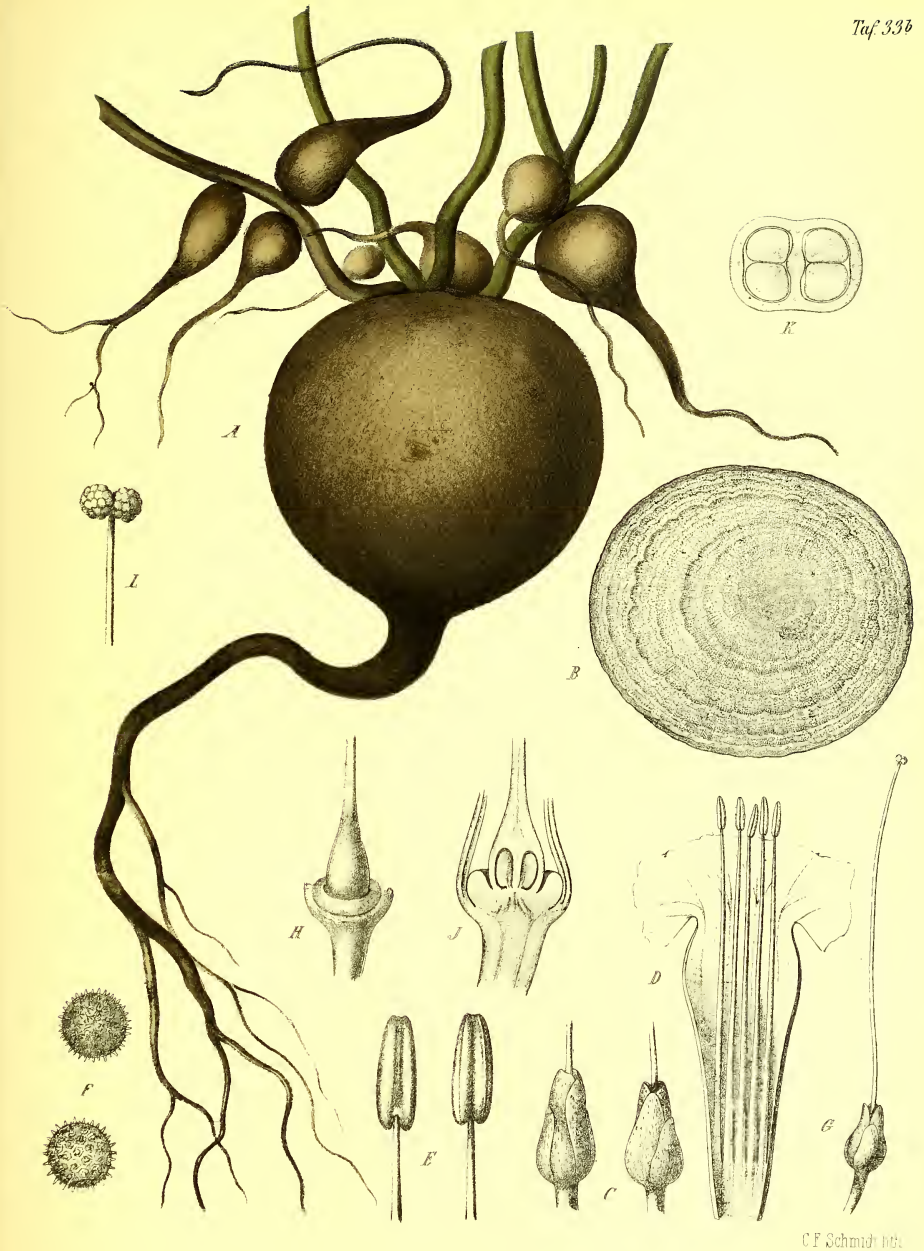

Jpomoea purga Wenderoth 



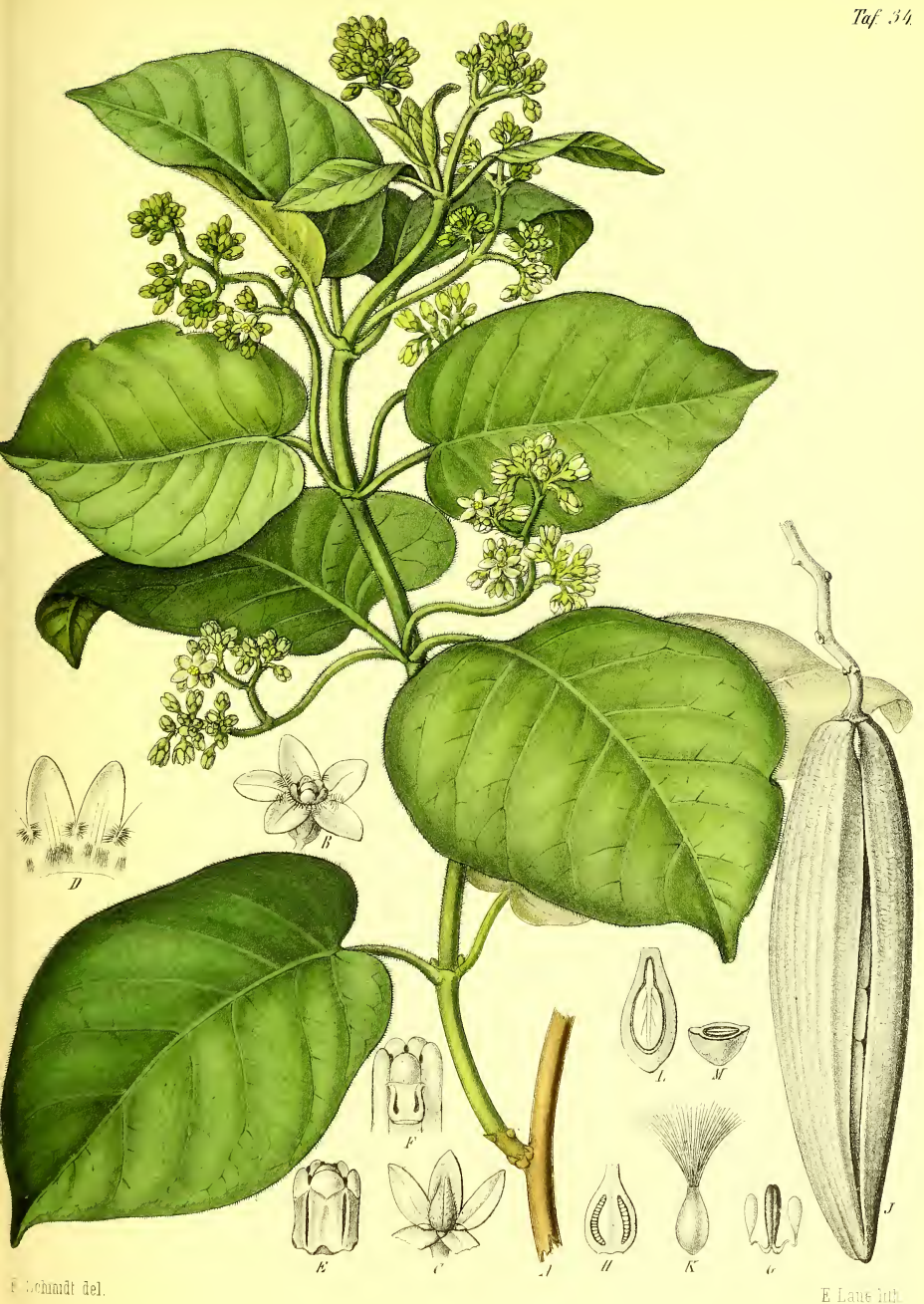

Marsdenia Condurango Richb 



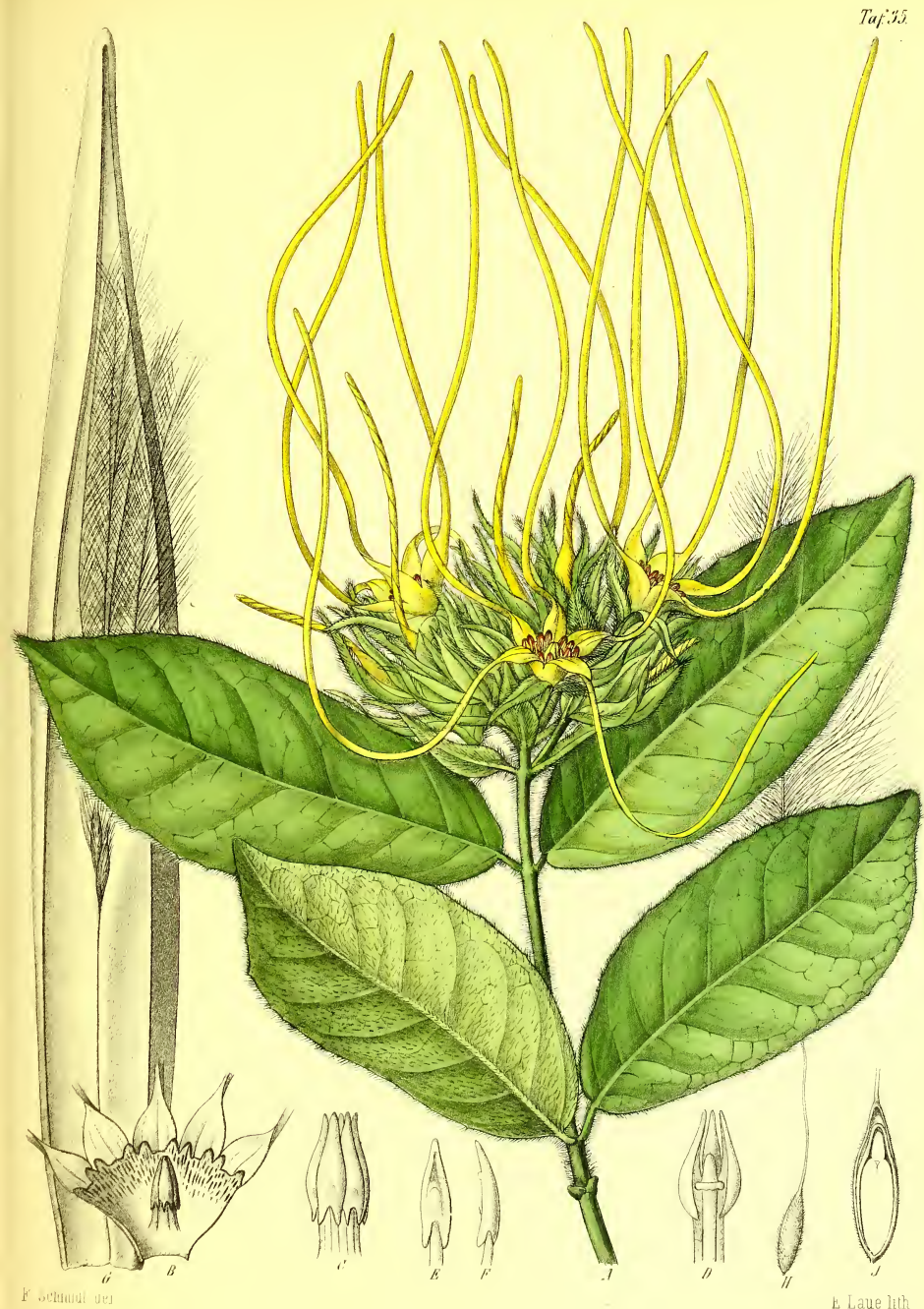

Strophanthus hispidus I) C 



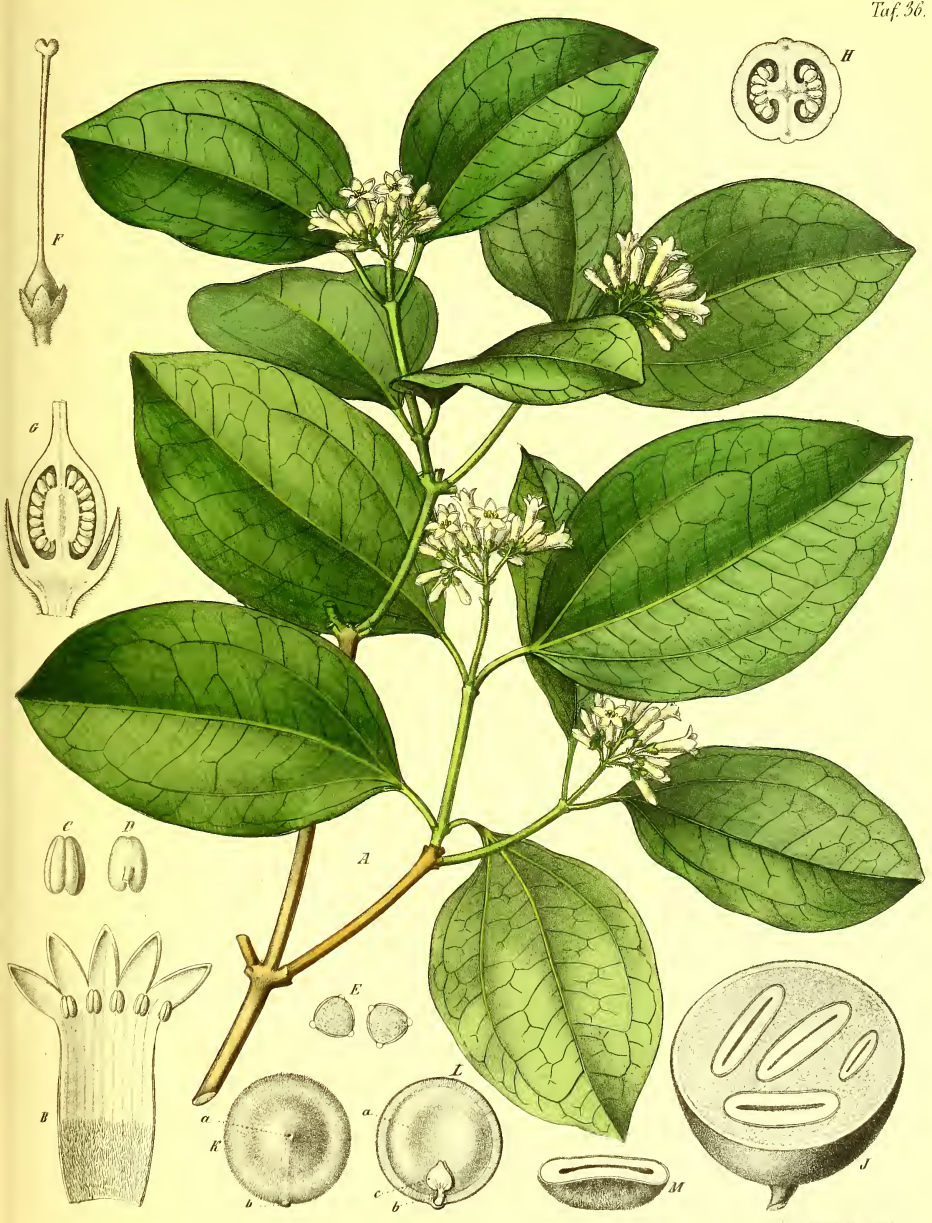

Sirvethosos Jux vomica L. 



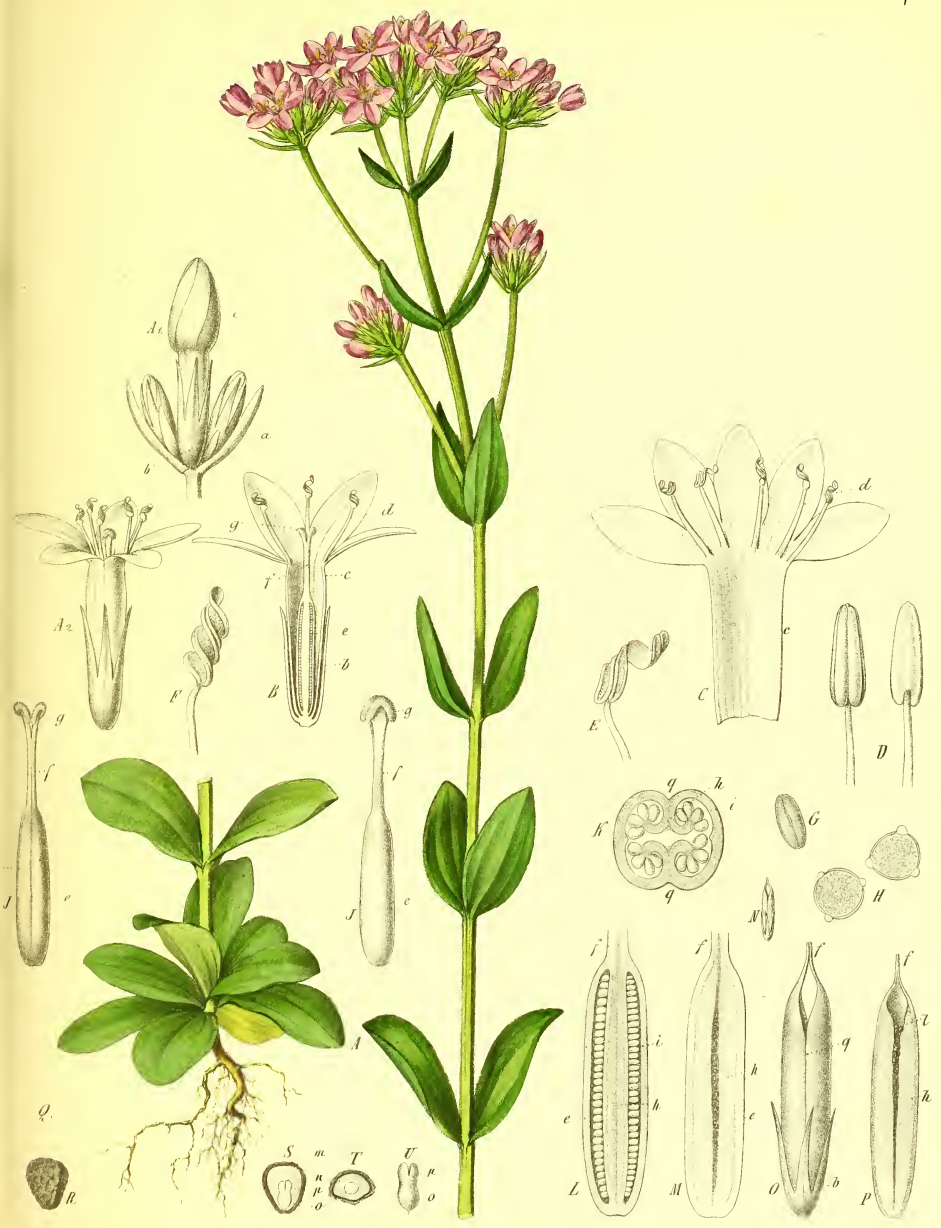

firvthatea l'molurium Pers 



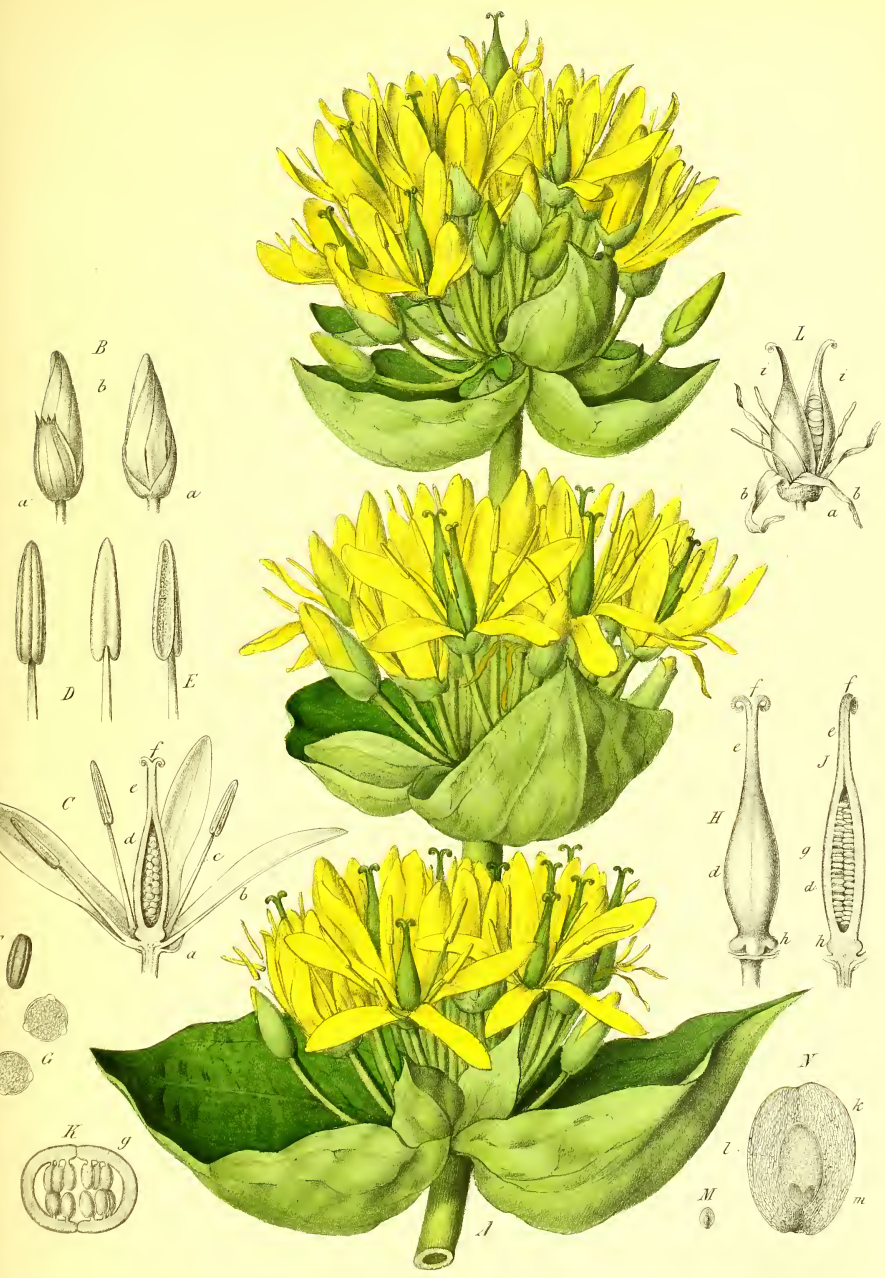

Cienliama bulea I. 

Tup 39

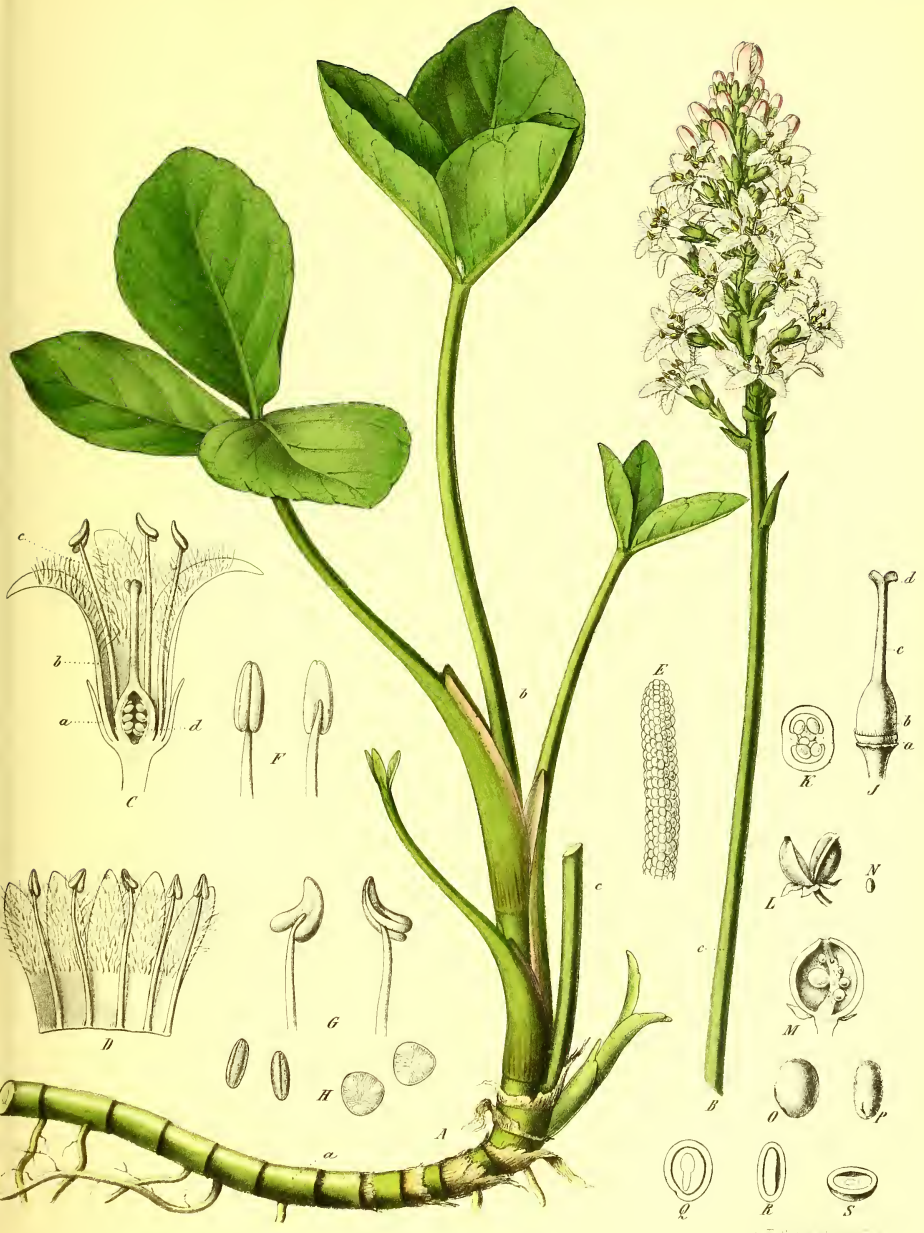

Menvanthes mifolialda L 



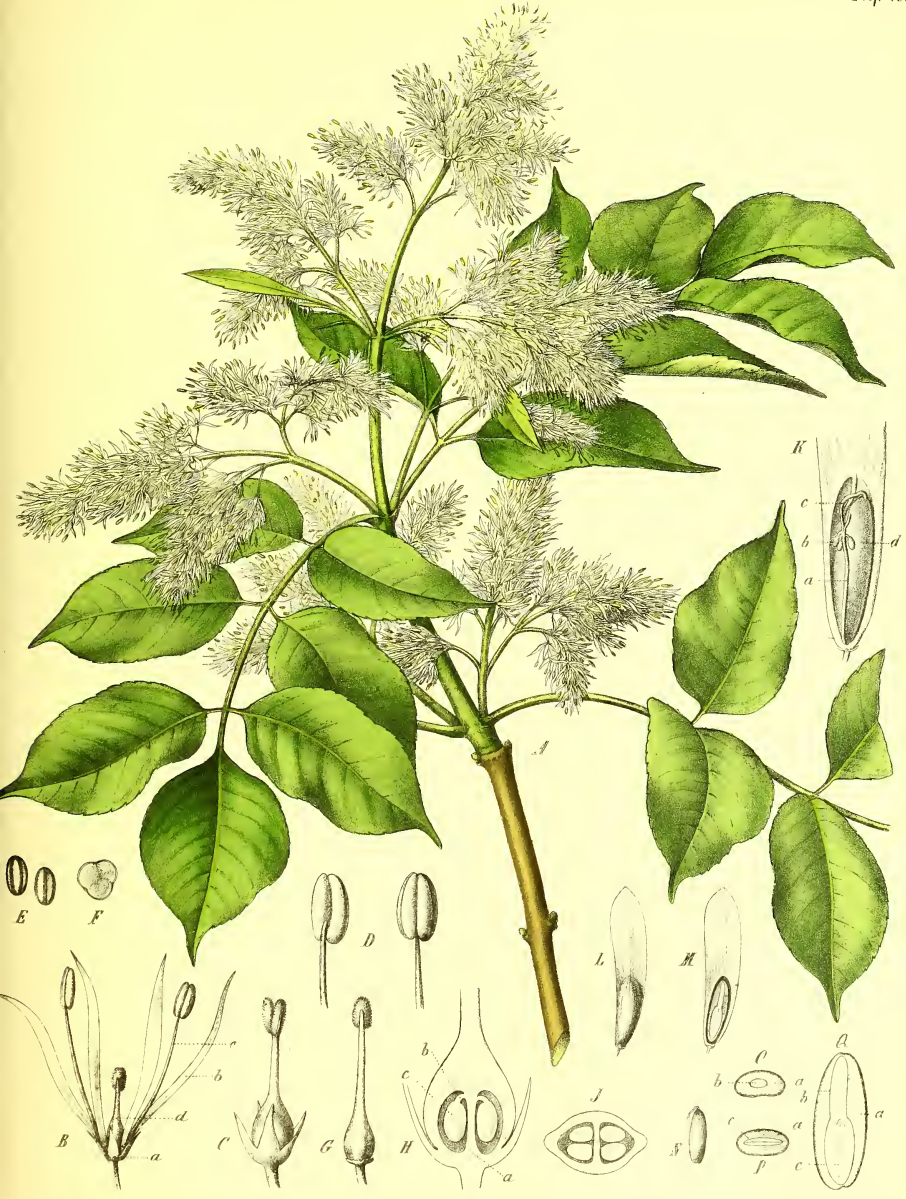

Fradximlls ()houls I. 



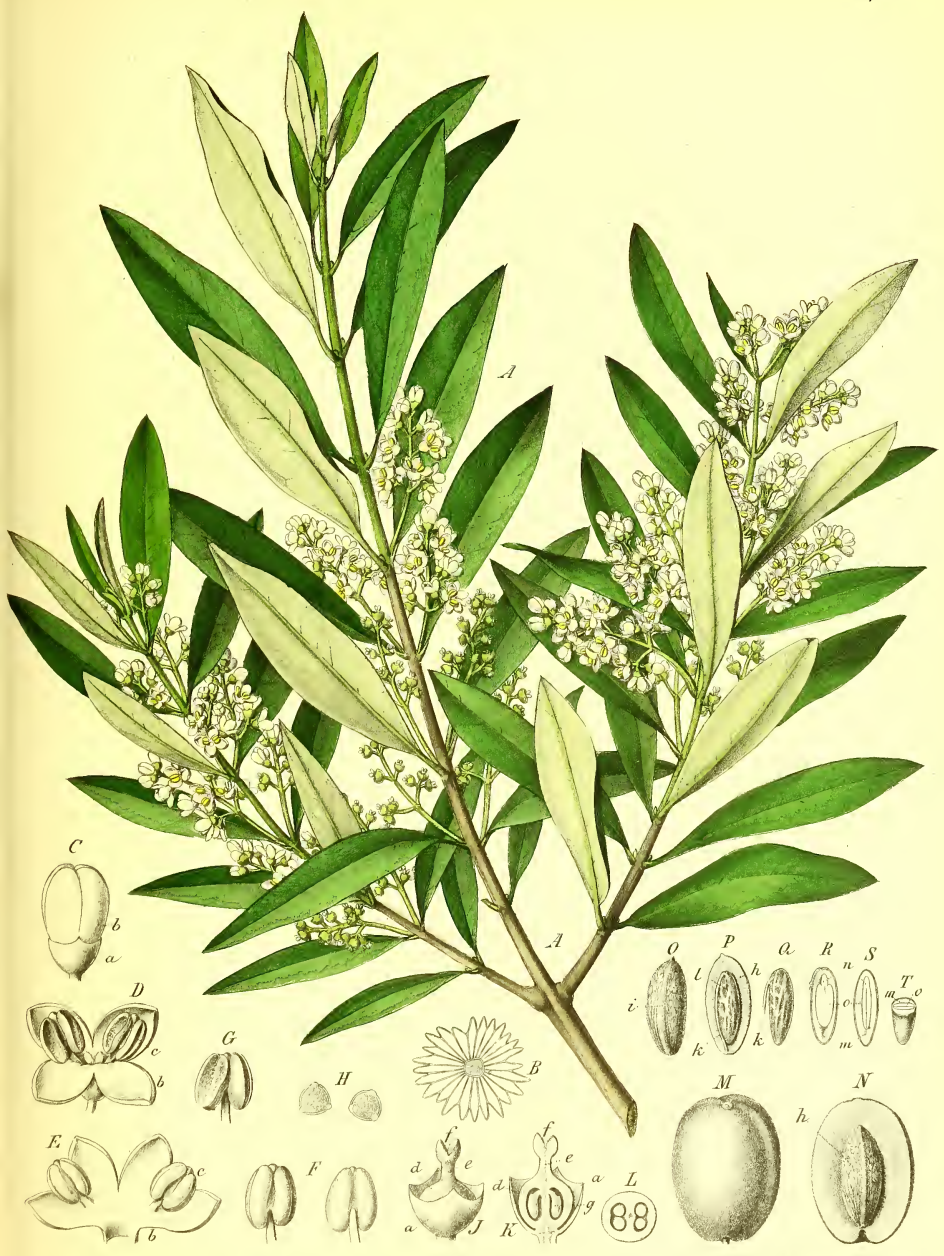

()lea Enopara 



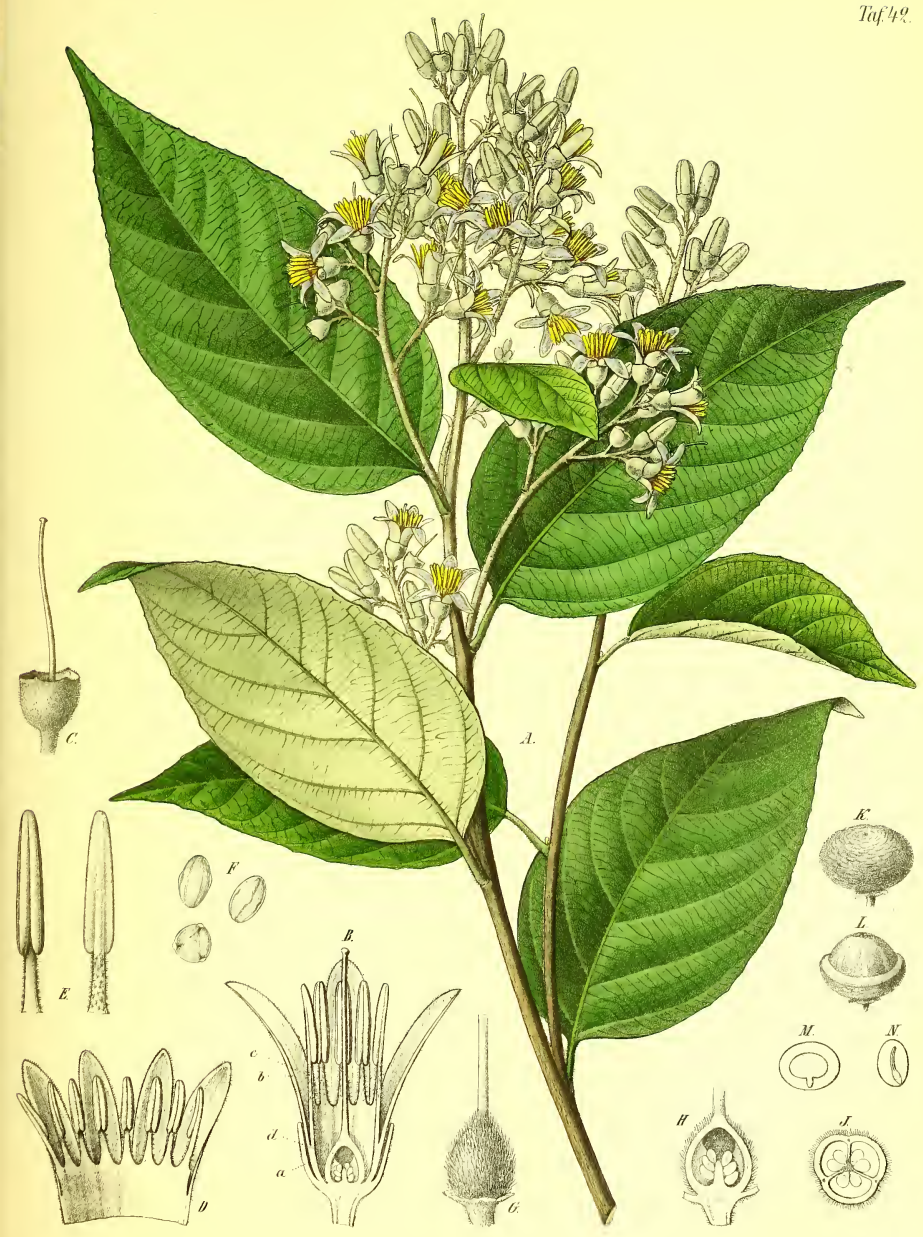

S'lytax Benzom Dryand 




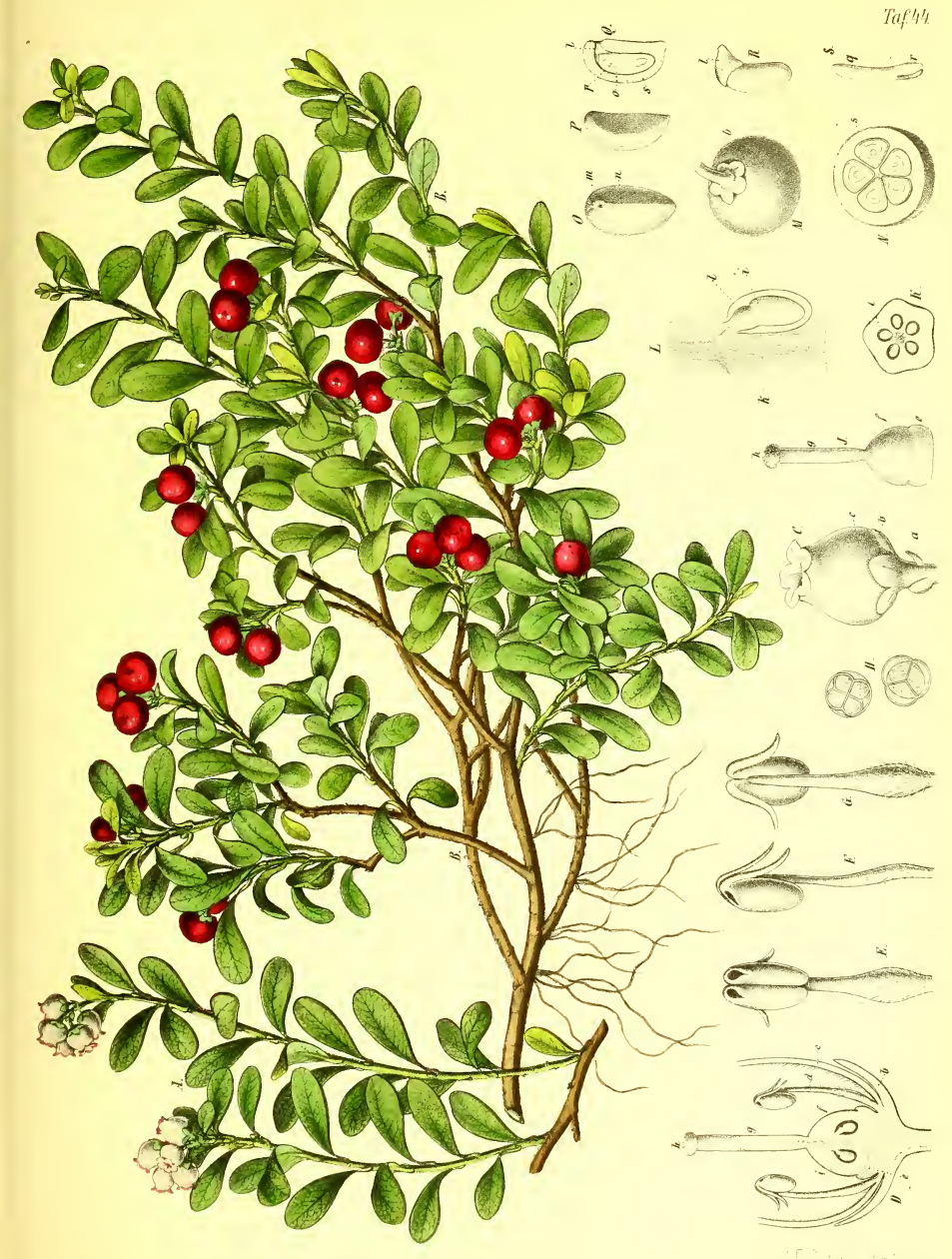

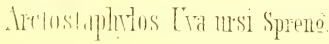





\title{
ATLAS
}

DER

\section{OFFICINELLEN PFLANZEN.}

\author{
DARSTELLUNG UND BESCHREIBUNG \\ DER
}

III ARZNEIBUCHE FÜR DAS DEUTSCHE REICH ERWÄHNTEN GEWÄCHSE.

\section{ZWEITE VERBESSERTE AUFLAGE}

voN

\section{DARSTELLUNG UND BESCHREIBUNG}

SÄMMTLICHER IN DER PHARMACOPOEA BORUSSICA AUFGEFÜHRTEN

$$
\text { OFFICINELLEN GEWÄCHSE }
$$

voN

\section{O. C. BERG}

HERAUSGEGEBEN DURCH

DR. ARTHUR MEYER

PROFESSOR AN DER UNIVERSITÁT IN MARBURG.
DR. K. SCHUMANN

PROFESSOR UND KUSTOS AM KGL. BOT. MUSEUM IN BERLIN.

BAND II.

DIE CHORISTOPETALEN (I. HÄLFTE).

MUT TAFEL XLV-XCIV.

\section{LEIPZIG}

VERLAG VON ARTHUR FELIX 1896. 



\section{Namenregister der Pflanzen.}

Tafel

XLV. Acacia Catechu Willd.

XLVI. Acacia Senegal Willd.

LIX. Andira Pisonis Mart. 34

LXXX. Archangelica officinalis Hffm. . . 87

LIV. Astragalus gummifer Lab. '. . . . 23

LXXIII. Carum Carvi L. . . . . . . . . 73

LXIX. Caryophyllus aromaticus L. . . . . 61

XLVII. Cassia acutifolia Del. . . . . . . 7

XLVIII. Cassia angustifolia Vahl . . . . . 9

LXXII. Conium maculatum L. . . . . . 71

L. Copaifera Langsdorffii Hayne . . . 13

LXXXVI. Croton Eluteria Benn. . . . . 100

LXXXVII. Croton Tighium L. . . . . . 102

IXXXII.III,IV. Dorema Ammoniacum Don . . . 94 u.LXXXIV.

XCIV. Erythroxylon Coca Lam. . . . . 120

LXXXV. Euphorbia Canariensis L. u. E. resinifera Berg. . . . . . . . . 98

LXXXI. Ferula rubricaulis Boiss.. . . . . 89

LXXVII. Eoeniculum vulgare Gärtn. . . . 81

LV. Glycyrrhiza glabra L. . . . . . . 25

LXV. Hagenia Abyssinica Willd. . . . 50

LX. Krameria triandra R. et Pav.. . . 36

LXXIX. Levisticum officinale Koch. . . . 85

LXXI. Liquidambar orientale Mill. . . . 67

LXXXVIII. Mallotus Philippinensis Mull. Arog. 104
Tafel Seito

LXVIII. Melalenca Leucadendron L. . . . 58

LIII. Melilotus officinalis Pers. . . . . 20

LXXVIII. Oenanthe Phellandrium Lam. . . . 83

LI. Ononis spinosa L.. . . . . . 16

LVI. Physostigma venenosum Balf. . . 28

LXXV. Pimpinella Anisum L. . . . . . . 77

LXXVI. Pimpinella Saxifraga L. . . . . . 79

LXVII. Pirus Malus L. . . . . . . . . 55

XCIII. Polygala Senega L. . . . . . . 117

LXII. Prunus Amygdalus Stokes . . . . 43

LXI. Prunus Cerasus L. . . . . . . . 41

LXXIV. Ptychotis Ajowan P. DC. . . . . 75

LXX a u. b. Punica Granatum L. . . . . . . 63

LXIII. Quillaja saponaria Mol. . . . . . 45

XC. Rhamnus cathartica L., . . . . . 109

XCI. Rhamnus Frangula L.. . . . . . 111

LXXXIX, Ricinus communis L. . . . . . 106

LXVI. Rosa centifolia L. . . . . . . . 53

LXIV. Rubus Idaeus L. . . . . . . . . 47

LXXXII. I, II. Scorodosma foetidum Bge. . . . . 91

u. LXXXIII.
IL. Tamarindus Indica L. . . . . . . 11

LVII. Toluifera Balsamum L. . . . . . 30

LVIII. Toluifera Pereirae Baill.. . . . . 32

LII. Trigonella Foenum Graecum L. . 18

XCII. Vitis vinifera L. . . . . . . 113 


\section{Unterclasse: Archichlamydeae.}

(Polypetalae, Eleutheropetalae, Choripetalae, und Apetalae).

Blüthenhülle entweder ganz fehlend, oder einfach oder doppelt und dann in Keleh und Krone geschieden, die letztere mit getrennten Blättern.

\section{Reihe: Rosales Lindl.}

Blüthen aktinomorph oder häufig zygomorph von wirteligem Ban; Blüthenhúlle meist in Kelch und und Blumenkrone gesondert, selten fehlend. Fruchtknoten ober- oder unterständig, Frachtblätter frei oder verbunden.

\section{Familie: Leguminosae Hall.}

Die Blüthen sind entweder aktinomorph oder hänfiger zygomorph mit einer Symmetrale, die meist mit der Mitte des Deckblattes zusammenfällt, gewöhnlich sind sie fünfgliedrig nnd zwittrig; Kelch und Krone sind deutlich von einander gesondert. Der Kelch wird entweder aus einzelnen freien Blättern gebildet, oder er ist röhren- oder becherförmig und gezähnt oder gelappt, dic Knospenlage ist dachziegelig oder klappig. Die Blumenkrone ist entweder fünf-(vier-) blïttrig oder einige, zuweilen alle Blätter sind durch Fehlschlag geschwunden; bei der Fünfzahl steht das nmpaare nach rïekwärts gevendet; häufig ist es sehr vergrössert und heisst dann die Fahne (vexillum); die beiden folgenden, seitlieh aúsgebreiteten führen den Namen Flïgel (alae), die beiden untersten, oft mit einander verbundenen die Bezeichnung Kiel (carina). Diese Form der Blithen heisst Sehmetterlingsblïthen, bei ibr ist die Deekung gemeinlich absteigend; die actinomorphen Blumenkronen haben klappige Knospenlage der Blïtter. Staubgefässe sind meist doppelt so viele als Blumenblätter, zuweilen aber sehr vicl mehr, manehmal durch Fehlschlag weniger vorhanden; neben den fruchtbaren finden sich dann anch zuweilen unfruehtbare; sie sind unter dem Fruchtknoten oder am Kelchrande befestigt nud hänfig mehr oder weniger unter sich verbunden; die Staubbeutel sind ditheeiseh und springen mit nach innen gewendeten Längsritzen, seltener mit Poren auf. Der Stempel besteht allermeist nur aus einem Fruchtblatte; die einzelnen oder zahlreichen Samenanlagen sind an dem Innenwinkel befestigt, der nach der Fahne hin geriehtet ist, sie sind gewendet und meist hängend; der Griffel ist einfach und trägt an der Spitze eine endständige oder scitenständige Narbe. Die Frucht ist eine Hülse (legumen), die entweder trocken ist und nur auf der Banchscite oder zugleich auf der Riickenseite und dann in zwei Klappen anfspringt, oder fleischig ist und geschlossen bleibt; sie ist entweder durchgehend einftichrig oder durch falsche Scheidewände in über einander stehende Fächer getheilt, nach denen sie zuweilen bei der Reife in einzelne Stïeke zerfällt (Gliederhülse). Die Samen sind an der oberen Naht der Hülse abweehselnd in zwei Reihen befestigt, selten stehen sie dort gepaart; der Nabelstrang ist an der Ansatzstelle zuweilen zu einem Samenmantel verbreitert; Nührgewebe fehlt fast stets, dafür sind die, Keimblaitter dick und fleisehig, das Würzelehen blickt meist nach oben und ist häıfig: den Keimblättern aufgelegt. 
Bäume, Sträucher oder Kräuter von sehr mannigfacher Tracht. Die Blätter sind mit zwei zuweilen sebr grossen Nebenblättern versehen und allermeist spiralig. gestellt, nur bei den windenden Formen sind sie oft dorsiventral zweizeilig geordnet. Sie sind meist gefiedert (einfach oder mehrfach) oder gefingert; selten sind sie bis auf den dann verbreiterten, blattartigen Stiel reduciert (Phyllodien) oder einfach. Bie Blithen stehen entweder in endständigen Trauben oder Rispen oder sind aus Laubblättern achselständig, sie sind meist mit Vorblättchen versehen.

Die Zahl der Arten muss auf mehr als 7000 gesehätzt werden, die in uiber 400 Gattungen vertheilt sind, sie wachsen in fast allen Theilen der Erde, sind aber in den Tropen, am Cap, in den Steppen Asiens und in Australien besonders entwickelt, in Neu-Seeland sind sie selten und auf den Inscln der südlich gemässigten und kälteren Zone fehlen sie.

Die officinellen Leguminosen gehören in folgende Gruppen:

Unterfamilic I. Mimoseae R. Br. Blithen stets aktinomorph. Keleh röhrenförmig mit klappiger oder dachziegeliger Knospenlage. Blumenblitter gleich, in der Knospenlage klappig, am Grunde oft verbunden. Staubgefüsse frei oder einbrïdrig verbınden, zuweilen sehr zahlreich, nicht selten aber von der einfachen oder doppelten Zahl der Kelch- und Blumenblïtter; Pollen zuweilen in Pollinien verklebt.

\section{Acacia Catechu Willd.}

2. Acacia Senegal Willd.

Unterfamilie II. Caesalpinieae R. Br. Blutthen hänfig zygomorph. Kelchblatter meist bis zum Grunde frei. Blımenblätter dachziegelig und zwar aufsteigend deckend. Staubgefässe meist frei. Würzelchen meist gerade.

3. Cassia acutifolia Del.

4. Cassia angustifolia Vahl.

5. Tamarindus indica $\mathrm{L}$.

6. Copaifera Langsdorffii Hayne.

7. Krameria triandra Ruiz et Pavon.

Unterfamilie III. Papilionatae Neck. Blithen zygomorph. Der Keleh röhren- oder becherförmig, meist gezähnt. Blumenblätter dachig deekend und zwar von oben nach unten absteigend (echte Schmetterlingsbluthen). Das Würzelchen ist meist gebogen und liegt den Keimblättern auf, selten ist es gerade und aufrecht.

TRIBUS I. Trifolieae Bronn. Aufrechte oder niederliegende Kräuter mit gedreiten Blättern, deren Nerven häufig in einen Zahn auslaufen. Die 10 Staubgefässe ein- oder zweibrüdrig verbunden (dann neun verwachsen und eins frei.

\section{S. Onomis spinosa L. \\ 9. Trigonella Foemum graecum L. \\ 10. Melilotus officinalis Pers.}

TRIBUS II. Galegeae Bronn. Aufrechte oder niedcrliegende, nicht windende Kräuter, seltener Sträucher oder Bäume mit gefiederten Blättern, die meist ganzrandig sind. Die 10 Staubgefässe zweibrüdrig, wenn einbrüdrig ist das einzelne wenigstens am Grunde frei. Hülse zweiklappig, selten nicht aufspringend und dann klein oder häutig geflügelt.

11. Astragahus gummifer Poir.

12. Glycyrrhiza glabra L.

TRIBUS III. Phaseoleae Bronn. Windende seltener aufrechte Kräuter, sehr selten baumartig mit gedreiten Blättern, die ganz oder gelappt und häufig mit Nebenblättchen versehen sind. Blüthen traubig oder gebuischelt, meist achselständig. Staubgefässe 10, meist zweibrïdrig. Hülse zweiklappig. 
13. Physostigma venenosum Balf.

TRIBUS IV. Sophoreae Spreng. Bäume, höhere Sträncher oder Lianen mit meist gefiederten Blättern. Stanbgefässe 10 , alle frei.

\section{Toluifera Balsamum L.}

15. Toluifera Pereirae Baill.

TRIBUS V. Dalbergieae Bronn. Bäume, höhere Sträucher oder Lianen mit gefiederten Blättern. Staubgefässe 10, ein- oder zweibrïdrig. Hülse nicht aufspringend.

16. Andira.

\section{ACACIA Willd.}

Blïthen vier- oder fünfgliedrig, zwittrig oder durch Fehlschlag der Samenanlagen vielehig. Kelch glockenförmig, gezähnt oder gelappt, seltener in freie Blätter aufgelöst oder ganz fehlend. Blumenblätter gewöhnlich mehr oder weniger hoch verbunden, selten völlig fehlend. Stanbgefässe meist sehr viele, bis 400, gewöhnlich viel auffälliger als die iibrigen Blïthenorgane und durch ihre weisse oder meist gelbe Farbe die Schaustellung der Blüthe bedingend, frei, oder hänfiger am Grunde becherförmig verbunden; Staubbeutel klein, mit Längsspalten aufspringend, die Pollenkörner zu 2-4 Massen (Pollinien) vereinigt. Fruchtknoten sitzend oder gestielt, mit $2-\infty$ Samenanlagen. Hülse sehr verschieden gestaltet, aufspringend oder geschlossen, einfächrig oder quergefächert. Samen zusammengedriickt mit langem Nabelstrange, der sich am Nabel zuweilen zu einem Arillus erweitert. - Bäume, Sträucher oder sehr selten Kräuter, die entweder mit Stacheln bewehrt oder unbewehrt sind, mit doppelt gefiederten Blättern; die Fiederchen meist klein und sehr zahlreich, nicht selten sind die Blätter auf die dann sehr vielgestaltig. verbreiterten und blattartigen Blattstiele reduciert (Phyllodien); sie sind mit Nebenblättern versehen, die häufig in Stacheln umgebildet werden. Die kleinen Blithen sind zu Köpfchen oder Ähren zusammengestellt, welche wieder einzeln oder gepaart aus den Blattachseln treten oder rispige, endständige Inflorescenzen bilden; sie werden von schuppenförmigen, meist leicht abfälligen Deckblättern gestiitzt, die anch fehlen können.

In der Gattung sind iiber 450 Arten beschrieben, welche in den Tropen beider Hemisphären und den subtropischen Gegenden gedeihen, besonders häufig sind sie am Cap und in Australien.

\section{Acacia Catechu Willd.}

Tafel 45 .

Ein hoher Baum, dessen jüngere Triebe mehr oder weniger behaart sind; Blätter doppelt gefiedert mit gepaarten, kurzen, gerade oder wenig gekrümmten Nebenblattdornen; Fiedern zehn- bis zwanzigpaarig, Blättchen in 20-30 Paaren, lineal, gewimpert oder kahl; Blïthen gelb in verlängerten Ähren; Blumenkrone $1 \frac{1}{2}-2$ mal so lang als der filzige Kelch; Hülse lineallanzettlich, sehr flach, zugespitzt an beiden Enden.

Acacia Cateehu Willd. Spec. pt. IV. 1079; Hayne, Arzneipf. VII. t. 48; Woodo. Med. pl. t. 157; DC. Prodr. II. 458; Guimp. et Schlccht. Pharm. Pfl. t. 151; Nees, Diisseld. Abbild. t. 335 ; Benth. in Hook. Lond. Journ. of bot. I. 510 ; Berg und Sehmidt, Darstell. und Beschreib. t.VTe; Baker, in Hook. Fl. Br. Ind. II. 295; Turz, F7. Brit. Burma I. 422; Tiohler, Med. Pf. t. 116 .

Acaeia polyacantha Willd. Spce. pl. IV. 1079.

Mimosa Catechu Linn. fil. Suppl. 439; Roxb. Coromand. pl. II. 40. t. 175; Ker, Med. Obs. t. 4. Mimosa catechoides Roxb. 17. ind. II. $562^{*}$ ).

Katechu-Aliazie; engliseh: Catcchu Aeacia; französisch: Acaeia catechu.

*) Ob A. Wallecleiana $D C$. hierher gehört, ist zweifelhaft; von $\mathrm{S}$. Kurz wird auch $A$. Sundra DC. mit $A$. Cateehu W. zu einer Art verbunden. 
Der Baum wird 16-20 $\mathrm{m}$ hoeh und hat dabei einen Stammumfang von 1,3-2 m; seine Zweige sind mit $1 \mathrm{~cm}$ langen, sehr spitzen, meist hakenförmig nach unten gekrümmten, zuweilen aber auch geraden, von der Seite zusammengedrückten, zuerst gelbbraunen, dann schwarzen Stacheln bewehrt, die den Nebenblättern homolog sind. Die jüngeren Triebe sind mehr oder weniger kurzhaarig; die älteren sind mit einer in Streifen sich ablösenden Rinde bedeckt, die längere Zeit haften bleiben; das Holz ist hart und schwer, roth- bis schwarzbraun, der Splint ist hell.

Die Blätter sind 10-14 em lang, paarig doppelt gefiedert und werden aus $12-20$ gegenständigen Fiederpaaren zusammengesetzt; jede Fieder hat 20-40 Paar Blättchen, die 4-6 mm lang und höchstens $1 \mathrm{~mm}$ breit sind; ihre Form ist linealiseh, am Grunde sind sie sehief, einseitig abgerundet, am Rande sind sie angepresst gewimpert, an dem oberen Ende stumpf oder spitz. Die Spindel ist sehr fein filzig, oberseits rinnig vertieft: in der Mitte des 3-4 em langen, unten verdickten Blattstieles sitzt eine fleisehige, schüsselförmige, kreisrunde Drise, zu der sich noch eine obere bei dem dritten bis sechsten Fiederpaare gesellt.

Der Blüthenstand ist eine 5-10 cm lange, dichte, unten lockere, walzenförmige, achselständige Ähre, welche von einem 1-2 cm langen, stielrunden, filzigen Stiel getragen wird; die Spindel ist ebenfalls grau- bis rostbraunfilzig.

Die Blüthen sind sitzend, sie werden von noch nieht $1 \mathrm{~mm}$ langen, lanzettlichen, aussen filzigen, innen kahlen Deckblättern gestiitzt und messen in der Vollblithe etwa 5-6 mm. Der Keleh ist $2 \mathrm{~mm}$ lang, glockenförmig, fein filzig, im oberen Drittel fünfzähnig; die Zähne sind dreiseitig, spitz, aussen behaart, gewimpert und in der Knospenlage klappig. Die Blumenblätter sind gewöhnlich nur um die Hälfte, zuweilen aber um das doppelte länger als der Keleh, sie sind häufig, hoch verwachsen und nur die fünf etwas nach aussen gekrlimmten, dreiseitigen Zipfel sind frei. Die Staubgefässe sind sehr zahlreich, etwa doppelt so lang wie die Blumenblätter, sie sind unter dem Fruchtknoten befestigt und unten einbrtidrig verbunden; die Fäden sind fast haarförmig, bei starker Vergrösserung betrachtet erweisen sie sich aber nicht glatt, sondern höckerig. Die Staubbentel sind kreisförmig, unterseits flach, oben und unten ein wenig ausgerandet und haben nur $0,1 \mathrm{~mm}$ Durchmesser. Die Pollenkörner sind zu 16 in kugel- oder gerundet wiirfelförmige Pollinien verbunden, deren je $2-4$ in einem Fache sich befinden. Der Stempel ist mit einem kurzen Stielehen einer fleischigen Seheibe aufgesetzt, er tiberragt die Staubgefässe nur wenig; der Fruchtknoten ist oblong lineal, noeh nicht $1 \mathrm{~mm}$ lang und umschliesst zahlreiche rückenständige Samenanlagen; der Griffel ist fadenförmig und endet in eine kopfförmige Narbe.

Die Hülse ist $6-14 \mathrm{~cm}$ lang und 1,0-1,3 cm breit, sie ist sehr flach, beiderseits zugespitzt und unten in einen Stiel endend, sie ist braun bis sehwarz, häufig glänzend und beiderseits gerandet.

Der Same hat einen Durehmesser von fast $1 \mathrm{~cm}$; er ist kreisförmig, zusammengedrỉekt, braun mit einem Stiche ins Graue und hat in der Mitte eine hellere Zone; er sitzt an einem fadenförmigen, gekrümmten, am Ende erweiterten Nabelstrange. Der Keimling hat dieselbe Gestalt, das Knöspehen besteht aus deutlieh gefiederten Blättern.

Die Katechu-Akazie wächst in Vorderindien längs des Himalaya bis zu einer Höhe von $13-1500 \mathrm{~m}$, auch in Birma ist sie verbreitet.

Das Holz des Baumes, welches auch als Nutzholz von Bedeutung ist, enthält in seinem Kernholze grosse Mengen von Catechu. Man koeht das Kernholz mit Wasser aus, dampft die Abkochung so lange ein, bis sie beim Erkalten erstarrt, giesst sie in Thonformen oder auf Matten und Blätter aus und lässt sie in der Sonne austrocknen.

Das so dargestellte Produkt ist das Catechu (Pegu-Catechu). 


\section{Erklärung der Abbildungen.}

Fig. A. Ein Zweig nach einer Pflanze aus Vorderindien.

Fig. B. Die Bliithe, 6mal vergrössert.

Fig. C. Die Blüthe im Längssehnitte, $7 \mathrm{mal}$ vergrössert.

Fig. D. Das Staubgefïss von der Vorder- und Rückseite betrachtet, $50 \mathrm{mal}$ vergrössert.

Fig. E. Pollinium, aus 16 Körnern zusammengesetzt, 200mal vergrössert.
Fig. $F$. Die aufgesprungene Hülse, natïrliche Grösse.

Fig. G. Der Same mit dem Nabelstrange.

Fig. H. Derselbe, im Quer- und Längsschnitte.

Fig. I. Der Keimling: $a$. das Würzelchen.

Fig. $K$. Derselbe, das eine Keimblatt entfernt.

Fig. $L$. Die Spitze desselben, 6mal vergrössert: $a$. Wïrzelchen; $b$. Keimblatt; $c$. Knöspchen.

\section{Acacia Senegal Willd.}

Tafel 46.

Ein niedriger Baum mit knorrigen, gewundenen Ästen; jüngere Zweige kahl, von bleicher Farbe; Stacheln 2-3 kurz, hakenförmig nach unten gekrümmt; Blätter doppelt gefiedert, Fiedern 3-5 Paare, Fiederchen 10-15 jochig, schmal linealisch, graugrïn, kahl; Blüthen weiss in verlängerten Ähren; Blumenblätter $1 \frac{1}{1} 2-2$ mal so lang wie der kahle Keleh.

Acacia Senegal Willd. Spec. pl. IV. 1077 (die cit. Abbildung ausgeschlossen); DC. Prodr. II. 459; Benth. in Trans. Linn. Soc. XXX. 516.

Mimosa Senegal Linn. Spec. pl. ed. I. 521 .

Acacia Verek Guill. et Perrott. Fl. Senegambiae 245. t. 56; Schweinf. in Linnaea XXXV. 374. $t$. 22; Reliq. Kotschyan. t. 3; Oliv. Fl. trop. Afr. II. 342; Köhler, Med. Pfl. t. 173; Fliick. Pharmacogr. 4.

Acacia rupestris Stocks in Boiss. Fl. orient. II. 63S.

Gummi-Aliazie; engliseh: Gum acacia; französisch: Acacie à gomme.

Der Ba um wird nicht über $6 \mathrm{~m}$ hoch; der aufrechte oder mehr oder weniger stark geneigte Stamm hat ungefähr 12-15 cm Durehmesser, das sehr harte Holz ist weiss und die Rinde ist aussen grau, der Bast aber rostfarbig; die sehr zahlreichen gewundenen Äste spreizen auseinander.

Die Blätter sind an der Spindel gemessen nur $2-3 \mathrm{~cm}$ lang; sie sind $3-5$ paarig gefiedert und die gegenständigen Fiedern werden aus $10-15$ Paar 3,5-5 mm langen und 1-1,3 mm breiten Fiederchen zusammengesetzt; die letzteren sind linealiseh, spitzlich, am Grunde ungleichseitig, sehr kurz gestielt und von graugrtiner Farbe; die Spindel ist kantig, oberseits von einer engen Rinne durehzogen, fein behaart und unterhalb der Blätter, so wie zwischen den obersten Blattpaaren mit je einer gelben, polsterförmigen, am Scheitel eingedrückten, fleischigen Drüse versehen; zu beiden Seiten des Blattstieles, zuweilen auch genau unter ihm steht je ein bis $5 \mathrm{~mm}$ langer, gekrummter, sehr spitzer, gelber, endlich brauner Nebenblattdorn.

Die Blüthenstände sind 6-10 $\mathrm{cm}$ lang, nur kurz, 1-2 cm lang gestielt und stellen walzigrunde, mässig dichte Ähren dar, die einzeln oder zu zweien und dreien aus den Blattachseln brechen. Deckblätter habe ich nicht gesehen.

Die Blüthen sind sitzend und weiss. Der Keleh ist becherförmig kahl, $2 \mathrm{~mm}$ lang und im oberen Drittel in 5 etwa gleichseitig dreieckige Zipfel getheilt. Die Blumenblätter messen $3-3,5 \mathrm{~mm}$, sie sind lanzettlich, spitz und bis zur Hälfte oder dariber hinaus verwachsen. Die Sta ubgefässe messen $6 \mathrm{~mm}$, ihre Staubfäden sind haarförmig und selbst bei sehr starker Vergrösserung nur sehr wenig höekerig, sie sind am Grunde durch einen fleischigen, fast becherförmigen Körper einbrïderig verbunden, in dessen Mitte der kurz gestielte etwa 0,8-1 mm lange, lineale, zusammengedrückte Fruchtknoten steht; die Staubbeutel sind breit elliptiseh, nur $1-1,5 \mathrm{~mm}$ lang und oben so wie unten tief ausgerandet; sie enthalten nur sehr wenige Pollinien, aus 16 Pollenkörnern bestehend. Der Griffel überragt die Staubgefässe kaum und endet in einer kopfförmigen aber nur sehr wenig verdiekten Narbe.

Die Frueht ist eine 7-10 em lange und 1,5-2,5 em breite, mehr oder weniger deutlich lineale, beiderseits spitze, flache, dünne, zwciklappige Hülse; die Klappen sind quer geadert, haben gerade 
oder gewellte Ränder und sind zuweilen unregelmässig hier und da zusammengeschnürt; sie enthalten 5-6 Samen.

Der Same hat 0,8-1 cm im Durehmesser; er ist fast kreisrund, nur an der Basis ein wenig ungleiehseitig ausgerandet, sehr zusammengedriekt und auf jeder Seite mit einem gekrümmten Eindrueke geziert, die Farbe ist braun, die Oberfläche glänzend; er hängt an einem langen gekrümmten, oben erweiterten Nabelstrange.

Diese Gummi-Akazie wächst in Senegambien, in der Nähe der grossen Wüste an einzclnen Stellen in sehr grossen Bestïnden, sie kommt aueh im südlichen Nubien am Astaboran und Atbara, bei Kassala und Gedaref, sowie in Kordofan vor; ausserdem findet sie sich in Arabien und zwar sieher bei Maskat, Aden und Dsehidda, vielleieht auch weiter verbreitet und endlieh in Belutsehistan. Der rothe Bast der Pflanze wird zu Strieken verarbeitet und zu diesem Zweeke in ganzen Kameellasten gesammelt.

Der Baum liefert vom 7. bis 45. Jahre reiehlich das Gummi arabicum (Gummi senegalense, SenegalGummi), welches ans den vorziglich in Folge austroeknender Ostwinde entstandenen Rissen der Rinde hervortritt. Über die Ursache des Gummiflusses von Acacia Senegal ist Sicheres noch nieht bekannt.

\section{Erklärung der Abbildungen.}

Fig. A. Ein Zweig der blühenden Pflanze, nach einem Exemplare aus Kordofan.

Fig. B. Die Blüthe, 5 mal vergrössert.

Fig. C. Die Staubgefïsse, am Grunde durch einen flcischigen Ring verbunden.

Fig. D. Das Staubgefïss, 40mal vergrössert.
Fig. E. Ein Pollinium, 200mal vergrössert.

Fig. F. Der Fruchtknoten mit einem Theile des Griffels, $10 \mathrm{mal}$ vergrössert.

Fig. G. Zwei Früchte, natïrliche Grösse.

Fig. H. Ein Theil der Fruchtklappe mit 3 Samen.

Fig. I. K. Der Same im Quer- und Längsschnitte.

\section{CASSIA Linn.}

Kelchblätter bis zum Grunde frei mit daehziegeliger Knospenlage. Blumenblätter abstehend, gleich oder etwas ungleich und dann die unteren grösser. Staubgefässe 10, die entweder alle vollkommen und gleieh, oder deren obere kurzer sind; oft aber werden die oberen drei, seltener fünf zu unfruehtbaren Staminodien umgebildet; die Staubbeutel sind entweder sämmtlieh gleieh, oder die der unteren Staubgefässe sind grösser; sie springen mit endständigen Poren oder kurzen Spalten, manehmal mit grundständigen auf; Pollenkörner einzeln. Fruchtknoten gestielt oder sitzend, gewöhnlich stark gekrümmt mit vielen Samenanlagen: Griffel kurz oder verlängert mit gestutzter, kleiner Narbe. Hülse stielrund oder flaeh und stark zusammengedrüekt, holzig oder häutig, meist zweiklappig aufspringend, innen zuweilen durch falsehe Scheidewände gefäehert, und mit saftigem Marke gefüllt. Samen versehieden gestaltet, bäufig zusammengedrückt; der Keimling liegt in einem deutlichen hornigen Nährgewebe; das gerade Würzelehen ist kurz, die Keimblätter sind flaeh oder gewellt. - Bäume, Sträueher oder Kräuter mit spiralig oder dorsiventral gestellten paarig gefiederten Blättern mit zuweilen sehr grossen Nebenblättern; Blätter selten auf den blattartig verbreiterten Blattstiel reduciert; Drüsen sitzen häufig auf den Blattstielen. Blüthen in end- oder seitenständigen Trauben oder Rispen, selten einzeln oder gepaart aus den Blattaehseln.

Die Zahl der Arten beläuft sieh auf über 350, die besonders den wärmeren Erdstriehen beider Hemisphären angehören, aber auch in Neu-Seeland, Argentinien und den nördlichen Vereinigten Staaten noeh gedeihen.

Die beiden officinellen Arten der Gattung gehören in die Seetion Senna Bth., die sich dureh drei obere unfruehtbare Staubgefässe und dureh sieben fruehtbare Staubgefässe auszeiehnet, von denen die unteren wieder viel länger als die mittleren sind. Die Hülse springt auf und ist flaeh zusammengedrüekt ebenso wie die Samen; die Trauben sind blattaehselständig. 


\section{Cassia acutifolia Del.}

Taf. 47 .

Halbstratehig mit 4-5jochigen Blättern; Blättehen oblonglanzettlich, spitz, behaart oder kahl; Stiel der Hülse seitlich gerückt, diese ein wenig sichelförmig gekrümmt.

Cassia acutifolia Del. Fl. Aegypt. II. 259. t. 27; Oliv. Fl. trop. Afr. II. 279; Benth. in Trans. Linn. Soc. XXVII. 553; Bentl. and Trim. Med. pl. t. 90; Köhler, Mediz. Pfl. t. 156; Flizck. Pharmacogr. 561; Arth. Meyer, Drogenkunde II. 231.

Cassia Senna Linn. Spec. pl. ed. I. 377; Woodv. Med. bot. 442. t. 159.

Cassia lanceolata Nectoux, Voy. en haut Égypte. 20. t. 2; Collad. Casses 93. t. 15. Fig. C; Hayne, Arzneigew. IX. t. 41; DC. Prodr. II. 492; Nees, Düsseld. Abbild. t. 343; Guimp. u. Schlecht. Pharmac. Pf. III. 6. t. 205; Bniss. Fl. orient. II. 632 nicht Forskal.

Cassia lenitiva Bisch. in Bot. Zeit. 1850. p. 885; Berg u. Schmidt, Darstell. u. Beschreib. t. VIII Senna lanceolata Link, Handb. II. 140.

Senna acutifolia Batka, Monogr. Gatt. Senna 27, 41. $t .1$.

Spitzblüttrige oder aegyptische Sennes Cassie; engliseh: Italian oder egyptian senna Cassia; französiseh. Séné d'Italie oder de l'Egypte.

Aus einer ausdauernden, kräftigen etwas hin und her gebogenen Pfahlwurzel erheben sich mehrere aufrechte, ästige, am Grunde verholzte, fast stielrunde, gestreifte Stengel, welche eine Höhe von $30-60 \mathrm{~cm}$ und eine Dicke von $3-5 \mathrm{~mm}$ haben; sie sind oben unregelmässig schwach gekantet und mehr oder minder behaart, zuweilen aber ganz kahl.

Die Blätter sind spiralig gestellt und zwar annähernd nach $2 / 5$ geordnet, sie sind paarig drei- bis fünfjochig gefiedert, ihre Spindellänge beträgt 4-6 em, davon kommen 1-1,5 $\mathrm{cm}$ auf den Stiel, der am Grunde mässig stark verdickt ist; die Spindel ist stumpf dreikantig, oben von einer Rinne, an beiden Seiten von je einer seichten Furche durchzogen, sie ist schwach behaart oder kahl; zwischen den Blättchen stehen kleine stiftförmige, rothe fleisehige Drïsen, das Blatt endet mit einer röthlichen, fleischigen Borste. Die Blättchen sind gewöhnlich fünfjochig zusammengestellt und stehen einander gegenüber, sie sind nur sehr kurz gestielt, 2-2,5 (1-3) em lang und in der Mitte oder mehr nach der Basis zu 6-8 (5-10) mm breit; ihre Form ist lanzettlich bis oblong lanzettlich, am Ende spitz, mit einem Stachelspitzehen, am Grunde ist sie ungleichseitig spitz oder ein wenig gerundet; sie sind deutlich fast knorplig gerändert, beinahe lederartig und mehr oder weniger behaart, in der Jugend sind sie manchmal von einfachen Haaren fast filzig, im Alter wenigstens unterseits auf dem Rüickennerven behaart, indess scheinen anch ganz kahle Formen vorzukommen. Die Nebenblätter sind etwa $3 \mathrm{~mm}$ lang, ans breiter Basis pfriemlich, am Grunde schief- und halbherzförmig; sie stehen horizontal oder schräg nach oben gerichtet und bleiben längere Zeit am Zweige sitzen.

Die Blütenstände sind tranbig und brechen aus den Blattachseln hervor, sie erreichen eine Länge von $10 \mathrm{~cm}$ und darüber und tragen die Blitthen am oberen Ende dureh Verkürzung der Axe dicht kopfig vereint, die unteren $B l$ iithen stehen lockerer. Sie werden von einem 4-5 mm langen, oblongen, stachelspitzigen, leicht abfälligen Deckblatte gestitzt und von einem 2-3 mm langen, später answachsenden Stielchen getragen. Die Kelehblätter sind $5-6 \mathrm{~mm}$ lang elliptisch oder fast kreisrund, aussen convex gebogen, die hinteren etwas grösser, sie fallen leicht ab. Die Blumenblätter sind $7-8 \mathrm{~mm}$ lang, verkehrt eiförmig, sehr kurz genagelt, die zwei untern sind etwas länger als die tibrigen, die Farbe ist gelb und braun geadert. Von den $10 \mathrm{Staubgefässen} \mathrm{sind} \mathrm{nur} \mathrm{die} 3$ oberen, welche $2 \mathrm{~mm}$ lang sind, steril und wie die 4 mittleren, $4 \mathrm{~mm}$ langen, fruchtbaren sehräg aufwärts oder nach vorn gerichtet; die beiden nun folgenden sind die grössten, $7 \mathrm{~mm}$ lang und sehr anffallend gekrimmt; das letzte unterste ist wieder 
etwas kleiner. Die Beutel sind linealisch und springen in Löehern auf, die nach der Blüthenmitte gewendet sind, der Grund derselben ist mehr oder minder deutlich pfeilförmig. Bei der durch Insekten besorgten Übertragung der Pollenkörner kommen diesen Formen der Staubbeutel verschiedene Obliegenheiten zu: Die unfruchtbaren sind Futterantheren, welche gefressen werden, die mittleren geben den Staub hauptsächlich her, die unteren dienen als Schauapparat. Der Stempel ist $10 \mathrm{~mm} \mathrm{lang,} \mathrm{deutlich} \mathrm{gestielt}$ und halbelliptisch gekrummt; der Fruchtknoten ist dicht grau behaart und enthält viele Samenanlagen, der fadenförmige Griffel wird nach oben hin kahl und ist aufsteigend, die Narbe ist wenig hervortretend und stumpf. Die Griffel sind bei der Vollblithe entweder rechts oder links schief nach oben gewendet, was ebenfalls für die Pollenübertragung von Bedeutung ist.

Die Frucbt ist eine pergamentartige, flache, oblonge oder breit lineale, an der Spitze abgerundete, am Grunde in den an der Rütckenseite befestigten Stiel zusammengezogene, kastanienbraune, an den Rändern hell olivenfarbige, $3-5 \mathrm{~cm}$ lange und $1,7-2,3 \mathrm{~cm}$ breite Hülse, die dort, wo die Samen liegen, ein wenig aufgetrieben ist.

Der Same ist $7-8 \mathrm{~mm}$. lang, sehr stark zusammengedrïekt, von fast quadratisehem Umrisse mit einer unteren stielähnlichen Verlängerung; die Oberfläche ist runzlig, grïnlich braun; in der Mitte des unteren Schnabels verläuft beiderseitig eine verdickte, gefurchte Schwiele. Das Würzelehen des Keimlings liegt im Schnabel, die blattartigen, flachen Keimblätter sind elliptisch.

Die aegyptisehe Sennes Cassie wächst von Oberaegypten durch Nubien bis nach Kordofan und in Central-Afrika bei Timbuktu und Sokoto.

Die getrockneten Ficderblättehen der Cassia acutifolia bilden fast auschliesslich die Folia Sennae Alexandrinae des Handels, welche von wild wachsenden Pflanzen gesammelt werden. Dieser Waare sind häufig Blättchen von Cassia obovata Collodon, ferner Frïchte der beiden Cassia-Arten und hier und da auch Blättchen von Solenostemma Argel Hayne beigemengt.

\section{Erklärung der Abbildungen.}

Fig. A. Ein blithender Zweig einer aus Nubien stammenden Pflanze.

Fig. B. Die Blüthe im Längsschnitte, 3mal vergrössert: a. Bliithenboden; $b$. der Kelch; $c$. die Blumenblïtter; $d$. die fehl geschlagenen Staubgefässe; $e$. die mittleren, $f$. eins d. längeren, $g$. das kürzere der unteren Staubgefässe; $h$. der Stempel.

Fig. C. Ein oberes und ein untercs Blumenblatt, $2 \mathrm{mal}$ vergrössert.

Fig. D. Die Blithe, von der Kclch und Blumenkrone entfernt sind.

Fig. E.G. Die Staubgefässe, 6mal vergrössert.
Fig. H. Die Pollenkörner unter Wasser und trocken, 300mal vergrüssert.

Fig. $I$. Der Stempel im Längsschnitte, 6mal vergrössert.

Fig. $K$. Die Frucht, natürliche Grösse.

Fig. L. Dieselbe, im Querschnitte, 2mal vergrössert.

Fig. $M$. Diesclbe, aufgesprungen, natürliche Grösse.

Fig. N. Der Same, natürliche Grösse.

Fig. O. Derselbe, 2 mal vergrössert: $a$. die Mikropyle; $b$. der Nabel; $c$. die Schwiele.

Fig. P. bis $R$. Derselbe im Querschnitte und im Längsschnitte senkrecht, so wie parallel zur breiteu Seite: $d$. Nährgewebe; $e$. Keimblätter; $f$. Wïrzclchen. 


\section{Cassia angustifolia Vahl.}

Tafel 48 .

Strauchartig mit funf- bis neunjochigen Blättern; Blättchen lanzettlich oder schmal lanzettlich, nach obenallmälig zugespitzt, später kahl; Stiel der Hülse seitlich gerỉckt, diese gerade.

Cassia angustifolia Vahl, Symb. I. 29; DC. Prodr. II. 499; Bentl. and Trim. Med. pl. t. 91; Berg und Schmidt, Darstell. und Beschreib. t. IX ${ }^{a}$; Köhler, Mediz. Pfl. unter t. 156; Oliv. Fl. trop. Afr. II. 279; Flück. and Hanb. Pharmacogr. 160; Flück. Pharmacogn. 561; Arth. Meyer, Drogenkunde. II. 231.

Cassia acutifolia Bischoff in Bot. Zeitg. II. 50, nicht Del.; Nees, Düsseld. Abb. t. 346 ; Hayne, Arzneigew. IX. $t .40$.

Cassia ligustrinoides Schrank in Denleschr. Münch. Akad. VI. 179; DC. Prodr. II. 492.

Cassia medicinalis Bisch, var. a. u. $\gamma$. in Bot. Zeitg. VIII. 888 .

Cassia lanceolata Royle, Illustr. Himal. bot. 186 u. 201. t. 37; Wight et Arn. Prodr. Fl. Ind. or. I. 288, nicht Nect.

Cassia elongata Lem.-Lisancourt, in Pharm. Journ. VII. 345.

Cassia Ehrenbergii Bischoff in Bot. Zeitg. II. 51.

Senna acutifolia Link, Handb. II. 140.

Senna angustifolia Batka in Bot. Zeitg. VII. 193; Monogr. Gatt. Senna t. 2., Mart. Monog. der Sennesbl. 65.

Indische, arabische oder Tinnevelly Sennes Cassie; englisch: Indian, Meccan oder Tinnevelly senna Cassia; französisch: Séné de Mecque oder de IInde.

Diese Pflanze ist ein Strauch, welcher eine Höhe bis zu $2 \mathrm{~m}$ erreicht und sehr reichliche hin and her gebogene, gestreifte, krautige, endlich verholzende, nur in früher Jugend spärlich behaarte Äste trägt.

Die Blätter sind meist fünf- bis sieben- (selten bis neun-) jochig, paarig gefiedert; die Spindel ist 10-12 (7-14) cm lang, sie wird oberseits von einer deutlichen Riefe durchzogen und ist am Grunde mässig verdickt; sie ist nur zuweilen und auch dann sehr spärlich behaart und geht in eine fleischige Drüse aus, deren sich auch zwischen den Blattpaaren finden. Die gegenständigen Blättchen sind $2-3$ $(1-4) \mathrm{cm}$ lang und meist unterhalb der Mitte 6-8 (4-10) $\mathrm{mm}$ breit, sie sind dünn lederartig, am Rande schwach knorplig und nur in der Jugend sparsam behaart; nach oben spitzen sie sich allmälig zu und enden in ein Stachelspitzchen, am Grunde sind sie ungleichseitig geschärft. Die Nebenblätter sind nur 3-4 mm lang, dreiseitig, zugespitzt und am Grunde halb herzförmig.

Die traubenartigen Blüthenstände treten aus den Blattachseln, sie werden $9-15 \mathrm{em}$ lang und uberragen in der Regel das stuttende Blatt; die sich verlängernde Spindel ist kahl. Die Bltithen sind 2-3 mm lang gestielt, und von einem bis $6 \mathrm{~mm}$ langen, häutigen, sehr leicht abfallenden, oblongen, spitzen Deekblatte gestutzt. Die oblongen bis elliptischen Kelchblätter sind 8-9 mm lang. Die gelben und braun geaderten Blumenblätter messen $1,2-1,4 \mathrm{~cm}$; das oberste ist verbältnissmässig schmal gegen die seitlichen und unteren; sie sind etwas länger genagelt als an der vorigen Art. Die unfruehtbaren Staubgefässe sind $2 \mathrm{~mm}$ lang; die mittleren der fruchtbaren messen $7 \mathrm{~mm}$, die grössten der unteren $12 \mathrm{~mm}$; die Pollenkörner sind ellipsoidiseh und werden von 3 Meridionalfalten durchzogen. Der Ste m pel misst $1,8-2,0 \mathrm{em}$, er ist dicht seidig behaart.

Die Frueht ist $4-5 \mathrm{~cm}$ lang und $1,4-1,7 \mathrm{~cm}$ breit und hat fast gerade, parallele Ränder, ihr Stiel befindet sich ebenfalls an der Rückenseite. Die Farbe ist dunkelbraun, nach den Rändern zu etwas heller.

Berg u. Schmidt, Offieinelle Gewăchse. II. 
Der Same ist blass bräunlich und hat eine warzige Oberfläche. Im Übrigen gilt die für die vorige Pflanze mitgetheilte Beschreibung.

Die arabische oder Tinnevelly-Senna ist im mittleren und suidlichen Arabien besonders in den Provinzen Yemen und Hadramaut verbreitet und lässt sich von hier einerseits über Maskât bis nach dem östlichen Vorder-Indien und anderseits tiber die Somâli-Länder bis nach Mozambique verfolgen.

Cassia angustifolia ist deshalb besonders von Interesse, weil diese Species in Vorder-Indien in ziemlicher Ausdehnung cultivirt wird. Die unter der Bezeichnung Folia Sennae Tinnevelly in den Handel kommenden Blättchen werden von diesen angebanten Pflanzen gewonnen.

\section{Erklärung der Abbildungen.}

Fig. A. Blïhender Ast von einer bei Mozambique gesammelten Pflanze.

Fig. B. C. Blumenblätter, $2 \mathrm{mal}$ vergrössert.

Fig. D. Die Blüthe, naeh Wegnahme von Kelch und Blumenkrone, 4 mal vergrössert: $a$. die unfruehtbaren Staubgefässe; $b$. die oberen fruchtbaren, $c$. und d. die unteren Staubgefässe; $e$. der Stempel.

Fig. E. $-G$. Die Staubgefïsse, 5mal vergrössert.

Fig. H. Pollenkörner unter Wasser und trocken, $300 \mathrm{mal}$ vergrössert.

Fig. $I$. Der Stempel im Längsschnitte, 3 mal vergrössert.
Fig. $K$. Die Frucht, natürliche Grösse.

Fig. $L$. Dieselbe im Querschnitte, 2mal vergrössert.

Fig. $\boldsymbol{M}$. Dieselbe, eine Klappe mit den Samen, natürliche Grösse.

Fig. $N$. Der Same, natürliche Grösse.

Fig. $O$. Derselbe, 3mal vergrössert : $a$. die Mikropyle; $b$. der Nabel; $c$, die Schwiele.

Fig. P. $-R$. Derselbe im Quer - und Längsschnitte senkrecht und parallel zur Breitseite: $a$. Nährgewebe; $b$. Würzelehen; $c$. Keimblitter.

\section{TAMARINDUS Linn.}

Kelchröhre kreiselförmig, am Rande derselben sitzen vier häutige, kreuzförmig gestellte Kelchblätter, von denen das obere und untere in der Knospenlage die beiden inneren umfassen. Blumenblätter 3, vor den Kelehblättern an der Röhre angefugt, die beiden seitlichen umschliessen in der Knospenlage das obere, welches in der Mitte znsammengebogen ist; die beiden unteren sind sehr reducirt, klein, stiftoder borstenförmig. Fruchtbare Staubgefässe 3, unter sich hoch verbunden, nur in der oberen Hälfte oder dem oberen Drittel frei; die Staubgefässverbindung ist oben offen und der Kelehröhre vor den Blumenblättern eingefügt; ausserdem sind zwischen den 3 Staubgefässen und an den Seiten noch 2 fadenförmige Staminodien vorhanden; Staubbeutel oblong, stumpf in Längsspalten aufspringend. Fruchtknoten kurz gestielt, der Rückseite der Kelchröhre angeheftet, seitlich zusammengedruickt; an der Ruickennaht sitzen zahlreiche campylotrope Samenanlagen in zwei Reihen; Griffel gebogen, unterseits mehr- oder weniger hoch behaart mit sehwach kopfiger Narbe. Hülse oblong-linealisch, dick, zusammengedrückt, gleichförmig oder hier und da eingeschnürt mit briichigem Exocarp; das Mesocarp saftig, das Endocarp fest, lederartig, so dass die Hülse gefächert erscheint. Samen von fast kreisförmigem Umrisse, zusammengedrückt, mit harter, glänzender Samenschale; Würzelchen kurz, gerade, von den planconvexen Keimblättern eingescblossen; Nährgewebe äusserst spärlich. - Ein Baum ohne Stacheln, mit spiralig oder zweizeilig gestellten, paarig gefiederten Blättern und kleinen, hinfälligen Nebenblättern. Die Bliithen sind spiralig gestellt in lockeren Trauben selten Rispen; sie werden vor dem Aufblühen von einem gefärbten Deckblatte und zwei Vorblättern umschlossen, die bei der Vollblüthe abfallen.

Eine Art, die in Afrika heimisch ist, aber schon seit langer Zeit in den Tropen beider Hemisphären cultivirt wird. 
Anmerkung. Um die Blithe von Tamarindus mit derjenigen einer Schmetterlingsblithe in Uebereinstimmung zu bringen, hat man einige Veränderungen vorzunehmen. Der vierblättrige Kelch wird dadurch als fünfgliedriger gedeutet, dass man die beiden obersten Kelehblätter in eins verwachsen sein lässt, für welehen Vorgang man in der Zweinervigkeit und der Ausrandung an der Spitze einen Hinweis erkennt. Von den fünf Blumenblätern sind 3 gross und petaloid entwickelt, 2 untere (s. Fig. $E$ unten an der Staubgefässverbindung, Fig. $F$ ebendort $d$ ) sind sehr weitgehend reducirt*); man erkennt ihre Natur aus der abwechselnden Stellung mit den Staubgefässen. Der gewöhnlich zehngliedrige Staubgefässkreis ist am wenigsten leicht zu recognoseiren. Die drei fertilen Staubgefässe sind sogleich zu erkennen: man betrachtet sie gegenwärtig als dem äusseren Kreise angehörig, die zwischen ihnen stehenden Spitzehen müssen dann dem inneren Kreise zugezählt werden; bezïglich der obersten Staminodien hat man freie Wahl, man kann sie ebensowohl dem äusseren, wie dem inneren Kreise zurechnen, das unpaare obere Staubgefäss, wie das eine seitliche obere Paar sind dann völlig abortiert. Neben dieser Deutung giebt es noeh eine frïhere, der zufolge das mittlere Stanbgefäss dem äusseren, die beiden oberen dem inneren Kreise angehören; diese ist in nnserer Figur dargestellt worden.

\title{
Tamarindus indica L.
}

\author{
Tafel 49 .
}

Baumartig; Zweige kahl oder nur an den äussersten Spitzen diinn und kurz behaart, manchmal bläulich grïn. Blättchen oblong, stumpf, netzig genervt; Deckblätter concav, elliptiseh bis umgekehrt eiförmig oder spathelförmig; Deckblättehen am Rande fein behaart.

Tamarindus indica Linn. Spec. pl. ed. I. 34; Burm. Fl. indica 15; Jacq. Stirp. Americ. 10. t. 13; Plenck, Pl. med. t. 31; Woodv. Med. pl. III. t. 161; Descourt. Fl. Antill. II. t. 120; Tussac, Fl. d'Ant. III. t. 35; Hayne, Arzneipf. X. t. 41; Pyr. DC. Prodr. II. 458; Roxb. F7. Ind. III. 215; Wight et Arn. Prod. F7. Ind. or. 285; Nees, Düsseld. Abbild. t. 341; Guimp. u. Schlecht. Pf. Pharmac. t. 44; Lemaire, Jard. Fleur. t. 133; Dalz. and Gibs. Bomb. Fl. 82; Beddome, F7. sylv. t. 184; Sulp. Turz, Fl. Brit. Burma I. 414; Bak. in Oliv. Fl. trop. Afr. II. 30s; Bak. in Hook. Fl. Brit. Ind. II. 273; Berg u. Schmidt, Darstell. und Bcschreib. ${ }^{+}$; Bentl. and Trim. Med.pl. t. 92; Köhler, Mediz. Pf. t. 131; Baill. Bot. médic. I. 595 c. xylogr. 2149-2151; Flück. and Ilanb. Pharmacogr. 197; Fliick. Pharmacogn. 846.

Tamarindus occidentalis Gürtn. Fruct. II. 300. t. 146. Fig. 2.

Tamarindus officinalis Hook. Bot. Mag. $t, 4563$.

Tamarindenbaum; englisch: Tamarind tree; französisch: Tamarindior.

Der schöne, stattliche Baum erreicht eine Höhe von $20 \mathrm{~m}$ und darüber und einen Durchmesser von 25-35 cm; der Splint ist gelblich weiss und leicht zerstörbar, das spärliche Kernholz wird aber ausserordentlich hart, nimmt zuweilen die Farbe des Ebenholzes an, ist aber auch nicht selten prachtvoll geadert; die Rinde ist schwarzbraun und sehr rissig, die der jüngeren, vielfach gekrïmmten Äste ist grau, die jüngsten, stielrunden Spitzen sind kahl oder sehr kurz behaart, nicht selten sind sie bläulich bereift.

Die Blätter stehen an den Langtrieben in spiraliger Folge, an den kürzeren scheinen sie in zweizeiliger Stellung angereibt zu sein; sie sind paarig 10-22jochig gefiedert, der Blattstiel ist kurz und am Grunde ein wenig verdickt, die Spindel ist gegliedert und wird oben von einer seichten Rinne durchlaufen, sie ist kahl oder schwach behaart; die gegenständigen Blïttchen sind 1,5-2,0 $(1,0-2,7) \mathrm{cm}$ lang und in der Mitte 5-6,5 (3-9) $\mathrm{mm}$ breit, oblong-lineal, an der Spitze ausgerandet oder gestutzt, am Grunde sind sie schief, die nach oben gewendete Seite ist stumpf, die andere spitz; sie werden von etwa 4-5 stärkeren Seitennerven durchzogen, von denen die untersten parallel mit dem Rande bis fast zur Spitze verlaufen; sie sind deutlich gerändert, im troeknen Zustande lederartig und auf der blaugrünen

*) Von einzelnen Autoren, so namentlieh auch von Eiehler, Bliithendiagramme II. 519, werden die redueirten Blumenblätter für Staminodien angesehen. Wenn man auch betreffs der Deutung der Blithe versehiedener Meinung sein kann, so ist wegen der Stellung dieser Körper eine andere Homologie als die oben entwickelte fiir diese Gebilde undenkbar. 
Unterseite netzig geadert; die Nebenblätter sind nur an den Knospen sichtbar, da sie sehr schnell abfallen, sie sind schief lanzettlich, zugespitzt, kahl und messen $5-6 \mathrm{~mm}$ in der Länge.

Die Blüthenstände sind 8-12 cm lang, selten werden sie länger, gewöhnlich traubig werden sie nur selten durch das Hinzutreten eines grundständigen Seitenastes rispig, gewöhnlich treten sie aus den Blattachseln an Kurztrieben hervor, die sie auch zuweilen abschliessen. Die Spindel ist, viclleicht nur durch das Trocknen etwas kantig, kahl oder kurzhaarig.

Die Blüthen sind spiralig angeordnet; sie werden von einem 6-9 mm langen, kahnförmig in der Mitte zusammengebogenen, stumpfen, lederartigen, bereiften Deckblatte gestlitzt und sind von zwei etwas kleineren, schief spatelförmigen Vorblättern, die an dem Gelenk der Blüthenstielehen befestigt sind, begleitet; die ersteren sind bäufig bläulich bereift und wie die zweiten am Rande fein behaart, beide Organe sind sehr leicht abfällig. In der Vollblüthe misst der Blïthenstiel $5-7 \mathrm{~mm}$, das Stielchen, welches allmälig in die Kelchröhre lubergeht, die Hälfte. Die kreiselförmige, lederartige Kelchröhre ist $3-4 \mathrm{~mm}$ lang und aussen bläulich bereift; die 4 Kelchblätter sind krautig, das obere grösste ist breit elliptisch, stumpf oder ausgerandet und zweinervig, die drei ibbrigen sind unter sich ziemlich gleich, oblong, spitzlich, einnervig, die Länge aller beträgt $10-12 \mathrm{~mm}$, ihre Farbe ist hellgrïn, später gelblich. Dic drei Blumenblätter messen 12-14 mm, sie sind oblong; stumpf, unten an den Rändern kraus gefältelt, sie sind zuerst weisslich, dann heller oder dunkler gelb, zuwcilen fast orangefarben und werden von purpurrothen Adern durehzogen, die zwei übrigen Blumenblätter sind in der Form von fadenförmigen Stiftchen entwickelt. Die drei fruchtbaren Staubgefässe sind $9-11 \mathrm{~mm}$ lang und bis über die Hälfte verbunden, zwisehen ihnen befinden sich zwei kaum $1 \mathrm{~mm}$ lange Spitzchen, die Staminodien darstellen, ausserdem sollen auch noch zuweilen zwei seitliche, zähnehenartige Staminodien vorkommen; dic oben offene, an dem Rande der Kelchrölıre angewachsene Staubgefässverbindung ist am Grunde fein behaart. Der Stempel ist am Grunde der Kelehröhre auf ihrer Rtickenseite angewachsen: er ist 10-13 mm lang, kurz gestielt und halbelliptisch nach oben gekrümmt; am Grunde ist er auf der abgeplatteten oder rinnig vertieften Rïckseite behaart, ausserdem trägt er dort, wo sich der Griffel sehärfer nach oben krümmt eine kurze Haarbekleidung; die Narbe ist ein wenig kopfig verdickt.

Die Frucht erreicht je nach der Zahl der Samen, die herangereift sind, eine verschiedene Länge, die zwischen 6 und $15 \mathrm{~cm}$ schwankt; ihre Höhe von der Naht zur Bauchseite gemessen beträgt 1,5-2,5 cm, die Dicke $1-1,5 \mathrm{~cm}$, sie ist entweder gleichmässig oder hier und da zwischen den Samen eingeschnürt; das Epicarp ist von Schuppen rauh, bräunlich grün und zerbrechlich; die süsssaurc Pulpa, welche die Samen umgiebt, ist in unreifem Zustande roth, wird dann aber bräunlich olivenfarbig.

Die Samen sind fast kreisrund, sic haben $1 \mathrm{~cm}$ im Durchmesser und sind etwa $5 \mathrm{~mm}$ dick, ihre äussere Schale ist glänzend schwarz und brüchig; der Keimling hat die Form des Samens, die Keimblätter sind herzförmig, planconcav; um das Würzelchen ist noch ein Rest des Nährgewebes nachweisbar.

Die Tamarinde ist sicher in Afrika heimisch, dass sie in Ost-Indien eingeführt worden ist, erscheint wahrscheinlich, obgleich sich Angaben finden, dass sie dort z. B. in Java wild wachse; dasselbe wird auch von Nord-Australien bemerkt, da sie aber innerhalb der T'ropen der ganzen Erde sehr häufig cultivirt wird, so sind diese Angaben mit Vorsicht aufzunehmen. Durchaus den Eindruck eines heimischen, grosse Wälder bildenden Baumes macht sie in den Gegenden am Zambesi, in Central-Afrika, in Kamerun, Abyssinien und Nubicn.

Als Tamarindenmus (Tamarindi oder Fructus Tamarindorum) kommt die Fleischschicht der gefächerten Frucht, welcher meist noch Leitbündel und die filzigen inneren Hautschichten der Fächer des Perikarps beigemischt sind, in den Handel. 


\title{
Erklärung der Abbildungen.
}

Fig. A. Ein bliihender Zweig nach einem auf St. Thomas gesammelten Exemplare.

Fig. B. Das Diagramm der Blüthe: $b$. Kelchblïtter; $c$. Blumenblätter; $d$. obere, nach der Theorie ergänzte Staubgefässe; $e$. das obere Paar der vorhandenen Staubgefässe; $f$. der Stempel.

Fig. $C$. Die Knospe, 2mal vergrössert: $a$, die abfallenden Vorblätter.

Fig. D. Die Blïthe, nach Entfernung der Blumenblätter, nattirliche Grösse: $b$. die Kelchblätter.

Fig. $E$. Dieselbe nach Entfernung von Kelch- und Blumenblättern, doppelt vergrössert: $g$. die Kelchröhre; $h$. die Staubgefässverbindung; $i$. der Stempel.

Fig. $F$. Die Staubgefässverbindung, 3 mal verorössert: $a$.am Grunde der Staubgefässverbindung die stiftförmigen verkïmmerten Blumenblätter; $d$, weiter oben die nach der Berg'schen Deutung zum äusseren, $e$, die zum inneren Staubgefässkreise gehörenden Glieder.

Fig. G. Pollenkörner, $300 \mathrm{mal}$ vergrössert.

Fig. $H$. Die Kelchröhre mit dem Stempel im Längsschnitte, doppelt vergrössert: $i$, der Fruchtknoten.

Fig. I. Die Frucht, nattirliche Grösse.

Fig. $K$. Dieselbe von dem Exocarp befreit, um die Pulpa und die beiden strangförmigen Gefüssbïndel zu zeigen.

Fig. $L$. Dieselbe im Längsschnitte.

Fig. $M$. Dieselbe im Querschnitte.

Fig. $N$. Der Same, natürliche Grösse.

Fig. O.-Q. Derselbe im Querschnitte und Längsschnitte senkrecht und parallel zur breiten Fläche: $k$. die Samenschale; $l$. das Würzelchen; $m$. die Keimblätter.

\section{COPAIFERA Linn.}

Blïthen zwittrig, sehwach aber deutlich zygomorph. Keleh mit kurzer, am Grunde verdickter, drüsiger Röhre (angewachsener Discus), lederartig, tief vierspaltig mit klappig oder leicht dachziegelig deckenden Zipfeln. Blumenblätter fehlen. Staubgefasse 8-10, frei mit kahlen Fäden und gleichgestalteten, in Längsspalten aufspringenden Beuteln. Fruchtknoten gestielt, ganz frei oder nur ausserst wenig aufsteigend dem Kelchgrunde angewachsen, mit 2 nahe an der Spitze befestigten hängenden Samenanlagen; Griffel fadenförmig, verlängert mit gestutzter, endständiger Narbe. Hülse gestielt, schief elliptisch oder gerundet rhombisch, seltener sichelförmig gekrümmt, von den Seiten her zusammengedrïckt, oder gedunsen, lederartig, zweiklappig. Same einzeln, hängend an langem Samenträger, mit einem mehr oder weniger umhïllenden Mantel, selten fehlt dieser; Keimling gerade mit kurzem Würzelchen und fleischigen Keimblättern. - Unbewehrte Bäume und Sträucher mit ein- bis mehrjochigen, abgebrochen gefiederten Blättern; Blättehen lederartig, häufig schief; Nebenblätter sehr klein. Blüthen klein, meist weiss in zweizeiligen Ähren oder Trauben, die häufig zu weitschweifigen Rispen zusammentreten, Deckund Vorblättchen sind sehr leicht abfällig, aber stets vorhanden. Etwa 16 Arten leben im tropischen Asien und in Süd-Afrika.

\section{Copaifera Langsdorffii Desf.}

\author{
Tafel 50 .
}

Baum- oder strauchartig mit vier- bis fünfjochig gefiederten Blättern; Blättchen meist abwechselnd, oblong, stumpf oder ausgerandet, lederartig, am Rande verdickt, unterseits wie die Spindel mehr oder minder weichhaarig oder häufiger kahl, von Sekretliicken durchscheinend punktirt.

Copaifera Langsdorffii Desf. in Mém. mus. de Paris VII. 377. t. 14; Hayne, Arzneigew. X. t. 19; DC. Prodr. II. 509; Nees. Diisseld. Abbild. Suppl. t. 41; Guimp. u. Schlecht. Pfl. der Pharmacop. III. t. 224; Mart. Mat. med. Brasil. 115; Benth. in Fl. Brasil. XV. (2). 242. t. 63. fig. 1; Berg u. Schmidt, 
Darst. u. Beschr. VIf; Bentl. and Trim. Med. pl. t. 93; Köhler, Med. Pfl. unter t. 171; Flïck. and Hanb. Pharmacogr. 201; Flïck. Pharmacogn. ed. III. 92; Baill. Bot. méd. I. 619. fig. 2182 u. $\$ 3$.

Copaifera Sellowii Hayne l. c. t. 22.

Copaifera nitida Hayne l. c. t. 17, Mart. Hb. Fl. Brasil. n. 127.

Copaifera laxa Hayne l. c. t. 18 .

Copaifera glabra Vog. in Linnaea. XI. 410.

Copaiva-Baum; englisch: Copaiva tree; französisch: Copayer.

Der Baum wird bis $20 \mathrm{~m}$ hoch, zuweilen bleibt die Pflanze aber viel niedriger und strauchartig, wie sie denn iberhaupt bei einer weiten Verbreitung auch ansserordentlich veränderlich ist. Die jüngeren blïhenden Zweige sind stielrund und mit einer grauschwarzen oder bräunlichen Rinde bekleidet, welche mit mehr oder weniger zahlreichen, spindclförmigen, gleichfarbigen Lenticcllen bestreut ist; die jüngsten Schosse sind gleich den Blüthenstandsspindeln gewöhnlich rostbraun behaart, zuweilen sind sic aber auch ganz kahl, die Haare sind einzellig, stark verdickt, versehiedenartig gekrümmt, zuweilen sind sie nach Art der Malpighiaceenhaare lang spindelförmig und in der Mitte befestigt.

Die Blätter sind gewöhnlich vier- bis fünfjochig, seltener zwei-, drei- oder sechsjochig; die kahlen oder braun behaarten, oberseits scicht gefurchten Spindeln haben in der Regel eine Länge von $5 \mathbf{- 7} \mathrm{cm}$; die Blättchen stehen bäufig abwechselnd, in der typischen Form sind sie 2,5-4 cm lang und in der Mittc 1,2-2,2 cm breit, sie erreichen aber auch eine Länge von $6,5 \mathrm{~cm}$ und eine Breite $3,5 \mathrm{~cm}$, sie sind meist oblong, an dem obcren Ende stumpf und scicht ausgerandet, am Grunde spitz oder abgerundet, ungleichscitig, in anderen Fällen sind sie aber breit clliptiseh oder eiförmig, selbst fast umgekehrt eiförmig; sie sind beiderscits glänzend und werden von cincm sowohl ober-wic unterseits sichtbaren fcinen Adernetze durchzogen; sie sind selten auf der ganzen Fläcbe, häufiger nur auf den Nerven und am verdickten, heller gefïrbten Blattstiele behaart, gewöhnlich aber wenigstens in älteren Zuständen ganz kahl; die Textur ist lederartig, die Farbe in trocknem Zustande gewöhnlich dunkel, fast schwarz, nicht sclten aber auch lederbraun; die Sekretlitcken sind punktförmig. Die Blättchenstielehen sind sehr kurz, meist nur $1-2 \mathrm{~mm}$ lang.

Der Blüthenstand ist eine cnd- oder seitenstïndige, sehr reichblithige Rispe, die in den letzten Verzweigungen aus lockeren Ähren zusammengesetzt wird. Die Bltithen sind regelmässig zweizeilig angereiht, sie sind vollkommen sitzend und werden von einem 1,5 mm langen, ticf ausgehöhlten, eiförmigen, spitzen, aussen und am Rande kurz gelblich behaarten, überaus leicht abfälligen Deckblatte gestiitzt; zwei Vorblättchen sind von ähnlicher Form aber kleiner, sie convergiren nach rückwärts und sind asymmetrisch gekielt, was durch den Druck gegen die Axe hervorgebracht wird.

Die 4 Kelehzipfel decken klappig, der oberste ist der grösste, er misst 3,5-4 mm; die übrigen sind 3-3,5 mm lang; sie sind flach ausgebreitet, nur der oberste ist etwas kahnförmig vertieft, lederartig, aussen kahl, innen aber gelblich striegelhaarig, seltener kahl; sie fallen schliesslich ab.

Die Blumenblätter fehlen. Die Staubgefässe sind gleich lang, ihre Fäden sind schlank pfriemlich, 4.5-5 mm lang; kahl; die Beutel sind am Grunde ausgerandet, ausserordentlich leicht abfällig und 1-1,2 mm lang; der Pollen ist gerundet dreiseitig, linsenförmig mit drei an den Ecken liegenden Poren. Der Stempel sitzt auf einem sehr kurzen, 0,5 mm langen, fast kablen Stiele; der Fruchtknoten ist 2,5-3 mm lang, etwas seitlich zusammengedrückt und von fast kreisrundem Umfange, er ist gelblich behaart, entweder auf der ganzen Fläche, oder am Grunde und auf dem Rücken; der fadenförmige, kahle Griffel misst 3,5-4 mm, die kreisförmige Narbe hat einen Durchmesser von $0,3 \mathrm{~mm}$.

Die Frucht ist $3 \mathrm{~cm}$ lang und $2 \mathrm{~cm}$ breit, kurz gestielt und schief umgekehrt eiförmig oder fast kreisförmig; sie ist linsenförmig, gekrümmt und an der Spitze mit einem kurzen, derben Schnabel versehen; sie springt zweiklappig auf, die Klappen sind lederartig, fast holzig, anssen kahl und unregelmässig kleinwarzig, die Farbe ist braunschwarz oder rothbraun.

Von den zwei Samenanlagen reift nur eine zum Samen; er ist 1,6-1,8 cm lang und 1,1-1,3 cm breit: er hängt an einem kurzen Nabelstrange und wird von einem schiefen, glockenförmigen, am Rande 
unregelmässig gekerbten, fleischigen Samenmantel (Arillus) zur Hälfte umhüllt; er ist zusammengedrüickt elliptischen, fast vierseitigen Querschnittes, rückseits an der Rhaphe gebogen, vorderseits weniger gekrümmt, die Testa ist schwarz, spiegelnd glatt. Der Keimling ist gerade, das Würzelehen sehr kurz; der Same riecht sehr stark nach Cumarin.

Bentham hat die Art in folgende Varietäten getheilt:

Varietät ๘. typica K. Seh. Blättehen mässig gross oder verhältnissmässig klein, unterseits kahl oder nur an den Nerven behaart; Kelehblätter innenseits zottig.

Varietät $\beta$. glabra Bth. Blättchen klein, kahl; Kelehblätter beiderseits kahl oder innen spärlieh behaart.

Varietät $\gamma$ grandifolia Bth. Blättehen $5-7 \mathrm{~cm}$ lang, beiderseits sehr stumpf, kahl; Kelehblätter innen behaart.

Varietät $\delta$. laxa Bth. Zweigehen und Blätter weichhaarig.

Der Langsdorff'sche Copaivabaum ist in den trocknen, besonders aus Bäumen mit wechselndem, in der heissen Jahreszeit abfallendem Laube zusammengesetzten Wäldern Brasiliens, Caa-tinga genannt, verbreitet; er findet sich auf der Ostseite und im Innern des Reiches von dem Staate S. Paulo, im Süden durch Minas Geraës, Mato Grosso, Goyaz bis Bahia.

Ausser der von uns abgebildeten Copaifera Langsdorffii liefern auch C. coriacea, C. guianensis, C. officinalis und andere Copaiferaspecies den sogenannten Copaivabalsam (Balsamum Copaivae), ein Sekret, welehes in Intereellularräume des Holzes der Pflanze abgeschieden wird. Man sammelt das Sekret, indem man in die Basis des Baumstammes einseitig ein Loeh sehlägt, welches Splint und Kernholz durehsetzt. In dieses Loch fliesst das Sekret aus den geöffneten Sekretbehältern.

\section{Erklärung der Abbildungen.}

Fig. A. Ein blühender Zweig nach einem von Sellow in S. Paulo gesammelten Exemplare.

Fig. B. Die Blüthe, 4mal vergrössert.

Fig. C. D. Das Staubgefïss von innen und aussen betrachtet, $10 \mathrm{mal}$ vergrössert.

Fig. E. Pollenkörner in Wasser, $350 \mathrm{mal}$ vergrüssert.

Fig. $F$. Der Fruchtknoten 6mal vergrössert.
Fig. G. Die Frucht, natürliche Grösse.

Fig. H. Dieselbe, geöffinet.

Fig. I. Der Same, natürliche Grösse.

Fig. K. L. Derselbe ohne Arillus von der Seite und vom Riicken betrachtet.

Fig. $M . N$. Derselbe im Quer- und Längsschnitte.

\section{ONONIS Linn.}

Blüthen zwittrig, zygomorph. Kelch kreiselförmig mit kurzer Röhre und ziemlich gleichen Zipfeln. Fahne fast kreisförmig mit kurzem Nagel, Flügel oblong umgekehrt-eiförmig, Kiel scharf gebogen, geschnäbelt, seltener stumpf, die Nägel sind nicht an die Staubgefüssröhre angewachsen. Fast stets sind sämmtliche Staubgefässe zu einer Röhre verwaehsen, sehr selten ist das oberste frei; die Staubbeutel sind abwechselnd grösser. Der häufig gestielte Fruchtknoten umschliesst zwei bis vier Samenanlagen; Griffel gekrimmt oder eingebogen mit kopfiger oder schiefer Narbe. Hülse oblong oder linealisch, gedunsen oder stielrund, zweiklappig, selten zusammengedriickt und zwischen den Samen gegliedert. Samen ohne Anhang. - Kräuter oder Stauden, seltener Halbsträucher oder Sträucher, häufig mit drüsiger Bekleidung und zuweilen dorniger Bewehrung. Blätter dreizählig mit zuweilen redueirter Spreite, Blättehen gezähnelt; Nebenblätter angewachsen. Blüthen rosenroth oder gelb, einzeln oder gepaart achselständig, zuweilen in Trauben zusammentretend; der Blithenstiel ist zuweilen grannenartig iber die Bliuthe verlängert. Vorblättchen klein oder fehlend.

Die etwa 60 beschriebenen Arten wachsen in Europa, West-Asien, Nord-Afrika und gehen bis zu den Canarisehen Inseln. 


\section{Ononis spinosa Linn.}

Tafel 51.

Ausdauernd, fast halbstrauchig; Stengel aufrecht oder aufsteigend, ein-oder zweireihig zottig und etwas drüsig, mit einfachen oder gepaarten Dornen bewehrt; Blüthen achselständig, einzeln oder gepaart; Hülsen so lang oder länger als der Kelch.

Ononis spinosa Linn. Spec. pl. ed. I. 716; F7. Dan. V. t. 783; Gärtn. Fruct. II. 343. t. 154. fig. 6; Plenck, Offiz. Pfl. t. 553; Schkuhr, Handb. t. 194; Schrank, Fl. Monac. IV. t. 333; DC. Prodr. II. 163 (var. $\gamma$. excl.); Nees, Diisseld. Abbild. t. 320; Guimpel, Holzgew. t. 124; Guimp. u. Schlecht. Pfl. der Pharmac. II. 76. t. 166; Hayne, Arzneigew. XI. t. 43; Mert. u. Koch Deutschl. F7. V. 114; Koch, Syn. 158; Sturm, Deutschl. Flora XVII. t. 72; Ledeb. Fl. Ross. I. 514; Aschers. Fl. Brandonb. 137; Berg und Schmidt, Darst, und Beschr. XXf; Köhler, Mediz. Pft. t. 126; Fliick. Pharmacogn. ed. III. 385; Baill. Bot. méd. I. 651; Arth. Meyer, Drogenkunde, I. 243.

Ononis arvensis Linn. Syst. nat. ed. XII. 540.

Ononis campestris Koch et Ziz, Cat. pl. Pulat. 22; Godr. et Giren. Fl. Fr. I. 373; Willk. et Lange, Prodr. Fl. Hisp. III. 392.

Haukechel, dorniger Hauhechel, Weiberkrieg ete.; englisch: Pettywhin, restharrow; französisch: Bugranc ćpineuse.

Die kräftige, zuweilen $50-60 \mathrm{~cm}$ lange und oben 1-1,5 cm dicke Pfahlwurzel ist nur spärlich verzweigt, die Rinde ist dunkelbraun bis schwarz, der Holzkörper ist gelblich weiss, sie ist unregelmässig mehr oder weniger zusammengedrïckt und gefurcht.

Die Stengel stehen zu mehreren 2-5) zusammen; sie erzeugen in frühester Jugend am Grunde 3-4 spreitenlose, stengelumfassende, zucrst scheidig geschlossene, dann tiefer geschlitzte, fast krautige, hyaline Niederblätter, die bald versehwinden, aus deren Achseln aber die Sprosse für das folgende Jahr hervortreten; sie erreichen eine Höhe von $60-70 \mathrm{~cm}$, sclten darïber und werden $2-5 \mathrm{~mm}$ dick; sie sind stielrund, oben krautig, unten verholzen sie stark, doch gehen auch diese Theile im Laufe des Winters sehr schnell zu Grunde. Die Bekleidung besteht aus zarten, ziemlich langen, zugespitzten, mehrzelligen, einfachen Haaren, die mehr oder weniger deutlich in ein oder zwei Längszeilen angeordnet sind; einige kleine Köpfchenhaare sind besonders in der Nähe der Blattansätze an jüngeren Zweigen eingestreut; an den langen, ruthenförmigen Tricben sitzen in spiraler Ordnung Kurztriebe, welche in gerade oder etwas gebogene, spitze, stechende Stacheln auslaufen; sie sind beblättert und aus den Achseln des einen Blattes tritt zuweilen ein ähnlicher Trieb hervor, wodurch die Stacheln "gegabelt « und "gepaart" erscheinen.

Die Blätter sind spiral angereiht; die unteren sind dreizählig, die oberen einzählig; diese stehen an den Kurztrieben gebuischelt, manchmal sind sie auf das Nebenblatt reducirt. Die Blättchen sind in der Grösse sehr verschieden, die der oberen Blätter messen zuweilen nur $4-5 \mathrm{~mm}$ in der Länge und etwa $2 \mathrm{~mm}$ in der Breite, während sie an den üppigeren Formen über $2 \mathrm{~cm}$ lang und $1 \mathrm{~cm}$ breit werden; sind oblong, eioblong oder fast lanzettlich, am Rande tragen sie bald cine grössere, bald eine geringere Zahl (manchmal jederseits nur 3-4) von Sägezähnchen; beiderseits sind sie mit sehr kleinen Köpfehenhärchen bestreut; ihre Farbe ist gesättigt grün. Die Nebenblätter sind breit eiförmig, unten gerundet, oben zweispitzig; am Rande hier und da gesägt.

Die Blüthen treten einzeln, sehr selten gepaart aus den Achseln der Kurztriebblätter, sind sie gepart, dann stehen die beiden gleichwerthig nebeneinander; die Blüthenstiele sind kurz, nur bis $3 \mathrm{~mm}$ lang, dünnzottig, gegen die Spitze hin mit Köpfehenhaaren verschen. Der Keleh ist 6-8, selten bis $10 \mathrm{~mm}$ lang und bis über die Hälfte in schief lanzettliche, zugespitzte, abstehende Zipfel getheilt, er ist grün und mit reichlicheren Köpfchenhaaren besetat; der untere Zipfel ist ein wenig länger 
als die iibrigen. Die Fahne ist an der Spitze abgerundet und in der Mitte zusammengebrochen, sie misst $13-16$, selten bis $20 \mathrm{~mm}$; sie ist rosenroth, aussen mit sehr kleinen Köpfchenhaaren bestreut, innen kahl; der kurze Nagel ist weiss; die Flügel sind schief, umgekehrt eioblong, stumpf, 9-11 selten bis $14 \mathrm{~mm}$ lang, am Grunde einseitig geöhrt und in einen kurzen Nagel zusammengezogen; innenseits sind sie mit einem kegelförmigen Zahne versehen, der in eine entsprechende Vertiefung des Kiels greift und durch den beide mit einander verbunden sind; die Farbe ist weiss mit einem rosarothen Längsstreifen; der Kiel ist fast ebenso lang wie die Flïgel, vorn aber $7-9 \mathrm{~mm}$ hoch und in einen spitzen, nach oben gewendeten Schnabel ausgezogen; er sowohl als die Flügel sind kahl. Die Staubgefässröhre ist ringsum geschlossen, seitlich zusammengedrïckt, weiss, die Länge beträgt $8-11 \mathrm{~mm}$, die rechtwinklig nach oben gebogenen abwechselnd grösseren Staubfäden sind 2,5-3,5 mm lang, die gelben Beutel messen kaum $1 \mathrm{~mm}$; der Pollen ist lang ellipsoidisch mit drei Meridionalfalten. Der Fruchtknoten ist nur 1-1,5 mm lang, schief ellipsoidisch und seitlich etwas zusammengedrückt, an dem oberen Theile ist er von reichlichen Köpfchenhaaren zottig; er umschliesst 5-6(-8) Samenanlagen; der Griffel ist etwas länger als der Staubgefässverband, die Narbe klein kopfig.

Die Frucht ist 7-9 mm lang und 6-7 mm breit, linsenförmig, schief, etwas gedunsen, sie überragt den Kelch vorn um ein Drittel bis um das Doppelte und ist ein- bis dreisamig; der niedergebogene Griffelrest bleibt lange stehen; die Klappen sind hellbrann und aussen mit Köpfchenhaaren bekleidet, deren Köpfchen endlich abtrocknen.

Der Same ist 1,5-2 mm lang und breit, kurz birnförmig, schwach von der Seite zusammengedrüekt, dunkelbraun bis schwarz, kleinwarzig punktirt; in dem gekrümmten Keimlinge liegt das Würzelchen an der Berührungsstelle der beiden Keimblätter.

Der dornige Hauhechel ist in Europa von Skandinavien und Schottland dureh Deutschland und Frankreich verbreitet bis nach Spanien und Portugal, er findet sich in der Schweiz, Italien, Österreich und geht von dem nördlichen Russland bis an den Kaukasus und über Serbien bis Konstantinopel; ausser in Armenien scheint er den asiatischen Kontinent nicht zu bewohnen.

Anmerkung. Über diese Pflanze herrscht bezüglich der Nomenclatur eine grosse Verwirrung, die keinem geringeren als Linné selbst ihren Ursprung verdankt. Er hat offenbar die allerdings sehwierig zu sondernden Arten der Verwandtschaft nicht genau genug gekannt. Darüber kann jetzt aber wohl kein Zweifel bestehen, dass seine Ononis spinosa Spec. pl. ed. I, und Ononis spinosa Spec. pl. ed. Il, $\beta$ mit unserer Pflanze ganz oder wenigstens theilweise übereinstimmt, Grund genug für uns, um dieser den Linné'schen Namen zu belassen und die Bezeichnung O. campestris Koch et Ziz, die jetzt von Einigen vorgezogen wird, zu verwerfen.

Die unterirdischen Theile der Pflanze kommen im getrockneten Zustande als Radix Ononidis in den Handel. Häufig spaltet man die Droge der Länge nach mehrfach durch.

\section{Erklärung der Abbildungen.}

Fig. A. Der obere Theil einer blühenden Pflanze, natïrliche Grösse: $a$. Langtrieb; $b$, und $c$. Kurztriebe mit Bliithen; $d$. unteres dreizähliges; $e$. oberes einzähliges Blatt.

Fig. $B$. Die Blithe im Längsschnitte $2 \frac{1}{2}$ mal vergrössert: $g$. der Kclch; $h$. die Fahnc; $i$. die Flügel; $k$. der Kiel; $l$. die Staubgefissröhre; $m$. der Fruchtknoten; n. der Griffel; o. die Narbe.

Fig. C. Der Kelch : $\alpha$. die oberen, $\beta$. der untere dcr Kelchzipfel.

Fig. $D$. bis $F$. Die Fahne, die Flügel und der Kiel, doppclt vergrössert.

Fig. $G$. Der Staubgefissverband, doppelt vergrössert: $t$. die Röhre.

Fig. $H$. Derselbe oben aufgeschlitzt.

Fig. $I$. $K$. Der Staubbeutel eines längeren Stanbgefässes von vorn und von hinten, $10 \mathrm{mal}$ vergrössert.

Berg n, Sclemidt, Officinelle Gewächse. II.
Fig. $L$. Dersclbe eines kleineren.

Fig. M.N. Pollenkörner, trocken und in Wasser, $300 \mathrm{mal}$ vergrüssert.

Fig. O. Der Fruchtknoten, 10mal vergrüss. : $m$. die Wandung, p. die Samenanlagen.

Fig. $P$. Der obere Theil des vorigen mit der Narbe.

Fig. Q. Die Frucht, natiirliche Grösse.

Fig. $Q^{\prime}$ Dieselbe, 3mal vergrössert: $q$. die Samenschale; a. der Griffelhaken.

Fig. $R$. Dieselbe im Längsschnitte: $r$, der Same.

Fig. S. Dieselbe im Querschnitte.

Fig. $T$. Der Same, natiurliche Grösse.

Fig. $U$. Derselbe 5 mal vergrössert.

Fig. $V . W$. Dersclbe im medianen und transversalen Längsschnitte: $s$, das Würzelchen; $t$. die Keimblitter. 


\title{
TRIGONELLA Linn.
}

Blithen zwittrig und zygomorph. Kelch röhrenförmig oder kïrzer mit fast gleichen Zipfeln. Blumenblätter nicht an die Staubgefässröhre angewachsen; die Fahne umgekehrt eiförmig oder oblong, sitzend oder in einen kurzen, breiten Nagel zusammengezogen; Flügel oblong; Kiel kürzer als diese, stumpf. Das oberste Staubgefäss ist frei oder mit der Röhre bis zur Hälfte verwachsen; die Beutel gleichförmig. Fruchtknoten sitzend oder kurz gestielt mit vielen Samenanlagen, Griffel fadenförmig oder dicker mit endständiger Narbe. Hülse sehr versehieden, häufig geschnäbelt und gekrümmt, geschlossen, oder auf der Rückenseite, seltener zweiklappig aufspringend. Samen ohne Anhang. - Häufig stark riechende Kräuter mit dreizähligen, gezähnelten Blättern und angewachsenen Nebenblättern. Blüthen gelb, blau oder weiss, einzeln oder gepaart achselständig, doldig, kopfig oder gedrängt traubig, dann Dcekblätter klein oder fehlend, Vorblättchen niemals entwickelt,

Etwa 50 Arten sind bekannt, von denen die meisten die Mittelmeerländer und West-Asien bewohnen, eine findet sich in Sid-Afrika, eine andere in Australien.

\section{Trigonella Foenum graecum Linn.}

\author{
Tafel 52.
}

Einjährig, krautartig mit einfachen oder vom Grunde verzweigten spärlich behaarten Stengeln und umgekehrt eiförmigen, oben gezähnelten Blättchen; Blüthen einzeln, selten gepaart, weiss; Hülse etwas seitlich zusammengedriickt und gebogen, von Nerven durchzogen; Samen fast quadratisch im Umrisse.

Trigonella Foenum graecum Linn. Spec. pl. ed. I. 777; Gürtn. Fr. t. 152; Schkuhr, Handb. t. 211; Lam. Illustr. t. 611; DC. Prodr. II. 1S2, Fl. de Fr. IV. (2). 551 a; Sibth. et Sm. Fl. Graec. prodr. II. 109, Fl. Graec. VIII. 45. t. 766 ; Desf. Atl. II. 205; Koch, Syn. ed. II. 181; Mert. u. Koch. Deutschl. Fl. V. 311; Woodw. Med. pl. III. t. 154; Hayne, Arzneigew. VIII. t. 41; Guimp. u. Schlecht. Pf. der Pharmac. III. t. 243; Nees, Dïsseld. Abbild. t. 324: Godr. et Gren. Fl. Fr. I. 397; Willk. et Lange, Prodr. Fl. Hisp. III. 391; Boiss. Fl. orient. II. 70; Parl. Fl. Ital. VIII. 270; Töhler, Mediz.-Pfl.t. 155; Bentl. and Trim. Med.pl. t. 71; Baker in Hook. Fl. Brit. Ind. II. 87; Schweinf. Beitr. Fl. Aeth. 255; Battand. et Trab. Fl. d'Alg. II. 220; Flück. Pharmacog. ed. III. 990; Baill. Bot. méd. I. 652, fig. 2211-17; Arth. Meyer, Drogenkunde. I. 137.

Bockhornklee, griechisches Heu; englisch: Fenu greek; französisch : Feun-grec.

Die Pfahlwurzel sendet zahlreiche, dünne Zweige aus.

Der Stengel ist $20-60 \mathrm{~cm}$ hoch, entweder einfach oder er verzweigt sich schon aus den Keim- und den untersten Stengelblättern, so dass sich von seinem Grunde aus 2-4, selten mehr Äste erheben, welche im Bogen aufsteigend, fast die Höhe der Hauptaxe erreichen; er ist krautig, stielrund, nur oben zusammengedrückt, besonders nach oben hin ist er mit einfachen, einzelligen, schlaffen, später abfälligen Haaren spärlich bekleidet.

Die Blätter sind zweizeilig, typisch dreizählig, nur die untersten sind zuweilen einzählig, sie sitzen auf einem $0,5-1,5$ selten bis $3 \mathrm{~cm}$ langen, flachen, nach oben hin verbreiterten Stiele; von den Blättchen ist das Endblättchen am grössten, es misst gewöhnlich c. 1,2-1,7 cm, selten wird es 2,0-2,5 cm lang; gewöhnlich ist es im oberen Viertel $0,8-1,2 \mathrm{~cm}$, selten bis 1,4 cm breit; die Seitenblättchen sind etwa um ein Drittel kleiner und mit einem viel kürzeren Stielchen als jene versehen; sie sind umgekehrt eiförmig und an der Spitze, bis höchstens zur Mitte, mit seichten aber sehr spitzen Zähnchen versehen; sie werden von meist 4 beiderseits vorspringenden grösseren Seitennerven durchzogen, sind kahl, lebhaft 
grün und krautig; die Nebenblätter sind tief zweispitzig, dünnhäutig und grủn geadert, sie, wie der gemeinschaftliche Blattstiel, sind ein wenig behaart.

Die Blüthen stehen einzeln oder gepaart in den Achseln der oberen Laubblätter; sind sie einzeln, so stehen sie schief gegen das letztere, sie tragen dann meistens kurz über dem Grunde des nur 1, höchstens $2 \mathrm{~mm}$ langen Blüthenstieles oberhalb einer ringförmigen Gliederung ein kleines Schuppenblättchen in seitlicher Stellung, welches der jüngeren Blithe eines Pärchens immer zukommt. Beide Blüthen treten dann entweder frei aus dem Blattachselgrunde oder sind unten auf kurze Strecke mit einander verbunden.

Der Kelch ist 7-8 mm lang, kreiselförmig und bis zur Hälfte in 5 fast vollkommen gleiche, lanzettlich pfriemliche zugespitzte Zipfel getheilt, die Röhre wird von 5 starken, grïnen und 5 schwächeren Nerven durchzogen. Die Fahne ist 13-15 mm lang, oblong umgekehrt-eiförmig, an der Spitze tief ausgerandet und eng zusammengebrochen, sie ist gelblich weiss; die Fligel messen 11-12 mm, sie sind einseitig geöhrt und haben auf dem nach oben gerichteten Rande einen seichten Ausschnitt. Der Kiel ist verhältnissmässig kurz $(6-7 \mathrm{~mm})$ und stumpf. Die Staubgefässröhre ist oben offen und wird dureh das freie Staubgefäss geschlossen, sie misst $5-6 \mathrm{~mm}$; die Staubbeutel sind kaum $0,3 \mathrm{~mm}$ lang. Der sanft gekrümmte, behaarte, seitlich zusammengedrückte Stempel ist $5-5,5 \mathrm{~mm}$ lang, in den kurzen Griffel verschmälert; die Narbe ist endständig, polsterförmig, sehr seicht zweilappig; die ganze blühende Pflanze riecht besonders getrocknet sehr eigenthümlich, man sagt nach » Kräuterkäse», der dureh sie gewlirzt wird,

Die Frucht erreicht eine Länge von $13 \mathrm{~cm}$ und ist $4-5 \mathrm{~mm}$ breit; sie ist linealisch, sehr lang schnabelförmig zugespitzt, gewöhnlich nach unten flach hornförmig gekrümmt und seitlich zusammengedrïekt; die Klappen bleiben auf der Unterseite zusammenhängend, an dem Oberrande sind sie verdickt, sie werden von anastomisierenden Längsnerven durchzogen.

Die Samen sind mehr rhombisch als quadratisch im Umrisse, sie messen 2,5-3 mm und sind bräunlich- oder dunkelgelb.

Der Hornklee wächst im nördlichen Indien und zwar im Pendschab und Kaschmir wild, wurde aber von Alters her in Griechenland und Italien als Futterpflanze cultivirt; hier sowohl wie in Ägypten und Klein-Asien findet sich die Pflanze auf Schuttplätzen, überhaupt in der Nähe mensehlicher Wohnungen oder Culturstätten als Flichtling; ob sie in den Wüsten von Mesopotamien und Persien wirklich wild vorkommt, ist nicht sicher auszumachen. Heute wird sie hauptsächlich in den Mittelmeerländern und in Indien gebaut.

Die Samen der Pflanze finden unter den Bezeichnungen Semen Faeni graeci, Semen foeni graeci, Semen Trigonellae Verwendung in der Thierarznei.

\section{Erklärung der Abbildungen.}

Fig. $A$. Die blühende und fruchtende Pflanze nach einem lebenden Exemplare aus dem Küniglichen Botanisehen Garten zu Berlin.

Fig. $B$. Die Blüthe, doppelt vergrössert.

Fig. C. $-E$. Die Fahne, die Flügel und der Kiel.

Fig. $F$. Die Staubgefïssröhre 5mal vergrössert: $a$. die verbundenen Staubgefïsse, $a^{\prime}$ das freie, $b$. der Stempel.
Fig. $G$. Der Stempel 6mal vergrössert.

Fig. H. Die Frucht in noch nicht ganz reifem Zustande.

Fig. $I$. Der Same, 4 mal vergrössert.

Fig. K. L. Derselbe im Längs- und Querschnitte. 


\section{MELILOTUS Linn.}

Blïthen zwittrig und zygomorph. Kelch röhrenförmig mit kurzen, sehmalen, gleichen, Zipfeln. Blumenblätter von der Staubgefässröhre frei; die Fahne umgekehrt eiförmig oder oblong, an der Basis verengt, sitzend; die Flügel oblong, der Kiel wenig kürzer als diese, stumpf. Das oberste Staubgefäss frei, oder bis zur Hälfte mit den übrigen verwachsen, Beutel gleichförmig. Fruchtknoten gestielt mit wenigen (bis 8) Samenanlagen, Griffel gekrïmmt mit endständiger Narbe. Hülse fast kugelig oder im Umfange kreisförmig und zusammengedrückt, gerade, länger als der Kelch, nicht oder nur zögernd vom Rüicken her aufspringend. Samen einzeln oder wenige, ohne Anhang. - Einjährige oder zweijährige Kräuter, zuweilen am Grunde verholzende Stauden mit dreizähligen, gezähnelten Blättern und angewachsenen Nebenblättern. Blüthen klein, weiss oder gelb in sehr zierliehen achselständigen Trauben. Deckblätter klein oder, wie die Vorblättchen stets, fehlend.

Etwa 10 Arten, welche in den gemässigten oder subtropischen Gegenden der alten und neuen Welt verbreitet sind.

\section{Melilotus officinalis Desrouss.}

Taf. 53.

Zweijährig oder ausdanernd, krautig mit aufrechtem, kahlem Stengel; Nebenblätter auch der unteren Blätter ganzrandig, pfriemlich; Trauben ziemlich locker; die Flïgel ein wenig länger als der Kiel; Hülse einsamig, querrunzlig und genetzt, kahl.

Melilotus officinalis Desrousseaux in Lam. Encycl. IV. 63; Pers. Ench. II. 34S; Schrank, Fl. Monac. IV. t. 322; DC. Prodr. II. 156; Guimp. u. Schlecht. Pf. der Pharmac. II. 115 t. 194; Baxter, Brit. bot. V. t. 363; Hert. u. Foch, Deutschl. Flora V. 250; Godr. et Gren. Fl. Fr. I. 402; Ledeb. Fl. ross. I. 537; Willk. et Lange, Fl. Hispan. III. 374; Boiss. Fl. orient. II. 109; Parlat. Fl. Ital. VIII. 84; Berg u. Schmidt, Darstell. u. Beschreib. t. XXVIf; Koehler, Mediz.-Pf. t. 52; Baill. Bot. méd. 651. fig. 2213.

Melilotus Petitpierreanus Reichb. Fl. excurs. 498; Koch, Syn. 167.

Melitotus diffusus Koch in DC. Fl. Fr. V. 654.

Melilotus arvensis Wallr. Sched. critic. $592 ;$ DC. Prodr. II. 158.

Trifolium Melilotus officinalis Linn. Spec. pl. ed. I. 765 z. Th.; Fl. Dan. VI. t. 934; Plenck, Icon. t. 567 ; Dreves, Bilderb. II. t. 44; Nees, Düsseldorf. Abb. t. 326.

Trifolium officinale Scop. Carniol. (ed. II.) II. 55; Svensk Bot. I. 69; Sm. Brit. Bot. II. t. 781; Hayne, Arzneigew. II. $t$. 31 .

Trifolium Petitpierreanum Hayne in Schrad. Neues Journ. II. 336.

Gebräuchlicher Honigklee; englisch: Honey-Lotus; französisch: Mélilot officinal.

Die Pflanze wächst im ersten Jahre zu einer $40-60 \mathrm{~cm}$ hohen Staude heran, die im Winter abstirbt und im zweiten Jahre aus den Blattachseln des stehenbleibenden Restes (selbst aus den Cotyledonenachseln) kräftige Seitentriebe entwickelt, die zur Blüthe gelangen. In der Cultur wenigstens erhält sich die Pflanze mehr als zwei Jahre; unter Umständen blüht sie schon im ersten Jahre.

Die Pfahlwurzel ist ausserordentlich (bis $1 \mathrm{~m}$ ) lang und oben 1-2 cm und mehr dick, sie ist besonders oben reichlich kräftig verzweigt, unten trägt sie nur dünne, zarte Seitenwurzeln (Faserwurzeln), an welchen die den meisten Leguminosen eigenthümlichen birnförmigen oder unregelmässig gestalteten weissen Knöllehen bemerkt werden; über ihren Inhalt ist man verschiedener Meinung, die Einen erkennen 
in sehr feinen Körnchen Bacterien, die anderen Bacteroiden (d. h. Stickstoffreservekörperchen); sie ist zuerst weiss, später wird sie durch Peridermbildung braun.

Der Stengel werden mehrere (wie oben gezeigt) aus dem Grunde hervorgetrieben*), sie erreichen eine Höhe von 1-2 m und haben am Grunde einen Durchmesser von $0,8-1,2 \mathrm{~cm}$; sie sind unten stielrund, oben werden sie durch die mehr oder weniger deutlich hervortretenden, von einem Blatte bis zum dritt- oder fünftuntersten herablaufenden Spuren mehr oder weniger deutlich kantig; die Farbe ist krautig grïn, auf der dem intensivsten Lichte zugekehrten Seite werden sie gern röthlich; sie sind auch in den jünsten Theilen kahl oder fast kahl.

Die Blätter sind spiralig gestellt und werden in ihrer Disposition durch $1 / 3$ oder $3 / 8$ bestimmt. Sie sind, zumal die unteren lang (bis $2,5 \mathrm{~cm}$ ) gestielt, bei den oberen geht der Stiel bis zu $1 \mathrm{~cm}$ und noch weniger herab; er ist gewöhnlich wagerecht abstehend, oberseits gerieft und mit spärlichen mikroskopisch kleinen, keulenförmigen, mehrzelligen Härchen bestreut. An den dreizähligen Blättern ist das Endblättchen um ein weniges länger als die seitlichen, es ist auch beträchtlich länger (bis $10 \mathrm{~mm}$ lang) gestielt; oberhalb des Stielehen ist ein callösses Gelenk von $1 \mathrm{~mm}$ Länge, auf welches das Stielehen der Seitenblättchen ausschliesslich reducirt ist; die Spreite des Endblättehens schwankt zwischen 1 und $3 \mathrm{~cm}$ und seine Breite zwischen 3 und $15 \mathrm{~mm}$; sie ist oblong oder fast rhombisch, an den kleineren oblong- oder lanzettlich umgekehrt-eiförmig, am oberen Ende ist sie gestutzt und mit einem winzigen Endzähnchen versehen, am unteren ist sie ganz und spitz, sie wird von etwa 10 grösseren Seitennerven durchlaufen und ist am Rande spitzlich gesägt-gezähnt; die Oberseite ist dunkelgrün und kahl, die Unterseite ist durch zahlreiche subepidermale Luftlïcken grau und spärlich behaart; die Seitenblättchen sind um $1 / 4$ oder $1 / 5$ kleiner, sonst den vorigen ähnlich; die Nebenblätter sitzen dem Blattstiele dort an, wo sein Gelenk in den Stengel tibergeht, sie sind 3-5 mm lang, sehmal lineal-pfriemlich, am verbreiterten Grunde ganzrandig.

Der Blüthenstand ist eine $5-7 \mathrm{~cm}$ lange, später bis $20 \mathrm{~cm}$ anwachsende, gestielte, lockere Traube; sie sitzt zuerst einzeln in den Achseln der oberen Blätter der zweijährigen Triebe und ist mit einer unteren Beiknospe versehen. Wenn die Fruchtreife herannaht, beginnt diese ihre Entwicklung, indem sie aus dem zweiten der transversal gestellten Primärblätter einen Blüthenstand treibt, der wieder eine untere Beiknospe von gleicher Beschaffenheit hat; die Knospe aus dem ersten Primärblatt wird aber ein Langtrieb, doch kommt es auch vor, dass erst das dritte Blatt einen Bliithenstand hervorbringt und beide untere Blätter entweder früher oder später anstreibende Laubtriebe entwickeln. Die Blüthenspindel ist kantig, seicht gefurcht und nur sehr spärlich behaart; die Deckblätter sind linealisch-pfriemlich, kaum $1 \mathrm{~mm}$ lang, Vorblättchen fehlen; die gelben Blüthen nicken an dem 1-2 mm langen, fast kahlen Stiele.

Der Kelch ist 2-2,5 mm lang und kahl oder fast ganz kahl, die kaum $1 \mathrm{~mm}$ langen, linealisch-pfriemlichen Lappen sind durch gerundete Buchten getrennt. Die Fahne misst 6-6,5 mm in der Länge und 3 bis $3,5 \mathrm{~mm}$ in der Breite, sie ist an der Spitze gestutzt und mit den Rändern nach oben geschlagen; die mit dem Kiel auf kurze Strecke verklebten Flïgel sind einscitig tief geöhrt, vorn stumpf, sie sind kurz genagelt und $6 \mathrm{~mm}$ lang; der Kiel hat nur eine Länge von $5-5,5 \mathrm{~mm}$, er ist schmal und vorn stumpf. Die weisse Staubgefässröhre ist 3 , die freien Staubgefässe sind ausserdem $2 \mathrm{~mm}$ lang; das zehnte obere ist zwar am Grunde deutlich frei, hängt aber sonst mit der Röhre ziemlich fest zusammen; die gelben Beutel sind $0,5 \mathrm{~mm}$ lang. Der Stempel ist $0,5 \mathrm{~mm}$ hoch gestielt; der kahle, griine, oblonge, etwas zusammengedrtickte Fruchtknoten ist 1-1,2 mm lang und umschliesst 5-8 Samenanlagen, von denen aber nur eine zur vollen Entwicklung gelangt, der 2,5-3 mm lange Griffel ist sanft gekrimmt und trägt an der Spitze die schief nach unten aufgesetzte Narbe.

Die einsamige $\mathrm{H}$ ii lse ist $2,5-3 \mathrm{~mm}$ lang und in der Mitte $2 \mathrm{~mm}$ breit, sie wird von dem bleibenden Kelche gestïtzt, sie ist gerundet rhombisch, beiderseits spitz, an den Rändern gekielt; sie springt nur sehr zögernd am Rücken auf; die Klappen sind strohgelb oder heller, kahl und werden von queren Leistchen tiberzogen, die gelegentlich anastomosiren.

*) Die älteren Botaniker drückten dies Verhältniss dadurch aus, dass sie die Wurzel mehrköpfig nannten. 
Der Same misst $2-2,5 \mathrm{~mm}$ in der Länge und 1,2-1,5 $\mathrm{mm}$ in der Breite, er ist hell gelbbraun und glatt; das Würzelchen tritt sehr deutlich hervor.

Der gebräuchliche Honigklee wächst in Europa von dem mittleren Schweden und Finnland über Dänemark, Deutschland, England, Schweiz, Frankreich bis nach den mittleren Spanien (fehlt in Portugal), Italien, Dalmatien; von Österreich geht er durch die Donauländer bis Thrazien; von Central-Russland dringt er ïber Polen nach Armenien bis Nord-Persien, iber den Ural bis zum Altai vor.

Anmerkung. Die Analysen des Fruchtknotens, der Frucht und des Samens sind der verwandten Mel. macrorrhizus Pers. entnommen, der sich dureh behaarte Früchte und dadureh unterseheidet, dass Flügel und Kiel von gleicher Länge sind.

Die getrockneten oberirdischen Theile der blïhenden Pflanze kommen als Herba Meliloti in den Handel.

\section{Erklärung der Abbildungen.}

Fig. A. Die Spitze eines blihenden Zweiges.

Fig. $B$. Die Blithe, 5 mal vergrössert: $a$. der Kelch; $b$. die Fabne; $c$. die Flügel; $d$. der Kiel.

Fig. C.-E. Fahne, Flügel, Kiel, 6mal vergrössert.

Fig. $F$. Die Blüthe nach Entfernung der Blumenblätter e. Staubgefässröhre.

Fig. $G$. Die Staubgefässröhre, smal vergrössert, ausgebreitet.

Fig. H. Staubbeutel von innen und aussen, $40 \mathrm{mal}$ vergröss.

Fig. I. K. Pollenköruer trocken und in Wasser.
Fig. L. Der Stempel von Melltotus macrorrhizus Pers. 10mal vergrössert.

Fig. $M$. Derselbe im Längsschnitte: $f$. der Fruchtknoten; $g$. der Griffel; $h$. die Narbe; $i$. die Samenanlagen.

Fig. N. Die Narbe $25 \mathrm{mal}$ vergrössert.

Fig. O. Die Frucht, 8 mal vergrössert.

Fig. P. Q. Dieselbe im Längs- und Quersehnitte: $l$. die Samenschale; o. das Wïrzelehen; $p$. die Keimblätter.

Fig. $R$. Der Same: $m$. der Nabel; $n$. die Micropyle.

\section{ASTRAGALUS Linn.}

Blüthen zwittrig, zygomorph. Kelch röhren- bis kreiselförmig, tief gctheilt, die Zähne ziemlich gleich. Blumenblätter häufig langgenagelt, die Fahne aufrecht, eiförmig, oblong oder geigenförmig, die Flügel oblong, der Kiel ziemlich gerade, stumpf, so lang wie die Flügel oder wenig kürzer. Stanbgefässe bis auf das obere freie, zu einer geschlitzten Röhre verwachsen. Fruchtknoten gestielt mit mehreren bis sehr zahlreichen Samenanlagen; Griffel gerade oder gekrümmt mit einfacher, endständiger Narbe. Hülse sehr verschieden, zuweilen stark aufgeblasen, manchmal durch eine dorsale Längsfalte in zwei Längsfächer getheilt. Samen meist nierenförmig, ohne Anhang, mit fadenförmigem Samenstrange. - Aufrechte oder niederliegende Stauden oder sehr verästelte Halbsträucher oder Sträucher, die entweder unbewaffnet oder durch die dornig gewordenen Blattstiele stark bewehrt sind. Blätter unpaarig, oder an den dornigen Ästen abgebrochen paarig gefiedert, selten drei- oder einzählig, mit ganzrandigen, nebenblattlosen Blättchen. Nebenblätter frei oder dem Blattstiele angewachsen. Blithen violett, purpurroth, weiss oder blassgelb, in Trauben oder Ähren, selten in Dolden, oder einzeln oder gepaart achselständig; die Deckblätter sind meist häutig und klein, die Vorblättchen winzig oder fehlen ganz.

Eine der grössten Gattungen der Schmetterlingsbluthler mit über 1200 beschriebenen Arten, die hauptsächlich im russischen Asien, im Himalaya und dem Oriente gedeihen; einige wachsen auch im gemässigten Europa und dringen bis in die arktischen Gegenden vor; Nord- und Suid-Amerika sind namentlich in den Anden und deren nördlicher Fortsetzung reich an Arten, in Afrika sind weniger Arten, doch wächst noch eine im südöstlichen Afrika; im Caplande und in Australien fehlt die Gattung. 


\section{Astragalus gummifer Labill.}

\section{Tafel 54 .}

Strauchartig, durch die verholzten, bleibenden Blattspindeln stechend bewehrt, jährige blühbare Zweige stark verkürzt; Deckblätter abfällig, Vorblättchen fehlend; Kelehröhre bis zum Grunde behaart und in Lappen gespalten; Fahne mit breitem Nagel, die Blumenblätter der Staubgefässröhre hoch angewachsen; Blättchen fünf- bis siebenjochig, oblong bis oblong-lanzettlich, kahl.

Astragalus gummifer Labillard. Journ. phys. 1790. p. 46 mit Abbild.; DC. Prodr. II. 296; Hayne, Arzneigew. X. t. 8; Guimp. u. Schlecht. Pfl. der Pliarmac. II. t. 155; Nees, Diisseld. Abbild. Suppl. t. 62; Bentl. and Trim. Med. pl. t. 73; Köhler, Mediz.-Pfl. unter t. 19; Boiss. Fl. orient. 1I. 318; Baill. Bot. méd. I. 639. fig. 2200 u. 2201.

Astragalus erianthus Willd. Spec. pl. III. 1332.

Traganthstrauch; englisch: Gum-bearing-mill-vetch; französisch: Astragale gummifère.

Der sehr sparrig und reichlich verästelte Strauch ist $50-70 \mathrm{~cm}$ hoch, seine oberen blühenden Zweige haben ein sehr hartes und gelblich-weisses Holz, das von einer gran- oder gelbbraunen, in diinnen Borkenblättchen abschülfernden Rinde bedeckt ist, die vorjährigen sind von den verholzten, empfindlich stechenden Spindeln der Blätter geschützt und dicht weiss behaart.

Die Blätter sind spiralig angeordnet, sie haben eine Länge von $2,5-4,5 \mathrm{~cm}$, sie sind paarig und zwar funf- bis siebenjochig gefiedert; die Spindel ist schon in friher Jugend verholzt, gelb, stielrund und zugespitzt, stehend; auf ihrer Oberseite stehen auf fast völlig gleicher Höhe in Grübchen eingesenkt die Blättchen; diese sind mit dem kaum $1 \mathrm{~mm}$ langen Stielehen 7-8 mm lang und in der Mitte 2,5-3 mm breit, sie sind oblong bis oblong-lanzettlich, beiderseits spitz und blaugrï; sie fallen bald ab; die Nebenblätter messen 7-9 mm; sie sind dem Blattstiele angeheftet, zweispitzig und spitz, sehr diunnhäutig, leicht vergänglich; ursprünglich ganzrandig, fasern sie an den Seiten leicht aus, sie sind kahl, nur am Grunde etwas behaart.

Die Blithen stehen gepaart und sitzend in den Blattachseln, sie scheinen schief nach vorn gewendet zu sein und werden von einem 6-7 mm langen, oben bis zu einem Drittel eingeschnittenen, in der Mitte zusammengebrochenen, gekielten, dünnhäutigen, gelben kahlen Deckblatte gestiitzt; dieVorblättchen fehlen.

Der Kelch ist $7 \mathrm{~mm}$ lang und bis zur Hälfte fünftheilig; die Zipfel sind linealisch-pfriemlich zugespitzt, sie reissen schr leicht bis auf den Grund auf und sind aussen, wie die kreiselförmige Röhre von langen weissen Haaren dicht seidig-zottig bekleidet. Die Blithe ist gelblich weiss; die spathelförmige, oben ausgerandete Fahne ist 14-16 mm lang. Die Flïgel messen $12-14 \mathrm{~mm}$ in der Länge, sie sind mittelst des 8-9 mm langen sehmalen Nagels der Staubgefässröhre angewachsen; der Kiel misst $12-13 \mathrm{~mm}$, er ist schmal und stumpf. Die weisse Staubgefässröhre misst $10-11 \mathrm{~mm}$, sie ist nur äusserst wenig gekrimmt und auch die $2 \mathrm{~mm}$ langen Staubgefässe sind ihr nahezu gerade aufgesetzt; die Staubbeutel messen $0,6-0,7 \mathrm{~mm}$. Der St e mpel hat eine Länge von $12-13 \mathrm{~mm}$; der Fruchtknoten ist 3,5-4 mm lang, umschliesst etwa 10 Samenanlagen und ist angedritekt, an der Spitze aber schopfig behaart; der Griffel verjuingt sich allmälig und wird nach und nach kahl.

Die Frucht der Pflanze haben wir nicht gesehen, die des ahnlichen $A$. aristatus $L$. ist eine $7-8 \mathrm{~mm}$ lange, oblonge, zugespitzte, lange Zeit von dem bleibenden Griffel gekrönte, wenig gedunsene, kurzhaarige Hülse, die zögernd zweiklappig aufspringt.

Der nierenförmige Same derselben Pflanze missi 2-2,5 mm, er ist kastanienbraun und kahl.

Die Traganthpflanze findet sich in den trockenen alpinen und subalpinen Gegenden Syriens und zwar am Hermon und Libanon, ferner in Cappadocien und Armenien. 
A nmerkung. In Figur $K$. unserer Tafel haben wir ein Zweigstïck eines anderen Traganthstrauches, nämlich des Astr. leioclados Boiss. abgebildet, um jene eigenthümliche Schmarotzerpflanze zur Darstellung zu bringen, die für diese Strïucher charakteristisch ist: Pilostyles Hausknechtii Boiss. gehört in die Familie der Rafflesiaceae; die Pflanze wuchert zuerst nach Art eines Pilzmycels in den jüngsten Enden des Strauches und zwar im Rinden- und Markparenchym; dann bilden sich rundliche Gewebekörper, aus denen sich die Blïthe differenzirt. Die Gewebeballen sind derartig angeordnet, dass immer zwei Blithen unterhalb eines Blattes, rechts und links zu seiner Mittelrippe die Rinde durchbrechen.

Astragalus gummifer ist eine der vielen Astragalus-Arten, welche Traganth (Tragacantha) liefert. Der Traganth entsteht durch eine vermuthlich durch Pilze veranlasste Metamorphose des Mark- und Markstrahlgewebes der oberirdischen Achsen der Pflanze.

\section{Erklärung der Abbildungen.}

Fig. A. Ein Zweig von Astragalus gummifer Labill. nach einem von EHRENberG in Syrien gesammelten Exemplare.

Fig. $B$. Die Blïthe, 3mal vergrüssert.

Fig. C. Der Kelch, vorn aufgeschlitzt, mit dem Fruchtknoten, $6 \mathrm{mal}$ vergrössert.

Fig. D. E. Dic Fahne, die Flügel und der Kiel, aus dem die Staubbeutel hervorsehen, $3 \mathrm{mal}$ vergrössert.
Fig. F. Die Staubgefässröhre mit dem einzelnen, freien Staubgefaisse.

Fig. G. H. Hiilse und Same von Astrag, aristatus L, aus den tyroler Alpen.

Fig. I. Verdornte Blattspindel mit dem Nebenblatt, natïrliche Grösse.

Fig. $K$. Zweig von Astrag. leioclados Boiss. mit Pilostyles Hausslinechtii Boiss. in blïhendem Zustande. 


\section{GLYCYRRHIZA Linn.}

Blïthen zygomorph, vollständig. Kelchzipfel gleich oder die zwei oberen kürzer und mit einander am Grunde verbunden; Fahne oblong oder schmaleiförmig, aufrecht, am Grunde kurz zusammengezogen; Flïgel schief oblong, spitzlich, frei; Kiel kiirzer als diese, spitz oder stumpf. Staubblätter mit Ausnahme des obersten, welehes frei ist, zu einer oben gespaltenen Röhre vereinigt, oder auch jenes ist am Grunde mit in den Verband aufgenommen; Beutel durch Längsspalten, welche iber den Scheitel zusammenfliessen, fast zweiklappig aufspringend, abwechselnd grösser und kleiner. Fruchtknoten sitzend mit zwei bis vielen Samenanlagen; Griffel gekrïmmt, an der Spitze mit kopfiger Narbe. Hiilse eiförmig, oblong oder selten kurz linealisch, gerade oder gekrümmt, hänfig stachelig oder driisig, nicht oder nur zögernd geöffnet. Samen nierenförmig oder fast kugelförmig, ohne Anhang. - Ausdanernde Stauden mit oft drïsiger Bekleidung und umpaarig gefiederten Blätter; Blättchen in meist vielen, selten nur drei Paaren, ganzrandig oder drïsig gezähnt; Nebenblätter schmal, häutig, abfällig. Die verhältnissmässig nicht grossen Blüthen stehen in lockereren oder dichteren, sitzenden oder gestielten Trauben und werden von kleinen, schmalen, leicht abfallenden Deckblättern gestiltzt, Vorblïttchen fehlen.

Man kennt nur etwa 12 Arten, die Gattung hat aber die weiteste Verbreitung; die grösste Zahl der Arten kommt dem Mittelmeergebiete und dem gemässigten Asien bis nach China zu, vereinzelt leben sie in Nord- und Suidamerika und in Australien.

\section{Glycyrrhiza glabra Linn.}

Tafel 55 .

Stengel einfach, am Grunde in der Erde Ausläufer treibend; Blätter vielpaarig gefiedert mit eioblongen, stumpflichen, an der Spitze meist etwas ausgerandeten, kurz stachelspitzigen, oberseits kahlen, unterseits schwach drüsigen und sonst kahlen oder behaarten Blättchen; Ähren gestielt, später wenigstens locker, kürzer als die Blätter; Hïlse kahl, glatt und glänzend oder bestachelt und matt, zwei- bis sechssamig.

Glycyrrtiza glabra Limn. Spec. pl. ed. I. 742; Woodv. Med. pl. III. t. 152; Plenck, Offiz. Gew. t. 570; Lam. Illustrat. t. 625. Fig. 2; Hayne, Arzneigew. VI. t. 42; DC. Prodr. II. 217; Sibth. Fl. Graec. t. 709; Guimp. und Schlecht. Pfl. der Pharm. t.156; Koch, Syn. 178; Bertol. Fl. Ital. VII. 572, Grodr. et Gren. Fl. de Fr. I. 455; Willk. et Lange, Prodr. Fl. Hisp. III. 290; Berg und Schmidt, Darst. und Beschreib. t. XIIf; Bentl. and Trim. Medic. pl. t. 74; Köhler, Mediz.-Pfl. t. 135; Boiss. Fl. orient. II. 202; Flïck. Pharmacogn. ed. III.218, 376; Battand. et Trab. Fl. d'Alg. II. 264; Arth. Meyer, Drogentunde. I. 230.

Glycyrrhiza glandulifera Waldst. et Kit. Pl. rar. Hung. I. 20. t. 21; DC. Prodr. II. 247; Ledeb.

Fl. alt. III. $261 ;$ Fl. ross. I. $565 ;$ C. Koch in Linnaea. XV. 719.

G. hirsuta Linn. l. c.; Pall. It. I. 154, 366, app. 498, 11. 486, III. 665.

G. laevis Pall. It. I. 370, app. 405; III. 556, 655; Less. in Linn. IX. 168.

G. officinalis Lepech. It. I. 235.

G. vulgaris Güldenst. It. II. 32, 43, 4 .

G. violacea et pallida Boiss. Diagn. ser. II. (2). 23, 24.

G. brachycarpa Boiss. Diagn. ser. I. 2.

Liquiritia officinalis Moench, Meth. 132, 152; Pers. Syn. II. 313 ; Nees, Dïsseld. Abb. t. 327.

Gemeines Süssholz; engliseh: licorice; französisch: réglisse.

Berg v. Schmidt offeinelle Gewiche. If. 
Aus einer mehr oder weniger tief im Boden kriechenden, horizontalen Grundaxe erheben sich mehrere unten gewöhnlich paarig gabelig verbundene, straff aufrechte Stengel, aus deren untersten, schuppenartigen Niederblättern Knospen entspringen, die im nächsten Jahre wieder den Stock erneuern können. Neben den Ausläufern treten auch aus dem Rhizome kräftige 4-25 mm dicke, runde Wurzeln hervor, welche den Ausläufern gleichen, aber kein Mark umschliessen und keine Knospen wie jene erzeugen. Die unterirdischen Organe sind aussen von schwarz- oder heller brauner Rinde umgeben, der Holzkörper ist schön gelb und schmeckt, namentlich getrocknet, angenehm siiss.

Der Stengel ist 7-8, zuweilen bis $10 \mathrm{~mm}$ dick und $1,3-2 \mathrm{~m}$ hoch; er ist straff aufrecht und bis in die Blïthenregion einfach, am Grunde stielrund, kahl, dunkel berindet und verholzt, oben wird er von den herablaufenden und stark vorspringenden Blattspuren kantig und erscheint wenigstens an der Spitze, zuweilen auch tiefer unten von geschlïngelten oder gebogenen, stark verdickten Haaren, denen sich Köpfchenhaare zugesellen, mehr oder weniger dicht filzig und grau bekleidet.

Die Blätter sind einfach und unparig gefiedert; die Spindel ist 10-15 cm lang, am Grunde stark angeschwollen verdickt, auf der Oberseite schwach rinnig, fast kahl oder wie die Stengelspitze behaart; Fiederpaare sind (das Endblättchen nicht eingerechnct) 5-8 vorhanden; die Blättchen stehen deutlich an der Oberseite der Spindel, genau gegenständig; sie sind $3-4(2-4,5) \mathrm{cm}$ lang und im unteren Drittel etwa $1,3-1,7(1-2,2) \mathrm{cm}$ breit; sie werden ron einem kurzen, höchstens $2 \mathrm{~mm}$ langen, kahlen oder behaarten, etwas verdiekten Stielchen getragen, sie sind oblong oder eioblong, seltener lanzettlich oder umgekehrt eiförmig, am Grunde spitz, oben stumpf oder stumpflich, wenig ausgerandet und zuweilen kurz stachelspitzig; neben dem deutlichen Mittelnerven werden sie von $7-9$ wenig vorspringenden Seitennerven durchlaufen; eine Bekleidung mit einfachen Haaren fehlt entweder ganz oder sie ist nur unterseits am Nerven vorhanden, zuweilen ist sie auch reichlicher; dagegen werden sitzende Schülfern unterseits niemals vermisst; auch oberseits sind sie, obgleich viel spärlicher wahrzunehmen. Die Nebenblättchen sind schmal pfriemlich, meist nur bis $2 \mathrm{~mm}$ lang, fein bchaart und leicht abfällig.

Der Bluthenstand ist eine zuerst dichtere, dann lockerere Traube; sie tritt aus der Achsel der oberen Blätter und ist stets von einer unteren Beiknospe begleitet, die sich auch zuweilen schon während der Blüthezeit entfalten kann. Er misst 10-15 cm; der blüthenfreie Stiel beträgt etwa $1 / 3$ der Länge. Die Spindel ist unten stielrund, aber oben kantig und mehr oder weniger behaart. Die Deckblätter der Bluthen sind 3-4 mm lang, entweder sind sie lanzettlich, lang zugespitzt oder breiter, fast umgekehrt eiförmig und kurz zugespitzt, sie fallen in der Regel bei der Vollbluthe ab. Die Blüthen sind sehr kurz (kaum $1 \mathrm{~mm}$ lang) gestielt.

Der Kelch ist 4,5-6 mm lang, röhrenförmig, am Grunde etwas schief und fast bis zur Hälfte in gleiche, pfriemliche, zugespitzte, krautige Zipfel getheilt, nur zuweilen ist der untere etwas länger, die beiden oberen aber sind höher verbunden; er ist aussen sehr spärlich behaart und von Köpfchendruisen klebrig; die Zipfel sind schwach gewimpert. Die Fahne ist $1-1,3 \mathrm{~cm}$ lang, lineal oblong, spitz und am Grunde allmälig verschmälert, sie ist in der Mitte zusammengefaltet und nur wenig nach aufwärts gekrümmt. Die Farbe ändert wie die der übrigen Blüthenblätter von röthlich weiss bis violett. Die Flügel sind nur wenig kürzer, lanzettlich linealisch, einseitig geöhrt und plötzlich in den schmalen Nagel zusammengezogen, an der Spitze sind sie gestutzt. Der Kiel ist um 1/3 kürzer; seine Blätter sind schief, fast halbherzförmig und spitz. Von den 10 geraden Staubgefässen sind 9 beinahe bis zur Hälfte in eine oben geschlitzte Röhre verwachsen, aber auch das zehnte hängt am Grunde mit dieser zusammen; sie sind ungleich lang, indem sie von dem untersten nach dem obersten allmälig an Länge abnehmen; das grösste misst $7-8 \mathrm{~mm}$. Die Beutel haben eine Länge von wenig über $0,5 \mathrm{~mm}$, dabei lassen sich aber die abwechselnden grösseren von den kleineren unterscheiden, sie sind herzförmig und springen durch zwei über den Scheitel zusammenlaufende Längsspalten auf; die Pollenkörner sind ellipsoidisch und werden von 3 meridionalen Falten durchzogen, sie sind sehr fein in der Exine gekörnt. Der Stempel ist etwa $6-7 \mathrm{~mm} \mathrm{lang}$, sitzend und hat einen lineal-lanzettlichen, von den Seiten her zusammengedrickten kahlen oder mit sitzenden Köpfehenhaaren bestreuten Fruchtknoten, welcher 6-8 Samenanlagen von 
campylotroper Form einschliesst; der Griffel ist fadenförmig, gerade, kurz, vor der Spitze etwas gebogen und trägt eine gerade aufgesetzte, kopfförmige Narbe,

Die Frucht ist gerade, 1,2-3,2 cm lang und 5-6 mm breit, am Grunde ist sie mehr allmälig verjüngt, oben kurz in eine Stachelspitze zusammengezogen; sie ist linealisch, kahl und glatt oder warzig, von den Seiten zusammengedrückt und bei den Samen ein wenig gedunsen, zwischen ihnen aber durch Verbindung der Wände gefächert; ihre Farbe ist schön kastanienbraun, sie ist glänzend oder matt, besonders an der Rückseite gerandet und umschliesst bald nur einen, bald mehrere, bis 8 Samen und scheint nicht aufzuspringen.

Der Same hat $3-3,5 \mathrm{~mm}$ im Durehmesser und ist bald mehr, bald weniger zusammengedrückt, im Umfange kreisförmig oder fast quadratisch; er ist glänzend kastanienbraun, glatt, nicht skulpturirt. Das kurze, dicke, gekrümmte Würzelchen liegt an der Berïhrungsfläche den oblongen, dicken Keimblättern auf.

Man unterscheidet gegenwärtig folgende Varietäten, die friher gemeinlich als eigene Arten angesehen wurden.

Varietät a. typica Reg. et Herd. Ziemlich kahl; Kelchzähne linealisch pfriemlich, so lang wie die Röhre, Fahne bläulich, Hülse kahl, drei- bis sechssamig.

Varietät 3. violacea Boiss. Ziemlich kahl; Blättchen kleiner, elliptisch; Kelchzähne breiter pfriemlich, etwas kürzer als die Röbre; Fahne violett; Hülse kahl, etwas schmäler, vier- bis siebensamig.

Varietät $\gamma$. glandulifera Reg. et Herd. Stengel behaart oder etwas rauh; Fahne violett; Hülsen zerstreut oder dichter stachelig, drüsig, bald mehr- bald wenigsamig.

Varietät ò. pallida Boiss. Stengel angepresst und kraus kurzhaarig; Kelchzähne schmal pfriemlich, bis doppelt so lang als die Röhre; Fahne röthlich weiss.

Das Süssholz ist verbreitet im ganzen Mittelmeergebiete von Portugal bis nach Kleinasien, ausserdem findet es sich an der unteren Donau, in Mittel- und Süd-Russland und lässt sich von hier einerseits durch West-Sibirien bis in die transbaikalischen Länder und Dahurien, südlich aber über den Kaukasus bis Nord-Persien verfolgen; ausserdem wird es in Deutschland und England, sowie an manchen Orten in der Heimath (Spanien, Syrien ete.) cultivirt.

Wurzeln und unterirdische Axen der Pflanze kommen im getrockneten Zustande als Süssholz, Radix Liquiritiae oder Radix Glycyrrhizae in den Handel. Nicht selten kommt das wSüssholz a auch geschält, d. h. von der äussersten Rindenschicht befreit als Droge vor. Das Schälen erfolgt nach dem Trocknen. Das Extract der im frischen Zustande zerquetschten Ausläufer und Wurzeln findet, im eingedickten Zustande und in Stangenform gebracht, als Succus Liquiritiae, Succus Glycyrrhizae crudus oder Lakrize Verwendung.

\section{Erklärung der Abbildungen.}

Fig. A. Oberer Theil einer im Universitätsgarten von Berlin cultivirten Pflanze.

Fig. $B$. Die Blïthe etwas mehr als 2mal vergrössert: $a$. das Deckblatt; $b$. der Kelch; $c$. die Fahne; $d$. die Flügel; $e$. der Kiel.

Fig. C. Dieselbe ohne die Blüthenblätter 5 fach vergrössert: $f$. die Staubgefässe; $g$. der Stempel.

Fig. D. $-F$. Die Fahne, ein Flügel und ein Kielblatt 5mal vergrössert.

Fig. G. Die Staubgefässe, 5mal vergrössert, den Stempel umschliessend.

Fig. $H$. Die Verbindung derselben flach ausgebreitet,

Fig. I. Der Staubbeutel von der Vorder- und Rückseite.
Fig. $K$. Pollenkörner trocken und in Wasser, 300mal vergrössert.

Fig. $L$. Der Stempel, 6mal vergrössert.

Fig. $M$. Der Fruchtknoten im Längsschnitte.

Fig. N. Die Hülse, natürliche Grösse.

Fig. $O$. Dieselbe geöffnet.

Fig. $P$. Dieselbe im Quersehnitte, 3mal vergrössert.

Fig. Q. Der Same 6mal vergrössert.

Fig. R. u. S. Derselbe im Lïngsschnitte, parallel und senkrecht auf die Keimbliatter: $a$. das Würzelchen; $b$. die Keimblätter.

Fig. T. Der Keimling. 


\section{PHYSOSTIGMA Balfour.}

Bluthen zygomorph, vollständig. Kelchzipfel kurz und breit, spitzlich, die zwei oberen verschmolzen. Fahne eiförmig bis kreisıund, stark gekrimmt und eng zusammengebrochen, am Grunde mit eingebogenen Öhrchen versehen und kurz genagelt; Flìgel umgekehrt eiförmig, gestutzt, stark gekrimmt, am Grunde geöhrt; der Kiel ist in einer vollen Windung eingerollt, vorn vollkommen verwachsen, auf der einen Seite trägt er einen hohlen, hornartigen Fortsatz*). Von den Staubgefässen sind 9 zu einer Röhre verwachsen, das oberste zehnte ist frei; die Staubbeutel sind gleichförmig. Der Fruchtknoten ist gestielt, am Grunde wird er von einem röhrenförmigen Diseus *) gestitzt; er umschliesst 2 oder 3 campylotrope Samenanlagen; der Griffel ist spiral mit 11/2 Windung eingerollt, nach der Spitze zu ist er verdickt, innenseits gebärtet; die Narbe ist kopfig, nach aussen aber befindet sich neben ihr ein blattartiger, gerundet dreiseitiger Anhang. Hitlse breit linealiseh lanzettlich, zwischen den 2 oder 3 Samen eingeschnürt, von der Spitze her in zwei Klappen aufspringend; das Exocarp löst sich von dem genetzten, hornartigen Endocarp. Samen im Umfang halbelliptisch, dick, an dem linienförmigen Nabel dick gerandet. - Eine oben krautige Liane mit dreizählig gefiederten Blättern, Blättchen ansehnlich, mit Stipellen versehen. Bltithen gross, gestielt, wahrscheinlich zu mehreren aus verdickten Polstern, die an einer gemeinschaftlichen, seitenständigen Spindel zweireihig gestellt sind.

Nur eine Art im tropisehen West-Afrika.

\section{Physostigma venenosum Balf.}

Tafel 56 .

Strauchartig, oben mit krautigen Zweigen, hoch in den Bäumen aufsteigend; Blattstiele kahl, Blättchen eiförmig, am Grunde gestutzt, spitz oder herzförmig, kahl; Blüthenstielehen mässig lang; Fahne viel länger als die Flügel; Hülse mit hornartigem Endocarp.

Physostigma venenosum Balf. in Trans. Roy. soc. Edinburgh XXII. 310. t. 16-17; Baker in Oliv. Fl. trop. Afr. II. 191; Flück. and Hanb. Pharmcop. 167; Flïck. Pharmacogn. 994; Arth. Meyer, Drogenkunde 1. 176; Bentl. and Trim. Med.pl. t. 80; Köhler, Mediz. Pf. t. 177; H. Baill. Hist. pl. II. 206.

Calabar-Bohne; englisch: Calabar Bean, Ordeal Bean of Old Calabar, Chop nut; französisch: Fève de Calabar.

Der holzige Stamm erreicht etwa die Dicke eines Daumens und steigt mit links (in mechanischem Sinne genommen) aufsteigenden Windangen an den Bäumen in die Höhe, oben werden die Zweige krautig, stielrund und sind kahl; die Pflanze erreicht eine Höhe von mehr als $15 \mathrm{~m}$; die Internodien sind ziemlich lang (bis $10 \mathrm{~cm}$ und darüber).

Die Blätter erreichen mit den 3-9 $\mathrm{cm}$ langen, oberseits ausgekehlten, unten mit einem fleischigen Bewegungspolster versehenen Stielen, eine Länge von $10-22 \mathrm{~cm}$; sie sind am Grunde mit $1-2 \mathrm{~mm}$ langen, pfriemlich oblongen, nur äusserst wenig behaarten Nebenblättern versehen, die bald abtrocknen und oblitteriren; sie sind stets dreizählig gefiedert. Die Blättchen sitzen an 3-5 mm langen, feinbehaarten, drehrunden, in getrocknetem Zustande etwas gerunzelten Stielchen, an ihrem Grunde befinden sich linealisch oblonge, kaum $1 \mathrm{~mm}$ lange Stipellen. Von den Blättchen ist das endständige symmetrisch, die beiden seitenständigen sind asymmetrisch geformt; jenes ist eiförmig, kurz, in einen Schnabel zusammen-

- Dieses Organ ist bis jetzt stets tubersehen worden. 
gezogen, am Grunde gestutzt oder kurz zugeschärft, es ist dreinervig und ausser den beiden Grundnerven wird es noch jederseits des Mittelnerven von 3-4 Paar stärkeren Seitennerven durchzogen. Die Seitenblättchen sind schief eiförmig, sonst dem Endblättchen ähnlich; beide Arten von Blättchen sind krantig, beiderseits kahl, glänzend und auch getrocknet lebhaft, etwas gelblich grün.

Die Blüthentrauben sind 4-10 cm lang und werden von einem $2-3 \mathrm{~cm}$ langen, kräftigen, stielrunden, kahlen Stiele gestiitzt; an der fein und kraus behaarten Spindel befinden sich 4-8 fleischige, zweizeilig abwechselnd gestellte Polster, aus denen mehrere Bliithen, wie bei unserer Bohne hervortreten ${ }^{*}$ ). Deckblättchen sind unterhalb der Polster nicht mehr wahrzunehmen. Die Blïthenstielchen sind fadenförmig 4-7 mm lang, sie sind völlig kahl; Vorblättchen fehlen.

Der Kelch misst 6-7 mm, er ist schief kreiselförmig und hat am Rande 4 kaum $1 \mathrm{~mm}$ lange, breit eiförmige, spitze, am Grunde sich deckende Zipfel, die hier deutlich auf der Innenseite seidig behaart sind, sonst sind sie sehr kurz gewimpert; die Röhre ist nur sehr spärlich behaart. Die Fahne hat an der äusseren Kante gemessen eine Länge von $4 \mathrm{~cm}$; sie ist bis zur Hälfte von oben her mit den Rändern verklebt; ausgebreitet misst sie $2,5 \mathrm{~cm}$ in der Breite und ist fast kreisförmig, an der Spitze ausgerandet; sie ist sebr stark nach rïckwärts gebogen; ihr Nagel ist kaum 1,5 mm lang, an der Innenfläche befindet sich oberhalb desselben je ein blättchenartiger Vorsprung. Die Flïgel sind, ebenfalls an der Aussenkante gemessen $3,0 \mathrm{~cm}$ lang, sie haben einen $5 \mathrm{~mm}$ langen Nagel; ein callöser Vorsprung oberhalb desselben entspricht einer Vertiefung in den Blättern des Kieles; die Gestalt der Flügel ist schief umgekehrt eiförmig, oben sind sie gestutzt. Die Farbe dieser beiden Blumenblätter ist zart violett mit dunkleren Streifen. Der Kiel ist stark spiral eingerollt, seine Blätter sind 4,4 cm lang und wieder von der Spitze bis zur Mitte verklebt, der Nagel beider misst $5 \mathrm{~mm}$. Aus der linken Seite des Kiels tritt ein schlank kegelförmiger, häutiger, spitzer Sack, der $11 \mathrm{~mm}$ an Länge erreicht und auf die Spitze des cbenfalls stets linksseitig gewendeten Kieles zugeht. Diesem merkwürdigen, bis jetzt selten in dieser einseitigen Entwicklung bei den Leguminosen bemerkten Organe kommt wahrscheinlich bei der Pollenübertragung eine besondere Aufgabe zu. Das freie Staubgefäss hat auf seiner Rüekseite nahe am Grunde eine verdickte, fleischige Platte, auf welcher der Nagel der Fahne aufgelegt ist; die ibrigen Staubgefässe sind hoch zu einer oben offenen Röhre verwachsen; sie sind wie jenes $4 \mathrm{~cm}$ lang, die Beutel messen $1 \mathrm{~mm}$; hier und da scheint das unterste Staubgefäss keinen Blüthenstaub zu erhalten. In Wasser beobachtet ist der letztere gerundet tetraëdrisch, von netzig sich kreuzenden, zarten Leisten skulpturirt. Der Discus, welcher den Fruchtknoten umgiebt, ist $2 \mathrm{~mm}$ hoch, schief gestutzt und gerieft. Der Stempel misst im Ganzen $4 \mathrm{~cm}$; er steht auf einem $3 \mathrm{~mm}$ hohen Stiele; der $5 \mathrm{~mm}$ lange, kahle Frnchtknoten ist linealisch, seitlich stark zusammengedrückt und umschliesst 2-3 Samenanlagen. Der Griffel ist drehrund, in seinem gekrïmmten Theile verhältnissmässig dick, verholzt und sehr elastisch, von seiner Einrollung hängt offenbar die Drehung der ganzen Blithe ab. Oben ist er innenseits auf eine Strecke von $6-7 \mathrm{~mm}$ steif borstig behaart; am Ende, wo die eigentliche Narbe sitzt, wird er knopfig verdickt, riickseits ist jene ebenfalls behaart, an der Vorderseite sitzt aber an der Narbe ein häutiger, gerundet dreiseitiger, spitzer, dïnner Hautlappen.

Die Frucht ist $12-16 \mathrm{~cm}$ lang und $3-3,5 \mathrm{~cm}$ an den Stellen, wo die Samen sitzen, breit; sie ist in getrocknetem Zustande schwarz und erscheint von den durchdringenden netzigen Leisten des weissgelben, hornigen Endocarps ebenfalls netzig sculpturirt; später springt das dïne, sehwarze Exocarp ab. Der Rücken ist breit und beiderseits gerandet.

Der Same ist $2,7-3 \mathrm{~cm}$ lang und 1,6-1,8 cm breit, an der Nabelseite gewölbt, an der anderen gewöbnlich flacher, dort wird er von zwei vorspringenden Leisten gesäumt; er ist dunkel kastanienbraun, ins Schwarze gehend, an den beiden Rändern gewöhnlich hcller.

*) An den uns vorliegenden, sonst vortrefflich erhaltenen Pflanzen, sind die Blithen abgefallen und nur aus den ziemlich undeutlichen Narben an dem Polster ist dieses Verhältniss, welches auch von Balfour beschrieben wird, zu schliessen. 
Die Calabar-Bohne wächst an der Westseite des tropischen Afrikas von Cap Palmas bis nach Kamerun; am wichtigsten ist ftir den Export die Mündung des Cross River, die Bucht, welche frïher Old Calabar River genannt wurde.

Die Calabar-Bohne, Semen Calabar, Semen Physostigmatis, Faba calabarica, dient hauptsächlich zur Darstellung des von Joвst und Hesse 1863 entdeckten, von ihnen Physostigmin genannten Alkaloides, welehes später, als man es krystallisirt dargestellt hatte, als Eserin bezeichnet worden ist.

\section{Erklärung der Abbildungen.}

Fig. A. Ein Zweig nach einem Exemplare, das Dr. Preuss in Kamerun sammelte.

Fig. $B$. Die Blüthe nach Weguahme der Blumenblätter, natïrliche Grösse.

Fig. C. Dieselbe nach fernerer Wegnahme der Staubblattröhre, um den Discus $d$ und die Narbe $N$ zu zeigen, 2 mal vergrössert.

Fig. D. Die Fahne, natïliche Grösse.
Fig. $E$. Einer der Flïgel, natïrliche Grösse.

Fig. F.u. G. Der Kiel im jugendlichen und erwachsenen $Z_{u-}$ stande, natürliche Grösse.

Fig. H. $-K$. Der Same von der Seite, vom Rïcken her betrachtet und aufgeschnitten, um den Keimling zu zeigen.

Fig. L. Die reife Frucht, natürliche Grösse.

\section{TOLUIFERA Linn.}

Blïthen zygomorph, vollständig. Kelch etwas schief, unregelmässig gezähnt. Fahne gross, genagelt, fast kreisrund, an der Spitze ansgerandet, am Rande kraus, am Grunde fast herzförmig; die vier tibrigen Blumenblätter gleich oder fast gleich, lanzettlich, spitz, viel schmäler und kleiner. Staubgefässe alle gleich, abfällig, völlig frei oder am Grunde verbunden; die Beutel linealisch oblong mit spitzem Mittelbande, in Längsspalten aufspringend. Fruchtknoten lang gestielt mit zwei Samenanlagen; Griffel kurz aufgebogen mit kleiner, endständiger Narbe. Hülse gestielt, sehr stark zusammengedrückt, nicht aufspringend, oben stark verdickt nnd gedunsen; beidseitig, aber auf der Bauchseite viel sehmäler geflügelt, im oberen kopfartig angeschwollenen Theile mit zwei an den Seiten gelegenen Balsamhöhlen. Samen einer, gekrümmt, vorn gestutzt, mit eingebogenem Wirzelchen. - Bäume mit unpaarig gefiederten Blättern; Blättchen dureheinend punktirt, ohne Stipellen. Blüthen weiss, die Fahne oft lebhafter gefärbt, in endständigen oder achselständigen Trauben oder Rispen.

6 Arten von Mittel- bis Stid-Amerika, in der Provinz Rio de Janeiro ist noch eine Art vorhanden.

\section{Toluifera Balsamum Lin.}

\section{Tafel 57.}

Ein sehr hoher Baum mit hohem, einfachem Stamme und halbkugelförmiger Krone; Blätter unpaarig gefiedert, höehstens mit dem unpaaren vierjochig; Blättchen kurzgestielt, oblong oder eioblong, kurz zugespitzt, am Grunde abgerundet; Trauben oben abgerundet, zusammengezogen.

Toluifera Balsamum Linn. Spec. pl. ed. I. 384; Mat. med. lib. I. de plantis 69. n. 201; Bentl. and Trim. Med. pl. t. 84; Baill. Bot. méd. I. 676; Flück. Pharmacogn. III. ed. 146; Taub. in Engl.-Prtl. Natürl. Pflanzfam. III. (3). 189. fig. 101. 
Myroxylon peruiferum Mutis in Linn. fil. Suppl. 233; Ruiz in Lamb. Ill. Cinchona t. 1. fig.1-4; Kth. in Humb. et Bonpl. Nov. gen. et spec. VI. 373, Syn. pl. aeq. IV. 68; A. Rich. in Annal. scienc. nat. 1824. p. 168; Nees, Düsseld. Arzneipfl. t. 320; Klotzsch in Hayne Arzneigew. XIV. t. 11, in Bonpl. V. 275 .

Myroxylon pedicellatum Klotzsch in Bonpl. $V$. 275.

Myroxylon punctatum Klotzsch in Hayne, Arzneigew. XIV. t. 12, in Bonpl. $V .276$.

Myrospernum pedicellatum Lam. Encycl. IV. 191, Ill. t. 341. fig. 1. a-g; DC. Prodr. II. 93.

Tolubalsambaum; französisch: Baumier de Tolou; englisch: Tolu balm-tree.

Der Baum erreicht eine Höhe von mehr als $40 \mathrm{~m}$ und ist oft bis zu $25 \mathrm{~m}$ Höhe vollkommen astfrei; der Stamm hat etwa in Mannshöhe einen Umfang bis über $2 \mathrm{~m}$. Die blühenden, ziemlich schlanken Zweige sind mit gelbgrauer Rinde bedeckt, die dureh zahlreiche kreisrunde bis elliptische, höchstens $1 \mathrm{~mm}$ lange Lenticellen kleinwarzig und heller punktirt erscheint.

Die B1ätter sind 12-15 (9-18) em lang, unpaarig gefiedert; die Fiedern stehen abwechselnd; durch die Seitwärtsstellung des Endblättchens nehmen sie zuweilen das Aussehen von paarig gefiederten Blättern an. Die braune Spindel ist wenigstens in der Jugend von sehr kleinen, einzelligen, gekrimmten Haaren kurz braunsammtig, später ist sie kahl; auf der Oberseite wird sie von einer engen Rinne durchzogen. Die Blättchen sind abwechselnd meist zu 3 Paaren angeheftet; sie erreichen eine Länge von $10 \mathrm{~cm}$ und eine Breite von $5 \mathrm{~cm}$, sind aber gewöhnlich nur 5-7 cm lang und 2,5-4 cm breit; im Umfange sind sie oblong, eioblong oder namentlich das Endblättchen fast umgekehrt eiförmig, dieses ist auch am Grunde spitz, während die Seitenblättchen gewöhnlich asymmetrisch gestutzt oder gernndet sind; sie werden von sehr vielen (bis über 20) grösseren Seitennerven durchzogen, und sind beiderseits kahl, anf der Oberseite schwach glänzend, auf der unteren matt; die sehr zahlreichen Sekretliicken sind punkt- oder kurz strichförmig; die Blattsubstanz ist in getrocknetem Zustande lederartig; der Blattstiel ist kurz (nur 2-4) mm lang und in lebendem Zustande wahrscheinlich etwas fleischig.

Der Blïthenstand ist traubig, seltener rispig, er tritt immer aus der Achsel eines Blattes und zwar an der Spitze der Zweige bald ans der eines bleibenden Laubblattes, bald ans der eines abfälligen Hochblattes hervor; dureh ein lebhaftes Wachsthum der obersten Traube wird die Endknospe ubergipfelt und bei Seite geworfen, so dass diese den Ast zu beschliessen scheint. Die Blüthen sind gestielt und riicken gegen das Ende des Blüthenstandes nahe zusammen, so dass der letztere halbkugelig gewölbt ist; sie brechen aus den Achseln von kaum $1 \mathrm{~mm}$ langen, dreiseitig lanzettlichen, kurzsammtigen Deckblättern hervor. Die Stiele sind 1-1,5 cm lang, dünn, drehrund und wie die Spindel sehr kurz graugelb-filzig. Die Blüthen sind rechtwinklig gegen den Stiel geneigt.

Der Keleh ist 7-8 mm lang, ein wenig schief, glockenförmig mit kurzen, breiten, spitzen, dünnbäutigen Zähnen; der Grund ist auf $1 \mathrm{~mm}$ Höhe etwas fleisehig verdickt, und über diesem „Diseus « sind die Staubgefässe angewachsen; er ist grün und aussen sehr kurz filzig. Von den Blumenblättern ist die Fahne am grössten, sie misst e. $15 \mathrm{~mm}$ in der Länge und $6-7 \mathrm{~mm}$ in der Breite; sie ist querelliptisch, an der Spitze ausgerandet, am Grunde herzförmig und in einen schmalen (kaum $1 \mathrm{~mm}$ breiten), langen Nagel zusammengezogen; die Platte ist weiss, der Nagel grün und dort, wo dieser in jene tibergeht, setzt sich ein grüner Streif in die Platte fort; die übrigen 4 Blumenblätter sind nur wenig länger als der Kelch, schmal lanzettlich, spitz, über den Keleh gebogen, ihre Farbe ist weiss. Die Staubgefässe sind ziemlich gleich lang; ihr weisser Faden misst 3, der Beutel von gelbrother Farbe 4-5 mm. Der grüngelbe Stempel tiberragt schon in der Vollblüthe die Staubgefísse um die Länge der Beutel, er ist stark seitlich zusammengedrückt und wendet seine pfriemliche Spitze bei hängender Blithe nach oben.

Die Frucht ist 8-10 cm lang, im oberen verdickten Theile, welcher den Samen umschliesst 3, im fluigelartig verbreiterten Stiele 2-2,5 cm breit; sie ist gelbbraun und der Flïgel geht zmerst sehr allmälig, dann schneller in den Stiel über; die in der Vollblüthe nach oben gewendete Seite des Flïgels ist vielmals breiter als die nach unten blickende, jene endet mit einem gerundeten, diese mit einem scharfen Abschlusse in den Fruchtstiel. 
Der Same ist fast nierenförmig, etwas ungleichseitig, an beiden Enden gestutzt, im Querschnitte fast kreisförmig; er misst $1,5-1,7 \mathrm{~cm}$ in der Länge und hat einen Durchmesser von $8-9 \mathrm{~mm}$.

Der Tolubalsambaum wächst im Norden von Süd-Amerika und'zwar ist er dort von Venezuela (Puerto Cabello) bis nach Peru verbreitet. Seine ergiebigste Ausbeutung findet in Columbien, im unteren Gebiete des Magdalenenstromes, besonders bei Turbaco, Las Mercedes, Plato bis Mompos, auch noch in der Gegend von Tolu an der Bucht von Morosquillo statt.

Der Tolubalsambaum liefert den Balsamum tolutanum oder Tolubalsam. Man schneidet zur Gewinnung des Balsams die Rinde des Baumes an und fängt den austretenden Balsam in Kürbisflaschen oder auf Blättern auf. Die Gewinnung des Tolubalsams wird vorzïglich im unteren Gebiete des Magdalenenstromes betrieben.

\title{
Erklärung der $A$ bbildungen.
}

Fig. A. Ein blühender Zweig, nach einem Exemplar ans dem Hanbury Herbarium aus Columbia.

Fig. $B$. Die Bliitlıe, 2 mal vergrössert: $a$. die Fahne; $b$, die kleinen Blumenblätter; $c$. der Stempel.

Fig. $C$. Eins der kleinen Blumenblitter.

Fig. D. u. E. Das Staubgefäss, von der Vorder- und der Rüickscite, 3mal vergrössert.

Fig. F. Die Blüthe im Lïngsschnitte, der Stempel nicht durchschnitten.
Fig. $G$. Dieselbe, der Stempel ebenfalls im Längsschnitte.

Fig. H. Pollenkörner trocken und im Wasser, 250mal vergrüssert.

Fig. I. Die Frucht, natiirliche Grösse.

Fig. $K$. Dieselbe im Querschnitte; $d$, der Keimling; $e$. die Balsamböhlen.

Fig. L. Der Same, natürliche Grösse.

\section{Toluifera Pereirae Baill.}

\author{
Tafel 58.
}

Ein hoher Baum, der sich schon in geringer Höhe uber dem Boden verzweigt; Blätter unpaarig gefiedert, mit dem unpaaren mindestens vier-, gewöhnlich fünf-, nicht selten sechs-jochig; Blättchen oblong, nicht selten lineal-oblong, kurz zugespitzt, am Grunde abgerundet; Trauben sehr verlängert, oben spitz.

Toluifera Pereirae Baill. Bot. méd. I. Gi6 (var. der vor.); Bentl. and Trim. Med. pl. t. 83; Flück. Pharmacogn. ed. III. 137.

Myrospermum Pereirae Royle, Man. mat. med. ed. II. 414 (1853).

Myroxylon Pereirae Klotzsch in Bonpl. V. 275; Cars. in Americ. Journ. of Pharm. 1860. November, mit Abbild.; Hemsley, Biot. centrali-americ. I. 322.

Myrospermum pedicellatum Descourtilz, Flore pittoresque et méd. des Antill. V. 213; non Lam.

Myroxylon toluiferum Kth. in Humb. et Bonpl. Pl. Nov. gen. et spec. VI. 204; A. Rich. in Ramon de la Sagra, Flora. Cub. t. 35 .

Myroxylon peruiferum Guimp. et Schlecht. Pfl. d. Pharmac. III. 94. t. 278, non Mutis.

Der Baum wird nur bis $17 \mathrm{~m}$ hoch und sendet schon von Mannshöhe an seine horizontalen oder wenig aufstrebenden Äste aus, die sich zu einer eiförmigen Krone vereinigen; die blühenden Zweige sind mit grau- oder gelblichbrauner Rinde bedeckt und mit spärlichen, punktförmigen, helleren Lenticellen bestreut.

Die Blätter sind 15-16 (13-20) cm lang, unpaarig gefiedert; die Fiedern stehen fast stets abwechselnd, das Endblättchen ist seltener bei Seite gedrängt, nimmt vielmehr gewöhnlich eine deutlich endständige Stellung ein. Die kantige Spindel wird am Grunde oberseits von einer flachen Rinne durchzogen, sie ist fast kahl und matt, unter dem Mikroskope lassen sich auch an ibr winzige Härchen nachweisen. Die 
Blättchen sind in der Regel zu 4, nicht selten auch zu 5, minder häufig zu 3 Paaren vorhanden; sie erreichen höchstens eine Länge von 7 und eine Breite von $3 \mathrm{~cm}$, gewöhnlich sind sie nur 4,5-5 cm lang und 2-2,5 $\mathrm{cm}$ breit; die lineal oblonge, oben zuweilen etwas verbreiterte Form scheint vorzuwalten, das Endblättchen ist oft ziemlich auffallend obovat; häufig ist die Spitze lineal schnabelförmig ausgezogen; auch sie werden von vielen parallel verlaufenden, stärkeren Seitennerven durchsetzt und sind beiderseits, kahl; unter den sehr zahlreichen, punktförmigen Secretlïcken sind häufig längere, strichförmige eingestreut; die Blattsubstanz ist nur papierartig; der Blattstiel ist $2-4 \mathrm{~cm}$ lang.

Der Blïthenstand ist eine 16-18 $(13-22) \mathrm{cm}$ lange, schlanke, spitze, verlängert pyramidale, häufig achselständige, etwas gekrümmte Traube, deren Spindel im trocknen Zustande mit einem sehr kurzen, hell rostfarbenen Filze bedeckt ist; die Bluthenstiele sind 1-1,5 $\mathrm{cm}$ lang, diunn, drehrund und wie der Kelch und die Spindel bekleidet; sie treten ans der Achsel von kaum $1 \mathrm{~mm}$ langen, dreiseitig-oblongen Deckblättern.

Die Blithen sind rechtwinklig gegen den Stiel befestigt und nicken. Der'Keleh ist 7-8 mm lang, ein wenig sehief glockenförmig, am Grunde auf $1 \mathrm{~mm}$ Höhe etwas verdickt und an dem häntig verdünnten Saume unregelmässig breit gezähnt; aussen ist er sehr dïnn filzig, seine Farbe ist bläulich weiss. Das längste Blumenblatt, die Fahne ist $15-17 \mathrm{~mm}$ lang und hat in der Platte eine Breite von $7-10 \mathrm{~mm}$; die letztere ist weiss und dort, wo sie in den gleichfarbigen Nagel ïbergeht gelb, die schmal lanzettlichen Blumenblätter sind nur 10-12 mm lang, von der Farbe der Fahne. Die Staubgefässe überragen den Kelch, ihre weissen Fäden messen 5 , die rothen Bentel ebenfalls $5 \mathrm{~mm}$. Der grüne Stempel überragt in der Vollblïthe die Staubgefässe nicht.

Die Frucht ist etwas kleiner als die der vorigen Art, ist aber sonst ebenso wie der Same kaum von jener zu unterscheiden.

Der Perubalsambaum wächst vorzüglich an der Balsamkïste (Costa del Balsamo) des grossen Oceans in dem Staate San Salvador, zwischen der Hafenstadt Acajutla und dem Flitssehen Comalapa; ferner findet er sich in der Gegend von Vera Cruz; anf Cuba, Trinidad, bei Singapore und auf Java wird er cultivirt.

Anmerkung. Wenn es auch keine Schwierigkeit macht, den Peru- und Tolubalsambaum zu unterseheiden, nach den typischen Exemplaren, wie sie uns durch die liebenswürdige Bereitwilligkeit des Curators am Hanbury Museum in London, Herrn E. M. Holmes, dem wir auch hier nochmals unseren verbindlichsten Dank abstatten, zum Studium vorlagen; so wird es doch in gewissen Fällen kcineswegs leicht sein, ein Urtheil über getrocknete Exemplare abzugeben. Baillon hat desswegen anch beide Arten vereinigt und die zuletzt besprochene nur als Varietiit des Tolubalsamba umes betrachtet. Kein Zweifel kann darüber bestehen, dass die von Klot zsch aufgestellten Arten nicht haltbar sind, zumal sie nach den uns zur Einsicht vorliegenden Originalen auf Grund eines durchaus mangellaften Materiales besehrieben worden sind. Den Ansichten Baillons möchten wir aber so lange nicht beipflichten, als nicht umfangreichere und sorgfältigere Studien an genigendem Materiale gemacht worden sind. Die wesentliche Verschiedenheit der Balsame spricht doch auch sehr stark für die Wahrung der speeifischen Differenz. Sollte sich indess herausstellen, dass das Produkt seine andere Natur nur der Versehiedenheit in der Gewinnung verdankt, so wïrde der Gedanke an eine Verbindung beider Arten mehr Gewicht erhalten.

Der Perubalsambaum liefert den Balsamum peruvianum, den Perubalsam. Zur Gewinnung des Balsams wird die Rinde des Baumes zuerst an vielen Stellen weich geklopft. Die kleine Menge des danach ausfliessenden Balsams wird aufgefangen. Eine Woche später erhitzt man die weich geklopften Rindenpartien bis zum Anbrennen der Rinde langsam, wonach ein reichlicher Balsamerguss erfolgt. Der Ausfluss dauert wochenlang; nach Abfallen der Rindenfetzen findet er im gesteigerten Maasse statt und wird durch nochmaliges Erhitzen der Wundflächen verstärkt. Man sammelt den Balsam bis zum Ende des Ausflusses dadureh, dass man die Wunden mit Lumpen umwickelt, welche das Sekret anfsaugen. Die Lumpen werden dann im Wasser ausgekocht; der sich absetzende Balsam wird, nach dem Abgiessen des Wassers mehrmals für sich erhitzt und mittelst Durchseihens gereinigt. Ein Baum kann bis 30 Jahre lang zur Gewinnung des Balsams dienen. 


\section{Erklärung der Abbildungen.}

Fig. A. Ein blühender Zweig, nach einem Exemplar aus dem Hanbury Herbarium von der Balsamkïste in S. Salvador.

Fig. B. Die Blithe, 2mal vergrössert.
Fig. C. Dieselbe im Längsschnitte.

Fig. D. Das Staubgef tiss von der Vorder- und der Rückseite.

Fig. E. Die Frucht, natürliche Grösse.

Fig. $F$. Dieselbe, im Kopftheile längs aufgeschnitten.

\section{ANDIRA Linn.}

Blïthen zygomorph, vollständig. Keleh gestutzt oder mit kleinen, geschweiften Zähnen. Fahne fast kreisrund, ziemlich lang genagelt, ohne Anhängsel; Flügel ziemlich gerade, schief oblong, stumpf, sie hängen mit dem Kiele nicht zusammen; die Blätter des Kieles ibergreifen einander, sind aber nicht verwachsen. Staubgefässe, das oberste meist ausgesehlossen, zu einer oben gespaltenen Röhre verbunden; Beutel versatil. Stempel stark gekrlimmt; Fruchtknoten gestielt mit zwei bis vier, seltener mehr Samenanlagen; Narbe gestutzt, endständig. Hülse steinfruchtartig, schief, fast kugel- oder eiförmig mit einem Samen, der mit einem kurzen, geraden Würzelehen versehen ist. - Ansehnliche Bäume mit spiralig gestellten, unpaarig gefiederten Blättern; Blättehen meist gegenständig an der Oberseite der Blattspindel angeheftet, mit borstenförmigen Stipellen, die seltener fehlen. Bluthen in endständigen Rispen, von meist kleinen Deck- und Vorblättchen gestiltzt, die bald abfallen, seltener grösser sind.

Etwa 20 Arten, die fast ausschliesslich dem wärmeren Amerika, von Mexiko bis Brasilien angehören; nur eine derselben wäehst auch in Senegambien, eine zweite ungenuigend bekannte, aussehliesslich afrikanische Art wird vom Gabun genannt.

Anmerkung. Leider sind unsere Bemlihungen, die Stammpflanze des Araroba-Pulvers, Andira Araroba Aguiar zu erhalten, vollst:̈ndig fruchtlos gewesen; die Pflanze seheint gegenwärtig noch in den europäischen Sammlungen zu fehlen Um die Gattung nicht ganz ausfallen zu lassen, haben wir eine andere Art zur Darstellung gebracht.

\section{Andira Pisonis Mart.}

\section{Tafel 59.}

Baumförmig mit drei- bis fünfjochig gefiederten Blättern; Blättchen oblong, spitz, am Grunde gerundet, lederartig, oberseits kahl, unterseits seidig behaart; Nebenblätter schmal und leicht abfällig. Rispe filzig; Vorblättchen klein, abfällig, Fruchtknoten zottig.

Andira Pisonis Mart. bei Benth. in Annal. Mus. Vindob. II. 108; Fl. Brasil. XV. (1), 294. t. 111.

Ein Baum, welcher die Höhe von 5-7 m erreicht. Die jungen $\mathrm{Zweige} \mathrm{sind} \mathrm{ziemlich} \mathrm{dünn,} \mathrm{stiel-}$ rund, gefurcht oder auch ganz oben kantig, mit einem hell rostfarbenen Filze bekleidet.

Die Blätter haben mit dem Endblättehen eine Länge von $12-24 \mathrm{~cm}$; sie sind von einem $3-4,5 \mathrm{~cm}$ langen, oberseits flachen, etwas ausgekehlten, wie die gesammte Spindel filzig bekleideten Stiele gestïtzt; Fiedern sind mit dem unpaaren Blatte 3- höchstens 5 Paare vorhanden; sie sind kurz (bis höchstens $5 \mathrm{~mm}$ lang) gestielt; die Stielchen sind deutlich fleisehig verdiekt, an ihnen sitzen die etwa $2 \mathrm{~mm}$ langen, pfriemlichen, zugespitzten Stipellen. Die Blättchen messen 5,5-6,5 $(3-7,5) \mathrm{cm}$ in der Länge und um die Mitte 
oder tiefer $2-3,2(1,8-3,5) \mathrm{cm}$ in der Breite; sie sind oblong oder nähern sich etwas dem Eiförmigen, oben sind sie gewöhnlich kurz und stumpf zugespitzt, am Grunde sind sie gerundet, seltener fast herzförmig; sie sind lederartig, am Rande etwas zurïckgebogen, oberseits kahl, unterseits granlich oder gelblich und seidenglänzend behaart; sie werden von meistens $7-8$ stärkeren Nerven zn beiden Seiten des Mittelnerven durchzogen. Die Nebenblätter sind schmal pfriemlich, zugespitzt $5-7 \mathrm{~mm}$ lang, sie vertrocknen bald und fallen ab.

Die reichblüthige $\mathrm{Rispe}$ wird bis $20 \mathrm{~cm}$ lang und darüber, sie ist straff anfrecht und an ihrer Spindel filzig behaart; die Blüthen sitzen an den Verzweigungen letzten Grades zweizeilig. Die Deckblätter sind nur 1-2 mm lang und aussen behaart, sie wie die noch kleineren Vorblättchen fallen aber leicht ab und sind sonst wegen der dichten, filzigen Bekleidung der $3-5 \mathrm{~mm}$ langen Blithenstielehen schlecht zu beobachten.

Der lederartige Kelch ist $5-5,5 \mathrm{~mm}$ lang, an der Mündung nur wenig schief und ganz kurz und geschweift fünfzähnig, aussen ist er dicht rostfarben filzig, innen ist er kahl. Die Fahne ist $10-11 \mathrm{~mm}$ lang, flach ausgebreitet fast kreisförmig, an der Spitze ansgerandet, am Grunde in einen linealen Nagel zusammengezogen, der so lang ist wie der dritte Theil der ganzen Fahne; sie ist kahl, ihre Farbe ist fahl violett und dunkler geadert. Die Flügel sind halb eiförmig, ebenfalls lang genagelt und von ähnlicher Farbe; ihre Länge kommt jener der Fahne gleich. Die Blätter des Kieles sind fast gleich den Flägeln gebildet; sie sind nicht verwachsen, sondern übergreifen einander. Die Staubgefässe nehmen an Grösse von unten nach oben $\mathrm{ab}$, das grösste misst $10-11 \mathrm{~mm}$; das kleinste, oberste, freie $8-9 \mathrm{~mm}$; die 9 verbundenen sind zu einer 7-8 mm langen, oben offenen Röhre vereinigt. Der Stempel ist 12-13 mm lang, an der Spitze in einem Viertelkreise nach oben gebogen. Der Stiel, welcher den Fruchtknoten trägt, ist $5 \mathrm{~mm}$ lang, beide sind dicht seidig behaart, der Griffel aber ist kahl; die Narbe ist gestutzt und klein. In dem lanzettlichen, zusammengedrïckten Fruchtknoten befinden sich 5-6 campylotrope Samenanlagen.

Die Frucht ist fast kugelig, schief d. h. an der Oberseite etwas weniger gekrtimmt, zugespitzt, 5-5,5 cm lang; sie hat 3,5-4 cm Durchmesser und ist mit einer duch das Eintrocknen gerunzelten, braunschwarzen Rinde bedeckt; sie ist im Innern gelbbraun faserig, die innerste Schicht ist hart und holzig.

Der Same ist $3-3,5 \mathrm{~cm}$ lang und hat $1,8-2,2 \mathrm{~cm}$ im Durehmesser; er ist aussen in trocknem $\mathrm{Zu}$ stande querrunzlig und schwarz; die mehligen Keimblätter sind gelblich weiss.

Die Piso-Andira wächst in den Staaten Rio de Janeiro, Espiritu Santo und Bahia von Brasilien, an den Rändern der Urwälder.

Andira Araroba lagert in Höhlnngen ihrer Stämme ein gelbes Pulver ab, welches Goapulver oder Ararobapulver genannt wird. Zieht man dieses Pulver mit Benzol aus, so gehen ungefähr 80 Procent Chrysarobin (Chrysarobinum) in das Benzol iber, welches sich aus der Benzollösung in Krystallen ausscheidet.

\section{Erklärung der Abbildungen.}

Fig. A. Ein blühender Zweig nach einem von Sellow in Brasilien gesammelten Exemplare.

Fig, $B$. Die Btüthe, 3mal vergrössert.

Fig. $C$, Die Fahne.

Fig. D.u. E. Die Flïgel.

Fig. $F$.u. G. Die Blättchen des Kieles.

Fig. H.u. $I$. Der Staubbeutel von vorn und von hinten, $10 \mathrm{mal}$ vergrössert.
Fig, $K$. Derselbe, aufgesprungen.

Fig. L. Der Stempel im Längsschnitte, nach Entfernung des halben Kelches, 3mal vergrössert.

Fig. M. Derselbe mit der Staubgefässverbindung.

Fig, N. Die Frucht, natürtiche Grösse.

Fig. O. Dieselbe im Längsschnitte mit den Samen. 


\section{KRAMERIA Linn.}

Blüthen zygomorph, vollständig. Kelch vollkommen freiblättrig, fünf- oder viergliedrig, die Blätter entweder ziemlich gleich oder das äusserste viel grösser, das innerste viel kleiner, zuweilen fehlt das letztere vollkommen. Blumenblätter vier oder fünf, die 2 oder 3 oberen, von dem grossen Kelchblatte abgewendeten langgenagelt; wenn 3 , so sind sie mehr oder weniger verwachsen, wenn 2, dann sind sie frei; die 2 vorderen*) sind dick fleischig, kreisrund und an dem Staubgefissverbande oder unter dem Fruchtknoten angeheftet. Staubgefässe 3 oder 4, frei oder verwachsen an dem oberen Theile der Blithe unter dem Fruchtknoten angeheftet; Beutel an der Spitze, unterhalb des häutigen Mittelbandes mit einer Pore, welche beide Theken öffnet, anfspringend. Fruchtknoten einfächrig oder durch die vom Ruicken her eindringende Samenleiste bis zur Hälfte zweifüchrig; Samenanlagen 2, vom oberen Theile der Rüickenseite hängend, anatrop, die Micropyle nach oben und innen gewendet. Frucht eine einsamige, lederartige, häufig mit Widerhakenstacheln bekleidete Nuss, die einen anhangslosen Samen ohne Nährgewebe umschliesst; die Keimblätter sind dick und schliessen mit nach unten gezogenen Lappen das Würzelchen ein. - Sträucher, Halbsträucher oder am Grunde verholzende Stauden, die häufig an der Erde liegen und seidenartig behaart sind, mit einfachen oder selten dreizähligen Blättern und achselständigen, einzelnen Blithen, die von zwei Vorblättchen gestlitzt werden; wenn sich die Deckblätter verkleinern, so entstehen Trauben.

15-20 Arten in Nord- und Stid-Amerika.

\section{Krameria triandra Ruiz et Pav.}

Taf. 60 .

Strauchartig mit einfachen, oblongen oder obovat-oblongen, ganzrandigen, spitzen, dicht seidenhaarigen, glänzenden Blättern. Blithen fast in Trauben mit 4 Kelchblättern, 2 oberen, freien, spathelförmigen Blumenblättern und 3 freien Staubgefässen.

Krameria triandra Ruiz et Pav. Prodr. Fl. Peruv. t. III; Fl. Peruv. I. 61. t. 93; Willd. Berl. Jahrb. Pharmac. XI. 139. t. 1; Roem. et Schult. Syst. III. 458, Mantissa III. 302; Hayne, Arzneigew. VIII. t. 14; Humb. Bonpl. Kth. Nov. gen. et spec. VIII. 245; P. DC. Prodr. I. 341; Nees, Düsseld. Abb. t. 15; Berg und Schmidt, Darst. und Beschreib. t. IIIf; Bentl. and Trimm, Med. pl. t. 30; Köhler, Mediz. Pf. t. 166; Flück. and Hanb. Pharmacogr. 74; Fliick. Pharmacogn. 387; H. Baill. Hist. pl. V. 79; Bot. méd. II. 910. fig. 2626-2631; Arth. Meyer, Drogenkunde. I. 236.

Ratanhia-Strauch; englisch: Rhatany oder Rhatanhia shrub; französisch: Arbuste de Ratanhia.

Aus einer zuweilen sehr stark knollig verdickten, aus der Pfahlwurzel entstandenen, nicht allzureich, aber kräftig verzweigten, aussen rothbraunen, innen schön rothen Hauptwurzel mit zimmtfarbenem, marklosem Holze erheben sich mehrere Stämmchen, die eine Höhe von $60 \mathrm{~cm}$ erreichen und entweder aufrecht stehen, oder an der Erde liegen; sie sind stielrund, in der Jugend von einfachen, stark verdickten, fadenförmigen, zugespitzten Haaren gelblichweiss bekleidet und seidenglänzend, später werden diese abgestossen und die Zweige sind dann mit schwarzer Rinde bekleidet.

*) Vergleiche die Anmerkung am Schlusse. 
Die Blätter stehen in spiraliger Ordnung, sie sind 6-9, höchstens bis $11 \mathrm{~mm}$ lang und im oberen Drittel 2-2,5 höchstens $3 \mathrm{~mm}$ breit; ihre Form ist lanzettlich, oblong oder obovat-oblong, sie sind sitzend, spitz und beiderseits gleichmässig gelblichweiss behaart und seidenglänzend.

Die Blïthen stehen an den Spitzen längerer Zweige und sind eigentlich, da die Deckblätter niemals Hochblattnatur annehmen, achselständig; es sind ihrer immer eine grössere Zahl vorhanden, so dass der Gipfel des Triebes ein traubenartiges Aussehen aufweisst. Sie sitzen auf einem 1, höchstens 1,5 cm langen Stiele, der dünner als die Axe, drehrund und wie diese behaart ist und werden von zwei aufrechtstehenden, lanzettlichen oder linealisch lanzettlichen Vorblättchen, die sonst den Stengelblättern gleichen und von den Blïthen selbst um 1-2 mm abgerïckt sind, gestützt.

Der Keleh ist vierblättrig, wobei die Blätter ein ziemlich regelmässiges aufrechtes Kreuz bilden; die beiden äusseren Kelchblätter sind etwas grösser, sie sind e. $1 \mathrm{~cm}$ lang und $6 \mathrm{~mm}$ breit, eioblong spitz, aussen sind alle grün und behaart, innen blutroth und kahl; das innere Paar ist schmäler und etwas kürzer. Mit den Kelchblättern wechseln zwei obere, spatelförmige, spitze, in einen langen Nagel verschmälerte Blumenblätter ab, die völlig frei sind und die halbe Länge des hinteren Kelehblattes überragen, auch sie sind roth gefärbt; zwei vorn unter dem Fruchtknoten befestigte, kreisrunde, auf der Aussenseite unregelmässig blasig aufgetriebene, fleischige Organe von 2,5 mm Durchmesser sieht man gewöhnlich für hochgradig veränderte Blumenblätter an. Die drei Staubgefässe sind vollkommen frei und sitzen unterhalb des Stempels an der Riuekseite der Bliuthe, die beiden seitlichen sind 5,5-6 mm lang, das mittlere ist um fast $1 \mathrm{~mm}$ kürzer; der Faden ist sehr kräftig, fast kenlenförmig und der Beutel von etwas mehr als $1 \mathrm{~mm}$ Länge, fast flasehenförmig und an der Spitze mit einer, beiden Theken gemeinsamen, gerade oder schräg gestutzten Oeffnung versehen. Die Pollenkörner sind unter Wasser kugelig und werden von drei Meridionalfalten durchlanfen. Der Stempel ist 6,5-7 mm lang und etwas nach vorn gekrümmt; der Fruchtknoten nimmt die Hälfte der Länge ein; er ist zottig und weich behaart und trägt schon zur Blüthezeit warzige Höcker, aus denen die späteren Stacheln werden; die Samenleiste springt in den Hohlraum vor, und von ihr hängen die 2 mit der Mikropyle nach innen und oben gewendeten Samenanlagen herab; der Griffel verjüngt sich etwas nach oben, ist kahl und läuft in eine gestutzte Narbe aus.

Die Frucht hat einen Durchmesser von etwa 8-10 mm, wozu dann noch die etwa $3-4 \mathrm{~mm}$ langen Stacheln zu rechnen sind; sie ist kugelig und granhaarig; die braunen Stacheln sind am Grunde verdiekt, an der Spitze gehen sie stumpf aus und unterhalb derselben sitzen bis 3 Reihen gekrümmter Widerhaken.

Der Same hat die Form eines Doppelkegels, der auf der einen Seite abgestumpft ist; er misst $3,5-4 \mathrm{~mm}$ in der Länge und fast ebenso viel in der Breite und wird von einer rothbraunen, häntigen Testa lose umschlossen; cr ist völlig nährgewebslos; *) die Keimblätter zeigen die Form des halbirten Samens, sie liegen flach an einander, sind aber im unteren Theile an der Fugenfläche rinnenartig zur Aufnahme des langen Würzelchens ausgehöblt.

Der Ratanhia-Strauch wäehst in Peru und zwar in der Breite von Payta, seinem nördlichsten Ausfuhrhafen bis zum Titicaca-See und der Breite des Hafens von Islay.

Anmerkung. Bezüglich der Stellung der Gattung Krameria im System herrscht unter den Botanikern noch eine verschiedene Auffassung: die einen, unter ihnen noch Bentham-Hooker, sind der Meinung, dass sie zu den Polygalaceen gehöre, andere, darunter Eichler und Taubert schliessen sie an die Legrminosen; in neuester Zeit hat Chodat eine eigene Familie Krameriaceen daraus gemacht. Ich halte die Eichler'sche Auffassung für richtig, obgleich ich in dem Versuche, die Organe zu homologisiren, nicht mit derselben iibereinstimme; ich meine nämlich, dass diejenigen Körper, welche mit den vorderen Blumenblättern gemeinlich verglichen werden, als fehlgeschlagene Staubgefässe zu betrachten sind. Eine eingehendere Behandluug der Frage gedenke ich anderwärts zu geben.

K. Schumani.

*) Nach dieser Beschreibung ist die Figur des Samens zu corrigiren; wir haben erst nach Herstellung derselben den Samen untersuchen können und waren desshalb nicht im Stande, die Correctur anzubringen. 
Die Droge Radix Ratanhiae, die Ratanhiawurzel, besteht aus dem Verzweigungssystem der Hauptwurzel; sie wird von wildwachsenden Pflanzen gesammelt.

\section{Erklärung der Abbildungen.}

Fig. A,1. Wurzel einer Pflanze, natürliche Grösse.

Fig. A.2. Blïhender Zweig nach einem Originalexemplare, gesammelt von Raiz in Peru.

Fig. B. Die Blithe ohne die Kelchblätter, 3 mal vergrössert: b. das Blumenblatt; $c$. das Staubgefäss; $d$. eines der vermeintlichen vorderen Blumenblätter.

Fig. D. Dieselbe von der Rlickseite betrachtet, 4mal vergrössert.

Fig. $E$. Eins der hinteren Blumenblätter.
Fig. $\boldsymbol{F}$. Das Staubgefüss, $8 \mathrm{mal}$ vergrüssert.

Fig. $G$. Pollenkörner in Wasser, 150 mal vergrössert.

Fig. $H$. Der Stempel, 5mal vergrössert.

Fig. I. u. K. Die Fruchtknoten im Quer- und Längsschnitte. Fig. L. Die Frucht, natürliche Grösse.

Fig. M. Dieselbe im Längsschnitte.

Fig. N.u. O. Der Same im Längs- und Querschnitte (s. oben). Fig. $P$. Ein Widerhaken der Frucht, 10mal vergrössert. 


\section{Familie: Rosaceae.}

Die Blüthen sind gewöhnlich zwittrig und aktinomorph, nur selten sind sie getrennt gesehlechtlich und zygomorph mit einer Symmetrale, welche nicht in die Mitte des Deckblattes fällt. Der Kelch ist entweder ober- oder unterständig; seine Blätter sind entweder völlig frei oder sie sind am Grunde zu einer mehr oder weniger verlängerten Röhre (die auch als Axenbecher angesehen wird) verbunden; die letztere ist entweder enger oder erweitert sich glocken- oder schüsselförmig; gewöhnlich sind die Bluthen fünfzählig, die dieser Zahl entsprechenden Kelehblätter decken gewöhnlich dachziegelig und bleiben häufig an der Frucht sitzen. Die Blumenblätter sind entweder jener Röhre am Rande, unterhalb der Kelchbuchten angeheftet oder sitzen unter dem Fruehtknoten, meist sind sie in der Zahl der Kelehblätter vorhanden, selten sind ihrer weniger entwiekelt, noch seltener fehlen sie. Staubgefässe sind meist sehr viele vorhanden; sie sitzen entweder unter dem Gynaeceum oder an der Röhre, welche die Kelchblätter trägt: seltener geht ihre Zahl zurück, zuweilen sind sogar nur zwei oder einzelne Staubgefässe ausgebildet; sie sind in der Knospenlage eingebogen, entweder frei oder am Grunde manchmal verwachsen; die Staubbeutel sind klein, zweiknöpfig, seltner verlängert, ditheeiseh und springen in Längsritzen auf der Innenseite auf. Die Fruchtblätter sind einzeln oder sehr zahlreich; entweder sind sie frei und dann stehen sie in einer oder mehreren Reihen und sind einfächrig oder sie bilden in geringerer Zahl einen unterständigen Fruchtknoten; Griffel sind entweder so viele wie Fruchtknoten und frei, oder sie sind in selteneren Fällen zu einem einfachen Organe verbunden; die freien Griffel sind fast niemals genau endständig, sondern nehmen ihren Ursprung aus einer höheren oder niedrigeren Stelle an der Banchseite des Fruchtblattes; die Narben sind punktförmig oder gebüschelt. In jedem Fruchtblatte oder jedem Fache des Fruchtknotens befinden sich meist 2, sehr selten mehr Samenanlagen; sie sind anatrop und entweder aufstrebend mit grundständiger, oder hängend mit gipfelständiger Mikropyle. Die Früchte sind sehr verschieden, entweder becren- oder steinfrueht- oder nüsschenartig, zuweilen bekleiden die saftigen Frïchtchen den Blithenboden, manchmal wird auch dieser oder die Kelchröhre fleisehig und schliesst dic Früchtehen ein; sehr selten sind echte Kapseln. Die Samen werden von einer diunnhäutigen oder lederartigen Samenschale umschlossen; sie enthalten gewöhnlich kein Nährgewebe; die Keimblätter sind häufig ziemlich dick und fleischig, das Würzelchen ist sehr kurz.

Einjährige Kräuter oder ausdauernde Stauden, Halbsträucher, Sträucher oder Bäume mit einfachen oder zusammengesetzten, gewöhnlich spiralig gestellten, oft gesägten Blättern, die am Grunde häufig verbreitert sind; Nebenblätter sind meist vorhanden, entweder sind sie frei oder dem Blattstiele angewachsen. Die Blüthenstände sind sehr mannigfaltig.

Die Schätzung bezüglich der Zahl der Arten wird sehr verschieden ausfallen, je nachdem der Begriff der Art in den vielgestaltigen Gattungen Potentilla, Crataegus, besonders aber Rosa und Rubus enger oder weiter gefasst wird. Nach der früheren Auffassung würde man etwa 1000 Arten zählen, die aber von einzelnen Autoren um weit tiber die Hälfte vermehrt worden sind.

Die officinellen Rosaceae gehören in folgende Gruppen:

Unterfamilie I. Prunoideae Engl. Fruehtblätter einzeln, selten mehrere (aber höchstens 5), frei, oberständig mit endständigem Griffel; Frucht steinfruchtartig; Blätter einfach.

1. Prunus Cerasus L.

2. Prumus Amygdalus Stokes. 
Unterfamilie II. Spiraeoideae Engl. Fruchtblätter meist viele (bis 12), seltener einzeln, in 2-5 Quirlen, auf dem flachen Blitthenboden sitzend, also weder eingesenkt, noch emporgehoben, mit je 2 bis vielen Samenanlagen; Früchte meist Balgkapseln; Staubfäden aus breiter Basis verschmälert; Blätter einfach oder gefiedert.

\section{Quillaja Saponaria Mol.}

Unterfamilie III. Rosoideae Engl. Fruchtblätter sehr viele auf gewölbtem oder kegelförmigem Träger, seltener wenige; entweder freiliegend, oder in die Kelchröhre bez. den vertieften Blithenboden eingeschlossen. Früchte stets nüssehen- oder karyopsenartig; Blätter häufig zusammengesetzt.

4. Rosa centifolia L.

5. Rubus Idaeus $\mathrm{L}$.

6. Hagenia Abyssinica Willd.

Unterfamilie IV. Pomoideae Engl. Fruchtblätter 5 bis 2 untereinander verbunden, einen unterständigen Frnchtknoten bildend; Frneht beerenartig; Blätter meist einfach.

7. Pirus Malus L.

\section{PRUNUS Linn.}

Blithen zwittrig, aktinomorph, meist vollständig, fünfzählig. Kelchröhre meist glockenförmig, zuweilen krug- oder länger röhrenförmig, grỉn, innen mit einem Honig absondernden Gewebe bekleidet; Kelchblätter dachziegelig deckend. Blumenblätter kurz genagelt, sehr selten fehlend. Staubgefässe nahe am Rande der Kelchröhre eingefitgt, zahlreich, etwas ungleich lang. Fruchtknoten sitzend, aus einem Fruchtblatte gebildet, nnd einfächrig, sehr selten zwei- bis mehrfächrig, mit 2 nebenständigen, hängenden, anatropen Samenanlagen, die Rhaphe ist bauchständig und die Mieropyle nach oben gewendet; Griffel einfach mit knopf- oder schildförmiger, etwas gewölbter Narbe. Frucht steinfruchtartig, kahl, bereift oder sammetartig behaart, nicht anfspringend, mit saftiger oder trockener Fruchthaut; Steinschale eben oder grubig punktirt und gefurcht; durch Fehlschlag einer Samenanlage einsamig. Same umgekehrt eiförmig, seitlich zusammengedríckt, ohne Nährgewebe. - Bäume oder Sträucher, die zuweilen durch verkümmerte, zugespitzte, stechende Äste dornig sind, mit einfachen, gestielten, spiralig gestellten Blättern, welche in der Knospenlage in der Mitte und der Länge nach eingeschlagen oder eingerollt sind; die Äste sind entweder Langtriebe oder Kurztriebe, nur die letzteren tragen Blitthen, sie beginnen mit trockenhäutigen Knospenschuppen, welche allmälig in die Laubblätter übergehen; die Nebenblätter sind den Blattstielen, welche am Ende häufig 2 Drïsen tragen, angewachsen und asymmetrisch. Die Blüthen stehen entweder in Dolden oder in Trauben, sie werden von Deckblättern gestiitzt, Vorblättchen fehlen.

Die Gattung umschliesst etwa 80 Arten, welche besonders in der nördlich gemässigten Zone entwickelt sind; auch in den wärmeren und heissesten Gegenden von Suid-Amerika gedeihen nicht wenige Arten, spärlich sind sie im tropischen Asien; dem tropischen und südlichen Afrika, dem kälteren StidAmerika, Australien und Polynesien fehlen sie. 


\title{
Prunus Cerasus Linn.
}

\author{
Tafel 61.
}

Ein niedriger Baum oder strauchartig, Ausläufer treibend; Zweige hängend, mit etwas lederartigen, oblongen, spitzen, gesägten, kahlen, in der Knospenlage zusammengeschlagenen Blättern, meist ohne Drüsen; Blüthen mit Ausbruch der Blätter erscheinend, doldenartig. Frïehte niedergedrüekt kugelförmig, unbereift, kahl, glänzend.

Prunus Cerasus Limn. Spec. pl. ed. I. 474; All. Fl. Pedemont. II. t. 134; Ic. Taurin. X1II. t. 85; Hayne, Arzneigew. IV. t. 42; Schrk. Fl. Monac. IV. t. 377; Mert. und Koch, Deutschl. Flora III. 408; Nees, Düsseld. Abl. t. 316; Guimp. und Schlecht. Pf. der Pharmac. t. 63; Ledeb. Fl. Ross. II. 6; Godr. et Gren. Fl. de Fr. I. 515; Willk. et Lange, Fl. Hisp. III. 245; Boiss. Fl. orient. I. 649; Berg und Schmidt, Darst. und Beschr. $t$. IV $V^{e}$; Köhler, Medizinalpft. $t .36$.

Prunus austera et acida Ehrh. Beitr. VII. 129 et 130.

Cerasus vulgaris Mill. Dict.; Mönch, Meth. G72.

Cerasus acida Gärtn. Fl. Wetter. II. 185; Endl. Fl. Poson. 468.

Cerasus austera Leight. Fl. Shropsh. add. 524.

Cerasus effusa Hort.

Cerasus Caproniana P. DC. Fl. Fr. IV. 482; Prodr. II. 536.

Saure Kirsche, Weichselkirsche; englisch: Cherry tree; französisch: Cérisier.

Ein Baum von sehr mässiger Höhe, der mit seinen niedergebogenen Ästen eine gleichmässig gerundete Krone bildet, nicht selten ist sie auch stranchartig; die graubraune Rinde löst sich in pergamentartigen Streifen ab. Die saure Kirsche erzeugt 2 Arten von Trieben: die Langtriebe, welche die Blätter dureh grosse Internodien getrennt tragen, sind unfruchtbar; in den Achseln dieser Blätter aber werden gestauchte Kurztriebe erzeugt, welche die Blüthenstände an ihrer Spitze hervortreiben.

Die Blätter stehen in spiraliger Anreihung; sie sind gestielt, oblong oder umgekehrt eiförmig, spitz oder kurz zugespitzt, am Rande doppelt gesägt oder doppelt gekerbt gesägt, die an der Spitze drilsigen Sägezähne werden nach unten zu kleiner; die Spreite erreicht gewöhnlich eine Länge von $5-7 \mathrm{~cm}$, selten darüber und ist meist 2,5-3, seltener bis $4 \mathrm{~cm}$ breit; sie wird in der Regel von 10 Paar grösseren Seitennerven durchlaufen und ist mehr oder weniger lederartig, oberseits glänzend, dunkelgrün, unterseits matt und blasser, beiderseits kahl. Der 1-1,5, höchstens $2 \mathrm{~cm}$ lange Blattstiel ist oberseits rinnig und trägt an seinem oberen Ende 2 ungleich hoch gestellte, knopfförmige Drüsen, die aber nicht selten fehlen. Die Blätter sind in der allerfrühsten Jugend mit 2 linealisehen, spitzen, drüsig gezähnelten, bleichen, bald abfälligen Nebenblättern versehen; man kann in derselben Knospe leicht alle Zwischenbildungen von Laubblättern mit ihren Nebenblättern bis zu den scariösen Decksehuppen auffinden.

Die Blüthen bilden wenig- $(1-9)$ blüthige Dolden, welche am Grunde von aufrechten, scariösen Knospenschuppen und von einzelnen oder wenigen Laubblättern derselben Knospe gestiitzt werden. Die Blüthen werden von einem stielrunden 2-4 cm langen, kahlen Stiele getragen und von einem kleinen, blattartigen, lanzettförmigen, drüsig gezühnten, den Nebenblättern ähnlichen Deckblatte begleitet. Der Axenbeeher (oder die Kelchröhre) ist etwa $4 \mathrm{~mm}$ hoch, glockenförmig, krautartig, aussen kahl, bräunlich, innen honiggelb und mit einem Honig ausseheidenden Gewebe (Disens) ausgekleidet; er löst sich dureh einen kreisrunden Spalt vom Fruehtknoten und fällt bald nach der Befruchtung ab. Der Keleh ist funfblättrig, jedes Blatt ist 3,5-4,5 mm lang, oblong oder elliptisch, stumpf, ganzrandig, selten drüsig gezähnelt, ausgehöhlt; die Knospenanlage ist dachziegelig, bei der Vollblitthe ist er zurückgeschlagen, endlich fällt er mit dem Becher ab. Die Blumenblätter sind fast kreisförmig, 9-12 mm im Durchmesser 
haltend, sehr kurz genagelt, oben seicht ausgerandet, in der Vollblithe ebenfalls ausgehöhlt, leicht abfallend, weiss, seltener rötblich. Die Staubgefässe sind zahlreich (meist 30) von verschiedener Länge, bis $8 \mathrm{~mm}$ messend, nur sehr wenig deutlich in 5 Gruppen zwischen den Blumenblättern aufgestellt; die Staubfäden sind weiss, nach innen gebogen, die Beutel kaum $0,7 \mathrm{~mm}$ lang, fast kreisförmig umrissen, goldgelb. Die Pollenkörner sind ellipsoidisch, von 3 meridionalen Längsfurchen durehzogen. Der Ste mpel ist 9-12 mm lang; er besteht nur aus einem Fruchtblatte; der kahle, grüne Fruchtknoten ist von oblongeiförmigem Umrisse und geht allmälig in den cylindrischen, wie der Fruchtknoten auf der Rückseite gefurchten, dunkel grünen Griffel über; er umschliesst zwei nebenständige Samenanlagen, die von der Mitte der Fruchtknotenwand zu beiden Seiten der Furehe herabhängen; sie sind anatrop und mit der Mikropyle nach oben gewendet; die Narbe ist fast schildförmig und an der Rückseite schwach ausgerandet.

Die Steinfrucht ist niedergedrïckt kugelig, am Grunde genabelt, von einer sehr schwachen Längsfurche durchzogen, sie ist braunschwarz, glänzend und hat ein dunkel purpurrothes, süsssäuerliches Fleisch. Der Stein ist fast kugelig, nur wenig von der Seite her zusammengedrickt, an beiden schärferen Kantcn, namentlich aber an der Banchseite gerandet, an der Basis gestutzt, oben spitzlich, knochenhart, gelblich weiss.

Der Same bat die Form des Steines, ist aber erheblich kleiner; er ist rein weiss, die Chalaza ist braunroth; er enthält kein Nährgewebe, sondern umschliesst nur den Keimling mit 2 planeonvexen Keimblättern und dem kurzen nach oben gewendeten Wtirzelchen.

Die saure Kirsche wächst in Macedonien, am Bithynisehen Olymp (in der Kastanicn-Region), an beiden Seiten des Kaukasus und in Ossetien wild; in den Waildern des mittleren Europas ist sie nicht selten verwildert. Ihre Cultur erstreckt sich über das gesammte Europa und die vereinigten Staaten von Nord-Amerika; sie geht bei weitem mehr nach Norden hinauf, als dic süsse Kirsche.

Die schwarzen, sauren Kirschen werden zur Darstellung des Sirupus Cerasorum, des Kirschsirup, benutzt.

Anmerkung. Man hat schon in früherer Zeit bei der sauren Kirsche zwei scharf gesonderte Varietäten unterschieden: z. acida Ehrh. (die Glaskirsche) ist ein höherer Baum mit aufrechten Zweigen, der wenig Neigung zur Wurzelbrut d. h. zur Bildung von Ausläufern hat und dessen Früchte mit farblosem Safte gefüllt und kurz gestielt sind; ihre Blätter sind am Grunde häufig zweidrïsig - and $\beta$. austera Ehrh. (die schwarze, saure Kirsche) ein niedriger Baum oder Strauch mit hängenden Zweigen, der viele Ausläufer durch Wurzelbrutaustrieb bildet und dessen Früchte von der oben beschriebenen Art sind; die Bliitter haben weniger häufig zwei Drüsen am Grunde der Spreite. Die Scheidung wurde zuerst unter den Titeln von eigenen Arten durch Ehrhart (Beiträge zur Naturkunde VII. 129, Hannover 1792) vollzogen; auch gegenwärtig ist man vielfach zu der Meinung zurïckgekehrt, dass beide Varietiiten specifisch zu trennen seien. Unsere Beschreibung bezieht sich, wie auch die Abbildung auf die schwarze, saure Kirsche.

\section{Erklärung der Abbildungen.}

Fig. A. Ein blühender Zweig.

Fig. B. Ein Blatt mit den Nebenbliattern.

Fig. C. Die Blïthe, von der die Blumenblätter entfernt sind, 3 mal vergrössert: $a$. Axenbecher; $b$. Kelchblatt; d. Staubgefässe; $e$. Stempel.

Fig. D. Dieselbe, hinten angeschnitten.

Fig. $E$. Das Staubgefäss, von innen und von aussen betrachtet, $12 \mathrm{mal}$ vergrössert.

Fig. F.u. G. Pollenkörner, trocken und in Wasser betrachtet, $300 \mathrm{mal}$ vergrössert.

Fig. H. Der Fruchtknoten, längs durchschnitten, 6mal vergrössert: $b$. Fruchtknoten; $c$. die Samenanlage.
Fig. J. Derselbe, im Querschnitt.

Fig. $K$. Die Narbe, 8mal vergrössert.

Fig. L. Die Frucht, natürliche Grösse.

Fig. M. Dieselbe, die Hälfte des Fruchtfleisches ist abgetragen.

Fig. $N$. Der Steinkern.

Fig. 0 . Derselbe, mit zur Hälfte entfernter Steinschale: a. Nabelstrang; $b$. Same.

Fig. P.-R. Der Same im doppelten Längs-und Querschnitte: a. Wtirzelchen; $b$. Keimblätter; $c$. Knospe. 


\title{
Prunus Amygdalus Stokes.
}

\author{
Tafel 62.
}

Blätter lanzettlich oder länglich lanzettlich; Stiel so lang wie ihre Breite oder länger, oben drüsig; Steinschale mit Poren.

Prunus Amygdalus Stokes, Botanical mat. med. III. 101; H. Baill. Botan. médic. I. 565. fig. 21132118; Flïck. Pharmacogn. ed. III. 984; A. Koehne, Dendrol. 315.

Amygdalus communis Linn. Spec. pl. ed. I. 473; Duham. Arbr. I. t. 17; Allione, Fl. Pedem. II. 136; Plenck, Pl. med. t. 385; Hayne, Arzneigew. IV. t. 39; DC. Prodr. I1. 530; Guimp. Holzgew. $t$. 141; Guimp. und Schlecht. Pfl. d. Pharmac. t. 6; Mert. und Koch, Deutschl. Fl. III. 402; Woodw. Med. pl. III. 193; Ledeb. Fl. Ross. II. 2; Willk. Prodr. Fl. Hisp. III. 242; Godr. et Gren. Fl. Fr. I. 512; Boiss. Fl. or. II. 641; Bertol. Fl. Ital. V. 125; Bentl. and Trim. Med. pl. t. 99; Berg und Schmidt, Darstell. und Beschr. t. $4^{d}$; Köhler, Mediz. Pf. t. 94; Battand. et Trab. Fl. d'Alg. II. 296; Willk. Forstl. Fl. 889 ; A. Meyer, Drogenkunde. I. 129.

Mandelbaum; engliseh: Almond tree; französisch: Amandier.

Ein mässig hoher Baum, der 5-10 m Höhe erreicht und eine breitästige, gerundete Krone besitzt, selten ist er strauchig, mit langen, ruthenförmigen Zweigen, die bei der Normalform aufrecht stehen oder horizontal spreizen; auch sie tragen wieder Kurztriebe, welche allein blithbar sind; jene sind stielrund, mit brauner, ins Graue gehender Rinde bekleidet; an der, mit graugrüner Epidermis bekleideten Spitze sind sie meist ein wenig zusammengedriekt und stets kahl. Die trockenhäutigen, braunen, gerundeten oder sehr kurz zugespitzten, am Grunde gelblichen Knospenschuppen, welche die Blattknospen umgeben, sind kahl oder nur schwaeh gewimpert; die aber, welche die Blüthen einschliessen, sind häufig auf dem Rücken spinnewebig wollig.

Die Blätter stehen in spiraliger Ordnung; sie werden von einem 1,2-2,5 cm langen Stiele, der anf der Oberseite rinnig ausgekehlt ist, getragen; ihre Länge betrïgt $4-10 \mathrm{~cm}$, ihre Breite in der Mitte oder häufig im unteren Drittel 1,5-2,5 cm; die Form der Spreite weehselt von dem Lanzettlichen bis ins Eilanzettliche, meist ist sie spitz, seltener zugespitzt, sie ist drüsig, zuweilen nur sehr schwach gekerbt gesägt; sie wird jederseits des Mittelnerven von etwa 10 grösseren Seitennerven durchzogen, die beiderseits, wie das Nervennetz ein wenig hervortreten; sie ist völlig kahl, am Grunde, dort wo sie in den Blattstiel übergeht, trägt sie hänfig eine Drüse oder ein Paar derselben; ihre Farbe ist oberseits hellgrún, unterseits mehr graugrün; die Nebenblätter fallen bei dem Austrieb der Blätter ab; sie sind schmal linealiseh und spitz, sehr fein drüsig gezähnelt.

Die Blüthen erseheinen mit Austrieb der Blïtter oder kurz vorher einzeln, gepaart oder als Drillinge doldenartig verbunden an der Spitze der Kurztriebe; sie sind, wie man besonders nach Abfall der Knospenschuppen wahrnimmt, kurz (höchstens 3-4 mm lang) gestielt. Der Axenbecher (die Kelchröhre) ist 4-5 mm lang, glockenförmig, kahl, wenig deutlich zehnnervig, gegen die Basis hin griln, oben braunroth, innen wird er von einem gelben, Honig absondernden Gewebe ausgekleidet, am unteren Drittel oder bis zur Hälfte ist er behaart; er löst sich von der heranreifenden Frucht durch einen ringförmigen Spalt ab. Die 5 Kelchblätter sind abstehend, oblong bis oblong lanzettlich, stumpf, wenig vertieft, am Rande gewimpert oder drïsig gezähnelt, aussen kahl, ihre Farbe ist unten braunroth, oben grün. Die Blumenblätter sind oblong bis breit umgekehrteiڤ̈rmig, an der Spitze sind sie etwas ausgerandet, am Grunde keilförmig, sie messen bis $2 \mathrm{~cm}$ in der Länge und $1,5 \mathrm{~cm}$ in der grössten Breite, die Farbe ist zart rosenroth, von dunkleren Adern längs durchzogen. Staubgefässe sind meist mehr als 30 vor- 
handen, die in 5 wenig deutlichen Gruppen zwischen den Blumenblättern stehen; sie sind ungleich lang und ihre Länge wechselt zwischen 9 und $13 \mathrm{~mm}$; die dünn pfriemlichen Staubfäden sind rosenroth, die etwa $1 \mathrm{~mm}$ langen, elliptischen Beutel sind gelb; die Pollenkörner sind von denen der Kirsche nicht verschieden. Der Stempel besteht aus einem Fruchtblatte und gleicht ebenfalls dem der vorigen Pflanze, nur ist er viel länger, er wird bis $1,7 \mathrm{~cm}$ lang, und ist am Grunde dicht, fast zottig behaart, in abnehmender Dichte setzt sich dann die Bekleidung bis über die Hälfte des Griffels fort.

Die Frucht ist $3,5-4 \mathrm{~cm}$ lang und $2,5-3 \mathrm{~cm}$ breit, sie ist eine trockne Steinfrucht von eiförmiger, etwas seitlich zusammengedrückter Gestalt; die äussere Fruchthaut ist lederartig, zäh, graugrünlich, geschmacklos, sammtig behaart; an ihrer Rückseite befindet sich eine Furche, dort springt sie auf und von hier aus löst sie sich von dem Steine allmälig ab. Die Steinschale ist entweder steinhart oder dünner und zerbrechlich, an der Vorder- und Rïckseite ziemlich breit und scharf gerandet, gelb oder hellbraun, mit unregelmässigen Vertiefungen versehen, innen ist sie glatt und glänzend.

Der Same liegt einzeln oder gepaart in jeder Steinschale (im letzteren Falle hat sich die zweite, gewöhnlich fehlschlagende Samenanlage auch entwickelt), ist eiförmig, spitz; er wird von einer rauhen, bräunlichgelben Samensehale umgeben; der Keimling besteht aus 2 sehr ölreichen, planconvexen, weissen Keimblättern und dem sehr kurzen Würzelehen, er schmeckt entweder süsslich oder sehr charakteristisch bitter.

Anmerkung I. Man unterscheidet von der Mandel verschiedene Varietäten, die sich durch die schon oben berührten Eigenthïmlichkeiten der Frïchte und Samen unterscheiden: Var. $\alpha$. dulcis P. DC. hat harte Steinschalen und süsslich schmeckende Samen; var. $\beta$. amara Hayne, harte Steinschalcn und bittere Samen; var. $\gamma$. fragilis Borkhausen, zerbrechliche Steinschalen und sïssliche Samen (Knack-oder Krachmandeln); die var. persicoides Sér. (Pfirsichmandel) mit mehr fleischiger Frucht, ist wohl sicher ein Bastard mit dem Pfirsich.

Anmerkung II. In vielen Büchern findet sich die Angabe, dass der Autor von Prunus Amygdalus H. Baillon sei; er selbst ist auch der Meinung. Da aber Stokes bereits 1812 dcn Namen gegeben hat, so ist jene Meinung irrthümlich. Übrigens ist die Benennung nach den Regeln der Priorität nicht haltbar; wer sich streng nach diesen richtet, wird Prunus communis vorziehen mïssen. Jene könnte nur dann cinen Anspruch auf allgemeinc Berücksichtigung erheben, wenn Linné in der Gattung Amygdalus nur eine Art beschrieben hätte; nun finden sich aber in dem Species plantarum ed. $I$. drei derselben, demzufolge müssen die drei Arten bei der Überführung in die Gattung Prunus in ihrem specifischen Namen erhalten bleiben.

Der Mandelbaum wächst mit Sicherheit wild in dem Hochthale des Sarafschan in Turkestan, am Hermon, wo er zwischen 1000 und $1600 \mathrm{~m}$ gebtischbildend auftritt, an buschigen, felsigen Orten von Mesopotamien und Persien, so z. B. am Berge Avroman in Kurdistan zwischen 2200 und $2900 \mathrm{~m}$; an anderen Orten, besonders des Mittelmeergebietes scheint er nur verwildert zu sein, wenn auch dort Formen vorkommen, die wegen der kleinen Blththen und Früchte der wilden Pflanze sehr nahe kommen.

Die Samen der cultivirten Varietäten amara und dulcis des Mandelbaums werden als Amygdalae amarae und Amygdalae dulces in den Apotheken zur Darstellung von Emulsionen, von Bittermandelwasser (Aqua Amygdalarum amararum) ınd Bittermandelöl, sowie von fettem Mandelöl (Oleum Amygdalarum) angewendet.

\section{Erklärung der Abbildungen.}

Fig. A. Ein Blüthenzweig nach einer im Universitätsgarten zu Berlin gezogenen Pflanze.

Fig. B. Die Blüthe, nach Entfernung der Blumenblätter, 2 mal vergxüssert: $a$. der Axenbecher; $b$. die Kelchblätter; $d$. die Staubgefüsse; e. der Stempel.

Fig. C. Dieselbe, ein Stüek des Axenbechers vorn abgetragen, 4mal vergrössert.

Fig. D. Das Staubgefäss von innen und aussen betrachtet, $12 \mathrm{mal}$ vergrössert.

Fig. E. u. F. Pollenkörner, trocken und in Wasser, $300 \mathrm{mal}$ vergrössert.

Fig. G. Der Fruchtknoten im Längsschnitte, 6mal ver- grössert: $b$. Fruchtknotenwand; $c$. Samenanlagen; d. Griffel.

Fig. $H$. Derselbe im Querschnitte, 10mal vergrössert.

Fig. $I$. Die Narbe, $8 \mathrm{mal}$ vergrössert.

Fig. $K$. Die Frucht, natiirliche Grösse; bei $a$. springt sie auf.

Fig. $L$. Dieselbe, nach Abtragung der halben Fruchthaut.

Fig. M. Der Same, nach Abtragung der halben Steinschale: $a$. Steinschale; $b$. Nabelstrang; $c$. Same.

Fig. N.-P. Der Keimling im doppelten Längs- und im Querschnitte: a. Würzelchen; b. Keimblätter; c. Knüspchen.

Fig. Q. Das Würzelehen und Knöspehen, 4mal vergrössert. 


\title{
QUILLAJA Molina.
}

Blïthen vielehig, getrennt geschlechtlich, fünfgliedrig, aktinomorph. Axenbecher (Kelchröhre) klein, lederartig, bleibend, flach becherförmig; Kelchblätter breit eiförmig mit klappiger Knospenlage. Blumenblätter 5, klein, sitzend, spatelförmig; Disens fleischig, dem Axenbecher angewachsen, in 5 dicke, flache, den Kelchblättern am Grunde angeheftete, an der Spitze verbreiterte und ausgerandete Zipfel ausgehend. Staubgefässe 10, von denen 5 mit den Blumenblättern abwechselnd aus den Discuslappen hervortreten, 5 aber zwischen diesen am Grunde des Discus befestigt sind. Fruchtblätter 5, mit einem sehr feinen Filze bekleidet; Samenanlagen zahlreich, an der binnenwinkelständigen Samenleiste befestigt, zusammengedrückt, anatrop, horizontal aufgehängt, sich gegenseitig kaum berührend; Grifiel endständig, frei, mit stumpfen, an der Spitze etwas eingedriickten Narben. Balgfriichte 5, oblong, gestutzt und ausgerandet, am Grunde zusammenhängend, lederartig, spreizend, vielsamig. Samen zusammengedrïckt, aufsteigend, an der Spitze lang und breit geflügelt mit bäutiger, äusserer Samenschale; das Nährgewebe fehlt, die Keimblätter sind eingerollt; das Würzelchen ist nach unten gewendet. - Immergrïne, ganz kahle Bäume, mit spiralig gestellten, lederartigen, ganzrandigen oder oberfläehlich gekerbten Blättern und kleinen, abfälligen Nebenblättern. Blüthen einzeln oder in armblüthigen, end- oder seitenständigen Dichasien mit 2 abfälligen Vorblättchen; oft sind nur die endständigen fruchtbar, die seitenständigen männlich.

Man kennt nur 3-4 Arten, welehe in Süd-Amerika und zwar von Brasilien bis Chile und Peru verbreitet sind.

\section{Quillaja saponaria Mol.}

\author{
Tafel 63.
}

Baumartig mit elliptischen oder eioblongen, lederartigen, schwach und weitläufig gekerbten, zuweilen fast ganzrandigen Blättern, die an der Spitze stumpf, an beiden Seiten glänzend und kurz gestielt sind.

Quillaja saponaria Mol. Saggio sull. hist. nat. del Chili 175 (1782); Poir. Dist. VI. 33; Gay, Fl. Chil. II. 274; Phil. in Bot. Zeitung 1864 Beibl. 23; Fliick. La Mortola 21, Pharmacogn. 614; Baill. Bot. méd. 554, fig. 2092; Köhler, Mediz. Pfl. t. 189.

Quillaja Molinae P. DC. Prodr. II. 547.

Quillaja Smegmadermos P. DC. l. c.

Smegmadermos emarginatus Ruiz et Par. Fl. peruv. 258.

Der Baum wird bis $10 \mathrm{~m}$ hoch; die jüngeren, Blätter und Blïthen tragenden Zweige sind stielrund mit dunkel bleigrauer bis sehwärzlicher Rinde bedeckt, die jüngsten Spitzen sind mit äusserst kurzen, nur unter der Lupe wahrnehmbaren Härchen bekleidet.

Die Blätter sind spiralig angereilit und nur durch kurze Internodien von einander getrennt; sie sitzen auf gewöhnlich sehr kurzen, 2-3 mm an Länge nicht ïbertreffenden, oben ein wenig rinnig vertieften, selbst unter der Lupe kaum deutlich behaarten Stielen; die Spreite ist 2,5-3,3 $(2-4) \mathrm{cm}$ lang und in der Mitte oder etwas weiter unten 1,5-2,3 $(1,2-2,7) \mathrm{cm}$ breit, meist elliptisch, zuweilen ins Eiförmige gehend, stumpf, am Grunde gerundet oder spitz; sie wird jederseits des Mittelnerven von meist 4-5 grösseren, beiderseits etwas vortretenden Seitennerven durchlaufen; der Rand ist nicht selten vollkommen ganz, häufig sieht man aber einzelne oder mehrere kleine, wenig hervortretende, etwas callöse Zähnchen aus dem hell gesäumten Rande hervortreten; sie ist lederartig, beiderseits stark glänzend, 
immergrün und nahezu völlig kahl, nur am Grunde ist der Mittelnerv mit äusserst winzigen, fast mikroskopisch kleinen, einfachen, einzelligen Härchen bekleidet. Die Nebenblätter sind linealisch, an der Spitze abgerundet, etwas schief; sie erreichen kaum $2 \mathrm{~mm}$ Länge, werden schnell gebräunt und fallen ab.

Die Blüthen beschliessen entweder einzeln wenig beblätterte Kurztriebe oder häufiger treten sie zu einem einfachen, dreiblüthigen Dichasium zusammen; nur die Gipfelblithe ist dann fruchtbar, die seitlichen, männlichen, mit unentwickelten Stempeln versehen, fallen sehr schnell ab. Der Bluthenstiel ist, wenigstens im trocknen Zustande, etwas zusammengedriickt, höchstens $1 \mathrm{~cm}$ lang und wie die Begleitblätter und der Keleh von einem Filze mikroskopisch kleiner Härchen grau. Die Deckblätter sind lanzettlich, stumpflich oder spitz, etwas gekrümmt, höchstens 2-3 nım lang; die Vorblättehen sind ähnlich, nur etwas kleiner. Der Kelch ist 6-7 mm lang, davon kommt auf den kurzen Axenbecher kaum $1 \mathrm{~mm}$; die lederartigen Kelchblätter sind oblong bis eiförmig, spitz, in der Knospe decken sie klappig, sie sind aussen und innen sehr kurz filzig, innen gran, aussen grïnlich. Die dïnhäutigen Blumenblätter sind etwa so lang wie die Kelehblïtter, spathelförmig, spitzlich, ganz kahl und weiss. Der Honig absondernde Diseus kleidet nicht blos den Axenbecher ans, sondern zieht sich auch noch in 5 umgekehrt eiförmigen, oder kreisrunden, an der Spitze ansgerandeten Lappen auf die Kelehblätter hinüber, die er bis zur Hälfte bedeckt. Die Stanbgefüsse, welche zwischen den Kelchblättern stehen, sind 5-6 mm, die, welche aus den Kerben der Diseuslappen hervortreten, sind $4-5 \mathrm{~mm}$ lang; die Fäden sind schlank pfriemenförmig, sie sind den breit elliptischen, 2 mm langen, gelben Beuteln in der Mitte des Rïckens angeheftet; die Pollenkörner erscheinen im Wasser betrachtet ellipsoidisch und werden von 3 meridionalen Längsfurchen durehzogen. Die 5 Stempel hängen fest aneinander und bilden einen tief fünffurchigen Körper von c. $3 \mathrm{~mm}$ Höhe. Der Frnchtknoten ist mit jenem sehr feinen Filze bedeckt, der nur unter der Lupe deutlich wird; der Griffel ist kahl; er wird innenseits von einer Längsfurehe durehzogen, die in einer kleinen Vertiefung, unterhalb der stumpfen Spitze, endet. Die Samenanlagen sind sehr klein, es stehen ihrer etwa 6-7 an jeder der beiden Samenleisten eines Fruchtblattes; sie sind anatrop, horizontal aufgehängt und berühren sich fast oben und unten.

Die Frucht misst $3 \mathrm{~cm}$ im Durchmesser, sie wird von dem stehenbleibenden Kelche gestütat und besteht aus 5 sternförmig spreizenden, sehr fein filzigen, graugelben Balgkapseln, die zuerst auf der Bauch-, dann aber auch auf der Rückenseite fast bis zum Grunde anfspringen; die beiden benachbarten, fast holzigen, innen glatten und glänzenden H:alften je zweier solcher Theilfruchte bleiben miteinander in engerer Verbindung.

Die Samen sind zahlreich in jedem Fache, doch scheinen nicht alle voll entwickelt zu werden; sie sind gefligelt, 8-10 mm lang, wovon auf den dunkelkastanienfarbenen, spindelförmigen Nucleus $5 \mathrm{~mm}$ kommen; der dreiseitige bis eiförmige, spitze oder stumpfe, häutige Flügel ist hellbraun; sie sind alle senkrecht aufsteigend und wie die Blätter eines Buches an einander gelagert; der Keimling hat das Würzelchen nach unten gewendet, die am Grunde gelappten Keimblätter sind in einander gewickelt, sehr ölreich und fleischig.

Der Quillajabaum wächst ziemlich häufig auf den mittelhohen Bergen und in den Thälern von Chile bis zu einer Höhe von etwa $2100 \mathrm{~m}$; seine Nordgrenze liegt bei Illapel unter dem $31^{\circ} \mathrm{s}$. Br., die Südgrenze bei den Flìssen Angol und Levu, $38^{\circ} \mathrm{s} . \mathrm{Br}$.

Die von der Borke völlig befreite, secundäre Rinde des Baumes diente in Chile schon vor dem Eindringen der Europäer als Reinigungsmittel. Sie wird jetzt hauptsächlich in der Technik als Waschmittel zur Entfettung und Reinigung der Stoffe angewandt und hat als Cortex Quillajae neuerdings in der Medizin Anwendung und damit Aufnahme in das Arzneibuch gefunden. 


\section{Erklärung der Abbildungen.}

Fig. A. Ein blühender Zweig, nach einem von Dombey gesammelten Exemplare.

Fig. $B$. Die Blüthe, 2mal vergrössert.

Fig. C. Ein Kelchblatt mit dem ihm angehefteten Discuslappen und dem aus ihm hervortretenden Staubgefässe, und ein Blumenblatt, 3mal vergrössert.

Fig. D. Das Staubgefäss von innen und von aussen, 5mal vergrössert.
Fig. E. Der Stempel, 5mal vergrössert.

Fig. $F$. Derselbe, im Längsschnitte, 6mal vergrössert.

Fig. G. Derselbe im Querschnitte.

Fig. $H$. Die Frucht, natürliche Grösse.

Fig. $K$. Der Same, natürliche Grösse.

Fig. I. Der Keimling, 3mal vergrössert.

\section{RUBUS Linn.}

Blüthen aktinomorph, strahlig und zwittrig. Axenbecher (Kelchröhre) seicht aber breit, in der Mitte gewölbt, mit 5 in der Knospenlage dachziegelig deckenden Kelchblättern. Blumenblätter 5, dem Axenbecher eingefügt, sehr kurz genagelt, abfällig. Staubgefässe sehr viele, selten wenige, am Rande des Axenbechers befestigt, mit fadenförmigen Filamenten. Stempel meist sehr zahlreich, dem gewölbten Theile des Axenbechers angeheftet, jeder aus einem Fruchtblatte bestehend, mit einem fast scheitelständigen Griffel, der in eine kleinköpfige Narbe ausgeht; Samenanlagen typisch zwei, anatrop, hängend, die eine zuweilen ausserordentlich klein. Früehtehen steinfruchtartig, selten trocken, einsamig, auf dem vergrösserten convexen Theile des Axenbechers zusammengedrängt, eine Sammelfrucht bildend. Samen mit häutiger, dünner Testa; Keimblätter fleischig, planconvex, Würzelchen kurz, nach oben gewendet; das Nährgewebe fehlt. - Aufrechte oder hänfiger am Boden kriechende oder kletternde, mit Stacheln bewehrte Halbsträucher oder Sträucher selten Stauden, die kahl oder mit einfachen oder Drüsenhaaren bekleidet sind. Blätter spiralig gestellt, selten einfach, meist gefingert oder gefiedert mit am Blattstiele befestigten Nebenblättern. Blïthen in end- oder seitenständigen Rispen, seltener einzeln und achselständig, weiss oder roth .

Die Zahl der Arten wird sehr versehieden gesehätzt, es sind sicher mehr als 600 beschrieben worden, die sich aber auf wenig ïber 100 zusammendrängen lassen, wenn sie mit dem sonst übliehen Artbegriff gemessen werden; sie sind in der nördlichen Erdhälfte bis in die kalte Zone verbreitet, finden sich aber auch noch ziemlich zahlreich in den tropischen und subtropisehen Theilen der beiden Hemisphären; seltener sind sie in Süd-Afrika und Australien.

\section{Rubus Idaeus Linn.}

\section{Tafel 64 .}

Zweijähriger Halbstrauch mit anfreehten Trieben, die spätor verholzen; Blätter unpaarig gefiedert, dreizählig oder gefingert, Blättchen zweifarbig, unterseits zart weissfilzig, eiförmig, zugespitzt, am Grunde gerundet, doppelt gesägt, Blithen in end- oder seitenständigen, meist dreibliithigen Trauben, die an der Spitze der Triebe des zweiten Jahres zuweilen rispig zusammentreten; Blumenblätter kürzer als die Kelchzipfel: Steinfrueht meist roth, zuweilen gelblich, sehr kurz flaumig behaart.

Rubus Idaeus Linn. Spec. pl. ed. I. 492; Fl. Dan. V. t. 755; Allione, Fl. Pedem. II. t. 132; Plenck, Off. Pfl. t. 407; Svensle Bot. t. 181; Engl. Bot. IXXIV. t. 24t2; Hayne, Arzneipfl. III. t. S; 
Schrk. Fl. Monac. IV. t. 341; Weihe et Nees, Rub. Germ. 107. t. 47; P. DC. Prodr. II. 558; Nees, Dïsseld. Abb. t. 311; Wagner, Pharm. t. 47; Mert. und Koch, Deutschl. Fl. III. 490; Woodv. Med. pl. III. t. 176; Guimp. und Schlecht. PA. d. Pharm. t. 74; Koch, Syn. 210; Guimp. Holzgew. t. 97; Ledeb. Fl. Ross. II. 65; Willk. et Lange, Prodr. Fl. Hisp. III. 219; Godr. et Gren. Fl. Fr. I. 551; Boiss. Fl. orient. II. 692; Aschers. Fl. Mark Brand. 186; Focke, Syn. Rub. 97; Berg und Schmidt, Darst. und Beschr. XXI ; Köhler, Mediz. Pf. t. 43; Parl. Fl. Ital. X. 40; Flück. Pharmacogr. ed. III. 860 .

Die Himbeere vermehrt sich durch Wurzelbrut: die zuerst steif aufrechten, später oben etwas uibergebogenen Triebe des ersten Jahres gehen aus Knospen hervor, welche den fast ausläuferartigen Wurzeln entspringen. Diese Stengel haben die Höhe von 1-2 m, sie sind entweder völlig kahl oder an den Spitzen behaart, die Keimpflanzen und juingsten Wurzeltriebe aber sind stets dicht mit braunen, abstehenden Borsten bedeckt, zwischen denen einzelne Drüsenhaare eingestreut sind; in den unteren Theilen befinden sich an jenen meist kleine, kurze, kegelförmige, schwarzrothe Stacheln; oberwärts sind sie meist unbewehrt. Die einjïhrigen Triebe verholzen im Laufe des Sommers, sind dann mit grauer, bräunlicher bis kupferrother Rinde bekleidet, das $\mathrm{Holz}$ ist grïn und das umfangreiche Mark gelblichbraun; sie schliessen endlich mit einem Knospenpaar ab, von denen die eine das Achselprodukt des obersten Blattes, die andere die Endknospe zu sein scheint. Im nüchsten Frühjahre treiben alle Seitenknospen in viel kürzere, fertile Zweige aus, welche schon mit den während des vergangenen Hochsommers in allen Theilen angelegten Blithen von der Form sehr kleiner Knospen ausgestattet sind.

Die Blätter sind spiralig angereiht und sehr mannigfaltig gestaltet. Die Keimpflanzen bringen nach den Kotyledonen einfache, herzförmige, spitze, ganze oder nur wenig gelappte, beiderseits, besonders aber unten, sowie an den Blattstielen mit Borsten und Drisenhaaren reichlich besetzte Blätter hervor, die durch tiefer gelappte Formen in dreizählige übergehen; am häufigsten sind an den einjährigen Trieben nnpaarig gefiederte, dreijochige (das unpaare Blättchen mitgezählt) und weiter oben dreizählige Blätter; neben diesen kommen, wenn immerhin sehr selten, aber auch vierjochige und (häufiger) gefingert fünfja sogar siebenzählige Blittter*) vor; an den bliihenden Trieben sind die Blätter fast stets dreizählig. Alle Blätter sitzen auf einem ziemlich langen, zierlichen Stiele, der oberseits nur schwachrinnig und spärlich behaart ist; das Endblättchen ist symmetrisch, eiförmig, zuweilen mehr oder weniger dreilappig, spitz oder allmälig zugespitzt, am Grunde abgerundet oder fast herzförmig; am Rande ist es doppelt gesägt, die Sägezähne sind znweilen fast stachelspitzig, immer aber callös; die Oberseite der Spreite ist in der Regel spärlich behaart, die weisse Unterseite aber ist mit einem zarten Filze, der aus sehr langen, vielfach gebogenen, dünnwandigen, einzelligen Haaren gebildet wird, dicht bedeckt; die grösste von uns beobachtete Länge der Endblättchen beträgt $10 \mathrm{~cm}$, die grösste Breite $6 \mathrm{~cm}$; die Seitenblättchen sind durchgehends etwas kleiner, immer schief, wobei die grössere Hälfte nach unten gewendet ist, sie sind stets, mit Ausnahme der mittleren bei den gefingerten Blättern, sitzend; ihre Form ist elliptisch oder eiförmig, zuweilen sind sie einseitig gelappt, sonst stimmen sie mit den Endblättchen überein. Die an den Blattstielen angehefteten Nebenblätter sind schmal linealisch; indem sie sich an den Rändern leicht umrollen, werden sie fadenförmig.

Die Blüthen stehen im oberen Theile der fertilen Kurztriebe und entspringen entweder einzeln, oder gepaart oder zu dreien, höchstens vieren einen traubigen Blüthenstand bildend, aus den Achseln der Laubblätter; werden die letzteren aber weiter reducirt, so dass nur einzählige, kleine Blätter ihre Stelle einnehmen, so entstehen rispige Blüthenstände; die Blüthenstiele, wie die Stielchen, sind ziemlich lang $(1-2,5 \mathrm{~cm})$, zierlich und mit einfachen, kurzen Haaren, sowie nach rückwärts gekrïmmten Stachelchen bekleidet.

Der Axenbecher ist fast völlig flach, in der Mitte trägt er eine halbkugelige Erhöhung, auf welcher die Fruchtknötchen sitzen; er ist unterseits wie die Kelchblätter sehr kurz filzig und wie jene

* Die letzteren gleichen den fünfzählig gefingerten, aber das Endblättchen ist dreizählig. 
bis zur Fruchtreife bleibend. Die Kelchblätter sind etwa 6-7 mm lang, oblong eiförmig, zugespitzt, beiderseits dünn filzig, grangrün, am Rande weisslich; sie decken in der Knospe dachziegelig. Die Blumenblätter sind spathelförmig, an der Spitze abgerundet, so lang oder etwas kiirzer als der Kelch, abfällig. Die zahlreichen Staubgefässe stehen in einer Reihe und sind unmittelbar vor den Blumenblättern an dem Axenbecher befestigt; sie sind kürzer als die Blumenblätter und zuerst anfgerichtet; sie bleiben nach der Vollblithe stehen und sind dann nach aussen gebogen; ihre Fäden sind fast gleich lang und dïnn; die Staubbeutel sind elliptisch, beiderseits ausgerandet; die ellipsoidischen Pollenkörner werden von 3 meridionalen Falten durehlanfen. Die einzelnen Stempel bestehen aus einem schief umgekehrt eiförmigen, behaarten, 0,6-0,8 mm langen Fruehtknoten, der scheinbar eine einzelne Samenanlage umschliesst, neben ihr aber erkennt man, bei sehr genauer Betrachtung, das nur 0,2 mm grosse Rudiment einer verkümmerten zweiten Anlage; jene ist anatrop nnd nach dem Scheitel des Faches an der nach innen gewendeten Seite befestigt; der $3 \mathrm{~mm}$ lange Griffel ist nur wenig zur Seite geriickt, einfach, vielmals länger, als der kaum $1 \mathrm{~mm}$ lange Fruchtknoten und geht in eine kopfige Narbe aus.

Die Himbeere ist eine Sammelfrucht, welche aus zahlreichen kleinen, rothen, flaumigen, sich leicht von einander trennenden Steinfrichten zusammengesetzt wird; sie stellt ein hohles, halbes Ellipsoid dar, in welehem die Höhlung durch den sich ablösenden und an der Pflanze verbleibenden Blithenboden ausgefüllt wurde; sie nickt an dem Fruchtstielehen und wird von dem bleibenden, zuriickgebogenen Kelche und den abgetrockneten Staubgefässen gestiitzt. Die saftigen Steinfriichtehen sind dureh gegenseitigen Druck an den Seiten abgeplattet, aussen und oben gewölbt, sie werden von dem trocknen Griffel gekrönt und sind gewöhnlich roth, seltener gelb oder weisslich; die Steinschale ist knöchern, von kleingrubigen Vertiefungen punktirt, am Grunde gęspitzt, auf der scharfen Innenkante wulstig.

Der einzelne Same wird von einer dünnen, braunen Samenhaut umsehlossen und enthält kein Nährgewebe; der Keimling ist nur wenig gekrümmt, das kurze Würzelchen zenithwärts gewendet, die Keimblätter sind fleisehig, oblong; planeonvex.

Anmerkung. Von der Himbeere sind nur 2 Varietäten bekannt, die eine R. Idaeus L. var. viridis Al. Br. ist durch gleichfarbig grüne Bliitter und $R$. Idaeus L. var. anomala Arrh. durch ganze, nierenförmige Blïtter, geüffnete Friichte und stets fehl geschlagene Samen ausgezeichnet.

Die Himbeere ist vom arktischen Russland und Sibirien dureh das gesammte Europa bis nach Nord-, Mittel- und Ost-Spanien, durch Italien, die Balkanhalbinsel bis zum Peloponnes und zum Kaukasus verbreitet, nach Osten zu erreicht sie in Kamtschatka die Grenze.

Der Presssaft der Sammelfrichte der Himbeere, der Fructus Rubi Idaei, wird zur Darstellung des Sirupus Rubi Idaei (Himbeersirup) verwendet.

\section{Erklärung der Abbildungen.}

Fig. A. Ein Stüick des erstjährigen, verholzten Triebes mit einem blühenden, zweijilhrigen Zweige.

Fig. B. Die Blitthe im Längsschnitte, 4mal vergrössert: $a$. der Axenbecher; $b$. das Kclchblatt; $c$. das Blumenblatt; $d$. das Staubgefïss; $e$. der Fruchtträger.

Fig. C. Das Blumenblatt, 6mal vergrössert.

Fig. D.u. E. Das Staubgefiss, von innen und von aussen, 12 mal vergrössert.

Fig. $F$. Dasselbe mit geijffnetem Beutel.

Fig. G.u. $H$. Pollenkörner, trocken und im Wasser.

Fig. I. Ein Stempel, 12 mal vergrössert: $g$. der Fruchtknoten; $h$. die Samenanlage; $i$. der Griffel; $k$. die Narbe.
Fig. $K$. Die Samenanlage, 1smal vergrüssert: 7 . der Nabelstrang; $m$. die Mikropyle.

Fig. L. Die Frucht: n. Steinfriehtehen; b. der Keleh.

Fig. $M$. Die vorigen im Längssehnitte.

Fig. N. Das Steinfríchtehen, 3mal vergrössert.

Fig. O. Dasselbe, im Längssehnitte: o. das Fruchtfleisch; $p$. die Steinschale; $q$. der Keimling.

Fig. P.u. Q. Der Steinkern, von der Seite und von innen gesehen, 6inal vergrössert.

Fig. R., S. u. T. Derselbe im Quer- und doppeltem Längsschnitte: $r$. Würzelchen; $s$. Keimblätter. 


\title{
HAGENIA Lam.
}

Blithen aktinomorph, vollständig, zweihäusig. Axenbecher (Kelchröhre) kreiselförmig, am Schlunde durch einen häutigen Anhang verengt. Kelch doppelt, aus 10 (8) Blättern in zwei Reihen geordnet, gebildet, von denen die äusseren in der männlichen Blithe kleiner und oblong, bei den weiblichen aber grösser als die immeren sind. Blumenblätter sehr klein, lanzettlich, leicht abfällig. Staubgefässe $15-20$ an dem Asenbecher befestigt, etwas ungleich lang, in der weiblichen Blithe viel kleiner und ohne Bluthenstaub; Staubbeutel ditheeisch mit Längsspalten aufspringend. Stempel gewöhnlich aus 2 Frueltblättern gebildet; in jedem eine anatrope, längende Samenanlage; die Mikropyle ist nach oben und aussen gerichtet; Griffel endständig mit grosser, fleisehiger, kurz gelappter Narbe. Fritehte nussartig mit lederartiger Fruchtbaut, von dem Axenbecher umgeben, der von dem ausgewachsenen und bunt gefärbten Kelche gekrönt wird. - Ein mehr oder minder hoher, vielfach verästelter Baum mit ansehnlichen, umpaarig und unterbrochen gefiederten Blïttern, die am Grunde mit einer grossen Blattseheide versehen sind; Blättchen am Rande gesägt, Blüthen klein, zu ausserordentlich reichblithigen, grossen Rispen vereinigt, von grossen häutigen Deckblättern und 2 Vorblättchen gestutzt.

Nur eine Art, welehe im östlichen und mehr centralen tropischen Afrika heimisch ist.

\section{Hagenia Abyssinica Willd.}

\author{
Tafel 65 .
}

Zweige dick, zottig, so wie die jüngeren Blätter; die Blätter zweizeilig geordnet; grössere Blättchen oblong oder oblong lanzettlich, spitz oder zugespitzt, am Grunde schief herzförmig; Blüthen, besonders die weiblichen, durch die gefärbten Kelehblätter rosa- bis purpurroth.

Hagenia Abyssinica Gimel. Syst.nat. II. (1.) p.613'); Poir. Encycl. Suppl. II. 422, V. 645, Ill. gen. t. 311; Berg und Schmidt, Darstell. und Beschr. XXVf; Bentl. and Trim. Med. pl. t. 102; Baill. Bot. méd. I. 541, fig. 2062-2066; Luerss. Ilandl. syst. Bot. II. S4f; Köhler, Medizinalpft. t. 84; Flück. and Hant. Pharmacogr. 225: Flück. Pharmacogn. ed. III. S06; Engl. Hochgebirgsfl trop. Afr. 235; Arth. Meyer, Drogenkunde. II. $32 t$.

Brayera anthelmintica Kth. in Brayer Not. 1; DC. Prodr. II. 555; A. Rich. Tent. Fl. Abyss. I. 258, t. 45; Fresen. in Abh. Mus. Senkenberg. II. 162; Clarke in Hook. Journ. bot. 1850. t. 10.

Banksia (Bankesia) Abyssinica Bruce, Reisen zur Entd. d. Quell. d. Nils, deutsche Ausg. V. 81. t. 22.

Trussobaum abyssinisch auch Cotz oder Cabotz ausgesprochen); englisch: Cusso tree; französisch: Arbre de Kosso.

Der Baum erreicht bald nur eine Höhe von $6-8 \mathrm{~m}$, bald von $20 \mathrm{~m}$, er ist selten gerade gewachsen, meist, besonders in den hängenden Ästen mehr oder weniger gewunden; die Rinde ist glatt, gelblich weiss mit bräunlichen Streifen; das Holz ist weich und faserig; die jungeren Äste sind sehr dick und von einem umfangreichen, braunen Marke erfullt; sie sind mit einem dichten Überzuge von langen, steifen, gelbbräunlichen, einzelligen, stark verdickten Haaren bekleidet; nach Abfall der Epidermis sind sie von einer rothbraunen Rinde überzogen.

Die grossen Blätter sitzen an den Enden der Zweige, sie sind zweizeilig angereiht, und erreichen eine Länge von $30 \mathrm{~cm}$ und darüber, wovon auf den Blattstiel ein Drittel bis ein Viertel kommt. Dieser

* Mein sehr verehrter College, Herr Garcke, hat zuerst nachgewiesen, dass Gmelin und nicht Willdenow als Autor der Pflanze zu citiren ist.

K. Sch. 
ist jederseits von einem $1-1,5 \mathrm{~cm}$ breiten, oben gestutzten, am Grunde den Zweig vollständig umfassenden Flügel wie von einer Scheide umgeben, die als die beiden angewachsenen Nebenblätter anzusehen ist; die Scheide ist besonders nach dem Grunde mit einer dichten, gelben Haarbekleidung versehen und stark gestreift; fällt das Blatt ab, so hinterlässt sie am Zweige eine kreisförmige, lineare Marke. Es sind 6-8 Paare grösserer Federblättchen vorhanden, zu denen noch das endständige Blättchen kommt; jene sind $6-9(5-12) \mathrm{cm}$ lang und 2-2,5 höchstens $3 \mathrm{~cm}$ breit, das unterste Paar ist stets auffallend viel kleiner; zwischen ihnen befinden sich jederseits der Spindel einzelne, oder paarige ausserordentlich winzige, häufig nur $1 \mathrm{~mm}$ lange und breite Blättchen. Die grösseren Fiederblättchen sind sehr kurz gestielt, oblong oder oblong lanzettlich, zuweilen linealisch oblong, sie sind spitz oder zugespitzt, am Grunde asymmetrisch gerundet oder fast herzförmig, am Rande drüsig gesägt, und werden von 20 oder mehr parallel verlaufenden, oben etwas eingesenkten, unten vorspringenden Paaren von Seitennerven durchlaufen; sie sind oberseits mit ausserordentlich kleinen Härchen und mit winzigen, gelben Drïsen bestreut, unterseits aber weich- und seidenhaarig. Der ziemlich kräftige Spindel ist fast eylindrisch und wird oberseits von einer seichten Furche durchzogen.

Die Blïthen bilden eine äusserst reichblüthige, hängende, oben abgerundete Rispe, die bis $40 \mathrm{~cm}$ lang wird und bis $25 \mathrm{~cm}$ im Durchmesser hält; sie beschliesst die Enden der Zweige und wird dureh kräftige Seitensprosse aus den Achseln der obersten Blätter bereichert. Die Hauptspindel ist stark zusammengedrückt, hin und her gebogen und spärlich mit langen Haaren besetzt. Die Zweige letzter Ordnung, welche die sehr kurz (höchstens $2 \mathrm{~mm}$ lang) gestielten Bluthen tragen, sind dünn, flaumig, weichhaarig und ebenfalls häufig zickzackförmig hin und her gebogen.*) Die Deckblätter sind etwa $4-5 \mathrm{~mm}$ lang, häutig, fast kreisförmig, stumpf, dünn. behaart und netzig geadert; die Vorblättchen, unmittelbar unten dem Axenbecher befestigt, sind jenen ähnlich, nur etwas kleiner; beide tragen, besonders auf der Rückseite, gelb schimmernde Drüsen. Die männliche Blüthe hat folgende Beschaffenheit: Der Axenbecher ist kreisförmig, aussen behaart; die äusseren, kürzeren, oblongen, stumpfen Kelchblätter sind kaum 2,5 mm lang, aussen behaart, netzadrig; die mit ihnen abwechselnden, inneren sind breiter, elliptisch und etwas länger $(3-3,5 \mathrm{~mm})$; zur Zeit der Vollblüthe sind die letzteren eigenthitimlich zuritckgeknickt. Die Blumenblätter sind wenig über $1 \mathrm{~mm}$ lang, lanzettlich, fast spitz; sie können sehr leicht übersehen werden. Die Staubgefässe messen $1,5-2,5 \mathrm{~mm}$ in der Länge, der im Umfange fast kreisförmige, introrse Beutel ist 1 mm lang, die Pollenkörner sind im Wasser kugelig und werden von 3 Meridionalfalten durchlaufen. Von dem Stempel sind nur Rudimente mit einem dünnen, einfachen Griffel vorhanden. - Die weibliche Blithe ist der vorigen ähnlich, doch ist der äussere Keleh etwas länger als der innere und wächst zur Zeit der Fruchtreife noch um mehr als das doppelte heran, so dass er wie ein Flügel wirkt; die Blätter beider Kreise sind zuerst grïnlich roth, werden aber später ausgesprochen purpurfarben. Die Blumenblätter sind ähnlich denen der männlichen Blithe. Die Staubgefässe verkümmern hochgradig, doch sind sie so wie die pollenleeren Beutel immer noch zu erkennen. Der Schlund der Blüthe wird durch einen aufreehten, kurzen, gestutzten Sehlott verengt, der von den Griffeln durchwachsen wird. Der Ste mpel ist $3 \mathrm{~mm}$ lang; er wird aus 2 (selten 3 ) Fruchtblïttern gebildet, die nur wenig zusammenhängen; die einzelne Samenanlage hängt von der Innenseite des Fruchtknotens nahe dem Scheitel herab und ist mit der Mikropyle nach aussen und oben gewendet; der fadenförmige Griffel ist so lang wie der Fruchtknoten und endet in eine grosse, fast blumenkohlartige, rothe Narbe.

Die Frucht ist in der Regel ein einziges Nïsschen, da das zweite Fruchtblatt gewöhnlich fehl schlägt; es wird von dem wenig heranwachsenden Axenbecher umhiillt und dieser ist von den bis $12 \mathrm{~mm}$ vergrösserten, äusseren Kelchblättern geflügelt; auch die Bracteolen bleiben bei der Fruchtreife erbalten. Die Fruchthaut ist diunn lederartig und brïchig.

*) Aus diesem geschlängelten Verlauf der Axe hat man geglaubt, dass die letzten Trauben Wickeln wären. 
Der same ist etwa $5 \mathrm{~mm}$ lang, hängend, von der Form des Nüsschens; das nach oben gewendete Würzelchen ist sehr kurz, die dicken Keimblätter sind planconvex; das Nährgewebe fehlt.

Der Kussobaum wäehst in Abyssinien und zwar im centralen Theile, an dem Oberlaufe des Tacase und des Abas, der unter dem Namen Bahr-al-asrek oder blauer Nil besser bekannt ist; dort steigt er bis $3000 \mathrm{~m}$ hoch empor; neuerdings ist er auch in grosser Ausdehnung am Kilimandscharo gefunden worden, in dessen sogenannten Urwäldern er bei $2400 \mathrm{~m}$ ansserordentlich häufig ist; hier steigt er bis $1400 \mathrm{~m}$ herab. FLüCKIGER hat auch Kusso von Madagaskar gesehen, uns ist die Pflanze von dort nicht begegnet.

Die getrockneten, eben verblüten, weiblichen Blüthenstände der Pflanze kommen als Flores Koso (Kusso, Flores Brayerae, Koso, Kosobliuthen) in den Handel. In der Medicin sollen die von Blithenstandaxen abgestreiften weiblichen Blüthen allein Verwendung finden.

\section{Erklärung der Abbildungen.}

Fig. A. Ein blühender, klcinerer Zweig weiblichen Geschlechts, nach einem Excmplare, das von W. Schimper in Abyssinien gesammelt wurde: $a$. das Blatt; $b$. die Nebenblitter; $c$. die Rispe.

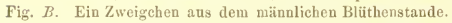

Fig. C. Die Knospe der männliehen Blïthc, 4 mal vergrössert: $e$. iusserc, $f$. inncre Kelchblitter.

Fig. D. Dic männliche Blüthe, 3mal vergrössert: $g$. die selır kleinen Blumenbliitter; $h$.Staubgefïssc ; $i$. Stempelrest.

Fig. E.u.F. Das Staubgefäss von innen und aussen betrachtet.

Fig. G. Pollenkürner in Wasser, 300 mal vergrössert.

Fig. $H$. Die weibliche Blïthe, 5 mal vergrüssert: $h$. verkümmerte Staubgcfisse; i. die Narbe.
Fig. I. Diesclbe, vorn angeschnitten, 8 mal vergrössert: d. Vorblätchen; $i$. Fruchtknoten; $k$. Axenbecher; l. Schlott dessclben.

Fig. K. Ein Fruchtblatt, 12mal vergrössert: $m$. Fruchtknotenwand; $n$. Samenanlage; $o$. Griffel; $p$. Narbe. Fig. L, u.M. Die Frucht, natïrliche Grösse.

Fig. $N$, Dieselbc im Läingsschnitte, 2mal vergrössert: $o$. Fruchthaut; $p$. Same.

Fig. O. Der Same, natürliche Grösse.

Fig. $P$. Derselbc, doppelt vergrössert.

Fig, Q. u.R. Derselbe im doppelten Längsschnitte: $q$. Würzelchen; $r$, Keimblïtter.

\section{ROSA Linn.}

Blithen aktinomorph, vollständig, zwittrig. Axenbecher krugförmig verticft oder kugelförmig an der Mündung stark eingeschntirt. Kelchblïtter 5, am Saume des Bechers befestigt, häufig fiederschnittig, abfällig oder bleibend mit quincuncialer, dachziegeliger Deckung in der Knospe; Blumenblätter 5, ausgebreitet; ein Honig absonderndes Polster kleidet den oberen Theil des Axenbechers aus und tritt oft aus ihm in der Form eines Wulstes hervor. Staubgefässe sehr zahlreich, meist in mehrere Reihen geordnet, dem Axenbecher am Rande angeheftet mit fadenförmigen Filamenten. Stempel sehr zahlreich, die Innenseite des Axenbechers auskleidend, frei; Fruchtknoten einfächrig, mit einer einzelnen hängenden, anatropen Samenanlage; Griffel wenig schief gestellt, hervorragend, frei oder an der Spitze verbunden mit verdickter Narbe. Friichte nüsschenartig, sehr zahlreich von dem fleischig gewordenen Axenbecher umschlossen, kahl oder einseitig behaart, mit knochenharter oder lederartiger Fruchthaut. Same hängend mit kurzem, zenithwärts gerichtetem Würzelchen und fleischigen, planconvexen Keimblättern. - Aufrechte oder kletternde, häufig stachlig bewehrte, kahle, behaarte, oft drüsig bekleidete Sträucher mit spiralig angereihten, unpaarig gefiederten Blättern, deren Blättehen meist gesägt sind; die Nebenblätter sind dem Blattstiele angewachsen und umfassen scheidig den Zweig. Blüthen einzeln oder in Rispen, gross und schön, weiss, roth oder gelb.

Die Zahl der Arten ist gegenwärtig sehr schwer zu bestimmen; nach dem früher landläufigen Artbegriffe duirten etwa 100 anzunehmen sein, die Rhodomanen haben aber in Europa allein mehr als 300 Arten untersehieden. 


\section{Rosa centifolia Linn.}

Taf. 66 .

Stacheln ungleichartig, die grösseren derb, sichelförmig gekrümmt, die kleineren fast gerade; Blüthen nickend, rosa, fast stets stark gefüllt; Kelehblätter breit eiförmig, zugespitzt, ganz, und einseitig und beidseitig fiederspaltig; Axenbeeher zur Fruchtzeit eiförmig.

Rosa centifolia Linn. Spec. pl. ed. I. 491; Plenck, Offiz. PA. t. 402; Rössig, Rosen t. 1; Redouté, Roses t. 1; Woodv. Med. pl. t. 17S; Séringe in P. DC. Prodr. II. 619; Nees, Dïsseld. Abbild. t. 302 ; Wagner, Pharm.-medic. Pfl. t. 24; Hayne, Arzmeigev. XI. t. 29; Guimp. und Schlecht. Pfl. der Pharmac. I. 106. t. 49; Ledeb. Fl. Ross. II. 93; Boiss. Fl. or. II. 676; Berg und Schmidt, Darstell. und Beschreib. t. XXXIVt; Köhler, Medizinalpft. t. 12t; Bentl. and Trim. Med. pl. t. 105; Baill. Bot. méd. I. 536; Flück., Pharmacogn. ed. III. 167, 783.

Centifolie, Gartemrose; englisch: Garden rose; französisch: Rose des jardins.

Die im zweiten und in den späteren Jahren blühenden, aufreehten Stämmchen entspringen aus einer kriechenden, unterirdischen Grundaxe; bei uns wird aber die Centifolie allermeist auf andere Rosentriebe durch Oculiren veredelt. Jene werden bis $2 \mathrm{~m}$ hoeh, sind stielrund, bram, mit grösseren, haken- oder sichelförmig gekrümmten, von der Seite zusammengedrückten und kleineren, pfriemlichen, sehr spitzen Staeheln bewehrt, sie bilden oben'eine runde Krone; die jüngeren Zweige sind grïn mit kleinen Stacheln versehen und drisig behaart.

Die Blätter stehen besonders an den langen, sogenannten Wassertrieben in sehr grosser Zahl spiralig angereiht; sie sind unpaarig gefiedert und zwar sind meist 2-3 Paar Fiederblättchen $\left.{ }^{*}\right)$ entwickelt, zu denen noch das unpaare hinzu kommt, die oberen sind dreizäblig und die Begleitblätter der Bliithen werden endlich einfaeh; jene sind gestielt, dabei ist der drisig behaarte, flaumige und etwas stachelige Stiel von den angewachsenen, im freien Ende spitzen Nebenblättern ziemlieh breit gefliggelt. Die Blättchen sind elliptisch oder eirund, stumpf oder kurz zugespitzt, am Grunde gerundet bis herzförmig; am Rande sind sie mit breiten, drüsigen, einfachen oder gewöhnlich gezähnelten Sägezähnen versehen.

Die grossen, nickenden Blüthe n stehen einzeh am Ende der Zweige, sie sind lang gestielt, die Stiele sind rund und dichter drisig behaart als die ibrigen Theile der Pfianze; unter ihnen treten nieht selten 1-2 weitere Blithen aus den Achseln der einfachen, hoehblattartigen, breit linealischen, zugespitzten Blätter.

Der A xenbecher ist fleischig, krugförmig, eioblong, am Schlunde eingesehnürt, aussen grïu und drüsig behaart, innen ist er mit kurzen, steifen, starren und brïehigen Haaren ausgekleidet. Die 5 Kelehblätter sind länger als der Axenbecher, dreiseitig ins Eiförmige gehend und in eine lange, oben meist spatelförmig verbreiterte Spitze ansgezogen, an der entweder ein- oder beidseitig Fiederläppeben befestigt sind; diese Differenziation der Kelchblätter nimmt von imen nach aussen zu, so dass die beiden in der Knospenlage innersten Kelchblätter meist ohne seitliche, das folgende Blatt mit einseitigen, die beiden äusseren Blätter mit beidseitigen Anbängen versehen sind. Die Blumenblätter sind sehr gross, meist breiter als lang, querelliptisch oder umgekehrt herzförmig, kurz genagelt, ausgehöhlt, rosenroth, wohlrieehend, sie fallen endlich ab; in der Regel ist die Bluthe gefullt d. h. die Zahl der Blumenblätter ist auf Kosten der Stanbgefässe sehr bedentend vermehrt; sie werden dann nach innen zu immer kleiner; bisweilen geht die Veränderung der mittleren Organe in Blumenblïtter auch noeh auf die Fruchtblätter itber. Die Stanb-

\footnotetext{
* Sehr selten sind die Laubblitter einfach.
} 
gefässe sind nur in den minder gefüllten Formen vorhanden; die Fäden sind blassgelb, dünn, etwa 6-7 mm lang; die im Umrisse fast kreisförmigen Beutel messen kaum 0,7 mm, sie sind gelb; die Pollenkörner sind ellipsoidisch und werden von 3 Meridionalfalten durchlaufen. Die einzelnen Stempel sind 1-1,3 cm lang; sie werden von den steifen Borsten des inneren Axenbechers umgeben, sind sitzend, ellipsoidisch und gehen an der Spitze allmälig in den verlängerten, fadenförmigen, behaarten Griffel über, der von einer kopfig verdickten, einseitig ausgerandeten, papillösen, am Scheitel wenig gewölbten Narbe geschlossen wird. Der behaarte Fruchtknoten enthält eine fast vom Scheitel herabhüngende Samenanlage, welehe anatropisch ist und die Mikropyle nach oben und aussen kehrt.

Die Früchte sind nüssehenartig mit steinharter Fruchtschale, sie werden von dem etwas saftig werdenden, rothgefärbten Axenbecher umschlossen (Hagebutte), kommen aber, wie die Samen, fast niemals zur Reife.

Die Centifolie wächst im Orient, zumal in den Wäldern an den Ostabhängen des Kaukasus und auf dem Pir Omar Gudrun in Assyrien wild, wird aber ganz allgemein in den Gärten cultivirt; neuerdings glaubt man in ihr eine Varietät der Rosa gallica Linn., die durch das gesammte gemässigte und wärmere Europa von Belgien und Frankreich bis Stud-Russland verbreitet ist, erkennen zu müssen.

Als Flores Rosae (Flores Rosarum pallidarum, Flores Rosae incarnatae, Rosenblätter), kommen die getrockneten Kronenblätter der Pflanze in den Handel. Ans den lebenden Kronenblättern stellt man dureh Destillation mit Wasser das Oleum Rosae (Rosenöl) dar.

\section{Erklärung der Abbildungen.}

Fig. A. Ein Blithenzweig.

Fig. B. Die Bliithe im Längssehnitte, $2^{1}$ 2 mal vergrössert $a$. der Axenbecher; $b$. der verdickte Schlund desselben; $c$. das Kelchblatt; $d$. das Blumenblatt; $e$. die Staubgefïsse; $f$. dic Stempel.

Fig. C. Das Staubgefäss von innen und von aussen, $12 \mathrm{mal}$ vergrössert.

Fig.D.u.E. Pollenkörner trocken und im Wasser, 300mal vergrüssert.
Fig. $F$. Der Stempel, 5 mal vergrüssert: $g$. der Fruchtknoten; h. der Griffel; i, die Narbe.

Fig. G.u. $H$. Der Fruchtknoten im Längs- und Querschnitte, 8 mal vergrössert: $k$. die Samenanlage; $l$. der Nabelstrang.

Fig. I. Der Griffel und die Narben, smal vergrössert.

\section{PIRUS Linn.}

Kelchröhre (Achsenbecher krug- oder kreiselförmig mit den Fruchtblättern der ganzen Länge nach verwachsen oder über dieselben verlängert. Kelchblätter 5, zurückgeschlagen, bleibend oder mit dem verlängerten, freien Theile des Bechers abfällig. Blumenblätter 5, fast kreisförmig, kurz genagelt. Das Honig absondernde Gewebe (Discus) bekleidet den freien Theil des Bechers oder überragt ibn in der Form eines wulstigen Polsters. Staubgefässe zahlreich mit freien oder nur am Grunde leicht verbundenen Fäden. Fruchtknoten aus 2-5 Blättern aufgebaut, zwei- bis fünffächrig; in jedem Fache gewöhnlich 2, sehr selten mehr, aufstrebende, anatrope Samenanlagen, deren Mikropyle nach unten und aussen gewendet ist; Griffel frei oder am Grunde verwachsen mit gestutztem Narben. Frucht fleisehig, ei-, kugel- oder birnförmig, vom Kelche häufig gekrönt, zwei- bis fünffächrig; Fächer mit einem ledernen, selten zarteren Endocarp ausgekleidet, niemals aufspringend. Samen 1-2, seltener mehr in jedem Fache, aufrecht mit lederartiger oder fast knorpliger Samenschale; Keimling mit bodensichtigem Würzelchen und planconvexen Keimblättern. - Bäume oder aufrechte Sträucher, die zuweilen durch Dornen bewehrt sind, mit spiralig gestellten, ganzen, gestielten Blättern und angewachsenen, bald vertrocknenden Nebenblättern. Blüthen in Dolden oder Doldentrauben von pfriemlichen, abfalligen Vorblïttchen gestiutzt. 
Etwa 30 Arten, welehe in der nördlich gemässigten Zone beider Hemisphären bis naeh Californien und dem Himalaya, besonders aber in Japan und China waehsen.

Anmerkung. Neuerdings hat man die Gattung Pirus (häufig auch Pyrus geschrieben) viel enger als früher gefasst, indem man in ihr nur die mit unserer Birne verwandten Arten beliess und alle anderen, also die mu unseren Apfel sich gruppirenden Arten zu einer eigenen Gattung Malus vereinigte. Beide zeigen auch bemerkenswerthe Untersehiede, indem Pirus den oben erwähnten, wulstigen, den Axenbecher stark einengenden Diseus besitzt, der Malus fehlt; ausserdem bat die Frucht von Pirus knochenharte Coneretionen von Steinzellen im Fruchtfleische, die der M alus fehlen. Auch die Gattung Sorbus wurde friiher und wird noch heute von einigen Botanikern zu Pirus gerechnet; sie ist aber durch gefiederte Blätter und sehr zähes Fruchtgehäuse gut geschieden.

\title{
Pirus Malus Linn.
}

\author{
Tafel 67 .
}

Baumartig mit abstehenden Zweigen; Blätter eiförmig, gesägt, kahl oder unterseits behaart bis fast filzig; Blüthen in einfachen, wenigblüthigen, endständigen Doldentrauben; Kelchröhre nieht über den Fruchtknoten verlängert; Blumenblätter aussen rosaroth; Griffel am Grunde verwachsen, kahl; Frucht kugel- oder gestutzt kegelförmig, am Grunde, häufig auch an der Spitze, eingedrückt.

Pirus Malus Linn. Speo. pl. ed. I. 479 ; Allion. Fl. Pedem. II. 143; Plenck, Med. Pfl. t. 394; Fl. Dan. VII. t. 1101; Engl. Bot. III t. 179; Duham. Arbr. ed. II. t. 45; Schrank, Fl. Mon. IV. t. 339; Hayne Arzneigew. IV. t. 46; Nees, Düsseldorf. Abbild. t. 303; P. DC. Prodr. II. 635; Guimp. und Schlecht., Holzgew. t. 61; Mert. und Toch, Deutschl. Fl. III. 421; Ledeb. Fl. Ross. II. 96; Willh. et Lange, Prodr. Fl. Hisp. III. 193; Godr. et Gren. Fl. Fr. I. 571; Boiss. Fl. orient. II. 656; Bertol. Fl. Ital.V. 169; Berg und Schmidt, Darst. und Beschreib. IV ; Köhler, Mediz. Pf. t. 35; H. Baill. Bot. médic. I. 55s, fig. 2103, 2104.

Apfelbaum; englisch: Apple tree; französisch: Pommier.

Der Baum erreicht eine Höhe von $12 \mathrm{~m}$ und träigt eine weitschweifige, nieht sehr diehte, halbkugelförmige Krone. Der Stamm ist nicht selten schief aufsteigend, und wird von einer schuppigen, graubraunen Borke bedeckt; die abstehenden, häufig gekritimmten oder gebogenen Äste sind zuerst mit einer glatten, leder- später kastanienbraunen Rinde bedeekt, die von Lenticellen weiss punetirt ist; die jüngsten Spitzen sind krautig, und mehr oder weniger dicht behaart.

Die Blätter sind spiralig angereiht, in der Knospenlage eingerollt; sie werden von einem mässig langen, halbeylindrischen, oberseits seicht gefurchten, böchstens 3 em langen Stiele getragen, dem die linealischen, spitzen, grünen, bald welkenden und verschwindenden Nebenblatter, die kürzer als der Stiel sind, angewachsen sind; die Spreite ist $5-7(4-10) \mathrm{cm}$ lang und in der Mitte $4-5,5(3-6,5) \mathrm{cm}$ breit, von eiförmiger oder elliptischer Form; sie ist spitz oder kurz zugespitzt, am Grunde ebenfalls spitz oder gestutzt, am Rande gesägt; sie wird von 4-5 Paar stärkeren Seitennerven zu jeder Seite des Mittelnerven durchlaufen, welche oberseits etwas eingesenkt sind und unterseits sehwach vorspringen; eine Behaarung fehlt entweder ganz oder sie ist, besonders unterseits, dentlieher und fast filzig zu nennen.

Die Blïthen erscheinen mit den Blättern am Ende von Kurztrieben, welche aus den reiehblättrigen, gedehnten Langtrieben im zweiten Jahre entspringen; sie sind zu 4-6 doldig verbunden und werden dureh linealisehe, spitze Deckblätter gestiitzt. An den 1,5-3 cm langen, stielrunden, gewölnnlich weissfilzigen, zuweilen aber auch fast ganz kahlen, anfrechten Stielen sitzen gewöhnlich nahe der Basis, zuweilen aber auch in der Mitte und höher 2 linealisch-pfriemliche, häutige, bis zu $1 \mathrm{~cm}$ lange, abfällige Vorblättchen.

Der Fruchtknoten ist unterständig, das heisst, der etwa $3-4$, zuweilen $5-6 \mathrm{~mm}$ lange, kreiseloder krugförmige, häufig weissfilzige Axenbeeher ist mit den Frnehtblittern verwachsen; der Beeher uberragt aber etwas als verdiekter Wulst die Fruehtblätter und stellt dort eine fleisehige, offene, Honig absondernde schiissel dar. Kelehblätter sind 5 vorhanden; sie sind eiförmig oder oblong eiförmig, 
zugespitzt, zurückgeschlagen und bleiben an der Frucht sitzen; ihre Länge wechselt zwischen 3 und $7 \mathrm{~mm}$ und ihre äussere Bekleidung stimmt mit derjenigen des Fruchtknotens ïberein. Die 5 Blumenblätter sind verkehrt eiförmig oder fast kreisrund, an der Spitze etwas ausgerandet, am Grunde kurz genagelt, oberseits vertieft, am Rande etwas gewellt, innen sind sie weiss, aussen schön rosenroth gefärbt; gewöhnlich sind sie nach der Spitze zu mit einigen langen, feinen, schlaffen Haaren besetzt; sie messen 1,5-2,0 cm in der Länge, manchmal werden sie aber bis $3,5 \mathrm{~cm}$ lang; sie fallen nach der Vollblïthe ab. Sta ubgefässe sind meist 20 vorhanden, sie stehen fast in einer Reibe neben einander und sind von versehiedener Länge; aber selbst die grössten erreichen nicht die Spitzen der Blumenblätter; die Fäden sind pfriemlich, oben etwas nach aussen gebogen, sonst aufrecht; die etwa $1 \mathrm{~mm}$ langen Beutel sind oben und unten ausgerandet; die Pollenkörner sind sehr sehmal ellipsoidisch und werden von 3 meridionalen Längsfalten durchlaufen. Die 5 Fruchtknotenfächer stossen in der Mitte nicht zusammen; jedes umschliesst 2 nebenständig angeheftete, aber ïber einander stehende Samenanlagen von anatroper Form; die Mikropyle ist nach aussen und unten gewendet; die 5 Griffel sind stielrund, am Grunde auf eine weite Strecke verwachsen, oberhalb der Verbindungsstelle sind sie behaart; die Narben sind schief abgestutzt, ellipsoidisch, und in der Mitte längs gefurcht; sie uiberragen nur wenig die Staubgefässe.

Die Frucht ist von mannigfacher Gestalt, meist fast kugelförmig, aber am Stiel und an der Spitze eingedriickt, zuweilen mehr kegelförmig oder ellipsoidisch; an der Spitze wird sie von dem vertrockneten, bleibenden Kelche gekrönt; sie ist fünffäcbrig, die Fïcher berühren sich aber in der Mitte nicht, sondern lassen einen centralen, zuweilen sehr grossen Hohlraum zwisehen sich; im Innern sind sie mit einer pergamentartigen Hant ausgekleidet; das Fruchtfleiseh ist gewöhnlich weiss, seltener röthlich, fest und enthält keine Steinzellconcretionen; die äusserste Fruchthaut ist etwas lederartig und sehr mannigfach, roth oder gelb, weiss oder grin gefärbt.

Die Samen liegen paarig in jedem Fache; sie sind schräg aufsteigend, umgekehrt eiförmig und von der Seite her etwas zusammengedrückt; die kastanienbraune Testa ist lederartig. Der Keimling ist gerade, weiss und hat ein kurzes, bodensichtiges Würzelehen; die Keimblätter sind planconvex und fleisehig.

Der cultivirte und ron uns beschriebene Apfelbaum ist, wie besonders neuere Untersuchungen gezeigt haben, keine selbständige Art, sondern ein aus versehiedenen Arten der Gattung Pirus gebildeter Bastard. Die Grundlage seheint bei den meisten Sorten der Paradiesapfel (Malus paradisiaca Med.) auszumachen, dessen Heimath von Süd-Ost-Russland bis zum Altai, der Tartarei und bis Nord-Persien zu suchen ist, der aber in Deutschland kaum ursprünglich wild sein dürfte; die zweite Art, welche in Frage kommt, ist Pirus prunifolia Willd. aus Sibirien und Nord-China, doch sind je nach den Orten, von denen die Culturformen stammen, auch andere Arten mitwirkend gewesen; unser Holzapfel (Malus sitvestris Mill.) ist wohl unbedingt umbetheiligt daran. Der Apfel wird mit Ausnahme des höchsten Norden in ganz Europa cultivirt und gedeiht noch in Norwegen unter $66^{\circ} 26^{\prime}$, in Schweden unter $64^{\circ} 45^{\prime}$, ebenso kann er noch im südlichen Finnland und um Petersburg gebaut werden; in Tirol steigt er bis $1360 \mathrm{~m}$ hoch; in wärmeren Climaten werden die Früchte wässerig und fade.

Saure Aepfel finden zur Darstellung des Extractum Ferri pomati (Eisenextrakt) Verwendung.

\section{Erklärung der Abbildungen.}

Fig. A. Ein Blïthenast.

Fig. B. Die Bliithe, von der die Blumenblätter entfernt sind, $3 \frac{1}{2}$ mal vergrössert.

Fig. C. Dieselbe im Längsschnitte, 5 mal vergröss. : $a$. Unterständiger Fruchtknoten; $b$. freier Achsenbecher; c. Kelchblätter; d. Staubgef isse; e. Stempel.

Fig. D. Das Staubgefäss, von innen und aussen betrachtet, $10 \mathrm{mal}$ vergrössert.

Fig. E. Die Pollenkörner, im Wasser und trocken, 300mal vergrössert.

Fig. F. Der Fruchtknoten im Querschnitt, 5mal vergrössert.
Fig. G. Die Griffel, $5 \mathrm{mal}$ vergrössert.

Fig. H. Die Narbe, $15 \mathrm{mal}$ vergrössert.

Fig. $I$. Die Frucht.

Fig. $K$, u. $L$. Dieselbe im Längs- und Querschnitte : $a$. Fruchtfleisch; $b$. das lederartige Endocarp; $c$. der Same.

Fig. $M$. Der Same, natürliche Grösse: $a$. der Nabel; $b$. die Chalaza; $c$. die Micropyle.

Fig. $N$. $-P$. Derselbe im Längs- u. im doppelten Querschnitte, 2 mal vergrössert: $a$. dieSamenschale; $b$. das Würzelchen; $c$. die Keimblätter. 


\section{Reihe: Myrtiflorae Endl.}

Blïthen meist aktinomorph von wirteligem Bau; Blïthentheile fast stets in Kelch und Krone g'esondert, selten fehlend. Fruchtknoten in der Regel unterständig, aus 2 bis vielen Fruchtblättern aufgebaut. Blätter häufig kreuzgegenständig oder wirtelig gestellt.

\section{Familie: Myrtaceae Pers.}

Die Bliithen allermeist aktinomorph, zwittrig und vollständig, selten durch Abort polygam. Der Fruchtknoten ist meist ganz, seltener halb- oder noch weniger unterständig, zuweilen einfächrig, häufiger aber zwei- bis vielfächrig mit binnenwinkelständigen Samenleisten; die anatropen Samenanlagen stehen meist zu vielen, seltener zu zwei oder einzeln an der Samenleiste, ihre Mikropyle ist nach unten gewendet. Der Keleh ist meist vier- bis fünfblättrig, seltener gelappt; die Blätter decken dachziegelig; seltener ist er vor der Vollblüthe völlig geschlossen und spaltet unregelmässig auf. Blumenblätter sind meist vier bis fünf vorhanden, seltener sind durch Fehlschlag weniger, oder sie fehlen ganz; sie sind entweder alle gleich oder die äusseren sind etwas grösser; in der Knospenlage decken sie dachziegelig; zuweilen bilden sie eine geschlossene Mütze, die bei der Vollblïthe abgeworfen wird. Die meist sehr zahlreichen Staubgefässe sitzen, nicht selten gebindelt, am Kelchrande und sind in der Knospe gewöhnlich nach innen gebogen; die Bündel stehen meist den Blumen-, seltener den Kelchblättern gegenüber; die Staubbeutel sind meist klein, zweifächerig, am Riicken versatil aufgehängt und springen mit zwei nach innen gewendeten Längsritzen auf; das Mittelband läuft nicht selten in eine callöse Endigung (Dríse), selten in ein blattartiges Gebilde aus. Der Griffel ist einfach und endet mit einer kleinen, gestutzten, einfachen, seltener gelappten Narbe. Die mehr oder minder unterständige Frucht ist trocken und dann kapselartig, oder saftig und beerenartig; sie wird bäufig vom Kelche oder dessen Röhre gekrönt; die erstere springt wenigstens an der Spitze fachspaltig-klappig auf; die einsamigen Friichte, sowie die Beeren bleiben geschlossen. Die Samen haben eine häutige, krustenartige oder steinharte Schale und entbehren gewöhnlich des Nährgewebes; der Keimling ist gerade, gekrümmt oder spiralig aufgerollt mit blattartigen, dicken oder fast fehlenden Keimblättern, die flach oder gefaltet sind.

Bäume oder Sträucher, selten Halbsträucher mit anfrechten Axen und einfachen, kreuzgegenständigen, seltener spiralig angereihten, allermeist ganzrandigen, lederartigen, hänfig immergrünen und deutlich punktirten Blättern; Nebenblätter fehlen. Die Blithen bilden kreuzgegenständige Rispen, welche zuweilen einfachen Trauben gleichen, häufig aber deutlich in Dichasien ausgehen; seltener sind reine Dichasien; sie sind end- oder seitenständig, zuweilen werden sie durch eine Laubknospe geschlossen. Deckblätter sind stets vorhanden, anch die Vorblättchen sind meist entwickelt, wenn sie auch zuweilen sehr früh abfallen.

Über 2500 Arten sind beschrieben, welche aber auf ea. 2000 zu reduciren sein dürften; sie gehören hauptsächlich den Tropen beider Hemisphären und dem Australcontinent an.

Die drei offizinellen Myrtaceae gehören in folgende Gruppen:

A. Fruchtblätter in einfacher Reihe.

Unterfamilie I. Leptospermoideae Niedenzu. Blätter kreuzgegenständig oder spiralig angereilt: Früchte kapselartig.

\section{Melaleuca Leucadendrom Linn.}


Unterfamilie II. Myrtoideae Vent. Blätter stets kreuzgegenständig; Früchte beerenartig.

2. Caryophyllus aromaticus Linn.

B. Fruchtblätter in doppelter Reihe.

Unterfamilie III. Punicoideae K. Sch.

3. Punica Granatum Linn.

\section{MELALEUCA Linn.}

Bluthen fünfgliedrig, zwittrig oder vielehig (mit besonderen männlichen Blüthen), aktinomorph. Fruchtknoten unterständig oder halbunterständig mit convexem, behaartem Scheitel, um den Griffel cingedrückt, dreifächerig mit sehr vielen anatropen, aufrechten Samenanlagen in jedem Fache, welche einer schildförmigen, selten zweispaltigen Samenleiste so angewachsen sind, dass die Mikropyle nach dem Boden des Frnchtknotens hingewendet ist. Kelch fünfblättrig- oder lappig, abfällig oder bleibend. Blumenblätter fünf, in der Knospenlage dachziegelig deckend, in der Vollblüthe wagerecht ausgebreitet. Staubgefässe sehr viele in fünf, vor den Blumenblättern stehende Bïndel mehr oder weniger hoch und deutlich verbunden; Beutel versatil mit zwei Längsspalten aufspringend. Kapsel von dem bleibenden Kelche odcr dem ringförmigen, unteren Theile dessclben gekrönt, an der Spitze fachtheilig aufspringend. Samen feilspähnartig oder keilförmig mit dünner Schale; Keimling anfrecht mit schmalen planconvexen oder breiteren, häufig gefalteten Keimblättern, die länger als das Würzelchen sind. — Sträucher oder Bänme mit immergrünen, spiralig gestellten, seltener kreuzgegenständigen Blättern und sitzenden, von leicht abfälligen Deckblattern gestiitzten Blithen, welche eine kugelförmige, häufiger aber verlängerte, von einer Knospe geschlossene, zusammengesctzte Traube bilden; Vorblïttchen fchlen.

Über 100 Arten, welche bis auf eine, ansschliesslich Australien angchören; jene ist bis nach Hinterindien nud bis zn den Molukken verbreitet.

\section{Melalenca Leucadendron Linn.}

Taf. 68 .

Hoher Baum mit dicker, schwammiger Rinde; Blätter spiralig angereiht, elliptisch oder lanzettlich, mehr oder weniger schief mit anastomosirenden Längsnerven; Ähren endständig, mehr oder weniger deutlich unterbrochen mit einer laubigen Endknospe, die später auswächst; Spindel wie Kelch kahl oder wollig.

Melaleuca Leucadendron Linn. Mant. 105, Suppt. 342; Sm. in Act. Soc. Linn. III. 274; DC. Prodv. III. 212; Bl. Mus. bot. I. 66; Woodv. Med. III. t. 195; Hayne, Arzneigew. X. t. 9.; Nees, Diisseld. Abb. t. 299; Miq. Fl. Ind.-Bat. I. (1.) 401; Benth. Fl. Austr. III. 142; Kurz in Journ. Asiat. soc. XLVI. (2.) 61, For. Fl. Br. Burma I. 472; Duthie in Hook. fil. Fl. Br. Ind. III. 465; Bentl. and Trim. t. 105; Köhler, Medizinalpfl. t. 141; Baill. Bot. méd. II. 1018, fig. 2835; Flück. and Hanb. Pharmacogr. 247; Flïck. Pharmacogn. 163.

Melaleuca Leucadendra Lour. Fl. Cochinch. (ed. Willden.) 573.

Myrtus Leucadendron Linn. Spec. pl. ed. II. 6iG.

Melalenca minor Sm. in Rees Cycl. 23; DC. l. c.; Bl. Mus. bot. I. 67; Miq. l. c. 403; Berg und Schmidt, Darstell. und Beschreib. $t$. $I I I^{c}$.

Melaleuca Cajaputi Roxb. Fl. Ind. 1II. 394; Wight et Arn. Prodr. 326; Miq. l. c. 403.

Melaleuca saligna Bl. l. c. 66 .

Myrtus saligna Gmel. Syst. 793.

Melaleuca viridiflora Gaertn. Fr. I. 173. $t .35 ; D C . \quad l$. c.

Melaleuca Cumingiana Turcz. in Bull. soc. imp. nat. Mose. XX. 164.

Melaleuce lancifolia Turcz. l. c.

Kajuputi d. h. Weissbaum bei den Malayen; Cajeputbaum; französisch : Cajeputier; englisch: Cajuput tree. 
Der immergrüne Baum erreicht eine Höhe von $8-12 \mathrm{~m}$ und einen Umfang von $0,60-1,00 \mathrm{~m}$; bis $\mathrm{zu}$ 3-6 m ist der Stamm frei von Ästen; die Rinde ist weiss, schwammig blättrig und löst sich an älteren Exemplaren in papierdiunnen Lamellen ab. Die Zweige hängen schlaff herab, sie sind stielrund und entweder ganz kahl oder nur in der Jugend mit einem Flaum von einzelligen, verdickten Haaren bedeckt.

Die Blätter sind immergruin, mehr oder weniger schief, manchmal sichelförmig; sie sind spiralig angereiht, gewöhnlich mit der scharfen Kante nach oben gewendet und mannigfach gestaltet, gewöhnlich oblonglanzettlich oder lanzettlich, seltener breiter elliptisch, spitzlich, stumpf oder zugespitzt und am Grunde in den 5-10 mm langen, kräftigen, oberseits flachen Blattstiel verschmälert; ihre Länge beträgt ohne den letzteren 8-10 $(3-16) \mathrm{cm}$, ihre Breite $1,0-2,0(0,5-5,0) \mathrm{cm}$; ihre Consistenz ist gewöhnlich lederartig, zuweilen ist sie sehlaffer. Die Spreite ist zu dick, als dass dnrehscheinende Punkte bemerkt werden; sie wird jederseits des Mittelnerven von 2 beiderseits vorspringenden, stärkeren, vom Grunde aufsteigenden und an der Spitze sich wieder vereinigenden Nebennerven durchzogen, die unter einander anastomosiren; sie ist häufig deutlich verdickt gerandet, im frischen Zustande blaugriin, im getroekneten braun: in der Jugend erscheinen die Blätter von einer dünnen Bekleidung seidenglänzend, später sind sie kahl.

Der Blüthenstand ist eine zusammengesetzte Traube, von dem Aussehen einer einfachen; gewöhnlich nur 5-10 em lang, erreicht er bisweilen eine Länge von 20-25 cm; er beschliesst zunächst die Enden von spärlich beblätterten Zweigen und schliesst mit einer von schuppigen Tegmenten gesehützten Laubknospe ab; zuweilen seheint diese am Grunde wiederum Blüthen einzuhüllen. Die abfalligen Deckblätter sind scarios, eiförmig, concav-convex, stumpf oder spitz, zum mindesten an der Spitze, meist auch am Rücken fein grau behaart und am Rande sehr fein gewimpert; sie sind spiralig nach der Hauptreihe $(2 / 5,3 / 8$ etc.) angeordnet und umschliessen stets 3 Blüthen, von denen die mittelste am weitesten entwickelt ist; diese Drillinge stellen somit einfache Dichasien dar und der Gesammtbluthenstand ist demnach nicht, wie man bisher gemeint hat, eine einfache, sondern eine zusammengesetzte Traube; die Spindel ist verholzt bei der Vollblutthe und gewöhnlich seidig behaart oder fast wollig, seltener ist sie ganz kahl.

Die Blüthen sind völlig sitzend und werden nicht von Vorblättchen gestützt. Der unterständige, fast kugelförmige, mehr oder minder behaarte, seltener kahle Fruchtknoten misst 1-2,5 mm; er ist dreifächerig und trägt an einer sitzenden, flach gewölbten, im Umfange kreisförmigen oder elliptischen Samenleiste zahllose sitzende, aufrechte, mit der Mikropyle nach unten gewendete Samenanlagen. Die Kelchblätter sind gewöhnlich kaum $1 \mathrm{~mm}$ lang, skariös, am Rande häutig, halbkreisförmig oder halbelliptisch, rüekseits sehr spärlich behaart, am Rande gewimpert. Die Blumenblätter sind von der doppelten Länge der vorigen, breit eiförmig, stumpf, gerundet, am Grunde in einen breiten, kurzen Nagel zusammengezogen, ihre Consistenz ist mehr häutig, am Rande sind sie fein gewimpert, ihre Farbe ist grünlich weiss. Öldrüsen sind an ihnen deutlich sichtbar. Die Staubgefässe sind 7-20 mm lang, sie stehen bald mchr, bald weniger deutlich zu 5 vor den Blumenblättern befindlichen Bündeln vereint; die Fäden sind dünn, fadenförmig, bald weiss, bald gelb, bald rosa- oder purpurroth; die $0,5-1,0 \mathrm{~mm}$ messenden, an der Spitze callös verdickten Bentel sind gelb oder roth; die Pollenkörner sind linsenförmig zusammengedrückt, dreiseitig und mit drei Poren versehen. Der Griffel ist fadenförmig, von der Länge der Stanbgefässe, er trägt an der Spitze eine nur änsserst wenig verdickte, gestutzte Narbe.

Die Frucht misst $2-3 \mathrm{~mm}$ im Durchmesser, sie ist von kugelförmiger bis halbkngeliger Gestalt, oben wird sie von dem stehenbleibenden Theile des Kelches ringförmig gekrönt; die Kelch- und Blumenblätter, sowie die Staubgefässe fallen nach der Vollblüthe ab; sic öffnct sich an der Spitze mit drei kurzen Klappen porenartig, und ist von brïchiger, schwach holziger Beschaffenhcit; ihre Farbe ist dunkelgrau.

Der Same ist kaum $1 \mathrm{~mm}$ lang, fast feilspähnartig oder zusammengedrückt keilförmig, an beiden Seiten gestutzt, gelb bis braun, glänzend und fein gestreift. 
Anmerkung. Der Cajeputbaum ist ein in seinen Merkmalen ausserordentlich veränderliches Gewïchs, wie schon aus der Beschreibung zur Geniige hervorgeht; es ist auch bis jetzt nicht gelungen, die zahllosen Formen in einigermassen gut begrenzte Varietäten zu bringen; selbst die gewöhnlich abgetrennte Var. minor ist durchaus unsicher von einer Menge ähnlicher Formen geschieden. Die von Bentham erwähnte var. parvifolia (= Leptospermum nervosum Mitch.) kennen wir nicht; der Autor lässt es unentschieden, ob sie nicht besser als besondere Art betrachtet werden sollte.

Der Cajeputbaum ist auf der Ostseite von Australien und zwar von Neu-Süd-Wales über Queensland bis Nord-Australien weit verbreitet; von hier dringt er einerseits über Timor bis Malacea und Tenasserim, anderseits bis Borneo, Celebes, Buru und Ceram vor; an letzterem Orte bedeckt er noch weite Bergstrecken. Wahrscheinlich findet er sich auch noch auf Nen-Guinea; auf den Philippinen fehlt er aber.

Aus den Blättern des Baumes wird durch Destillation mit Wasser das Oleum Cajaputi (Cajeputöl) gewonnen.

Erklärung der Abbildungen.

Fig. A. Ein bltihender Zweig nach einem Exemplar aus dem friher Sonder'schen Herbarium, natïrliche Grösse.

Fig. $B$. Die Blüthe, 6 mal vergrössert: $c$. der Keleh; $d$. das Blumenblatt; e. das Staubgefiss.

Fig. C. Dicselbe, der Länge nach durchschnitten, $8 \mathrm{mal}$ vergrössert: $a$. der unterstïndige Fruchtknoten; $b$. der obere, freie Theil dessclben; $f$. der Griffel.

Fig. D. Der Fruchtknoten im Querschnitte, 15 mal vergrössert.
Fig. E. Das Blumenblatt, 10mal vergrössert.

Fig. $F$. Ein Staulggefüssbündel, smal vergrössert.

Fig. $G$. Staubgefïsse, von der Innen- und Aussenseite, $24 \mathrm{mal}$ vergrössert.

Fig. H. Pollenkörner, trocken und im Wasser, 250mal vergrössert.

Fig. I. Der Griffel mit der Narbe, 24mal vergrössert.

Fig. K. Ein Fruchtzweig.

\section{CARYOPHYLLUS Linn.}

Blithen viergliederig, zwittrig, aktinomorph. Fruchtknoten unterständig, cylindrisch, nicht über den Kelch hinaus verlängert, um den Griffel schüsselförmig vertieft, zweifächrig mit vielen Samenanlagen in jedem Fache, welche an zwei wenig von einander gesonderten Samenleisten befestigt sind; sie sind schief aufreeht angeheftet, anatrop und wenden die Mikropyle nach unten. Kelch tief viertheilig, lederartig, wie der Fruchtknoten von reichlichen Ölbehältern durelısetzt. Blumenblätter 4, in der Knospenlage dicht dachziegelig deekend, sie öffnen sich nicht bei der Vollblüthe, sondern werden vereinigt als Kuppel abgeworfen. Staubgefässe sehr zahlreich, unter sich frei, in der Knospenlage nach innen gebogen; Beutel am Rücken versatil aufgehängt, ditheeisch mit 2 Längsspalten aufspringend. Griffel einfach mit wenig deutlicher, gestutzter Narbe. Beere elliptisch, von den stchenbleibenden eingekrümmten Kelchblättern gekrönt, ein-oder höchstens zwcisamig; Nührgewebe fehlend; Keimling mit dicken, unregelmässig in einander greifenden, scbildfồmig befestigten Keimblättern. - Bäume mit immergrünen, kreuzgegenständigen, lederartigen, parallelnervigen Blättern und mässig grossen oder ansehnlichen Blüthen, welche zu endständigen, krenzgegenständigen Rispen verbunden sind; sie werden von Deckblättern gestützt und sind mit Vorblättchen versehen.

Etwa 10 Arten, welche von Java bis nach den Fidji Inseln verbreitet sind; eine Art, ursprünglich auf den Molukken heimisch, wird jetzt in den gesammten Tropen eultivirt. 


\title{
Caryophyllus aromaticus Linn.
}

\author{
Tafel 69 .
}

Blätter gestielt, oblong, zuweilen etwas verkehrt eiförmig, zngespitzt mit stumpfer Spitze, oder stumpf, am Grunde spitz, lederartig, parallelnervig, mit einem sammelnden Randnerven, glänzend; Bliithenstand mässig vielblüthig.

Caryophyllus aromaticus Linn. Spec. pl. ed. I. 515 (1753); Gürtn. Fr. I. 167. t. 33. fig. 2; Lam. Encycl. t. 417; Descourt. Fl. Ant. VIII. t. 566: Hayne, Arzneigew. X. t. 38; Nees, Dïsseldorf. Abbild. t. 298; DC. Prodr. III. 262; Guimp. u. Schlecht. Pfl. der Pharm. t. 72; Woodv. Med. pl. III. t. 193; Bot. Mag. t. 2749, 2750; Berg und Schmidt, Darstell. und Beschreib. t. III ; Miq. Fl. Ind.-Bat. I (1.) 462; Griseb. Fl. Br. W.-Ind. 235; T. Schumann, in Jahrb. Berl. bot. Gart. III. 119.

Eugenia caryophyllata Thbg. Diss. de Caryophyllis aromaticis Upsal. 178s; Flïkig. and Hanb. Pharmacogr. 246; Bentl. and Trim. Med. pl. t. 112; Flück. Pharmacogn. 796; Arth. Meyer, Drogenkunde II. 331 .

Jambosa Caryopliyllus Niedenzu in Engl.-Prtl. Nat. Pflanz. Fam. III. (7). 85. fig. 41.

Eugenia aromatica H. Baill. Hist. pl. VI. 311, 345 c. xylogr., Bot. méd. II. 1015, fig. 2532-34; K. Schumann in 7 . Kaiser Withelmsland 91 .

Myrtus Caryophyllus Spr. Syst. II. 485 .

Gewürznelkenbaum; französisch : Giroflier; engliseh: Clove tree.

Der Baum wird bis zu $20 \mathrm{~m}$ hoeh, er hat einen etwas kantigen Stamm und theilt sieh hänfig sehon in geringer Stammhöhe in mehrere gleichstarke Äste; die Rinde ist glatt und glänzend; die Zweige hängen in einem eleganten Bogen herab; die blühenden sind stumpf vierkantig und mit grauer Rinde bekleidet.

Die immergrünen Blätter werden von einem 2-3, zuweilen 4 em langen Stiele gestiitzt, der auf der Oberseite eine Rinne zeigt; die Spreite hat eine Länge von 9-12 (5-15) em und in der Mitte eine Breite von 3,5-4,5 $(1,5-6) \mathrm{em}$, sie ist lederartig, oberseits glänzend, unterseits matter, elliptisch bis lanzettlieh, stumpflich oder kurz zugespitzt mit stumpfer Spitze, am Grunde ist sie in den Blattstiel versehmälert; beiderseits des Mittelnerven verlaufen zahllose, parallele Nebennerven, die von einem Randnerven gesammelt werden; sie ist vollkommen kahl, aneh im jugendliehen Zustande, und zeigt mit Hülfe der Lupe zahlreiche durchseheinende Ölbehälter.

Der Blüthenstand ist eine nicht sehr reiehblïthige, kurz gestielte, krenzgegenständige Rispe von 4-6 cm Länge; die unteren Seitenstrahlen gehen entweder sogleieh oder nach einer nochmaligen, diehasialen Theilung in einfache Diehasien aus; die Deckblätter und Vorblätter sind sehuppenförmig, lederartig und sehr schnell abfällig; die Spindel ist verbältnissmässig kräftig, zusammengedriickt vierkantig, ganz kahl.

Die Blüthen werden von einem 2-5 mm langen, kräftigen, grünen Stielchen gestiitzt. Der Fruchtknoten ist etwa $1 \mathrm{~cm}$ lang, stielrund und purpurroth gefärbt; nur in seinem obersten Theile liegt die kleine, hohlkugelförmige, zweifächrige Kammer, welehe die zahllosen, an zwei wenig geschiedenen Sonderleisten sitzenden, aufrechten, anatropen Samenanlagen umsehliesst; nahe an der Oberflïche liegen in ihm die zahlreichen ölbehälter in zwei Sehichten. Die vier fast gleiehseitigen, dreieckigen, lederartigen, abstehenden, purpurrothen Kelchzipfel sind $2 \mathrm{~mm}$ lang, sie sind nur am nntersten Grunde verbunden. Die Blumenblätter sind 4-5 mm lang, fast kreisrund, nieht genagelt, coneav-eonvex, kahl und von milehweisser Farbe; sie deeken sich dachziegelartig und sind so fest mit einander verbunden, dass sie bei der Vollblïthe kappenförmig abgeworfen werden. Die Staubgefässe sind sehr zahlreieh, bis zum 
Grunde vollkommen frei und gleichförmig vertheilt; *) die Fäden sind 5-6 mm lang und dünn; die runden, in ein kallöses Mittelbandknöpfchen ausgehenden, kaum 0,5 mm langen Beutel sind gelb. Die Pollenkörner sind flach linsenförmig zusammengedrückt und dreieckig. Die Decke des Fruchtknotens ist um den Griffel herum schüsselförmig vertieft, an dieser Stelle liegt das Honig absondernde Gewebe. Der Griffel ist von der Länge der Staubblätter oder etwas kürzer; er ist sanft gebogen und läuft in eine seicht vertiefte, einfache Narbe aus.

Die Frueht ist eine 1,5-2 cm lange und 0,8-1 cm im Durchmesser haltende, purpurrothe, ellipsoidische Beere, die von den mehr oder weniger nach innen gekrümmten Kelehblättern gekrönt wird; sie ist völlig kahl und glatt und umschliesst gewöhnlich nur einen, selten zwei Samen.

Der Same ist entweder von der Form der Frueht oder von der Gestalt der halben Frucht; er enthält kein Nährgewebe; die Keimblätter sind fleischig und auf der Berührungsfläehe unregelmässig ansgehöhlt, so zwar, dass die Höhlungen des einen die Vorsprïnge des anderen Keimblattes aufnehmen; das Würzelchen wird von ihnen vollkommen eingeschlossen.

Anmerkung. Die Stellung der Gewïrznelke im System ist, wie oben aus der Synonymie bervorgeht, eine sehr verschiedene gewesen; diese Unsicherheit entspringt aus der Schwicrigkeit, die Gattungen in der Verwandtsehaft von Eugenia seharf zu sondern. So viel seheint uns sieher, dass die Gattung Caryophyllus nicht haltbar ist, da sich zu viele Übergänge nach der Gattung Eugenia vorfinden. Neuerdings hat man von Eugenia dic Gattung Jambosa getrennt und zwar auf Grund eines allerdings nieht sehwer wiegenden Merkmales; bei der ersteren nämlieh ist der kurze Fruehtknoten von dem Blïthenstielehen scharf abgesetzt und trägt seine Hühlung in dor Mitte; bei Jambosa aber reieht der Fruehtknotenkürper unter der apieal gelegenen Höhlung noch weiter herab. Da die Gew ürznelke das letzt erwähnte Verhältniss zeigt, so gehört sie zu Jambosa. Bei der Übertragung in diese Gattung hat Niedenzu dem Sprengel'schen Namen Myrtus Caryophyllus den Vorzug gegeben. Nach den gegenwiitig geltenden Regeln der Nomenelatur hat man aber nur den LiNné schen Namen zu berïeksiehtigen und die Pflanze müsste also Jambosa aromatica genannt werden.

Der Gew ïrnelkenbaum ist nach den ältesten holländischen Nachrichten ursprünglich nur auf der kleinen Insel Makian unter den Molukken heimisch gewesen; aber sehon vor der Entdeckung jener Inselgruppe durch die Portugiesen wurde er auf benachbarten Inseln enltivirt. Jahrhunderte lang wurde die Cultur durch die Holländer nur anf Amboina und den drei kleinen Inseln Oma, Honimoa und Nusa Lant geduldet; überall sonst wurden die Bäume ausgerodet und die Einsammlung der Nelken an anderen Orten mit dem Tode bestraft. Gegenwiirtig wird er in den Gegenden beiderseits des Äquators überall gebaut und namentlich von Zanzibar und Pemba an der Kuiste von Ostafrika werden heute grosse Mengen einer allerdings geringwerthigen Gewiirznelke ausgeführt. Ob er, wie angegeben wird, auf den südlichen Philippinen (den Inseln Mindanao, Samar) wirklich wild vorkommt oder ob die dort wachsenden Bäume von früheren Culturen herrühren, ist noch nicht ausgemacht.

Die getroekneten Blathen eultivirter Bäume sind dic Caryoplaylli oder Gewürznellen. Die Bliithenstandachsen kommen als Stipites Caryophyllorum, Nelkenstiele, in den Handel und werden nicht selten zur Verfälschung des Nelkenpulvers verwendet. Die fast reifen Früchte werden unter dem Namen Anthophylli oder Mutternelken verkauft.

\section{Erklärung der Abbildungen.}

Fig. A, Ein blïhender Zweig, aus dem früher Sonder'sehen Herbarium.

Fig. B. Die Bliithenknospe, 5mal vergrössert: $a$. der Fruchtknoten; b. die Hühlung desselben; $c$. ein Fach; d. die Honig absondernde Grube; e. das Kelehblatt; $f$. das Blumenblatt; $g$. die Staubgefässe; $h$. der Griffel.

Fig. C. Die Blithe im Zustande des Aufblïhens, ${ }^{21} / 2 \mathrm{mal}$ vergrössert: $f$. die abgestossene Kuppel der Blumenblïtter.

Fig. D. Der Fruchtknoten im Querschnitte, 9mal vergrössert.
Fig. E. Das Staubgefäss von innen und von aussen betrachtet, $20 \mathrm{mal}$ vergrössert.

Fig. $F$. Die Pollenkürner, 200mal vergrüssert.

Fig. $G$. Der obere Theil des Griffels mit der Narbe, 12mal vergrüssert.

Fig. $H$. Die Frueht, natürliche Grösse.

Fig. I. Dieselbe, im Querschnitte: a. das Würzelehen; $b$, dic Keimblätter.

Fig. K. L. Der Keimling.

Fig. M. Ein Keimblatt mit dem Wirzelehen.

* Sie sind nieht, wie vielfaeh angegeben wird, zu 4 gesonderten Gruppen zusammengefasst oder gar gebündelt. 


\title{
PUNICA Linn.
}

Blïthen 5-7gliedrig, zwittrig, vollständig, aktinomorph. Fruchtknoten halb oder ganz unterständig, vielfächrig, die Fächer in zwei übereinander gestellten Reihen; Samenlagen sehr zahlreieh, anatrop, aufrecht, wagerecht oder hängend; in den unteren minder zahlreichen Fächern einer boden- oder innenwinkelständigen, in den oberen einer wandständigen Samenleiste angeheftet. Kelchzipfel 5-7, lederartig, abstehend, in der Knospenlage klappig deckend. Blumenblätter ebenso viele, umgekehrt eiförmig oder kreisförmig, kurz genagelt, in der Knospenlage daehziegelig deekend und geknittert. Staubgefässe sehr zahlreich, mehrreihig befestigt, frei, in der Knospenlage eingebogen; Bentel von fast kreisförmigem Umrisse, versatil, am Rïcken aufgehängt. Griffel am Grunde verdickt, einfach mit kopfiger, mehrlappiger Narbe. Frueht beerenartig mit lederartiger Schaale, von dem bleibenden Kelehe gekrönt, fast kugelförmig, vielfächrig mit übereinandergestellten Fächern und häutigen Scheidewänden, vielsamig. Samen gross, durch gegenseitigen Druek kantig, umgekehrt pyramidenförmig mit saftiger Schale, ohne Nährgewebe; Keimling gross mit blattartigen, am Grunde geöhrten, spiralig in einander gewickelten Keimblättern und sehr kurzem Würzelchen. - Niedrige, sehr verästelte Bäumehen oder Sträneher mit oft in dornige Endigungen ausgehenden Zweigen und kreuzgegenständigen, oft an Kurztrieben gebischelten, abfälligen, ganzrandigen Blättern. Blïthen einzeln oder zu wenigen gebüsehelt, an den Enden von Kurztrieben, ansehnlieh, scharlachroth.

2 Arten, von denen die eine in Persien, Armenien, Belutschistan und Afghanistan, die andere auf Sokotora wächst; die erstere wird in allen tropischen und subtropischen Gegenden als Obstbaum häufig cultivirt.

\section{Punica Granatum Linn.}

\author{
Tafel $70 \mathrm{a}$ und $\mathrm{b}$.
}

Baum- oder strauchartig mit lanzettlichen oder oblonglanzettlichen, zuweilen viel breiteren, fast kreisförmigen, stumpflichen oder spitzen, am Grunde stumpfen, kahlen, kurzgestielten Blättern. Frueht ganz unterständig.

Punica Granatum Linn. Spec. pl. ed. I. 172; Trew et Elret. Pl. t. 71. fig. 1; Allione, Fl. Pedem. JI. 140, Icon. Taur. XXI. t. 73; Plenck, Off. Gew. t. 376; Gürtn. Fr. I. t. 35; Lam. Encycl. t. 415; Woodo. Med.pl. t. 130; Andr. Reposit. II. t. 96; Duham. Arbr. II. ed. IV. t. 11., Bot. Mag. t. 1832; Descourt. Fl. Ant. I. t. 35; Heyne, Arzneigew. X. t. 35; Sibth. Fl. Gr. t. 476; Nees, Dïsseld. Abbild. t. 300; P. DC. Prodr. III. 3; Guimp. u. Schlecht. Pf. Pharm. t. 89; Mcrt. und Koch, Deutschl. F7. III. 401; Berg in Fl. Bras. fasc. XVIII. t. 8. 9; Berg u. Schmidt, Darst. u. Beschreil. t. III. a, b; Köhler; Medizinalpfl. t. 110; Bentl. and Trim. Med. pl. t. 113; Bertol. Fl. Ital. V. 122; Ledeb. Fl. Ross. II. 104; Willk. et Lange, Prodr. F7. Hisp. III. 191; Boiss. F7. or. II. 736; Flück. and Hanb. Pharmacogr. 257; Flück. Pharmacogn. 513; Baill. Bot. méd. II. 1023. fig. 2841-46; Arth. Mey. Dirogenkunde II. 134; Niedenzu in Engl. u. Prtl. Natürl. Pflanz, fam. III (7). 25. fig. 9.

Punica spinosa Hall. Hist. II. n. 1098; Lam. F7. Fr. III. $4 \$ 3$.

Granate oder Granatbaum; französiseh: Grenadier; englisch: Pomegranate.

Die Granate ist ein bis höchstens $8 \mathrm{~m}$ hoher Baum oder Stranch, der sieh ausserordentlich reich verästelt und im ersteren Falle häufig eine fast kugelförmige Krone trägt; der Stamm ist meist sehr uneben, nicht selten aueh unregelmässig gekrümmt und mit reichlichen, gefurchten Korkleisten bedeekt. Die letzten $Z$ weige sind schwach vierkantig und mit einer brannen oder gelblich grünen Rinde bekleidet; man kann an ihnen Lang- und Kurztriebe unterseheiden, die letzteren gehen oft in scharfe Dornen aus. 
Die Blätter sind kreuzgegenständig angereiht, an den Kurztrieben oft buischelig gehäuft; sie sind sehr kurz (bis höchstens $4 \mathrm{~mm}$ lang) gestielt, der Stiel verdickt sich nach dem Grunde zu und wird oberseits von einer sehr seichten Rinne durchlaufen. Die Spreite ist $4-6(1-7,5) \mathrm{cm}$ lang und in der Mitte $1-2(0,5-2,5$ selten bis 4$) \mathrm{cm}$ breit, meist lanzettlich oder oblonglanzettlich, zuweilen nach dem umgekehrt ei- oder kreisförmigen gehend, diinn lederartig, spitz oder stumpflich und mucronat, am Grunde in den Stiel versehmälert; sie ist ganzrandig, kahl und jederseits des Mittelnerven von 3-5 Paar unterseits nur wenig, oberseits fast gar nicht vorspringenden, stärkeren Nerven durchzogen; sie ist unpunktirt.

Die Blüthen beschliesssen in der Regel einzeln die kurzen Zweige und werden von 2 häufig klein blattartigen Vorblättern gestiitzt; diesc sind $3-6 \mathrm{~mm}$ lang, lanzettlich oder spathelförmig und abfällig; indem sich aus ihren Achseln Blüthen entwiekeln, entstehen die ebenfalls nieht allzu seltenen Drillinge, welche die Spitzen der Zweige einnehmen. Vermehrungen der Blithen kommen auch dadureh zu Stande, dass Einzelblithen aus den Laubblättern unterhalb der Gipfelblithe oder aus weiteren Hochblattpaaren hervorbrechen. Die Blüth en sind kurzgestielt. Der kriftige, kreiselförmige, rothe, unterständige Fruehtknoten misst 6-8 mm., an cultivirten Exemplaren ist er häufig etwas grösser; er hat zwei, sehr selten (bei der gelbblühenden Form) drei Stockwerke von Kammern, von denen die oberen in der Zahl der Keleh- und Blumenblitter, die unteren in der halben Zahl derselben auftreten. Die Samenanlagen sind in jedem Fache sehr zahlreich, sie sitzen in den unteren anf einer bodenstiandigen, halbkugeligen, in den oberen an einer wandständigen, halbellipsoidisehen Samenleiste; in der entwickelten Frucht werden die bodenständigen Samenleisten durch eine eiugeschaltete Zone nach dem Innenwinkel der Fächer herübergeschoben; die Samenanlagen sind anatrop, in dem oberen Theile anfrecht, im mittleren wagerecht, im unteren hängend. Die Blïhenaxe setzt sich ïber den Fruchtknoten heraus als ein röhrenförmiger, dick lederartiger Körper fort, der an seinem Rande, die 5-9 ebenfalls lederartigen, fast gleichseitig dreieckigen, spitzen, in der Knospenlage klappigen, 5-7 mm langen Kelchblätter trägt. Die seharlachrothen, zarten, 10-20 cm im Durehmesser haltenden Blumenblätter, von der Zahl der Kelehblätter, sind umgekehrt eiförmig oder fast kreisrund, stumpf, am Grunde in den sehr kurzen Nagel zusammengezogen, etwas kraus; in der Knospenlage geknittert, decken sie dachziegelig. Die Staubgefässe sind der oberen Hailfte des Axenbechers in mehreren Reihen angeheftet und 5-6 mm lang; die oberen erreichen die Spitzen der Kelchblätter; die Fiiden sind nach innen gekrümmt und röthlich gefärbt; die gelben Beutel haben einen fast kreisförmigen Umriss und einen Durchmesser von 1-1,5 mm. Die Pollenkörner sind elliptisch und werden von drei meridionalen Längsfalten durchlaufen, in deren Mitte die Poren liegen. Der Stempel ist $1-1,5 \mathrm{~cm}$ lang, am Grunde kegelförmig verdickt, oberhalb des unteren Drittels cylindrisch. etwas gekrimmt und läuft in eine gestutzte, schwach gelappte Narbe aus.

Die Frucht hat einen Durchmesser von 6-10 cm; sie ist fast kugelförmig oder mehr apfelförmig, hat eine hart lederartige Schale und wird von dem bleibenden Kelche gekrönt; sic ist kahl und chagrinartig sculpturirt, rosenroth oder grünlich, später mehr hell lederbraun; dic innere Struktur ist der oben bcim Fruchtknoten beschriebenen entsprechend; die Scheidewände sind häutig, die Samenleisten schwammig; sie ist sehr vielsamig.

Die purpurrothen, am Grunde helleren Samen sind durch den gegenseitigen Druck umgekehrt pyramidenförmig, 5-7 kantig, an der Aussenfläche leicht gewölbt; die äussere Samenhaut ist sehr saftig, die innere ist knochenhart. Der Keimling hat ein kurzes Würzelchen; die blattartigen Keimblätter sind spiralig um einander gerollt.

Anmerkung. Die zweite Art Punica Protopunica Balf. von Sokotra ist eine ausgezeichnete, dureh kleinere, langgestielte Blïthen, kreisrunde, ausgerandete Blätter und kleinere, halb oberständige Früchte verschiedene Art.

Die Granate wächst im nördlichen Persien, in den Felsspalten der Berge Avroman und Schahu bei 1000-1600 m, auf den Felsen der Gebirge von Armenien und Belutschistan bis $2000 \mathrm{~m}$, und in Afghanistan wild; im Gebiete der ostindisehen Flora ist ihr Indigenat bis jetzt nicht nachgewiesen worden; auch aus Griechenland. Macedonien und von der Küste des sehwarzen Meeres sind sichere Fundorte der wilden Pflanze nicht bekannt, obwohl sie in den quaternären Tuffen von Südfrankreich nachgewiesen 
wurde. Sie wird gegenwärtig tiber die ganze Erde in wärmeren Gebieten cultivirt und ist vielfach bereits verwildert.

Punica Granatum liefert die als Wurmmittel benutzte Cortex Granati, welche von Stämmen und Wurzeln gewonnen wird. Als Cortex Granati fructus findet die getrocknete äussere Partie des Pericarps der als Obst geschätzten Frucht, des Granatapfels, in der Medicin Verwendung.

\section{Erklärung der Abbildungen.}

Tafel $70 \mathrm{a}$.

Fig. A. Ein blühender Zweig nach einem cultivirten Exemplar.

Fig. B. Die Bliithe im Längsschnitte, nach Entfernung der Blumenblätter, 2mal vergrössert: $a$. der Fruchtknoten; $b$. das untere Stockwerk der Fächer; $c$. das obere Stockwerk; $d$. der Griffelgrund; $e$. der untere angeschwollene Theil des Axenbechers; $f$. der Griffel; g. der Keleh; $h$. die Staubgefässe.

Fig. C.u. D. Quersehnitt durch das obere und untere Stockwerk der Fächer, 2mal vergrössert.

Fig. $E$. Das Staubgefäss von innen, aussen und von der Seite, $10 \mathrm{mal}$ vergrössert.

Fig. F. Pollenkörner trocken und im Wasser, 200mal vergrössert.

Fig. $G$. Die Narbe.
Tafel $70 \mathrm{~b}$.

Fig. $A$. Die Frucht, natürliche Grösse.

Fig. B. u. C. Dieselbe, Längs- und Querschnitt: a. untere Scheidewand; $b$. Höhlung einer unteren Kammer; c. Samenleiste; $d$. obere Scheidewand.

Fig. D. Samen, natürliche Grösse.

Fig. E. Querschnitt durch den Samen, 80 fach vergrössert: a. äussere saftige Schale, $b$, innere steinharte Schale.

Fig. $F$. Der Same im Längsschnitt, 3 mal vergrössert; $c$. Würzelchen; $d$. Keimblätter.

Fig. G. Derselbe im Querschnitte, 5mal vergrössert. 


\section{Reihe: Saxifraginae Brongn.}

Blüthen allermeist aktinomorph, zwittrig, von wirteligem Bau; Blüthentheile in Kelch und Krone gesondert, selten fehlend. Staubgefässe meist in zwei Kreisen. Fruchtknoten häufig oberständig, mit den übrigen Blüthentheilen in gleichzähligen Blättern oder gemindert; Samenanlagen zahlreich. Blätter in der Regel spiralig angereiht.

\section{Familie: Hamamelidaceae Lindl.}

Die Blüthen sind entweder zwittrig, vielehig oder einhäusig mit einer in Kelch und Krone geschiedenen Hülle; die letztere ist zuweilen durch Fehlschlag geschwunden, selten sind die Blïthen ganz nackt. Der Kelch ist gewöhnlich vier- oder fünfblättrig mit dachziegeliger, seltener klappiger Knospenlage. Die Blumenblätter, an Zahl derjenigen der Kelchblätter gleich, sind häufig sehr lang und schmal und dann uhrfederartig eingerollt, sonst decken sie meist klappig, selten dachziegelig. Staubgefässe sind so viele wie Blumenblätter oder doppelt so viele und noch mehr vorhanden, von denen einzelne zuweilen staminodial entwickelt sind; sie sind unter sich frei; die Beutel springen in Längsspalten, zuweilen aber auch mit Klappen auf, das Mittelband endet häufig in ein callöses Knöpfehen. Der Fruchtknoten ist ober- oder mehr oder weniger unterständig, vollkommen zweifächrig und enthält einzelne, oder viele Samenanlagen in jedem Fache. Die letzteren sind anatrop und hängen von der an der Scheidewand befindlichen Samenleiste herab; die beiden Griffel sind häufig bis zum Grunde frei, sie erbärten und krönen die Frucht. Die letztere ist eine fach - und zuweilen überdies wandtheilige Kapsel, bei der sich die äussere lederartige oder holzige Fruchthaut gern von der inneren horn- oder knorpelartigen loslöst. Die Samen sind zuweilen geflügelt; sie umschliessen ein meist spärliches Nährgewebe und einen geraden Keimling, dessen Würzelchen kurz ist und dessen blattartige Keimblätter flach aneinander liegen.

Bäume und Sträucher mit meist spiralig gestellten, ganzen, seltener getheilten Blättern; Nebenblätter sind fast immer vorhanden. Die Blïthen sind gewöhnlich unansehnlich und bilden Ähren oder Köpfchen, die zuweilen von gefärbten Hochblättern umgeben werden; Deckblätter und Vorblättchen sind nicht vorhanden.

Die Familie umfasst in 19 Gattungen etwa 45 Arten, welche besonders den subtropischen Gegenden angehören, nur eine Art geht bis nach Kanada, andere bis in die Tropen.

\section{LIQUIDAMBAR IIIn.}

Blüthen aktinomorph, unvollständig, einhäusig seltener zwittrig. Die männlichen wie die weiblichen Blüthenstände werden in der Knospenlage von 4 dachziegelig deckenden Hochblättern umbüllt. Kelch und Blumenkrone fehlen. Die Staubgefässe haben mässig lange Fäden und ellipsoidische oder fast umgekehrt herzförmige, am Grunde befestigte Beutel mit einem schmalen Mittelbande; sie springen in zwei seitlich gelegenen Längsspalten auf. Der Fruchtknoten der weiblichen Blüthen ist halb unterständig, zweifächrig, in jedem der Fächer befinden sich sehr viele anatrope, bängende Samenanlagen, welche an der ganzen Scheidewand befestigt sind. Der Kelchsaum ist undeutlich, oder geschlitzt, oder gestutzt und trägt an seinem Rande rudimentäre, sitzende, mit Längsspalten aufspringende, spitze Staubbeutel. Die beiden Griffel sind pfriemförmig, an der Spitze spiralig nach aussen gerollt, an der Innenseite flach und mit Narbenpapillen bekleidet. Die Frucht ist ein kugelförmiges, vielkapseliges Köpfehen, welehes von den stehenbleibenden 
Griffelbasen igelstachelig erscheint; jede Kapsel springt im oberen freieren Theile wandtheilig auf und nmschliesst wenige gefliigelte, zusammengedrỉekte Samen. Das Nährgewebe der letzteren ist mässig reichlich, der Keimling besitzt blattartige, flache Keimblätter und ein kurzes, nach oben gewendetes Würzelchen. Bäume mit Balsamsäften, abfälligen, handförmig getheilten, lang gestielten Blättern und kleinen, spitzen Nebenblättern. Blüthenstände aus den Achseln von büschelartig an den Enden der Zweige zusammengedrängten Blättern; die männlichen in aufrechten, zusammengesetzten Ähren, die weibliehen in kugelrunden Köpfchen, beide lang gestielt.

Zwei Arten, von denen die eine in Kleinasien, die andere in Amerika und Süd-China verbreitet ist.

\section{Liquidambar orientale Mill.}

\section{Tafel 71 .}

Blätter handförmig fünf- bis siebenlappig, mit stumpfen oder spitzlichen, häufig dreilappigen $\mathrm{Ab}$ schnitten; fast ganz kahl; Balsam flüssig.

Liquidambar orientale Mill. Dict. spec. n. 2; Spach, Hist. vég. phanér. XI. 86; Hanb. Science papers 127-150, in Seem. Bonpl. V. 114 c. ic. pag. 119; Planch. in Journ. pharm. XXIV. 173; Alph. DC. Prodr. XVI. 158; Boiss. Fl. or. II. 819; Hook. Icon. pl. t. 1019; Bentl. and Trim. Med. pl. t. 107; Köhler, Mediz.-Pfl. t. 101; Flück. and Hanb. Pharmacogr. 241; Flück. Pharmacogn. 126; Baill. Bot. méd. II. 770, fig. 2401-3; Niedenzu in Engl. u. Prtl. Nat. Pfanzfam. III (2a). 124.

Platanus orientalis Pococke, Descr. of the East II. $t .89$.

Liquidambar imberbe Ait. Hort. Kew. III. 365; Nouv. Duham. II. 44; Loud. Enc. trees 933, Ag. 1739.

Storaxbaum; französisch: Copalme ou Liquidambar; englisch: Ambertree.

Der orientalische Storaxbaum ist ein stattlieher, an die Platane vermöge der Blattform erinnernder

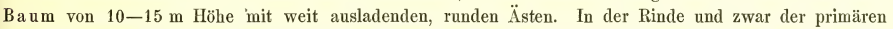
sowie der secundären, besonders in den Strahlenzellen, und den Markstrahlzellen befinden sich Balsamzellen, die im primären Holze zu Balsamgängen auf lysigenem Wege zusammentreten; die diinnen, schlanken, jüngeren Arten sind stielrund und werden von einer glatten, braunen Rinde bedeckt, die, wie auch die jüngsten Spitzen, ganz kahl sind. Auch die Wurzel enthält Balsamgänge, die sich aber nur im Leptom der Leitbündel vorfinden.

Der Blattstiel ist 5-7 (3-8) em lang, dünn und zierlich, seltener etwas kräftiger, stielrund, nur an dem etwas verdickten Grunde oberseits abgeflacht. Die Spreite ist gewöhnlich $6-8(4-10) \mathrm{cm}$ lang und 7-9 (5-11) $\mathrm{cm}$ breit, meist handförmig, fünf-, seltener mehr oder minder deutlich siebenlappig, wobei die oblong lanzettlichen oder breitlinealen, am Rande wenig drüsig gesägten, stumpfen, seltener spitzen Zipfel fast stets eine Neigung zum dreilappigen aufweisen; sie ist am Grunde herzförmig, seltener gestutzt und sie wird von fünf hand- oder etwas deutlicher fussförmig verbundenen, starken, beiderseits, aber unterseits stärker vorspringenden Nerven durchzogen; in den Achseln dieser Nerven ist eine nur sehr geringe, aber doch, wenigstens häufig, bemerkbare, wollige Bekleidung vorhanden. Die Nebenblätter sind nur 1-1,5 mm lang, linealisch, leicht abfällig; sie treten ein wenig oberhalb des Ansatzes ans dem Blattstiele hervor.

Die Blüthenstände erscheinen mit Ausbruch der Blättcr in den Achseln derselben, welche an Kurztrieben biischelig zusammengestellt sind. Die männlichen bilden 1,5-2 cm lange, walzenförmige Ähren, welehe wieder aus $6-8$ kleinen, kugelförmigen Ährchen oder Köpfehen zusammengesetzt sind. Sie stehen auf geraden, dimnen, 3-4 em langen Stielen. Jedes Ährehen wird in der Jugend von einer aus 4 oblongen, spitzen, sitzenden, aussen behaarten, innen fast kahlen, dachziegelig deckenden Blättern gebildeten Hülle umsehlossen. Da weder Keleh noch Blumenkrone an ihnen entwickelt sind, so ist eine scharfe Sonderung in einzelne Bliithen nicht angängig; jedes Ährehen wird aus sehr vielen mit kurzen, 
kaum $1 \mathrm{~mm}$ messenden Fäden versehenen Staubgefässen zusammengesetzt, deren Beutel von breit elliptischer oder fast umgekehrt herzförmiger Gestalt, am Grunde befestigt sind und an den Seiten mit Längsspalten aufspringen; die Pollenkörner sind äusserst klein, kugelrund, glatt und mit drei Poren versehen, der Rest eines Stempels ist nicht zu sehen. Die weiblichen Blüthenstände sind ebenfalls, gewöhnlich aber etwas küzer gestielt. Der unterständige Fruehtknoten ist 2fächrig und umschliesst viele (18-20) anatrope, hängende Samenanlagen, die an der ganzen Scheidewand oben in 2, unten in 3 Reihen befestigt sind. Jene sind in ihrer Gesammtheit zu einem vielfächrigen Körper verschmolzen. Ibre Höhlung ragt kaum über die Oberfläche des Mittelkörpers hervor, von dem aus sich für jeden Fruchtknoten 2 hornförmige, fleischige, 3-4 mm lange, nach oben sich pfriemlich verjüngende, an der Spitze spiralig eingerollte Griffel erheben, die auf der etwas abgeflachten Innenseite Narbenpapillen tragen. Die Griffel werden von einem fleischigen, dünnen, etwas gelappten Ringe umgeben, auf dem, wie es scheint in der Regel vier fleischige, eiförmige, spitze, auf der Innenseite zweispaltig aufspringende, aber keinen Pollen enthaltende Staubgefässrudimente sitzen. Dieser Ring wird für den Kelch gehalten.

Die Frueht ist ein $2 \mathrm{~cm}$ im Durchmesser haltendes Köpfehen, welehes durch die verhärteten Reste der Griffel igelstachelig erscheint. Sie enthält sehr viele Doppelfächer, welche sich an der Spitze zweiklappig öffnen, indem die Griffelreste auseinander treten.

Die Samen sind in geringerer Zahl in jedem Fache, als ehedem Anlagen waren, enthalten; gewöhnlich finden sich nur 4-6; sie liegen dachziegelig übereinander und sind durch den gegenseitigen Druck sehr unregelmässig gestaltet; doch herrseht die oblonge oder subquadratische Form vor; ihre Länge beträgt etwa $1 \mathrm{~mm}$, die Breite etwas weniger; ein am oberen Ende befindlicher, meist sehr kurzer Fligel ist an der Spitze gestutzt; die Farbe ist ein glänzendes gelbliches Braun. Der Keimling ist wenig kürzer, als der Samenkörper, er liegt in einem spärlichen Nährgewebe und trägt an dem kurzen Würzelchen die oblongen, stumpfen, blattartigen Keimblätter.

Der Storaxbaum wächst, dichte Wälder bildend, an der Küste von Kleinasien in den alten Landsehaften Lycien und Karien; besonders sind die Gegenden um die Ortschaften Mughla, Ulla und Mermeridje gegenüber den Inseln Kos, Simi, Rhodos durch sein Vorkommen berihmt; auch um den Golf von Alexandrette (das heutige Iskenderûn) wurde er gesammelt, dagegen ist er von den Inseln des Archipels bis heute nicht bekannt.

Anmerkung. Nach einem äusseren Merkmale ist der orientalische Storaxbaum von dem amerikanischen (Liquidambar styracifurum L.) zuweilen nur sehr schwer zu unterscheiden; wenn schon der letztere gewöhnlich durch lang zugespitzte, nicht gelappte Blattabschnitte erkennbar bleibt. Offenbar ist jener ein direkter Abkömmling der im Tertiär ïber die gesammte nördliche Erdhälfte verbreiteten Stammart, von welcher $L$. styracifluum kaum unterscheidbar ist. Das letztere wächst ausser in Amerika bis Mexico, auch noch in Süd-China und auf Formosa.

Durch Auskochen und Pressen der von der Borke befreiten Rinde von Liquidambar orientale wird der Storax, Styrax liquidus gewonnen.

\section{Erklärung der Abbildungen.}

Fig. A. Blühender Zweig eines weiblichen Baumes.

Fig. $B$. Blühendes männliches Zweigchen.

Fig. C. Das weibliche Köpfchen, doppelt vergrössert.

Fig. D. Ein männliches Ährchen von Liquidambar styracifluum L., 6mal vergrössert.

Fig. $E$. Same von derselben Pflanze, im Längsschnitt, $30 \mathrm{mal}$ vergrössert.
Fig. $F$. Same von $L$. orientale Mill., ebenso vielmal vergrössert.

Fig. $G$. Same von $L$. styraciflum $\mathrm{L}$. den nicht entwickelten Samenanlagen angepresst.

Fig. H. Keimling derselben Pflanze.

Anmerkung. $D-H$ sind Copien aus Niedenzu 1.c., da uns Material zu Originalzeichnungen fehlte. 


\section{Reihe: Umbelliflorae Bartl.}

Blüthen aktinomorph, selten etwas zygomorph, von wirteligem Bau, meist vollständig, mit unterständigem Fruchtknoten und doppelter, in Kelch und Krone gesonderter Hälle, häufig zwittrig. Staubgefässe meist in einem Kreise. Fruchtblätter gewöhnlich 1-5, selten sehr viele, unter einander verwachsen, gewöhnlich mit einer einzelnen, hängenden, anatropen Samenanlage in jedem Fache. Same mit reichlichem Nährgewebe. Blüthen sehr häufig in Dolden, seltener in Köpfchen.

\section{Familie: Umbelliferae Jun.}

Die Blüthen sind entweder völlig aktinomorph oder durch Vergrösserung der nach anssen gewendeten Blumenblätter mehr oder weniger deutlich zygomorph, zwittrig oder durch Fehlschlag eingeschlechtlich oder polygam und zwar dann meist ein-selten zweihäusig. Der Fruchtknoten ist unterständig, zweifächrig, in jedem Fache befindet sich eine, von der Spitze herabhängende, anatrope Samenanlage. Der Kelch kann hänfig nicht bemerkt werden, zuweilen ist er aber auch ring-oder becherförmig, oder gelappt; sehr selten, weist er blattartige, in der Knospe dachziegelig deckende Abschnitte anf. Blumenblätter sind fünf vorhanden; gewöhnlich sind sie sämmtlich gleich, seltener sind die äusseren grösser; häufig zeigen sie eine eingebogene Spitze und erscheinen deshalb zweilappig; in der Knospe decken sie dachziegelig, seltener (die flachen) klappig. Die fünf Staubgefässe haben fadenförmige, eingebogene Fäden; die meist kreisförmig umrissenen Beutel sind am Rücken versatil aufgehängt und springen mit zwei nach immen gelegenen Längsspalten auf. Auf dem Fruchtknoten liegt ein zweilappiges, halbirtes Griffelpolster, dessen Theile sich allmälig in die beiden Griffel fortsetzen; diese sind aufrecht, meist aber nach anssen gebogen und tragen je eine kopfförmige, endständige Narbe. Die Frucht ist ein Doppelachaenium d. h. eine Schliessfrucht, welche in zwei Hälften (Theilfriichtehen, mericarpia) zerfällt, die den Fruchtblättern entsprechen. Die Theilfrichte springen nicht auf und sind einsamig; sie liegen ursprïnglich mit flachen oder ausgehöhlten Seiten (commissura) an einander, lösen sich dann von unten nach oben ab und bleiben an einem fadenförmigen, steifen Leitbündelstrange (Fruchtträger, carpophorum) sitzen, der entweder einfach bleibt oder mehr oder weniger tief zweispaltig ist; von seinen Ästen hängen sie endlich herab. Hänfig wird die Theilfrucht von 5 Rippen (juga) durchlaufen, zwischen den 4 Thälchen (valleculae) liegen; auch ans den letzteren können sich Rippen (juga secundaria) erheben, die an der Vierzahl kenntlich, zuweilen höher sind als die ersten Rippen. Unter der Oberfläche der Frucht liegen häufig sehr regelmässig geordnete Ölgänge (vittae). In jeder Theilfrucht befindet sich ein einziger Same, der von der Spitze des Faches herabhängt und meist mit der Fruchthaut verwachsen ist; das ziemlich reichliche Nährgewebe ist knorplig; der Keimling ist verhältnissmässig klein, die Keimblätter sind eiförmig, oblong oder linealisch, das Wurzelehen ist kurz.

Meist einjährige oder zweijährige Kräuter oder Stauden, seltener Sträucher oder Bäume mit spiralig gestellten, am Grunde gewöhnlich scheidig erweiterten, selten ganzen, gewöhnlich mehrfach gefiederten, dreitheiligen oder fiederschnittig getheilten Blättern; allermeist ohne Nebenblätter. Blüthen gewöhnlich weiss, seltener gelb, sehr selten blau, in der Regel klein, zu Köpfen, Dolden, meist aber zusammengesetzten Dolden vereinigt, die zuweilen von einem Blättchenkranze (Hülle, involucrum, - an den Theildolden oder Döldehen Hüllehen, involucellum) gestütst werden; Vorblättchen fehlen.

Man kennt etwa 1500 Arten, die hauptsächlich in der nördlich gemässigten Zone und zwar in Europa und Asien verbreitet sind; einige dringen bis in die arktische Zone vor und steigen auf die höchsten 
Berge bis in die Nähe der Schneegrenze; auch das nördliche und südliche gemässigte Amerika, sowie Sud-Afrika und Australien besitzen eine ziemliche Anzahl von Arten; innerhalb der Wendekreise bewohnen sie in minder zahlreichen Formen die Bergregionen. Viele Arten werden seit den altesten Zeiten cultivirt und sind über die ganze Erde verbreitet.

Die offizinellen Umbelliferen gehören in folgende Tribus. Sie werden sämmtlich untergebracht in der Reihe Haplozygae Benth. et Hook.: Dolden zusammengesetzt. Theilfrüchte mit Ölstriemen unter den Thälchen. Frïchte nur mit Hauptrippen, Nebenrippen fehlen.

I. TRIBLS Ammineae Koch. Theilfrüchte von der Seite her zusammengedrückt, flügellos, mit schmaler Berührungsfläche.
1. Conium maculatum Linn.
2. Carum Carvi Linn.
3. Ptychotis Ajowan DC.
4. Pimpinella Anisum Linn.
5. Pimpinella Saxifiaga Linn.

II. TRIBUS Seselineae Koch. Theilfriichte halb cylindrisch oder vom Rücken her zusammengedrückt mit breiter Berührungsfläche.
6. Foeniculum capillaceum Gil.
7. Levisticum officinale Koch.
8. Oenanthe Phellandrium Lam.
9. Archangelica officinalis $\mathrm{Hffm}$.

III. TRIBUS Peucedaneae Reichb. Theilfrüchte vom Rücken her stark zusammengedrückt; Seitenrippen geflugelt.

10. Ferula rubricaulis Boiss.

11. Ferula Scorodosma Benth. et Hook.

12. Dorema Ammoniacum Don.

\section{CONIUM Linn.}

Blüthen fast völlig aktinomorph, nur die randlichen eines Döldchens in den Blumenblättern ein wenig zygomorph, vielehig, meist vollständig. Fruchtknoten unterständig, zweifächrig, mit deutlich vorspringenden Rippen. Kelch wulstig, sehr undeutlich. Blumenblätter umgekehrt eiförmig oder keilförmig, nicht immer mit eingebogener Spitze. Griffelpolster niedergedrückt, getheilt. Frucht von der Seite her zusammengedrückt, eiförmig, an der Berührungsfläche eingezogen. Theilfrucht fünfkantig, die Hauptrippen vorspringend, stumpf, knotig gekerbt oder glatt; Ölstriemen sehr viele, dünn, zu einer zusammenhängenden Schicht geordnet. Fruchtträger ungespalten. Samen an der Bauchseite tief gefurcht. - Zweijährige, hohe, kahle Kräuter mit doppelt bis dreifach gefiederten Blättern, deren Fiederchen gezähnt und fiedertheilig sind. Dolden zusammengesetzt, sehr vielstrahlig; Hülle und Hüllchen aus mehreren kleinen Blättchen zusammengesetzt. Blüthen weiss.

Angeblich 2 Arten, von denen die eine über die nördliche Hemisphäre der alten Welt weit verbreitet und heute bereits nach Amerika übergeführt ist, die andere in Süd-Afrika und Abyssinien wächst; beide sind aber wahrscheinlich nicht specifisch zu trennen. 


\section{Conium maculatum Linn.}

Tafel 72.

Stengel aufrecht, steif, verzweigt, kahl, gestreift und roth gefleckt; untere Blätter gross, eiförmig im Umfang, dreifach gefiedert, Fiederchen fiedertheilig, oblong oder eiförmig; Dolden zwölf- bis zwanzigstrahlig, kahl; Hülle aus zurückgebogenen, lanzettlichen, zugespitzten Blättern gebildet; Hüllchen aus 2-5 Blättchen bestehend, die einseitig verwachsen sind.

Conium maculatum Linn. Spec. pl. ed. I. 243; Scop. Fl. Carniol. II. n. 240; Jacq. Austr. II. t. 156, Huds. Fl. Angl. 115; Allione, Fl. Pedem. II. 15; G. F. Hoffm. Umbellif. 2. I. 101. t. 1, fig. 3, p. 210. t. 1. B. fig. 13, t. 3. fig. 2; Plenck, Off. Pfl. t. 483; Sm. Br. Fl. t. 302; Engl. Bot. XVII. t. 1191; Svensk bot. IV. t. 226; Fl. Dan. XIII. t. 2165; Schk. Handb. t. 62; Hoffm. Deutschl. Fl. I. t. 95; Bigel. Med. pl. I. t. 11. Mert. u. Koch, Deutschl. F7. II. 464; Hayne, Arzneigew. I. t. 31; Nees, Dïsseld. Abb. t. 282; Guimp. und Schlecht. Pfl. Pharm. I. 22. t. 12; DC. Prodr. IV. 242; Brandt und Ratzeb. Giftgew. t. 25; Baxter, Br. bot. IV. t. 303; Ledeb. F7. Ross. II. 359; Godr. et Gren. Fl. Fr. I. 750; Willk. et Lange, Prodr. Fl. Hisp. III. 67; Boiss. Fl. orient. II. 922; Berg und Schmidt, Darstell. und Beschreib. t. XXIV ; Bentl. and Trim. Med. pl. t. 118; Köhler, Medizinalpf. t. 154; Flück. and Hanb. Pharmacogr. 266; Flück. Pharmacogn. 697; Baill. Hist. pl. VII. 134. fig. 145-148, Bot. méd. II. 1058; Battand. et Trab. Fl. d'Alg. II. 359.

Conium croaticum Waldst. et Fit. in Willd. Enum. 305.

Cicuta major Bergen, F7. Francof. 182; Lam. Encycl. II. 3; DC. Fl. Fr. IV. 324.

Cicuta maculata Lam. Fl. Fr. III. 104.

Coriandrum maculatum Roth, F7. Germ. I. 130. II. (1.) 348.

Coriandrum Cicuta Crantz, Stirp. austr. 24.

Schierling, Gefleckter Schierling, Tollkerbel, Wütherich; französisch: Grande ciguë; englisch: Hemlock.

Die zweijährige Pfahlwurzel ist spindelförmig, meist einfach, mit wenigen sehr dünnen Ästen versehen und aussen, wie innen weisslich.

Der im zweiten Jahre aus einer grossen Blattrosette sich erhebende Stengel erreicht eine Höhe von mehr als $2 \mathrm{~m}$, er ist straff aufrecht, gefurcht, gewöhnlich blau bereift und roth gefleckt und wie die ganze übrige Pflanze kahl; er ist, mit Ausnahme der nur sehr wenig angeschwollenen Gelenke, röhrenförmig und stark verästelt.

Die Blätter sind im ersten Jahre zu einer Rosette gedrängt; diese sind langgestielt, der kräftige im Querschnitte fast vierseitige Stiel ist nach unten hin oberseits abgeflacht und geht in eine breite Scheide aus; der Umfang dieser grundständigen Blätter ist eiförmig, sie sind dreifach gefiedert; die Seitenfiedern ersten und zweiten Grades sind dentlich, die des dritten Grades kürzer gestielt. Die letzterwähnten Blattgliederungen sind von eiförmiger Gestalt, sitzend und tief fiederspaltig, nach der Spitze hin aber werden sie gesägt; die Abschnitte gehen endlich in eine feine, kurze Stachelspitze aus. Die Blätter sind schlaff, oberseits dunkelgrün, wenig glänzend oder ganz matt, unterseits etwas heller, sie sind völlig kahl; ibre Länge kann $40-50 \mathrm{~cm}$, die Breite $30-35 \mathrm{~cm}$ erreichen. Die untersten Stengelblätter haben dieselbe Gestalt and Bildung, nach oben hin werden sie nicht bloss kleiner, sondem auch einfacher (meist sind sie dann nur einfach gefiedert) und der Stiel verschwindet: während sie sich am unteren Theile des Stengels in spiraliger Anreihung folgen, stehen sie an den Seitenzweigen in einem Paare gewöhnlich einander gegenüber.

Die Blüthenstände beschliessen die Hauptaxe und die Seitenzweige; bei den letzteren erseheinen häufig aus den zwei Primärblättern nene Zweige, wodurch das Sprosssystem ein dichasiales Aussehen erhält; beschliesst endlich ein Bliithenstand diese Axe und entwickelt sich unter ihm nur aus einem Blatte ein Seitenstrahl, der wieder ein Blatt erzeugt und damn in einen Blithenstand ansläuft; so wirft der letztere jenen ersten Bluthenstand bei Seite. Dieser wird blattgegenständig und beginnt ein monochasiales Verzweigungssystem, das bis zu vier Gliedern verfolgt werden kann; wenn der Fortsetzungszweig zum letzten Deckblatte immer nach derselben Seite fällt, so hat das Monochasium Schraubeltypus. Die Dolde ist doppelt, zwölf- bis zwanzigstrahlig, wenig gewölbt; die Döldehen besitzen ebenso viele mässig lang 
gestielte Bliithen. Die Hïlle besteht gewöhnlich aus 5-6 schmalen, rückwärts geschlagenen, kaum 3-4 mm langen, häufig bald vertrocknenden, manchmal aber auch um die Hälfte längeren, dauerhafteren Blättchen. Das Hzillchen ist fast um die Hälfte kürzer, es besteht aus $3-5$ nach aussen gestellten, unter einander verwachsenen grünlichen, am Rande weisshäutigen Blättchen.

Der Fruchtknoten ist zur Blüthezeit etwa 1,5 mm lang und $1 \mathrm{~mm}$ breit; er ist seitlich zusammengedrückt, an der Berührungsseite der beiden Fruchtblätter deutlich eingezogen; jedes der letzteren wird von 5 meist etwas knotig gegliederten Rippen durchzogen.

Der Kelch ist nur sehr undeutlich in der Form eines niedrigen Wulstes entwickelt. Die weissen, ein wenig ins gelbliche fallenden, umgekehrt ei- oder spatelförmigen Blumenblätter sind an der Spitze nur wenig eingebogen, sie sind etwa $2 \mathrm{~mm}$ lang, die äusseren an den randlich stehenden Blüthen sind etwas länger. Die Staubfäden sind weiss, eingebogen, meist länger als die benachbarten Blumenblätter; die fast kreisrunden, oben und unten ansgerandeten Beutel sind hell schwefelgelb, dithecisch und springen mit 2 Längsspalten auf. Die ellipsoidischen Pollenkörner werden von drei Längsfalten durehlaufen. Das Griffelpolster ist durch eine Furche in 2 Theile zerlegt; die Griffel sind entweder sehr kurz, aufrecht und tragen eine gestutzte, kaum empfängnissfähíge Narbe, oder sie sind beträchtlich länger, zuriickgebrochen und haben eine kopfförmige Narbe.

Die Frucht hat eine Länge von 2,5-3 mm und eine Breite von 2-2,5 mm; die Theilfrüchtchen lösen sich leicht von dem nicht gespaltenen Fruchtträger ab; sie sind von dem Griffelpolster und dem Griffel gekrönt, an der Berihhrungsseite etwas gekrïmmt und werden von 5 Hauptrippen durchzogen, welche sich durch etwas hellere Farbe von der braungrinen Frucht abheben und durch eine leichte, knotige Gliederung auszeichnen. Ölstriemen in der für viele Umbelliferen charakteristischen Vertheilung fehlen, dafür liegt dem Nährgewebe eine zusammenhängende Schicht längs gestreckter, heller Zellen auf, welche das ätherische Öl und Coniin enthalten.

Der Same ist mit der Fruchthaut verwachsen; er hat ein reichliches auf der Berülırungsseite mit einer tiefen Längsfurche versehenes Nährgewebe und umschliesst in dem oberen Ende den kleinen Keimling mit stumpfen Keimblättern.

Anmerkung. Der gemeine Schierling zeigt manche Abänderungen, von denen uns diejenige mit ungekerbten, glatten Rippen (var. leiocarpa Boiss.) die wichtigste zu sein scheint. Von ihr können wir die unter dem Namen Conium chaerophylloides Ecki. et Zeyh. aus dem Caplande beschriebene Pflanze nicht unterseheiden; noch weniger bemerkenswerth ist die var. divaricata Boiss. mit mehr spreizenden Blithenstandszweigen und etwas breiteren Blattabschnitten.

Der Schierling ist vielleicht wie viele Schuttpflanzen in Europa eingefuhhrt; sicher ist er erst in der neueren Zeit an vielen Orten in Nord- und Süd-Amerika eingebürgert worden; wir sahen ihn aus der Republik Argentina, aus Brasilien, Chile etc. Gegenwärtig gehört er zu den in Deutschland zwar verbreiteten, aber durchaus nicht ubberall gemeinen Pflanzen; im nördlichsten Russland fehlt er, sonst aber findet er sich durch ganz Europa, in Nord-Afrika, Abyssinien und am Cap; in Asien ist er bis Persien und Sibirien nicht selten, hier bewohnt er aber in den stidlicheren Gegenden nur die Gebirge.

Die getrockneten Blätter und Sprossspitzen der blühenden Pflanze finden als Herba Conï medicinische Verwendung.

\section{Erklärung der $\Lambda$ bbildungen.}

Fig. A. Oberer Theil einer blithenden Pflanze.

Fig. B. Ein Blattfiederpaar.

Fig. C. Ein Döldchen, 3mal vergrössert: $a$. Hüllchen.

Fig. D. Die Blüthe vom Döldchenrande, $10 \mathrm{mal}$ vergrössert: $f$. das Blumenblatt; $g$. das Staubgefäss.

Fig. $E$. Der Stempel einer männlichen Bliithe, 12mal vergrössert: $b$. der Fruchtknoten; e. der Kelchwulst; $h$. das Griffelpolster; $i$. die kurzen Griffel.

Fig. E. Der Stempel der Zwitterblïthe.

Fig. $F$. Derselbe, im Längsschnitte, $15 \mathrm{mal}$ vergrössert: c. die Berührungsfläche der beiden Fruchtblätter.

Fig. G. Derselbe, im Querschnitte, $12 \mathrm{mal}$ vergrössert: $d$. die Samenanlage; $k$. die Rippen; $l$. die Thälchen.
Fig. $H$. Ein Blumenblatt, $15 \mathrm{mal}$ vergrössert.

Fig. I. Das Staubgefäss aus der Knospe, von innen und von aussen betrachtet, 20 mal vergrössert.

Fig. $K$. Dasselbe, aufgesprungen.

Fig. L. u. M. Die Pollen trocken und im Wasser, 250mal vergrössert.

Fig. N. Die Frucht in natürlicher Grösse.

Fig. O. Dieselbe, 8 mal vergrössert: $m$. die Theilfrüchte,

Fig. $P$. Dieselbe im Querschnitte, 12mal vergrössert: $o$. die olführende Schicht; $p$. das Nührgewebe; $r$. der Keimling.

Fig. Q. Ein Theilfrüchtehen im Längsschnitte, 8mal vergrössert: $r$. das Würzelchen; $s$, die Keimbläter. 


\title{
CARUM Linn.
}

Blïthen nicht immer gleichförmig, vielehig, dann die unfruchtbaren zygomorph mit grösseren, äusseren Blumenblättern. Fruchtknoten unterständig, zweifächrig, kahl. Kelch meist sehr undentlich, selten fünfzähnig. Blumenblätter mit eingebrochener, ganzer Spitze, zweilappig. Griffelpolster zweilappig, die Griffel parallel, nur an der Spitze auseinanderstrebend. Frucht von oblongem Umrisse, von der Seite her zusammengedrïckt, kahl; sie zerfällt stets in 2 Theilfrïchte, die an dem bis zur Mitte gespaltenen Fruchtträger hängen. Theilfrüchte mit 5 deutlichen Rippen, unter den Thälchen einzelne Ölcanäle, an der Fugenfläche 2, hier mässig eingezogen. - Einjährige oder zweijährige, meist völlig kahle Kräuter oder ausdauernde Stauden, bisweilen mit knollig angeschwollenen Grundaxen. Blätter gefiedert oder doppelt und dreifach gefiedert. Dolde zusammengesetzt, vielstrahlig, oft ohne Hülle, Hüllehen vielblättrig; Blättehen ganz; Blithen weiss.

Etwa 30 Arten, die alle in der alten Welt, besonders im Mittelmeergebiete, zum Theil aber auch in der ganzen nördlich gemässigten Zone gedeihen.

\section{Carum Carvi Linn.}

\author{
Tafel 73 .
}

Zweijährig; Pfahlwurzel spindelförmig; Stengel kahl, gefurcht; Blätter dreifach gefiedert, Fiedern sitzend, die untersten Fiederchen an den grösseren Blättern fast rechtwinklig gekreuzt; letzte Ausgliederungen linealisch.

Carum Carvi Linn. Spec. pl. ed. I. 263; Jacq. Fl. Austr. IV. t. 393; Allione, Fl. Pedem. II. 25; Gürtn. Fr. I. t. 23; Plenck, Offiz. Pf. t. 214; F7. Danica VII. t. 1091; Smith, F7. Brit. I. 330; Soensk Bot. II. t. 115; Engl. Bot. XXI. t. 1503; Schk. Handb. I. t. 77; Hoffm. Umbellif. I. 86. t. I. A. fig. 25; Hayne, Arzneigew. VII. t. 19; Mert. u. Kroch in Roeht. Deutschl. FI. II. 437; Nees, Diisseld. Abbild. t. 276; P. DC. Prodr. IV. 115; Guimp. u. Schlecht. Pfl. Pharm. II. 35. t. 131; Baxt. Brit. Bot. III. t. 232; Koch, Syn. 286; Dietr. Fl. Bor. XI. t. 753; Ledeb. Fl. Ross. II. 249; Willk. et Lange, Prodr. Al. Hisp. III. 92; Boiss. Fl. orient. II. 879 ; Aschers. Fl. M. Brandenb. 242; Garcke, Fl. Deutschl. ed. XVII. 244 cum ic.; Reichb. Icon. t. 1872; Berg u. Schmidt, Darst. u. Beschr. t. XXV ; Bentl. and Trim. Med.pl.t.121; Koehler, Mediz. Pf. t. 91; Flück. and Hanb. Pharmacogr. 291; Flïckig. Pharmacogn. 941; C. B. Cl. in Hook. fil. Fl. Br. Ind. II. 680; Battand. et Trab. Fl. d'Alg. II. 347; Baill. Pl. méd. II. 1050. fig. 2561. 2862; Arth. Meyer, Drogenk. II. 440.

Apium Carvi Crantz, Fl. Austr. III. 218.

Seseli Carum Scop. F7. Carniol. I. 215.

Ligusticum Carvi Roth, Fl. Germ. I. 121. II (1). 324.

Aegopodium Carum Wib. F7. Werth. 199.

Lagoecia cuminoides Willem. Phyt. I. 254.

Bunium Carvi Marsch. v. Bieb. F7. Taur,-Cauc. 211, suppl. 206; Godr. et Gren. Fl. Fr. I. 729.

Küimmel, Karbe, Garbe; französich: Carvi; englisch: Caraways.

Die etwas fleischige, wenig verzweigte Pfahlwurzel ist innen und aussen weiss, oder später aussen bräunlich, sie wird bis $20 \mathrm{~cm}$ lang und fingerdick.

Der aufrechte, ganz kahle Stengel wird $30-90 \mathrm{~cm}$ hoch; er ist gefureht und stielrund, vom Grunde an veristelt und mit lückigem Marke gefüllt.

Die spiralig angereihten Blätter crreichen eine Länge von $20 \mathrm{~cm}$ und mehr; nur die unteren sind deutlich gestielt, die oberen sitzen unmittelbar der grossen, häutigen Scheide auf; sie sind dreifach gefiedert; die obersten sind minder complicirt gebaut, die letzten Ausgliederungen sind linealisch, gespitzt und werden kaum länger als $1 \mathrm{~cm}$. Die untersten Fiedern sitzen wie die übrigen; ibre Hauptabschnitte 
sind so gestellt, dass sie an der Blattspindel ein horizontales Kreuz bilden. Am Grunde der Scheide befinden sich an den Stengelblättern gegenüiber dem Hauptblatte noch ein Paar kleiner, doppelt gefiederter Blätter, die man häufig für Nebenblätter angesehen hat. Die Blätter sind stets ganz kahl.

Der Bltuthenstand ist eine zusammengesetzte Dolde, welche den Ausgang aller Seitenäste bildet, sie ist gestielt und wird häufig durch Übergipfelung blattgegenständig, sie besteht meist aus 7-10, selten aus mehr Strahlen; eine Hülle ist meist in der Form einiger weniger linealischer Blättchen vorhanden, bisweilen fehlt sie aber ganz. Die flachen Döldchen bestehen aus 10-13, seltener mehr oder weniger Blüthen, sie entbehren der Hüllchen stets.

Die Blüthen sind polygam, und zwar sind die inneren eines Döldchens bisweilen nur männlich, der Fruchtknoten ist dann nicht entwickelt. Der Fruchtknoten der Zwitterblüthen ist von den Seiten her etwas zusammengedrickt, oblong und wird von 10 schwachen Rippen durchlaufen, die an der Fugenfläche liegenden berühren sich fast. Der Kelch ist nur in der Form eines schmalen gefältelten Saumes oberhalb des Fruchtknotens zu erkennen. Die Blumenblätter sind weiss, in gebirgigen Gegenden aber bisweilen schön roth, umgekehrt eiförmig und durch die Umbiegung einer Spitze schwach ausgerandet, sie messen kaum $1 \mathrm{~mm}$ in der Länge. Die Staubblätter sind um dic Hälfte länger; der Pollen ist schmal ellipsoidisch mit 3 meridionalen Längsfalten, in deren Mitte die Poren gelegen sind. Das Griffelpolster ist geschwollen, weiss und tief zweitheilig; die beiden nur an der Spitze spreizenden Griffel messen ebenso viel wie jenes in der Höhe.

Die Frucht wird etwa 4, selten bis $5 \mathrm{~mm}$ lang und etwa $2-2,5 \mathrm{~mm}$ in der Mitte breit, sie zerfällt sehr bald bei der Reife in die beiden sich häufig krümmenden Theilfrüchte, die an dem bis zur Hälfte gespaltenen Fruchtträger hängen bleiben. Jedes der Theilfriichtehen wird von 5 deutlich vortretenden Rippen durchzogen, zwisehen dewen die Wölbungen der braungefärbten ölcanäle hervortreten; ausser den unter den Thälchen befindlichen liegen noch 2 an der Fugenfläche; die Griffel sind an der Frucht schief nach unten gedrükt.

Der Kümmel wächst in ganz Europa, von den arktischen Gegenden bis Spanien und Italien, er steigt von den Ebenen bis in die höheren Gebirge; in Griechenland scheint er zu fehlen; in den Kaukasusländern bewohnt er nur die Gebirge und zwar bis $2500 \mathrm{~m}$ Erhebung; ïber die Provinzen Talysch und Aderbidjan kann man ihn bis zum westlichen Himalaya, nach Kaschmir und West-Tibet verfolgen; ausserdem findet er sich überall im nördlichen Asien, feblt aber in China und Japan. Ob er in Nord-Afrika ursprünglich heimisch oder nur cultivirt ist, bleibt bis heute unentschieden; aus Nord-Amerika findet er sich mehreren Ortes erwähnt, doch dürfte er hier biswcilen verwildert sein. Er wird auch nicht selten in Deutschland, Holland, Central-Russland, England cultivirt; Indien, Persien und Maroceo füren gleichfalls Kümmel aus.

Die Fribehte der Pflanze (Fructus Carci) werden als Gewurz und Arzneimittel verwendet. Vorzuglich gebraucht man jetzt in der Medicin das Karvol (das Oleum Carvi des Arzneibuches), welches aus dem ätherischen Öle der Kümmelfruchte hergestellt wird. Das ätherische öl ist in den intercellularen Secretbehältern der Frucht entbalten.

\section{Erklärung der Abbildungen.}

Fig. A. Grundblatt.

Fig. $B$. Ein blïhender Zweig.

Fig. C. Die Blüthe, 10mal vergrössert: d. das Blumenblatt; e. das Staubblatt; $f$. das Stempelpolster mit den Griffeln.

Fig. D. Der Fruehtknoten und das Griffelpolster, 15mal vergrössert: $a$. der Fruchtknoten; $c$. der Kelch; g. die Griffel.

Fig. $E$. Derselbe im Längsschnitte: $b$. die Samenanlagen.

Fig. $F$. Derselbe im Querschnitte, 22mal vergrössert: $h$, die
Theilfrüchtchen; $i$. die Fugenfläche; $k$. die Rippen; $l$. die Thälchen; $m$. die Ölcanälchen.

Fig. $G$. Das Blumenblatt, 12mal vergrössert.

Fig. H. Das Staubblatt von der Mitte der Blüthe und von aussen betrachtet, $20 \mathrm{mal}$ vergrössert.

Fig. I. u. K. Pollenkörner, trocken und im Wasscr.

Fig. $L$. Die Frucht, natürliche Grösse.

Fig. M. Dieselbe, $8 \mathrm{mal}$ vergrösscrt.

Fig. $N$. Dieselbe im Querschnitte: $o$. Nïrgewebe; $p$. Keimling.

Fig. 0 . Die Theilfruchtchen im Längsschnitte. 


\title{
PTYCHOTIS Koch.
}

Blüthen aktinomorph, die randlichen kaum deutlich zygomorph, alle gleichförmig, zwittrig. Frueitknoten unterständig, zweifächrig mit sehr undeutlichen Rippen, glatt oder von feinen Papillen matt. Kelch meist in der Form eines kurzen, mehr oder weniger deutlich fünfzähnigen Wulstes ausgebildet. Blumenblätter umgekehrt eiförmig, dureh die eingebogene Spitze tief zweilappig. Frucht von der Seite zusammengedrïekt, eiförmig, kahl oder papillös, stets in zwei Theilfrüchtehen zerfallend, die an dem Fruchtträger hängen; letztere von 5 fadenförmigen Rippen durchlaufen, unter den Thälchen mit einzelnen, an der Fugenfläche mit gepaarten Ölcanälen. - Einjährige oder zweijährige Kräuter mit mehrfach gefiederten Blättern, letzte Ausgliederungen derselben meist schmal. Dolden zusammengesetzt, mit oder ohne Hüllen, Hüllchen vielblättrig; Blüthen weiss.

Etwa 15 Arten im Mittelmeergebiete, Arabien, Ost-Indien und am Cap.

Anmerkung. Die Gattung ist mit Carum durch Übergänge so allmälig verbunden, dass man sie mit Recht eingezogen und die Arten jener zugerechnet hat.

\section{Ptychotis Ajowan P. DC.}

\author{
Tafel 74 .
}

Die letzten Ausgliederungen sämmtlicher Blätter linealisch; Hülle und Hüllchen mehrblättrig; Blättehen selten getheilt; Frucht weiss, papillös, sehr stark nach Thymian duftend.

Ptychotis Ajowan P. DC. in Mem. soc. gen. IV. 39, Prodr. IV. 109; Wight, Icon. t. 566; Bentl. and Trim. Med. pl. t. 120.

Ligusticum Ajouan Roxb. Cat. hort. Calc. 21.

Ligusticum Ajowain Roem. et Schult. Syst. VI. 556; Fleming, Ind. med. pl. in Asiat. research. I. 170, in Journ. bot. IV. 200.

Athamantha Ajowan Wall. ms, in P. DC. Prodr. l. $c$.

Ammi copticum Linn. Mant. I. 56; Boiss. Fl. orient. 1I. 891; Flück. and Hanb. Pharmacogr. 269; Aschers. et Schwfth. Illustr. Al. d'Égypte so.

Ptychotis coptica P. DC. Prodr. IV. 108.

Carum copticum Benth. in Benth. et Hook. Gen. pl. II. 891; Flück. Pharmacogn. 731; C. B. Cl. in Hook. fil. Fl. Brit. Ind. II. 682 .

Daucus copticus Pers. Enclir. I. 307.

Trachyspermum copticum Lk. Enum. pl. hort. berol. I. 267.

Bunium copticum Spreng. Umbellif. 28.

Bunium aromaticum Linn. Mant. II. 218.

Seseli ammoides Jacq. Hort. Vindob. t. 52.

Sison Ammi Jacq. Hort. Vindob. t. 200.

Ajowan; englisch: Juvanee, Ajouan, Ajawain, True Bischop's weed; französisch: Ajowan.

Die dünne, weisse, fast ganz gerade Pfahlwurzel der einjährigen Pflanze macht nur wenige Äste.

Der am Grunde einfache, weiter oben verästelte Stengel wird $30-90 \mathrm{~cm}$ hoch; er ist stielrund, weiss gestreift, aber kaum gerieft, entweder völlig kahl oder spärlich behaart, fast nur papillös.

Die am unteren Theile des Stengels stehenden Blätter sind verhältnissmässig lang, die oberen kürzer gestielt; der auf der Oberseite mit einer Regenrinne versehene Stiel erweitert sich am Grunde zu einer weiss berandeten Scheide; die Spreite ist zwei- bis dreifach, die obersten sind nur einfach gefiedert, die Fiederehen sind sehmal linealisch, zuweilen fast haarförmig und bis $3 \mathrm{~cm}$ lang. 
An dem Blïthenstande einer zusammengesetzten Dolde sind bisweilen nur 6-7, bisweilen bis 20 Strahlen vorhanden, sie sind kahl oder manchmal kurhaarig; die Hülle besteht aus 4-6, zuweilen auch mehr Blättern, die oft nur $2-5 \mathrm{~mm}$, zuweilen aber auch $10-15 \mathrm{~mm}$ und darïber lang sind; sie soll auch manchmal ganz fehlen; in der Regel sind die Blätter der Hülle ganz, seltener sind sie getheilt. Die Hüllchen, welche die acht- bis sechzehn-, zuweilen noch mehrstrahligen Döldchen stützen, werden aus $3-5$, wohl nicht über $3 \mathrm{~mm}$ langen Blättchen zusammengesetzt; die Länge der Bliithenstielchen beträgt bei der Fruchtreife $2-8 \mathrm{~mm}$.

Die Blüthen sind verhältnissmässig sehr klein, sie haben kaum 1,5 mm Durchmesser. Der unterständige Fruchtknoten misst wenig iiber $0,5 \mathrm{~mm}$; er ist von kurzen Papillen eher matt und grau gefärbt, als wirklich behaart. Der änsserst kurze Kelch erscheint nur wie ein wenig gegliedertcr Wulst auf dem Fruchtknoten. Die Blumenblätter sind etwa $0,6 \mathrm{~mm}$ lang und ebenso breit; die Mittelzipfel sind sehr weit übergebogen, so dass die subquadratischen Blumenblïtter tief ausgerandet erscheinen; sie sind riickseits behaart und an den Seiten vertieft, so dass 2 sich berihrende Blätter eine Grube bilden, die zur Aufnahme der sehr kleinen Staubgefässe, die sie kappenförmig fast umschliessen, bestimmt ist. Das Griffelpolster ist zweilappig und ziemlich gedunsen. Die selr kurzen, kaum 0,3 mm langen Griffel spreizen mässig auseinander.

Die Frucht ist etwa $2 \mathrm{~mm}$ lang und ebenso breit, eiförmig, ein wenig geschnäbelt und von der Seite etwas zusammengedrïckt; sie crscheint von sehr kurzen Härchen oder Papillen gran und zerfällt leicht in die beiden Theilfrïchte, die durch den tief getheilten Fruchtträiger zusammengehalten werden. Die 5 Rippen werden nur an dem schnabelförmigen Ende deutlicher sichtbar. Anf dem Querschnitt erkennt man leicht die 5 einzelnen Öleanäle zwischen den schwach hervortretenden Rippen; die nur mässig eingezogene Fugenseite zeigt deren 2; die Früchte riechen sehr stark nach Thymian.

Anmerkung. Wir haben schon oben gesagt, dass die Gattung Ptychotis kein Anrecht auf ferneren Bestand hat; aber auch der Speciesname Ajonan ist sehr anfechtbar. Nach den jetzt geltenden Regeln für die Nomenclatur der Pflanzen, hat allein Carum copticum Benth. zu gelten.

Die Ajowanpflanze hat eine ziemlich weite Verbreitung von Ägypten durch Mesopotamien, Assyrien, Persien, Affghanistan bis nach Indien; trotz der wiederholten Angaben, dass sie auch Süd-Europa bewohne, haben wir keine verbürgten Angaben daruber finden können; in Ost-Indien wird sie cultivirt und zwar von dem Pendschab und Bengalen bis zum siidlichen Dekkan.

Die Frichte der Ajowanpfanze sind reich an ätherischem Öle, welches neben Kohlenwasserstoffen viel Thymol enthält; die grösste Menge des im Handel vorkommenden Thymols (Thymolum) wird aus diesem ätherischen Öle gewomnen.

\section{Erklärung der Abbildungen.}

Fig. A. Oberer Theil einer Pflanze aus Ost-Indien.

Fig. $B$. Die Blüthe im Begriff aufublühen, 20mal vergrössert.

Fig. C. Dieselbe, in der Vollblüthe.

Fig. D. Das Blumenblatt, 25mal vergrössert.
Fig. $E$. Das Staubgefäss, 20mal vergrössert.

Fig. $F$. Die Frucht, 12mal vergrüssert.

Fig. $G$. Dieselbe, in die Theilfruichte zerfallend.

Fig. $H$. Dieselbe, im Längsschnitte.

Eig. I. Dieselbe, im Querschnitte. 


\title{
PIMPINEIIA Linn.
}

Blüthen völlig aktinomorph, auch die randliehen kaum zygomorph, zwittrig. Fruchtknoten unterständig, zweifächrig mit wenig vorspringenden Rippen. Kelchzähne undeutlieh, oder sehr klein aber etwas deutlicher. Blumenblätter an der Spitze weit eingebogen, selten ausgebreitet und dann sehr schmal, an der äussersten Spitze ausgerandet oder ganz. Griffelpolster dick und breit, zuweilen kurz kegelförmig; Griffel meist verlängert. Frucht im Umrisse eiförmig oder breiter als lang, von der Seite mehr oder weniger zusammengedrüekt, an der breiten Berührnngsfläche häufig eingezogen; Theilfrüehtchen gerundet oder etwas zusammengedriuckt fünfkantig, alle Hauptrippen gleich, dünn, gleich weit von einander abstehend; Ölstriemen sehr viele, sehr dünn, gleichmässig vertheilt oder unter den Thälchen gehäuft. Griffelträger zweitheilig. - Ausdanernde Stauden, selten einjährige Kräuter, die meist kahl, selten an Bliuthen und Früchten behaart sind. Blätter nur selten, und zwar die unteren ganz, gewöhnlich gefiedert oder mehrfach gefiedert. Dolde zusammengesetzt, vielstrahlig; Hülle meist fehlend, selten ein- bis zweiblättrig; Hüllehenblätter ebenfalls in der Regel wenige oder 0. Bluthen weiss oder gelb; Samen oft nur lose von der Fruchthaut umgeben.

A. Einjährig; Fruehtknoten behaart; Hülle und Hüllchen vorhanden; unterste Grundblätter ganz. P. Anisum Linn.

B. Ausdanernd; Fruchtknoten kahl; Hülle und Hüllchen fehlend; Grundblätter gefiedert. P. Saxifraga Linn.

\section{Pimpinella Anisum Limn.}

\author{
Tafel 75 .
}

Einjähriges Kraut. Untere Grundblätter ganz, herzförmig, gesägt, bisweilen kurz gelappt; die oberen dreizählig; Stengelblätter fiederspaltig mit endlich linealisehen Zipfeln; Stengel gestreift, kurz rauhhaarig; Fruchtknoten behaart; Frueht eiförmig mit sehwach vortretenden Hauptrippen, wenig behaart.

Pimpinella Anisum Linn. Sp. pl. ed. I. 264; Plenck, Off. Pf. t. 223; Hayne, Arzneigew. VII. t. 22; Mert. u. Koch in Roehl. Deutschl. Fl. II. 436; Nees, Dïsseld. Abbild. t. 275; P. DC. Prodr. IV. 122; Woodv. Med. pl. I. t. 52; Guimp. u. Schleclt. Pf. Pharmac. II. 32. t. 129; Ledeb. Fl. Ross. II. 294; Willk. et Lange, Prodr. F7. Hisp. III. 97; Boiss. F7. orient. II. 86G; Berg u. Schmidt, Darst. u. Beschr. t. XVIII ${ }^{l}$; Bentl. and Trim. Med. pl.t. 122; Köhler, Mediz. Pfl. t. 93; Flück. and Henb. Pharmacogr. 276; Flück. Pharmacogn. 945; Arth. Mcyer, Drogenkunde II. 443.

Anisum officinale Mönch, Meth. 100.

Carum Anisum H. Baill. in Hist. des pl. VII. 119 et 17S; Pl. méd. II. 1053. fig. 2864.

Sison Anisum. Spreng. Umbellif. prodr. 35; Roem. et Schult. Syst. veg. VI. 407.

Apium Anisum Crantz, Umbellif. 101; Parl. Fl. Ital. VIII. 462.

Tragium Anisum Hoffm. Umbellif. 91; Lk. Enum. hort. Berol. pl. I. 255.

Gemeiner Anis; engliseh: Anise; französiseh: Anis.

Das einjährige Kraut erreicht eine Höhe von $15-60 \mathrm{~cm}$; seine dinne, weisse Wurzel ist nur mit spärlichen Zweigen versehen.

Der Stengel ist krautig, nur bei den in den wärmeren Gegenden, wie in Ägypten, cultivirten Exemplaren ist er bisweilen verholzt; er ist aufrecht und nach oben hin manchmal reichlich verzweigt, stielrund, gestreift, kahl oder mässig behaart und dann etwas rauh.

Die Blätter umfassen mit der seheidenförmigen Erweiterung den Stengel und sind spiralig angereiht. Die untersten Grundblätter sind häufig vollkommen ganz und dann herzförmig oder eiförmig und spitz, am Rande sind sie bisweilen ziemlich tief eingeschnitten gesägt; in anderen Fällen sind sie dentlich dreilappig; diese sind stets sehr lang gestielt. Die folgenden Blätter sind entweder dreispaltig oder öfters 
unpaarig gefiedert mit einem einzigen Fiederpaar; hier sind die Fiedern ähnlich den ganzen Blättern, aber am Grunde breit keilförmig. Die oberen Blätter sind viel kürzer gestielt und doppelt bis dreifach gefiedert, wobei die Zipfel endlich lanzettlich und linealisch werden und zugespitzt erscheinen; die Blätter sind entweder ganz kahl oder nur sehr spärlich behaart.

Die Dolde ist doppelt zusammengesetzt; sie besteht aus 10-15 Strahlen; die Hülle fehlt meist oder sie wird nur aus $1-2$, selten 3 , feinen, fädlichen, kaum 1-2 mm langen Blättern zusammengesetzt. Die fast kugelförmigen Döldchen haben 5-15 Strahlen; die Hüllchen fehlen ebenfalls entweder ganz oder werden durch ein einfaches, bisweilen zwei- oder dreitheiliges Blättchen ersetzt.

Die Blüthen sind sämmtlich gleichartig und frnchtbar, verhältnissmässig klein, auf dem Grunde des Döldehens sitzen bisweilen einzelne oder mehrere nicht entwickelte Blüthen. Der Fruchtknoten ist fast eiförmig, nur von der Seite her ein wenig zusammengedrückt, nur undeutlich gerippt und schwach behaart. Der Kelch ist sehr wenig in der Form eines schwachen Saumes ausgebildet. Die weissen Blumenblätter werden kaum 1,5 mm lang; sie sind flach ausgebreitet von eioblonger Gestalt, zugespitzt und an der Spitze ausgerandet; das obere Drittel ist nach oben eingebrochen. Die 5 Staubgefässe sind mit verhältnissmässig ziemlich langen, dünnen Fäden versehen; die Beutel haben fast kreisförmigen Umriss, sind oben und unten ausgerandet und öffnen sich mit 2 nach innen gewendeten Längsspalten; die schmal elliptischen Pollenkörner sind an beiden Polenden stumpf, sie werden von 3 Meridianfalten durchlaufen, die in der Mitte die Poren tragen. Die beiden Griffel sind verhältnissmässig lang (sie glcichen dem $1 \mathrm{~mm}$ hohen Fruchtknoten), spreizen auseinander und sitzen auf dem zweilappigen, ziemlich hohen Griffelpolster.

Die etwa birnförmige Frucht ist c. $3,5 \mathrm{~mm}$ lang und hat $2 \mathrm{~mm}$ im Durchmesser; die Farbe ist graugriin, im trocknen Zustande bräunlich, seltener gelblich; sehr characteristisch ist für sie die kurze Behaarung aus geraden einfachen Trichomen; sie zerfällt gewöhnlich nicht in die beiden Theilfrüchte und auch die Fuge zwischen ihnen ist wegen der engen Annäherung der 2 Paar Seitenrippen wenig deutlich; ausser ihnen wird sie noch von 3 Paar an der trockenen Frucht häufig geschlängelten Dorsalrippen durchzogen, die stumpf sind und mässig vorspringen. Die Ölstriemen werden nur auf den Querbruch deutlich sichtbar; ihrer sind etwa 30 vorhanden, sie haben einen flach elliptischen Quersehnitt und sind braun gesäumt; zunächst dem Träger der Theilfrỉchte liegen in jeder dersclben 2 sehr grosse Ölgänge.

Der Anis ist wohl sicher ursprünglich in den Ländern des östlichen Mittelmeergebietes heimisch, wird aber gegenwärtig höchstens noch unter Getreide auf der Insel Cypern wild gefunden; er wird in umfangreichem Maasse cultivirt und zwar vorziglich in Sachsen, Thüringen und Franken, ausserdem in West-Frankreich, Spanien, Griechenland und der Türkei, so wie Japan; die grössten Mengen Früchte liefert Russland, die beste Waare Spanien und Malta.

Die Frucht der Pflanze, der Anis, wird als Droge (Fructus Anisi) in den Handel gebracht und auch zur Gewinnung des Anisöles des Oleum Anisi) benutzt.

\section{Erklärung der Abbildungen.}

Fig. A. u. B. Blühende Pflanze, nach einem cultivirten Exemplare.

Fig. C. Die Blüthe, 6mal vergrössert: $a$, das Blumenblatt; b. das Staubblatt; $e$. das Griffelpolster.

Fig. D. Der Fruchtknoten, 10mal vergrössert: $f$. der Griffel; g. die Narbe.

Fig. $E$. Derselbe, 12mal vergrössert: $d$. die Samenanlage.

Fig. $F$. Derselbe, im Querschnitte, $16 \mathrm{mal}$ vergrössort: $k$. seitenstïndige; $l$. bauchständige Ölcanäle.
Fig. $G$. Das Staubblatt, 18mal vergrössert, vom Innern der Blïthe und von aussen betrachtet.

Fig. II. Pollenkörner im Wasser, 250mal vergrössert.

Fig. I. Die Frucht, natürliche Grösse.

Fig. $K$. Dieselbe, 8mal vergrössert: $h$. die Theilfrüchtchen.

Fig. $L$. Dieselbe, im Längssehnitte: $n$. das Nährgewebe; o. das Würzelcheu; $p$. die Blätter des Keimlings.

Fig. M. Dieselbe, im Querschnitte: $i$. die Rippen. 


\title{
Pimpinella Saxifraga Linn.
}

\author{
Tafel 76 .
}

Ansdauernde Staude mit kahlem oder behaartem Stengel; Blätter sämmtlich einfach gefiedert; Blättchen der unteren Blätter oblong oder eiförmig, gesägt (selten fiedertheilig); Griffel kürzer als der Fruchtknoten.

Pimpinella Saxifraga Linn. Spec. pl. ed. I. 263; Flora Danica IV. t. 66; Woodo. Med. pl. I. t. 51; Jacq. Fl. Austr. IV. t. 395; Plenck, Off. Pfl. t. 221; Svensk Bot. t. 160; Schkuhr, Handb. t. 78; Engl. Bot. VI. t. 407; Hayne, Arzneigew. VII. t. 20; Nees, Diisseld. Abb. t. 17; P. DC. Prodr. IV. 120; Mert. u. Koch in Roehl. Fl. Deutschl. It. 435; Guimp. u. Schlecht. Pfl. Pharm. t. 130; Dietr. F7. Bor. X. t. 704; Ledeb. Fl. Ross. II. 255; Willk. et Lange, Prodr. Fl. Hisp. III. 98; Godr. et Gren. Fl. Fr. I. 727; Boiss. Fl. orient. II. 573; Garcke, Fl. Deutschl. ed. XVII. 245 cum ic.; Aschers. F7. Brand. 397, Berg u. Schmidt, Darst. u. Beschr. fig. It ; Köhler, Mediz. Pfl. t. 142; Flück. Pharmac. 462; Arth. Meyer, Drogenkunde I. 248.

Pimpinella nigra Willd. Spec. pl. I. 1471; Fl. Dan. t. 669; Reichb. Icon. fl. Germ. XXI. t. 28. fig. 1. $u .2$.

Pimpinella alpina Host, F7. Austr. 1. 399.

Pimpinella hircina Leers, Herb. 79; Mnch. Fl. Hass. n. 255.

Pimpinella genevensis Vill. Dauph. II. 604.

Apium Tragioselinum Crantz, Umbell. 100; Parl. F7. Ital. VIII. 455.

Pimpinelle oder Bibernelle, Steinpeterlein oder Bockspetersilie; französisch: Boucage; englisch: Cockweed, Dittander, Pepperwort.

Die sehr kräftige Pfahlwurzel geht bis zu einer Tiefe von bisweilen mehr als $30 \mathrm{~cm}$ senkrecht in die Erde und erreicht oben einen Durchmesser von mehr als $3 \mathrm{~cm}$; auf ihr sitzt die kurze verästelte Grundaxe, ein Verhältniss, das man frïher durch den Ausdruck, die Wurzel sei mehrköpfig, bezeichnete; sie ist spärlich verästelt, aussen hellgelblich, braun bis schwärzlich, innen weiss; die Rinde ist schwammig und enthält zahlreiche Gänge eines weissen Balsams, der bei einer Varietät (var. nigra) an der Luft schön himmelblau gefärbt wird; auch dieser wird aber, wie bei den gewöhnlichen Formen bald braun.

Der Stengel erreicht eine Höhe von $70 \mathrm{~cm}$; sehr selten wird er höher, meist ist er niedriger, er ist im oberen Theile reich verästelt, jeder Ast geht in einen Blüthenstand aus; am Grunde wird er von einer Rosette von Grundblättern und den geschwärzten Scheiden der vorjährigen Blätter umgeben, aus der Achsel der ersteren erscheinen im nächsten Jahre die neuen Triebe, wodurch die oben erwähnte Vielköpfigkeit bedingt wird. Der Stengel ist stielrund gestreift oder seicht canellirt, entweder rein grün oder roth gestreift, kahl oder mehr oder minder kurz grauhaarig.

Die Blätter besitzen am Grunde eine umfangreiche, häutige Scheide; der Stiel hat auf der Oberseite eine seichte Regenrinne, die sich auch auf die Blattspindel ausdehnt; sämmtliche Blätter sind einfach gefiedert, gewöhnlich mehr oder minder stark behaart; die Grundblätter können eine Länge von $25 \mathrm{~cm}$ erreichen, sie sind unpaarig und zwar gewöhnlich vier- bis fünfjochig gefiedert (das Endblättchen eingerechnet); die Fiedern erreichen eine Länge von $3 \mathrm{~cm}$ und eine Breite von $2 \mathrm{~cm}$; ihre Form ist elliptisch oder eiförmig, oben sind sie spitz, am Grunde breit keilförmig oder gerundet, meist sind sie sitzend der Spindel angeheftet, zuweilen aber auch kurz gestielt, am Rande sind sie mehr oder minder tief gesiigt. Die Stengelblätter werden kleiner, haben weniger Fiederblättchen und diese sind kleiner und weniger gegliedert, bis schliesslich an den obersten die Scheide nur in ein fün- oder dreizähniges Spitzchen ausgeht, das bisweilen auch noch fehlt.

Die Doppeldolde hängt vor der Vollblithe über, Hülle und Hüllchen fchlen; sie besteht aus 10-20 Strahlen, und auch die Döldchen werden aus einer ansehnlichen Zahl von Blithen aufgebaut, die auf fadenförmigen Stielen stehen; sämmtliche Blüthen sind gleichgestaltet nnd zwittrig. 
Der unterständige Fruchtknoten ist eiförmig, doch von der Seite her zusammengedrüekt, vollkommen kahl und nur wenig deutlich gerippt; das Griffelpolster ist sehr hoch und geschwollen, mit ihm zusammen misst der Fruchtknoten kaum $0,7 \mathrm{~mm}$; die beiden spreizenden Griffel sind noch kürzer. Der Kelch ist nicht ausgebildet; die kaum 1,5 mm langen, im oberen Drittel eingeschlagenen, eioblongen, zugespitzten und an der Spitze gestutzten oder schwach ausgerandeten, weissen Blumenblätter sind wenig tiber $1 \mathrm{~mm}$ lang. Die Staubfäden sind weniger lang wie bei dem Anis.

Die Frucht hat eine Länge von $2,5 \mathrm{~mm}$ und eine grösste Breite von $2 \mathrm{~mm}$; sie ist eiförmig und ein wenig von der Seite her zusammengedriickt, an der Fugenseite ist sie deutlich eingezogen, die Farbe ist braun; die Rippen treten nicht auffallend hervor; unterhalb des Griffelpolsters ist der Kelch als gefalteter Kragen deutlicher sichtbar. Die Öleanäle liegen zu dreien zwisehen den Rippen; anf der Fugenseite befinden sich in jeder Theilfrucht 4 ; die letzteren lösen sich auch nur schwer von einander ab.

Anmerkung. Dic hier mitgetheilte Beschreibung bezieht sich lauptsächlich auf die typische Form und berïeksichtigt die var. nigra (Willd.), welche sich durch krïftigeren Wuchs, graue Behaarung in den oberen Theilen der Pflanze und die Blaufärbung der Wurzel unterscheidet. Andere Varietiten sind var. hircina (Leers als Art) mit fiedertheiligen Blïttchen der Grundblätter und var. alpestris Koch mit handförmig getheilten Blättchen. Dagegen möchten wir Pimpinella magna Linn., die von maschen Autoren ebenfalls für eine Varietït der Art angesehen wird, als cigene betrachten.

Die Bibernelle wächst an Wegen, an troekenen Abhängen, auf Rainen und Triften, an steinigen Stellen der Gebirge und in trockenen Birkenwäldern dureh ganz Europa, von Spanien bis Nord- und Süd-Russland, auch in Sibirien ist sie weit verbreitet; in Italien ist sie noch gemein, auf der Balkanhalbinsel ist sie aber nur noeh spärlich verbreitet; vom Kaukasus lässt sie sich bis Armenien verfolgen.

Als Bibernellwourzel, Radix Pimpinellae, werden die getrockneten unterirdischen Theile von Pimpinella Saxifraga und Pimpinella magna in den Handel gebracht.

\section{Erklärung der Abbildungen.}

Eine Pflanze der var. nigra (Willd.) von Rïdersdorf bei Berlin.

Fig. A. Die Bluthe, $12 \mathrm{mal}$ vergrissert: $a$. das Blumenblatt; b. der Staubfaden; $c$. der Griffel.

Fig. B. Das Staubgefïiss, 30ual vergrüssert.

Fig. C. Pollenkürner in der Luft und im Wasser, 250mal vergrössert.

Fig. D. Der Fruchtknoten, $12 \mathrm{mal}$ vergrössert: $a$. der Fruchtknoten; $b$. das Griffelpolster; $c$, der Griffel.

Fig. E. Die Frucht, $10 \mathrm{mal}$ vergrössert: $a$. der Träger der
Theilfrïchte; $b$. die Theilfrucht; $c$. das Griffelpolster; $\boldsymbol{d}$. der Griffel.

Fig. F. Dieselbe, im Querschnitte: $a$. die Fugenfläehe (Berührungsstelte der Theilfrüchte); $b$. die Rippen; $c$, die Ölcanäle; $d$. das Nährgewebe.

Fig. $G$. Die Theilfrucht im Längsschnitte: $a$. die Fruchthaut; $b$. der Same; $c$. der Keimling; $d$. die Keimblätter.

\section{FOENICULUM Gärtn.}

Blüthen völlig aktinomorph, gleichförmig, alle fruchtbar. Fruchtknoten unterständig, zweifächrig mit wenig deutlich vorspringenden Rippen. Kelch nur als undeutlich gegliederter, verdickter Wulst ansgebildet, Blumenblätter stumpf zugespitzt, an der Spitze kaum ausgerandet, im oberen Drittel nach innen eingerollt. Griffelpolster hoch kegelförmig, nur selten gefurcht, nicht bis auf den Grund getheilt. Frucht ellipsoidisch mit breiten Fugenflächen und sich hier berührenden Rippen; die Dorsalrippe stark hervortretend, unter den Thälchen einzelne, an der Fugenfläche gepaarte Ölcanäle; sie zerfällt leicht in Theilfrüchte, die an dem bis zur Mitte gespaltenen Fruchtträger hängen. - Zweijährige, oft bohe Kräuter oder Stauden mit mehrfach zusammengesetzten Blättern, die in linealische oder haarförmige Zipfel ausgehen. Dolden zusammengesetzt, Hiillen wie Hüllchen fehlen; Blüthen gelb.

4 Arten, welche sämmtlich im Mittelmeergebiet und auf den Canarischen Inseln wachsen; eine derselben wird in vielen Formen ubber die ganze Erde cultivirt und verwildert häufig. 


\section{Foeniculum capillaceum Gilib.}

\section{Tafel 77.}

Ausdauernde Stande mit kahlem, stielrundem, blaubereiftem Stengel; Fiedern und Fiederchen sparrig nach verschiedenen Richtungen gewendet, nicht in eine Ebene fallend.

Foeniculum capillaceum Gilib. Fl. lithuan. II. 40; Aschers. Fl. M. Brandenb. 247; Garcke, Fl. Deutschl. ed. XVI. 185; Baill. Pl. méd. II. 1050; Flïck. Pharmacogn. 948; Koehler, Mediz. Pfl. t. 88; Parl. Fl. Ital. VIII. 308 .

Foeniculum vulgare Mill. Dict. 1; Gürtn. Fr. I. 105. t. 23; Hoffm. Umbellif. I. 120; Mert. u. Toch in Roehl. Deutschl. Fl. II. 420; P. DC. Prodr. IV. 142; Guimp. u. Schlecht. Pf. Pharmac. III. 39. t. 232; Baxt. Brit. Bot. III. t. 176; Wight, Icon. t. 515; Godr. et Gren. Fl. Fr. I. 712; Battand. et Trab. Fl. d'Alg.II. 362; Flück. ct Hanb. Pharmacogr. 274.

Foeniculum officinale Allione, Fl. Pedem. 1I. 25; Koch, Syn. 293; Ledeb. Fl. Ross. II. 271; Willk. et Lange, Prodr. Al. Hisp. III. 50; Boiss. Flora orient. II. 975; Berg u. Schmidt, Darst. u. Beschr. t. XXVII ${ }^{d}$; Bentl. and Trim. Med. pl. t. 123.

Foeniculum dulce P. DC. Prodr. IV. 142.

Foeniculum sativum Bertol. Fl. Ital. III. 340.

Anethum Foeniculum Linn. Spec, pl. ed. I. 263; Plenck, Off. Pfl. t. 216; Engl. Bot. XVII. t. 120S; Hayne, Arzneigew. VII. t. 18; Nees, Düsseld. Abbild. t. 277.

Ligusticum Foeniculum Crtz. Umbellif. 82 .

Foeniculum piperitum Sweet, Hort. Brit. 151; P. DC. Prodr. IV. 142; Boiss. Fl. orient. II. 975.

Meum piperitum Roem. et Schult. Syst. VI. 435.

Foeniculum panmorium P. DC. l. c.; ITight, Icon. t. 570 .

Foeniculum divaricatum Gris. Spicileg. Rumel 358.

Anethum panmorium Roxb. Hort. Beng. 22; Fl. Ind. II. 94; Flem. Cat. Ind. med. t. 6.

Ozodia foeniculacea Wight et Arn. Prodr. Al. Ind. 375 .

Fenchel; französisch: Fenouille; englisch: Fennel.

Die Wurzel wird bei den ausdauernden Formen oder Varietäten bis $30 \mathrm{~cm}$ lang und 2,5 $\mathrm{cm}$ dick, ist aussen schmutzig, innen reiner weiss, fleischig und reichlich von Ölcanälen durchsetzt; bei gewissen einjährigen Culturformen ist sie dagegen dinner und kürzer.

Der im Herbste absterbende Stengel erreicht eine Höhe von $2 \mathrm{~m}$, er ist stielrund, kahl, aufrecht, vielfach verästelt, gestreift, dunkelgrïn und blau bereift, im Innern mit Mark gefüllt.

Die Blätter stehen in spiraliger Anreihung*), die grundständigen erreichen eine Länge von $25 \mathrm{~cm}$ und wohl auch noch dariber bei derselben Breite; sie sind mehrfach zusammengesetzt, gestielt und besitzen eine breite, am oberen Ende in 2 kurze Öhrchen ausgehende Scheide; sie sind völlig kahl, häufig: erscheinen sie in der Spindel mehr oder minder geknickt, so dass die Blattstrahlen nach allen Richtungen des Raumes gewendet sind; nach oben hin werden sie allmälig weniger gefiedert, so dass die sich verhältnissmässig vergrössernde Scheide schliesslich nur noch von einer einfach gefiederten, ja sogar nur gedreiten Spreite abgeschlossen wird, die manchmal auch noch fehlt; die gewöhnlich verlängerten (bis $3 \mathrm{~cm}$ langen) Blattabschnitte sind sehmal linealisch oder fast haarförmig und werden oberseits von einer Rinne dureblaufen.

Alle Äste gehen schliesslich in einen Bluthenstand aus, der durch Übergipfelung aus der Achsel des letzten Blattes blattgegenständig erscheint. Er ist eine zusammengesetzte Dolde, die aus 10-13 (8-16) Strahlen aufgebaut wird; die Hille fehlt. Die ziemlich flachen Döldehen bestehen aus gewöhnlich mehr als 15 Bluthen von gelber Farbe, die sämmtlich gleich gebant, vollständig und fruchtbar sind.

*) Bei der in Italien häufig cultivirten Form soll der Stengel flach gedrüekt und die Stellung der Blïtter abwechselnd zweizeilig sein.

Berg u. Schmidt, Officinelie Gewàchse. II. 
Der Fruchtknoten ist im Umrisse oblong, von den Seiten ein wenig zusammengedrïckt und trägt $10 \mathrm{nur}^{\circ}$ wenig dentlich vorspringende Rippen. Der Keleh ist kaum dureh einen Wulst angedentet. Die gelben, etwa 1,5 mm langen und $1 \mathrm{~mm}$ breiten Blumenblätter sind nieht wie meist in der Familie an der Spitze eingekniffen, sondern nach oben gerollt, daher erscheinen sie auch nicht ausgerandet; die Spitze ist stumpf; auf der Oberseite verläuft längs des Mittelnerven ein vorspringender kantiger Kamm. Die Staubblätter tiberragen an Länge die Blumenblätter; Staubbeutel und Pollenkörner wie bei anderen Verwandten. Das gelbe Griffelpolster ist in der Mitte nur oberflächlich gefurcht, nieht bis zum Grunde getheilt, die sehr kurzen Griffel stehen aufreeht.

Die Frucht wird 4-7 mm lang und $3-3,5 \mathrm{~mm}$ breit, falls beide Theilfriichte entwickelt sind; bisweilen sehlägt aber eine fehl, unter diesen Umständen ist die Frucht meist hornförmig gekrimmt, sonst ist sie ellipsoidiseh und trägt an der Spitze das erhärtende Griffelpolster; die Theilfrüchte lösen sieh meist leieht und werden von den bis zur Hälfte gespaltenen Fruchtträgern festgehalten. Die Farbe der Früchte ist hellgrïn mit blasseren oder bräunliehen Rippen, die mehr oder minder vorspringen, znweilen sogar fast geflügelt erseheinen; die seitliehen, sich dicht berïlurenden sind etwas grösser als die rïekenständigen. Auf dem Querschnitte sieht man die dunkelbraunen Ölcanäle unter den Thälchen.

Anmerkung. Die von Bertolini als besondere Arten aufgestellten $F$. sativum und $F$. dulce, von denen in Italien die Samen (frisch und getrocknet) bez. die gebleiehten, unteren Stengeltheile (Finocchi) gegessen werden, sind im Wesentlichen nur dadurch versehieđen, dass sie einjährig sein sollen; wir vermögen sie nicht als Varietäten anzuerkennen; dagegen ist F. piperitum Sw. wegen der kurzen, sehr krausen Blattabschnittc eine gut gekennzeichnete Form, der man den Character einer Varietiit belassen kann. - Der Name Foeniculum capillaceum Gil. wird besser fallen gelassen, da GiLIBERT ganz zweeklos Livsé's Namen veränderte; der folgende $F$. vulgare Mill. ist entschieden vorzuziehen.

Der Fenchel ist mit Sieherheit wohl nur in den Mittelmeerlïndern als wild anzusehen und geht von Spanien und Nord-Afrika bis naeh dem Peloponnes, Macedonien und Thrazien; in Süd-Russland ist er kaum ursprtinglieh heimisch, dagegen kommt er in den südlichen Kaukasusländern, in Nord-Persien vielfach vor und geht bis nach Vorder-Indien. Er wird häufig enltivirt und verwildert leicht; selbst aus Uruguay lag uns ein scheinbar wild gesammeltes Exemplar vor.

Die Frucht der Pflanze wird als Fenchel, Fructus Foeniculi, in der Mediein angewandt und als Gewürz gebrancht. Das in den Öleanälen der Frucht enthaltende Secret liefert das ïtherisehe Fruehtöl, welehes als Oleum Foeniculi offieinell ist.

\section{Erklärung der Abbildungen.}

Fig. A. Oberer, blithender Theil einer eultivirten Pflanze.

Fig. B. Eins der unteren Blätter.

Fig. C. Die Blüthe, 8mal vergrössert: $d$. das Griffelpolster; $f$. das Blumenblatt.

Fig. D. Der Fruchtknoten, 12mal vergrössert: $a$. der Fruehtknoten; $b$. der Keleh.

Fig. $E$. Derselbe, im Längssehnitte: c. die Samenanlage.

Fig. $F$. Derselbe, im Quersehnitte, $15 \mathrm{mal}$ vergrössert: $i$. die Rippen; $l$. die Ölcanälehen.

Fig. $G$. Das Blumenblatt.
Fig. $H$. Das Staubblatt vom Innern der Bltithe betrachtet und von aussen, $16 \mathrm{mal}$ vergrössert.

Fig. $K$. Das Pollenkorn, troeken und im Wasser, 250mal vergrössert.

Fig. $L$. Die Frueht, natürliehe Grösse.

Fig. M. Dieselbe, 4mal vergrössert.

Fig. $N$. Dieselbe im Quersehnitte, $7 \mathrm{mal}$ vergrössert; $m$. das Nährgewebe.

Fig. $O$. Dieselbe im Längssehnittc, 4mal vergrüssert; $n$. der Keimling. 


\section{OENANTHE Linn.}

Blüthen zuweilen vielehig, dann die männlichen häufig auffallend zygomorph. Fruchtknoten unterständig, wenig gerippt. Kelch mit deutlichen pfriemförmigen, bisweilen bei der Fruchtreife auswachsenden Blättern. Blumenblätter mit langer eingebogener und eingebrochener Endigung, an der Spitze ausgerandet oder zweilappig. Griffelpolster zusammengedriickt kegelförmig, ungefurcht, nicht gedoppelt; Griffel kurz, zuweilen bei der Fruchtreife heranwachsend und steif, seltener abfällig. Frucht eiförmig, cylindrisch, birnoder kugelförmig mit breiter Fugenfläche; die Dorsal- und Seitenrippen bald mehr, bald minder vortretend, bisweilen gefurcht oder korkig verdickt, sie fliessen auch manchmal zusammen, die Commissuralrippen sind stets verdickt. Je ein einzelnes Ölcanälchen liegt unter den Thälchen, je zwei sind an der Fugenfläche. Die Theilfrüchte hängen nicht an einem Fruchtträger herab. - Kahle Stauden, die meist am Wasser oder in Sümpfen wachsen, mit faserigen oder spindelförmig verdickten Wurzeln. Blätter einfach oder mehrfach gefiedert, selten auf röhrenförmig-linealische Blattstiele reducirt. Dolde zusammengesetzt, Hïlle und Hïllchen häufig entwickelt. Blüthen weiss.

Wohl kaum mehr als 20 Arten, die in der nördlichen Erdhälfte, ausserdem aber in Siid-Afrika und in Australien gedeihen.

\section{Oenanthe Phellandrium Lam.}

\section{Tafel 78}

Zweijähriges Kraut, vielleicht anch ansdanernde, sparrig verzweigte Staude mit fadenförmigen Wurzeln; Blätter mehrfach gefiedert; die Fiederblättchen an den Wasserblaittern haarförmig, an den Luftblättern eiförmig und doppelt, die der obersten einfach gefiedert, an den Fiederinsertionen sind die Blätter nach rïckwärts gebrochen; Dolden vielstrahlig, ohne Hülle; Hillchen vielblättrig; Frïchte fast ellipsoidisch; Griffel kürzer als die Frucht.

Ocnanthe Phellandrium Lam. Fl. Fr. III. 132; Mert. u. Koch in Rocht. Doutseht. Fl. II. 417; Nees, Diisseld. Abbild. t. 281; P. DC. Prodr. IV. 135; Koch, Syn. 293; Ledeb. Fl. Ross. II. 269; Willk. et Lange, Prodr. Fl. Hispan. III. 53; Godr. ct Gren. Fl. Fr. I. 716; Boiss. Fl. orient. II. 910; Relk. fil. Icon. Fl. Germ. Umbellif. 29.t. 1596; Berg u. Schmidt, Darst. u. Beschr. XXV'; Köhler, Mcliz. Pf. t. S5; Parlat. Fl. Ital. VIII. 500; Baill. Fl. méd. 1062; Flïck. Plarmacogn. 950; Arthur Meyer, Drogenk. II. 435 .

Oenanthe aquatica Lam. Encyel. méthod. IV. 530; Garcke, Fl. Deutschl. 249.

Phellandrium aquaticum Linn. Spec. pl. ed. I. 255; All. Fl. Pcdem. II. 17; Plenck, Offiz. Pfl. t. 210; Fl. Dan. VII. t. 1154; Engl. Bot. X. 1. 684; Sm. Brit. Fl. t. 321; Socnst. Bot. III. t. 155; Haync, Arzneigew. I. t. 40; Hoffm. Umbellif. I. 71. t. I. fig. 17; Guimp. u. Schlecht. Pf. Pharmac. III. 22. t. 217.

Ligusticum Phellandrium Crtz. Umbellif. 83; Roth, Fl. Germ. I. 123. 11. 321.

Phellandrium conioides Nolte.

Wasserfenchcl, Pferde- oder Rosshïmmel; französisch: Phellandre; engliseh: Waterfonnel.

Die Hauptwurzel entwickelt sich nur zu mässiger Grösse, dafür treten aus den unteren Knoten des Stengels zahlreiche quirlförmig gestellte, fadenförmige, verästelte, weisse Nebenwurzeln hervor; die an den oberen Knoten sind dïnner, die unteren dicker; sie werden von zahlreichen Luftgängen, die durch einschichtige Wände getrennt sind, durchzogen.

Der blühende Stengel entwickelt sich erst im zweiten Jahre aus einer Rosette, die im ersten Jahre gehildet wurde; er hat eine Höhe von $0,60-1,50 \mathrm{~m}$, wird häufig sehr dick und ist anfrecht, hohl, nur an den Knoten mit Querböden versehen, aussen gestreift und vollkommen kahl; der unter dem Wasser 
befindliche Theil ist hänfig verkürzt; uiber dem Wasser ist er oft zickzackförmig hin- und hergebogen und sehr reich verästelt. Auch in der Rinde verlaufen Lufteanäle.

Die Blätter des Stengels stehen spiralig angereiht; sie erreichen biswcilen eine Länge von 2 dem und werden unten fast ebenso breit; sie sitzen auf einem ziemlich langen, schwach rinnigem Stiel, der sich am Grunde zu einer dünnen, mässig umfangreichen Scheide verbreitert; sie sind meist drei- bis vierfach gefiedert, die obersten im minderen Grade gegliedert; die untersten Blätter sind ihrer Funetion als Wasserblätter entsprechend mit schmalen, linealischen, herabhängenden Fiederchen versehen; diese sind sehr vergänglich und versehwinden vor der Vollblüthe der Pflanze. Die Luftblätter sind an der Einsatzstelle der Fiedern und Fiederehen zurüekgebrochen; die letzten Ausgliederungen der Blätter sind eiförmig und fiedersehnittig mit kurzen, lineallanzettlichen Absehnitten.

Die Hauptaxe geht endlich in einen Blüthenstand aus, der durch cinen Zweig ans der Achsel des obersten Laubblattes uibergipfelt, zur Seite geworfen und blattgegenständig wird; auch diescr Zweig endet nach mehreren Blättern oder endlich einem einzclnen mit cinem Blïthenstande, der ebenfalls wieder in die seitliche Stellung ibbergeführt wird. Ganz gleich verhalten sich auch die Äste, welche aus den unteren Blättern des Stengels hervorbrechen. Der kurzgestielte Blüthenstand ist eine zusammengesetzte Dolde mit 6-12 Strahlen, der die Hülle fehlt. Die Döldehen sind sehr viclstrahlig und werden am Grunde von einem Huillehen gestiitzt. Dieses besteht aus mehr als 10 lanzettlichen bis pfriemförmigen, zugespitzten, grinen, schwach weissgerandeten Blätchen, dic kaum länger als $3 \mathrm{~mm}$ sind.

Die auf 2-4 mm langen Stielen sitzenden Blïthen scheinen immer sümmtlich zwittrig zu scin; der unterständige Frnehtknoten ist zur Blithezeit noeh nicht $1 \mathrm{~mm}$ lang und sehr wenig deutlich gerippt. Die pfriemlichen Kelchblätter sind cbenso lang und am Grunde frei. Die weissen Blumenblätter der äusseren Blüthen sind ungleich lang, die nach aussen gewendeten am längsten, so dass die Blüthe zygomorph crscheint; sie sind umgekehrt eiförmig und laufen in eine lange, pfriemliche Spitze aus, die scharf eingebrochen ist und eine Längsleiste des Blumenblattes berührt; die Spitze des Blattes erscheint deshalb ausgerandet. Die Staubgefäisse sind verhältnissmässig lang (bis $2 \mathrm{~mm}$ ) und mit haarfeinen Fäden versehen, die braunen Beutel haben einen Durchmesser von kaum 0,25 mm. Das weisse Griffelpolster hat die Länge des Fruehtknotens; es ist kegelförmig, etwas seitlich zusammengedrückt und oberflächlich gefureht; die aufrechten, wenig spreizenden Griffel mit kopfiger Narbe sind ebenso lang wie das Griffelpolster.

Die Frueht hat eine Länge von $3,5-4,5 \mathrm{~mm}$; sie ist ellipsoidisch, von den Seiten her sehr mässig zusammengedriickt und wird von den Kelehzipfeln, sowie dem Griffelpolster mit den herangewachsenen spreizenden Griffeln gekrönt. Ihre Farbe ist brann; die Dorsalrippe sowic die Seitenrippen treten an den Theilfrüchtehen wenig hervor, die Commissuralrippen sind etwas stärker; bei der Lösung fallen sie sogleich ab; bleiben also nicht an dem Fruchtträger hängen. Auf dem Querschnitte sieht man unter den 4 Thälchen je ein braunes Ölcanälchen, unter der helleren Fugenfläche liegen deren 2.

Der Wasserfenchel findet sich am Rande von stehenden und langsam fliessenden Gewässern dureh ganz Europa bis Nord-Spanien und Italien; auf der Balkanhalbinsel scheint er zu fehlen; in Russland ist er jedoch weit verbreitet und geht von hier einerseits bis nach Sibirien und dem Altai, andererseits über den Kaukasus und Nord-Persien bis zum Kaspi-See.

Die getrockneten Frïchte der Pflanze werden als Fructus Phellandrii, Semen Foeniculi aquatici, Wasserfenchel oder Rossfenchel in den Apotheken geführt.

\section{Erklärung der Abbildungen.}

Fig. A. Zweig einer blühenden Pflanze.

Fig. B. Die änssere Blüthe eines Döldchens, 8 mal vergrössert: $d$. das Blumenblatt; $e$. das Staubgefäss; $f$. das Griffelpolster.

Fig. C. Der Fruchtknoten mit dem Stempel, 12mal ver- grössert: $a$. der Fruchtknoten; $c$. der Kelch; $g$. die Griffel; $h$. die Narben.

Fig. D. Längsschnitt durch denselben, $15 \mathrm{mal}$ vergrössert: b. die Samenanlagen.

Fig. E. Querschnitt durch denselben, 25 mal vergrössert. 
Fig. $F$. Das Blumenblatt, 18 mal vergrössert.

Fig. G. u. $H$. Das Staubgefäss von innen und von aussen betrachtet, $30 \mathrm{mal}$ vergrössert.

Fig. I. u. K. Pollenkörner trocken und im Wasser, $300 \mathrm{mal}$ vergrössert.

Fig. L. Die Frucht, natürliche Grösse.

Fig. M. Dieselbe, 6 mal vergrössert: i. Theilfrüchtchen; $k$. Commissuralrippen; $l$. Ölcanälchen.
Fig. $N$. Dieselbe im Quersehnitte, 15 mal vergrössert: $n$. Nährgewebe.

Fig. $O$. Das Theilfriichtehen von der Fugenfläche gesehen: m. Fruchtträger.

Fig. $P$. Dasselbe im Längsschnitte: $o$. Würzelchen; $p$. Blättehen des Keimlings.

\section{LEVISTICUM Koch.}

Blüthen gleichförmig und aktinomorph. Fruchtknoten unterstïndig mit stark vorspringenden Rippen, kahl. Kelch undeutlich. Blumenblätter mit breiter, flach eingebogener Spitze, daher seicht ausgerandet. Griffelpolster tief zweilappig, Griffel spreizend. Frucht von oblongem Umriss, wenig vom Ritcken her zusammengedritekt, mit 5 stark vorspringenden Rippen, von denen die an der Fugenfläche grösser und fast flügelartig verbreitert sind; unter jedem Thälchen liegt ein Ölcanälchen, unter der Fugenfläche befinden sich 2, einander sehr genähert. Fruchtträger zweispaltig. - Eine hohe, aufrechte, verzweigte Staude, mit doppeltgefiederten Blättern und fiederschnittigen Blättchen. Dolde zusammengesetzt, vielstrahlig, mit Hülle und Hüllchen versehen.

Eine Art, deren Heimath nicht sicher bekannt ist.

\section{Levisticum officinale Koch.}

Tafel 79 .

Aufrechte, kahle, verzweigte Staude mit gestreiftem Stengel; Blätter doppelt gefiedert, glänzend, mit keilförmigen bis lanzettlichen, fiedertheiligen bis ganzrandigen Blättehen; Blättehen von Hülle und Hulllehen breit, weiss gerandet; Blüthen gelb.

Levisticum officinale Koch, Umbellif. 101. fig. 41; Mert. u. Koch in Roehl. Deutschl. Fl. II. 393; P. DC. Prodr. IV. 165; Koch, Syn. 300; Dictr. Fl. bor. XI. t. 755; Ledeb. Fl. Ross. II. 292; Willl. et Lange, Prodr. Fl. Hispan. III. 58; Godr. et Gren. Fl. Fr. I. 654; Parlat. Fl. Ital. VII; Berg $u$. Schmidl, Darst. u. Beschr. XXV' Föhller, Mediz. Pf. t. 120; Fliickig. Pharmacogn. 459; A. Meycr, Drogenkunde I. 247; Gareke, Flora von Deutschl. 255 eum ic.

Levisticum vulgare Rchl. Fl. Germ. excurs. 463.

Levisticum paludapifolium Aschers, F7. M. Brand. 250; Rchb. fil. Icon. Fl. Germ. Umbcllif. 50. t. $19+1$.

Ligusticum Levisticum Linn. Spec. pl. ed. I. 250; Plenck, Offiz. Gew. t. 169; Gürtu. Fr. II. 85; Hayne, Arzneigew. VII. t. 6; Nees, Dïsseld. Abbild. t. 278; Guimp. u. Schlecht. Pfl. Pharmac. II. 9t. 1. 178 ; Parlat. Fl. Ital. VIII. $3+3$.

Angelica Levisticum All. Fl. Pedem. 1I. 10; P. DC. Fl. Fr. IV. 306; Baill. Pl. méd. 1049.

Angelicu paludapifolia Lam. F\%. Fr. III. 451.

Liebstöckel; französisch: Livèche oder Ache de montagne; englisch: Bladderseed.

Die Keimpfanze erzeugt im ersten Jahre eine kräftige, mässig verzweigte Pfahlwurzel und eine Rosette aus grossen Blättern, die im zweiten zu einem blihhenden Stengel auswächst; anstatt dass aber, wie bei sehr vielen Familienverwandten, mit jenem die ganze Pflanze nach der Samenerzengung zu Grunde geht, wird aus dem Grunde des Stengels eine Grundaxe (Rhizom), welehe in den Achseln der Blätter 
Knospen birgt; im nächsten Jahre treiben dann 1 oder 2 oder mehrere aus und es entsteht jenes Verhältniss, welches die frühere Botanik als mehrköpfige Wurzel fälschlich bezeichncte. Dicse Grundaxe ist von den Ansätzen der Blattscheiden geringelt, verzweigt, dick, anssen bräunlich-gelb, innen weisslich und mit umfangreichem Mark versehen; von ihr gehen bis $40 \mathrm{~cm}$ lange, bis fingerdicke Wurzeln aus, die mit regelmässig gestellten Querhöckern, unentwickelten Zweiganlagen, versehen sind.

Der Stengel erreicht oft eine Höhe von mehr als $2 \mathrm{~m}$, er ist dunkelgrïn, steif aufrecht und besonders oben reichlich verästelt, gestreift, kahl und im Innern hohl, nur an den Blattcinsatzstellen durch Querböden gefächert.

Die Blätter stehen in spiraliger Anreihung, die beiden obersten an der Hauptaxe aber, wie an den Seitenzweigen, sind so weit genähert, dass sie, wenn auch in bemerkbar verschiedener Höhe, einander gegenüberstehen, desswegen sind auch die beiden obersten Äste fast gegenständig. Die untersten Blätter erreichen oft die sehr bedentende Grösse von $60 \mathrm{~cm}$, sind lang gesticlt und doppelt gefiedert; der Stiel erweitert sich am Grunde zu einer breiten, lederartigen Scheide; die Fiedern sind auf der Oberseite einander sehr genähert eingelenkt, zwischen ihnen geht die auf der Oberseite längs verlaufende, schwache Regenrinnc hindurch; die Zahl der Joche schwankt zwischen 4 und 6 ; die Fiederchen sind mehr oder weniger, die Endfiederchen bisweilen sehr ticf geschlitzt oder gelappt, am Grunde sind sic keilförmig oder schief gerundet; die Textur ist etwas fleischig, ihre Farbe ist dunkclgriin, sie sind auf beiden Seiten lebhaft glänzend. Dic oberen Blätter vereinfachen sich in der Blithenregion schr schnell, so dass auf der Scheide nur eine dreilappige, endlich eine ganzrandige Spreite aufgesetzt ist, welche bisweilen nur $1 \mathrm{~cm}$ oder noch weniger misst.

Die Hauptaxe geht in einen gestielten Blithenstand aus, der von den beiden benachbarten, cbenfalls blïhenden Asten iiberragt wird. Er ist eine zusammengesctzte, zicmlich flache Dolde, dic 8-15, selten mehr oder weniger Strahlen trägt; sie wird von einer sechs- bis fünfzehnblättrigen, zurïckgeschlagenen Hiille gestitzt, deren Blättchen meist $5-10$, sclten bis $15 \mathrm{~mm}$ lang, lanzettlich oder eilanzettlich, zugespitzt, grün und weiss gerandet sind. Die auf $1-3 \mathrm{~cm}$ langem Stiele sitzenden, gewölbten Döldchen sind reichbliuthig und tragen am Grunde ein Hüllehen aus ebenfalls zahlreichen Blättchen, welche denen der Hülle ähnlich, nur kleiner sind. Dic Blüthenstielchen messen in der Zeit der Vollblithe kaum mehr als $1,5 \mathrm{~mm}$.

Die Blithen sind sämmtlich glcich gebildet, zwittrig und aktinomorph. Der dunkclgrüne Fruchtknoten ist sehr deutlich gerippt, in der Vollblüthe etwa $1 \mathrm{~mm}$ lang und kahl. Der Kelch ist nur in der Form eines geschweiften Wulstes angedeutet. Dic gelben, 1-1,5 mm langen Blumenblätter sind an der Spitze breit eingebogen und erscheinen desswegen nur ausgerandet, unter der Lupe sind sie schr fein behaart. Die Staubgefässe sind nur wenig länger als die Blumenblätter, die kreisrunden, bräunlichgelben Beutel halten etwa 0,5 mm im Durchmesser; die letzteren sprcizen schliesslich am Grunde auseinander. Das Griffelpolster ist gelb und ragt an den Seiten iber den Fruchtknoten hinweg; es ist tief getheilt; die 2 spreizenden Griffel sind so lang wie das Polster; sie biegen sich nach der Befruchtung zuriick.

Die gelblich-braune Frucht ist 5-6,5 mm lang und 4-5 mm breit; im Umfang elliptisch, ist sie vom Rïicken her zusammengedrïekt; die beiden Theilfrüchte sitzen an dem tief zweispaltigen, haarförmigen Fruchtträger. Die Dorsalrippe sowie die beiden Seitenrippen springen deutlich vor, noch grösser aber sind die beiden Commissuralrippen, welche vollkommen geflügelt erscheinen; unter den 4 Thälchen liegen ansehnliche einzelne Ölcanälchen, auf der etwas gewölbten Fugenfläche befinden sich deren 2, sie sind dunkelbraun gefärbt.

Es ist uns nicht gelungen, einen Standort des Liebstöckels zu ermitteln, an dem die Pflanze wirklich wild vorkommt; iberall erscheint sie, namentlich in den Gärten der Gebirgsbewohner, angepflanzt oder ist, wie sich nachweisen lässt, verwildert; dies gilt namentlich von der Umgebung des Bades Spaa bei Lüttich, von dem Ritten bei Bozen, von dem Riesengebirge und dem Gesenke; er wird ferner aus den Pyrenäen, den oberitalienischen Alpen, aus Mittelrussland, dem uralisehen Sibirien (hier ebenfalls cultivirt) erwähnt. 
Die Pflanze gehört zu dem alten Bestande der Pflanzen in den Bauerngärten, die schon seit der Zeit Karls des Grossen angepflanzt worden sind; für den Handel baut die Umgebung von Cölleda die grössten Mengen.

Die meist der Länge nach durchsehnittenen getrockneten Rhizome und getrockneten Wurzeln der Pflanze sind als Radix Levistici (Liebstöckelwurzel) officinell.

\title{
Erklärung der Abbildungen.
}

Fig. A. Eins der unteren Blätter.

Fig. B. Ein Zweig der blühenden Pflanze nach einem im Berliner Universitätsgarten gebanten Exemplare: $a$. Hülle; $b$. Hüllehen.

Fig. C. Die Blüthe, 10 mal vergrössert: e. das Blumenblatt; $f$. das Staubgefäss; $g$. das Griffelpolster.

Fig. D. Der Stempel, 12 mal vergrössert: $c$. der Fruchtknoten; $h$. die Griffel.

Fig. E. Derselbe im Längssehnitte: $d$. der Kelehsaum; $i$. die Samenanlage.

Fig. $F$. Der Fruehtknoten im Quersehnitte, 24 mal ver- grösscrt: $k$. die Fruchtblätter; $l$. die Rippen; $m$. die Thälehen; $n$. die Öleanälchen.

Fig. $G$. Das Blumenblatt, $15 \mathrm{mal}$ vergrössert.

Fig. $H . I$. u. $K$. Das Staubgefaiss, von innen, aussen und von der Seite betrachtet, das letztere aufgesprungen.

Fig. $L$. Pollenkörner, 300 mal vergrössert.

Fig. $M$, Die zerfallende Frueht, natürliehe Grösse.

Fig. N. u. O. Das Theilfritiehtehen von aussen und von innen gesehen, $6 \mathrm{mal}$ vergrössert.

Fig. P. Dasselbe im Querschnitte, 15 mal vergrössert.

Fig. Q. Dasselbe im Längssehnitte, $7 \mathrm{mal}$ vergrössert: $o$. das Nährgewebe; $p$. der Keimling.

\section{ARCHANGELICA Hoffm.}

Blüthen sämmtlich gleichförmig, zwittrig, aktinomorph. Fruchtknoten unterständig, wenig aber deutlich gerippt. Keleh wenig deutlich oder mit 5 etwas vorspringenden Zähnehen verseben. Blumenblätter mit breit eingebogener, scharfer Spitze, daher nur ausgerandet. Griffelpolster wulstig, tief getheilt, am Rande oft gewellt; Griffel spreizend. Frucht mit breit elliptischem Umrisse, von dem Rücken her stark zusammengedrïckt. Dorsal- und Seitenrippen mässig vorspringend, Commissuralrippen breit geflügelt; Ölcanälehen sehr zahlreich. - Zweijährige, hohe Kräuter mit zusammengesetzten Blättern, deren letzte Ausgliederungen breit und gezähnt sind. Dolde zusammengesetzt, Hülle ans wenigen kleinen Blättern gebildet oder fehlend; Hüllchenblättehen borstenförmig, klein, zahlreiche oder sehr wenige.

5 Arten in der nördlichen gemässigten und kalten Zone, eine davon auch in Europa verbreitet.

\section{Archangelica officinalis Hoffm.}

\author{
Tafel 80 .
}

Stengel stielrund, gestreift, hohl, kahl; Blätter doppelt gefiedert; Fiederchen eiförmig oder oblong; häufig gelappt, scharf gesägt, mit sehr grossen, sackförmigen Seheiden; Hülle aus wenigen, Hüllchen aus sehr zahlreichen Blättchen gebildet.

Archangelica officinalis Hoffm. Umbell. I. 166; Mert. u. Koch in Roehl. Deutsehl. Fl. II. 389; P. DC. Prodr. IV. 169; Toch, Syn. 302; Dietr. Fl. Boruss. XII. t. \$45; Rchb. fil. Icon. Fl. Germ. Umbellif. 49. t. 1940; Ledeb. Fl. Ross. II. 297; Aschers. Fl. M. Brandenb. 252; Parlat. Fl. Ital. VIIl. 290; Berg u. Sclemidt, Darst. u. Beschr. XXVII ; Köhler, Mediz. Pf. t. 97; Flïck. Pharmacogn. 45t; Arth. Meyer, Drogenk. I. 245; Garcke, Fl. Deutschl. 258 c. ic.

Angelica Archangelica Linn. Spec. pl. ed. I. 250; Fl. Dan. II. t. 206; Crtz. Umbellif. 65; Allione, Fl. Pedemont. II. 9; Plenck, Offiz. Pfl. t. 197; Guertn. Fr. II. S5; Engl. Bot. XXXIT. t. 2561; 
Hayne, Arzneigew. VII. t. S; Lam. Encycl. t. 195; Svensk. Bot. IX. t.633; Nees, Dïsseld. Abbild. t. 279. 280; Guimp. u. Schlecht. Pfl. Plarmac. II. 114. t. 193; Baill. Pl. méd. 104S. fig. 2560.

Angelica officinalis Mnch. Meth. 81.

Selinum Archangelica Link, Enum. pl. hort. Berol. I. 269.

Archangelica sativa Mill. Gard. Dict. ed. VII. n. 1.

Angelica littoralis Fr. F7. Hall. 51 .

Angelica norvegica Nym. Syll. Suppl. 26.*)

Angelicawurz, Engelvourz; französisch: Angélique des jardins oder A. de Bohême; englisch: Officinal longwort.

Im ersten Jahre entwickelt die Pflanze eine grosse Blattrosette mit einer bis $4 \mathrm{~cm}$ dicken, rübenförmigen, wenig verzweigten Pfahlwurzel, die entweder im zweiten Jahre, wenn die Rosette den Blüthenschaft treibt, noch erhalten oder theilweise zu Grunde gegangen ist; dann treiben aus dem Grunde der Axe bis fingerdicke, weisse, verzweigte Nebenwurzeln hervor.

Der sehr kräftige aufrechte Stengel wird $1,3-2,3 \mathrm{~m}$ hoch und bei uns in der Regel nicht uber $5 \mathrm{~cm}$ dick, im hohen Norden soll er aber viel beträehtlichere Dimensionen erhalten; er ist verästelt, stielrund, gestreift und kahl, am Grunde ist er röthlich, weiter oben dunkelgriin und von einem dinnen, abwischbaren Wachstiberzug blan bereift; im Innern ist er hohl.

Die unteren Blätter erreichen cinc Länge von $30-50 \mathrm{~cm}$ und bisweilen wohl noch mehr, ihre Breite ist meist etwas geringer; sie sind gestielt und der Stiel crwcitert sich am Grunde zu einer sehr grossen, blasenartigen Scheide, welehe die jüngeren Organe einschliesst; die Spreite ist doppelt gefiedert, die endständigen Fiederblättehen sind dreilappig, auch die untersten haben meist einen äusseren Seitenlappen, ihr Umfang ist eiförmig bis oblong, meist sind sie an beiden Enden spitz, am Rande scharf gesägt, oberseits sind sie dunkel-, unterseits bläuliehgriin, beiderseits kahl. Die oberen Stengelblätter werden nach und nach einfacher, bis die Vorbliitter der Blüthenstände, welehe wiederum fast gegenständig befestigt sind, dreiblättrig werden oder gar nur noch die Seheide mit einem Zipfelchen zurïckbleibt.

Die Hauptaxe, sowie die Seitenästc gehen in einen Blüthenstand aus. Dieser ist eine grosse zusammengesetzte Dolde von fast kugelförmigem Umfange und schr zahlreichen, häufig mehr als 30 Strahlen; die Hülle fehlt oder wird durch ein unter der Dolde befindliches, sehr reducirtes Laubblatt vertreten. Die 4-7 cm langen Doldenstrahlen sind mit einfachen, kurzen Haaren bekleidet und stielrund. Die vielblüthigen Döldehen sind halbkugelig und werden von sehr zahlreichen linealischen, grünen, 5-10 mm langen Hüllblättchen gestiitzt.

Die Blüthen sind alle gleichförmig, zwittrig, von grüner Farbe. Der dunkelgrine Fruchtknoten ist etwa $1 \mathrm{~mm}$ lang; von der Seite zusammengedritckt, wie der Blüthenstiel fein behaart und deutlich gerippt. Der Kelch erseheint als sehr schwach gezähnelter Wulst. Die Blumenblätter sind bis auf die breit eingebogene, lanzettliche, zugespitztc obere Endigung elliptisch und sind an der Spitze nur wenig ausgerandet. Die Staubgefässe sind länger als die Blumenblätter; die kaum 0,5 mm im Durchmesser haltenden gelbgrünen Beutel werden von fadenförmigen Fäden getragen. Das grüne Griffelpolster ragt über den Fruchtknoten binweg, ist tief getheilt und trägt die oben schwach spreizenden Griffel mit kopfigen Narben.

Die Frucht ist $6-7 \mathrm{~mm}$ lang und 4,5-5 $\mathrm{mm}$ breit, in Umfang kurz elliptisch, vom Rücken her zusammengedrïckt, kahl; die Griffel sind zurïckgekrimmt; die Theilfrïchte bleiben nur kurze Zeit an den haarförmigen Schenkeln des tief getheilten Fruchtträgers hängen, sind erst grün und etwas fleischig, trocknen aber stark ein und werden strohgelb und flach planconvex. Die Dorsal- und Lateralrippen springen deutlich kielförmig, wenn auch nicht zu stark vor, die Commissuralrippen sind geflugelt. Der völlig reife Same läest sich leicht von der etwas korkigen Fruchthaut trennen und zeigt auf seiner Oberfläche zahlreiche strichförmig verlaufende Ölcanälchen.

\footnotetext{
* Es erscheint sehr fraglich, dass diese Pflanze eine eigene gute Art ist.
} 
Die Engelwurz wächst an fenchten Orten, an Bächen, Gräben, Flussufern, namentlich auch hänfig an den bergigen Abhängen der Meereskiiste und in Gebirgen, aber auch in der Ebene; sie ist im arktisehen Russland, in Skandinavien, in Grossbritannien, ferner in Norddentschland von Holstein bis Preussen an der ganzen Kiiste, in Posen, der Mark Brandenburg und Provinz Sachsen, im Riesengebirge, auf der Grenze von Nieder-Österreich und Ungarn, in Galizien, Polen und Volhynien verbreitet; in Italien wächst sie auf dem Apennin; von Russland geht sie durch Sibirien bis Kamtschatka und Unalaschka; endlich wächst sie auf Island und im südwestlichen Grönland; auch auf der Insel Disco soll sie noch vorkommen. Zu Handelszwecken wird sie bei Cölleda, Jena und Würzburg, aber auch im Riesengebirge gebaut.

Unter der Bezeichnung Radix Angelicae (Angelikawurzel) haben die getrockneten unterirdischen Organe der Pflanze Aufnahme in das Arzneibuch gefunden.

\section{Erklärung der Abbildungen.}

Fig. A. Ein Blatt aus dem unteren Theile des Stengels.

Fig. B. Dasselbe aus der Mitte des Stengels.

Fig. C. Ein bliihender Zweig von einer cultivirten Pflanze.

Fig. D. Die Bliithe, 10 mal vergrössert: $d$. das Blumenblatt; $e$. das Staubgefäss; $f$. das Griffelpolster.

Fig. $\boldsymbol{E}$. Der Stempel, $15 \mathrm{mal}$ vergrössert: $a$. der Fruchtknoten; $b$. der Kelehsaum; $g$. der Griffel.

Fig. $\boldsymbol{F}$. Derselbe im Längsschnitte: $c$, die Samenanlage.

Fig. $G$. Derselbe im Querschnitte, 30 mal vergrössert.

Fig. H. Das Staubgefiiss, von innen und von aussen gesehen.
Fig. I. Pollenkörner, trocken und im Wasser, 300 mal vergrössert.

Fig. K. Ein Fruchtlöldchen.

Fig. $L$. u. $M$. Das Theilfrüchtehen, $3 \mathrm{mal}$ vergrössert, vom Rïcken und von der Bauchseite gesehen.

Fig. $N$. Die Frucht im Querschnitte, 7mal vergrössert: $h$. die Rippen; $i$. dic Thälchen; $k$. der locker von der Fruchthaut nmschlossene Same; $l$. die ölcanälchen.

Fig. $O$. Das Theilfriichtchen im Längsschnitte, 3 mal vergrössert; $n$. das Nürgewebe; $p$. der Keimling.

Fig. $P$. Der Same mit den Ölcanälchen.

\section{FERULA Linn.}

Blïthen regelmässig, zwittrig und alle gleichförmig, vielehig, oder durch vollkommenen Fehlschlag des einen Geschlechtes getrennt-geschlechtlich einhäusig. Kelch meist undeutlich, seltener werden die Zähnchen etwas grösser. Blumenblätter an der Spitze mehr oder weniger eingebrochen oder nur eingebogen, daher an der Spitze melır oder minder, bisweilen sehr wenig ansgerandet. Griffelpolster flach kegelförmig oder seltener (nur an den weiblichen Blithen) schüsselförmig vertieft, mit gewelltem oder gelapptem Rande. Frucht im Umrisse kurz elliptisch bis fast kreisförmig, nach der Lösung in die dicken Theilfriichte bleiben diese an dem tief zweischenkligen Fruchtträger hängen; Dorsal- und Lateralrippen fädlich, wenig vorspringend, Commissuralrippen flügelförmig; Ölcanälehen zahlreich, bisweilen wenig deutlich oder mit blossem Auge unsichtbar, - Ausdanernde, aber nach der Blüthe bisweilen vollkommen absterbende Stauden, nicht selten blau bereift. Blätter vielfach zusammengesetzt mit sehmalen Zipfeln. Dolden doppelt zusammengesetzt, vielstrahlig mit oder ohne Hïlle und Hïllehen. Blitthen häufig gelb.

An 60 Arten, die von Stud-Europa und Nord-Afrika bis Central-Asien verbreitet sind, einige auch in Nord-Amerika.

\section{Ferula rubricaulis Boiss.}

Tafel 81.

Mässig hohe Staude mit vierfach gefiederten Blättern, die flaumig behaart sind; Blüthen getrenntgeschlechtlich, die endständige Dolde weiblich, kurz gestielt, bisweilen sitzend, die seitlichen, länger gestielten männlich; Blumenblätter orangefarben, aussen behaart; Stengel und Früehte wenigstens oft roth angelaufen. 
Ferula rubricaulis Boiss. Diagn. II. ser. II. 92, Fl. orient. II. 995.

Ferula galbaniflua Boiss. et Buhse Aufzähl. 99; Buhse in Bull. soc. imp. nat. Mose. XXIII. 548; Bentl. and Trim. Med. pl. t. 125; Köhler, Mediz. Pf. t. 153; Boiss. Fl. orient. 988; Aitchison in Pharmac. Journ. and Trans. III. ser. XVII. 466, in Trans. Linn. soc. II. ser. III. 65; Flück. and Hanb. Pharma$\operatorname{cog}: 295$.

Ferula erubescens Boiss. Ann. se. nat. III. ser. I. 316; Berg u. Schmidt, Darst. u. Beschr. XXXI . Peucedanum galbaniflum et rubricaule H. Baill. Pl. méd. 1043. 1044; Flück. Pharmacogn. 62.

Mutterharzpflanze, Galbanumdolde; französisch: Plante de Galbanum; engliseh: Galbanum plant.

Diese Pflanze verhält sich in der Jugend ganz wic die beiden folgenden, d. h. sie erzeugt cine grosse Blattrosette mit einer dicken rubenartigen Pfahlwurzel.

Der mit markigem Gewebe geftillte, gestreiftc, kahle, blan bereifte Stengel erreicht cine Höhe von $1 \mathrm{~m}$ und am Grunde eine Dicke von $4-5 \mathrm{~cm}$; er wird am Grunde von einem Faserschopfe, der von den Gefässbindeln der verwitterten Blattscheiden herrihht, umgeben und trïgt unter demselben etwa 5 bis $0,5 \mathrm{~m}$ lange Blätter, die auf einem ansehnlichen, fast cylindrischen Stiele sitzen und besonders in der Jugend grau behaart sind; die Spreite ist vierfach gefiedert und die letzten Ausgliederungen sind noch fiederschnittig getheilt, die letzten Läppehen erreichen eine Länge von 1-2 mm; auch diesc sind noch fein behaart. Die spiralig angereiliten Stengelblïtter verkitrzen sich schnell und vereinfachen sich, bis zuletzt nur dic Scheiden übrig bleiben, ans deren Achseln die Bluthenstände tragenden Äste treten.

Diese Äste laufen in eine weibliche, sehr kurz gestielte, bisweilen auch sitzende Dolde aus, unter der in der Regel mehrere männliche, gestielte Dolden spiralig angereiht aus der Achsel von häutigen, scheidenartigen Hochblättern hervortreten; diese tiberragen die weibliche Dolde, so dass diese Verbindungen wie dreifach zusammengesetzte Blithenstände ausschen; Hülle und Hiillehen konnten wir nicht nachweisen. Während die Stiele der weiblichen Dolden sehr kurz, diejenigen der männlichen gestreckt sind, herrscht beziiglich der zahlreichen Doldenstrahlen das umgekehrte Verhältniss: die Döldehen des weiblichen Blüthenstandes werden von kräftigen, bis $6 \mathrm{~cm}$ langen Sticlen gestiitzt, während die des männlichen nur 1-2,5 cm lang werden; die Blithenstielchen sind wieder bei beiden ziemlich gleich, $4-6 \mathrm{~mm}$ lang und besonders oben mit einigen wenigen schlaffen, dïnnen Hïrchen besetzt,

Die männlichen Blüthen besitzen keinen Fruchtknoten. Der Keleh ist schwach fünfähnig. Die 1,5 mm langen, orangefarbigen Blumenblätter sind eiförmig, spitz, aussen behaart und am oberen Ende eingekrümmt. Die Staubgefässe sind ctwas länger als jene und tragen auf einem dünnen Staubfaden den kaım $1 \mathrm{~mm}$ langen, elliptisehen, gelben Bentel. Das Griffelpolster ist flach kegelförmig, am Rande gewellt, die Griffel sind kurz warzenförmig. Die weiblichen Bluthen besitzen einen kahlen oder sehr spärlich behaarten, fast eylindrischen, sehwach gerippten Fruchtknoten von 2 mm Länge. Die Kelchzähnchen sind wenig deutlich. Die Blumenblätter messen etwa $2,-2,5 \mathrm{~mm}$ in der Länge, sonst sind sie von der Beschaffenheit derjenigen der männlichen Blithe. Das Griffelpolster ist schüsselförmig vertieft nnd am Rande gezähnelt. Die am Grunde verdickten Griffel sind etwa $3 \mathrm{~mm}$ lang, haben eine kopfförmige Narbe und krtimmen sich nach aussen; nach der Befruchtung biegen sie sich nach unten.

Die verhältnissmässig grosse Frucht hat eine Länge von $15-17 \mathrm{~mm}$ und eine Breite von $9-11 \mathrm{~mm}$; sie ist elliptisch oder etwas umgekehrt eiförmig im Umriss, von dem Riucken her flach zusammengedrickt; die dünnen Theilfriiehtehen bleiben nach der Lösung an dem tief gespaltenen Fruchtträger mit fädlichen Sehenkeln hängen. Sie sind deutlich gerandet, werden von 3 fädlichen Dorsal- und Lateralrippen durehlaufen, während die Commissuralrippen breit geflugelt sind; auf dem Querbruch sind meist 4 grosse Ölcanälchen unter den Thälchen deutlich zu sehen, 2 minder umfangreiche liegen an der Fugenfläche.

Anmerkung. Wir waren in der Lage, Originalexemplare der Bunge'schen, Kotscrix'schen und ArTchison'schen Pflanzen zu untersuchen und sind zu der Überzeugung gekommen, dass dieselben und mithin auch Ferula erubescens Boiss. nicht von der typischen $F$.galbaniflua Boiss. et Buhse abweichen und dass sie alle zu einer Art zusammen zu fassen sind; namentlich ist die Ansicht Borssien's, dass F. galbaniflua. Boiss. et Buhse in eine andere Section gehöre wie $F$. rubrieaulis, sicher irrthümlich, sofern die von Artchison gesammelte Pflanze wirklich die echte $F$, galbaniflua ist; über diese Thatsache haben wir aber gar keinen Zweifel. 
Die Galbanumpflanze wächst vom Demawend und der Alpe Kuh Daëna (zwischen Chusistan und Farsistan) in Persien bis nach dem Lande Badghis zwischen dem Heri Rud und dem Murghab, in manchen Strichen so massenhaft, dass sie ausschliesslich die Vegetation zusammensetzt und zur Zeit der Blithe eine Zierde des Landes ist.

Die Pflanze liefert das Galbanum (Mutterharz) des Arzneibuches. Es besteht die Droge ans dem freiwillig aus verletzten intercellularen Secretbehältern der Pflanze, vorziliglich an der Basis der Blätter, ausgetretenen, erstarrten Milchsafte.

\section{Erklärung der Abbildungen.}

Fig. A. Ein Theil des mittleren Stengels mit einem Deekblatte und einer fruchtenden Dolde, nach einer Koтschy'schen Originalpflanze.

Fig. B. Ein Stiick eines unteren Blattes.

Fig. C. Das Ende eines blithenden Zweiges.

Fig. D, u. $\boldsymbol{E}$. Die männliche Blüthe von oben und von der Seite gesehen, 8 mal vergrössert: $d$. das Blumenblatt; $e$. das Staubgefäss; $g$. das Griffelpolster.

Fig. $F$. Die weibliche Blüthe, 6 mal vergrössert: $a$. der Fruchtknoten.

Fig. $G$. Der Fruehtknoten: $c$. das Griffelpolster; $f$. der Griffel.

Fig. $H$. Derselbe im Längssehnitte: $b$. die Samenanlage.
Fig. I. Derselbe im Quersehnitte, 16 mal vergrössert: g. die Samenanlage; $l$. das Öleanälchen.

Fig. $K$. Das Blumenblatt, $12 \mathrm{mal}$ vergrössert.

Fig. $L$. Das Staubgefaiss von innen und von aussen gesehen, $16 \mathrm{mal}$ vergrössert.

Fig. $M$. Pollenkörner, 300 mal vergrössert.

Fig. $N$ u. $O$. Das Theilfrüichtchen, 2 mal vergrössert, vom Rïeken und von der Fugenflïche betrachtet.

Fig. 1. Dasselbe im Querschnitte, 6 mal vergrössert: $i$. die Dorsalrippe; l. das ölcanälehen*); $m$, das Nährgewebe.

Fig. Q. Dasselbe im Längssehnitte, 3 mal vergrössert: $n$. das Wïrzelchen; o. die Keimblätter.

\section{SCORODOSMA Bunge.}

Blitthen vielehig, bisweilen dureh Fehlsehlag getrennt-geschlechtlich einhäusig, aktinomorph. Kelch mit wenig deutlichen Zähnen, klein. Blumenblätter mit mehr oder weniger eingebogener Spitze. Griffelpolster flach und schiisselförmig vertieft, dann tiefer getheilt, am Rande gewellt. Frucht im Umfange kreisförmig oder elliptisch, flach zusammengedriickt; Dorsal- und Lateralrippen wenig vorspringend, fadenförmig, Commissuralrippen dïnn, geflügelt, gerandet; Ölcanälchen sehr viele, mit blossen Angen kaum oder überhaupt nicht sichtbar; Fruchtträger zweitheilig. -- Ausdanernde kahle oder behaarte Pflanzen mit zusammengesetzten Blättern und zusammengesetzten, vielstrahligen Dolden. Hülle und Hïllehen nicht vorhanden, Blïthen weiss oder gelb.

Wenige, im westlichen und centralen Asien bis zum Himalaya verbreitete Arten.

\section{Scorodosma foetidum Bge.}

Tafel 82. Fig. I. II. u. 83.

Aufrechte, nur an der spitze verästelte Staude mit grossen, drei- bis vierfach gefiederten, kahlen oder feinbehaarten Blättern, die letzten Ausgliederungen oblong, ganzrandig, an der Spindel mehr oder minder herablaufend; Dolden am Ende des Stengels zahlreich an verzweigten Ästen, oben gebiischelt, die mittleren weiblich, die seitlichen männlich.

Scorodosma foctidum Bunge, Delect. sem. Dorp. 1546; Reliq. Lehm. in Mem. acad. St. Petersb. 1850 p. 309 ; Borsez. in Mem. acad. St. Petersb. 1560 p. 1; Berg u. Schmidt, Darst. XXVI , XXVI ; Flïck. et Hanb. Pharmacogr. 280.

*) Die Öleanälchen sind naeh unseren Beobaehtungen meist in der Einzahl unter den Thälchen und in der Zweizahl an der Fugenfläche entwickelt. 
Ferula Scorodosma Bentl. et Trim. Medic. pl. $t$. 127.

Ferula Assa foetida Linn. Spec. pl. 248*); Nees, Düsseld. Abbild. t. 293; P. DC. Prodr. IV. 173; Guimp, u. Schlecht, Pf. Pharmac, III. 21. t. 216; Boiss, flor. orient. II. 994.

Ferula foetida Reg. in Act. horti Petr. V. 592; Aitchison in Pharmac. Journ. and Trans. III. ser. XIII. 465, in Trans. Linn. soc. II. ser. III. 68, t. 12-14.

Peucedanum Asa foetida Baill. Pl. méd. 1038, cum xylogr. 2844. 2845; Flück. Pharmacogn. 52.

Stintasantpflanze, Teufelsdreckpflanze; französisch: Plante d'Asa foetida; englisch: Asa foetida plant.

Ehe die Pflanze zur Blïthe gelangt, erzeugt sie eine bis schenkeldicke, stark verzweigte Pfahlwarzel von rïbenförmiger Gestalt und aussen graubrauner, innen auf dem Querschnitte weisser, gelbgefleckter Farbe, welche von Milchsaft strotzt. Auf ihr sitzt eine Blattrosette, welche aussen von einem Faserschopfe aus den Leitbiindeln der Scheiden der frïher abgestorbenen Blätter gebildet wird. Dic Rosette wird viele Jahre hindnreh immer von neucm gebildet, ehe der Stengel austreibt; nach der Samenreife geht nicht blos er, sondern anch die Wurzel zu Grunde.

Die Blätter der Rosettc und die unteren am Stengel sind sehr gross, sie erreichen mehr als $1 \mathrm{~m}$ in der Länge und sind zwischen den äussersten Spitzen auch lüufig tiber $1 \mathrm{~m}$ breit; sic sind gestielt und der halbeylindrische Stiel geht am Grunde in eine umfangreiche, lederartige Scheide iiber; in der primären Gliederung sind sic dreizählig, die Fiedern sind wieder doppelt bis dreifach gefiedert oder zuletzt fiedertheilig; der dicke Blattstiel ist mit markigem Gewebe gefillt; dic Fiederehen letzten Grades erreichen die Länge von 10-20 cm, sind oblong oder linealisch-oblong, stumpf und ganzrandig, meist kahl, asymmetrisch und laufen an der Spindel herab; ihre Farbe ist blaugrïn, in der Jugend sind sie aber weissflaumig behart und auch im Alter bisweilen noch bekleidet; die wenigen oberen Stengelblätter werden kleiner und cinfacher, bleiben aber in der Spreite noch doppelt gefiedert.

Der unverhältnissmässig dicke, säulenförmige Stengel erreicht eine Höhe von $2-3,5 \mathrm{~m}$ und ist am Grunde bis $10 \mathrm{~cm}$ dick; er ist steif aufreeht, walzig rund und gestreift; im Innern ist er von cinem weissen, markigen Gewebe dicht erfullt; am Grunde bleibt er unverzweigt, während cr in dem oberen Drittel oder Viertel mit spiralig gestellten Ästen beladen ist, dic aus bescheideten, kurzen Deckblättern hervortreten; dic unteren derselben sind wieder spiralig verzweigt, die oberen, bissehelig gestellten dagegen theilen sich nicht mehr. Im ersten Knospenzustand gleicht er einem Kohlkopf, öffnen die sich entwickelnden Bliithenstände die Sehciden, eincm Carviolkopfe.

Die Zweige gehen in die Blithenstände von der Form kugclförmiger Dolden aus, welche Blüthen getreunten Geschlechtes tragen; die endständigen, kïrzer gestielten, bisweilen völlig sitzenden Dolden von $10-15 \mathrm{~cm}$ Durchmesser sind weiblich, die seitenständigen, länger (bis $12 \mathrm{~cm}$ ) gesticlten von $4-7 \mathrm{~cm}$ Durchmesser mäinnlich, zumal die letzteren sind kugelförmig; die oberen Enden der Zweige, wie die Stiele der Dolden und Döldchen sind spinnwebig weiss behaart, später verkahlen sie; durch Zusammendrängung der Dolden an den Zweigen erscheinen dieselben bis dreifach zusammengesetzt. Hulle und Hïllchen fehlen.

Die männliche Bltithe besitzt einen unvollkommen entwickelten sehr kurzen, kugelförmigen, behaarten Fruchtknoten, der keine Samenanlagen enthält; der Kelch lässt 5 kurze, dreiseitige Zähne nicht immer sehr deutlich erkennen. Die 2-2,5 $\mathrm{mm}$ langen, umgekehrt eiförmigen, gelben Blumenblätter sind an der Spitze stumpf und leicht eingebogen. Die Staubgefässe sind um die Hälfte länger als die Blumenblätter; die fast $1 \mathrm{~mm}$ messenden, kreisförmig umrissenen Beutel stehen anf fadenförmigen Fäden. Das Griffelpolster ist ziemlich flach, ragt etwas über den Fruchtknoten hervor, ist deutlich gelappt und trägt 2 kurze, warzenförmige Griffel. Die weibliche Blüthe hat einen 1,5 mm langen Fruehtknoten, der am oberen Rande den Kelch und die Blumenblätter der vorigen Blithe trägt, nur sollen die letateren weiss sein. Die Staubgefässe sind vollkommen verschwunden. Das Griffelpolster aber ist schüsselförmig vertieft, am Rande gelappt und aus seiner Mitte erheben sich die beiden bis $3 \mathrm{~mm}$ langen, am Grunde

*) Vergl. auch die instructiven Abbildungen in KäMPfer, Amoen. 535-537. 
allmählich verdickten, spreizenden, endlich zurückgebogenen Griffel mit kopfiger Narbe. Die Frucht ist 1,2-1,5 cm lang und 8-10 mm breit, im Umfang elliptisch, flach zusammengedriickt und wird von dem Griffelpolster mit den zurïckgeschlagenen Narben gekrönt. Anf dem Querschnitte sind die Öleanälehen mit blossem Auge nur sebr undeutlich oder ïberhaupt nicht zn sehen; die Dorsal- und Lateralrippen sind fadlich und springen wenig vor, die Commissuralrippen sind breit.

Die Assa-foetida-Pflanze wächst oft allein das Gebict beherrsehend in dichten Genossenschaften in den Steppen nördlich von der Insel Kischm am Persischen Meerbusen bis in die tïrkischen Chanate am Westabfall des centralasiatischen Hochlandes; aus Luristan der nördlichsten Provinz von Persien stammen die frühesten Berichte über die Ausbeute, die sehr genauen Angaben von KäMPFER; hier liegen die Steppen viel böher, bis $1000 \mathrm{~m}$ über dem Meere, als in den nördlicheren Gegenden. Am hänfigsten scheint sie ztvischen Turschiz, Herat und Chiwa zu sein, zwischen $35^{\circ}-42^{\circ} \mathrm{n}$. Br. und $58^{\circ}-62^{\circ}$ östlich von Greenwieh; sie wächst auf sandigem Boden mit salzhaltigem Untergrunde.

Anmerkung. Es ist beute noch nicht sicher, ob alle Pflanzen, welche Assa foetilla geben, zu derselben Art gehören jedenfalls zeigen sic manche Verschiedenheiten in der Tracht, der Form der Blattabsehnitte und der Bekleidung; nach dem vorliegenden Materiale scheinen die Merkmale aber hüchstens zur Aufstellung von Varietäten geeignet. Von botanischem Gesichtspunkte aus lïsst sich die Gattung Scorodosma nicht weiter aufrecht erhalten, weil sie mit Ferub dureh andere iranische Arten, namentlich auch durch die soeben besprochene $F$. galbaniflus Boiss. et Buhse, verbunden wird. Der Vereinigung aber mit Peucedanum, die BAILlon vorgeschlagen hat, müchten wir nicht beipflichten. Da LiNné's Ferula Assa foetida auf die Abbildung Kämpren's gegriindet ist und diese sicher mit Artohison's und Bonsczow's Pflanzen abereinstimmt, so liegt gar kein Grund vor, den alten guten Namen fallen zu lassen und ihn dureh andere, wic z. B. den in dem deutschen Arzneibuche gewählten zu ersetzen.

Die Angabe von Berg, dass neben den männlichen nud weiblichen Blithen anch zwittrige vorkommen, konnten wir nicht bestätigen; ebenso wenig halten wir seine Meinung für richtig, dass der äussere Rand des Griffelpolsters in der weiblichen Blithe als die verbundenen Reste der Stanbblätter zu betrachten sei; denn dieser Körper stimmt in den männlichen und weiblichen Blitthen so vollkommen in den wesentlichen Ziigen iiberein, dass wir beide als gleichwerthig betrachten. Überdiess wäre es höchst befremdlich, wenn bei einer Umbellifere die Staminodien zu einem einheitlichen Körper zusammenflössen. Wir haben sehr eifrig nach Staubgefässresten in der weiblichen Blithe gesucht, aber keine wahrgenommen.

Ferula Scorodosma liefert Assa foetida (Asant). Nach dem Anschneiden der unterirdischen Achsentheile der Pflanze fliesst der Milchsaft der intercellularen Sekretbehälter ans und erstarrt. Das so entstehende mehr oder weniger barte Gummiharz ist der Asant oder Teufelsdreck der Officinen.

\section{Erklärung der Abbildungen.}

Taf. 82. Fig. $I$. Eine ganze Pllanze, $t / 16$ der natiirlichen Grösse.

Fig. II. Stück eines der unteren Blätter, natürliche Grösse.

Taf. 83. Fig. $A$. Oberer Theil der Pflanze mit einer endständigen weiblichen und 2 seitenständigen miinnlichen Dolden.

Fig. B. Eine weibliche Dolde in der Entwicklung der Frucht.

Fig. $C$. Die männliche Blithe, 7 mal vergrössert: $c$. der Fruchtknoten; e. das Blumenblatt; $f$. das Staubgefäss; $g$. das Griffelpolster.

Fig. D. Dieselbe, nach Abfall der Blumenblätter und Staubgefässc; $d$. der Kelch.

Fig. $\boldsymbol{E}$. Das Staubgefüss, von innen und aussen betrachtet $15 \mathrm{mal}$ vergrössert.
Fig. F. Das weibliche Döldchen, 3mal vergrössert.

Fig. $G$. Die weibliche Bliithe, 6mal vergrössert: $h$. der Griffel.

Fig. $H$. Dieselbe, nach Abfall der Blumenblätter.

Fig. I. Dieselbe im Längsschnitte: $i$, die Samenanlage.

Fig. $K$. Der Fruchtknoten im Querschnitt.

Fig. $L$. Ein fruchttragendes Döldchen, natürliche Grösse.

Fig. $M$. Die Frucht, in der Lösung begrifien, 2mal vergrössert: $k$. der Fruchtträger; $l$, die Theilfrüichtehen.

Fig. $N$ u. $O$. Das Theilfrichtchen vom Rïcken und von der Fugenfläche gesehen: $m$. die Rippen.

Fig. $P$. Die Frueht im Quersehnitte, 4mal vergrössert.

Fig. $Q$. Dasselbe im Längsschnitte, 3 mal vergrössert: $o$. das Nährgewebe; $p$. der Keimling. 


\section{DOREMA Don.}

Blitthen sämmtlich gleichförmig, zwittrig, aktinomorph. Keleh wenig deutlieh, nur als sehwach gewellter; wulstiger Saum entwiekelt. Blumenblätter elliptisch mit seharfer eingebogener Spitze, wenig ausgerandet. Griffelpolster kegelförmig mit ganzem oder leicht gewelltem Rande, tief getheilt; Griffel kurz, etwas spreizend. Frucht von elliptischem Umrisse, flach zusammengedriickt, am Ruiicken kaum gewölbt; Dorsal- und Lateralrippen fädlich, Commissuralrippen breit geflitgelt; Öleanälehen einzeln unter den Thälehen und gepaart auf der Fugenseite, nicht selten sehr diłn oder kaum siehtbar; Fruchtträger zweischenklig. - Grosse, ausdauernde, oft blau bereifte Stauden mit dreifach gefiederten Blättern. Dolden einfach kopfig, an den Ästen spiralig angereiht, ohne Hüllchen.

5 Arten in Persien, Afghanistan und Belutschistan.

\section{Dorema Ammoniacum D. Don.}

\section{Tafel 82. Fig. III. IV. 'Tafel 84.}

Aufrechte, ausdauernde, nur an der Spitze verästelte Staude mit grossen fein behaarten Blättern, die letzten Ausgliederungen oblong, ganzrandig, mehr oder minder an der Spindel herablaufend, blau bereift; Dolden einfach, an den ruthenförmigen Ästen spiralig angereiht, kugelig, fast kopfig.

Dorema Ammoniacum D. Don. in Trans. Linn. soc. XVI. 601; Bunge in Mem. acad. St. Petersb, 1850. p. 305; Borsczow in Mem. acad. St. Petersb. 1560. p. 2S. t. 3-5; Bcrgu. Schmidt, Darst. u. Bcschr. XXVI; Köhler, Mediz. PA. t. 146; Bentl. and Trim. Med. pl. t. 130; Schindler in Zeitschr. Gesellsch. für Erdk. 1581 p. 362; Boiss. Flor. or. II. 1005; Aitchison in Pharmac. Journ. and Trans. XVII. 466. 474 u. Trans. Linn. soc. II ser. III. 70, t. 23-25; Jane Dieulafoy, La Pcrse, Paris 1587. p. 345; Fliicl. and Hanb. Pharmacogr. 25s;

Dorema hirsutum Loftus ex Borscz. l. c.

Disomeston gummiferum Jaub. ct Spach, Ill. pl. orient. I. t. 40.

Peucedanum Ammoniacum II. Baill. Pl. méd. 10t2*); Flück. Pharmacogn. 69.

Ammoniak Gummiharz-Dolde; französiseh: Plante de Gomme-résinc d'Ammoniac; engliseh: Ammoniac gum plant.

Diese Pflanze verhält sich bezüglich ihrer Jugendstadien, der Entwieklung einer rübenartigen Pfahlwurzel, einer Blattrosette und endlich der Stengel genau wie die vorige, der sie dann so ähnlich ist, dass sie vor der vollen Ausbildung kaum von ihr unterschieden werden kann, wenn sie, was bäufig vorkommt, mit ihr zusammen wächst. Desswegen soll auf jene verwiesen werden.

Der dieke, in der Jugend behaarte, später bisweilen verkahlende Stengel erreicht eine Höhe von 1,5-2,3 $\mathrm{m}$ und wird bis $5 \mathrm{~cm}$ dick; auch er wird am Grunde von dem Fasernetz der Gefässbündel aus den abgestorbenen Blattscheiden umbüllt; er ist blaubereift, langgestreift, innen hohl und trägt in der Nitte nur Blattscheiden in spiraliger Anreihung, die selten an der Spitze eine rudimentäre Spreite tragen. Aus diesen Scheiden findet weiter oben die Verzweigung statt in ruthenförmige Äste, die oben unmittelbar die kurz gestielten Dolden tragen, unter sich aber nochmals verzweigt sein können. Die Deckblätter dieser Secundärzweige sind schuppenförmig und abfällig.

Der Blüthenstand ist eine bis $1 \mathrm{~cm}$ lang gestielte, einfache, kugelförmige Dolde, die wegen der kurzen Bluthenstielehen fast kopfig erseheint; Deckblätter vermochten wir an derselben nieht zu sehen,

* Diese Verbindung von Dorema mit Peucedanum halten wir erst recht für sehr wenig glücklich, schon durch die einfachen kugelig kopfigen Dolden ist Dorema für eine Umbelliferen-Gattung ungewöhnlich gut gesondert. 
ebenso fehlt den Dolden gewöhnlich eine Hülle, in gewissen Fällen aber konnten wir sie bestimmt in der Form von kleinen pfriemlichen Blättern nachweisen. Die Blüthenstielchen sind nur höchstens 1,5 mm lang und wie der Stiel flaumig behaart.

Die Blithen sind alle gleichförmig gebaut, zwittrig und aktinomorph. Der 1,5 mm lange Fruehtknoten ist kegelförmig, im Querschnitte kreisförmig und dicht behaart. Der Kelch erscheint in der Form eines undeutlichen, wulstigen Saumes. Die an der Spitze eingebogenen Blumenblätter sind etwa $2 \mathrm{~mm}$ lang und aussen besonders in dem Verlanfe des Nerven behaart, ihre Farbe ist weiss. Die Staubgiefässe sind von der Länge der Blnmenblätter; die Staubbeutel von goldgelber Farbe sitzen anf pfriemlichen, schmalen Fäden. Das Griffelpolster von zicmlich hoch conischer Form ist in der Mitte tief gespalten und am Rande unten schwach gewellt; die Griffel mit kopfiger Narbe haben die Länge des letzteren und spreizen wenig auseinander.

Die im Umfange kurz elliptische Frucht erreicht höchstens eine Länge von 10 und eine Breite von $8 \mathrm{~mm}$; sie ist sehr flach zusammengedriickt und die sich lösenden Theilfriichtehen bleiben längere Zeit an den tief zweischenkligen Fruchtträgern mit fadenförmigen Schenkeln hängen. Die Dicke der Theilfrüchtchen beträgt kaum $0,5 \mathrm{~mm}$. Die Dorsal- und Lateralrippen sind auf der flachen Oberseite nur als fädliche Erhebungen zu sehen; die Commissuralrippen aber sind breit gefligelt; die Farbe ist rothbraun, die Flügel sind heller. Anf dem Querbruch vermochten wir; wie Artchrson auch angiebt, die Ölcanalchen selbst bei starker Vergrösserung nicht zu erkennen; während Bonsczow einzelne unter den Thälchen und gepaarte auf der Fugenflïche gesehen hat*).

Die Ammonialipflanze, deren Bezeichnung wahrscheinlich von dem Trivialnamen Ushał abzuleiten ist, wächst ebenfalls in den sandigen Steppen von Iran, Afghanistan und den türkischen Chanaten; sie kommt häufig mit der vorigen zusammen vor; beherrscht aber zuweilen ausschliesslich die Länder.

Als Ammoniacum kommt das Gummiharz der Pflanze in den Handel, welches ans den durch Insekten verletzten Sekretbehailtern der oberirdisehen Theile austritt.

\section{Erklärug der Abbildungen.}

Taf. 82. Fig. III. Eine ganze Pfanze zur Blithezcit, $1 / 12$ der natürliehen Grösse.

Fig. IT. Mittlerer Theil cines Grundblattes.

Taf. 84. Fig. $A$. Der obere Theil einer blïhenden Pflanze, natïrliche Grösse.

Fig. B. Die Blïthe, 10mal vergrössert: e. das Blumenblatt; $f$. das Staubgefäss; $g$. das Griffelpolster.

Fig. C. Der Stempel, 12mal vergrössert: $c$. der Fuchtknoten; $\boldsymbol{d}$, der Kelchwulst.

Fig. D. Derselbe im Längsschnitte: $i$. die Samenanlage.

Fig. E. Derselbe im Querschnittc: $n$. Ölcanälchen.

Fig. F. Das Blumenblatt, von aussen geschen.
Fig. $G$. Das Staubgefïs, von innen und aussen gesehen, 25 mal vergrössert.

Fig. $H$. Pollenkörner im Wasser, 300 mal vergrössert.

Fig. I. Eine Dolde mit Frïchten, natïrliche Grösse.

Fig. $K$. Dic Frucht in der Lösung begriffen, 2 mal vergrössert: $k$. der Fruchtträger; $l$. die Theilfrïchtchen.

Fig. $L$ u. $M$. . Die Theilfrucht vom Riicken- und von der Fugenflïche gesehen: $m$, die Rippen; $n$, die Thälchen.

Fig. N. Dieselbe im Quersehnitte, 6mal vergrössert.

Fig. $O$. Dieselbe im Längschnitte: o. das Nithrgewebe; p. der Keimling.

*) Ein ähnlicher Wechsel findet sich auch bei unseren Umbelliferen, wic z. B. bei der Gattung Silaus. 


\section{Reihe: Geraniales Lindl.}

Blïthen hänfig: aktinomorph, gewöhnlieh fünfglicdrig, von wirteligem Bau vollständig oder unvollstïndig, mit oberständigem Fruchtknoten und doppelter, in Kelch und Krone gesonderter, oder einfacher, kelchartiger, selten fehlender Hülle. Staubgefïsse in Zahl und Vertheilung sehr mannigfaltig. Fruehtblätter gewöhnlieh in geringer, selten in der Vielzahl, zil einem geschlossenen Fruchtknoten verbunden, spả̇ter aber häufig von einander g’clöst, g'ewöhnlich mit wenigen, oft nur mit ciner bis zwei Samenanlagen in einem Fache, die von anatroper Form sind und hïngend eine ventrale Raphe besitzen.

\section{Familie: Euphorbiaceae St. Hil.}

Die Blïthen sind stets eingeschleehtlich und zwar einhänsig oder zweihäusig, gewöhnlieh aktinomorph, nur selten cin wenig zygomorph. Die Blithenhülle ist meist entweder einfach oder sie fehlt völlig, nur selten ist Kelelı und Blumenkrone entwickelt, bisweilen ist die Hülle in männliehen und weibliehen Bläthen verschieden ausgebildet; gewöhnlieh ist sie kclehartig, entweder verwachsenblättrig mit klappiger oder dachziegeliger Deekung der Zipfel oder ibre Theile sind bis zum Grunde frei und deeken breit daehzicgelförmig; ist die Blumenkrone vorhanden, dann sind ihre Glicder klein und schuppenförmig oder sie überragen bei bedentender Lïnge den Kelch und sind dann manchmal auffallend gefärbt. Dic männlichen Blithen besitzen am Grunde in der Regel eine honigabsondernde Scheibe oder mehrere einzelne drüsenartige Gebilde. Die Zahl der Staubgefässe ist sehr versehieden, bald finden sich sehr viele (bei Ricinus mehrere Hundert bis an dic Tausend), bald sind nur wenige da, die bei Gleichzahl mit den Bluthenhullblïttern wechseln, bald noch weniger als die letzteren, bald nur ein einziges; die Fäden sind frei oder in verschiedener Weise am Grunde verbunden. Dic Beutel sind ditheeiseh und springen in mannigfaeher Weise, am häufigsten aber mit Längsspalten anf. In den beobachteten Fällen sind die Pollenkörner kugelförmig oder ellipsoidisch und von 3 Meridionalfalten durehlaufen, in denen die Keimporen liegen. Ein Stempelrest ist in manchen Fällen wahrnehmbar. Dic weibliehen Blïthen besitzen zuweilen Staminodien, ohne dass aber dieses Vorkommen selbst für cine Gattung eonstant zu sein braucht. Die honigabsondernde Seheibe ist häufiger ring-, polster- oder becherförmig ausgebildet. Der Fruehtknoten ist allermeist sitzend, normal dreifüehrig;, doeh kommen aueh andere Zahlenverhältnisse von einzelnen bis zu sehr vielen Fäehern vor. Der Griffcl ist sehr mannigfach gestaltet, typisch trägt er 3 Äste, die bisweilen fast oder ganz getrennt und häufig gespalten sind, anderseits aber sind sie aueh manehmal hoch zu einem säulen- oder sehirmförmigen Körper vercint. Die Samenanlagen finden sich stets nur einzeln oder gepaart in jedem Faehc; sic sind anatrop, aufsteigend dem Binnenwinkel der Fäeher angeheftet; die Raphe liegt fast stets ventral, die Mikropyle ist nach oben und aussen gewendet. Die Frueht ist typisch eine dreifächrige Kapsel, welche durch Spaltung der Scheidenwände und durch Lösung von einer bleibenden Mittelsäule in 3 Kokken zerfällt; jede der letzteren springt faehtheilig auf; häufig ist die Fruehthaut in eine äussere, dünne oder lederartige und in eine härtere, krustenförmige oder holzige, innere differenzirt, die sich bisweilen von einander trennen; die Spannung, welche der Sonderung und dem Aufspringen vorangeht, bewirkt nicht selten ein elastisches Aufspringen der Früchte, deren Theile dann weit fortgeschleudert werden; neben den Kapseln finden sich auch selten Beeren oder Steinfrüehte, welche nicht aufspringen. Die Samen sind entweder gleichzählig mit den Anlagen oder sie werden dureh Fehlschlag in der Zahl vermindert; cine sehon an dem Samenstrang oft bemerkbare Wucherung, dic sieh über die Mikropyle legt und bei der Pollinisation eine Rolle spielt, erzeugt 
an den Samen bäufig einen fleisehigen Anhang (Strophiola); das Nährgewebe ist gewöhnlich umfangreich, fleisehig oder knorpelig, selten ist es dünn oder fehlt ganz. Der Keimling liegt in der Mitte des Nährgewebes, ist gerade oder leicht gekrümmt und von der Länge desselben, selten kleiner; die Keimblätter sind flach, blattartig, breit, selten schmaler und halbstielrund; das kurze Würzelchen ist nach oben gerichtet.

Pflanzen von sebr verschiedener Tracht: entweder aufrechte, niederliegende, seltener schlingende Kränter und Stauden, oder Sträucher oder Bäume, bisweilen von kaktusähnlicher Tracht, fast stets von reichlichem Milchsafte, der in verzweigten Schläuchen sich befindet, durchtränkt. Blätter typisch spiralig angereiht und ungetheilt, doch kommen auch von beiden Verhältnissen Ausnahmen vor; Nebenblätter sind häufig vorhanden. Die Bekleidung wird aus einfachen, bisweilen aber auch aus Sternhaaren gebildet. Blüthenstände gewöhnlich zusammengesetzt, achsel- oder endständig, häufig cymös oder rispig; Bracteen und Bracteolen sind meist vorhanden.

Wohl über 3000 Arten, von denen der allergrösste Theil den Tropen beider Hemisphären angehört; in der kalten Zone und auf hohen Gebirgen fehlen sie ganz.

I. TRIBUS Euphorbieae Bl. Blüthenstände letzter Ordnung von einer kelehartigen Hülle umschlossen, einer Blüthe ähnlich, in der die einzelne weibliche gestielte Bliithe dem Stempel äbnlich ist, die ein männigen männlichen Blïthen den Staubgefässen gleichen.

\section{Euphorbia resinifera Berg.}

II. TRIBUS Crotoneae Bl. Die Blüthen nicht von einer kelehartigen Hülle umsehlossen, einzeln.

2. Croton Eluteria Benn.

3. Croton Tiglium Linn.

4. Mallotus Philippinensis Müll. Arg.

5. Ricinus communis Linn. 


\section{EUPHORBIA Linn.}

Bliithen getrenntgeschlechtlich einhäusig, beide Geschlechter stets vereint von einer kelchartigen Hitlle umgeben und einer einfachen Zwitterblüthe :ihnlich; Hiulle aktinomorph oder zygomorph, glockenoder becher- oder kreiselförmig, meist vier- bis fünf-, selten sechs- bis achtlappig, gewöhnlich krautig, am Rande mit gleich- oder ungleichzähligen Drüsen versehen. Männliche Blüthen einmünnig mit gegliedertem Faden, an dem Gelenk in sehr seltenen Fällen eine Schuppe als Rest einer Blithenhülle; Staubbeutel mit 2 spreizenden, in Längsspalten aufspringenden, kugelförmigen Theken. Weibliche Blüthe einzeln, von sehr zahlreichen männlichen umgeben, einem Stempel mit gesticltem Fruchtknoten ähnlich. Bliithenhülle meist fehlend, selten ans 3 kleinen Lüppchen gebildet. Fruchtknoten dreiknöpfig mit einer hängenden Samenanlage in jedem Fache; Griffel 3, entweder frei oder am Grunde mehr oder weniger hoch verbunden mit einfachen oder an der Spitzc getheilten Narbenstrahlen. Frucht cine dreiknöpfige Kapsel, die in 3, von der Mittelsäule sich lösende, zwciklappig elastisch aufspringende Kokken zerfällt. Samen mit reichlichem fleischigem Nährgewebc, in dessen Mitte der Keimling mit flachen, blattartigen Keimblättern liegt. - Kräuter, oder Stauden oder Holzgewächse von sehr mannigfaltiger Tracht, einen reichlichen weissen, meist sehr scharf giftigen Milchsaft in ungegliederten Schläuchen enthaltend. Blätter meist in spiraliger Anordnung; zuweilen oben oder am ganzen Stengel kreuzgegenständig, bei nicht wenigen Arten reducirt oder endlich ganz schwindend, ganzrandig, sclten gezähnelt. Dic blüthenähnlichen Specialinflorescenzen gervöhnlich in zusammengesetzten Dolden mit Gipfelblithenstand, deren Strahlen zuletzt in einfache Dichasien ausgehen, selten einzeln achselständig oder traubig. Deckblätter und Vorblätter sind meist vorhanden, letzterc imnerhalb der Blithenstandshülle in der Gestalt zahlloser borsten- oder haarförmiger Organe.

Mehr als 700 Arten, die hauptsüchlich in den gemässigten und subtropischen Zonen beider Hemisphï̈ren verbreitet sind.

\section{Euphorbia resinifera Berg.}

\section{Tafel 85.}

Anfrechter, steifer, am Grunde reich, oben wenig verästelter Strauch von kaktusähnlicher Tracht mit vier-, seltener dreikantigen Zweigen; auf den Kanten mässig vorspringende Blattpolster, welche gepaarte Nebenblattstacheln tragen; Blithenständehen zu einfachen gestielten Dichasien verbunden.

Euphorbia resinifera Berg in Berg u. Sehmidt, Darst. u. Beschr. $t$. XXXIV $M-X$; Coss. in Bull. soc. ray. Belg. X. 5; Ball, Spicil. Fl. Marocc. 661; Bentl. and Trim. Medic. pl. t. 240; Hook. and Ball, Journ. of a tour in Marocco, London 1875 p. 355; Payton in Pharmac. Journ. XII. 724; Fliek. and Hanb. Pharmacogr. 502; Flïck. Pharmacogn. 195; Baill. Bot. méd. 919, fig. 2639.

Gebräuchliche Wolfsmilch; englisch: Gum milkwort; französisch: Euphorbe de gomme.

Der aufrechte kaktusähnliche Strauch ist am Grunde sehr reich verästelt und stellt einen dichten Busch dar mit zahlreichen parallel aufstrebenden $0,25-1,5 \mathrm{~m}$ und dariber hohen, vier- seltener dreikantigen Zweigen, deren Flächen leicht concav sind, während die etwas verdünnten Kanten hervortreten. Nur selten geben sie einen seitlichen gleichgestalteten Ast ab, der Durchmesser der dunkelgrinen, kahlen, fleischigen $\mathrm{Z}$ weige beträgt selten mehr als $2 \mathrm{~cm}$.

Auf den Kanten sitzen in Entfernungen von etwa $1 \mathrm{~cm}$ nur wenig vorspringende Blattpolster, welche mit einer elliptischen Fläche enden; unterhalb derselben, sie berührend, stehen 2 auseinander fahrende, horizontal abstehende, ein wenig hornförmig gekrümmte, $3-4 \mathrm{~mm}$ lange Stacheln, die am Grunde der 
Zweige 5-10 mm Länge erreichen und welche den bei anderen Euphorbia-Arten oft normal entwickelten Nebenblättern homolog zu setzen sind; sie verbreitern sich am Grunde zu kleinen, von einander gesonderten Schildchen, die am Stamme nicht herablaufen. Die Blätter sind nur in der Jugend in der Form von Schüppchen nachweisbar; später vertrocknen sie und zerbröckeln.

Der Bltithenstand ist ein einfaches Dichasium, das von einem kräftigen, 5-9 mm langen Stiele gestützt wird; der mittlere Sonderblïthenstand (Cyathium) von dem Aussehen einer einfachen Blüthe sitzt stiellos zwischen den seitlichen, die von einem kurzen Stiele getragen werden; Deckblätter und Vorblättchen derselben sind in der Gestalt kurzer, fleischiger Schuppen entwickelt. Die Hülle des Sonderblüthenstands ist kelchartig, grïn, glockenförmig, sehr kurz fünflappig; am Rande trägt sie zwischen den Lappen 5 ziemlich grosse, trapezförmige, schwach ausgerandete, fleischige, goldgelbe Drüsen. Die männlichen Blüthen bestehen aus einem einzelnen Staubgefässe, welches in der Vollbliithe die 3-4 mm lange Hülle um die Hälfte uiberragt und im oberen Fünftel ein Gelenk besitzt; dieses wird als die Trennungsstelle zwischen Blïthenstiel und Staubgefäss angesehen; der zweiknöpfige Beutel sitzt auf der Spitze des Fadens, die Theken springen in scheitelständigen Längsspalten auf. Die Anordnung derselben vollzieht sich in Doppelreihen, nach welchen sie sich absteigend abwechselnd, zickzackförmig einander folgen und die vor den Hüllzipfeln, also zwischen den Drüsen stehen; aussen neben ihnen finden sich zahlreiche zerschlitzte sogenannte Spreuschuppen, die den Deck- bez. Vorblättchen der Blïthen homolog gesetzt werden. Nicht alle Blithenstände enthalten in der Mitte eine weibliche Blithe. Diese ist lang gestielt und trägt am Ende in nickender Stellung einen dreiknöpfigen Fruchtknoten mit einer Samenanlage in jedem Fache. Sehr viele der Cyathien sind übrigens rein männlich, die weibliche Mittelblüthe ist nur als niedriger Höcker im Rudiment ausgebildet.

Die Frucht ist eine ziemlich grosse, fast kngelförmige, an der Spitze niedergedrïkte, tief dreilappige Kapsel, die in 3 glatte, von der Seite etwas zusammengedrückte, gewölbte Kokken zerfällt; auf dem Rücken sind diese scharf gekielt. Die Samen sind ein wenig papillös.

Die gebräuchliche Wolfsmilch findet sich in Marocco am Fusse des grossen Atlas, siudöstlich von der Stadt Maroceo im Districte Mesfiwa und Netifa auf Hïgeln und in der Provinz Demenet ziemlich häufig; anch nordöstlich von jener Stadt kommt sie reichlich vor.

Anmerkung 1. In der Darstellung der Blüthenverhältnisse baben wir uns nach den in Deutschland und England geltenden Anschauungen gerichtet; wir wollen aber nicht wit Stillschweigen iibergehen, dass man in Frankreich und dass namentlich der ausgezeichnete Kenner der Fanilie, BALLoN, die Sonderblïthenständehen für hermaphroditische Bliithen ansieht. Sie sind zweifellos ein eigenartiges Mittelding, und wenn sich auch heute viele Momente anfïhren lassen, welehe sie als Bliithenstände characterisiren, so kann man sich doeh wohl vorstellen, dass sie, phylogenetisch gesprochen, einstmals aus polyandrischen Einzelbliithen entstanden sind.

Anmerkung 2. Da die Materialien der Euphorbia resinifera Berg in den Sammlnngen immer noeh äusserst mangelhaft sind, so haben wir zum Vergleich und zur Vervollstïndigung die verwandte E. Canariensis L. in detaillirter Zeichnung hinzagefügt.

Die Pflanze liefert das Euphorbium. Zur Gewinnung dieses Gummiharzes werden die Zweige der lebenden Pflanze an den Kanten mit Einschnitten versehen; der herausfliessende Milehsaft der Milchröhren erhärtet und wird als Droge gesammelt.

\section{Erklärung der Abbildungen.}

Bedeutung der kleinen Buchstaben: $a$. Blattpolster mit den beiden Stacheln; $b$. Vegetationskegel der Achselsprosse; c. Stiel des Dichasiums; d. Stiel des Cyathiums; $e$. männlicher, $f$. androgyner Sonderblithenstand; $g$. Deckbliitter und Vorblättehen des Cyathiums; $h$. Hitlle desselben; $i$. Drüsen; $k$. Zipfel der Hülle; $l$. innere Haare (Spreuschuppen, Deekund Vorblättchen der Bliithen); $m$. männliche Blüthe; $n$. Blüthenstielehen; $o$. Staubgefäss; $p$. weibliche Blüthe; $q$. Blüthenstielchen; $r$. Rest der Blïthenhülle; $s$. Fruchtknoten; $t$. Griffel; $u$. Samenanlage; $v$. Karunkcl; $v$. Stempelrest; $x$. Kapsel; $y$. Kokken; z. Nabel; $t z$. Raphe; aa. Chalaza.

A-L. Euphorbia Canoriensis Linn., nach Sehacht.

Fig. A. Oberer Theil eines Zweiges vor der Vollblïthe.

Fig. $B$. Derselbe schräg von oben gesehen.
Fig. $C$ u. D. Dichasien vor und zur Zeit der Vollblithe Fig. E. Lïngsschnitt durch ein Dichasium.

Fig. F. Spreuschuppe. 
Fig. H. Männliche und weibliche Blüthe in sehr jungem Zustande.

Fig. $I$ u. $K$. Männliche Blüthe vor und zur Zeit der Vollblüthe.

Fig. L. Pollenkörner.

$M-X$. Euphorbia resinifera Berg.

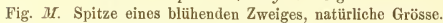

Fig. $N$. Ein Dichasium, 2mal vergrössert.

Fig. $O$. Ein männliches Cyathium, 6mal vergrössert.

Fig. $P$. Dasselbe im Längsschnitte, 6mal vergrössert.
Fig. Q. Ein fruchttragendes androgynes Cyathium, 3mal vergrössert.

Fig. $R$. Spreuschuppe, $12 \mathrm{mal}$ vergrössert.

Fig. $S$. Eine tunreife Kapsel.

Fig. T. Dieselbe von oben gesehen, 2mal vergrössert.

Fig. $U$. Dieselbe im Begriff aufzuspringen.

Fig. $V$. Eine aufgesprungene Kokke.

Fig. $W$. Der unreife Same.

Fig. $X$. Derselbe von der Bauchseite gesehen, 3mal vergrössert.

\section{CROTON Linn.}

Bliithen aktinomorph, eingeschlechtlich, ein- seltener zweihäusig, häufig mit Blumenblättern versehen. Männliche Blitthe: Keleh tief oder bis zum Grund in $5(4-6)$ Lappen getheilt, die in der Knospe klappig deeken. Blumenblätter jenen gleich gross oder kürzer. Honig absondernde Drüsen oder Schuppen am Kelehgrunde befestigt oder mit den äusseren Staubgefissen wechselnd. Die letzteren oft sehr zahlreich, mit in der Knospe eingebogenen Fäden, später aufrecht; Beutel dithecisch, Theken parallel mit Längsspalten aufspringend; Rest eines Stempels gewöhnlich nicht vorhanden. - Weibliche Blüthe: Abschnitte des Kelehes meist schmäler; Blumenblätter kleiner als in den männlichen Blüthen, zuweilen fehlend. Fruchtknoten dreifächrig and -knöpfig, mit drei zurtickgekrümmten Griffeln, die einfach oder mehrfach zweitheilig sind; Samenanlagen in jedem Fache einzeln und hängend. Frucht kapselartig in Kokken zerfallend, die sich von der Mittelsäule lösen und zweiklappig aufspringen. Samen glatt mit kleiner Karunkel; Keimling in reichlichem, fleischig-öligem Nährgewebe mit flachen, blattartigen Keimblättern. - Stauden, die nicht selten am Grunde verholzen oder Sträucher, seltener Bäume oder Kräuter mit gewöhnlich spiralig gestellten, ganzrandigen, gezähnten, seltener gelappten Blätern und Nebenblättern; eine aus Sternhaaren oder Schuppen gebildete Bekleidung ist nieht selten. Blïthen in endständigen Ähren oder Trauben mit meist kleinen Deckblättern.

Mindestens 600 Arten, die in den wärmeren Theilen beider Hemisphären, hauptsächlich aber in SïdAmerika gedeihen.

\section{Croton Eluteria Benn.}

\section{Tafel 86 .}

Strauchartig mit eioblongen bis eilanzettlichen, gestielten, ganzrandigen, lederartigen, zugespitzten, am Grunde herzförmigen, beschuppten Blättern und endständigen Tranben, die beiderlei Geschlecht, die weiblichen Blithen im unteren Theile, enthalten.

Croton Eluteria (Eleutheria) Benn. in Journ. Linn. soc. IV. 29 nicht Linn., Sw. ete.*); W. F. Daniell, On Cascarilla plants 4. t. 1; Bentl. and Trim. Med.pl.t. 238; Muill. Arg. in P. DC. Prodr. XV. (2). 516; Köllter, Medizinalpf. t. 170; Baill. Bot. méd. 943 fig. 2683.; Flïck. and Hanb. Pharmacogr. 505; Flick. Pharmacogn. 610; Arth. Meyer, Drogenkunde II. 116.

Clutia Eluteria Linn. Spec. pl. ed. I. 1042 (die Synonyme fast sämmtlich ausgeschlossen).

Clutia Eluteria seu Cascarilla Woodv. Med. bot. 633 t. 233 fig. 2.

*) Über die sehr complicirte Frage, welche Pflanze die Cascarill-Rinde liefert, haben die beiden erstgenannten Autoren klaren Aufschluss gebracht. 
Elutheria Linn. Hort. Cliffort. 486 .

Elutheria Providentiae folio corlato, subtus argenteo. Sweet bark seu cortex bene olens Petiv. coll. IV. n. 276 .

Cascarilla-Stranch; engliseh: Sweet wood; französisch: Cascarillier ou Chacrillier.

Der wenig ansehnliche, sparrig verzweigte Strauch erreicht eine Höhe bis zu $6 \mathrm{~m}$; die jüngeren stielrunden Zweige sind mit hellgraner, gerunzelter Rinde bedeckt, weiter oben sind sie mit Schuppen bekleidet, die im dickeren Mitteltheile braun, am ausgefransten Rande weiss gefärbt sind; an der Spitze sind die Zweige zusammengedriickt und mit den gleichen Schuppen gepanzert.

Die Blätter sind spiralig angereiht; sie sind an einem 1-1,5, selten bis $2 \mathrm{~cm}$ langen, drehrunden, oberseits schwach ausgekehlten, braun beschuppten Stiele aufgehangen. Die Spreite ist 4-6 $(2-7) \mathrm{cm}$ lang und unfern der Basis 2-2,5 (1,5-3) cm breit, eioblong oder dreiseitig ins Oblonge, lang oder sehr lang und stumpf zugespitzt, am Grunde gestutzt oder gerundet; sie wird jederseits des Mittelnerven von 4-6 grösseren, beiderseits schwach vorspringenden Nerven durchlaufen, oberseits ist sie mit einzelnen Schuppen bestreut, die unterseits zu einem dichten schülfrigen, silberfarbenen Überzuge zusammentreten; am Rande ist sie ganz, ihre Substanz ist dïnn lederartig. Nebenblätter haben wir auch an den jüngsten Knospen nicht gesehen.

Der Blithenstand ist eine einfache endständige Traube, die bisweilen durch seitenständige, aus den Achseln der oberen Blätter bereichert wird; die Deckblätter der weiblichen unteren, wie der männlichen oberen Blüthen sind kaum $0,5 \mathrm{~mm}$ lang, breit dreiseitig, eiförmig, spitz; die beiden Vorblättchen sind noch kleiner, beide sind wie die Spindel von dem reichlichen schülfrigen Schuppenbelag fast verdeckt.

Die Blithen sind kurz gestielt; die männliche misst etwa $3 \mathrm{~mm}$ im Durchmesser. Die Kelchblätter sind oblong, spitz, aussen dicht braunschuppig, innen mit einfachen Haaren versehen. Die zarteren Blumenblätter sind fast so lang wie jene, am Grunde dentlich genagelt, spärlich beschuppt, aber am Rande weiss zottig. Die Discusschuppen sind breit, gestutzt und wenig fleischig. Anf dem weiss behaarten Blüthenboden sitzen etwa 12 Staubgefässe mit pfriemlichen, weiss behaarten Fäden und kahlen, elliptischen, gestutzten Beuteln. Die weibliche Blüthe ist bezüglich Kelch und Blumenkrone jener sehr ähnlich; die schüsselförmige, Honig absondernde Scheibe trägt aber unterhalb schwacher Vertiefungen die Blumenblätter; der kugelförmige Fruchtknoten ist braun beschuppt und zeigt an der Spitze die 3 am Grunde vereinigten Griffelïste, welche sich zweimal dichotom theilen, kahl und fleischig sind.

Der Cascarilla-Strauch findet sich unter Gesträuch einzig und allein auf den Bahama-Inseln und zwar sahen wir ihn von Hog-Island.

Anmerkung. Die Pflanze wird nur sehr selten in den Herbarien angetroffen; wir verdanken dieselbe Herrn Prof. URBAN aus dem von ihm und Herrn Consul Krug begründeten Westindischen Herbar; sie war von EGGFRs gesammelt. Verwandtschaftlich steht sie Croton glabellus Linn. (Croton Sloanei Benn., C. nitens Sw.) nahe, während sie in der Tracht C. balsamifer gleicht. Von der ersteren haben wir auch die Früchte und Samen, die wir von dem Cascarill-Strauch nicht erhalten konnten, hinzugefïgt.

Die Stammrinde des Strauches kommt als Cortex Cascarillae (Cascarillinde) in den Handel.

\section{Erklärung der Abbildungen.}

Fig. A. Blïhender Zweig nach einem anf Hog-Island gesammelten Exemplare.

Fig. $B$, Eine Schuppe, $25 \mathrm{mal}$ vergrössert.

Fig. C. Die männlíche Blïthe, $10 \mathrm{mal}$ vergrössert.

Fig. $D$ u. E. Das Staubgefäss von innen und der Seite, 20 mal vergrössert.

Fig. F. Pollenkörner, $280 \mathrm{mal}$ vergrössert.
Fig. G. Die weibliche Blüthe, $10 \mathrm{mal}$ vergrössert.

Fig. H. Der Fruchtknoten, 20mal vergrössert, im Längsschnitte.

Fig. I. Dersclbe im Querschnitte.

Fig. K. Die Frucht von Croton glabellus L., 3mal vergxössert.

Fig. $L$ u. $M$. Der Same von der Bauch- und Rückenseite.

Fig. $O$ u. $P$, Derselbe im Längs- und Querschnitte. 


\section{Croton Tiglium Linn.}

\section{Tafel 87.}

Stranch oder Baum mit langgestielten eiförmigen oder eioblongen Blättern, dic am Rande gesägt sind, nnd lockeren Trauben; männliche Blithe mit 15 Staubgefässen; Frucht kahl und fast glatt, nur von den Basen der abgefallenen Haare ein wenig rauh.

Croton Tiglium Linn. Spec. pl. ed. I. 1004; Gürtn. Fr. I. 117; Plenck, Offiz. Gew. t. 689; Nees, Dïsseld. Abbitd. t. 13S; Woodo. Med. pl. V. t. 21; Guimp. u. Schlecht. Pfl. Pharmac. III. 72. t. 261; Blume, Bijdr. 602; Bentl. and Trim. Med. pl. III. t. 239; Müll. Arg. in P. DC. Prodr. XV. (2). 600; Kurz, For. Fl. Brit. Burma II. 374; Klotzsch in Hayne, Arzneigew. XIV. t. 3; Berg u. Schmidt, Darst. u. Beschreib. t. XVII ; Fliuck, and Hanb. Pharmacogr. 508; Hook. fil. Fl. Br. Ind. V. 393; Baill. Bot. méd. 940. fig. 2676-26s2.

Croton Jamalgota Ham. in Trans. Limn. soc. XIV. 25 S.

Croton Parana Ham. l. c.

Tiglium officinale Klotzsch in Nov. act. nat. cur. XIX. Suppl. I. 418, in IIayne, Arzneigew. XIV. t. 3 Text.

Purgirbaum; englisch: Till tree; französisch: Tiglium Croton.

Ein kleiner immergrtiner Baum von 5-6 m Höhe, der anch zuweilen strauchartig bleibt, mit glatter, aschgrauer Rinde; nur die jüngeren stielrunden Triebe sind mit spärlicher Sternbekleidung versehen.

Die Blätter stehen anf $2-5 \mathrm{~cm}$ langen, schlanken, kahlen Stielen, die oberseits mit einer schwachen Regenrinne versehen sind, und sich am Grunde nur mässig verbreitern; die Spreite ist 5-10, selten bis $12 \mathrm{~cm}$ lang und $3-5$, selten bis $7 \mathrm{~cm}$ breit, von oblonger oder eioblonger Gestalt, zugespitzt, am Grunde gernndet oder gestutzt, aber kaum herzförmig; am Grunde nahe am Blattstiele befinden sich 2 Schiisseldrüsen; sie ist dünnkrautig und wenigstens im Alter völlig kahl, dentlich dreinervig und wird ausserdem zu beiden Seiten des Mittelnerven von ca. 2-3 grösseren Seitennerven durchlaufen, die beiderseits hervortreten; ihre Farbe ist gelblich-grïn; der Rand ist mit kleinen und flachen, entfernten Sägezähnen besetzt. Die Nebenblätter sind meist kanm 2-3 mm lang, pfriemlich, mit einigen Stcrnhaaren besetzt und leicht abfällig.

Der Blüthenstand ist cinc lockere, gesticlte, 5-9 zuweilcn auch bis $15 \mathrm{~cm}$ lange androgyne Traube, welche wohl niemals tibergipfelt wird; die schlanke, drehrunde Spindel ist nur in der fruhesten Jugend ganz spärlich sternhaarig bekleidet; die Deckblätter sind kaum $3 \mathrm{~mm}$ lang, lanzettlich pfricmlich und bleiben wie die noch kleineren, nach rlickwärts am Grunde des Bltithenstieles zusammengerttekten Vorblättchen längere Zeit an der Spindel sitzen. Der Bluthenstiel misst $3-5$, selten bis $10 \mathrm{~mm}$, er ist an der weiblichen Blüthe kräftiger und mit eincr dichtcren Stcrnhaarbekleidung versehen, während derjenige der männlichen schlanker und kahl ist; meist steben die Bluthen einzeln, bisweilen aber werden die Vorblättchen der männlichen fruchtbar, so dass zwei- bis dreibluthige Büschel aus den Deckblättern treten.

Die männlichen Blüthen stehen entweder an dem oberen Theile des Blüthenstandes, oder der letztere trägt nur solche. Der Kelch ist grün, flach ausgebreitet, tief fünftheilig mit flach glockenförmiger Röhre; er hat etwa 2,7-3,2 mm im Durchmesser; die Abschnitte decken in der Knospe klappig, sie sind oblong lanzettlich, am Rande und an der Spitze dünn sternhaarig, an der Rïckseite kaum dichter bekleidet, oder völlig kahl. Die lanzettlichen Blumenblätter überragen den Kelch nicht; ihre Farbe ist weiss; zuerst sind sie flach ausgebreitet, später zurïckgerollt, am Grunde sind sie dicht zottig; ebenso ist der Blüthenboden bekleidet, an dessen Rande sich 5 dottergelbe, breit eiförmige, spitze Drïsen befinden. Staubgefässe sind 15-20 vorhanden, welche vollkommen frei sind und den Kelch ïberragen, auch ihre gelblich-griinen Fäden sind am Grunde behaart; die kleinen gelben Bentel werden durch cin sehr diekes nach aussen kielartig vorspringendes Mittelband vereinigt. Die Pollenkörner sind kugelrund, fein warzig, weisslich. 
Die weibliehen Blüthen stehen am Grunde der Blitthenstände. Der Keleh ist nur bis zur Mitte in 5 oblong dreiseitige, spitze Zipfel getheilt, aussen und innen am Grunde sternfilzig, sonst kahl; die Blumenblätter sind zu winzigen, kopfförmigen, kurz gestielten, dem Honig absondernden Ringe auf der Innenseite angewaehsenen Körperehen redueirt. Der Fruehtknoten trägt eine diehte, goldgelbe, sternfilzige Bekleidung, ist kugelförmig, sehwaeh dreilappig, und trägt an der Spitze 3 ziemlieh lange Griffel (bis $8 \mathrm{~mm}$ ), die bis zum unteren Drittel in 2 fadenförmige Arme gespalten sind.

Die Frueht ist eine kugelförmige oder ellipsoidisehe, sehwach dreilappige, erst lederartige, dann krustenförmige Kapsel, die in der Jugend sternhaarig bekleidet ist, später aber verkahlt und dureh die stehenbleibenden Haarbasen etwas rauh wird; ibre Länge beträgt 2-2,2 em, der Durehmesser 1,6 bis 2,0 em; die Farbe ist in getroeknetem Zustande hell bräunlieh-gelb, in lebendem wahrseheinlieh weiss; die Kokken, welehe bis zur Mitte zweiklappig aufspringen, bleiben oft längere Zeit im Zusammenhang.

Der Same ist 1-1,5 cm lang und hat einen Durehmesser von 8-10 mm; er ist ellipsoidiseh mit stärker gekrümmter Rüekenfläehe, an den Seiten ist er gerandet, die Karunkel ist klein; die Farbe wechselt von hell grau-gelb bis dunkelgelb, häufig erscheinen braune Striehe und Tupfen; nieht selten ist die Farbstoffsehicht abgerieben und dann wird er sehwarz. In der Mitte des ölig-fleisehigen Nährgewebes liegt der grosse Keimling, der mit blattartigen, drei- bis fünfnervigen Keimblättern versehen ist.

Der Purgirbaum ist in Ost-Indien heimiseh und findet sich von Bengalen und Assam über Birma bis Malakka und aueh in Ceylon wild, aber aueh sehr häufig kultivirt, besonders als Heekenpflanze; in Java, Borneo und auf den Philippinen duirfte er ebenfalls heimiseh sein; in China ist er aber wahrscheinlich, in Japan sieher eingefuhrt.

Das fette Öl, welehes aus den Samen, resp. aus Endosperm und Keimling, der Pflanze durch Pressen erhalten wird, findet als Oleum Crotonis (Crotonöl) medicinisehe Verwendung.

\section{Erklärung der Abbildungen.}

Fig. A. Ein blithender Zweig nach einem im Berlincr Universitätsgarten kultivirten Exemplare.

Fig. B. Die Knospe der männlichen Blïthe, 4 mal vergrössert. a. der Keleh.

Fig. $C$ u. $D$. Die männliche Blüthe von oben und von unten, $4 \mathrm{mal}$ vergrüssert: $b$. das Blumenblatt; $e$. die Stanbgefüsse.

Fig. E. Dieselbe im Längsschnitte, 10mal vergrössert: c. Blüthenboden; $d$. Drüse.

Fig. $F$. Das Blumenblatt, smal vergrössert.

Fig. G. Das Staubgefïss von der Seite und von innen, $10 \mathrm{mal}$ vergrössert.

Fig. II. Pollenkörner, 120mal vergrösscrt.
Fig. $I$. Die weibliche Blüthe, 4 mal vergrüssert: $f$. der Fruchtknoten; $g$. die Narben.

Fig. L. Dieselbe im Längsschnitte: 7 . die Samenanlage.

Fig. M. Dieselbe im Querschnitte.

Fig. $N$. Sternhaare, $40 \mathrm{mal}$ vergrössert.

Fig. o. Dic Kapsel, natïrliche Grösse: $i$, die Fruchthaut.

Fig. $P$. Ein Coccus: $h$, der Same.

Fig. $Q$. Der Same, natürliche Grüsse: 7 . Nabel, $m$. Raphe, n. Chalaza.

Fig. $R$ u. S. Derselbe 2 mal vergrössert, im Längs- u. Querschnitte: $o$. die Samenschale, $p$, das Nihrgewebe, $q$. das Würzelchen, $r$, die Keimblätter

\section{MALLOTUS Lour.}

Blüthen aktinomorph, getrenntgesehleehtlich, meist zweihäusiz, apetal. Männliehe Blüthe: Keleh vor der Vollbliithe gesehlossen, daun drei- bis viertheilig aufreissend. Staubgefässe sehr viele mit freien Fäden; Bentel am Grunde befestigt, ditheeiseh; Theken mit Längsspalten aufspringend; ein Stempelrest fehlt. Weibliehe Blüthe: Kelehblätter mehr gesondert, klappig oder daehziegelig deekend. Fruehtknoten drei- (selten zwei- bis vier-) fảehrig; Griffel getrennt oder am Grunde verbunden, ungetheilt, innen gefranst oder vorspringend papillös; Samenanlagen einzeln in jedem Fache, von oben hängend. Kapsel filzig, besehuppt oder bestaehelt, in zweiklappig aufspringende Kokken zerfallend. Samen wie gewöhnlieh in der 
Familie. - Bäume oder Sträucher mit spiralig, selten quirlig angereihten Blättern, dic ganzrandig, gezähnt oder gelappt sind; bisweilen sind sie schildförmig gestielt. Blïthen in einfachen Ähren oder diese treten zu Rispen zusammen. Ungeführ 80 Arten, welche ausschliesslich in der alten Welt, hauptsächlich aber im Malayischen Archipel bis Neu-Guinea und zu den Philippinen gedeihen.

\section{Mallotus Philippinensis Müll. Arg.}

Tafel 88.

Baumartig mit eioblongen oder oblonglanzettlichen, zugespitzten, dreinervigen, fast lederartigen Blittern, die auf den Ruckseiten von Drüsen roth punktirt sind; Staubgefüsse 15-25; Fruchtknoten mit scharlachspäter purpurrothen Drïsen besetzt; Kapsel kugelförmig; dreilappig.

Mallotus Phitippinensis Milll. Arg. in Linnaca XXXIV. 196, in P. DC. Prodr. XV. (2). 9S0; Brandis, For. Fl. 444; Kurz, For. Fl. Brit. Burma II. 351; Bedd. Fl. sylo. t. 259; Bentl. and Trim. Med. pl. t. 236; Hook. fil. Fl. Br. Ind. V. 442; Bcnth. Fl. Austr. VI. 141; K. Sch. Fl. Kais.-Wilh-Land 78; Köhler, Medicinalpfl. t. 50; Flück. Pharmacogn. 257; Flück, and Hanb. Pharmacogr. 515; Meyer, Drogenk. I1. 461.

Croton Plitippinensis Lam. Encycl. II. 206. (17S6).

Croton punctatus Retz. Obs. bot. V. 30. (1789).

Croton coccineus Vahl, Symb. II. 97.

Croton montanus Willd. Spec, pl. IV. 545.

Croton cascarilloides Raeusch. Nomencl. ed. III. 250.

Echinus Philippincnsis Baill. in Adans. VI. 314, Bot. méd. 934. fig. 2666.

Rottlera tinctoria Roxb. Corom. pl. II. 36. t. 165. (1798), Fl. Ind. III. 827; Thwait. Enum. pl. Zeyl. 273; Benth. Fl. Hongkong. 307; Miq. Fl. Ind.-Bat. Suppl. 454;

Rottlera aurantiaca Hook. ct Am. Bot. Beech. 270.

Rottlera affinis Hassk. in Flora 1544, Beibl. II. 41, Ilort. Bogor. 239.

Kamala-Baum; englisch: Kamala Trce; französisch: Arbre de Kamala.

Der immergrüne Baum erreicht eine Höhe von 8-15 m und der Stamm einen Durchmesser von 20-36 cm; das Holz ist sehr feinkörnig und zäh; die jungen, sehlanken, stielrunden oder gestreift kantigen Zweige sind von einem kurzen, rostfarbigen Sternfilze bekleidet, der endlich versehwindet.

Dic Blätter werden von einem $3-5(2-8$, selten bis 10$) \mathrm{cm}$ langen, schlanken, sticlrunden, oberseits schwach abgeflachten Sticle getragen, der sehr dünn rostfarbig filzig bekleidet ist; die lederartige Blattspreite ist $6-10(4-18) \mathrm{cm}$ lang und in dem unteren Drittel $4-6(2,5-9) \mathrm{em}$ breit, oblong oder eioblong oder mehr oder weniger ins rhombische gehend, kurz oder lünger und stets stumpflich zugespitzt mit kurzem Stachelspitzchen, am Grunde abgerundet oder breit keilförmig, deutlich dreinervig; ausserdem wird sie noch ron 4-5 seitlichen Nerven durehzogen, diese sind durch zahlreiche transversale Quernerven, die besonders unterseits netzig vorspringen, verbunden; die Oberseite ist später wenigstens kahl, die Unterseite in der Jugend immer, nicht selten aber auch im Alter sternhaarig filzig bekleidet und mit rothen Drüsen bestreut, welche das dünngeschabte oder jüngere Blatt durchscheinend punktirt erscheinen lassen; der Rand ist ganz oder schwach buchtig gezähnt, die Farbe frisch grün, unten bisweilen blaugrau, nahe am Blattstiele befinden sich 2 drüsige Stellen. Die Nebenblätter sind sehr klein, kaum $2 \mathrm{~mm}$ lang, fädlich pfriemlich, rostfarben filzig und sehr frïh abfällig.

Der Bluthenstand ist eine steife Ähre, welche entweder aus der Achsel der Laubblätter tritt oder endständig ist und durch Zweige aus Hochblättern zu rispigen Aggregaten bereichert wird. Die Spindel ist gewöhnlich 5-8, seltener bis $10 \mathrm{~cm}$ lang, schwach kantig und rostfarben filzig behaart; die Deckblätter sind schuppenförmig, kaum $1 \mathrm{~mm}$ lang und tragen in der Achsel entweder nur einzelne weibliche, oder 2-3 männliche Blitthen, welche aus den Achseln der noch kleineren Vorblïttchen hervorbrechen.

Die männlichen Bluthen sind sitzend oder ganz kurz gestielt. Der Kelch ist drei- oder viertbeilig, aussen kurz rostfarben filzig, etwa $2,5 \mathrm{~mm}$ lang; die Zipfel sind eifürmig spitz. Staubgefässe sind 
15-25, seltener mehr vorhanden, sie bilden in der Knospe ein kugelrundes Köpfehen, später stehen sie auf ziemlich langen Fäden sparrig auseinander, die beiden Theken sind durch ein breites, papillöses Mittelband verbunden. Weder Blumenblätter noch Drüsen noch Stempelreste sind vorhanden.

Die weiblichen Blitthen haben etwas schmälere Kelchzipfel, die unten angepresst, oben etwas auswärts gebogen sind. Der Fruchtknoten misst bei der Vollblüthe 1,5 mm im Durchmesser, ist schwach dreilappig und trägt 3 ebenso lange oder ein wenig längere, vollkommen freie, dick papillöse Griffel, die vollkommen ungetheilk. und zugespitzt sind; jener ist mit Sternhaaren bekleidet, zwischen denen zahllose rothgelb gefärbte, birnförmige Köpfchendriisen sitzen.

Die Frucht ist ein etwa 5-7 mm hohe und 8-9 $\mathrm{mm}$ im Durchmesser haltende, dreilappige Kapsel, welche mit braunrothen Drüsen reichlich besetzt ist; sie springt dreiklappig fachtheilig auf, wobei sich die holzigen Klappen von der concav dreiseitigen Mittelsäule lösen.

Der Same hat 4-5 mm im Durchmesser, ist fast kugelrund, nur an der Banchseite ein wenig zugeschärft, kastanienbraun und etwas dunkler marmorirt; die Samenschale ist brïchig und umschliesst einen flachen Keimling mit blattartigen Keimblättern in einem (im trockenen Zustande) dunkelgelben Nährgewebe.

Die Kamalapflanze findet sich sehr hänfig in trockenen, niedrig gelegenen Wäldern, besonders auch der Strandgegenden, von Kaschmir und am Fusse des Himalayagebirges, iuber Bengalen und Birma bis Ceylon und Singapore; auch im Malayischen Archipel ist sie häufig und geht bis Nen-Guinea und Australien, nach den Philippinen und China.

Als Kamala (Glandulae Rottlerae) kommen die vielzelligen Drisen und Bïschelhaare des Perikarps von Mallotus Philippinensis in den Handel. Diese beiden Organe sitzen zusammen an der Aussenseite der Frucht und werden dadurch gewonnen, dass man die Früchte in Körben schüttelt, wodurch Drüsen und Haare abgerieben werden und durchfallen. Am reichlichsten kommen in dem Gemische die Drüsen vor, und sie enthalten auch die medicinisch wirksamen Bestandtheile der Droge.

\section{Erklärung der Abbildungen.}

Fig. $A$ u. $B$. Ein Zweig der weiblichen und der männlichen Pflanze.

Fig. C. Die Knospe der männlichen Blïthe, 8 mal vergrössert.

Fig. $D$ u. $E$. Eine drei- und eine viergliedrige männliche Blïthe, $8 \mathrm{mal}$ vergrössert.

Fig. $F$. Das Stanbgeftiss, von der Seite gesehen, 20mal vergrössert.
Fig. G. Pollenkorn, $150 \mathrm{mal}$ vergrössert.

Fig. $H$ u. $I$. Eine drei- und eine viergliedrige weibliche Bliithe, 10 mal vergrössert.

Fig. K. Die Kapsel, 2mal vergrössert.

Fig. $L$. Der Fruchtknoten im Querschnitte, 10mal vergrössert.

Fig. M. Der Same.

\section{RICINUS Linn.}

Blïthen getrenntgesehlechtlich, einhäusig, apetal, aktinomorph, ohne Honig absondernde Scheibe. Männliche Blüthe: Kelch drei- bis fünftheilig mit klappiger Knospenlage der ziemlich breiten Zipfel, krautig. Staubgefässe sehr zahlreich, bisweilen mehr als 1000, die dïnnen Fäden sind am Grunde zu mehreren Biischeln verbunden; Staubbeutel dithecisch, Theken von einander gesondert, mit Längsspalt aufspringend, fast kugelförmig. Ein Rest des Stempels ist nicht vorhanden. - Weibliche Blüthe: Kelch von ähnlicher Beschaffenheit wie derjenige der männlichen Blïthe, aber die Zipfel spitzer und sehr schnell abfallend. Fruchtknoten oberständig, dreifächrig, mit einer einzelnen, hängenden Samenanlage in jedem Fache; Griffel 3, mässig lang oder kurz, ganz oder gewöhnlich zweispaltig. Kapsel dreiknöpfig in zweiklappige Kokken zerfallend. Samen ellipsoidisch, auf der Innenseite häufig ein wenig zugeschärft mit krustenförmiger Schale und reichlichem fleischigem Nälırgewebe; Keimblätter flach, blattartig. - Eine bei 
uns einjährige, krautige, sehr grosse und stattliche Pflanze, die in den Tropen baumartig wird, mit spiralig angereihten, grossen, gelappten Blättern, die schildförmig an dem Stiele befestigt sind. Die Blüthen sitzen gebüschelt an den Enden seitlicher Triebe oder beschliessen die Hauptaxe, die dann übergipfelt wird; die oberen sind weiblich, die unteren männlich.

Nur eine äusserst veränderliche Art, die wahrscheinlich in Afrika ihre ursprüngliche Heimath hat.

\section{Ricinus communis Linn.}

Tafel 89.

Blätter handförmig gelappt oder getheilt, Lappen einfach oder doppelt gezähnt, kahl, bisweilen wie der Stengel blau bereift; Blattstiel am Grunde und an der Spitze mit einem Drisenpaar; Ncbenblätter abfällig. Kapsel bestachelt oder glatt.

Ricinus communis Limm. Spec. pl. ed. I. 1007; Ledeb. Fl. Ross. I. 501; Mïller Argov. in P. DC. Prodr. XV. (2). 1016*); Willk. et Lange, Prodr. Fl. Hisp. III. 510; Boiss. Fl. orient. IV. 1143; Hook. fi. Fl. Brit. Ind. V. 547 ; Berg u. Schmidt, Darstell. u. Beschreib. $I^{c}$; Bentl. and Trim. Medic. pl. t. 237; Köhler, Medicinalpfl. t. 160; Baill. Bot. méd. 923. fig. 2645-2657; Flüch. and Hanb. Pharmacogr. 510; Battand. et Trab. Fl. d'Alger II. SAG; Aschers. et Schwfth., Illustr. Fl. de IEgypte 139.

Wunderbaum; englisch: Common oil nut tree, Palma Christi; französisch: Ricinus, Palma Christi.

Die bei uns krautige Pflanze erreicht hier eine Höhe von $2-4 \mathrm{~m}$, nimmt aber in den Tropen und schon in den subtropischen Gegenden Baumform an, wird bis $13 \mathrm{~m}$ hoch und erzeugt einen im Centrum wie der Krautstengel hohlen, aus weichem, weissem, leichtem Holze aufgebauten Stamm von $10-20 \mathrm{~cm}$ Durchmesser und dartiber, mit dünner, grauer Rinde. Jener ist meist grtin oder bräunlieh-roth gefärbt und zeigt häufig einen bläulichen, aus Wachs gebildeten Reifuberzug.

Die Wurzel ist eine mit reichlichen Ästen versehene Pfahlwurzel, die mehr oder weniger stark verholzt und aussen weiss bis braun gefürbt ist.

Die Blätter stehen in spiraliger Anordnung, sie sind sehr lang gestielt und excentrisch schildförmig aufgehangen. Der Blattstiel ist wie dic Fliche, die Stengel und Zweige kahl, fast stielrund, im Innern hohl, am Grunde innenseits etrras abgeflacht und wenig verbreitert; extranuptiale Nectarien, in der Form von halbkugeligen, oben schtisselförmig vertieften Drüsen, die paarig, an den jüngsten Blättern auch einzeln am oberen und unteren Theile zuweilen anch in der Mitte des Blattstieles angebracht sind, finden sich regelmässig; sie scheiden eine Flüssigkeit aus, welche die unberufenen Gäste von dem Bereiche der Bltithen abzulocken scheint. Die Blattspreite ist im Umrisse kreisförmig, sie misst bis $1 \mathrm{~m}$ im Durchmesser und ist etwa bis utber die Hälfte, bisweilen auch weniger tief in $7-11$ eioblonge oder lanzettliche, zugespitzte Lappen getheilt; die letzteren sind völlig kahl, glänzend oder matt und dann blaugrau bereift, bisweilen gerunzelt; die Farbe ist dunkelgrü, zieht sich aber häufig ins Braune, oder wird tief purpurroth; die Mittelnerven springen unterseits stark vor und verbinden sich handförmig dort, wo der Stiel cingesetzt ist; von ihnen gehen parallele Fiedernerven aus, welche in die einfachen oder doppelten, drüsigen, eingebogenen Randsägezähne auslaufen. Die Nebenblätter sind blattgegenständig, derb häutig und fallen, nachdem sie als Tegmente der Knospe gedient haben, ab.

Der Blüthenstand ist rispig, wobei der untere Theil die männliehen, gebüschelten, kurz gestielten Bläthen, die zuweilen durch einen gemeinsehaftlichen Stiel emporgehoben sind, der obere die weiblichen, sitzenden Blithen trägt; er wird bisweilen bis $1 \mathrm{~m}$ lang, ist aber gewöhnlich kürzer, hat zuerst terminale Stellung und wird später durch den Ast aus der Achsel des obersten Blattes tubergipfelt und zur Seite

*) Hier findet man auch die sehr umfangreiche Litteratur uber die zahlreichen von anderen Autoren aufgestellten Arten, welche jetzt nur als Varietäten und Formen einer einzigen aufgefasst werden. 
geworfen, so dass er dem Blatte gegeniibersteht; die Begleitblätter (Deckblätter und Vorblättchen) sind eiförmig, zugespitzt, ausgefressen gezähnelt, dünn häutig und durchscheinend.

Die männliche Bliithe ist in der Knospe fast kugelförmig und hält 8-10 mm im Durchmesser.

Die kelchartige Blüthenhülle ist fünflappig mit eiförmigen, concaven, spitzen, griinen, krautigen Lappen, die in der Knospe klappig decken und später zurückgeschlagen werden. Die Staubgefässe sitzen auf dem leicht gewölbten Blïthenboden in der Form zahlreicher, kleiner, reich verästelter Bäumchen, an deren letzten Verzweigungen je ein dithecischer Beutel mit gesonderten Theken sich befindet, die durch Längsspalten aufspringen; die Pollenkörner sind ellipsoidisch und werden von 3 Meridionalfalten durchlaufen, in deren Mitte die Poren liegen. Ein Stempelrest ist nur in äusserst seltenen Fällen wahrnehmbar.

Die weibliche Bltithe wird ebenfalls von einer der Norm nach fünfzähligen Hülle umschlossen, deren eioblonge, zugespitzte Glieder aber häufig enger unter einander zusammenhalten; sie fallen sehr früh ab. Staubgefässe fehlen völlig. Der Fruchtknoten ist eiförmig, dreifächrig, mit Weichstacheln reichlich bekleidet und von einem kurzen Griffel gekrönt, der in die langen, meist zweispaltigen Narbenäste ausläuft; diese sind dicht mit rothen, keulenförmigen Papillen besetzt, während der Fruchtknoten selbst gewöhnlich blaugrau aussieht. Die Samenanlagen sind anatrop und hängen einzeln in jedem Fache von dem oberen Theile der Mittelsäule herab; von dem Nabelstrang geht eine Wucherung ans, welche die Mikropyle itberdeckt, bei der Zuleitung des Pollenschlanches eine Rolle spielt und später zur Karunkel wird.

Die Frucht ist eine trockne, dreifüchrige Kapsel, welche mehr oder weniger deutlich kugelförmig und dreifurchig erscheint; häufig ist sie mit ziemlich weichen Stacheln bedeckt, manchmal glatt; sie zerfällt in 3 Kokken, die sich von der Mittelsäule lösen, elastisch aufspringen und den Samen fortschleudern. Dieser ist ellipsoidisch, ein wenig plattgedrickt und an der Bauchseite bisweilen zugeschärft; an der Spitze liegt die weisse, fleischige Karunkel; die äussere Samenschale ist grau oder bräunlich und dunkelbraun gestrichelt und gesprenkelt, sehr brïchig, glänzend und glatt. Der Keimling liegt zwischen den beiden Hälften des weissen öligen und fleischigen Nährgewebes und besteht aus den beiden dünnhärtigen, zarten, geaderten Keimblättern und dem dtunnen Würzelchen.

Der Wunderbaum ist ohne Zweifel im wärmeren Afrika heimiseh; schon zur Zeit der alten Ägypter wurde er sehr hïufig cultivirt.

Anmerkung. Nach dem Vorgange von MüLlek Arg. halten wic dafür, dass in der Gattung nur eine sehr formenreiche Art existirt; die von uns zur Darstellung gebrachte Varietät ist die Var. $\beta$. rugosa Mull. Arg.

Aus den von der Samenschale befreiten Samen wird das Oleum Ricini (Ricinusäl) dureh Pressen gewonnen.

\section{Erklärung der Abbildungen.}

Fig. A. Blïhende Plianze nach einem lebenden Exemplare aus dem königl. Universitätsgarten zn Berlin, 4mal verkleinert.

Fig. B. Der Blithenstand, natürliche Grösse: $a$. Blattstiel; $b$. später ïbergipfelnder Ast; $d$. männliche, $e$. weibliche Bliithen.

Fig. C. Die mïnnliche Blithe, 4 mal vergrössert: $a$. Blüthenboden; $b$. Blïthenhiille; $c$. Staubgefässe.

Fig. D. Das Staubgefässbündel, 6mal vergrössert.

Fig. $E$ u. $F$. Ein Staubgefïss mit aufspringenden Theken, 20 mal vergrössert.

Fig. $G$ u. H. Pollenkörner, trocken und in Wasser, 250mal vergrüssert.

Fig. I. Die weibliche Blïthe, 3mal vergrössert: $a$. die
Bliithenhïlle; $b$. der Fruchtknoten; $c$. der Griffel; a. die Narben.

Fig. $K$. Der Fruchtknoten im Lïngssehnitte, 4mal vergrössert: $b$. die Mittelsäule; $c$. die Samenanlage.

Fig. L. Derselbe im Querschnitte, 6mal vergrössert: $a$. die Samenanlage.

Fig. M. Die Frueht.

Fig. $N$. Eine der Kokken, aufgesprungen: $a$. der Same.

Fig. $O$ u. $P$. Der Same von der Batuch- und Rückenseite: a. die Raphe; $b$. die Karunkel.

Fig. Q. Derselbe einer grossfrüchtigen Varietät.

Fig. $R$ u. $S$. Derselbe im Längs- und Querschnitte: $a$. Samenschale; $b$. Nährgewebe; $c$. Keimbliutter; $d$. Würzelchen; e. Karunkel. 


\section{Reihe: Rhamnales Lindl.}

Blüthenblätter in regelmässigen Wirteln; Blüthenhẗlle in Kelch und Krone gesondert, bisweilen wird die letztere sehr klein oder vollkommen unterdrïckt. Staubgefässe in einem Kreise ausgebildet, vor den Blumenblättern stehend. Fruchtblätter entweder in der Zahl den übrigen Blithenblättern gleich oder weniger, je 1-2 aufsteigende Samenanlagen mit dorsaler Raphe umschliessend.

\section{Familie: Rham nace ae Lindl.}

Die Bltithen sind entweder vier- oder fünfliedrig, stets aktinomorph und meist zwittrig, wenn auch vielehige und zwar zweihäusige nicht fehlen. Die Kelchröhre oder besser der vertiefte Blüthenboden ist häufig lederartig, die Gestalt wechselt rom krciselförmigen bis zum eylindrischen; die Kelchblätter schliessen mit klappiger Deckung zusammen und werden innenseits von einer linienförmigen Leiste durehlanfen. Die Blumenblätter sind in den Liicken der Kelchblätter befestigt, meist kleiner als jene und häufig kappenförmig gestaltet; sie sind entweder ganz, ausgerandet oder gelappt, bisweilen fehlen sie. Die Staubgefässe sind vor den Blumenblättern befestigt und werden häufig von ihnen umhüllt und eingeschlossen; die Beutel sind ditheeisch, klein, häufig zweiknöpfig und auf der Spitze des Fadens schwebend angebeftet; die Theken springen in Längsspalten auf, die an der Spitze bisweilen hufeisenförmig zusammenfliessen. Eine Honig absondernde Scheibe ist fast stets vorhanden. Der Fruchtknoten ist ober- oder mehr oder minder unterständig, meist drei- aber auch nicht selten zwei- oder vierfächrig. Der aufrechte Griffel ist meist kurz und dick und geht in so viele $\ddot{A}$ ste aus, als Fruchtknotenfächer vorbanden sind. In jedem der letzteren befindet sich fast stets nur eine einzelne aufrechte, anatrope Samenanlage, deren Raphe dorsal ist, so dass die Mieropyle nach aussen und unten gewendet ist. Die Frucht ist sehr verschieden, sie ist beeren- oder steinfrucht- oder kapselartig und meist dreifächrig. Die in den Fächern stets einzelnen Samen besitzen aussen nicht selten einen Mantel; sie stehen aufrecht und sind häufig zusammengedrickt; das fleischige Nährgewebe ist meist verhältnissmässig umfangreich, selten fehlt es. Der grosse Keimling ist nicht selten gelb oder grün gefärbt, gerade oder spiral eingekrümmt; das Würzelchen ist kurz.

Bäume, Sträucher, sehr selten ausdauernde Stauden; jene haben bisweilen Neiguug zum Klettern mit Hülfe von Spiralfederranken; Stacheln sind häufig. Die Blätter sind einfach, spiralig angereiht, seltener sind sie kreuzgegenständig; Nebenblätter fehlen selten; die Spreite ist häufig lederartig und am Grunde deutlich drei- bis fünfnervig. Die kleinen gelblichen oder grtinen Blüthen bilden reichblüthige, achselständige Inflorescenzen.

Etwa 450 Arten sind beschrieben, welche die wärmeren Gebiete beider Erdhälften bewohnen.

\section{RHAMNUS Linn.}

Blüthen zwittrig oder nicht selten zweihäusig vielehig. Der kxugförmige Blüthenboden trägt $4-5$ dreiseitig eiförmige, aufrechte oder spreizende Kelchblätter. Blumenblätter in gleicher Zahl, kappenförmig oder flach, am Rande des Blüthenbodens befestigt; selten fehlen sie. Staubgefässe mit sehr kurzen Fäden. Fruchtknoten eiförmig, von dem Blüthenboden umschlossen, drei bis vierfächrig, an der Spitze in den kurzen drei- bis vierspaltigen Griffel zusammengezogen; die Narben stumpf und papillös. Die ellipsoidische oder kugelförmige Frucht ist eine Steinfrucht mit 2 oder 4 knochenharten oder knorpligen Steinen, die bisweilen auf der Innenseite eine Neigung zum Aufspringen zeigen. Die umgekehrt eiförmigen Samen 
haben eine häutige oder krustenförmige Samenschale; die Keimblätter sind flach oder am Rande zurïckgekrümmt und dünn; die Wurzel ist kurz. - Sträucher, seltener Bäume mit spiralig, selten fast kreuzgegenständig angereihten, gestielten, abfälligen oder immergrünen, ganzrandigen oder gezähnten Blättern; Nebenblätter klein und abfällig. Blüthen achselständig in rispigen oder traubigen Verbänden.

Ungefähr 60 Arten sind beschrieben worden, welche in den nördlich gemässigten und den wärmeren Theilen beider Erdhälften wachsen; auf der stidlichen fehlen sie fast ganz.

Zweige häufig in Dornen ansgehend; Blätter fein gesägt; Blüthen zweihäusig, viergliedrig; Griffel vierspaltig; Samen mit tiefer Furche; Cotyledonen bei der Keimung aus dem Stein tretend.

1. Rhamnus cathartica Linn.

Zweige unbewehrt; Blätter ganzrandig; Blüthen zwittrig, fünfgliedrig; Griffel mit kurzgelappter Narbe; Samen flach, linsenförmig, nicht gefureht; Cotyledonen bei der Keimung vom Stein umsehlossen.

2. Rhamnus Frangula Linn.

\section{Rhamnus cathartica Linn.}

Tafel 90.

Strauch- selten baumartig mit aufrechten, am Ende häufig verdorrten Zweigen, kahl oder flaumig behaart; Blätter gegenständig, oblong, am Grunde fast herzförmig, fein gesägt; Blüthen grün, gebüschelt, achselständig, vierzählig, zweihäusig, getrennt geschlechtig; Steinfrüehte meist mit 4 Steinen.

Rhamnus cathartica Linn. Spec. pl. ed. I. 193; Fl. Dan. V. 850; Allion. Fl. Pedem. II. t. 129; Plenck, Pf. Pharmac. t. 140; Sm. Fl. Brit. t. 261; Du Ham. Arbr. ed. II. vol. III. 10; Lam. Illustr. III. t. 128, fig. 2; Sow. Engl. Bot. XXIII. t. 1629; Svensk Bot. V. t. 307; Schkulir, Handb. I. 148. t. 46; Hayne, Arzneigew. V. t. 43; Schrk. Fl. Mon. IV. t. 304; DC. Prodr. II. 24; Nees, Diisseld. Abbild. t. 360; Guimp. u. Schlecht. Pf. der Pharm. I. 161. t. 84; Woodv. Med. pl. III. 210; Mert. u. Toch, Deutschl. Fl. II. 238; Koch, Syn. 148; Hart. Forstbot. 483; Aschers. Fl. M. Brand. 130; Bcrg u. Schmidt, Darst. u. Beschreib. t. XVI ; Köhlcr, Mediz. Pfl. t. 63; Ledeb. Fl. Ross. I. 501; Willk. et Lange, Prodr. Fl. Hisp. III. 484; Godr. et Gren. Fl. Fr. I. 335; Boiss. Fl. orient. II. 19; Parlat. Fl. Ital. V. 453; Bentl. and Trim. Med. pl. t. 64; Battand. ct Trab. Fl. d'Algcr I. 190; Flick, and Hanb. Plarmacogr. 139; Flück. Pharmacogn. 851; Willk. Forstl. Fl. 791; Garcke, Fl. Deutschl. ed. XVII. 125. fig. 450; Baill. Bot. méd. II. 976. fig. 2755-2757; Arth. Meyer, Drogenk. II. 397.

Cervispina cathartica Mnch. Meth. 686.

Kreuzdorn; englisch: Bucksthorn; französiseh: Nerprun.

Der Strauch wird bis $3 \mathrm{~m}$ hoch, selten darüber und dann wird er baumartig, er ist sehr reiehlich sparrig verästelt; die Äste sind kreuzgegenständig angeordnet, an der Spitze verkürzt sich häufig die Axe und läuft in einen Dorn und eine Gabel aus; auch die blattachselständigen Kurztriebe endigen häufig mit einem Dorn, der dann aehselständig erscheint. Die Rinde ist glatt und glänzend, roth oder graubraun, hier und da mit Lenticellen besetzt, später wird sie in papierdünnen Lamellen abgestossen, die secundäre Rinde ist rein grün, das Holz schmutzig weiss; die jungen Triebe sind von einzelligen, dünnen, bisweilen etwas geschlängelten Haaren, mehr oder minder flaumig, oft sind sie aber auch kahl.

Die Blätter sind kreuzgegenständig angereiht, an den nicht blühenden Lanstrieben entfernt gestellt, nicht selten stehen aber die Glieder eines Paares auf gleicher Höhe; an den blïhenden Kurztrieben sind sie meist büschelförmig genähert; sie sind $0,8-2,0 \mathrm{em}$ lang gestielt; der Stiel ist drehrund und oberseits von einer ziemlich tiefen Regenrinne durehzogen; die Nebenblätter stehen am. Grunde und an der Seite des Stiels, sind schmal linealiseh, spitz, besonders oben etwas behaart, abfällig, 3-5 mm lang; die Spreite ist $4-5,5(5-8) \mathrm{cm}$ lang und in der Mitte oder etwas tiefer $2-3(0,8-4,5) \mathrm{cm}$ breit, oblong, breit elliptisch oder eiförmig, spitz oder kurz und stumpf zugespitzt, am Grunde spitz oder kurz gespitzt oder fast berzförmig, krautig und wird von wenigen (meist 3) Paaren stärkerer, meist bis zur Spitze bogig vorlaufender Nerven durchıogen; am Rande ist sie fein gesïgt, oder gekerbt gesägt, die Zähne haben einen 
etwas verdickten Rand; besonders in der Jugend ist sie und zwar spärlich, selten reichlicher behaart, später dunkelgriin und glänzend, unterseits heller und matt.

Die Blüthen treten aus den Achseln der Niederblätter der Langtriebe und auch der unteren Laubblätter der Kurztriebe zu mehreren und bilden kugelförmige Aggregate von nicht näher zu analysirender Bildung; sie sind dureh Fehlschlag getrennt geschlechtlich. Zahlreichere $(6-10)$ männliche Blüthen werden von einem 8-12 mm langen, fadenförmigen Stiele getragen, sind viergliedrig und dunkelgrün. Der Axenbecher ist umgekehrt eiförmig, $2 \mathrm{~mm}$ lang; an seinem Rande sitzen die dreiseitigoblongen, gelblich grünen, spitzen, klappig deckenden, horizontal gestellten, dreinervigen Kelchblätter. Die Blumenblätter sind aufrecht, lanzettlich spathelförmig und halb so lang wie jene. Die Staubgefässe stehen vor ihnen und sind etwas länger als die Blumenblütter; die eioblongen, oben ausgerandeten Beutel sind am Grunde an dem pfriemlichen Faden aufgehangen. Die gelben Pollenköner sind ellpisoidisch und werden von 3 meridionalen Längsfurehen durchzogen. Der Stempel ist verkimmert. Die weiblichen Blithen sitzen auf einem kurzen Stiel, sind ein wenig kleiner und sitzen in geringerer Zahl an dem Grunde der Kurztriebe. Der Axenbecher ist breiter, halbkugelig und fällt am Grunde umschnitten ab. Kelch- und Blumenblätter sind denen der vorigen Blüthe ähnlich, die letzteren aber etwas schmäler und kiirzer. Die Staubgefässe sind unfruchtbar und stellen fadenförmige, an der Spitze knopfartig verdickte Staminodien dar. Der Fruchtknoten ist gedrückt kugelförmig, vierlappig und vierfächerig; jedes Fach umschliesst eine aufrechte anatrope Samenanlage, deren Raphe binnensichtig ist; der kräftige Griffel ist so lang wie die Kelchblätter und spaltet sich oben bis fast zur Hälfte in vier Strahlen mit kopfiger Narbe.

Die Steinfrucht ist kugelförmig und trägt am Grunde einen kurzen, kreisrunden Rest des Axenbechers, sie hat einen Durchmesser von $7-8 \mathrm{~mm}$, ist schwarz und enthält ein saftiges, bräunlich grünes Fleisch. Die 4 Steinkerne sind stumpf dreikantig, aussen gewölbt und werden von einer seichten Furche durehlaufen; die Steinschale ist pergamentartig, oben gestutzt, unten spitz; die Raphe ist fadenförmig und vorspringend. Der Same ist von der Form des Steinkernes, an der Seite eingerollt. Der ebenso gekrummte Keimling liegt in fleischigem Nährgewebe; das Würzelchen ist kurz, die Keimblätter sind blattartig.

Der Kreuzdorn wächst in Hecken, Gebuischen und an Waldräudern dureh fast ganz Europa von NordRussland an bis zum östlichen Theil von Spanien, ausserdem auch in Nord-Afrika, im Kaukasus und in der benachbarten Landschaft Talysch; von Russland aus kann man ihn nach Sibirien bis zum Altai verfolgen. In Nord-Amerika ist er an den entlegensten Orten des Hochlandes von New York und auch um Boston gefunden worden, doch scheint er hier nur verwildert zu sein.

Die Früchte werden nach Anordnung des Arzneibuches als Fructus Rhamni catharticae (Treuzbeeren) im reifen Zustande als Drogue in den Apotheken geführt, aber nicht angewendet; man gebrancht hie und da noch die ans unreifen Friichten hergestellte Drogue als Arzneimittel. Die frischen reifen Früchte finden Verwendung zur Herstellung des Sirupus Rhamni catharticae, des Kreuzdornbeerensirups.

\section{Erklärung der Abbildungen.}

Fig. A. Ein Zweig der münnlichen Pflanze mit Blüthe.

Fig. $B$. Die Knospe der männlichen Blïthe, 4 mal vergrössert.

Fig. C. Die männliche Bläthe, 4 mal vegrössert: $a$. der Axenbecher; $b$. das Kelchblatt; $c$. das Blumenblatt; d. das Staubgefäiss.

Fig. D. Dieselbe im Längsschnitte, 6mal vergrössert: $e$. der Stempelrest.

Fig. E. Das Blumenblatt, 12 mal vergrössert.

Fig. $F$ u. $G$. Das Staubgefäss, von innen und von aussen gesehen, $10 \mathrm{mal}$ vergrössert.

Fig. $H$ u. $I$. Pollenkorn trocken und im Wasser, 250mal vergrössert.

Fig. $K$. Ein Zweig der weiblichen Pflanze mit Blithen.

Fig. L. Die weibliche Blithe, 4mal vergrössert.
Fig. M. Dieselbe, 8mal vergrössert: $e$. der Fruchtknoten $f$. der Stempel; $g$. der Narbenstrahl; $h$. die Samenanlage.

Fig. N. Der Stempel, 8mal vergrössert.

Fig. $O$. Der Fruchtknoten im Querschnitte, 12 mal vergrössert.

Fig. $P$ u. $R$. Die Frucht in naturlicher Grösse.

Fig. Q. Dieselbe, 3mal vergrössert.

Fig. S. Dieselbe im Querschnitt, natürliche Grösse.

Fig. $T$. Der Steinkern, natürliche Grösse.

Fig. $U$ u. $V$. Derselbe, ${ }^{2} \frac{1}{2}$ mal vergrössert: $i$. der Nabel; $k$. die Raphe; $l$. die Furche.

Fig. $W$ u. $X$. Derselbe im Längs- u. Querschnitte: $m$. das Wïrzelchen; $n$. die Keimbliitter; o. das Nährgewebe. 


\title{
Rhamnus Frangula Linn.
}

\author{
Tafel 91.
}

Strauch - seltener fast baumartig, unbewehrt, kahl; Blätter spiralig gestellt, bisweilen paarweise genähert, elliptisch oder ins umgekehrt Eiförmige, spitz oder kurz zugespitzt, am Grunde spitz oder gerundet, ganzrandig; Blithen fünfgliedrig, zwittrig; Fruchtknoten dreifächrig, Narbe kurz gelappt; Steinfrucht mit $2-3$ Steinen.

Rhamnus Frangula L. Spec. pl. ed. I. 193; Fl. Dan. II. t. 278; Gärtn. Fr. t. 106; Engl. Bot. IV. t. 250; Du Ham. Arbr. ed. II. vol. III. 15; Svensk. Bot. t. 109; Schkuhr, Handb. t. 46; Plenck, Pf. Pharmac. t. 141; Schrk. Fl. Mon. II. t. 109; Hayne, Arzneigewüchse V. t. 44; P. DC. Prodr. II. 26; Guimp. Holzgew. t. 14; Mert. und Koch, Deutschl. F7. II. 243; Koch, Syn. 15 ; Nees, Düsseld. Abbild. t. 359; Baxt. Brit. Bot. III. t. 219; Berg und Schmidt, Darstell. u. Beschr. t. XIX ; Tröhler, Medizinalpft. $t$. 20; Ledeb. Fl. Ross. I. 502; Willk. et Lange, Prodr. Fl. Hisp. III. 486; Godr. et Gren. Fl. Fr. I. 338; Parlat. Fl. Ital. V. 469 ; Boiss. Fl. orient. II. 21; Bentl. and Trim. Med. pl. t. 65; Flikck. Pharmacogn. 519; Battand. et Trab. F7. d'Alger, app. II. p. VII; Willk. Forstl. Fl. 796. t. 74; Baill. Bot. méd. II. 977. fig. 2758, 2759; Arth. Meyer, Drogent. II. 126.

Frangula Alnus Mill. Dict. ed. VIII. n. 1; Aschers. Fl. Mark Brandenb. 131; Garcke, Fl. Deutschl. ed. XVII. 126. fig. 453 .

Frangula vulgaris Reichb. F7. excurs. 458; Hart. Forstgew. 45t. t. 66 .

Frangula pentapetala Gitib. Fl. Lithuan. V. 175.

Faulbaum, Schiessbeere, Pulverholz; englisch; Black elder tree; französisch: Bourdaine, bourgène, bois à poudre.

Der Strauch wird bis $2 \mathrm{~m}$ hoch, zuweilen erreicht aber die Pflanze baumförmige Gestalt und die doppelte Höhe; die Äste stehen gewöhnlich in spiraliger Anreihung und sind gestreckt, stielrund und mit graner, matter Rinde bedeckt, die von hellen Lenticellen reichlich weiss gefleckt erscheint; die seeundüre Rinde ist gelb; auch das Holz ist gelblich. Die jungen Zweige sind grün mit röthlichem Aufluge und von braunen, einfachen, spitzen, oft etwas gekrimmten Haaren bedeckt, die bald abgestossen werden.

Die Blätter sind spiralig angereiht, rücken aber bisweilen paarig oder zu dreien zusammen; sie sind 8-10 (4-13) mm lang gestielt; der Stiel wird oberseits von einer ziemlich breiten Regenrinne durchzogen und ist sehr kurz braun behaart, später wird er kahl; die Nebenblätter sind pfriemlicb, häutig, bis $3 \mathrm{~mm}$ lang, braun und fallen leicht ab. Die Spreite ist $4-6(3-8,5) \mathrm{cm}$ lang und in der Mitte oder im oberen Drittel 2-3 (1,2-4) em breit, krautig; sie wird von 8-10 (6-12) schräg verlaufenden, grösseren Nerven jederseits des Mittelnerven durchzogen, ist spitz oder kurz zugespitzt, am Grunde spitz oder gerundet, am Rande ganz, oberseits dunkclgriin und glïnzend, unterseits heller und matt, beiderseits kahl, nur in der Jugend ist sie unterseits besonders auf den Nerven behaart.

Die Blüthen sind zwittrig, fünfgliedrig und erscheinen gebiischelt zu 2-6 auch ans den Achseln der oberen Blätter, nahe der den ganzen Sommer fortwachsenen Spitze der Zweige; bei dieser Pflanze lässt sich der Büschel als ein zusammengezogenes Dichasium analysiren; die Primanblïthe trägt rechts und links zwei Vorblätter von der Gestalt der Köpfehendriisen oder schmaler Bläitehen, die oben wenigstens oft secernirende Köpfchen ähnlich den Colleteren tragen; ibnen entsprechen 2 Secundanbltithen, die wieder mehr oder weniger fruchtbare und gleich gestaltete Vorblätter besitzen; sie werden von einem $8-10 \mathrm{~mm}$ langen, fein behaarten, etwas kantigen Stiele getragen. Der Axenbecher ist glockenförmig, 1,5 mm lang, grünlich und fällt endlich durch einen Ringspalt ab. Die Kelchblätter sind breit dreiseitig, spitz, lederartig, weiss und decken klappig. Dic weissen Blumenblätter sind kappenförmig zusammengezogen, etwas kïrer als die Kelehblätter und am Grunde breit genagelt. Die mit einem sehr kurzen Faden versehenen Staubgefässe haben eiförmige, kurz gespitzte Beutel, welche bis etwa ein Drittel 
kürzer als die Blumenblätter sind und von ihnen umschlossen werden; die Beutel sind nahe am Grunde der Fäden und intrors angeheftet. Die Pollenkörner stimmen mit denen der vorigen Art uberein. Der Stempel ist so lang wie der Axenbecher. Der Fruchtknoten ist niedergedriickt, zwei- bis dreifächrig und umschliesst in jedem Fache eine aufrechte, anatrope Samenanlage mit binnensichtiger Raphe. Der Griffel ist kurz und dick und endet oben in drei kurzen, dicken Narben.

Die Steinfrucht ist niedergedrïckt kugelförmig, am Scheitel genabelt, zuerst grtin, dann roth, endlich schwarz, mit grünlich braunem, saftigem Fleisch erfüllt. Sie enthält $2-3$ flache, linsenförmige Steinkerne mit harter Steinschale, über die eine fadenförmig vortetende Raphe verläuft.

Der Same hat die Gestalt des Steinkerns und umschliesst einen flachen Keimling in einem ziemlich reichlichen, fleischen Nährgewebe. Der Keimling besteht aus einem kurzen Würzelehen und flachen, blattartigen kreisrunden Keimblättern von bräunlich gelber Farbe.

Der Faulbaum findet sich in feuchten, schattigen Laubwäldern, in Gebüsehen, häufig die Wasserläufe begleitend und an Rändern von Teichen und Seeen fast tiberall in Europa, von Nord-Russland (Finnland) bis Süd-Spanien, auch in Nord-Afrika wurde er neuerdings gefunden; er fehlt in Sieilien und in Griechenland; sonst tritt er im Kaukasus und in dem Talysch auf und geht über den Ural bis zum Baikalsee.

Anmerkung. Bei dem Gattungsbegriffe, den man sonst in den Rhamnaceen fest hält, ist es mehr als berechtigt, dass die Gattung Frangula von Rhamnus getrennt wird.

Die getrocknete Rinde der Pflanze wird als Cortex Frangulae (Faulbaumrinde) mediciniseh verwendet.

\section{Erklärung der Abbildungen.}

Fig. A. Ein blïhender und fruchtender Zweig.

Fig. B. Die Blitthenknospe, 5mal vergrössert.

Fig. C. Die Blïthe, $4 \mathrm{mal}$ vergrössert.

Fig. $D$. Dieselbe, 5 mal vergrïssert: $a$.der Axenbecher; $b$. das Kelchblatt; $c$. das Blumenblatt; $d$. das Staubgefäss.

Fig. $E$. Das Blumenblatt, $10 \mathrm{mal}$ vergrössert.

Fig. $F$ u. $G$. Das Staubgefäss, $8 \mathrm{mal}$ vergrüssert.

Fig. $H$ u. $I$. Pollenkürner, trocken und im Wasser, 200mal vergrössert.
Fig. $K$. Der Stempel, 8mal vergrüssert: $f$. der Griffel; $g$. die Narben.

Fig. $L$. Derselbe im Querschnitte.

Fig. $M$ u. $N$. Die Frucht, $2 \frac{1}{2} \mathrm{mal}$ vergrössert.

Fig. $O$ u. $P$. Dieselbe im Längs- und Querschnitte.

Fig. $Q$ u. $R$. Der Same von der Rücken- und Bauchseite, $21 / 2$ mal vergrössert: $h$. der Nabel; $i$. die Bauchnaht.

Fig. $S, T$ u. $U$. Derselbe im Quer- und doppelten Lïngsschnitte: $l$. das Würzelchen; $m$. die Keimblätter. 


\section{Familie: Vitaceae Lindl.}

Die Blithen sind zwittrig oder durch Fehlschlag getrennt geschlechtlich, meist fün- bisweilen aber auch vier- bis sechsgliedrig, vollständig. Der Kelch ist klein gezähnt, bleibend. Die Blumenblätter schliessen in der Knospe klappig zusammen und sind abfällig. Die Staubgefüsse sind mit ihnen gleichzählig und stehen vor ihnen; sie sitzen unterhalb des Fruchtknotens; mit ihnen wechseln häufig 5 kurze, blattartige, Honig absondernde Drüsen, die frei oder mit einander verwachsen sind; die Beutel sind in der Knospe eingeschlagen und springen mit nach aussen gewendeten Längsspalten anf. Der Stempel ist oberständig, bisweilen einer Honig absondernden Scheibe aufgesetzt; Fruchtknoten zwei- bis mehrfächrig, in den zweifächrigen finden sich 2 aufrechte anatrope Samenanlagen, deren Raphe rüickenständig ist; in den mehrfächrigen umschliesst das Fach je eine Samenanlage. Die Frucht ist beerenartig, zwei- bis sechsfächrig, oft sehr saftig und enthält einen oder mehrere Samen mit steinharter Schale; der Keimling: ist klein und liegt am Grunde des hornartigen Nährgewebes. -

Aufrechte Stauden oder viel häufiger mit Ranken kletternde, kahle oder behaarte Sträncher, sehr selten suceulente Pflanzen mit verdickten Knoten; Blätter meist zweizeilig abwechselnd oder paarig genähert, gestielt, mit Nebenblättern versehen, einfach oder gefingert, seltener gefiedert. Bliithen klein, grïnlich, selten roth, in blattgegenständigen Rispen.

An 400 Arten in 10 Gattungen uber die wärmeren Gegenden der ganzen Erde verbreitet, sie dringen bis in die kältere gemässigte Zone vor.

Anmerkung. Über den Umfang der Gattungen herrschen noch hente bei den verschiedenen Botanikern sehr abweichende Ansichten. Während die Engländer nach dem Vorgange von Bentham nur sehr wenige anerkennen, hat PLANCHon die grosse Gattung Vitis in 10 kleinere aufgelöst, welche sich durch feinere Merkmale unterscheiden.

\section{VITIS Iinn.}

Blithen zwittrig oder einzelne durch Fehsehlag nur männlich; aktinomorph fün- bis sechsgliedrig. Kelch napfförmig, gezähnt. Blumenblätter an der Spitze kappenförmig verbunden, am Grunde frei, im Zusammenhang abgeworfen. Staubgefässe frei; Beutel in der Knospe nach innen geschlagen, mit nach aussen gewendeten Längsspalten anfspringend, bald abfallend. Honigdrïsen flach, zwischen den Staubgefässen stehend. Fruchtknoten zweifächrig, die Fächer nicht immer vollkommen gesondert, in jedem zwei Samenanlagen; Griffel kurz, Narbe fast schildförmig. Beere kugelförmig oder ellipsoidisch mit $1-4$ kreiselförmigen Samen, die bisweilen völlig (in gewissen Culturformen) fehlschlagen; Samensehale steinhart. Hochaufsteigende, mit gespaltenen Ranken kletternde Lianen, mit einfachen ganzen oder gelappten Blättern. Blïthen in reichen Rispen.

28 Arten in den nördlich gemässigten Gegenden beider Hemisphären.

\section{Vitis vinifera Linn.}

Tafel 92 .

Eine durch blattgegenständige, verästelte Ranken kletternde Liane mit kahlen oder bebaarten, herzförmigen, gelappten und grob gesägten Blättern; Beere grin, gelblich, röthlich oder blan, sehr saftig, kugelförmig od. ellipsoidiseh. 
Vitis vinifera Linn. Spec. pl. ed. I. 202; Jacq. Icon. pl. var. I. 50; Allion. Fl. Pedem. II. 124; Gürtn. Fr. II. t. 106; Woodv. Med. pl. I. t. 57; Lam. Illustr. genr. I. t. 134; Sibth. Fl. Graec. III. t. 242; P. DC. Prodr. I. 633; Mert. u. Koch, Deutschl. Fl. II. 27s; Hayne, Arzneigew. X. t. 40; Nees, Diisseld. Abbild. t. 369-370; Guimp. u. Schlecht. Fl. Pharmac. II. t. 140, 141; Babo u. Metzger, Weinstock, $t$. 1-54; Berg u. Sehmidt, Darstell. u. Beschreib. t. XVIII ; Köhler, Modizinalpf. t. 51; Ledeb. Fl. Ross. I. 455; Godr. et Gren. Fl. Fr. I. 323; Willk. et Lange, Prodr. Fl. Hisp. III. 567; Boiss. Fl. orient. I. 955; Parlat. Fl. 1tal. V. 482; Bentl. and Trim. Med. pl. t. 66; Battand. et Trab. Fl. d Alger I. 171; Flick. and Hanb. Pharmacogr. 140; Baill. Bot méd. II. 1326. fig. 3315; Planch. in Suites au prodr. V. 21.

Der holzige, reich verästelte Straueh steigt in wildem Zustande hoeh in die Bäume oder kriecht am Boden hin und sendet zahlreiehe aufstrebende Äste aus. Der Stamm erreieht bisweilen die Dieke eines Mannesarmes und ist mit einem braunen, langfaserigen Periderm bedeekt; das zähe, biegsame, bräunliche Holz enthält sehr weite Gefässe und zeigt breite Markstrahlen, an jügeren Ästen ist es grïn. Die Äste sind stielrund, stark gestreift, an den Knoten rerdiekt, gerade oder ziekzaekförmig gebroehen. Sie sind von zweierlei Art, da Langtriebe (Loden oder Lotten) mit Kurtrieben (Geizen) in regelmässiger Folge wechseln. Jene beginnen mit mehreren regelmässig zweizeilig gestellten Blättern und gehen dann in eine meist zweitheilige Ranke aus, deren einer Arm von einem sehuppenförmigen Deckblatte gestlitzt wird; aus der Aehsel des obersten Blattes entspringt ein Seitenzweig, der nur ein Blatt erzengt und wieder in einer Ranke endet, worauf aus der Blattaehsel ein neuer, aber zweiblïtriger Zweig hervorgebraeht wird, diese Abweehslung von ein- und zweiblättrigen Zweigen kann sieh noeh mehrfaeh wiederholen. Dabei wirft :der kriftige Seitenstrahl das jeweilige Zweigende (die Ranke bei Seite und stellt sich in die Richtung der Mutteraxe. Auf diesem Wege entsteht ein gerades oder etwas geknicktes Sympodium, welehes die Ranken in blattgegenständiger Anordnung trägt. Unter jedem der Sympodialglieder steht wie in den Achseln der unteren Blätter eine Beiknospe, welche die Geize darstellt. Die Knospe aus dem untersten schupjigen Blattc derselben wird zur Lotte des folgenden Jahres.

Die Blätter sind streng zweizeilig angereilht, welehe Stellung ieh als dureh die Anwesenheit der verhältnissmässig grossen, sehiefen, lineal oblongen oder fast eiförmigen, spitzen, bald abfallenden Nebenbliitter begrindet naehgewiesen babe. Die in der Mitte während der Knospenlage gefalteten Blätter sind wie die jungen $Z$ weige mehr oder weniger filzig behaart, später verkahlen sie bisweilen vollständig; sie sind lang bis $10 \mathrm{em}$ gestielt, der Stiel ist etwas kantig, gestreift und wird oberseits von einer Regenrinne durchzogen. Die lebhaft grine, krautige Spreite erreieht eine Länge von $15 \mathrm{em}$ und ist ebenso breit, ihr Umriss ist herzformig, meist ist sie tief drei- bis funflappig, bei Culturformen aber ist sie bisweilen viellappig Petersilienwein. Der Rand ist sehr grob einfaeh und doppelt gesägt, von dem oft mit einem filzigen Knopfe rersehenen Grunde strahlen 5 gerade oder bogenförmig gekrïmmte stärkere Nerven aus, während der grösste Nittellappen von 5-6 Paar Fiedernerven durehzogen wird. Die Unterseite ist bäufig, besonders in den Nervenaehseln wollig behaart hier liegen die Domatien, Wohuräume für Blattmilben).

An dem unteren Theile der Langtriebe sitzen an Stelle der Ranken 2-5 Bltithenstände, so dass jene den letzteren morphologiseh homolog gesetzt werden müssen; der unterste Strahl der vielbluthigen Rispe ist häufig noeh als der von der Sehuppe gestiutzte Rankenast zu erkennen. Zuweilen trägt derselbe aueh einzelne Bltithen. Die Rispe wird von einem $4-6 \mathrm{~cm}$ langen Stiel getragen, ist pyramidenförmig und die Seitenstrahlen, welche dureh häutige, eiförmige, abfällige Deekblätter gestützt werden, sind ebenfalls zweizeilig angereiht; ihre Länge beträgt $5-8 \mathrm{em}$, bisweilen aueh mehr. Die Seitenstrahlen sind wiederum kleine Rispen, die sich oben zu Trauben vereinfachen; die kurzen Zweigchen der Rispe stellen Trauben mit Gipfelblutthen dar, die häufig in diehasiseher (d. h. dreigabliger) Verbindung endigen.

Die gelblichgrünen, sehr wohlrieehenden Blüthen werden von sehr kleinen, sehuppigen Deekblättern gestlitzt, sind verhältnissmässig lang gestielt, fünfgliedrig und zwittrig. Der grïne Keleh ist beeherförmig, gezähnt und kaum $1 \mathrm{~mm}$ lang. Die Blumenblätter sind spathelförmig, oben kappenförmig znsammengezogen und an der Spitze eingebogen, so dass die Knospe fast funflappig erscheint; mit den nach innen geschlagenen Rändern decken sie klappig und haften so fest zusammen, dass sie sich 
bei der Vollblithe nur unten lösen und sonst im Zusammenhange abgeworfen werden; sie sind etwa 4-5 mm lang. Nach dem Abfall der Blumenkrone richten sich die vor den Blumenblättern stehenden, nach innen geschlagenen Staubbeutel gerade auf und kippen nach aussen über, so dass die urspriinglich binnenwendigen Spalten nach aussen gerichtet werden. Die Pollenkörner sind ellipsoidisch und werden von 3 meridionalen Spalten durchzogen. Zwischen den Staubfäden von schmal pfriemlicher Gestalt befinden sich 5 elliptische, oben etwas ausgerandete, fleischige, Honig absondernde Driisen. Der Stempel ist flaschenförmig, von der Höhe der Blumenkrone; der Fruchtknoten ist mehr oder weniger vollkommen in 2 Fächer geschieden, von denen jedes 2 aufrechte, anatrope Samenanlagen umschliesst, ihre Raphe ist nach innen gewendet. Der kurze, dicke Griffel endet in eine sehr kurz gelappte, innen etwas vertiefte Narbe.

Die Frucht ist eine kugelförmige oder ellipsoidische, grüne, röthliche, gelbe oder blaue, bis schwarze, etwas bereifte Beere von 1-3 cm Länge; das Fleisch ist sehr saftig; sie umschliesst $1-4$ Samen, die zuweilen sämmtlich fehlschlagen.

Der steinharte Same ist birnförmig, grün oder braun mit fadenförmiger, vorspringender Raphe und einer auf dem Riucken eingedrickten Chalaza; zu beiden Seiten der ersteren liegt eine Furche, welche tiefe Eindrücke der steinharten inneren Schale andeutet. Das Nährgewebe ist hornig; es umschliesst am Grunde den kleinen geraden Keimling mit ziemlich langem, bodensichtigem Wiurzelchen und schmalen Keimblättern.

Die Weinrebe ist am Rhein, in den Donauländern, im mittleren östlichen Frankreich, und dem Mittelmeergebiete, sowie im Kankasus und in Mittelasien heimisch, wird aber jetzt in den gemässigten Zonen der ganzen Erde, besonders am Rhein und an der Mosel, in Stiddentschland, in der Schweiz, in Frankreich, dem Mittelmeergebiete, in Ungarn, Californien, dem Capland und in Australien cultivirt und zur Weinbereitung verwendet.

Die Früchte der Pflanze dienen zur Bereitung des Weines (Vinum).

\section{Erklärung der Abbildungen.}

Fig. A. Ein Stiick eines blïhenden $Z_{\text {weiges }} v^{1-1}$ Blätter; $u^{1}$ u. $u^{2}$. Bltithenstände; $u^{3}$. Ranke.

Fig. $B$. Die Blïthenknospe, 4mal vergrössert: $a$. der Kelch; b. die Blumenkrone.

Fig. C. Die Blïthe, im Begriffe aufzublïhen, $5 \mathrm{mal}$ vergrössert: e. die Honig absondernden Driisen; $d$. das Stanbgefäss; $e$. der Stempel.

Fig. $D$. Die Blithe in der Vollblithe, 6 mal vergrüssert: g. die Narbe.

Fig. E. Das Staubgefïss, $12 \mathrm{mal}$ vergrüssert.

Fig. F. Pollenkörner, trocken u. im Wasser, 250mal vergrössert.
Fig. $G$. Der Stempel, 6mal vergrössert.

Flg. $H$ u. I. Derselbe im Lïngs- und Querschnitte: $h$, die Samenanlage; $i$. die Scheidewand.

Fig. $K$. Die Frucht.

Fig. $L$ u. $M$. Dieselbe im Längs- u. Querschnitte, 2mal vergrössert: $\%$. das Fruchtfleisch; $l$. der Same; $m$. der Samenstrang.

Fig. N. Der Same von inpen u. aussen gesehen, $5 \mathrm{mal}$ vergrösert: $o$. die Raphe; $p$. die Chalaza; $q$. der Nabel.

Fig. $P, Q$ v. $R$. Derselbe im Quer- u. Doppellingsschnitte: $r$. die Samenschale; $s$. das Nährgewebe; $t$. der Keimling. 


\section{Reihe: Sapindales Lindl.}

Bliithen hänfig zygomorph, meist nach der Fünfzahl gebaut, häufig zwittrig, aber aueh durch Fehlschlag eingeschleehtlieh, sonst vollständig. Staubgefässe oft doppelt so viel als Blumenblätter oder einige dureh Fehlsehlag gesehwunden. Frnehtknoten häufig zwei- bis dreiblättrig, oberständig. Meist Holzgewäehse.

Anmerkung. Diese Reihe hat man neuerdings mit den Geraniales verbunden, in die noch andere Reihen aufgenommen worden sind. Durch die Verbindung wirden in der Reibenfolge nnserer Pflanzen manche Umstellung nothwendig werden.

\section{Familie: Polygalaceae Reichb.}

Die Blüthen sind zwittrig, vollständig und zygomorph. Kelehblätter sind 5 vorhanden, die sich breit dachziegelig decken, davon sind die zwei inncren sehr gross, häufig blumenblattartig gestaltet und gefärbt, sic werden die Fligel (alae) genannt. Dic Blumenblätter finden sieb zu 3 oder 5 , die unteren 3 sind naeh nnten geneigt und bisweilen unter einander zu einer rickseits gespaltenen Blumenkrone verwaehsen, dabei ist das mittlerc helm- oder kappenförmig und hcisst Kiel (carina); die beiden oberen Blumenblätter sind frei, den seitliehen gleieh nnd umfassen diese in der Knospenanlage, oder sie sind viel kleiner, nieht selten fehlen sie gänzlieh. Die 8 (seltener 5 oder 4) Stanbgefässe sind gewöhnlich unter sieh mit den Fäden einbrïderig verwachsen, wobei die Röbre hänfig der Blumenkrone angeheftet ist; dic Beutel sind aufreeht, ditheciseh, wobei die Inhalte der Theken früh zusammenfliessen und springen mit Poren, oder nach innen liegenden kurzen, selten längeren Spalten auf. Der meist zweifächrige Fruehtknoten ist oberständig und umsehliesst in jedem Faehe gewöhnlieh eine hängende, anatrope Samenanlage mit binnensiehtiger Raphe; der cinfache Griffel ist an der Spitze häufig cingekrimmt, zweilappig und ausgehöhlt. Die Frucht ist entweder eine faeh- oder eine wandspaltige Kapsel, oder sie ist nicht aufspringend, nüsschen- oder stcinfruehtartig. Die hängenden Samen sind bänfig behaart und haben an der Mieropyle einen fleisehigen Anhang stropliola; Nährgewebe ist vorhanden oder fehlt. Der gerade Keimling besteht aus einem kurzen, nach oben gekehrten Wiirzelehen und aus elliptischen Keimblïttern.

Gewöhnlieh ausdauernde Standen, in den wärmeren, besonders tropisehen Gegenden; aber aueh immergrine Sträueher oder Bäume mit einfaehen, meist ganzrandigen, spiralig angereilten Blättern ohne Nebenblätter. Blïthen einzeln aehselständig oder zu ähren- und trauben- seltener rispenförmigen Inflorescenzen verbunden, von Deekblättern und Vorblättehen gestützt.

Etwa $\$ 00$ Arten, die hauptsäehlieh in den wärmeren Gegenden beider Hemisphären verbreitet sind.

\section{POLYGALA Linn.}

Kelchblätter immer sehr ungleieh. Blumenblätter gewöhnlich nur 3, der Kiel ist vorn meist mit einem Kamme versehen; wenn die obersten zwei vorhanden sind, so bleiben sie sehr klein, schuppenförmig. Staubgefässe stets 8 in eine oben gespaltene, mit den Blumenblättern hoeh verbundene Röhre verwachsen; Beutel ein- oder zweifächrig, quer mit einem Loehe oder seltener schief, fast zweiklappig aufspringend. Fruchtknoten zweifächrig, er trägt in jedem Faehe stets nur eine hängende, anatrope Samenanlage. Der Griffel ist gekrimmt, an der Spitze erweitert und zwei- bis vierlappig. Kapsel häutig 
oder seltener lederartig, zusammengedriiekt, umgekehrt eiförmig, ellipsoidisch oder kreisförmig, gerandet oder flach, an den Seiten aufspringend. Die hängenden Samen sind meist mit einem Mantel (strophiola) versehen. - Ausdauernde Stauden oder Halbsträucher oder Sträucher mit spiralig gestellten, selten kreuzgegenständigen oder quirligen Blättern ohne Nebenblätter. Blutthen meist in endständigen Trauben, selten in Rispen, ansehnlich und bunt oder unansehnlich, klein, grtin oder gelblich.

Etwa 430 Arten in den gemässigten und wärmeren Gegenden beider Hemisphären, in Australien aber nur wenige, im tropischen Theile.

\section{Polygala Senega Iinn.}

\section{Tafel 93.}

Ausdauernde Staude mit einfachen, stielrunden Stengeln, lanzettlichen, oblongen oder fast rautenförmigen Blättern und endständiger, reichbliithiger Traube; Kelchflügel fast kreisrund; Samenmantel tief zweilappig; beinahe den Grund des Samens erreichend.

Polygala Senega Linn. Spee. pl. ed. I. 704; Amoenit. acad. II. 2; Willd. in Berl. Jahrb. 1804. t. 3; Woodv. Med. pl. III. t. 162; Plenck, Pf. Pharmac. I. 549; Bot. Mag. t. 1051; Pursch, Fl. Amer. II. 164; Hook. Fl. Boreal.-Amer. S5 (nicht P. DC. Prodr. I. 330); Nees, Dïsseld. Pfl. t. 410; Loddig. Cab. t. 1380; Guimp. u. Schlecht. Pf. Pharmac, t. 176; Hayne, Abbild. XIII. t. 21; Torr. and Gray, Fl. North Amer. 131; Berg u. Schmidt, Darst. $u$. Beschr. t. $\mathrm{X}^{a}$; Bentl. and Trim. Med. pl. t. 29; Fliick. and Hanb. Pharmacogr. 72; Flïck. Pharmacogn. 442; Baill. Bot. méd. II. 907. fig. 2624, 2625; A. Gray, Gen. II. 223. t. 183, Man. ed. VI. 120; Chodat, Monogr. Polyg. 275; Arth. Meyer, Drogenkunde. I. 283.

Senegapflanze; engliseh: Snakeroot, Senega or Senekaroot; französisch: Polygale de Virginie.

Die zuweilen sebr kräftige, weissliche oder hellbräunliche, ausdauernde Wurzel zeigt eine sehr abnorme Holzstructur, sie ist unregelmässig gekrümmt, bäufig gedrelit und in den Windungen binnenseits gekielt (ob nur durch das Trocknen?); aus ihr erheben sich mehrere bis sehr zahlreiche Stengel $d$. l. Sprosse aus schuppigen Niederblättern der vorjährigen Achsen; sie sind einfach, aufrecht im Innem hohl, zart, unten dimner, nach oben hin dichter behaart und erreichen eine Höhe von $40 \mathrm{~cm}$; gewöhulich aber zeigen sie nur die Hälfte dieser Länge, ihr Durchmesser tibersteigt kaum 2 mm.

Die untersten Blätter sind schuppenförmig, allmälig gehen sie in die Laubblätter tiber; diese sind sitzend oder sebr kurz gestielt, 2,5-5 cm lang und 0,5-1,3 cm breit, lanzettlich, linealisch lanzettlich oder oblong, seltener rhombisch, beiderseits spitz oder am oberen Ende stumpflich oder zugespitzt, krautig oder etwas lederartig; ganzrandig oder sehr fein gefranst-gesägt und hierdurch etwas schärflich, beiderseits kahl. Der traubige Bliuthenstand ist endständig, vielbluthig, cylindrisch, zugespitzt und wird oben von Deckblättern schopfig überragt; er ist $2-3$, endlich aber bisweilen bis $8 \mathrm{~cm}$ lang, die Spindel ist verhältnissmässig ziemlich kräftig. Die eiförmigen, im Schopfe eioblongen Deckblätter messen kaum 1,5 $\mathrm{mm}$ und sind sehr hinfallig; die des Schopfes aber bleiben; die Blithenknospen aus den letzteren entwickeln sich nicht.

Die Blüthen sind sehr kurz, lsaum $1 \mathrm{~mm}$ lang gestielt. Die flügelartigen Kelchblätter sind gelblichweiss, 2,5-3 $\mathrm{mm}$ lang, mit fiedernervigen, nicht anostomosirenden, gritnlichen Adern; dic kleineren sind kaum ein Drittel so lang, oblong und stumpf. Die obersten Blumenblïtter sind vollkommen fehlgesehlagen, die mittleren schief oblong-lanzettlich, stumpflich, sie tiberragen kaum oder überhaupt nicht die Fligel. Der Kiel ist stumpf und trägt am Vorderrande zwei, am Grunde genäherte, breite läntige Lappen, sowie einen Kamm aus 5-6 keulenförmigen, bisweilen an der Spitze getheilten, etwas papillösen, kurzen Zipfeln; die Blumenblätter sind fast bis zur Hälfte zu einer oben längs gespaltenen Rühre verwachsen. Die röhren- oder topfförmigen Staubbeutel sind kürzer als die Fälen, kamm 0,5 mm lang, sie springen mit einer fast dreiseitigen Öffnung auf und sind kahl. Der Frnchtknoten ist fast kreisrund, seitlich stark 


\section{8}

zusammengedrückt mit zwei Längsfurchen versehen; der nach unten geneigte Griffel trägt an der hohlen, zweilappigen Narbe einen Haarbüschel.

Die Frncht ist eine dünnwandige, von den Flügeln des Kelches umschlossene und diesen tiberragende znsammengedrückte, zweilappige und -fächrige, kahle, fast kreisrunde Kapsel, welche in jedem Fach einen Samen enthält; sie wird bis $4 \mathrm{~mm}$ lang, 4,5 mm breit und öfnet sich an den Seiten fachspaltig.

Der eiförmig längliche, etwas nach innen gekriimmte, schwarzbramne Same ist stark weiss behaart und trägt an der Bauchseite einen bis fast zum Grunde reichenden, tief zweitheiligen, braunen, häutigen Samenmantel.

Die Schlangenwurzel findet sich in Nordamerika von der Provinz Manitoba im Dominion of Canada über Minnesota, Wisconsin, Illinois, Arkansas, Tennessee, Nord-Carolina bis nach Ohio und New-York.

Anmerkung. Aus der breitblättrigen Form hat Asa Gray eine besondere Varietät gemacht, wie ChoDAT eine andere aus den Ab̈̈nderungen mit gezähnelten oder gefransten Blättern.

Das getrocknete Wnrzelsystem der Pflanze sammt den unterirdischen Achsentheilen bilden die Radix Senegae (Senegawurzel) des Arzneibnches.

\section{Erklärung der Abbildungen.}

Fig. A. Eln blühendes Exemplar der schmalblättrigen Form naeh einer bei New-York gesammelten Pflanze.

Fig. $B$. Die Bluthe, $7 \mathrm{mal}$ vergrössert: $a$, die kleinen, $b$. die grossen Kelchblätter; c. der Keleb; d. der Kamm; $e^{\prime}$ die mittleren Blumenblätter.

Fig. C. Dieselbe, ein Flïgel zurïekgesehlagen.

Fig. D. Die Blnmenkrone ausgebreitet, 10mal vergrüssert: $f$. die Staubgefässröhre.

Fig. E. Die Staubgefilissöhre, ausgebreitet, $20 \mathrm{mal}$ vergrössert: $g$. der Staubfaden; $h$. der Beutel.

Fig. $F$. Pollenkörner, im Wasser betraehtet, $200 \mathrm{mal}$ vergrössert.
Fig. $G$. Der Stempel, 10mal vergrössert: $i$, der Fruehtknoten; $k$, der Griffel; $l$. die Narbe.

Fig. $H$. Derselbe im Längssehnitte: $m$. die Samenanlagen.

Fig. $I$ u. $K$. Die Frueht, 5mal vergrössert, mit und ohne Keleh.

Fig. $L$ u. M. Dieselbe im Quersehnitte und längs aufgespalten.

Fig. $N$ u. $O$. Same mit dem Mantel, 10 mal vergrögsert, von der Seite und von vorn gesehen.

Fig. $P, Q$ u. $R$. Derselbe, ohne Mantel, im Längs- und Quersehnitte: o. der Mantel; $p$. der Nabel; $q$. das Nilhrgewebe; $r$. das Würzelehen; s. die Keimblätter. 


\section{Familie: Erythrozylaceae A. Rich.}

Die Blüthen sind aktinomorph, zwittrig, vollständig, nach der Fünfzahl gebaut. Die Kelchblätter sind klein, sie decken quincuncial und sind am Grunde bisweilen etwas verbunden. Die mit ihnen abwechselnden Blumenblätter tragen allermeist in der Mitte einen zweilappigen Anhang oder wenigstens eine Schwiele. Die Staubgefässe sind in der doppelten Zahl jener vorhanden und am Grunde ring- oder röhrenförmig verbunden, die abwechselnden sind kleiner; deutliche Honig absondernde Drüsen oder eine Scheibe fehlen. Der Fruchtknoten ist der Anlage nach dreifächrig, doch schlagen 2 Fächer häufig so weit fehl, dass kaum noch die Hohlräume angedentet sind, in dem bleibenden Fache befindet sich eine einzelne hängende Samenanlage. Die drei Grifiel sind bis zum Grunde frei. Die Frucht ist eine gewöhnlich einfächerige, einsamige Steinfrucht. Der Same umschliesst einen geraden Keimling in fleischigem Nährgewebe.

Sträucher oder gewöhnlich kleinere Bäume mit spiralig gestellten, sebr selten krenzgegenständigen Blättern, die Nebenblätter sind intrapetiolar. Aus den Achseln der Blätter oder der oft sehr zahlreichen nebenblattartigen Niederblätter von Zweigen treten die gebiischelten, meist kleinen Blüthen.

3 Gattungen in den tropischen Gegenden beider Halbkugeln, einige überschreiten auf der südlichen den Wendekreis.

\section{ERYTHROXYTHON ILINn.}

Blüthen zwittrig, vollständig, aktinomorph, fünf- oder sechsgliedrig. Kelchblätter frei oder verwachsen. Blumenblätter dachziegelig deckend, abfällig, innen mit einem einfachen oder gedoppelten, oben zweilappigen häutigen Anhange versehen. Staubgefässe zu cinem kurzen Ringe verbunden, zwischen deren Fäden liegen häufig verdickte Drïsenanhänge. Fruchtknoten drci- oder vierfäehrig mit einzelnen oder gepaarten Samenanlagen, die aber häufig schon während der Vollbliuthe in 1-2 Fächeru fehlgesehlagen sind; Grifiel frei mit kopfiger Narbe. Frucht steinfruchtartig, einsamig, Stein mit papierartiger odes holziger Wandung. Der Keimling ist gerade, das Würzelehen kurz, die Keimblätter sind blattartig und liegen in einem mehlig fleischigen Nahrgewebe, das selten fehlt.

Bäumc oder Sträucher mit spiralig gestellten, krautigen oder lederartigen, ganzrandigen Blättern und intrapetiolaren, häufig lange bleibenden Nebenblättern. Blithen klein, weiss, einzeln oder gebitschelt.

60 Arten, besonders in Süd-Amerika, nicht wenige aber auch in Afrika und auf den ostafrikanischen Inseln, einige in Ost-Indien, eine in Australien.

\section{Erythroxylon Coca Lam.}

\section{Tafel 94.}

Stranchartig, auch an den jüngsten Zweigspitzen kahl; Blätter kurz gestielt, lanzettlich oder oblong lanzettlich, stumpf mit kurzen Stachelspitzen, am Grunde spitz, getrocknet beiderseits, aber besonders unten mit zwei etwas gekrümmten Druckmarken versehen, krautig, kahl. Blüthen nicht selır zahlreich in den Blattachseln, griinlichgelb; Friichte zinnober- bis korallenroth. 
Erythroxylon Coca Lam. Encycl. II. 393; Cav. Dissert. VIII. 402, t. 229; Ruiz et Pav. Fl. Peruv, tab. ined. 398; DC. Prodr. I. 575; Hook. Companion to Bot. mag. I. 161, II. 25. t. 21; Mart. in Abh. Acad. Mïch. III. 367. t. 6; Bentl. and Trim. Medic. pl. I. t. 40; Köhler, Mediz. Pfl. t. \$2; Bot. magaz. t. 7334; Kew. Rep. 1589. p. 1; Journ. Linn. soc. XXV. 354. fig. 1 u. 2; Peyritsch, Flora Brasil. XII. (1); Done. et Maout, Traité 295; Baill. Hist. pl. V. fig. so-87*), Bot. méd. II. 900. fig. 2612-2619.

Erythroxylon Novo-granatensis Hieronymus in Engl. Jahrb. XX. Beib. 49. p. 35.

Erythroxylon Panamense Turcz, in Bull. soc. natur. Mosc. 1863. XXXVI. 581.

Der strauch wird bis $3 \mathrm{~m}$ hoeh, bisweilen auch darïber. Dic zierlichen Zweige werden von kastanienfarbener, glatter Rinde bekleidet, die von helleren Lenticellen gefleckt ist. Die Blätter stehen in spiraliger Anreihung; sic werden von einem 2-5 mm langen, oben flachen, unten rinnenförmigen, gerandeten Blattstiele gestiitzt, auf dem das $2-4 \mathrm{~mm}$ lange, eioblonge, in der Mitte längseingedrückte und zweikielige, spitze, am Rande häutige und fein gefranste, grüne Nebenblatt reitet. Die Spreite ist $3-4(2-5) \mathrm{cm}$ lang und in der Mitte oder weiter oben $1-1,8(0,8-2,5) \mathrm{cm}$ breit; sie ist entweder rein lanzettlich oder geht ins Oblonge oder fast Spatelförmige, oben ist sie stumpf und trägt ein sehr kurzes Stachelspitzchen, unten ist sic spitz und verschmälert sich allmälig in den Blattstiel; sie wird jederseits des Mittelnerven von 6-S stärkeren Seitennerven durchlanfen, die beiderseits nur sehwach vorspringen; sie zeigt zwei deutliche linienförmige, fast parallele, oben und unten convergirende Druckmarken, welche von der gefalteten Kinospenlage lerrtihren; die Spreite ist vollkommen kahl und oberseits lebhaft rein griun, unterseits heller, fast bläulicbgriin.

Dic Blithen treten gebilsehelt aus den Blattachseln; diese Busehel werden aus dichasialen, verkulizten Blithenständen gebildet, von denen 2-4 Bluthen deutlich zu gleicher Zeit sichtbar sind. Die Blithen werden von eiförmigeu, spitzen, in der Mitte gekielten, grlinen Deekblättern und Vorblättehen gestiitzt, nur die Primanbltithe hat das Laubblatt als Deckblatt. Der etwas kantige, oben verdickte Bluthenstiel misst 5-7 mm. Die Kelchbliitter sind 1,5-2 nm lang, oblong eiförmig, spitz und grü und am Grunde verbunden. Die lineal oblongen, gelblich weissen Blumenbläter messen $3,5-4 \mathrm{~mm}$; sie sind oben stumpf, am Grunde in einen ziemlich breiten Nagel zusammengezogen und tiber ihm geöhrt; unterhalb der unteren Hälfte sitzt innenseits ein tief zweilappiger Anhang, aus dessen Bucht ein kurzes Läppehen nach unten gezogen ist. Die 10 Staubgefàsse messen in dor langgriffligen Form 1,3 mm; sie sind zu einer kurzen Röhre verbunden, die kleineren Staubgefässe sind kaum 0,5 mm kürzer, als die langen; die winzig kleinen, seitlich in Längsspalten aufspringenden, eiförmigen Beutel tragen am Ende ein Knöpfehen. Der eiförmige Fruchtknoten ist einfächrig und hat nur sehwache Andeutungen der beiden anderen Fächer; die einzelne grosse Samenanlage ist hängend und anatrop; ihre Mieropyle wird von einem Lappen des Samenträgers fast ganz verdeckt; die drei Griffel mit knopfigen Narben liberragen die Staubgefässe um 1-2 mm. Die kurzgrifflige Form hat Staubgefässe von fast der doppelten Länge, die etwas höher verbunden sind und Stempel, welehe um $1,5 \mathrm{~mm}$ kleiner sind.

Die Frucht ist $1 \mathrm{~cm}$ lang, etwas schicf ellipsoidisch, scharlach- bis korallenroth und trägt an dem spitzen Ende die drei bleibenden Griffel; das spärliche, weisse Fleisch schmeckt fade und umschliesst einen vierkantigen Stein, dessen eine Kante stark verbreitert ist, während zwei schwach gestutzt sind und eine scharf ist. Die Steinschale ist knorplig und weiss.

Der Same enthält ein reichliches, fleischiges, weisses Nährgewebe; der smaragdgrüne Keimling hat ein Würzelehen von der halben Länge desselben, die flachen Keimblätter sind lanzettlich und stumpflich.

* Die umfangreiche Litteratur ist sehr vollstïndig zusammengestellt, bei Gorse in Hém. acad. Belgique XII. (1861); über Cultur und natïrliches Vorkommen vergl. ausserdem folgende Reisewerke: PöpPIG, Reisen II. 209, 248; MARTIUs, Reisen III. 1169, 1180; Meyen, Reise um die Erde II. 16; Tschud, Peru II. 299, Reisen V. 37; Weddell, Voyage dans le nord de la Bolivie 514; BrBRA, Narkot. Genussmittel 151. 
Anmerkung. Die Cocapflanze ist ein sehr variabeles Gewächs, dessen Varietäten man neuerdings als eigene Arten zu betrachten geneigt ist. Die von uns beschriebene, nicht selten in botanischen Gärten cultivirte*), ist die Neu-Granada Coca, Erythroxylon Coca Lam. var. Novo-granatensis Morris, welche nenerdings Hrenonymus als besondere Art beschrieben hat. Die bolivianische Yungas-Coca, welche besonders reich an Cocain sein soll und als der Typus betrachtet wird, hat grössere Blätter und die reichblïthigen Büschel der Blïthen stehen an Kurztrieben, welche mit zahlreichen nebenblattähnlichen Knospenschuppen bekleidet sind; die Blüthenstiele sind anch kürzer.

Die Cocapflanze ist in verschiedenen Varietäten verbreitet von Bolivia bis Nen-Granada; wird aber heute nicht blos in der Heimath, sondern auch in Brasilien, Paraguay und Argentinien, zum Theil in grossartigstem Maassstab cultivirt, so dass die jährliche Ausbeute 40 Mill. Pfund sicher ibersteigt; auch in den tropischen Berggegenden der alten Welt sind Versuche, sie zu cultiviren, gemacht worden.

Ans den Blättern, welche einem grossen Theile der südamerikanischen Bevölkerung als tägliches Genussmittel dienev, wird das Alkoloid Cocaïn dargestellt. Cocä̈num hydrochloricum hat in das Arzneibuch Aufnahme gefunden.

\section{Erklärung der Abbildungen.}

Fig. A. Ein Zweig der blithenden Pflanze nach einem Exemplare, das in königl. botanischen Garten zu Berlin eultivirt war.

Fig. $A^{1}$. Die Bliithenknospe, 5 mal vergrössert.

Fig. B. Die Bliithe, 5mal vergrössert, die langgrifflige Form.

Fig. C. Das Blumenblatt, 8mal vergrössert mit dem binnenseitigen Anhang.

Fig. D. Die Blüthe, 8mal vergrössert nach Entfernung der Blumenblätter, um die Stanbgefüssröhre zu zeigen,
Fig. E. Dieselbe im Längsschnitte.

Fig. $F$. Das Staubgefäss, $12 \mathrm{mal}$ vergrössert, von innen geschen.

Fig. G. Der Stempel, smal vergrössert.

Fig. $H$, Der Fruchtknoten im Querschnitte mit dem einen fruchtbaren und den 2 unfruchtbaren Fächern.

Fig. I. Die Frueht, etwas über natiirliche Grösse.

Fig. $K$. Dieselbe im Quersehnitte.

* Wir haben in der Cultur der botanischen Gärten nur die langgrifflige Form angetroffen; von Herrn Consul LFAMANN in Neu-Granada eingesandt lag uns aber auch die kurzgrifflige Form vor. Seiner Angabe zufolge wird diese Coca dureh das ganze Land in grossem Maassstabe angebant. 

$\operatorname{lin} 1,5$

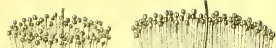

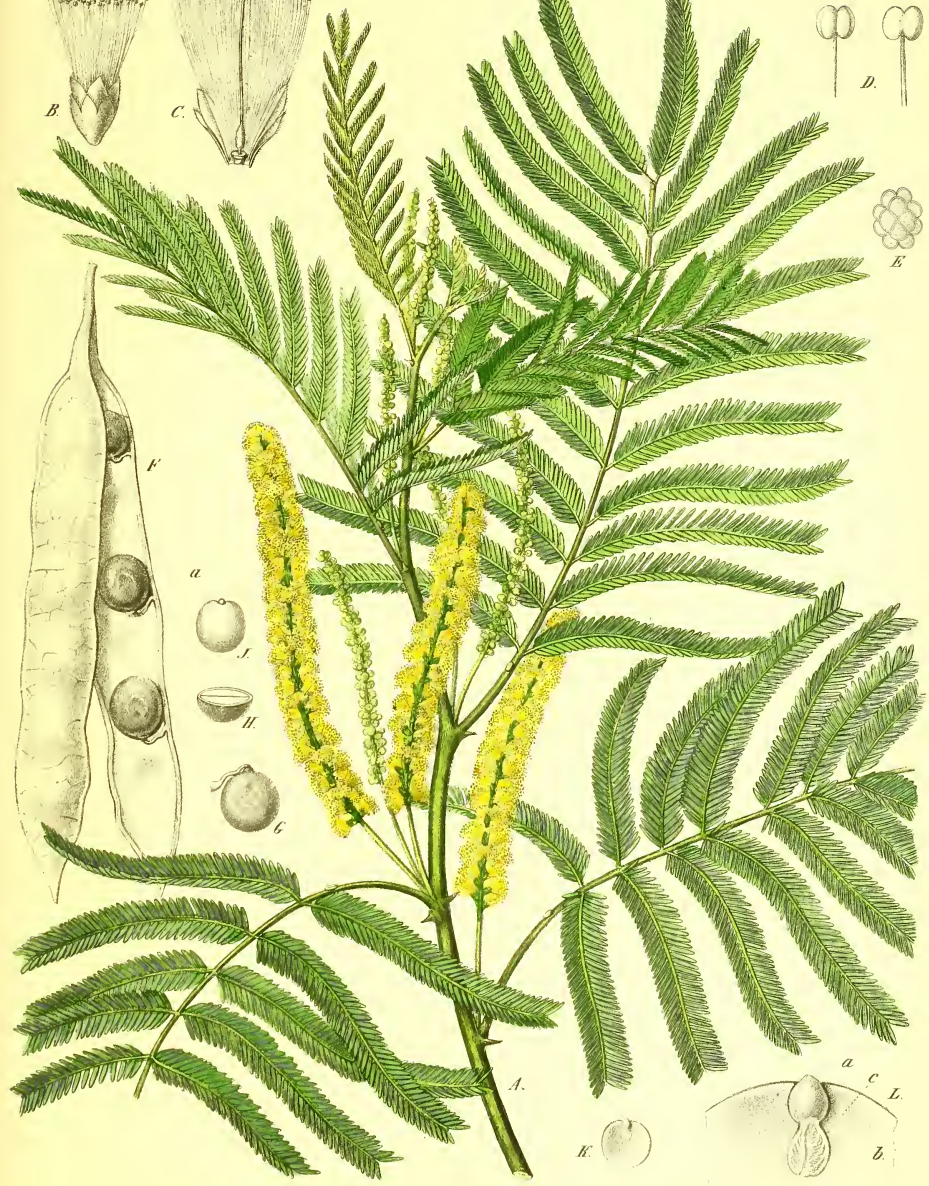



188

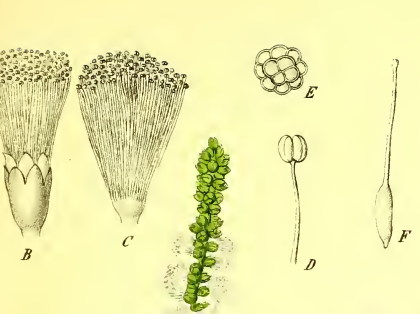

4

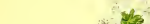

$+$

$+3$

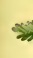

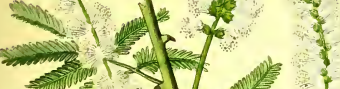
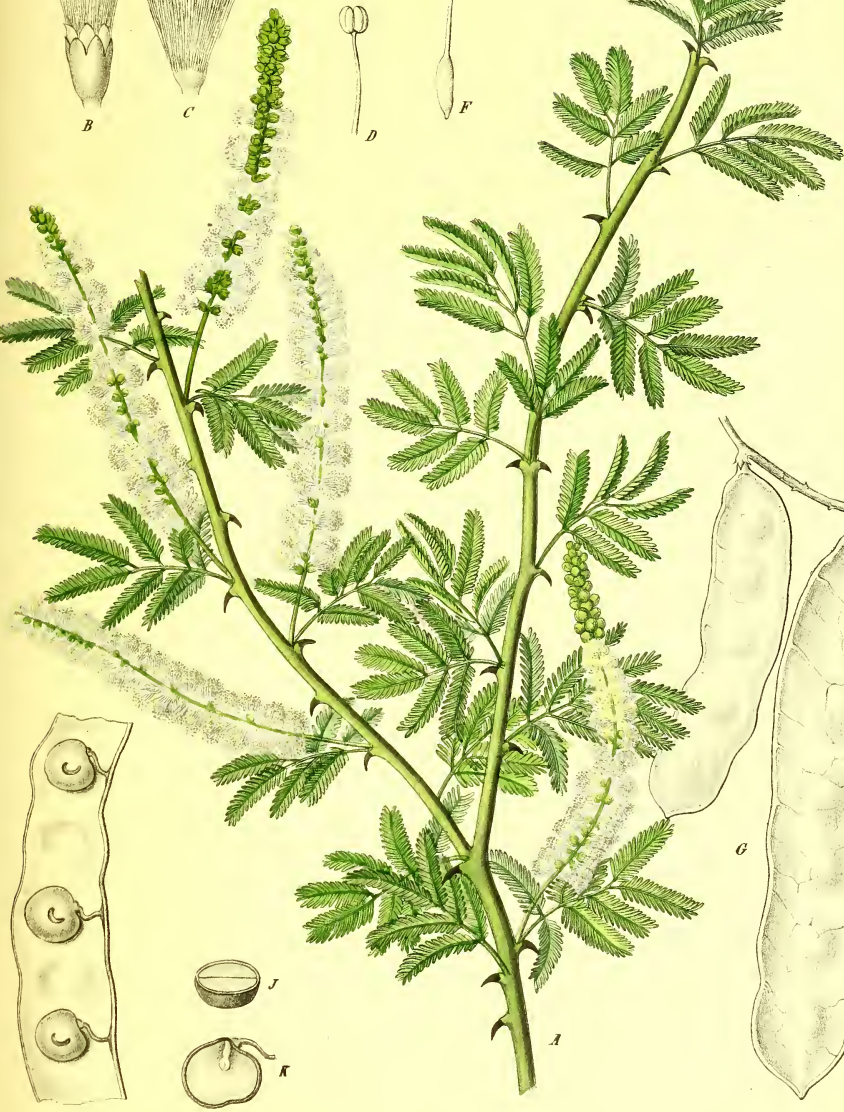

F Schindt ap?

E Laue lith

Acacia Seneogal W 

Tal' it

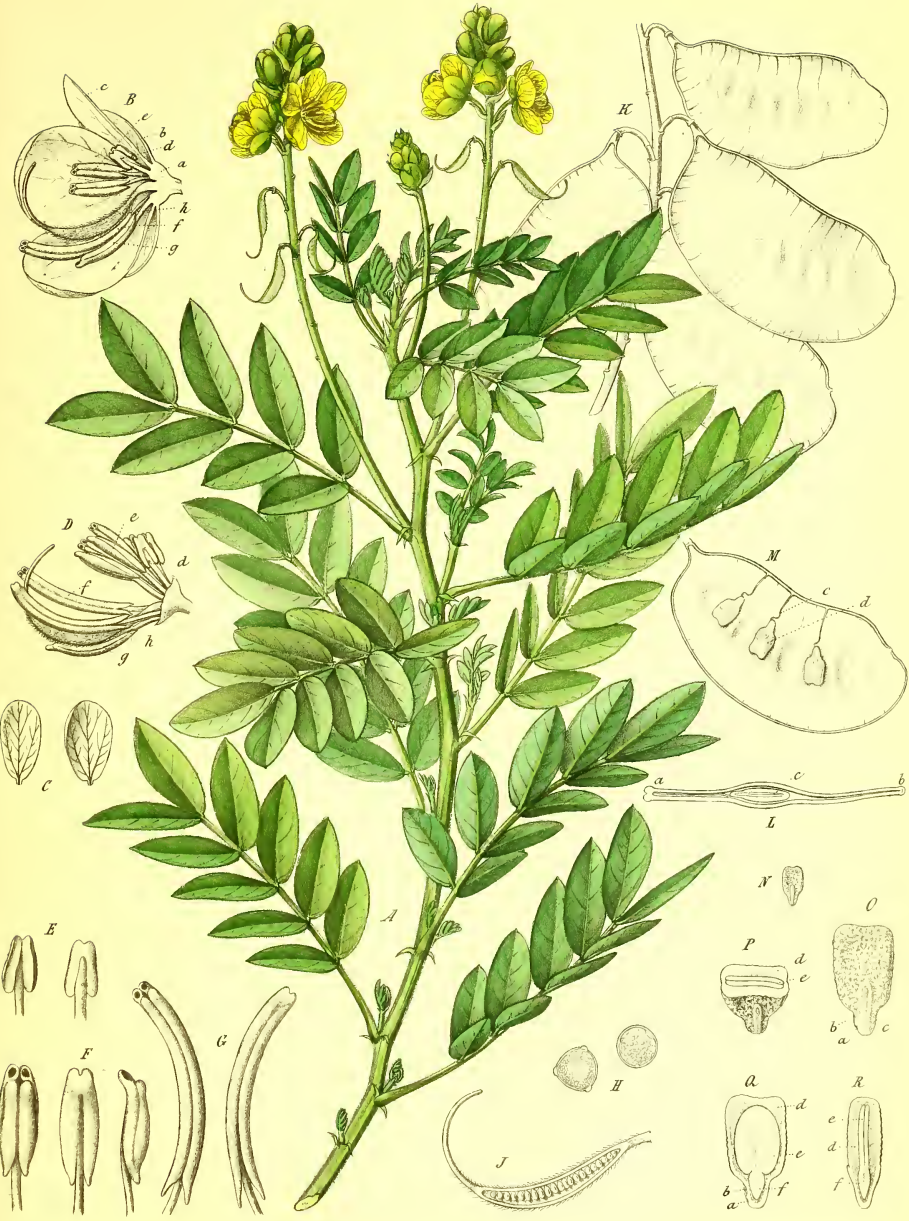

(asslia aculifolia bu 

Taf. 48
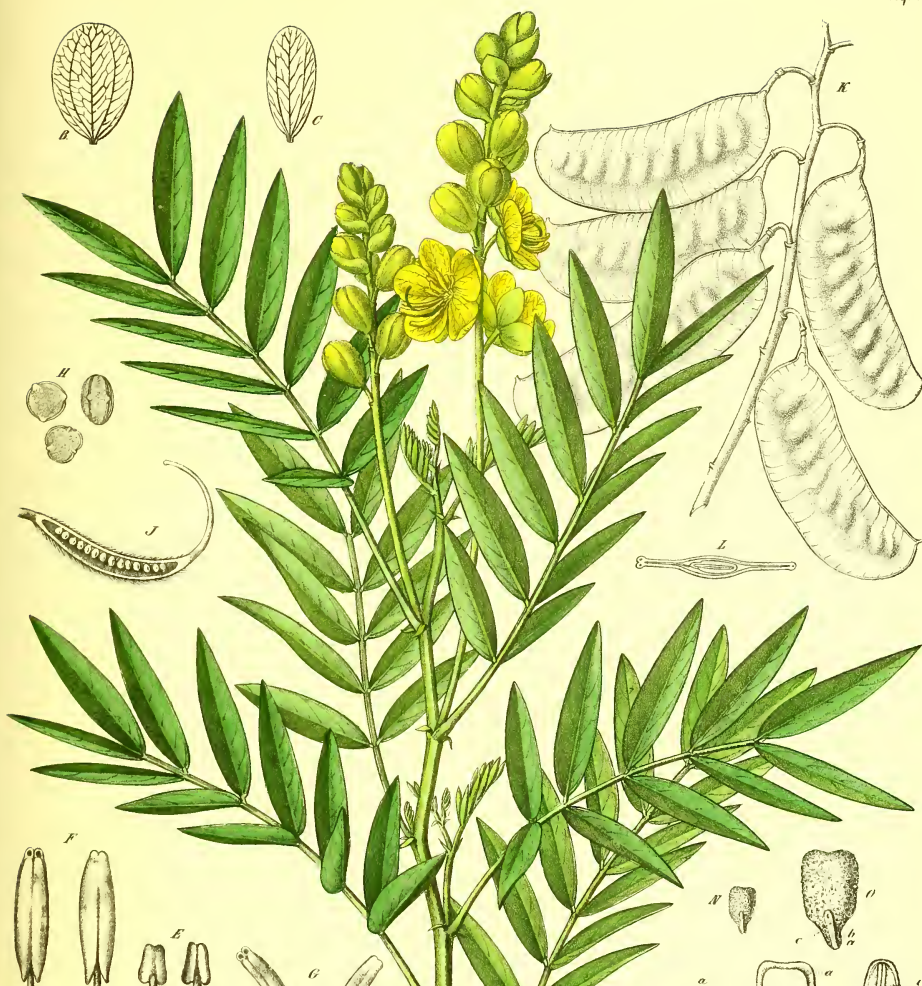

Tit4?

$B(\underbrace{6} \begin{array}{l}0 \\ 0\end{array})^{d}{ }^{c}$
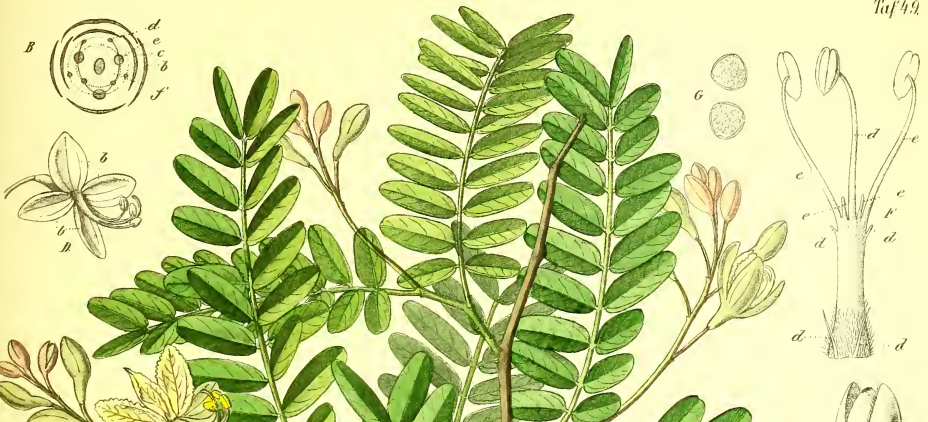

(1) Mul
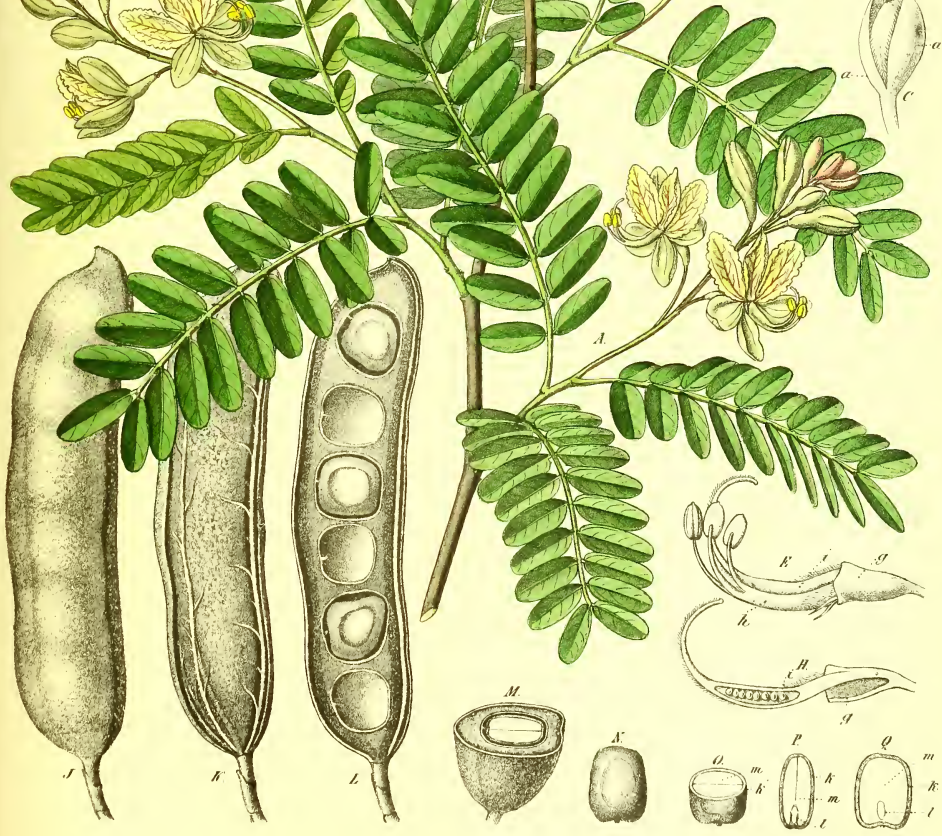

Taminindus Indiral I. 



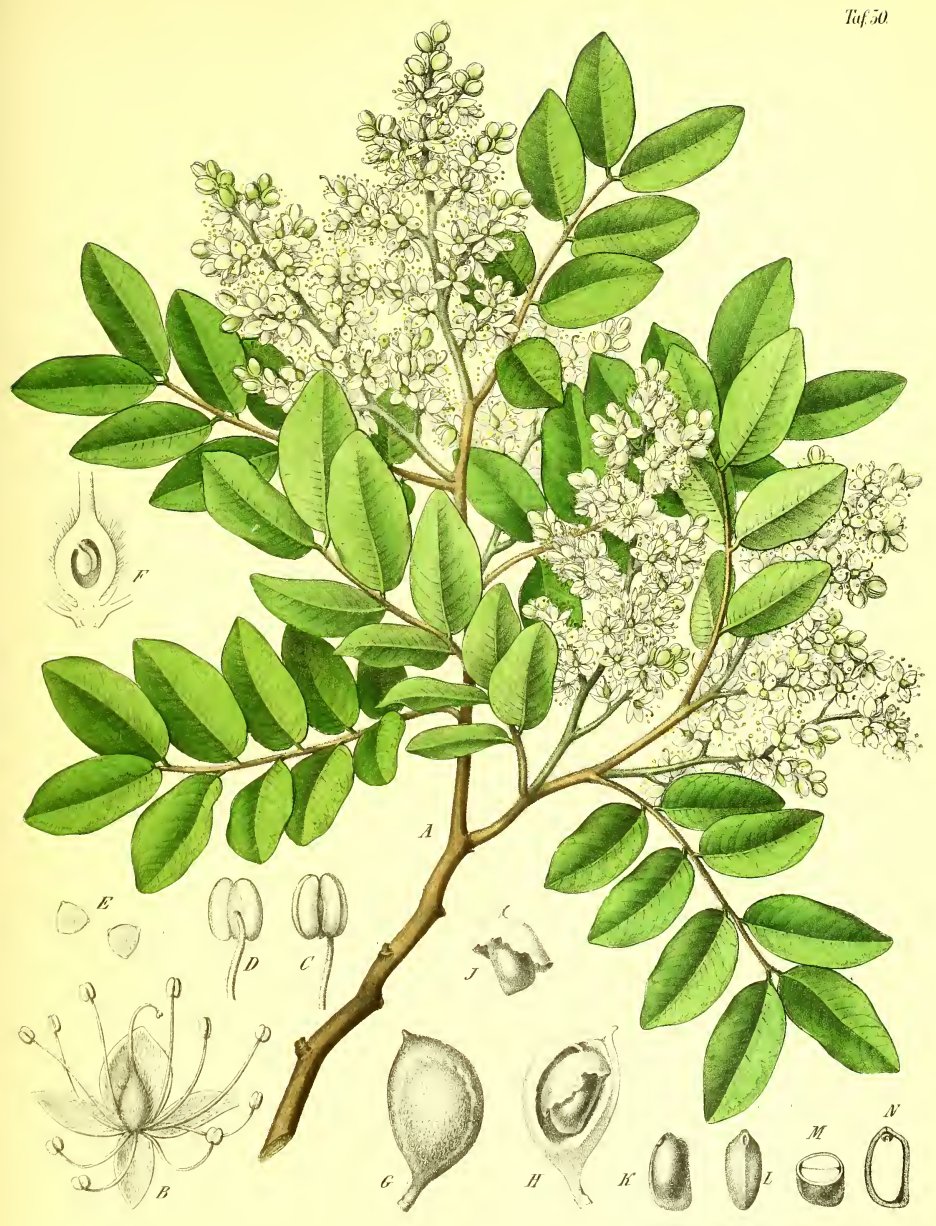

loparleca Lanosidorlli Hayne 



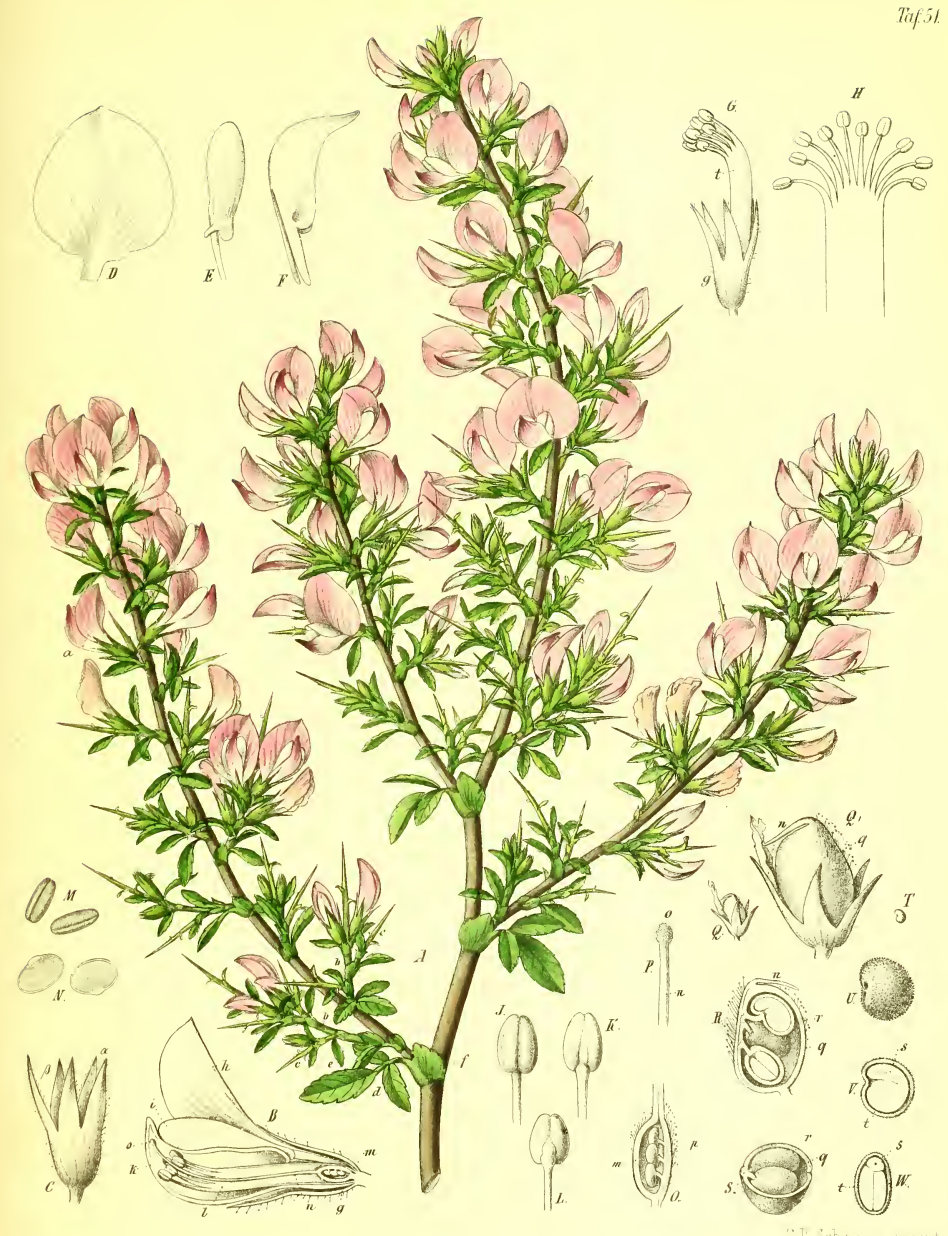

()momis spmosa L 

Taf. 52

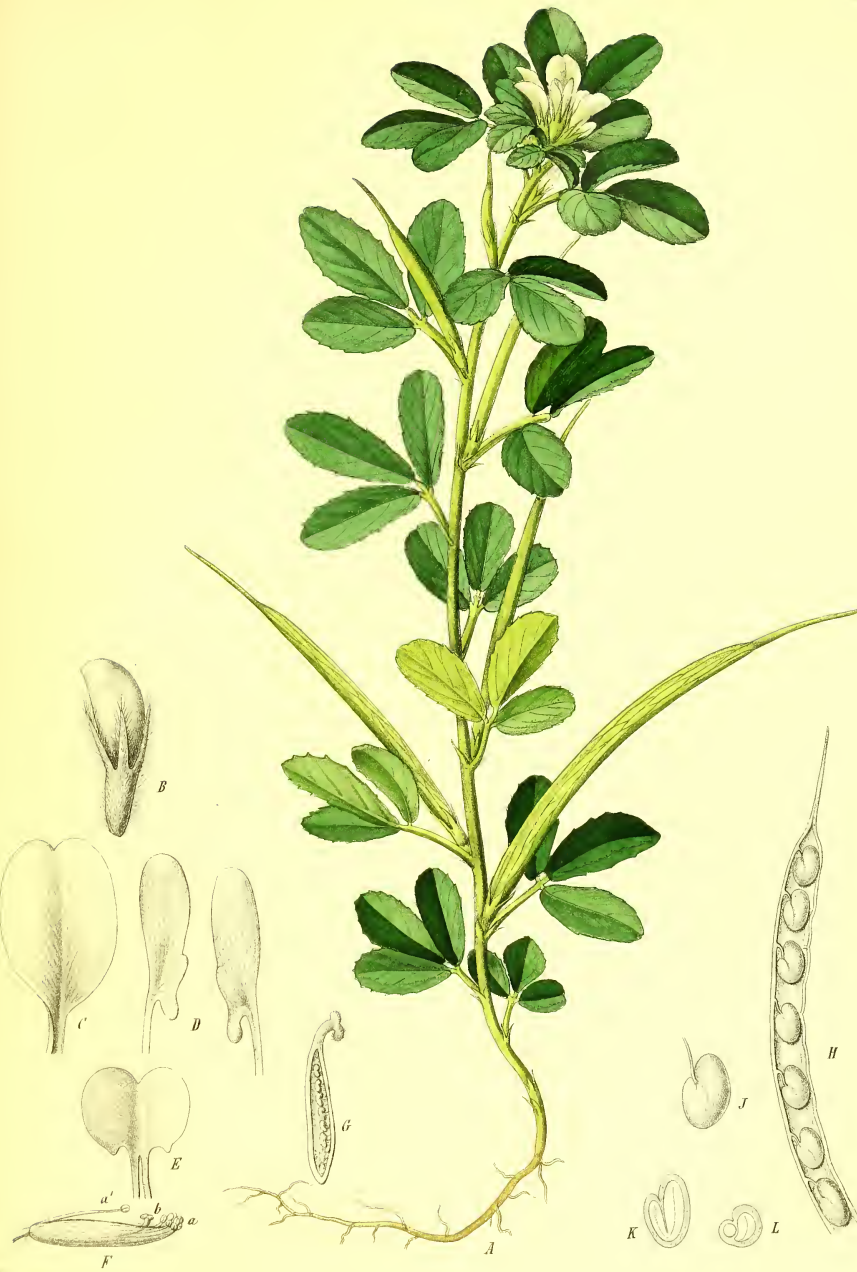

E Laue lith.

Trionella Fopmum oberimu Limn 

Taf. 59

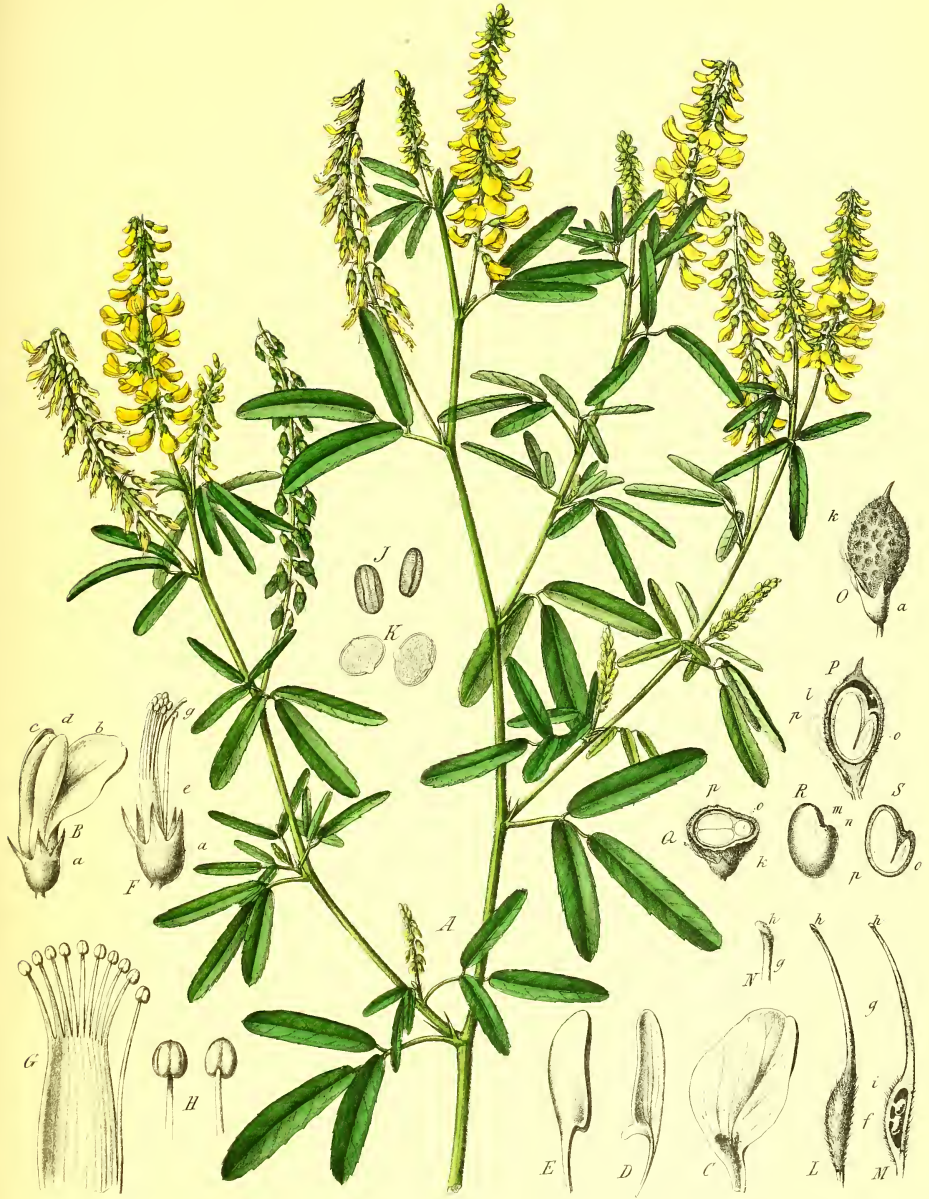

Nelilobus officintalis Pers 



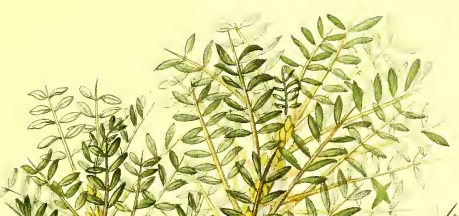

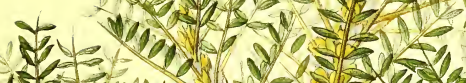

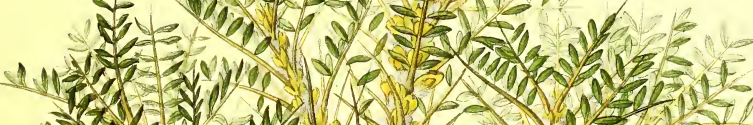

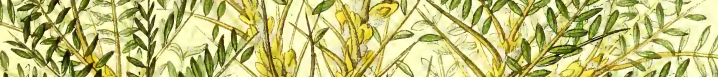

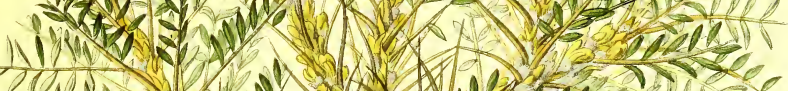
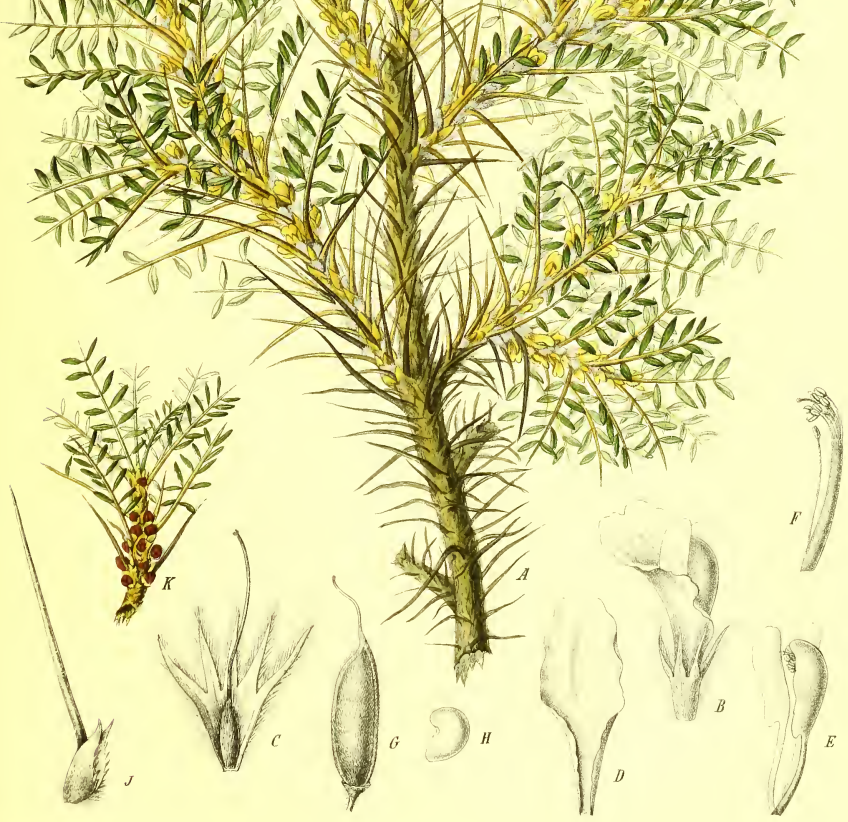

Astraéalus onmunifer Labull 



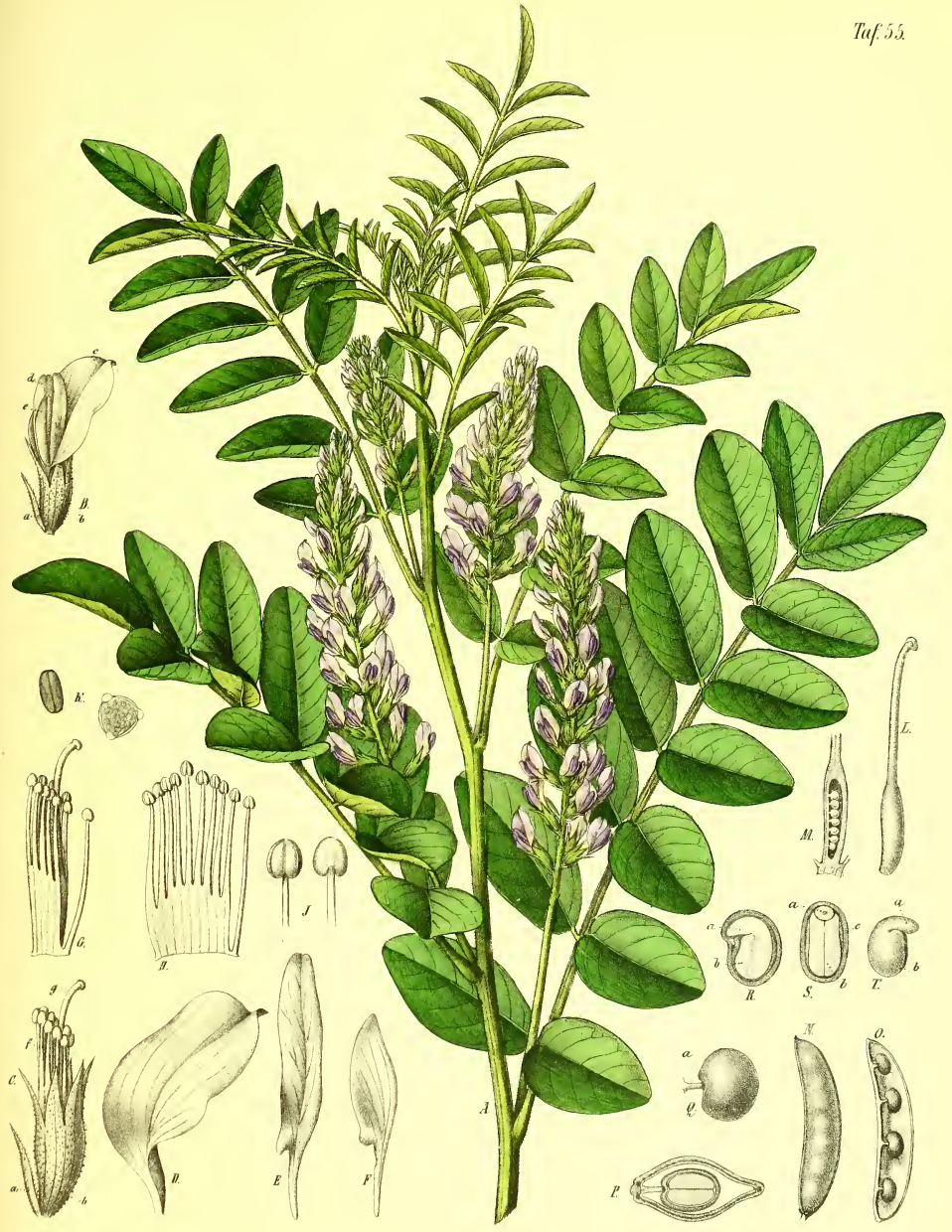

Glverrthza olabra L 

Til:56.

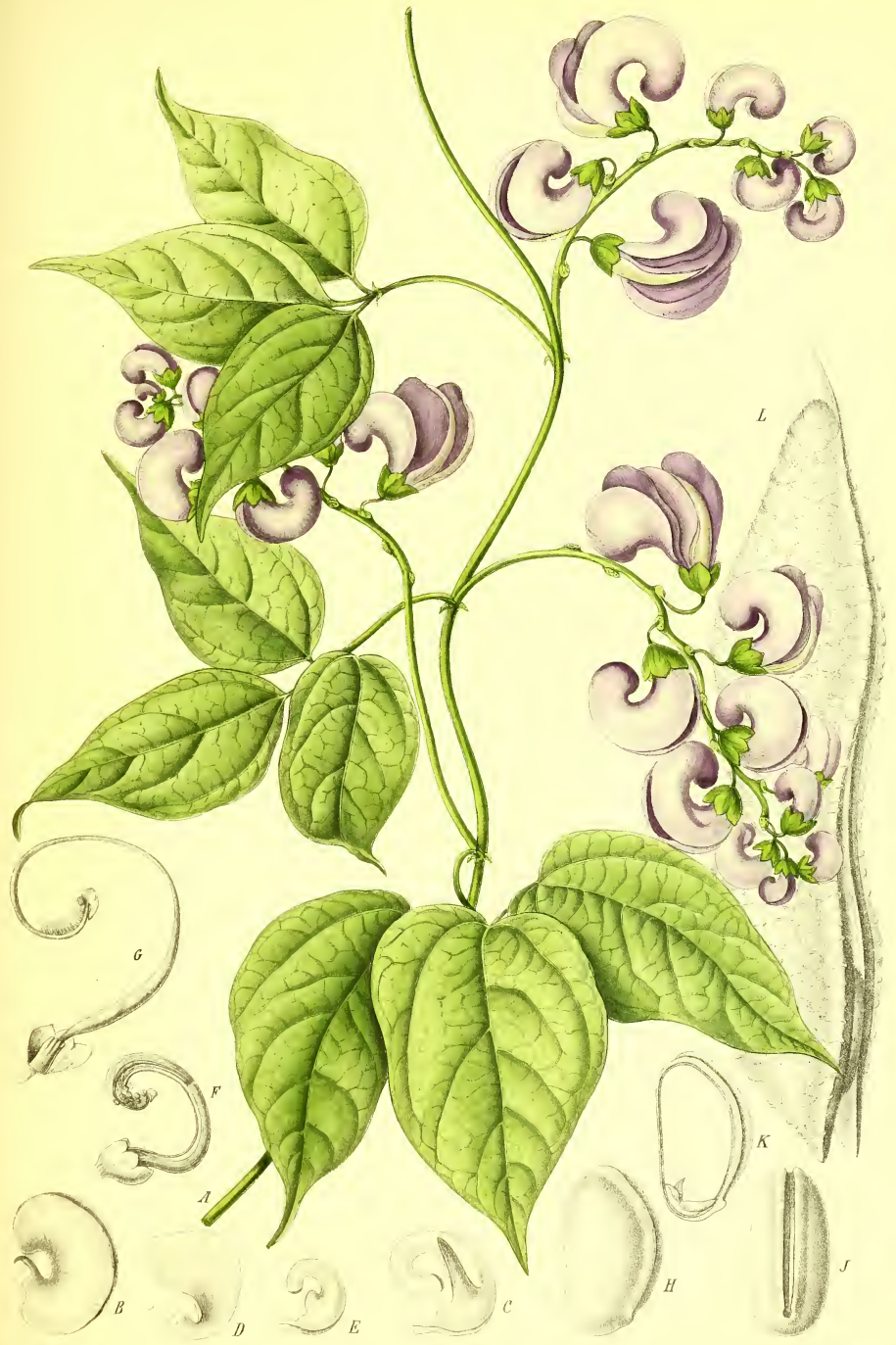

Physostigna vencenosum Ball 



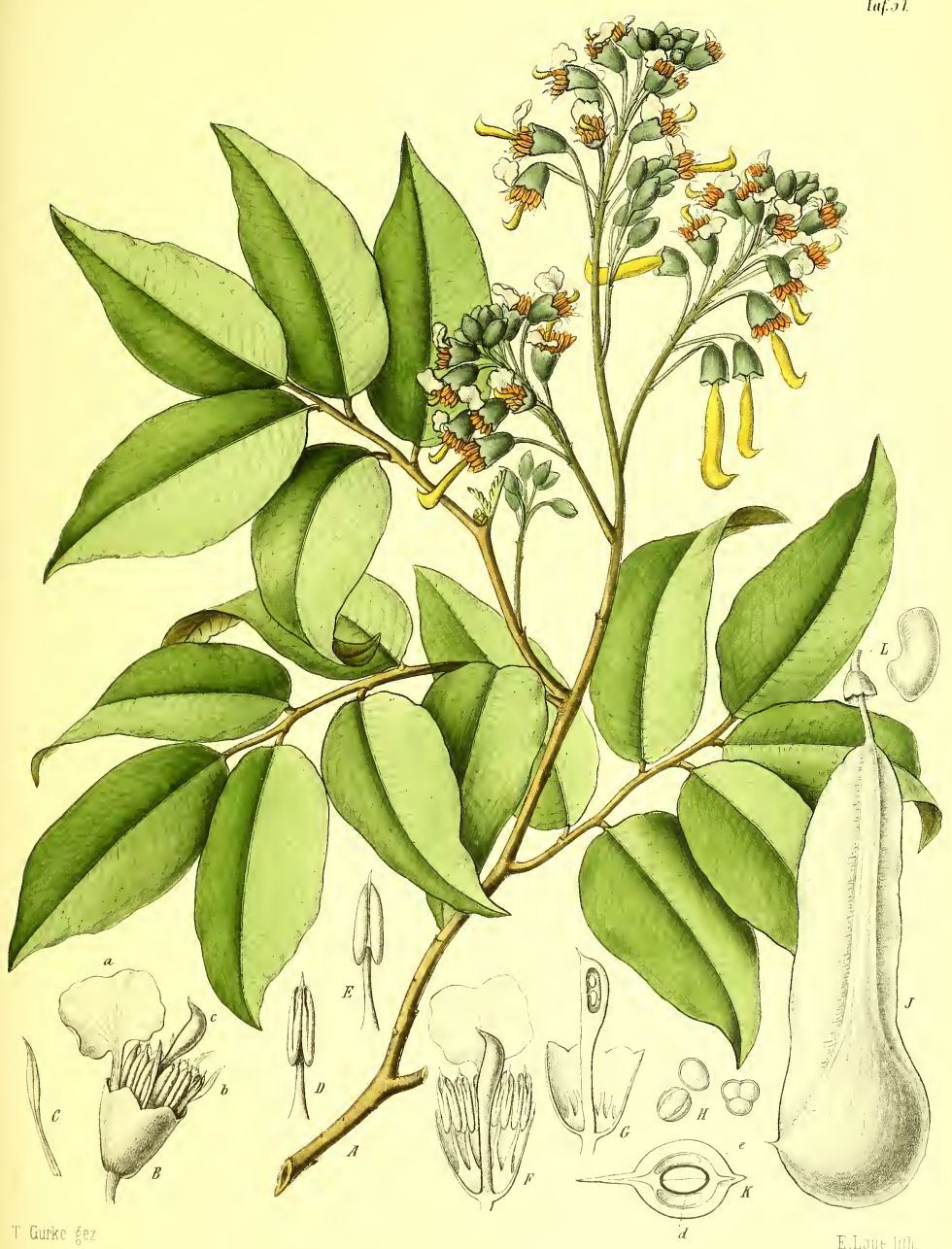

Toluifera Balsamum Limn. 



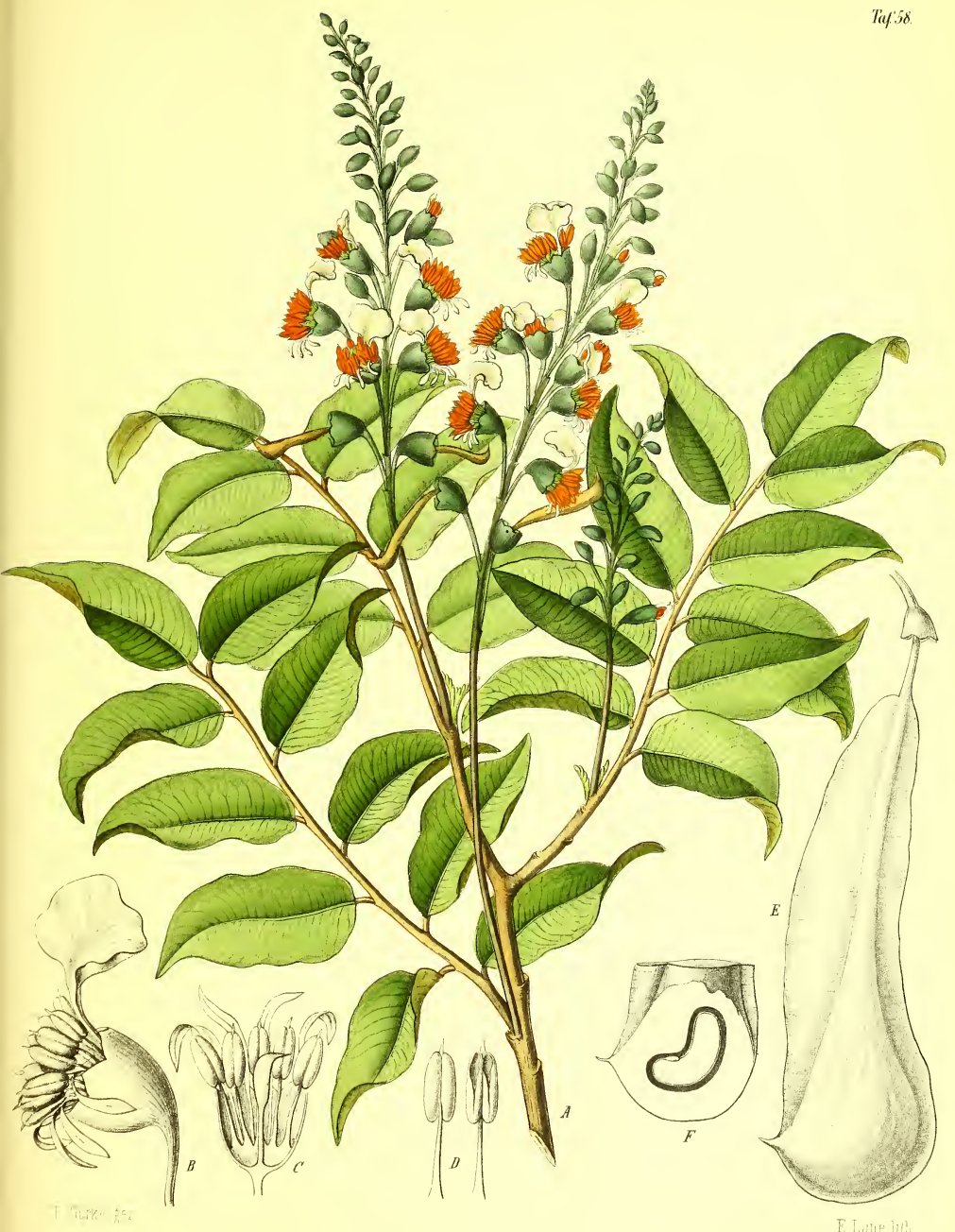

Tohnifera Pereniare Balll. 



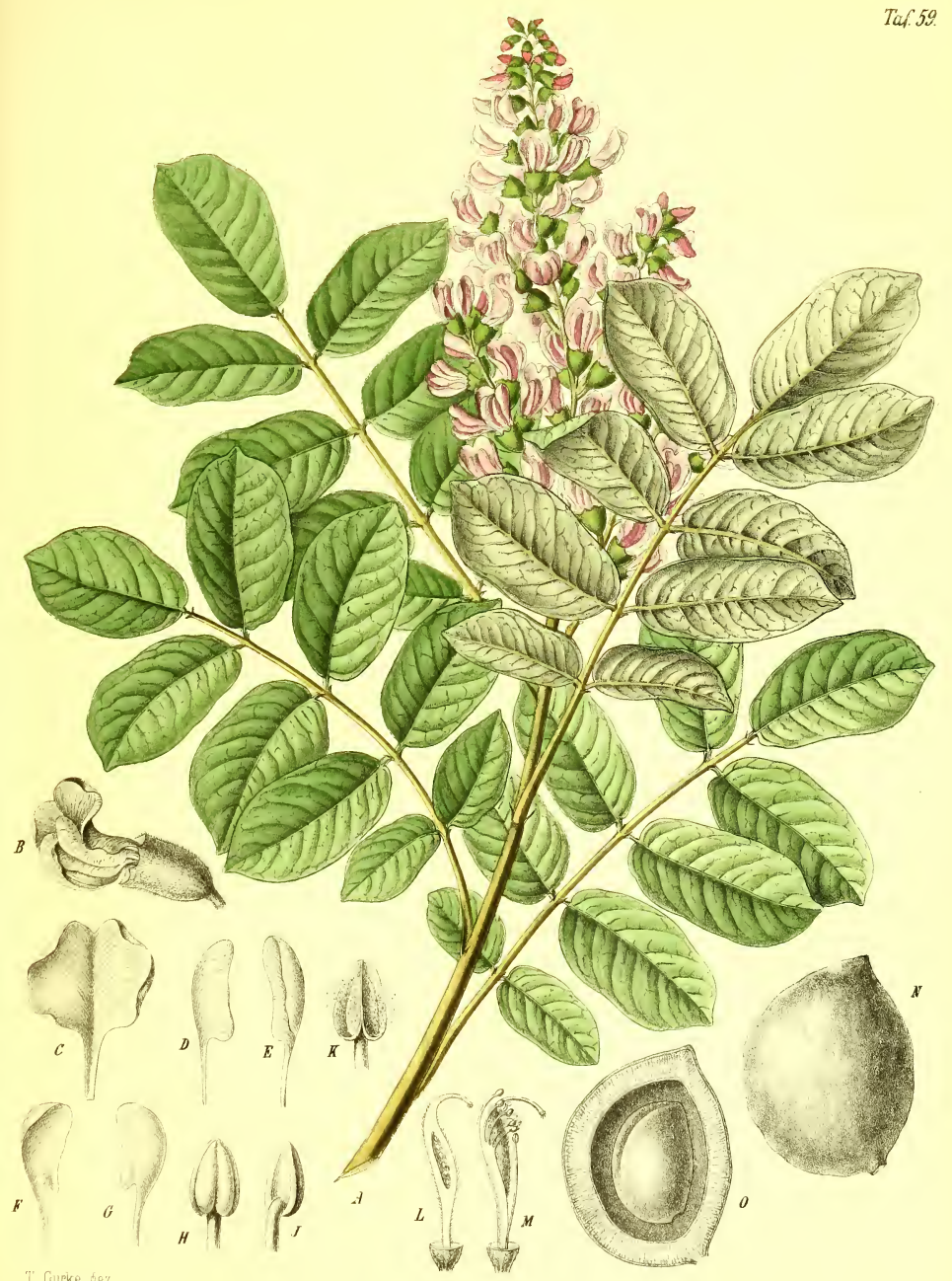

Andira l'isomes Mart 



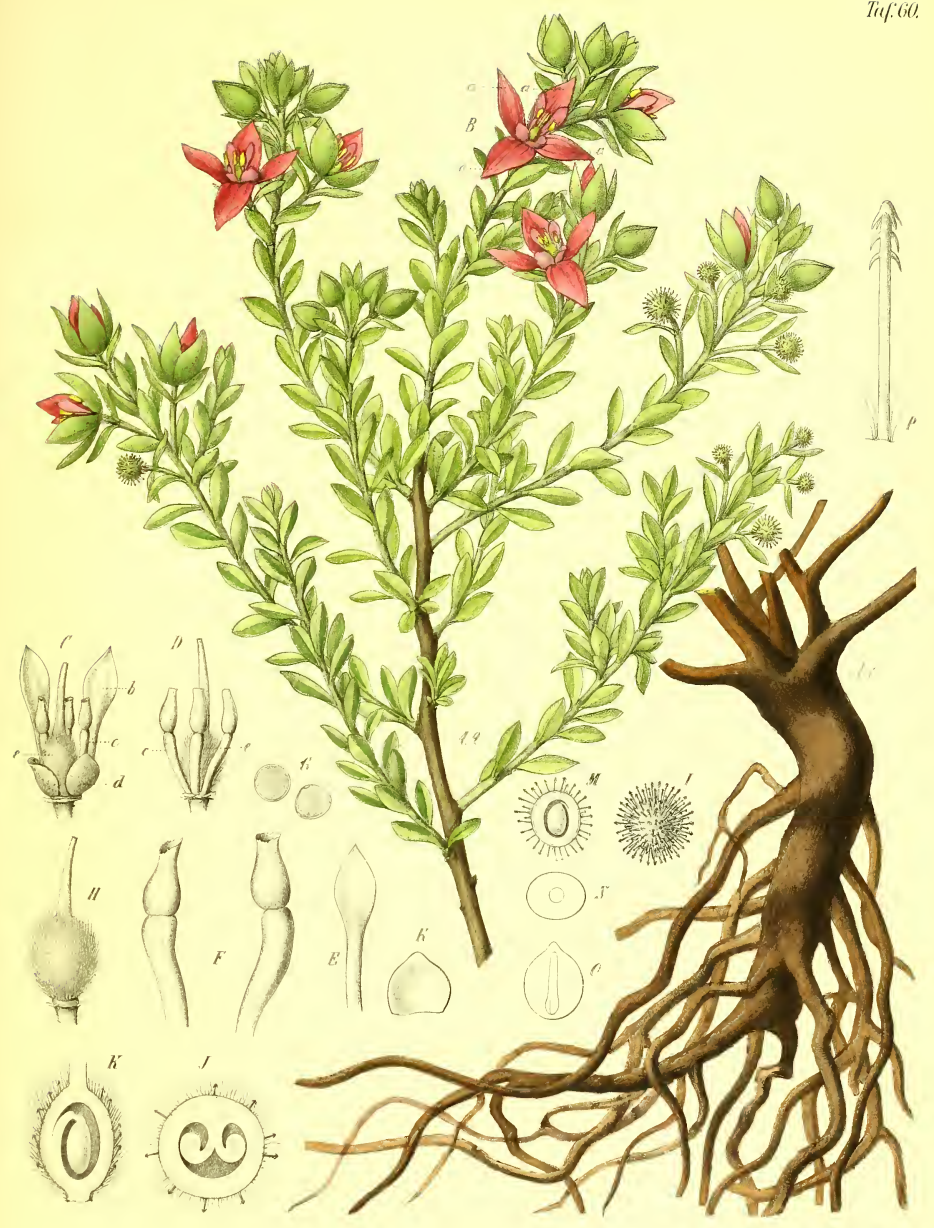

Krantuella Inandra Rumz et Paron 



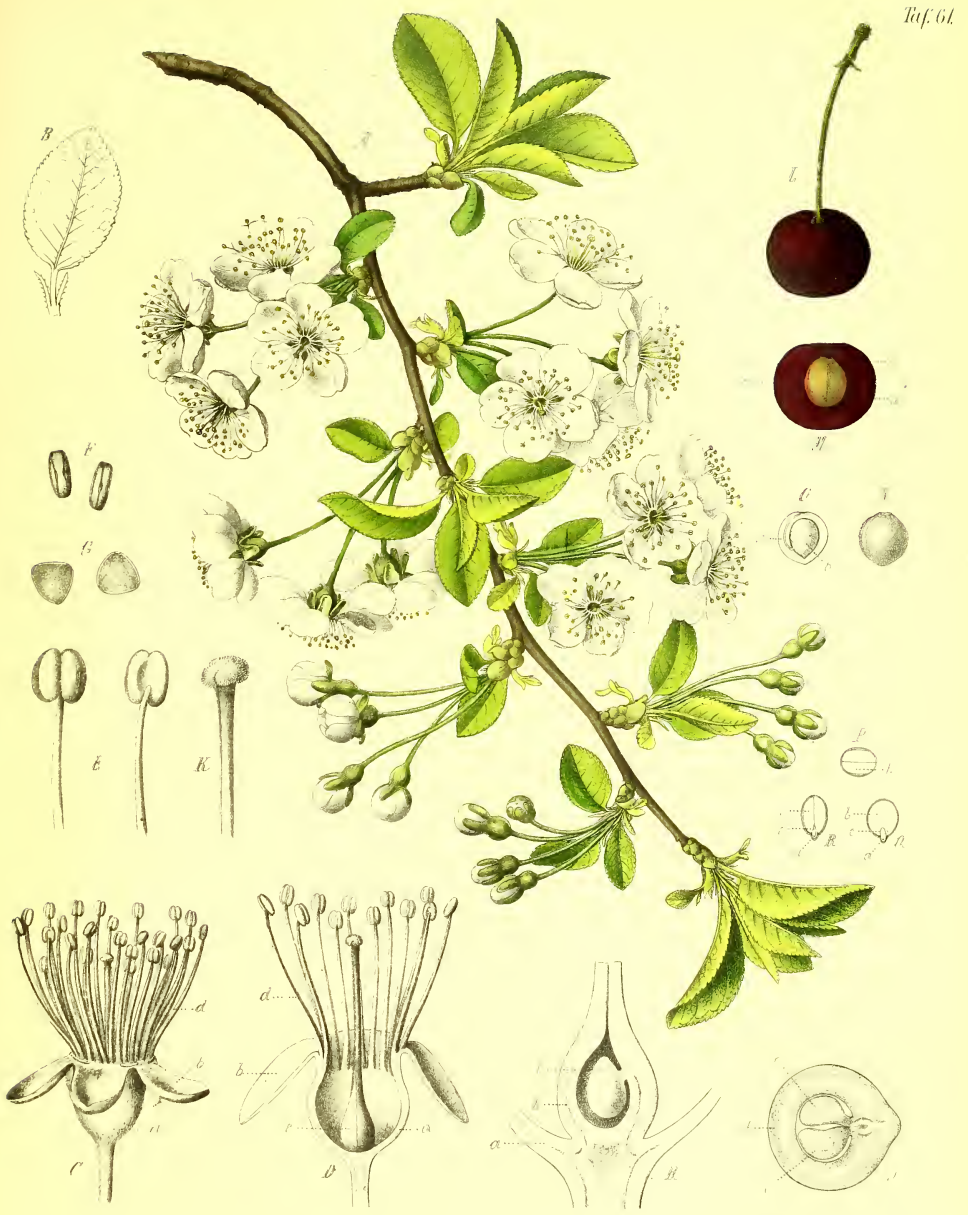

Prunus Cirasus L 



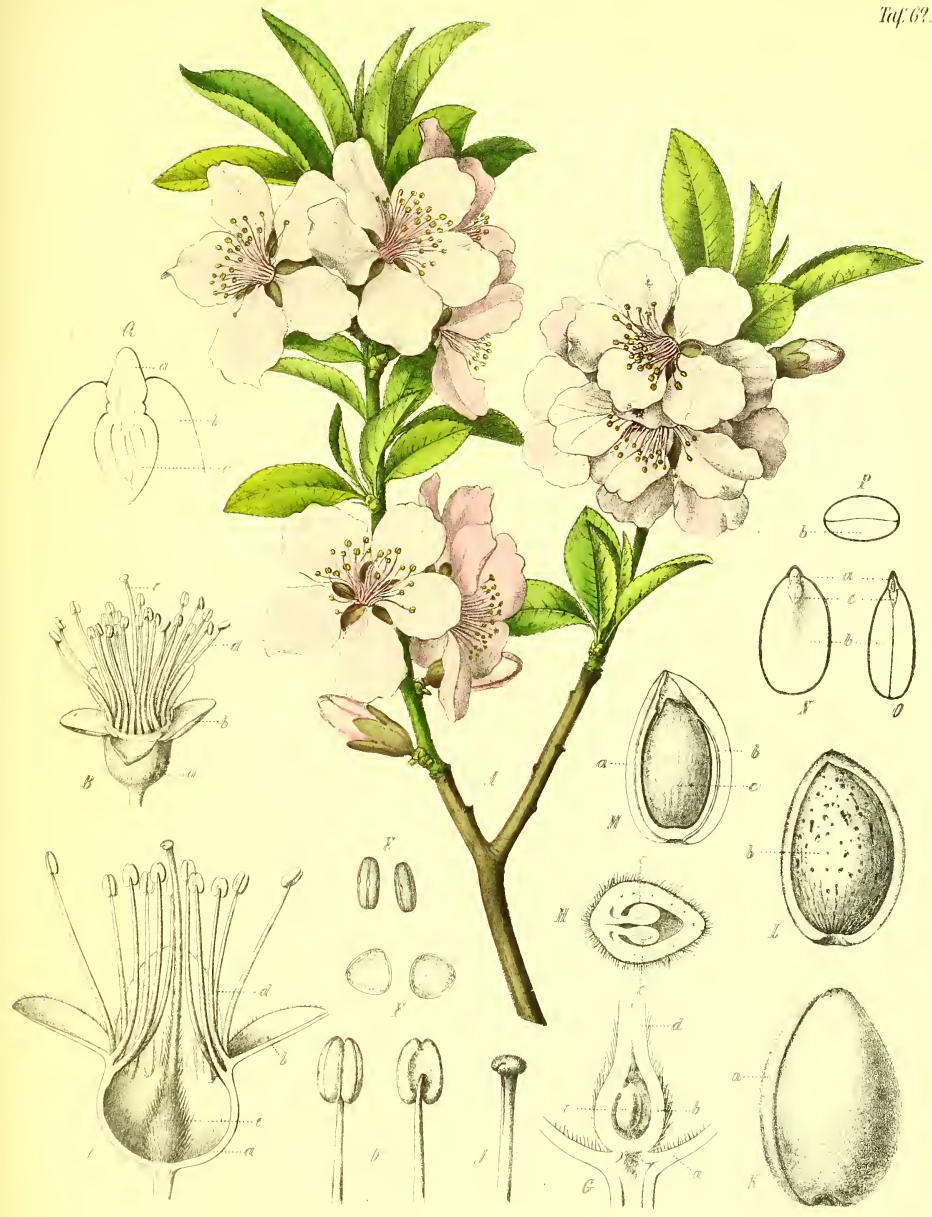

I'rumus Amtedialus stokes 

Taf 63

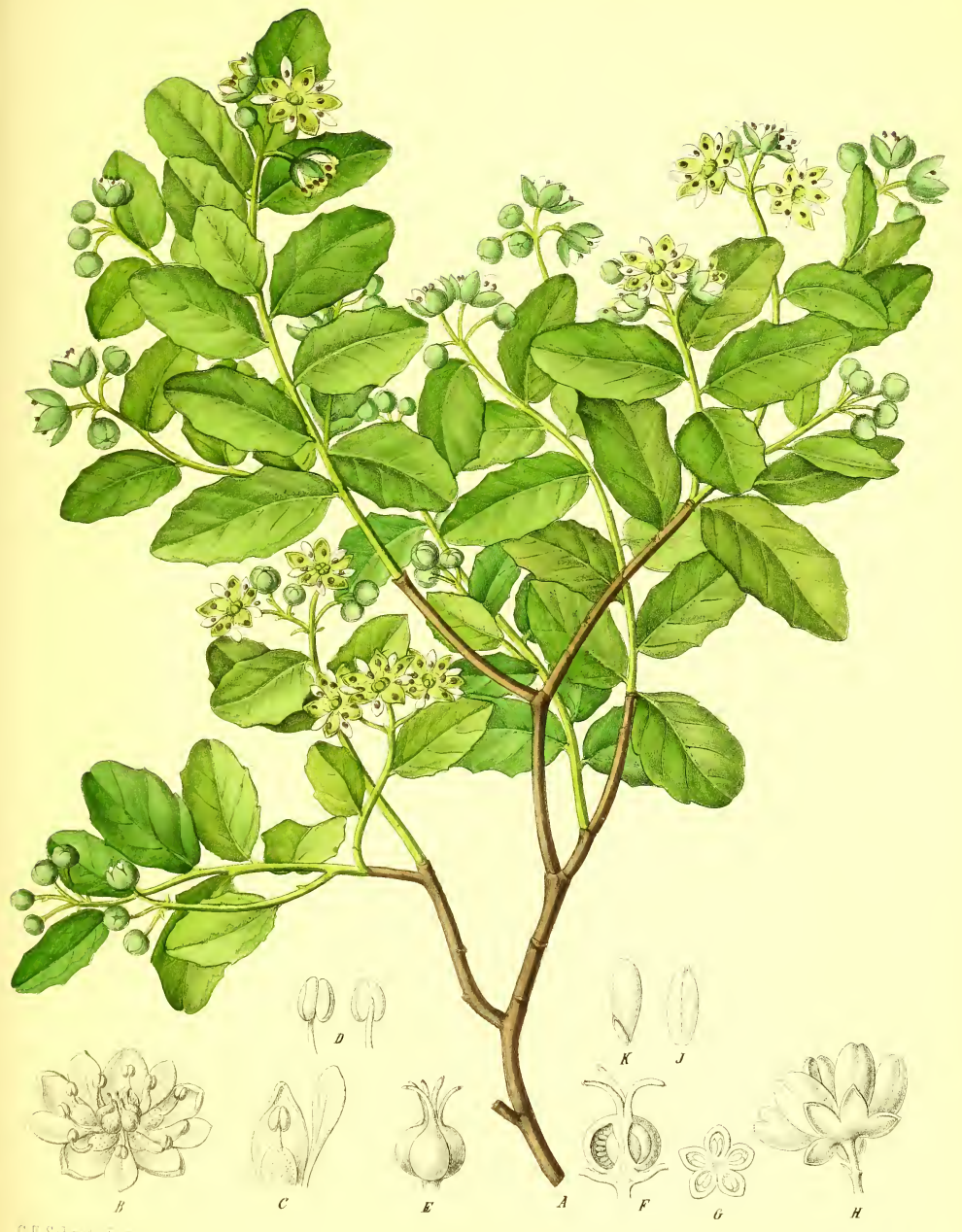

()uillaja Saponarla Mol. 



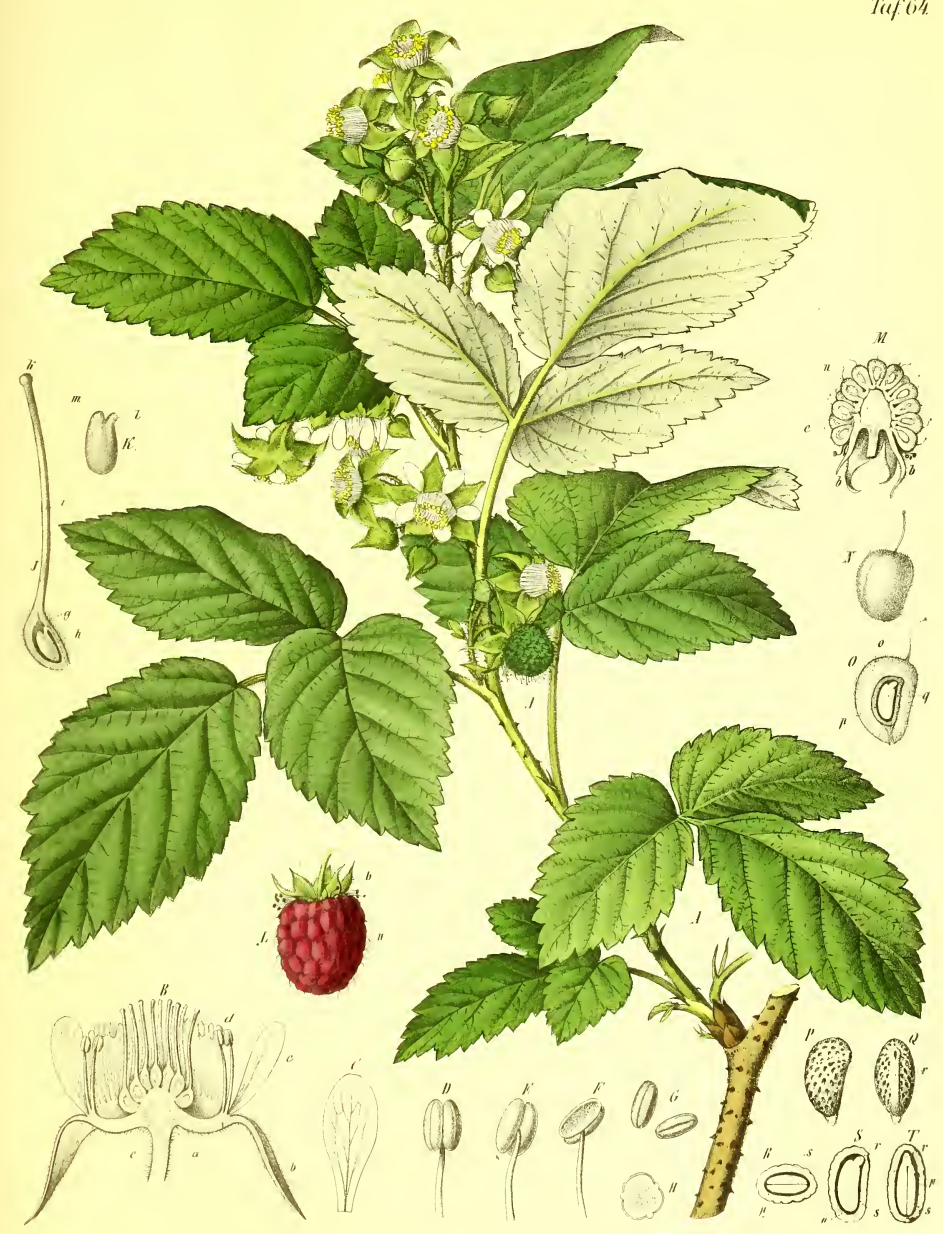

Rubus ldapus I. 

Tay.6.5.
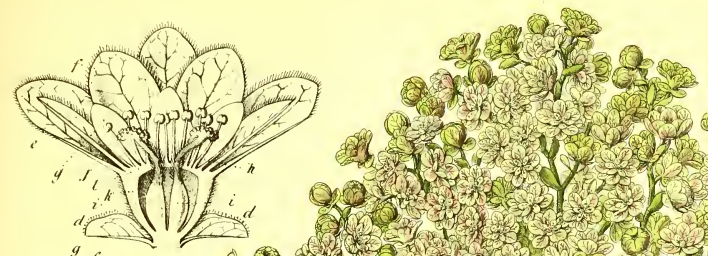

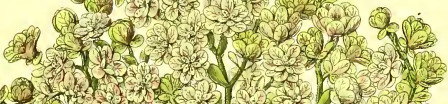

Q.2.

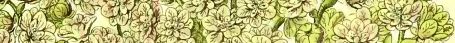

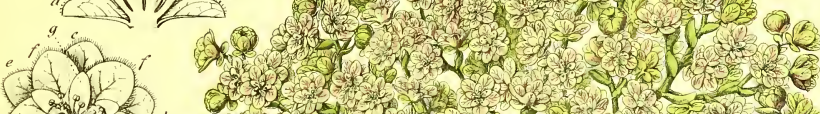

tै?

b.

$\log ^{2}$

$\lim _{2}$

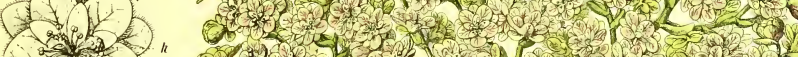

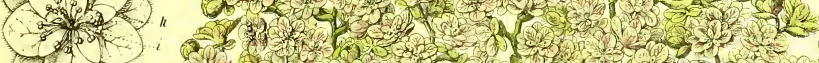

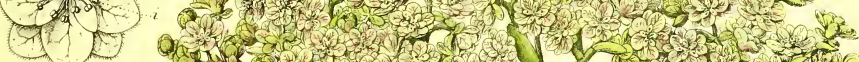

T.

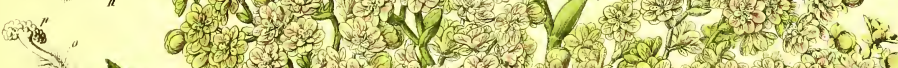

$7 y$
$\mathrm{i}$

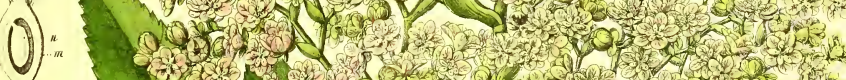

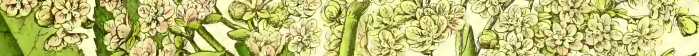
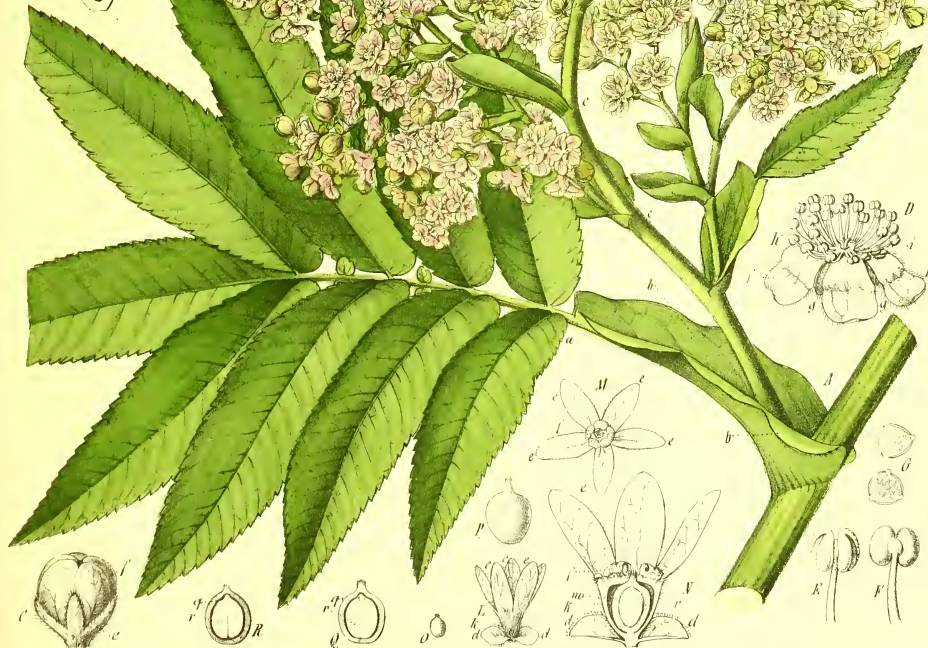

Hacomal Mbossmaral Hilld 



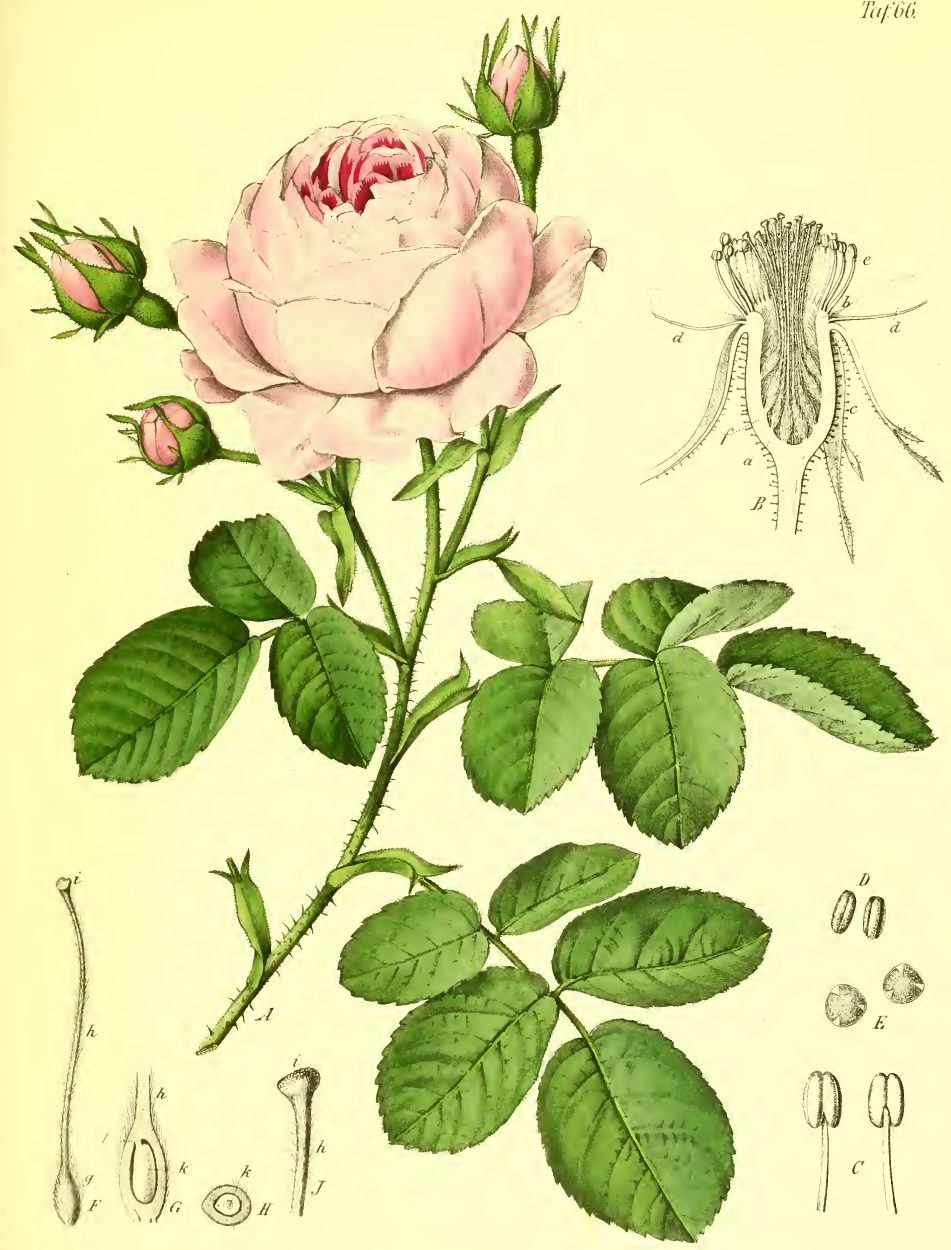

Rosid remlifolia l. 



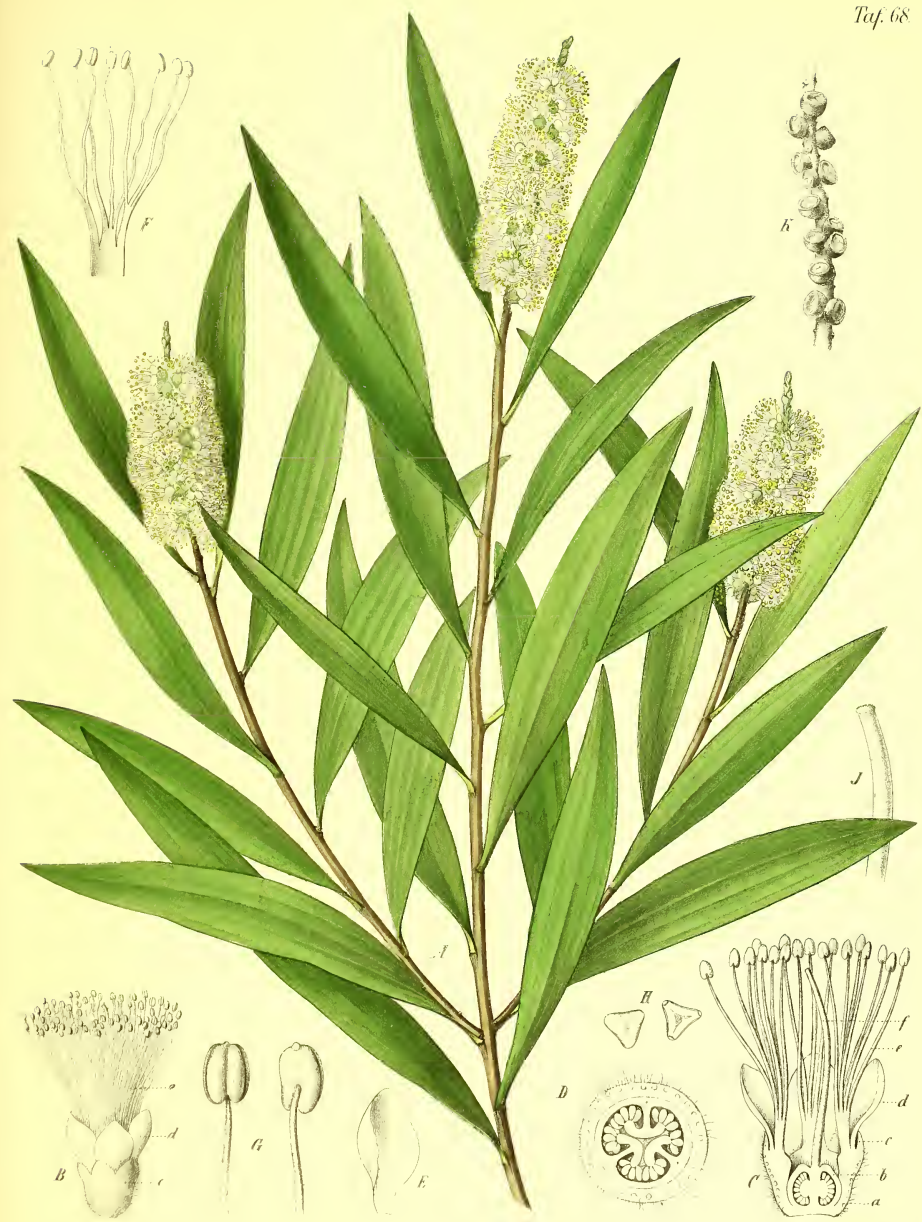

Melalenea Leucadenderon L. 

Taf.69.

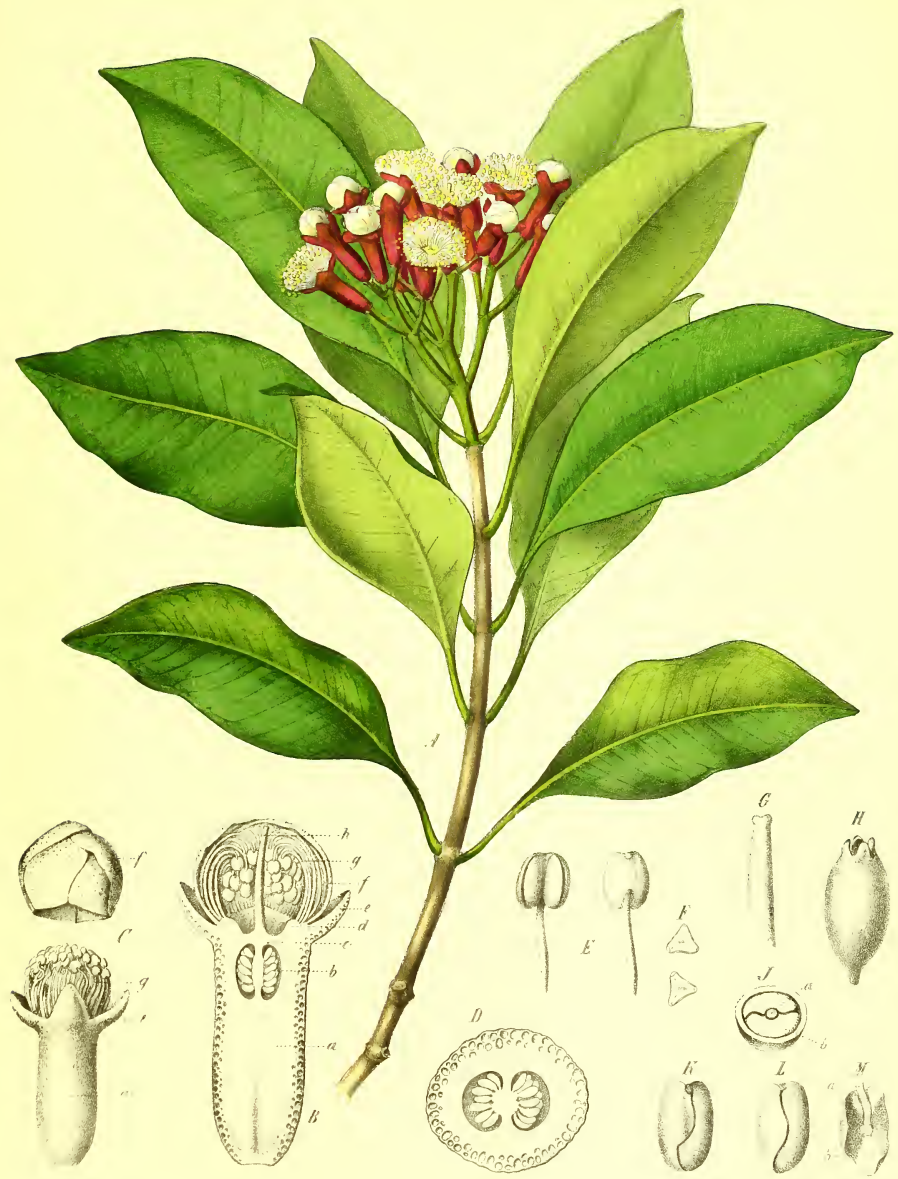

Caropluthes anomalicus I. 



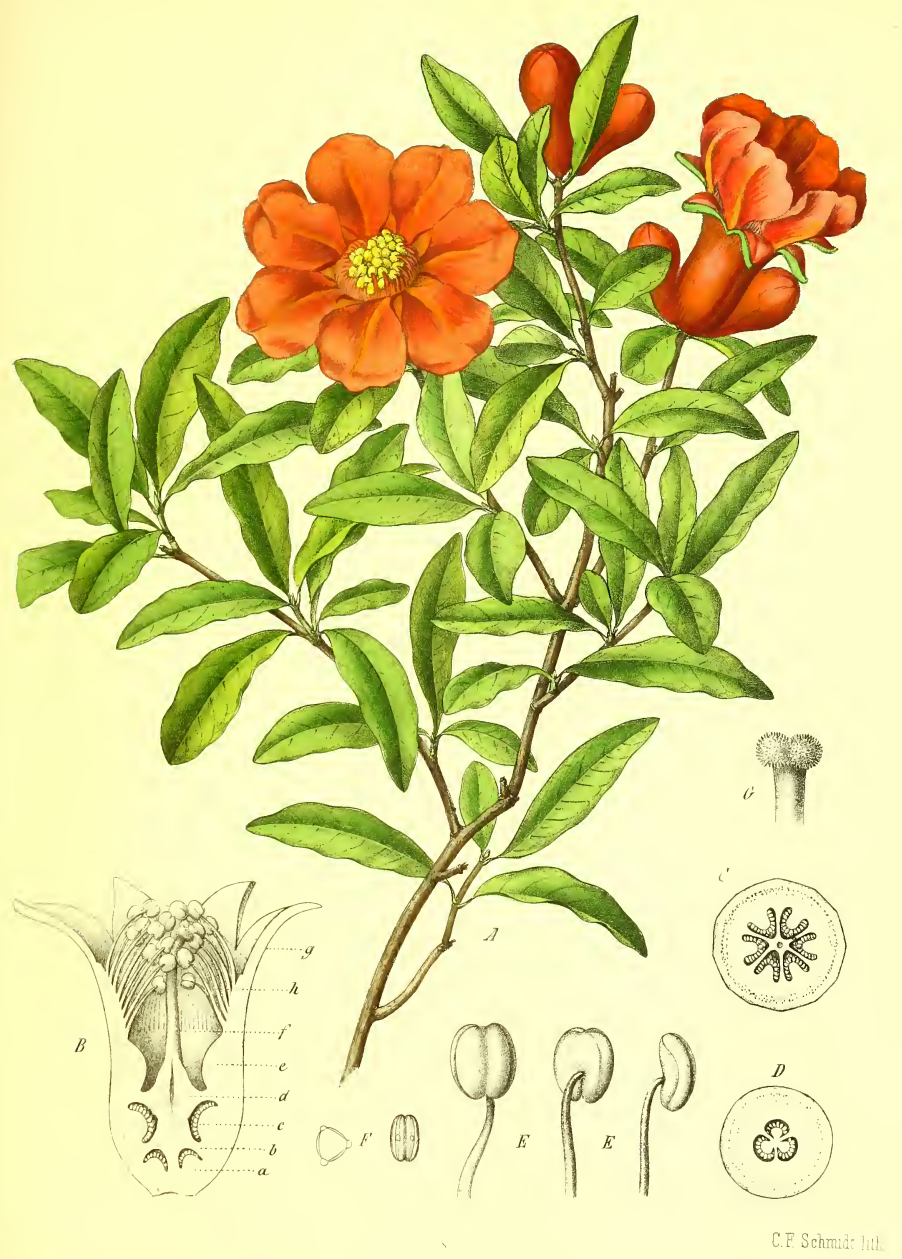

Thif ing

Pumica Granatum. L. 



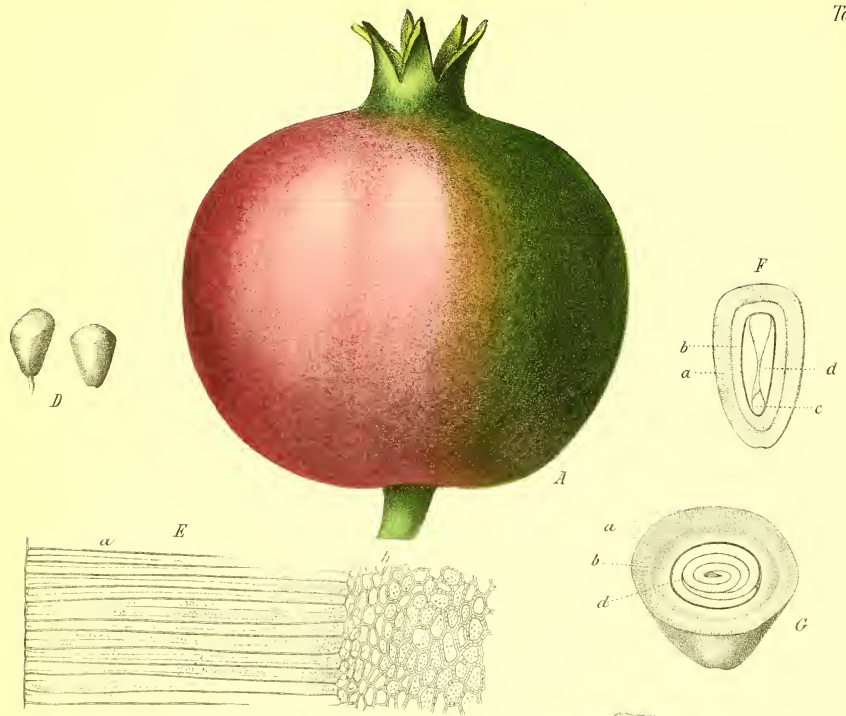

Tif. KO
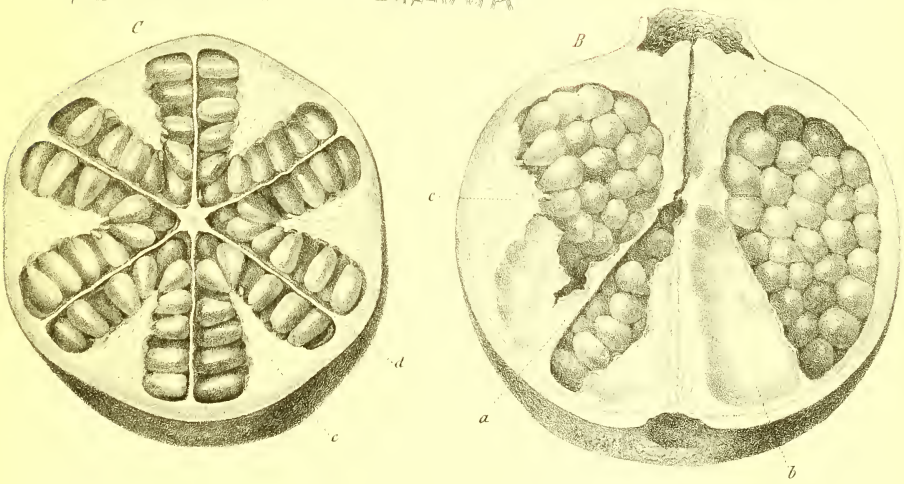

Punica Granatum. L 



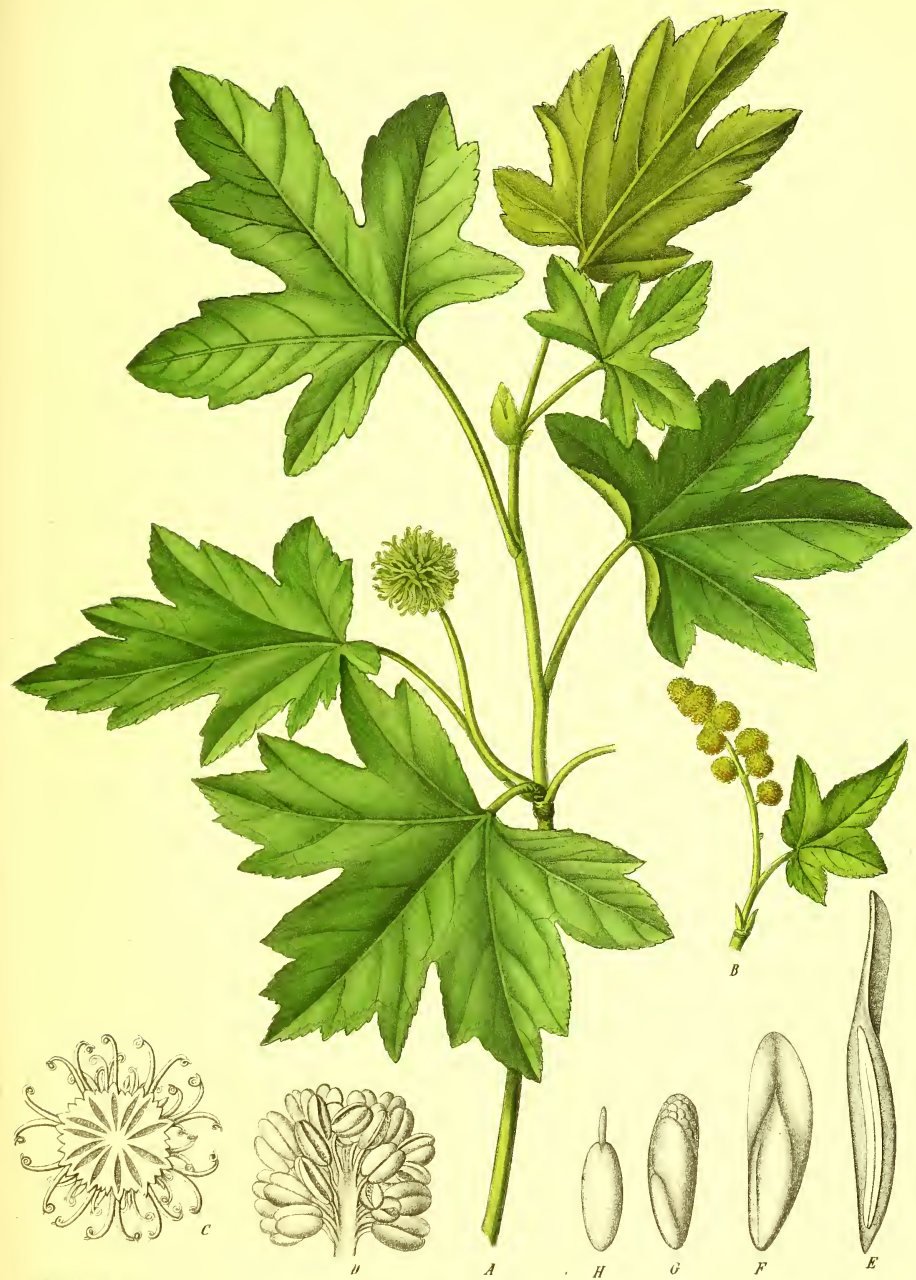

Liquidambar orientale Vill 

Taf. 79

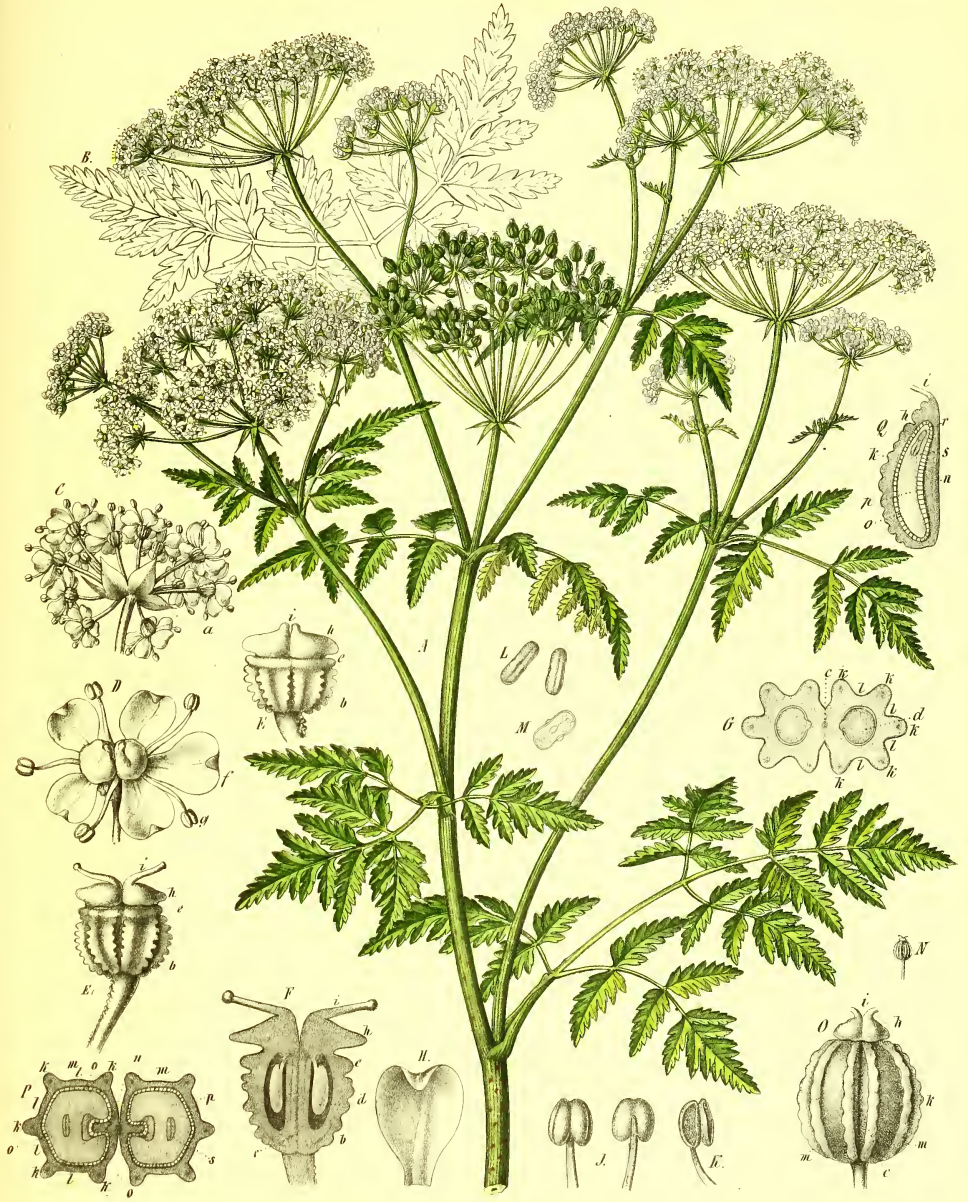

C.F Schmid: gez, uhth

Conium maculalum I. 



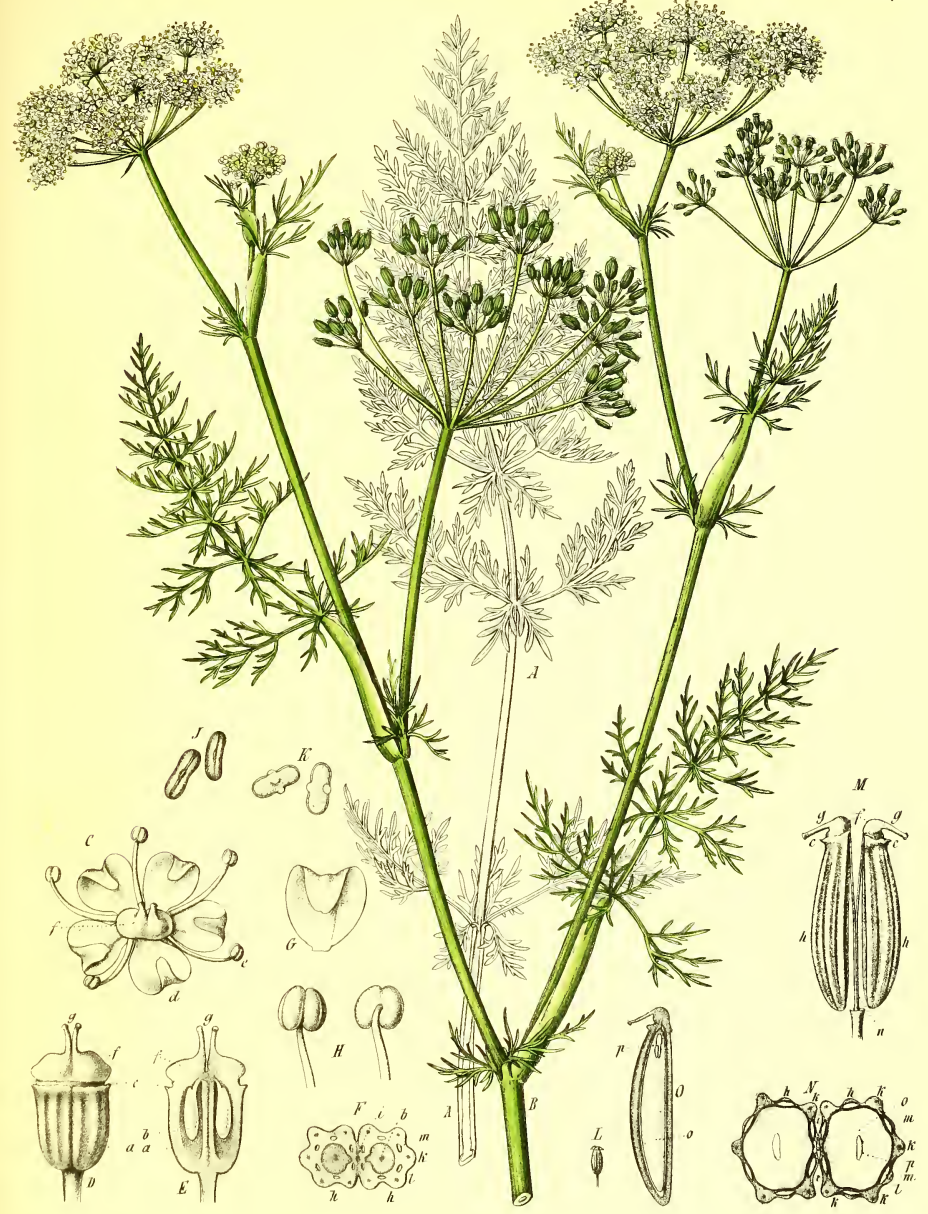

Camun Cimo. 1. 



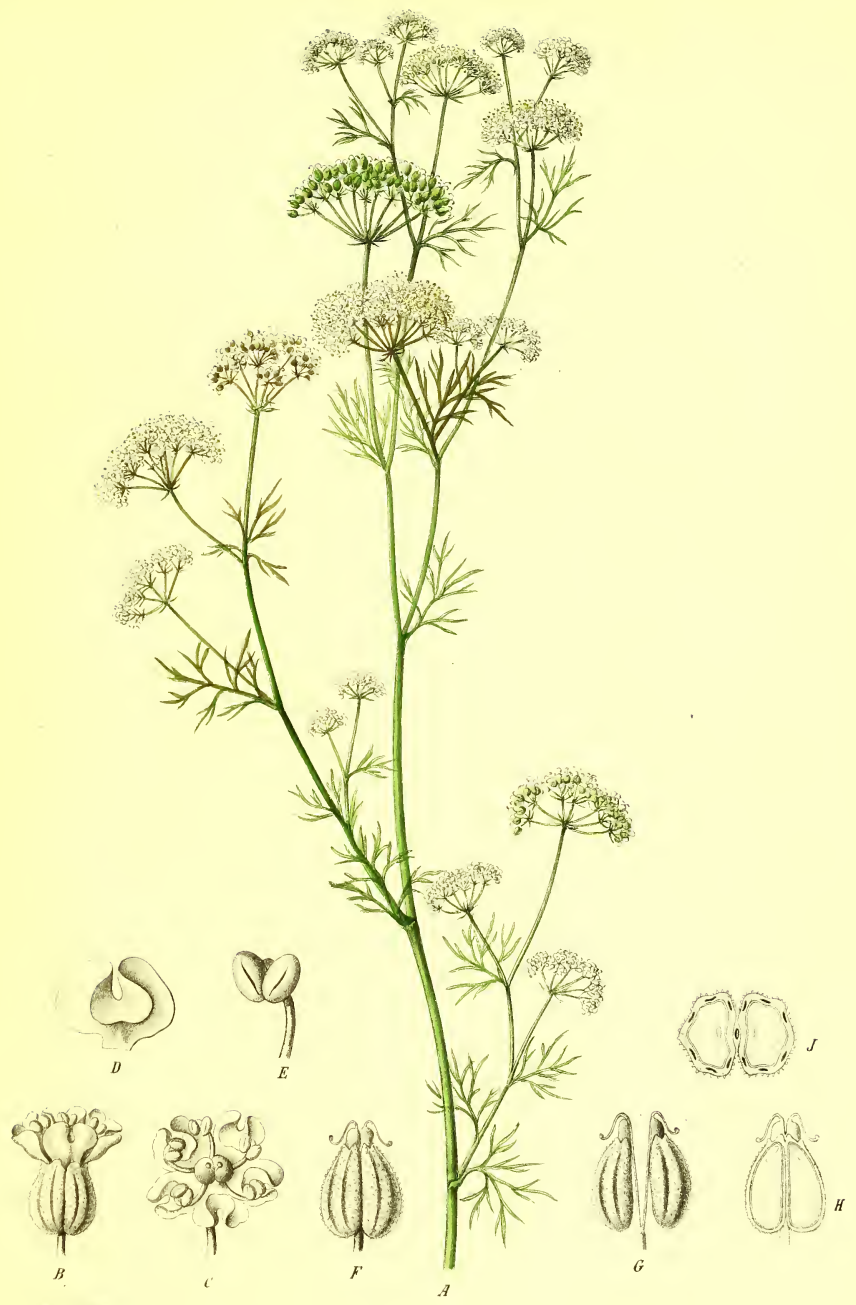

Ptychotis Ajowan PI.C. 



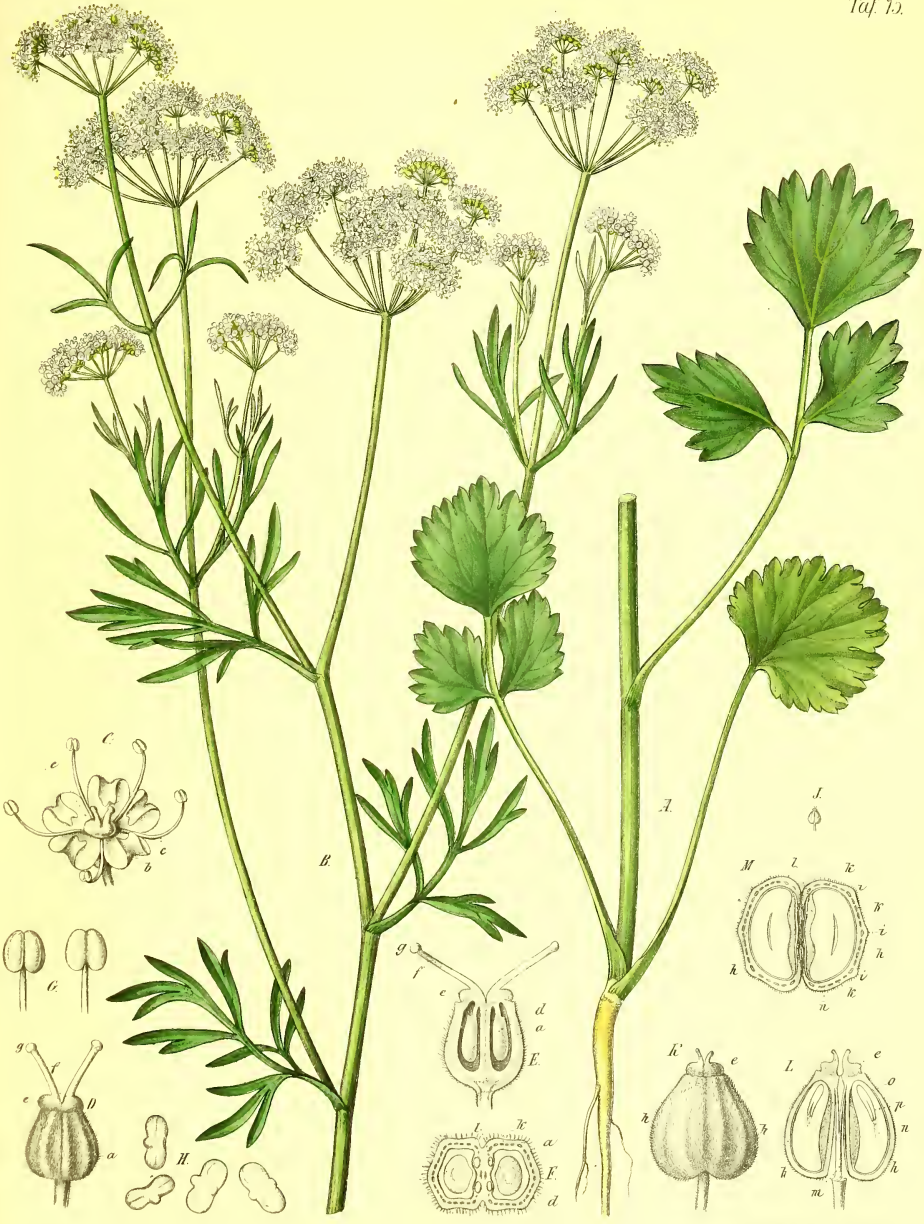





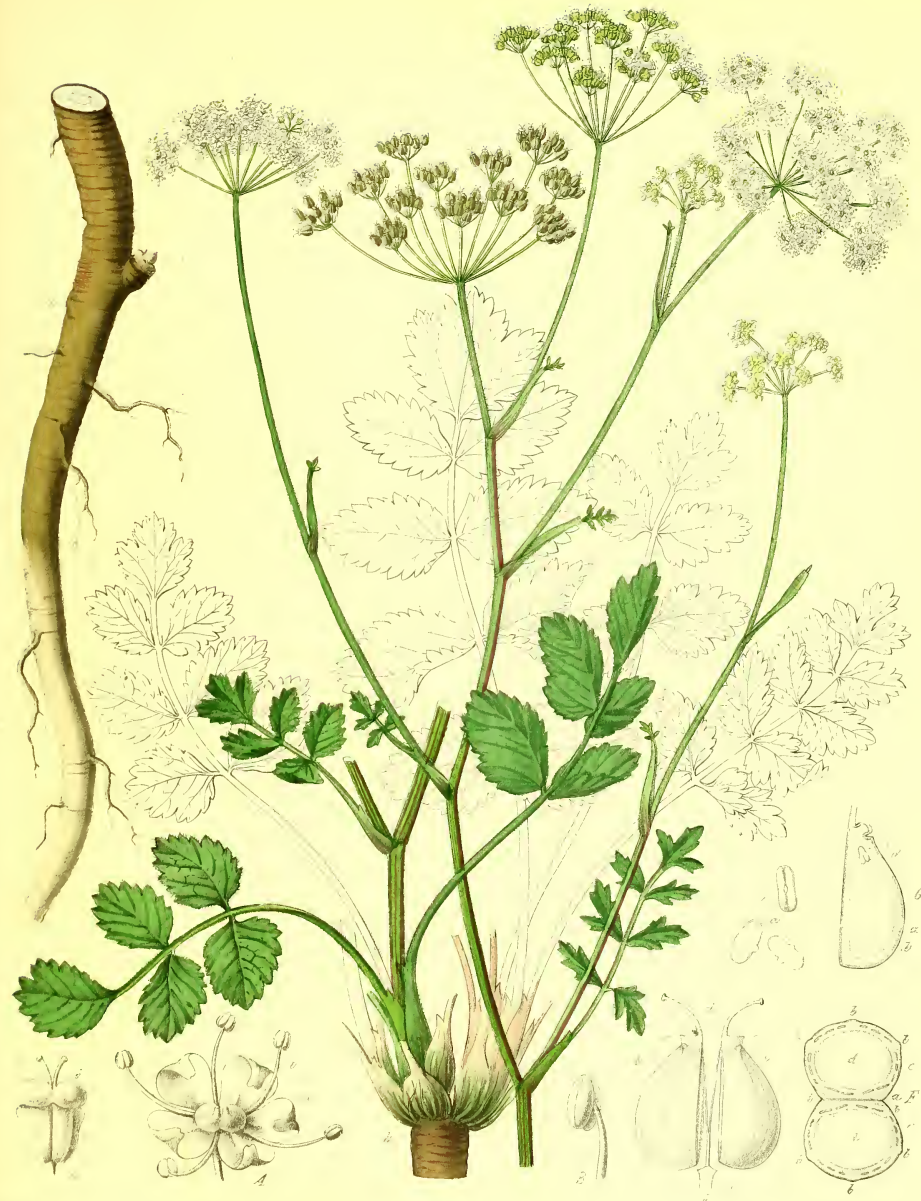

l'mupinclla Saxifiaga J, vall is niora. 

Lit

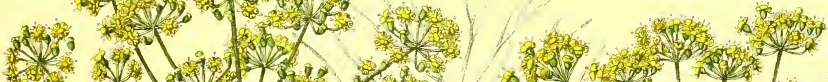

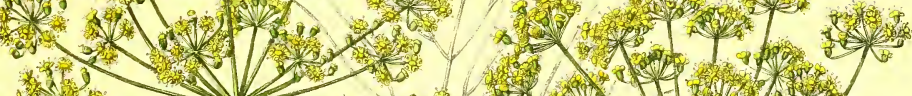

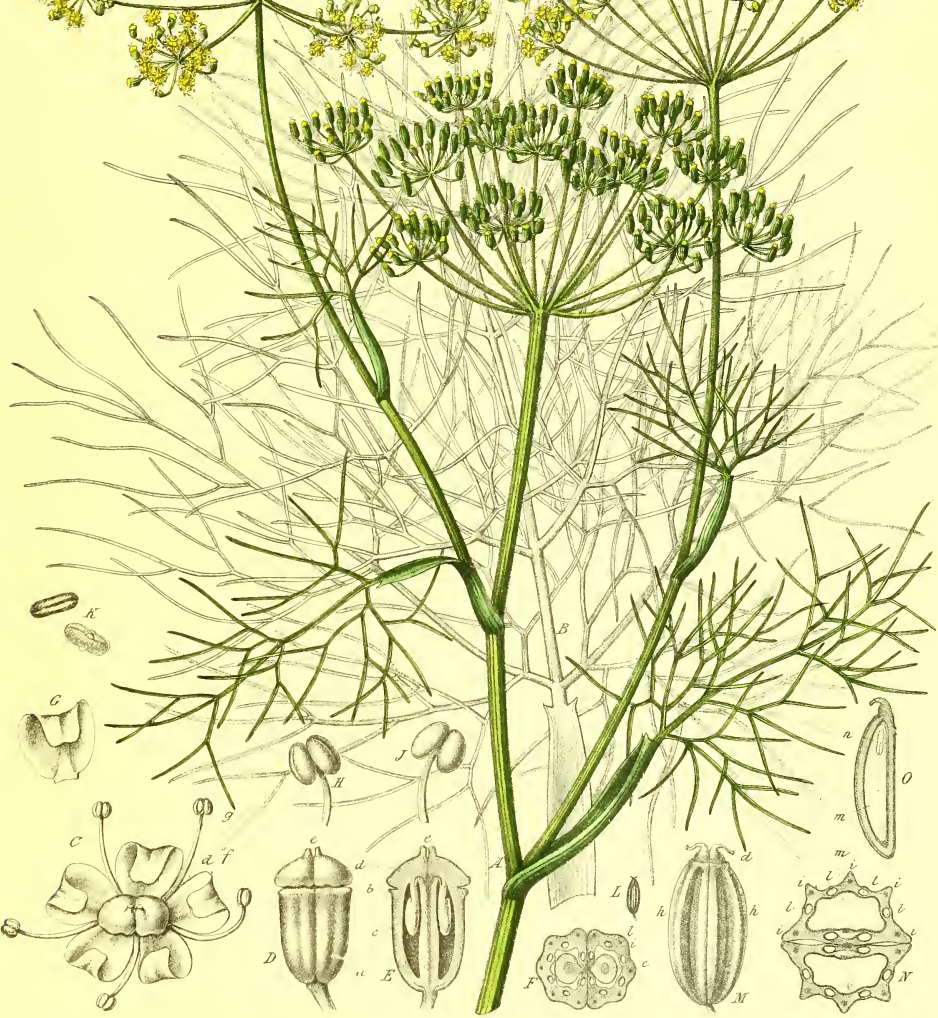

Foenculum capillaceum cil 



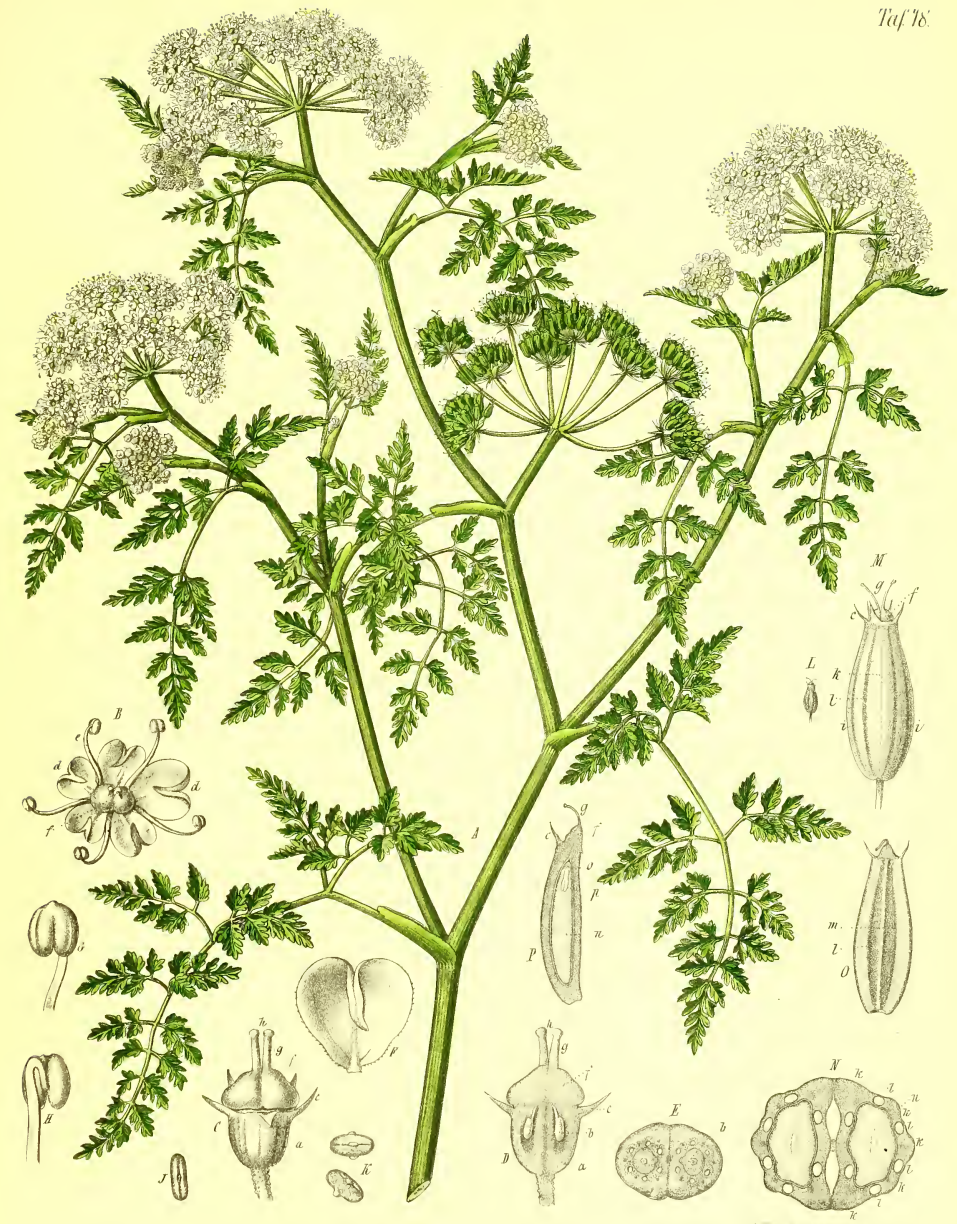

Denauthe Phellandrium Lamark 



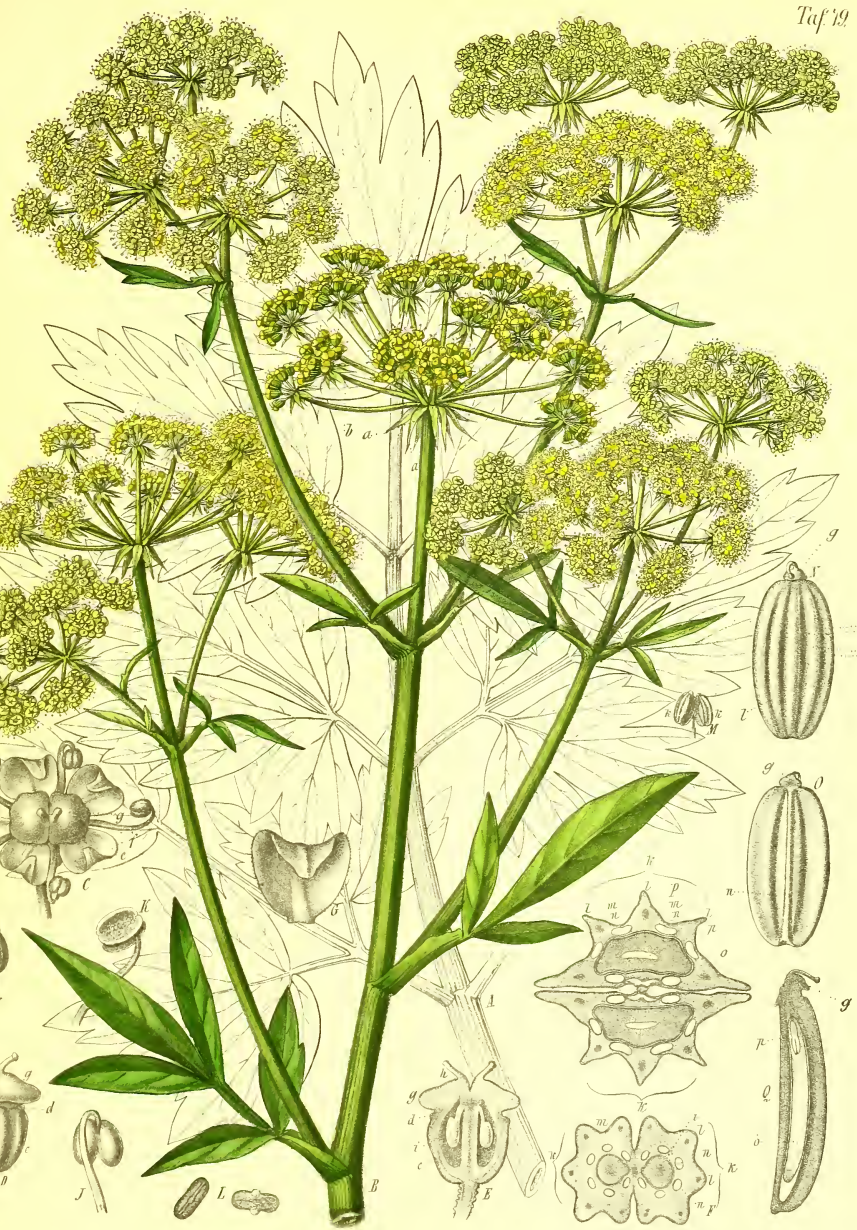





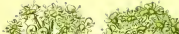

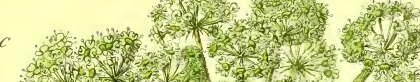

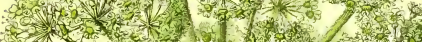
-

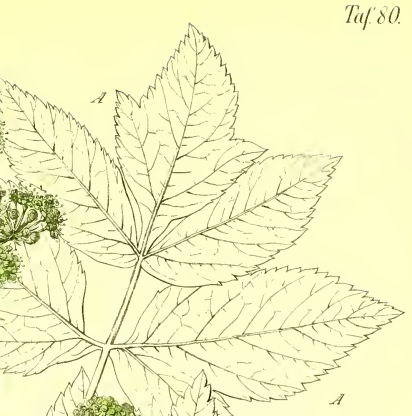

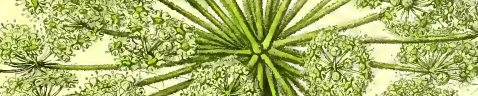
(5)

301 . and

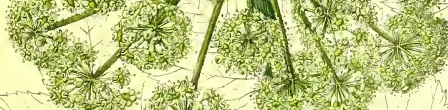
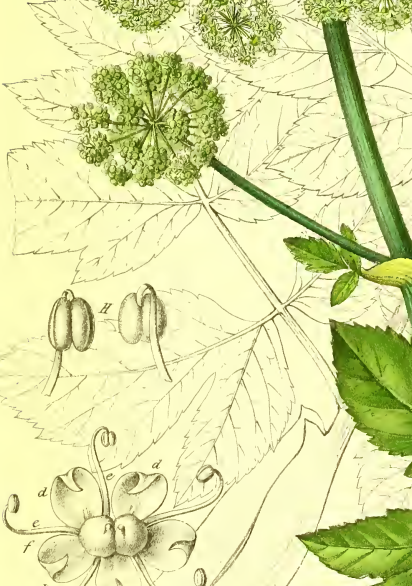



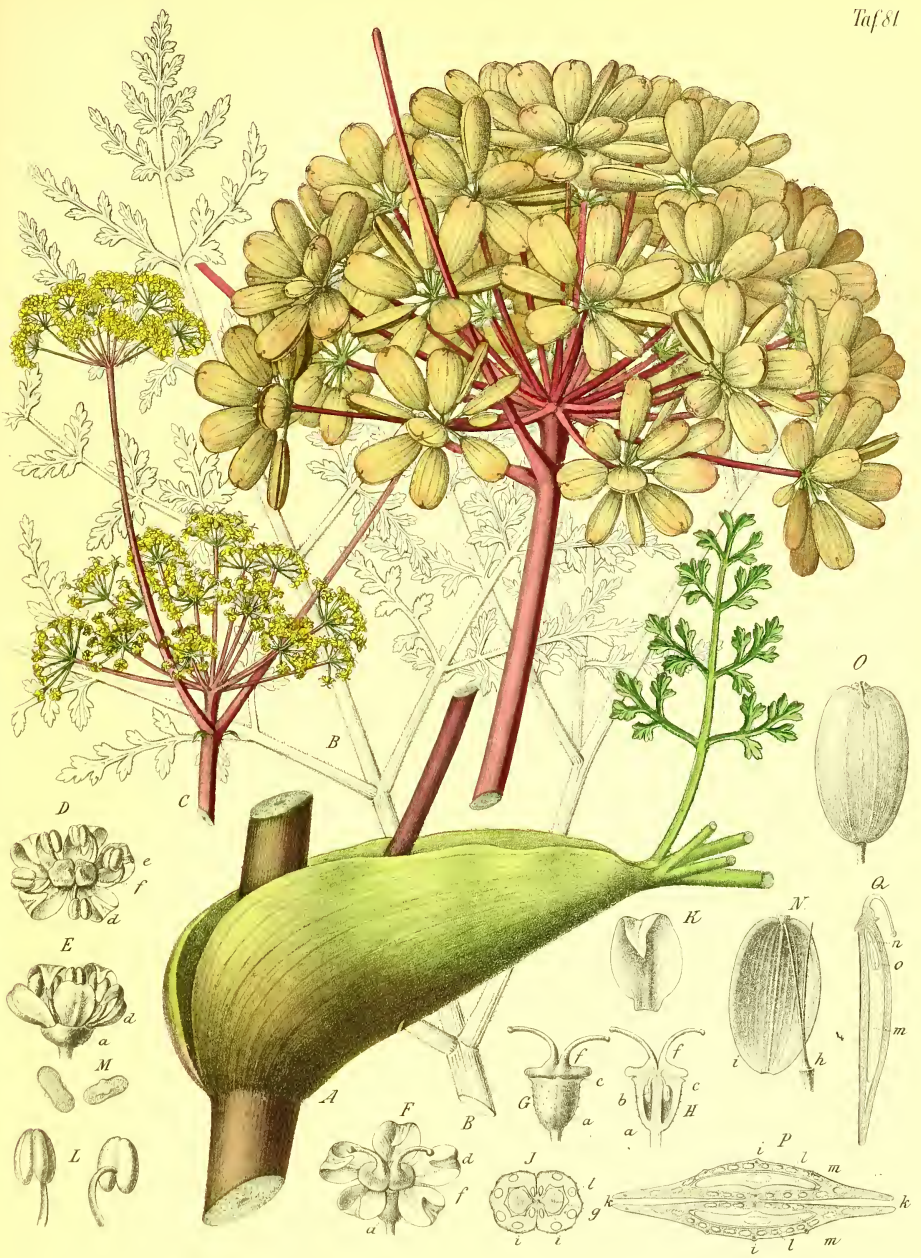

Ferula mbricanlis Boiss 

Taf $\delta \%$

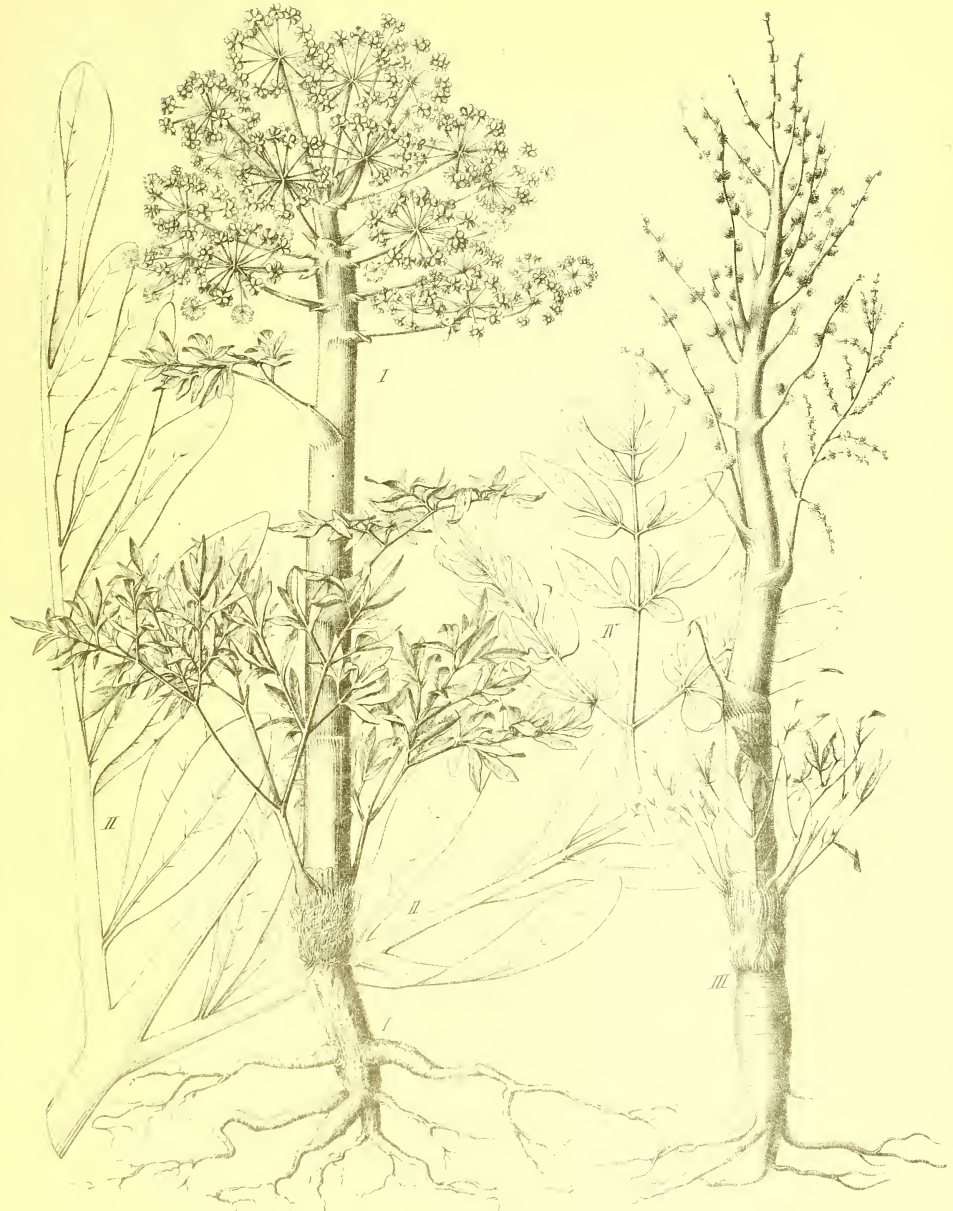



Taf 89
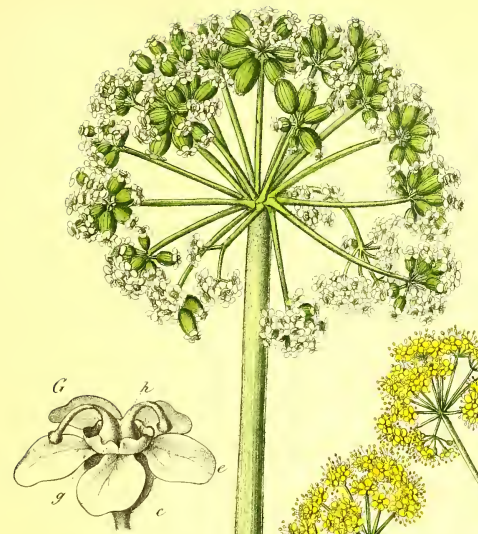

$3\left(\frac{a r g}{2}\right)^{h}$

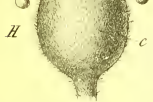

$\left.8(1) \int^{2}\right)^{h} a$

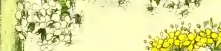

. 3 v
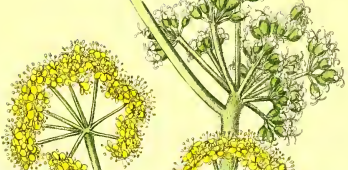

a

or. no

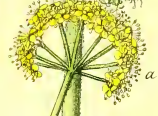

ris:
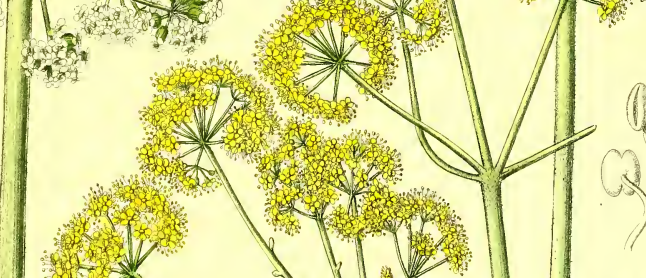

(a)

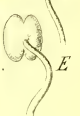

H. 10 .
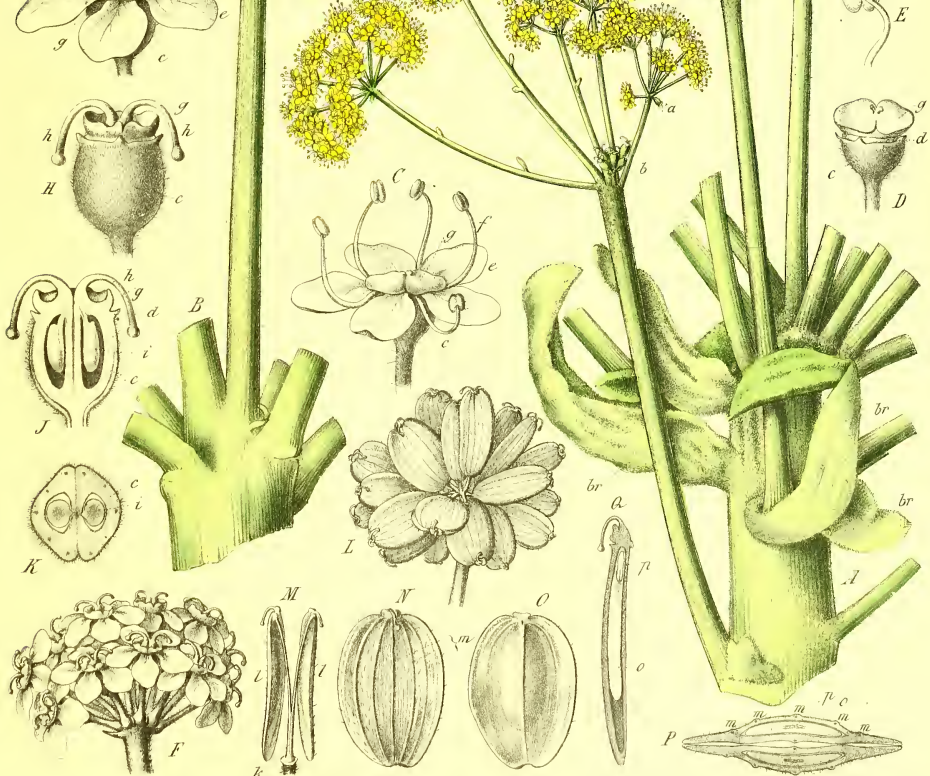



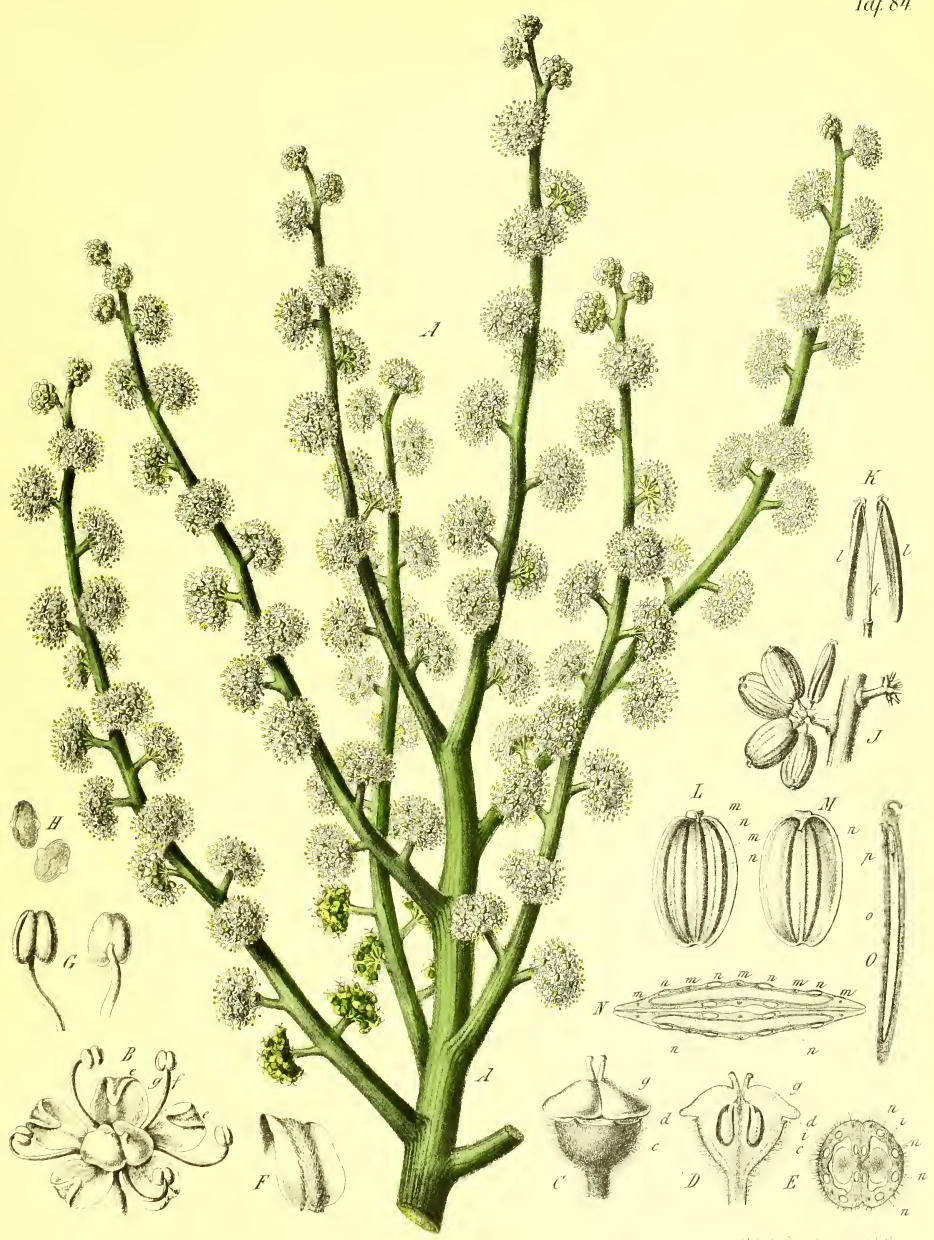

Dorema Ammoniacum 1)om 

Taf. 85
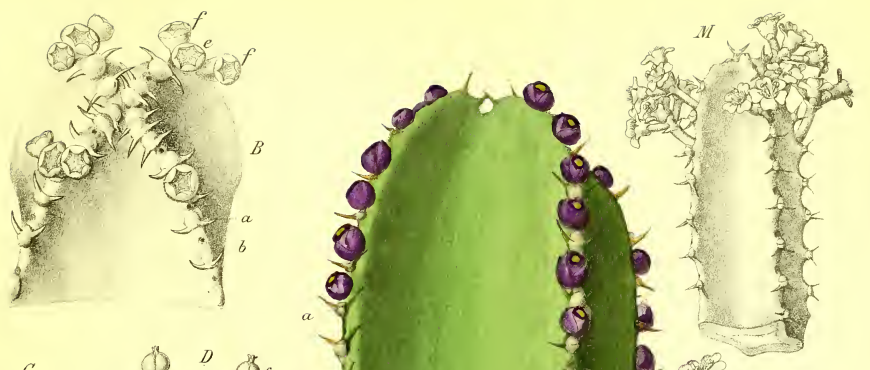

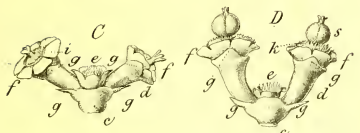
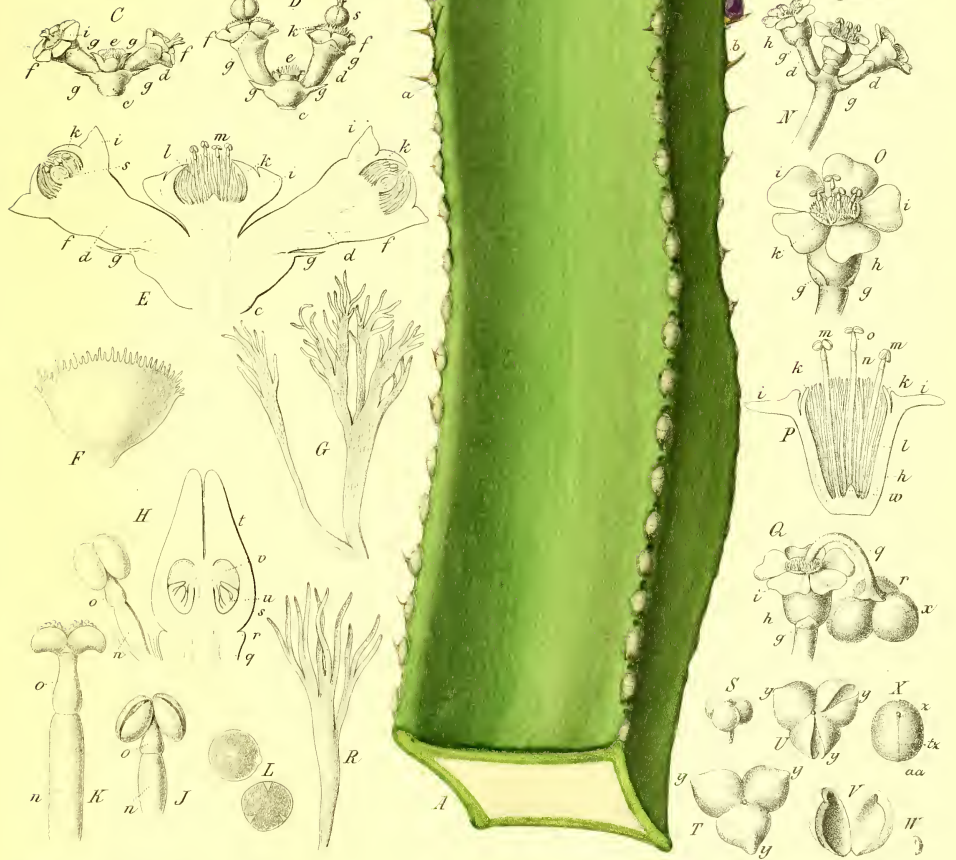

A. Fuphorbia Canaruensis L M-X Euphorbia resinifora Bo 



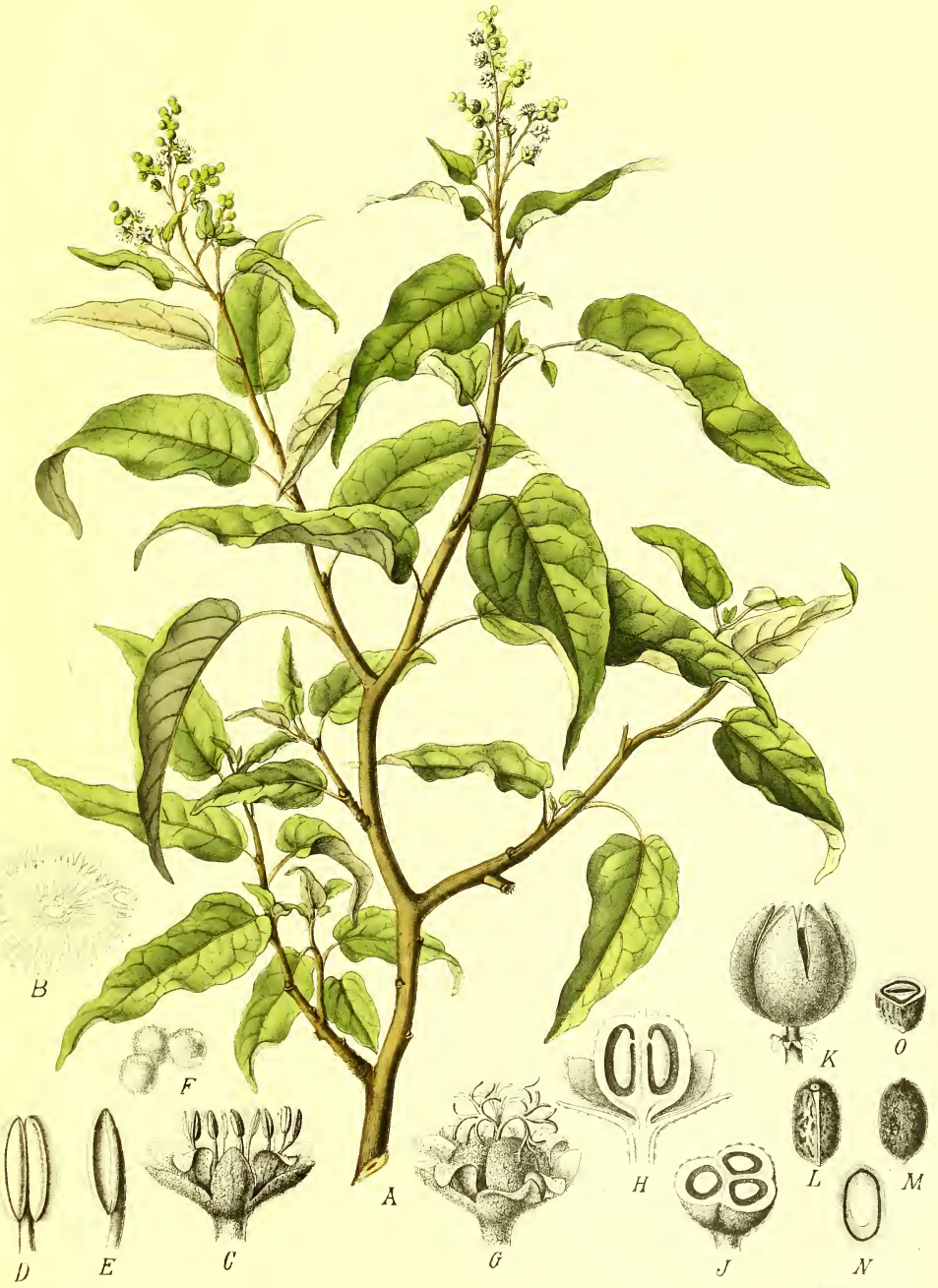

Croton Eluteria Bemn 



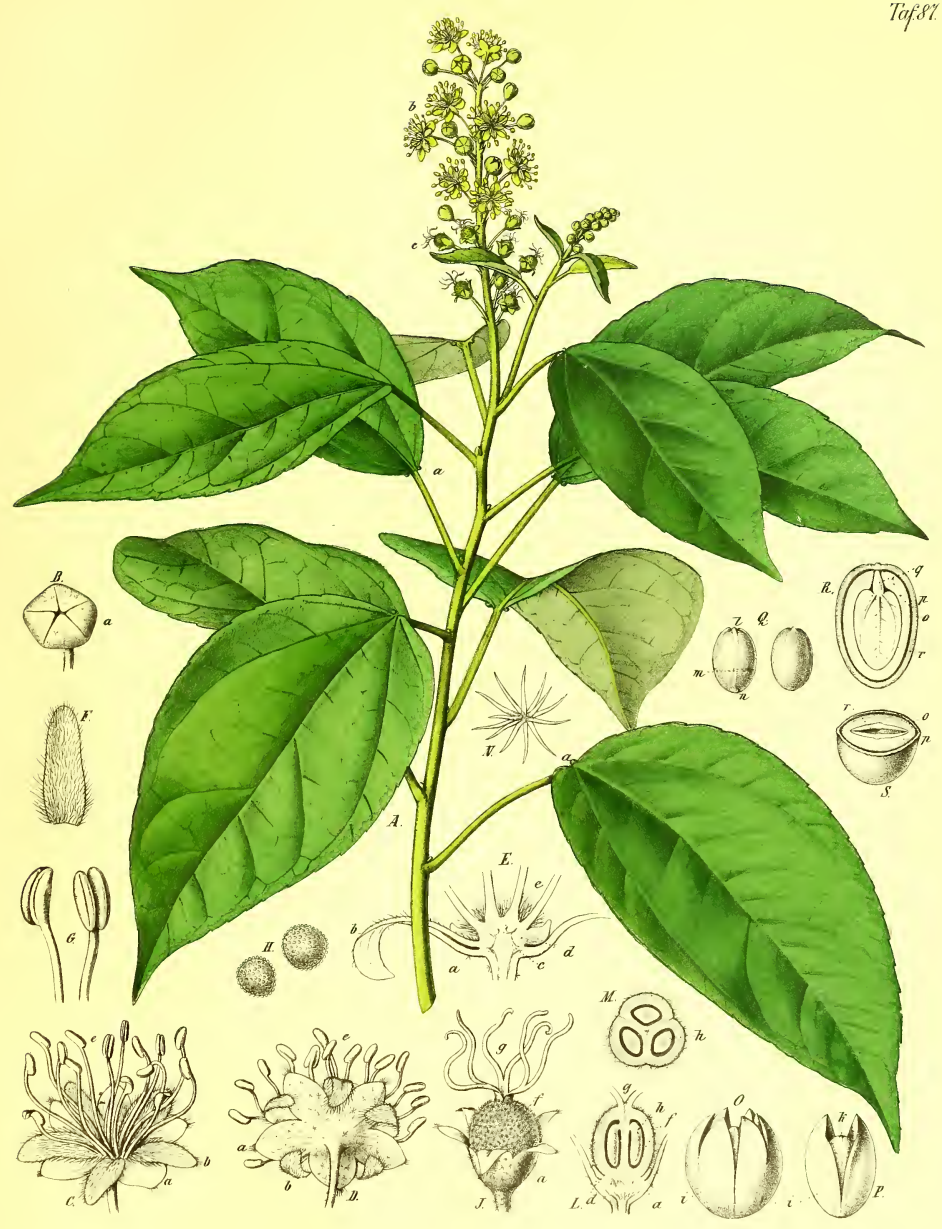

Croton Tiglium L. 

Iaf. 88 .

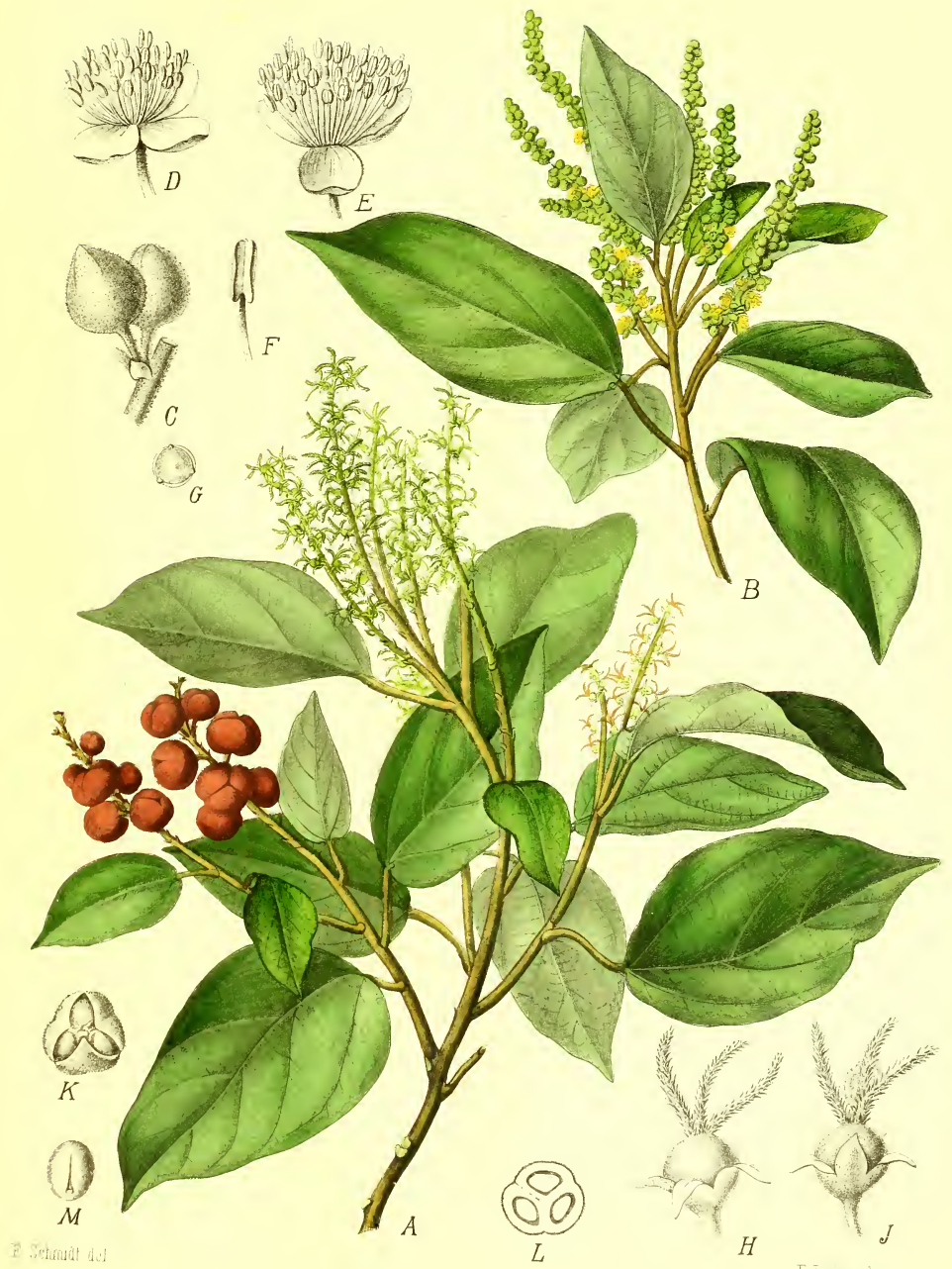

Vallotus Philippinensis Viull-Ary. 


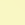




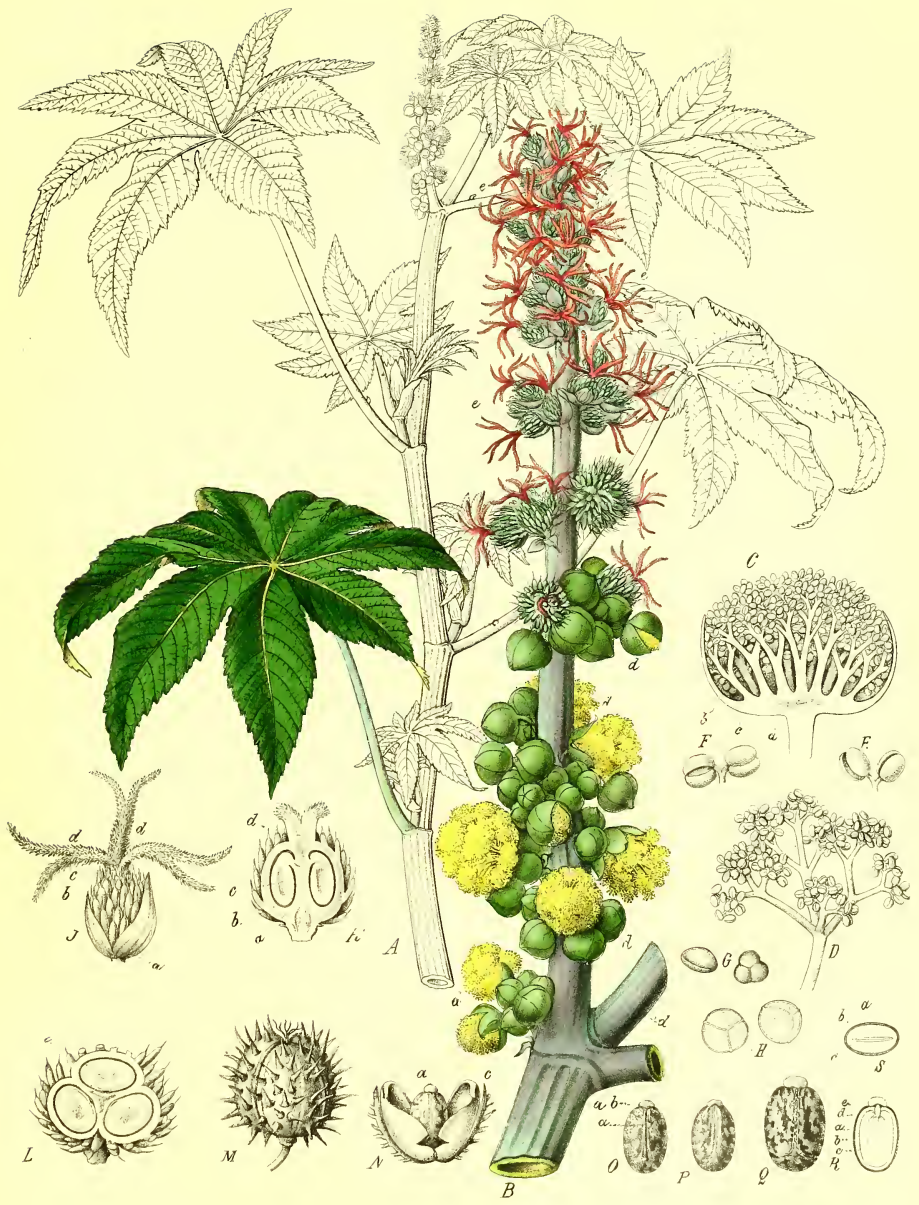

Ricinus communis L. 



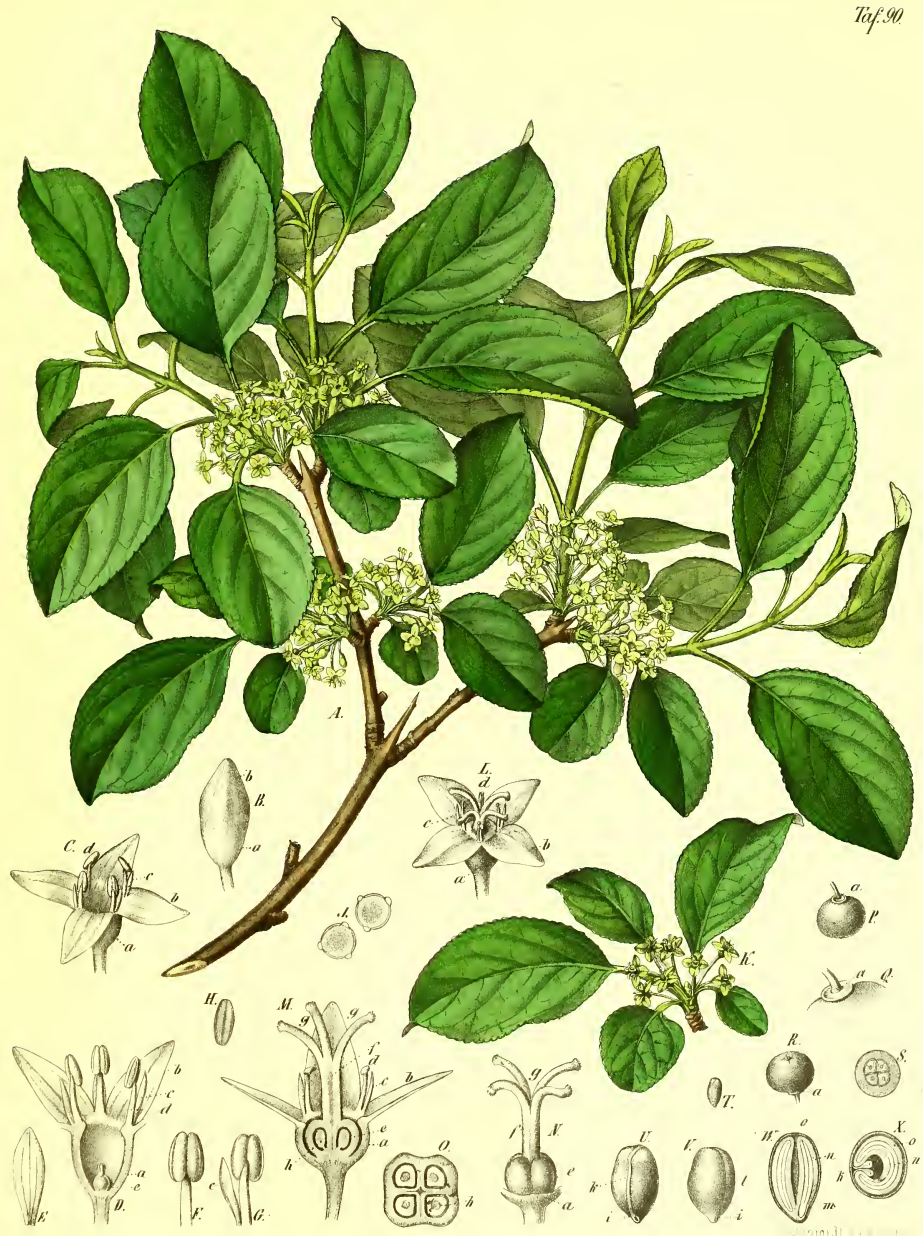

Phamnus cathartica I. 

TafY

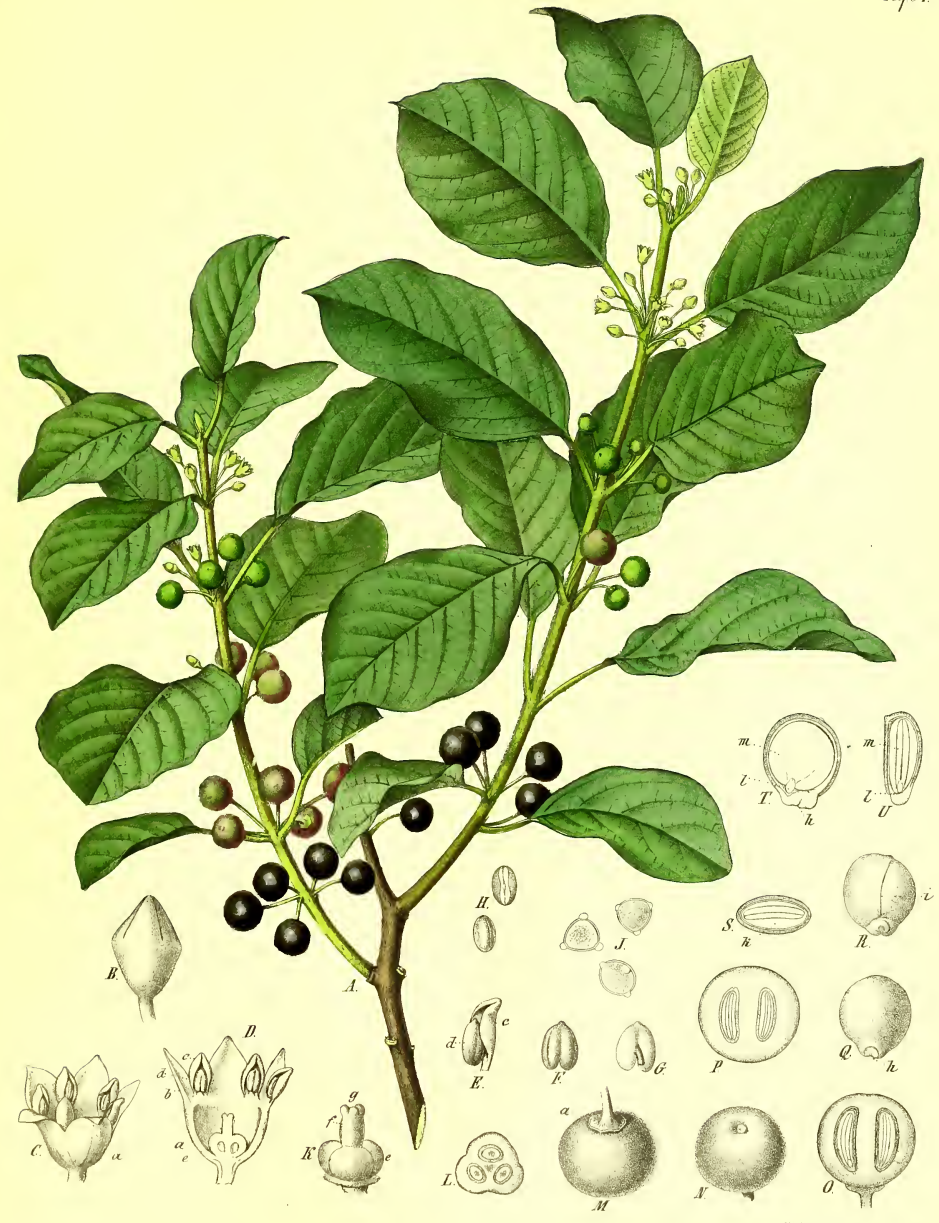

Rhammus Frangula L. 



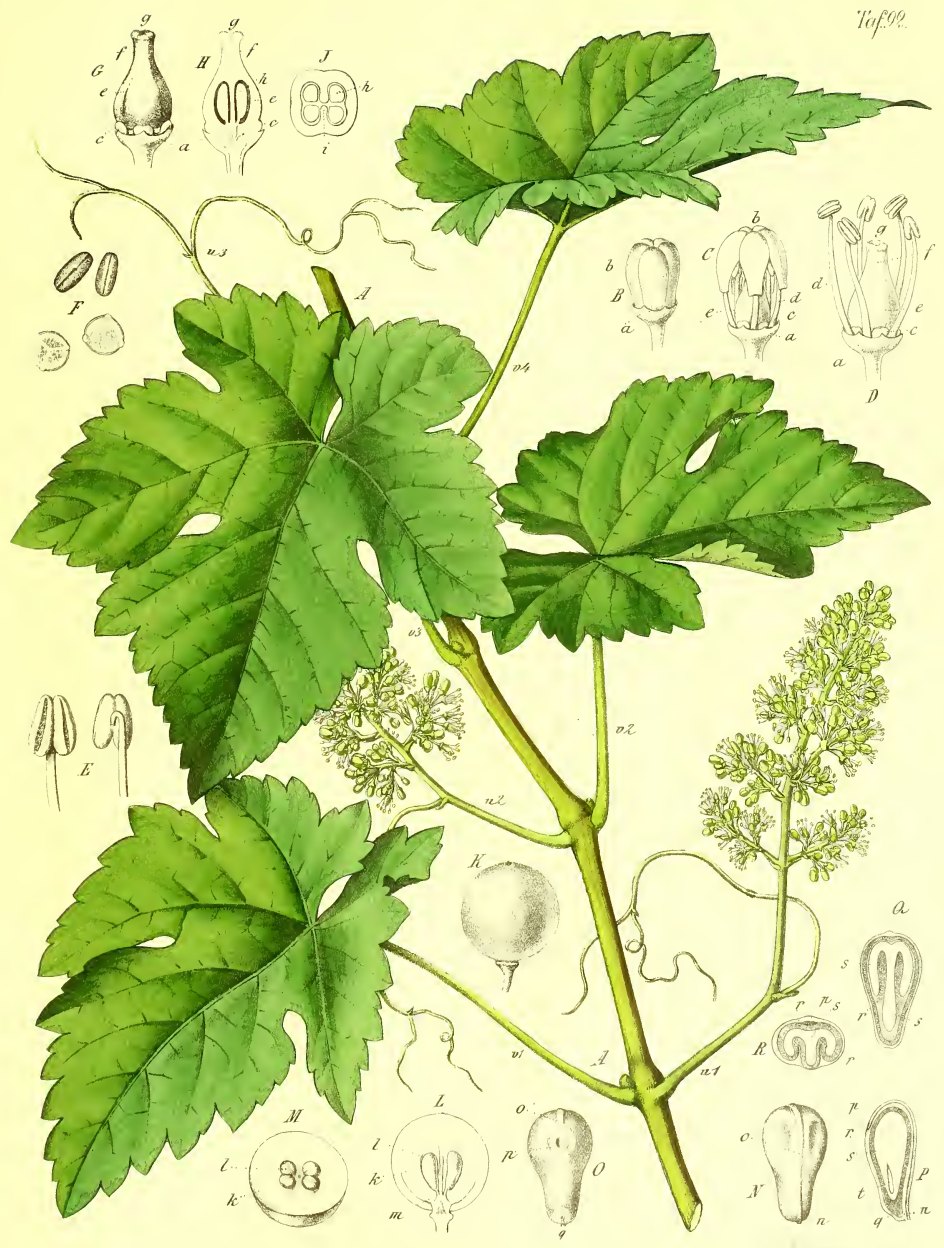

Vitis vinifera $\mathrm{L}$. 



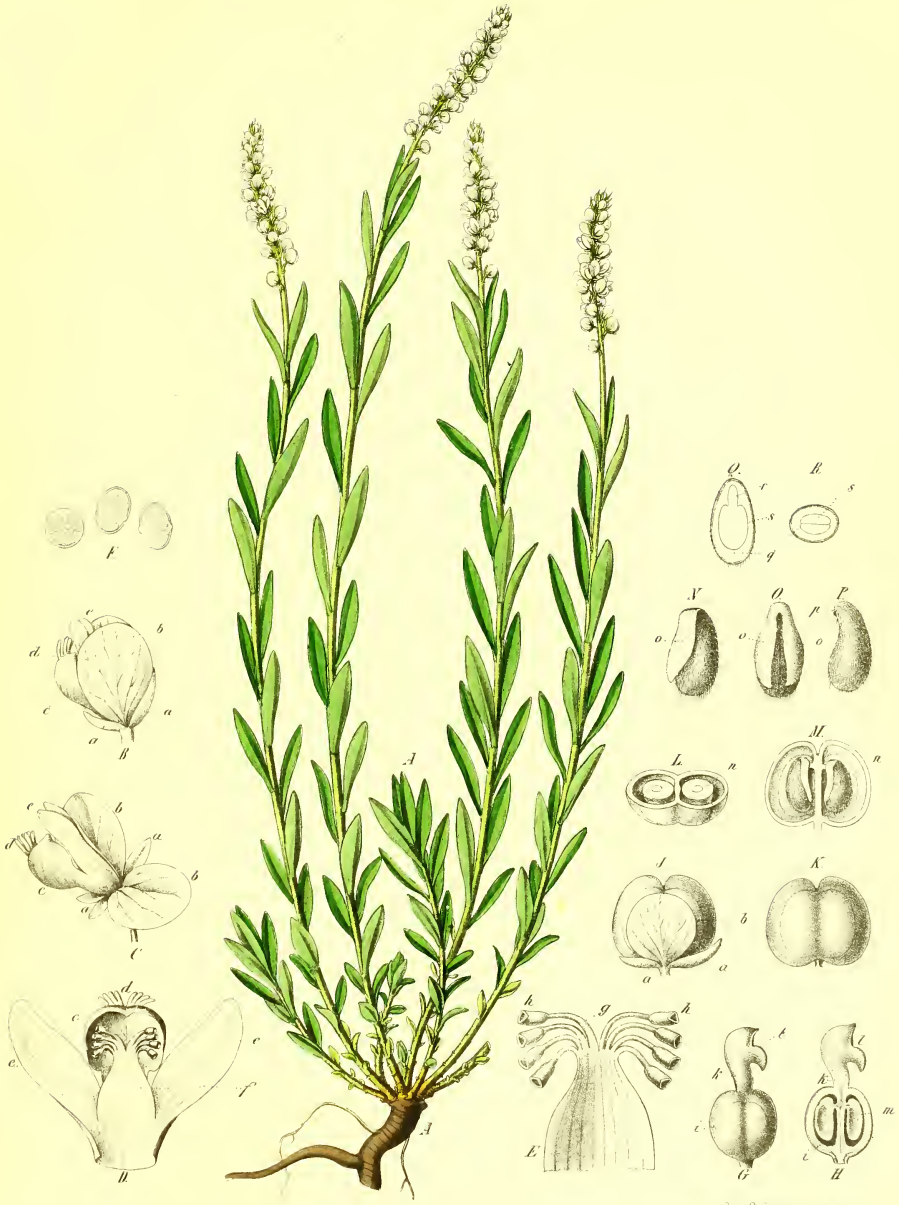

Polygala Seneǵa Linn 


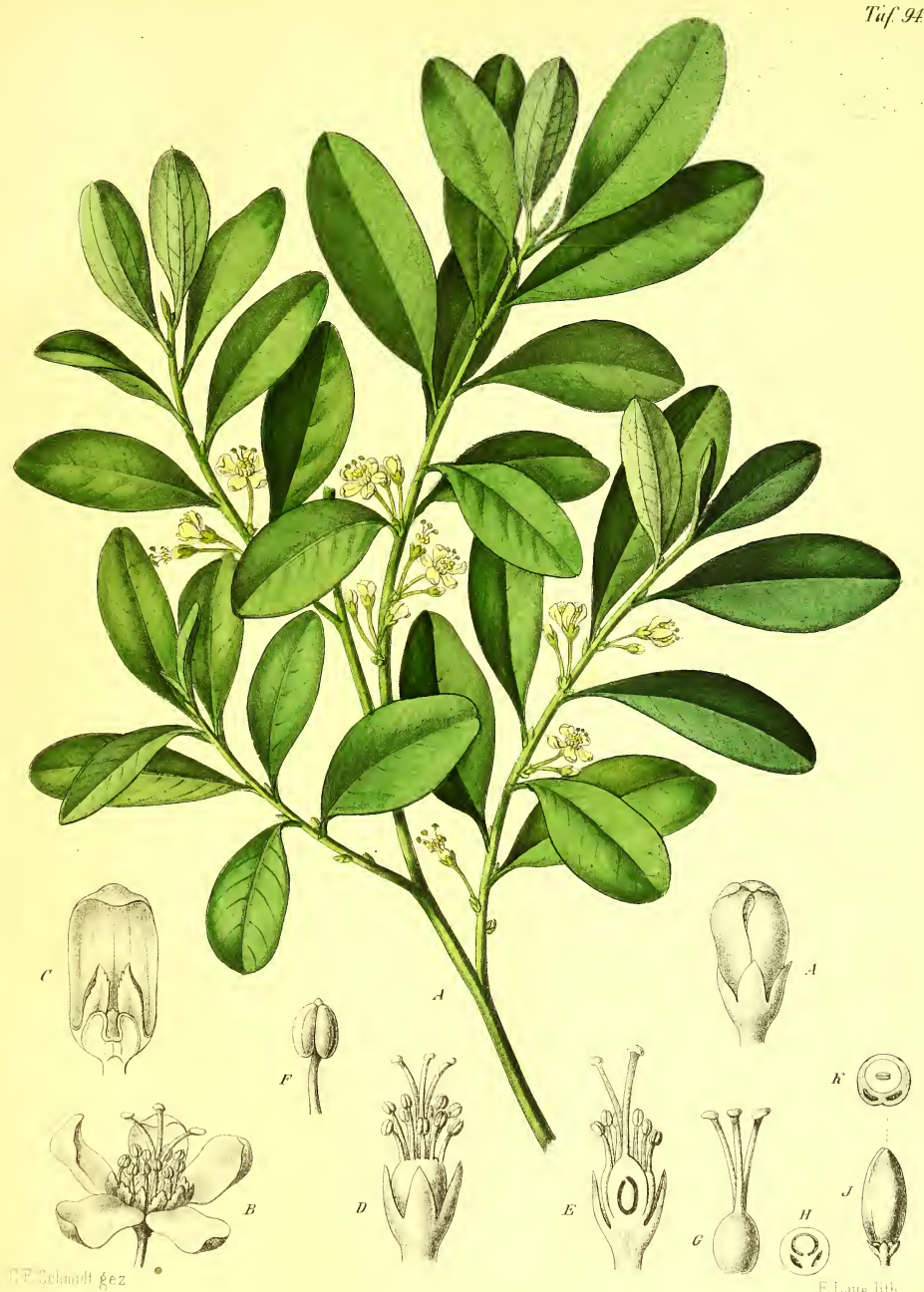

kirythroxylon C'oca Lam 



(1) 10.2 ar.

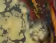

. 10

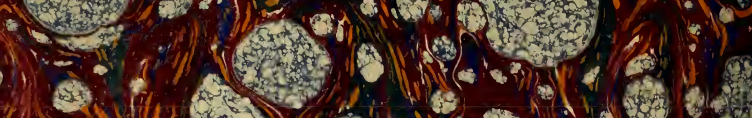

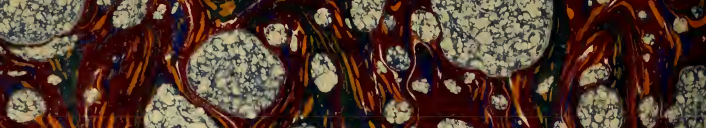

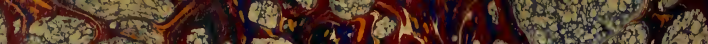

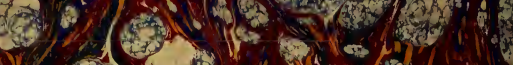

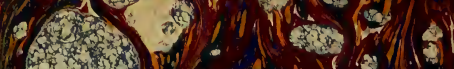

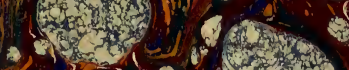

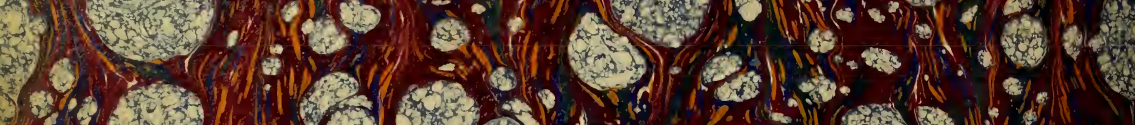

30.

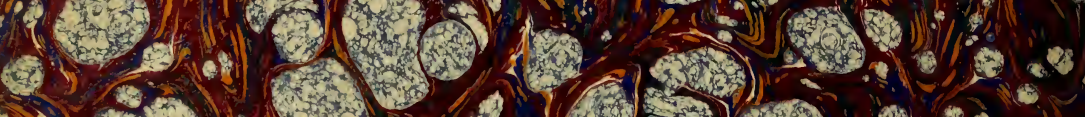
(5)

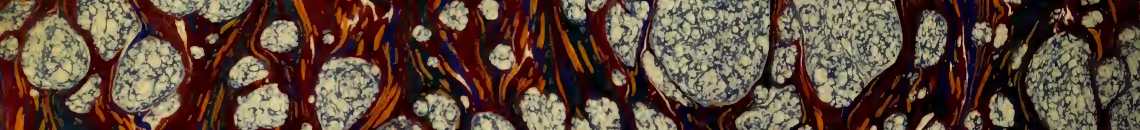

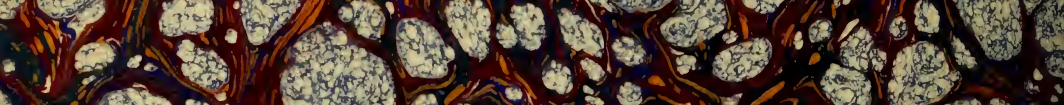

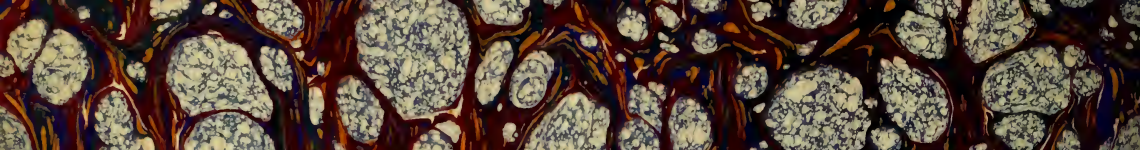

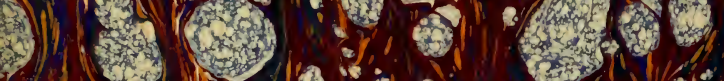

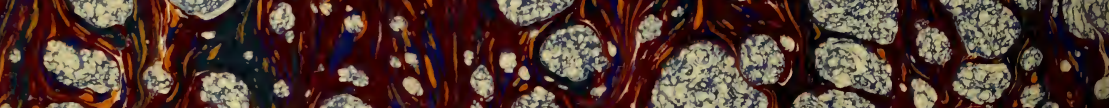

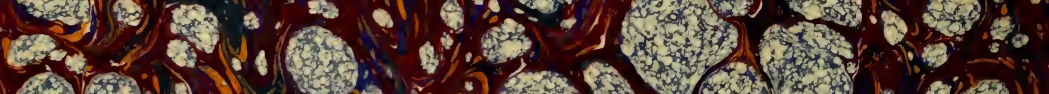

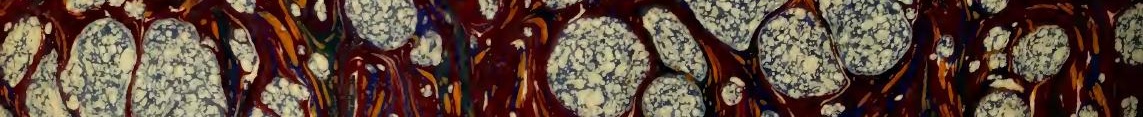

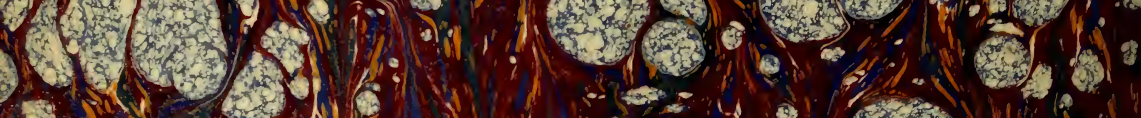

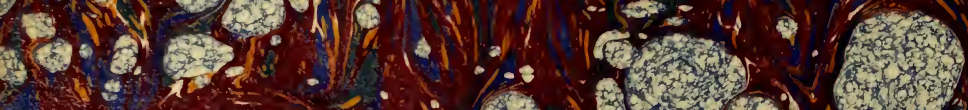

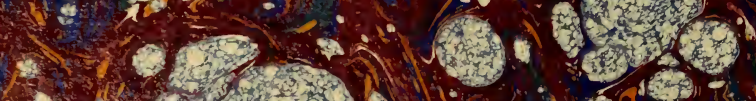

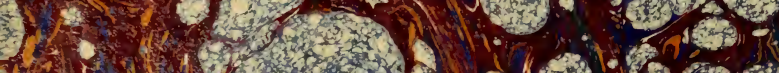

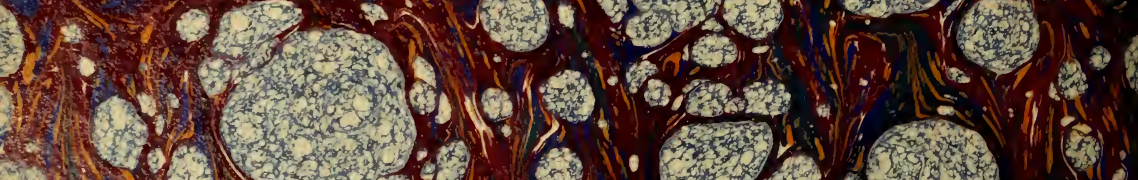

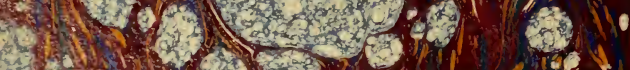
(x) $5,0.0$ exthosese 60
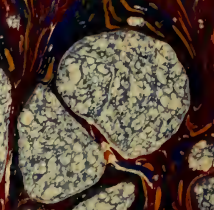

12 - 



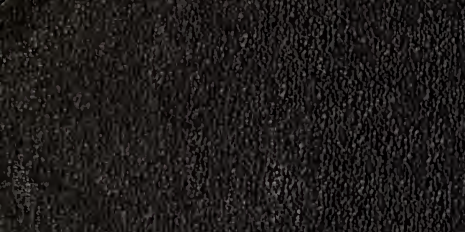

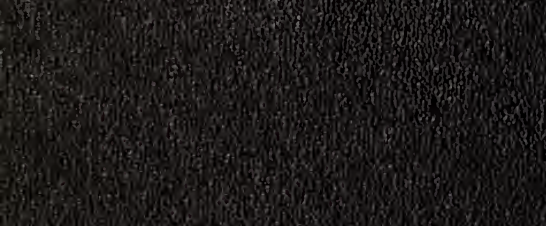

27.

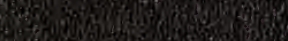

1.0. 